\begin{abstract}
Universidade de São Paulo
Faculdade de Economia, Administração e Contabilidade

Departamento de Contabilidade e Atuária

Programa de Pós-Graduação em Controladoria e Contabilidade
\end{abstract}

Juliana Ventura Amaral

Custos mais margem: A forma ou a essência do estabelecimento dos preços? 
Prof. Dr. Marco Antonio Zago

Reitor da Universidade de São Paulo

Prof. Dr. Adalberto Américo Fischmann

Diretor da Faculdade de Economia, Administração e Contabilidade

Prof. Dr. Ariovaldo dos Santos

Chefe do Departamento de Contabilidade e Atuária

Prof. Dr. Lucas Ayres Barreira de Campos Barros

Coordenador do Programa de Pós-Graduação em Controladoria e Contabilidade 
JULIANA VENTURA AMARAL

\section{Custos mais margem: A forma ou a essência do estabelecimento dos preços?}

\section{Versão corrigida}

(Versão original encontra-se na unidade que aloja o Programa de Pós-graduação)

Tese apresentada ao Programa de Pós-Graduação em Controladoria e Contabilidade do Departamento de Contabilidade e Atuária da Faculdade de Economia, Administração e Contabilidade da Universidade de São Paulo, como requisito parcial para a obtenção do título de Doutora em Ciências. Área de Concentração: Controladoria e Contabilidade.

Orientador: Prof. Dr. Reinaldo Guerreiro 
Autorizo a reprodução e divulgação total ou parcial deste trabalho, por qualquer meio convencional ou eletrônico, para fins de estudo e pesquisa, desde que citada a fonte.

Catalogação na publicação

Serviço de Biblioteca e Documentação

Faculdade de Economia, Administração e Contabilidade da Universidade de São Paulo

\section{Amaral, Juliana Ventura}

Custos mais margem: a forma ou a essência do estabelecimento dos preços ? / Juliana Ventura Amaral. - São Paulo, 2017.

$407 \mathrm{p}$.

Tese (Doutorado) - Universidade de São Paulo, 2017.

Orientador: Reinaldo Guerreiro.

1. Preços 2. Custos 3. Margem 4. Valor (Administração) I. Universidade de São Paulo. Faculdade de Economia, Administração e Contabilidade.

II. Título.

CDD - 338.52 
Dedico este trabalho à minha mãe 

Antes de tudo, agradeço a Deus por permanecer ao meu lado, protegendo-me e concedendome forças. Sou grata por todas as nossas conquistas!

À minha mãe e professora Cléa pelo apoio e por me incentivar, desde criança, a buscar o constante desenvolvimento intelectual e ao meu pai Carlos Alberto.

Ao meu orientador, professor Reinaldo Guerreiro, por aceitar me orientar também no doutorado e por todas as ideias que ajudaram a construir esta tese. Não há palavras para agradecer a parceria científica estabelecida desde o mestrado.

Aos professores Carlos Eduardo Facin Lavarda e Lauro Brito de Almeida pela detalhada análise da proposta do trabalho e pelas sugestões oferecidas na qualificação. As versões impressas comentadas disponibilizadas por ambos foram fundamentais na reestruturação do trabalho.

Aos professores Carlos Eduardo Facin Lavarda, Lauro Brito de Almeida, Marcio Luiz Borinelli e Marco Tullio de Castro Vasconcelos pela avaliação da versão original e pelas valiosas contribuições oferecidas na defesa. As recomendações de todos na data da defesa, o detalhado parecer do professor Lavarda e a disponibilização da versão impressa comentada pelo professor Borinelli viabilizaram a elaboração da versão corrigida e permitiram aprimorar não só este trabalho, mas também as pesquisas dele decorrentes.

Registro minha eterna gratidão à professora Silvia Casa Nova, por guiar meus primeiros passos científicos (TCC), e aos professores Carlos Alberto Pereira, Fábio Frezatti, Gilberto Martins e Welington Rocha por, em novembro de 2009, ao participarem da banca de seleção do mestrado, terem acreditado em mim, prestes a graduar, e terem me dado a oportunidade única de ingressar no mestrado. Sem essa oportunidade, nem minha dissertação nem a presente tese existiriam.

Repito os agradecimentos feitos na dissertação a todos os meus professores de graduação/mestrado. No que se refere aos professores que tive o privilégio de conviver durante o doutorado, acrescento os seguintes agradecimentos: Gilberto Martins, por mostrar o que é verdadeiramente construir ciência; Welington Rocha e Márcio Borinelli, por transmitirem ímpares conhecimentos sobre custos e por revelarem a importância da trilogia mensuração, informação e decisão; Andson Braga de Aguiar, por estimular a análise crítica da literatura; Carlos Alberto Pereira, por nos ensinar a ver como a gestão econômica pode melhorar todas as nossas decisões; Tânia Relvas, por me aceitar como monitora e por toda a sabedoria repassada; Eliseu Martins, por compartilhar a visão singular que ele tem sobre contabilidade; Edgard Cornacchione, por estimular a enxergar o impacto da tecnologia em 
nossos temas de pesquisa; Luís Eduardo Afonso, por incentivar a autoavaliação da produção científica; e Bruno Salotti, Fernando Murcia e Isabel Lourenço, pelo conhecimento transmitido sobre IFRS que acabou materializado em um livro.

Agradeço ao professor Ari, ao Nivaldo e à FIPECAFI pelos dados da Revista Exame M\&M.

À professora Joanília pelo agradável convívio durante o III Congresso Nacional de Administração e Ciências Contábeis da UFRJ.

Foi um privilégio ter estudado na FEA e vivido o mundo USP por mais de onze anos. Por isso, agradeço a todos os funcionários prestativos com os quais pude contar, em especial, aqueles do EAC, da SPG, da biblioteca e do STI.

Fico grata à Iracema, à Márcia e ao Rodrigo, por pré-avaliarem o questionário, e aos dois consultores que aceitaram participar do pré-teste: Bráulio Wilker Silva (BWS Consultoria) e Fabiano Coelho.

Finalmente, devo muitos agradecimentos a todos os profissionais que responderam os questionários e viabilizaram a realização desta pesquisa. Muito obrigada por dedicarem seu tempo à minha tese e pelas mensagens de apoio que muitos de vocês transmitiram durante o período de coleta de dados. 
'Jesus lhes disse: Tende fé em Deus. Em verdade vos digo, se alguém disser a esta montanha 'Levanta-te e atira-te no mar' e não duvidar no seu coração, mas acreditar que isso vai acontecer, assim acontecerá. Por isso vos digo, tudo o que pedires na oração, acreditai que já o recebestes e assim será." Marcos, 11:22-24 



\section{RESUMO}

Amaral, J. V. (2017). Custos mais margem: a forma ou a essência do estabelecimento dos preços? (Tese de Doutorado). Faculdade de Economia, Administração e Contabilidade, Universidade de São Paulo, São Paulo.

A teoria econômica explica que os preços necessariamente refletem a igualdade entre o custo marginal e a receita marginal. Já a teoria de marketing recomenda que os preços sejam definidos em consonância ao valor. O problema é que os estudos empíricos têm mostrado que a realidade não corresponde a nenhuma dessas duas teorias, pois, na realidade, a maior parte das empresas define os preços com base nos custos. Entretanto, esses estudos não têm evidenciado se a combinação dos custos à margem, recorrentemente encontrada, configura a forma ou a essência da determinação dos preços. Mais especificamente, pode-se afirmar que os estudos empíricos normalmente não têm aprofundado a investigação para avaliar se a fórmula "custos mais margem" refere-se apenas à forma mecânica de operacionalizar o estabelecimento dos preços ou refere-se tanto à forma quanto à essência do processo. Quando a fórmula designa a essência do processo, tem-se uma definição de preços marcada pela essência custos, na qual a margem é arbitrária e deixa de conectar os custos a outros tipos de informações. Nesse sentido, a fim de transcender as limitações dos prévios trabalhos empíricos, esta pesquisa teve a meta de investigar a forma e a essência do estabelecimento dos preços em empresas industriais localizadas no Brasil e, mais do que isso, averiguar os fatores que explicam o processo marcado pela essência custos. A coleta de dados aconteceu mediante um levantamento conduzido entre fevereiro de 2016 e junho de 2016. Esse levantamento implicou o envio de um questionário para a população da pesquisa, inicialmente formada por 1.616 empresas industriais relacionadas pela Revista Exame "Melhores e Maiores" e/ou pela Revista Noticiários de Equipamentos Industriais “Top Five” nas edições de 2014 e 2015. 380 respostas foram obtidas e propiciaram uma taxa de resposta de $28 \%$. Foram tomadas medidas para assegurar as validades de conteúdo, de critério e de constructo, com destaque a um préteste em três fases e a duas análises do viés da não resposta. O teste de confiabilidade da pesquisa resultou em um alfa de Cronbach de 0,794. Os dados foram analisados a partir de estatísticas descritivas, de análises de correspondência e de dois modelos de regressão ordinal. Os achados desta pesquisa ilustraram: (a) a importância de segregar as empresas em tomadoras e formadoras de preços; (b) as dificuldades de obtenção de informações sobre os preços da concorrência nos formadores de preços; e (c) os diferentes tipos de informações usados no processo de definição dos preços. Os resultados ainda sugeriram que dois fatores explicam positivamente a essência custos nos formadores de preços (a diferenciação e a percepção que há prejuízos na colocação de preços inferiores ao resultado indicado pelos "custos mais margem") e que um fator explica negativamente a essência custos (estratégia de preço premium). Nos tomadores de preços, três fatores explicam positivamente a essência custos (a percepção que há prejuízos na colocação de preços inferiores ao resultado indicado pelos "custos mais margem", o isomorfismo coercitivo e o uso dos custos totais) enquanto que cinco fatores explicam negativamente a essência custos (o grande porte, a propensão de cópia dos concorrentes, a não disposição dos clientes em pagar o valor, o isomorfismo normativo e a experiência). Finalmente, concluiu-se que a combinação "custos mais margem" pode ser a forma sem ser a essência do estabelecimento dos preços, uma vez que a margem pode conectar os custos aos demais tipos de informações. Implicações para os pesquisadores, para os profissionais, para os docentes e para os discentes foram discutidas.

Palavras-chave: Preços. Custos. Margem. Valor (Administração). 



\begin{abstract}
Amaral, J. V. (2017). Cost-plus: is it shape or essence of pricing? (Tese de Doutorado). Faculdade de Economia, Administração e Contabilidade, Universidade de São Paulo, São Paulo.

Economic theory explains how prices are set at a level that equates marginal cost and marginal revenue. On the other hand, marketing theory explains how prices should be set based on value. The problem is that researchers argue that neither of these two theories really explains the pricing practices because empirical studies have concluded that most companies set prices based on cost. However, the empirical studies have not yet examined whether costplus formulas represent either the shape or the essence of pricing. In other words, the empirical studies have not yet provided an in-depth analysis of the circumstances in which cost-plus formulas are shape rather than essence of pricing. It is important to mention that a cost-based essence is found when margin is arbitrary and does not connect cost to other types of information. In attempting to address this issue, the present research was designed with the purpose of investigating shape and essence of pricing in industrial companies located in Brazil. More specifically, the goal of this work was to draw attention to the factors that determine the adoption of a cost-based essence. Data for this study were gathered through a survey carried out between February 2016 and June 2016. A questionnaire was sent to 1,616 industrial companies included on the list of "Melhores e Maiores" Exame Magazine and/or on the list of "Noticiários de Equipamentos Industriais - Top 5" Magazine (2014 and 2015 editions). The total usable responses were 380 representing a $28 \%$ response rate. Content, criterion and construct validities were assessed through procedures that included both a threestage pre-test and two investigations for non-response bias. Reliability test resulted in a Cronbach's Alpha of 0.794. Descriptive statistics, correspondence analyses and two ordinal regressions were conducted for purposes of analysis. The findings from this research illustrated: (a) the importance of separating companies into price-takers and price-makers; (b) the price-makers' difficulties in obtaining data about competitors' prices; and (c) the different types of information used in the pricing process. The results also suggested that, for price makers, cost-based essence was positively associated with two predictors (differentiation and perception that prices lower than cost-plus calculations can lead to losses), but it was negatively related to one predictor (premium pricing strategy). For price-takers, cost-based essence was positively associated with three predictors (perception that prices lower than cost-plus calculations can lead to losses, coercive isomorphism and use of full costs), but it was negatively related to five predictors (large size, competitors' ability to copy products, customer's non-willingness to pay, normative isomorphism and experience). Finally, it was concluded that cost-plus may be the shape without being the essence of pricing because margin can connect costs to other types of information. Implications for researchers, practitioners, teachers and students were discussed.
\end{abstract}

Keywords: Pricing. Costs. Mark-up. Value. 



\section{LISTA DE ILUSTRAÇÕES}

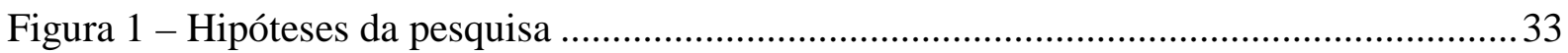

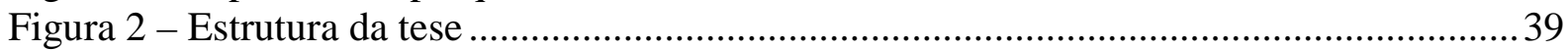

Figura 3 - Equilíbrio, preço de equilíbrio e quantidade de equilíbrio.................................... 44

Figura 4 - Diferentes métodos na prática de determinação dos preços......................................48

Figura 5 - Métodos de determinação dos preços .............................................................. 48

Figura 6 - Abordagem do preço baseado na concorrência.................................................49

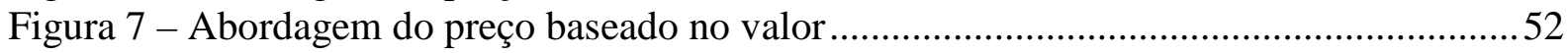

Figura 8 - Estruturação lógica do valor para o cliente ….......................................................53

Figura 9 - Valor econômico total: Valor de referência + valor da diferenciação .....................54

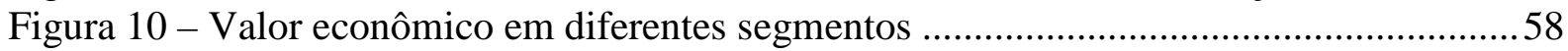

Figura 11 - Quatro diferentes tipos do valor para o cliente .................................................60

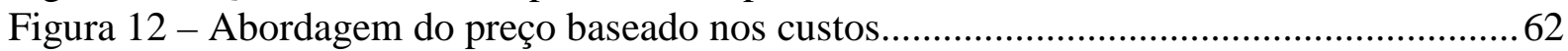

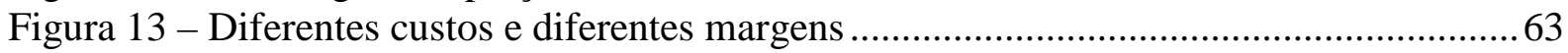

Figura 14 - Custos de acordo com métodos de custeio........................................................6 65

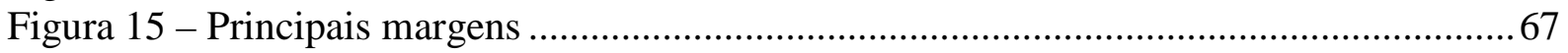

Figura 16 - Comparação entre markup e cost-plus ................................................................6

Figura 17 - Modelo de estabelecimento dos preços conforme o valor percebido ....................72

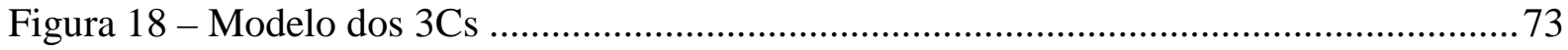

Figura 19 - Técnica integrada de determinação dos preços ................................................ 74

Figura 20 - Aplicação dos métodos na análise do triângulo estratégico................................74

Figura 21 - Abrangência mundial das pesquisas empíricas mais citadas .............................. 105

Figura 22 - Abrangência mundial das pesquisas empíricas (mais e menos citadas) ..............127

Figura 23 - Conclusão central das pesquisas empíricas (mais e menos citadas) ....................128

Figura 24 - Abrangência regional das pesquisas empíricas brasileiras................................ 141

Figura 25 - Conclusão central das pesquisas empíricas brasileiras ........................................ 142

Figura 26 - Prática do estabelecimento dos preços segundo pesquisas empíricas................... 143

Figura 27 - Supostos gaps entre a teoria e a prática de estabelecimento dos preços ............. 145

Figura 28 - Críticas à aplicação prática da teoria econômica ............................................ 147

Figura 29 - Gap entre teoria econômica e prática............................................................. 150

Figura 30 - Base dos custos segundo revisão de Hinterhuber (2008) ................................... 152

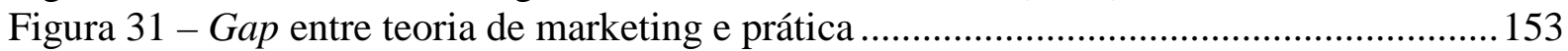

Figura 32 - Explicação para a existência dos gaps ............................................................ 154

Figura 33 - Reorganização do entendimento sobre a definição dos preços na prática .......... 155

Figura 34 - Tomadores e formadores de preços................................................................. 157

Figura 35 - Disponibilidade de informações nos tomadores de preços ............................... 163

Figura 36 - Disponibilidade de informações nos formadores de preços............................... 166

Figura 37 - Base da fórmula nos tomadores e nos formadores de preços.............................170

Figura 38 - Margem como um percentual sobre o preço de venda......................................172

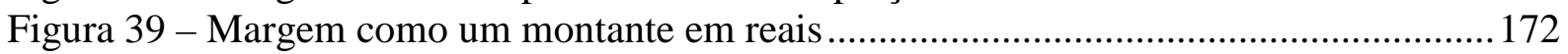

Figura 40 - Margem como um montante horário em reais ............................................... 173

Figura 41 - Margem como elemento caracterizador da essência custos .............................. 178

Figura 42 - Reavaliação do gap entre a teoria de marketing e a prática................................ 181

Figura 43 - Custos mais margem diante da intensidade da concorrência .............................. 188

Figura 44 - Inibidores do embasamento no valor segundo Hinterhuber (2008) .................... 194

Figura 45 - Estratégia e informações segundo Ingenbleek e van der Lans (2013) ................200

Figura 46 - Pressões isomórficas no estabelecimento dos preços.......................................210

Figura 47 - Ambientes de atuação .................................................................................. 211 
Figura 48 - Distribuição da amostra por número de reiterações ........................................ 233

Figura 49 - Operacionalização do enquadramento das empresas........................................ 241

Figura 50 - Estabelecimento dos preços e ambiente de atuação .......................................... 268

Figura 51 - Resultados esperados nas hipóteses de pesquisa .............................................. 271

Figura 52 - Relação entre modelos de regressão ordinal e definições constitutivas ............. 279

Figura 53 - Quantidade de participações com e sem reiterações ........................................ 285

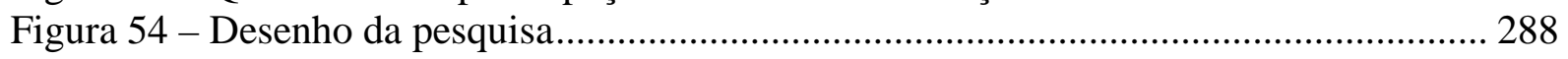

Figura 55 - Perspectivas de discussão dos resultados ........................................................ 289

Figura 56 - Localização da população e da amostra da pesquisa .......................................... 291

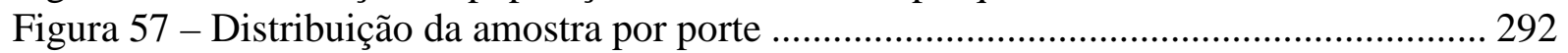

Figura 58 - Distribuição da amostra por quantidade de clientes ........................................ 292

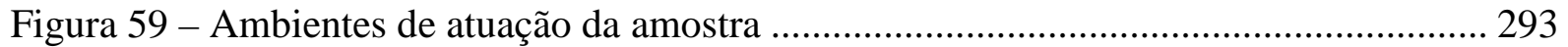

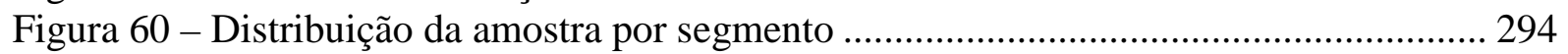

Figura 61 - Nível de qualidade ofertado por não líderes e líderes ........................................ 296

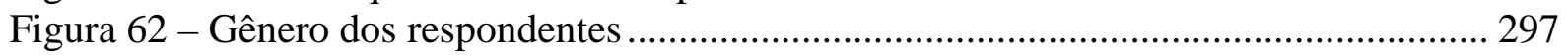

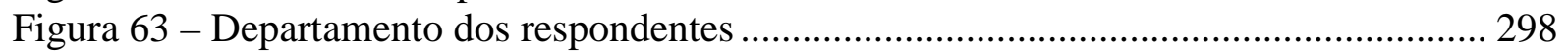

Figura 64 - Enquadramento das empresas na amostra ..................................................... 299

Figura 65 - Expectativas teóricas sobre o contexto empírico do estabelecimento dos preços 300

Figura 66 - Mapa perceptual: Enquadramento e diferenciação............................................. 304

Figura 67 - Mapa perceptual: Enquadramento e customização ........................................... 306

Figura 68 - Mapa: Enquadramento e dificuldade de uso das informações da concorrência. 307

Figura 69 - Mapas perceptuais: Enquadramento e informações usadas............................... 312

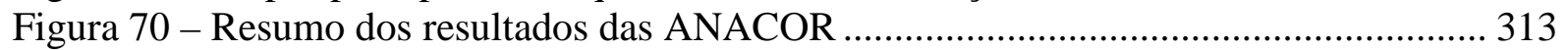

Figura 71 - Principais formas de estabelecer os preços..................................................... 314

Figura 72 - Principais formas nos formadores de preços ............................................ 316

Figura 73 - Principais formas nos tomadores de preços..................................................... 321

Figura 74 - Mapa perceptual: Problemas da essência custos e incorporação do valor ......... 330

Figura 75 - Fatores explicativos significativos da essência custos nos formadores .............. 342

Figura 76 - Fatores explicativos significativos da essência custos nos tomadores ............... 344 


\section{LISTA DE TABELAS}

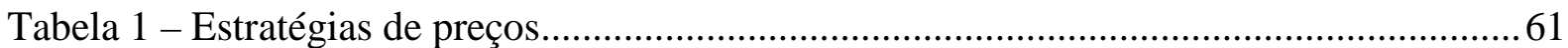

Tabela 2 - Custo e margem de acordo com o método de custeio ............................................66

Tabela 3 - Número de citações das pesquisas empíricas mais citadas......................................78

Tabela 4 - Resultados da pesquisa de R. C. Skinner (1970) ................................................ 80

Tabela 5 - Resultados da pesquisa de Govindarajan e Anthony (1983) .................................83

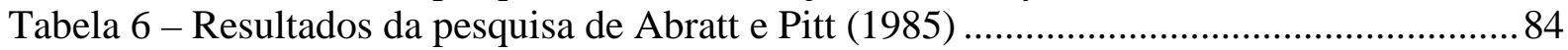

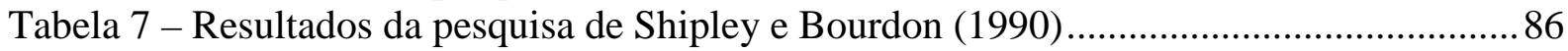

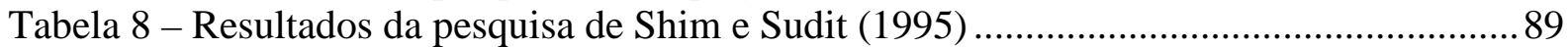

Tabela 9 - Resultados da primeira série de estudos de Avlonitis e Indounas ..........................94

Tabela 10 - Características dos levantamentos reportados por Fabiani et al. (2005) ..............96

Tabela 11 - Resultados da pesquisa de Fabiani et al. (2005) ...................................................97

Tabela 12 - Resultados da pesquisa de Drury e Tayles (2006)............................................99

Tabela 13 - Sumário dos resultados das pesquisas empíricas mais citadas .......................... 102

Tabela 14 - Sumário dos locais investigados nas pesquisas empíricas mais citadas .............. 104

Tabela 15 - Resultados de Morris e Schurink (1993) ....................................................... 108

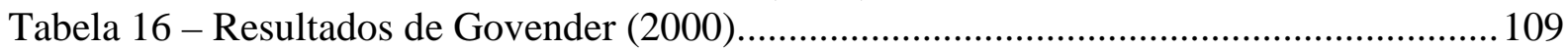

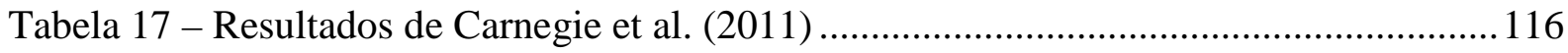

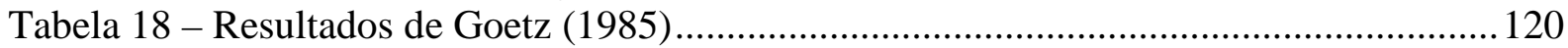

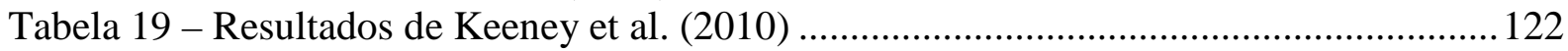

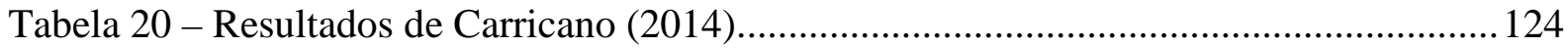

Tabela 21 - Sumário dos resultados das pesquisas empíricas menos citadas ......................... 125

Tabela 22 - Sumário dos locais investigados nas pesquisas empíricas (mais e menos

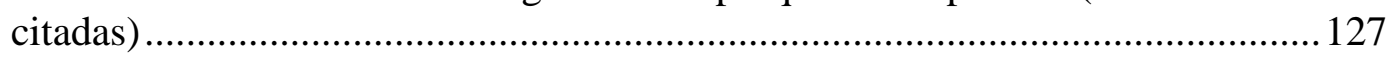

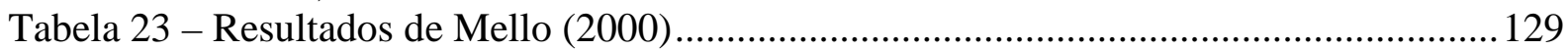

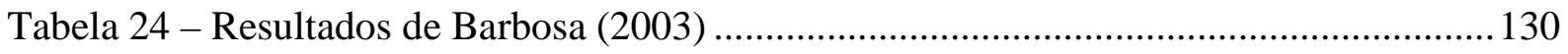

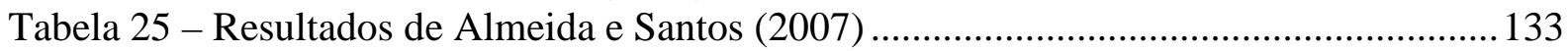

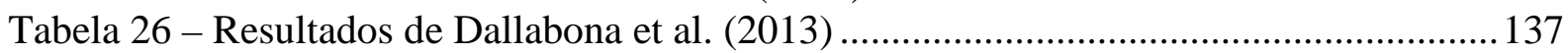

Tabela 27 - Sumário dos resultados das pesquisas empíricas brasileiras ............................ 140

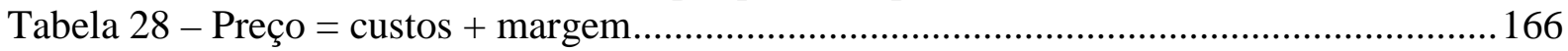

Tabela 29 - Comparação da margem no mercado do ouro ................................................. 170

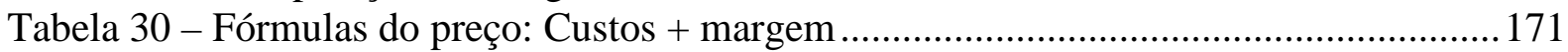

Tabela 31 - Hipóteses do estudo de Ingenbleek et al. (2003) .................................................. 185

Tabela 32 - Resultados do estudo de Ingenbleek et al. (2003) ............................................. 185

Tabela 33 - Hipóteses do estudo de Guilding et al. (2005) .................................................. 189

Tabela 34 - Resultados do estudo de Guilding et al. (2005) .............................................. 190

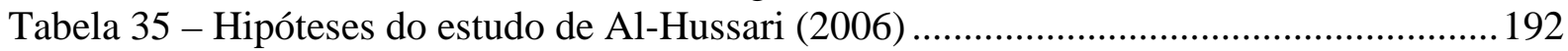

Tabela 36 - Resultados do estudo de Al-Hussari (2006) ....................................................... 193

Tabela 37 - Hipóteses do estudo de Ingenbleek e van der Lans (2013) .................................. 198

Tabela 38 - Resultados do estudo de Ingenbleek e van der Lans (2013).............................. 199

Tabela 39 - Sumário dos resultados dos estudos anteriores................................................202

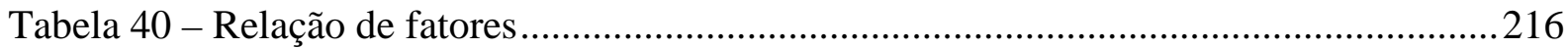

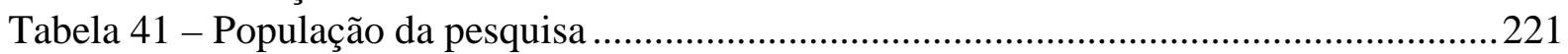

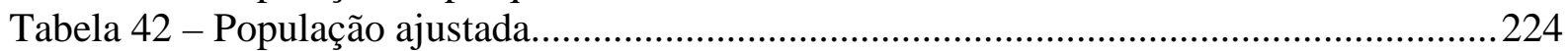

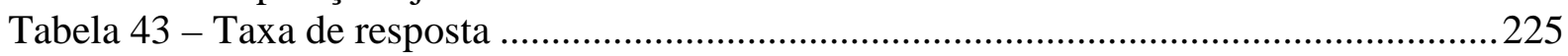

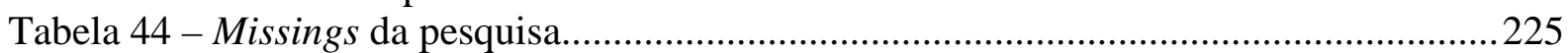

Tabela 45 - Resultados do teste Mann-Whitney para $1^{\mathrm{a}}$ análise do viés da não resposta......233

Tabela 46 - Resultados do teste Mann-Whitney para $2^{\mathrm{a}}$ análise do viés da não resposta......236 
Tabela 47 - Variáveis referentes ao enquadramento da empresa ....................................... 241

Tabela 48 - Variáveis referentes à dificuldade de uso das informações da concorrência ..... 243

Tabela 49 - Variáveis referentes às informações usadas ....................................................... 243

Tabela 50 - Variável referente à forma do estabelecimento dos preços............................... 244

Tabela 51 - Variáveis referentes à essência do estabelecimento dos preços ......................... 246

Tabela 52 - Variáveis referentes aos problemas da essência custos..................................... 248

Tabela 53 - Variáveis referentes à diferenciação ............................................................... 249

Tabela 54 - Variável referente ao tamanho da empresa ..................................................... 250

Tabela 55 - Variável referente à posição de liderança no mercado....................................... 251

Tabela 56 - Variável referente à estratégia de preços premium ........................................... 251

Tabela 57 - Variáveis referentes à intensidade da concorrência ......................................... 253

Tabela 58 - Variáveis referentes às dificuldades para definir os preços conforme o valor... 255

Tabela 59 - Variáveis referentes às pressões isomórficas .................................................. 256

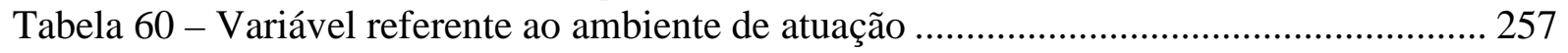

Tabela 61 - Variável referente à experiência no estabelecimento dos preços ....................... 258

Tabela 62 - Variáveis referentes aos custos totais na fórmula "custos mais margem”. ........ 259

Tabela 63 - Resultados esperados nas hipóteses de pesquisa............................................. 271

Tabela 64 - Tabulação para realização das 6 primeiras ANACOR ........................................ 273

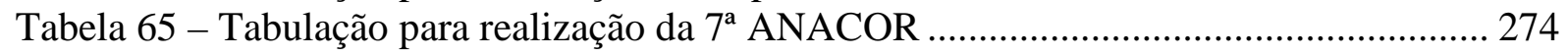

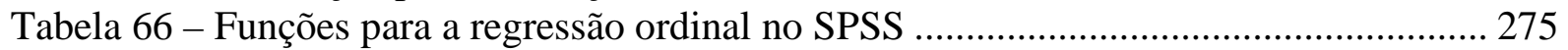

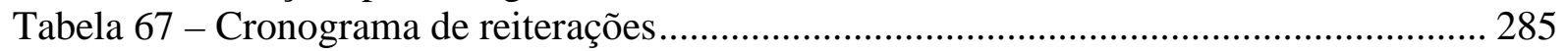

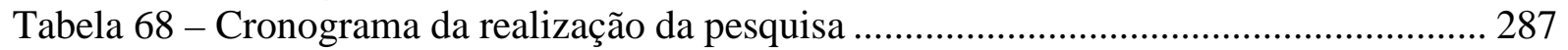

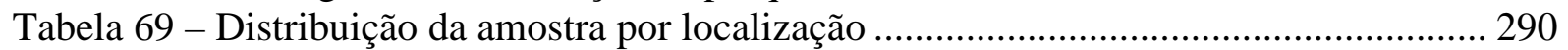

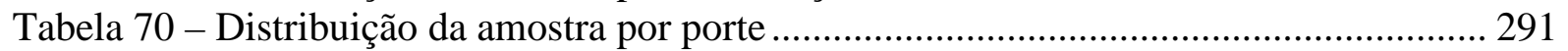

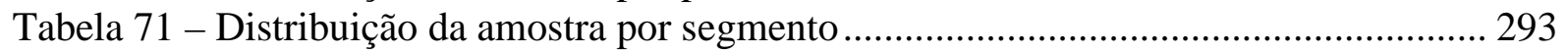

Tabela 72 - Percepção de liderança por segmento ........................................................... 295

Tabela 73 - Existência de área dedicada ao estabelecimento dos preços .............................. 296

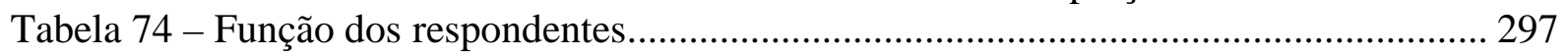

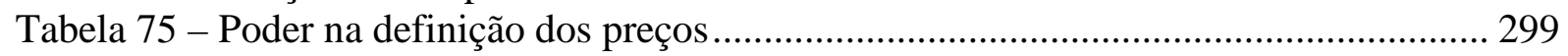

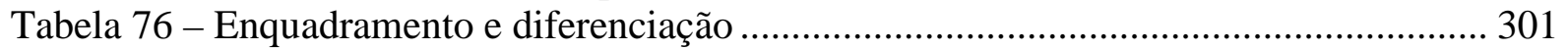

Tabela 77 - Teste qui-quadrado: Enquadramento e diferenciação ........................................ 301

Tabela 78 - Tabela de contingência: Enquadramento e diferenciação ................................... 301

Tabela 79 - Perfis das linhas: Enquadramento e diferenciação ............................................ 302

Tabela 80 - Perfis das colunas: Enquadramento e diferenciação ......................................... 302

Tabela 81 - Valor singular e inércia: Enquadramento e diferenciação ................................. 303

Tabela 82 - Coordenadas de linhas e colunas: Enquadramento e diferenciação..................... 304

Tabela 83 - Enquadramento e customização .................................................................. 305

Tabela 84 - Coordenadas de linhas e colunas: Enquadramento e customização................... 305

Tabela 85 - Enquadramento e dificuldade de uso das informações da concorrência............ 306

Tabela 86 - Coordenadas: Enquadramento e dificuldade de uso das informações da

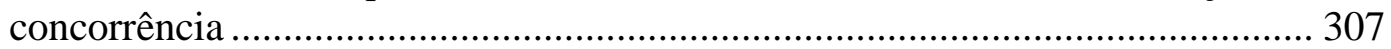

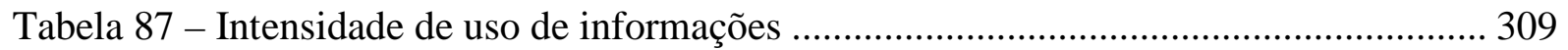

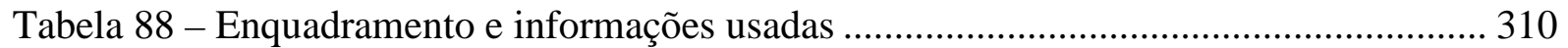

Tabela 89 - Testes qui-quadrado: Enquadramento e informações usadas............................ 311

Tabela 90 - Coordenadas de linhas e colunas: Enquadramento e informações usadas .......... 311

Tabela 91 - A "margem" dos custos mais margem ............................................................ 315

Tabela 92 - Formas de estabelecimento dos preços nos formadores de preços ................... 316

Tabela 93 - Formadores de preços e intensidade de utilização de informações.................... 317

Tabela 94 - Formadores de preços e avaliação do valor oferecido aos clientes.................... 318 
Tabela 95 - Formadores de preços e utilização dos custos mais margem

Tabela 96 - Formadores de preços e incorporação do valor nos custos mais margem ...........320

Tabela 97 - Formas de estabelecimento dos preços nos tomadores de preços .......................321

Tabela 98 - Tomadores de preços e intensidade de utilização de informações ......................322

Tabela 99 - Tomadores de preços e necessidade de seguir preços de referência ....................323

Tabela 100 - Tomadores de preços e utilização dos custos mais margem...............................323

Tabela 101 - Essência custos nos formadores e tomadores de preços ..................................325

Tabela 102 - Incorporação do valor nos formadores e tomadores de preços.........................327

Tabela 103 - Correlação entre incorporação do valor e variáveis da essência custos ............327

Tabela 104 - Resultados do teste Mann-Whitney para grupos de incorporação do valor .....328

Tabela 105 - Essência custos nos incorporadores e não incorporadores do valor ..................328

Tabela 106 - Problemas nos formadores e tomadores que adotam custos mais margem ......329

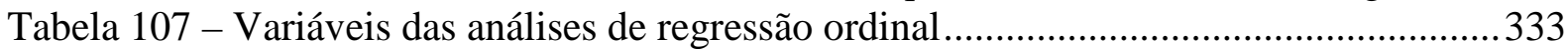

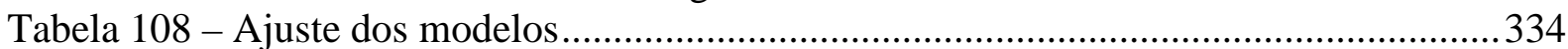

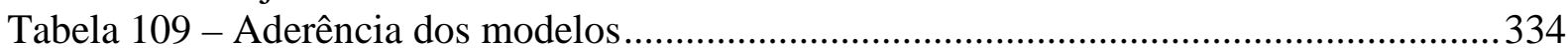

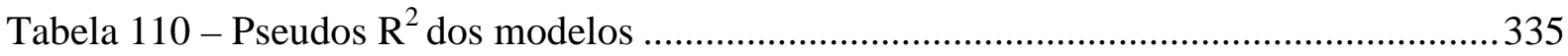

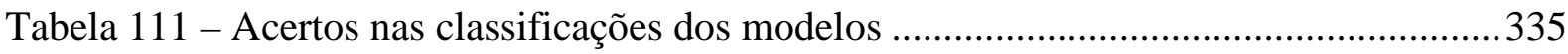

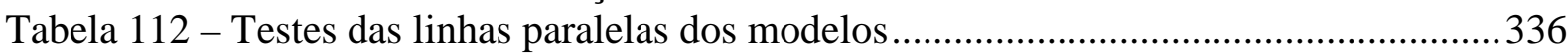

Tabela 113 - Resultados dos modelos de regressão ordinal .................................................336

Tabela 114 - Sumário dos resultados das análises de regressão ordinal ...............................339

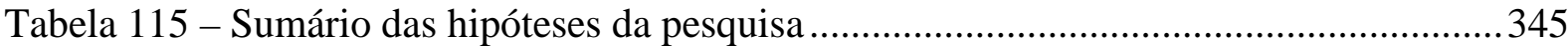





\section{SUMÁRIO}

1 INTRODUÇÃ

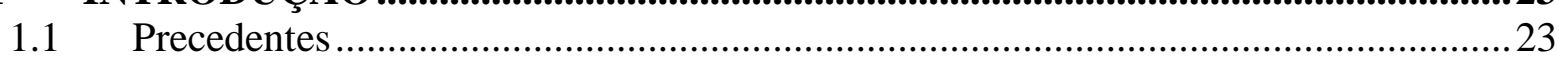

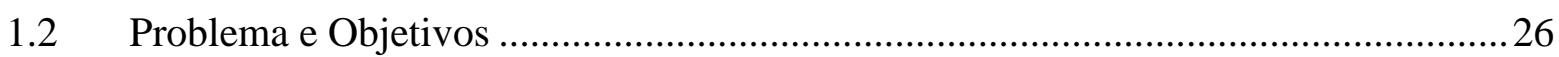

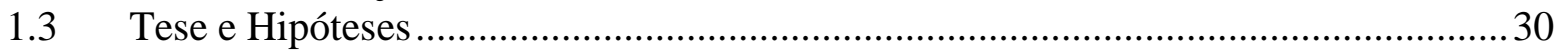

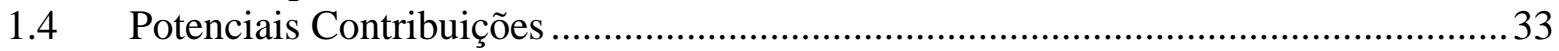

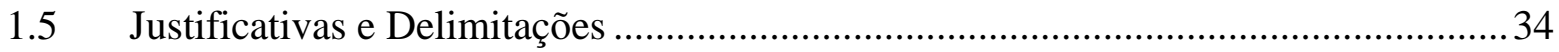

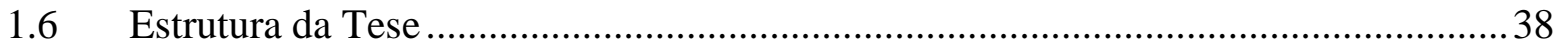

2 ESTABELECIMENTO DOS PREÇOS NA TEORIA ......................................41

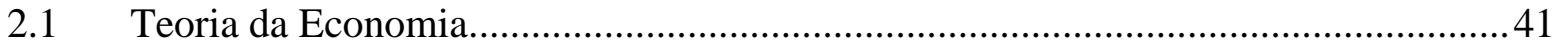

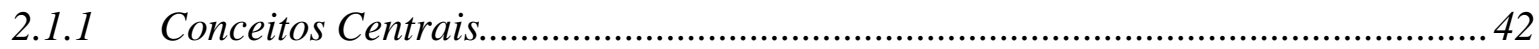

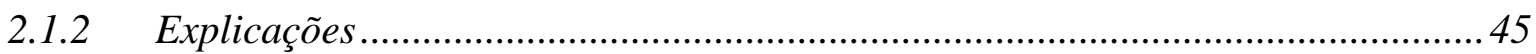

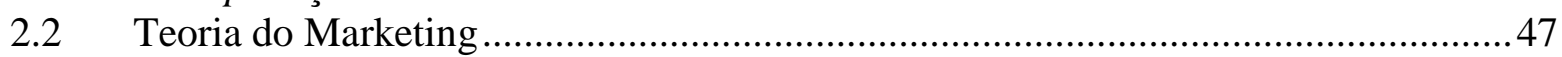

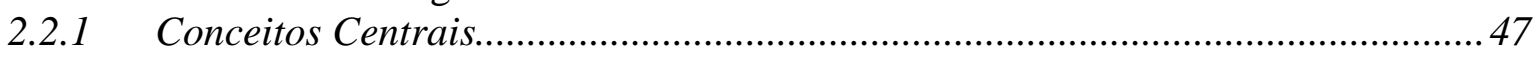

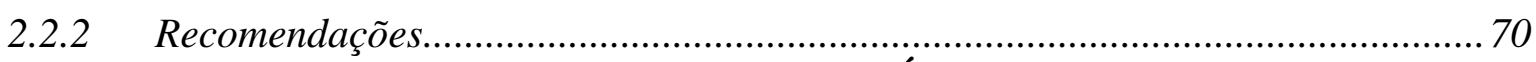

3 ESTABELECIMENTO DOS PREÇOS NA PRÁTICA..............................................77

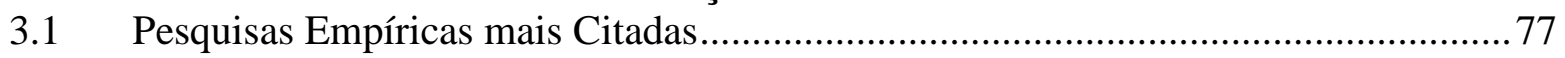

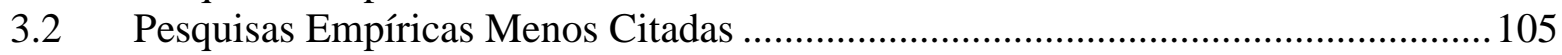

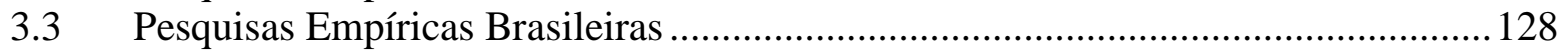

3.4 Sumário sobre o Estabelecimento dos Preços na Prática ......................................... 142

4 GAPS ENTRE TEORIA E PRÁTICA ............................................................145

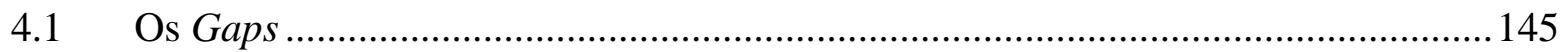

4.1.1 Gap entre a Teoria Econômica e a Prática .......................................................... 145

4.1.2 Gap entre a Teoria de Marketing e a Prática ..................................................... 151

4.2 Reavaliação do Gap entre a Teoria de Marketing e a Prática ................................... 153

4.2.1 Nem Todas as Empresas Têm Poder para Formar Preços ................................. 155

4.2.2 Tomadores e Formadores: Preços a partir de Diferentes Informações .............. 162

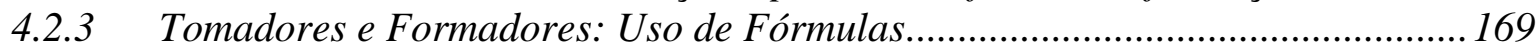

4.2.4 A Essência do Processo Não é Indicada pela Fórmula Usada............................ 175

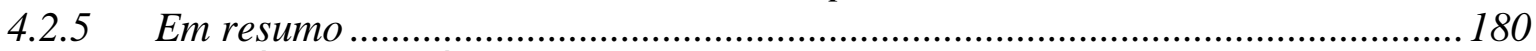

5 O PORQUÊ DA ESSÊNCIA CUSTOS............................................................183

5.1 Revisão Crítica de Fatores Sugeridos nos Estudos Prévios ...................................... 184

5.1.1 Estudo de Ingenbleek et al. (2003) ..................................................................... 184

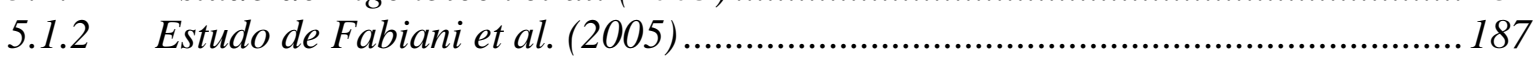

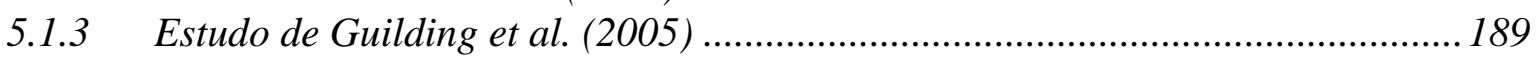

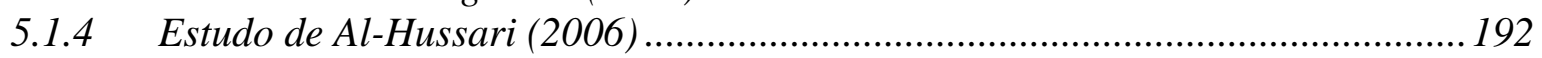

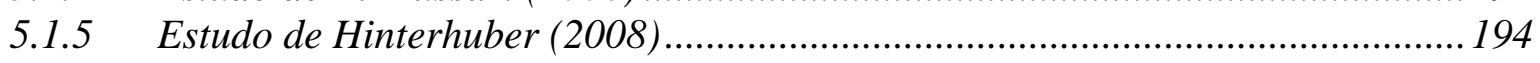

5.1.6 Estudo de Liozu, Hinterhuber, Perelli, e Boland (2012) .......................................... 196

5.1.7 Estudo de Ingenbleek e Van der Lans (2013).................................................. 197

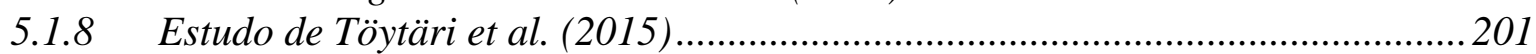

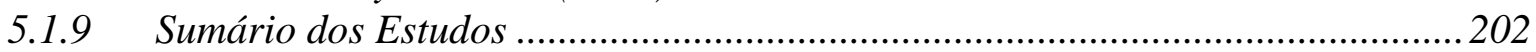

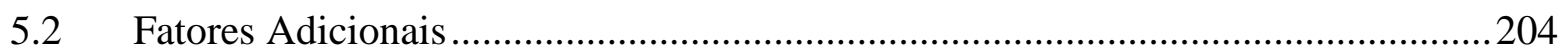

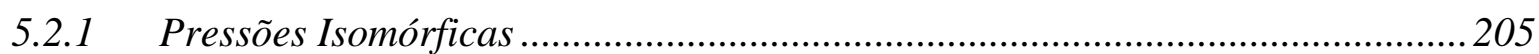

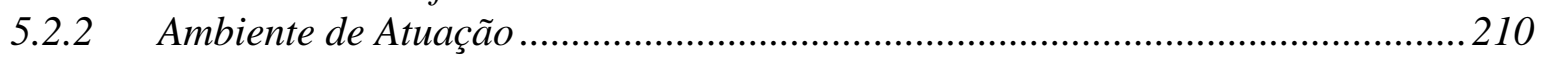

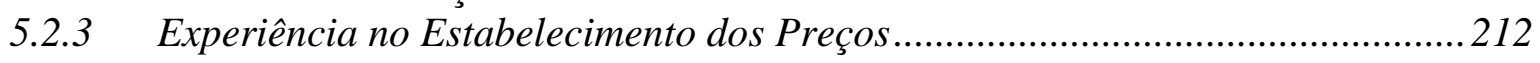

5.2.4 Custos Totais na Fórmula "Custos mais Margem” ".......................................... 213

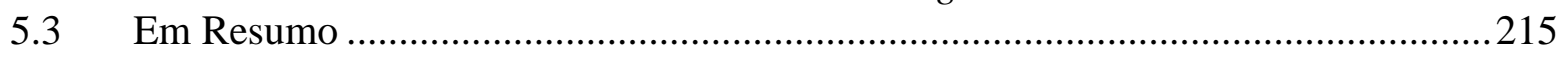


6 MÉTODOS DA PESQUISA ..................................................................................... 217

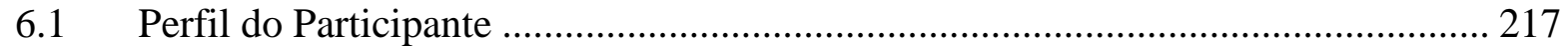

6.2 População e Amostra da Pesquisa ......................................................................... 218

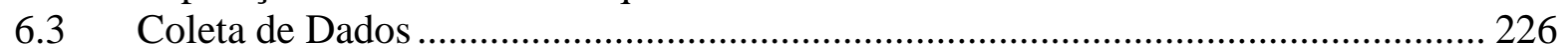

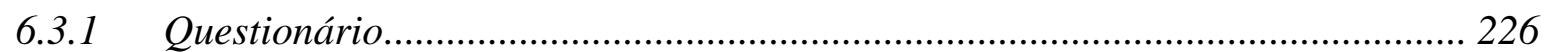

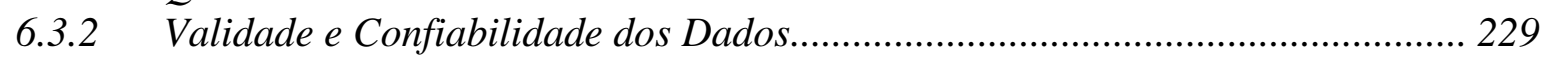

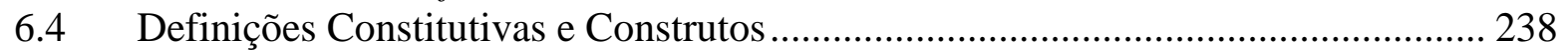

6.4.1 Constructos Referentes ao Estabelecimento dos Preços .................................... 239

6.4.2 Constructos Explicativos do Estabelecimento dos Preços................................... 248

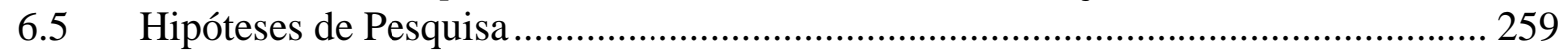

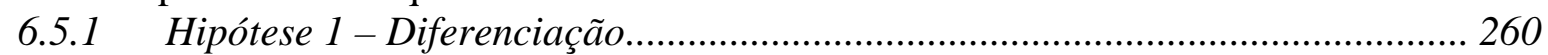

6.5.2 Hipótese 2 - Tamanho da Empresa ..................................................................... 261

6.5.3 Hipótese 3 - Posição de Liderança no Mercado ................................................. 263

6.5.4 Hipótese 4 - Estratégia de Preço Premium ......................................................... 264

6.5.5 Hipótese 5 - Intensidade da Concorrência......................................................... 264

6.5.6 Hipótese 6 - Dificuldades para Definir os Preços conforme o Valor ................. 266

6.5.7 Hipótese 7 - Pressões Isomórficas .................................................................... 267

6.5.8 Hipótese 8 - Ambiente de Atuação B2B ............................................................... 268

6.5.9 Hipótese 9 - Experiência no Estabelecimento dos Preços .................................. 269

6.5.10 Hipótese 10 - Custos Totais na Fórmula "Custos mais Margem" ...................... 270

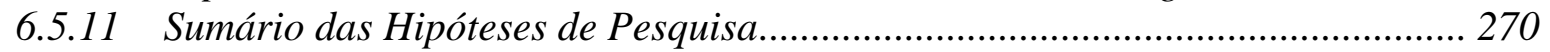

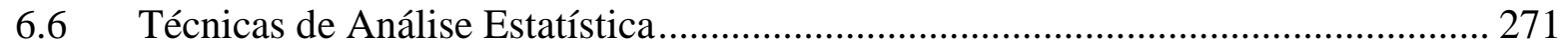

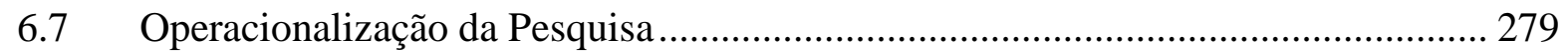

6.7.1 Identificação e Organização dos Dados de Contato das Empresas ................... 279

6.7.2 Contato com a População da Pesquisa ................................................................. 281

6.7.3 Envio de Mensagem de Agradecimento .............................................................. 284

6.7.4 Envio de Mensagem de Reiteração ....................................................................... 285

6.7.5 Entrega de Relatório Individualizado aos Respondentes .................................. 286

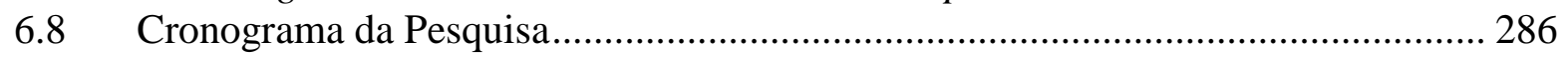

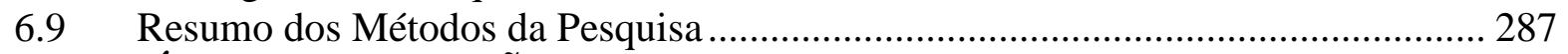

7 ANÁLISE E DISCUSSÃO DOS RESULTADOS.................................................... 289

7.1 Descrição da Amostra e dos Respondentes ........................................................... 289

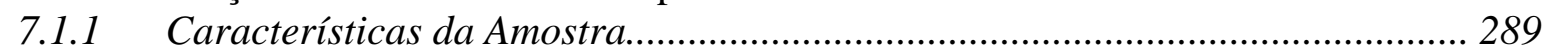

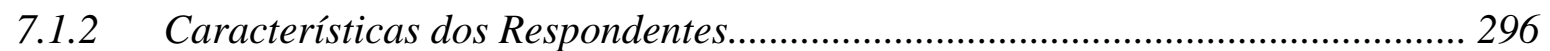

7.2 Contexto Empírico do Estabelecimento dos Preços ................................................ 298

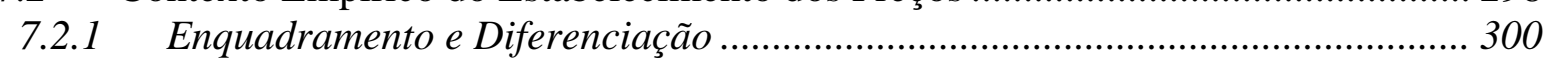

7.2.2 Enquadramento e Dificuldade de Uso das Informações da Concorrência ........ 306

7.2.3 Enquadramento da Empresa e Informações Usadas ......................................... 308

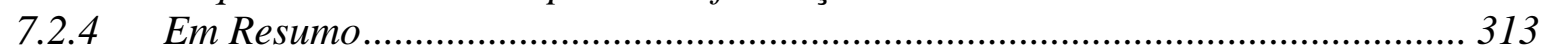

7.3 Forma e Essência do Estabelecimento dos Preços..................................................... 314

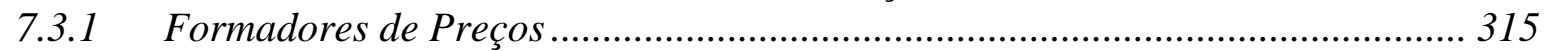

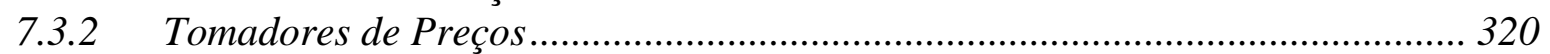

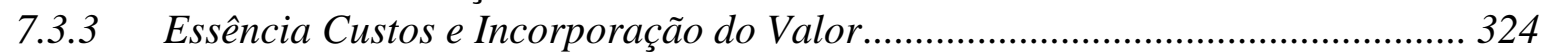

7.3.4 Problemas da Essência Custos e Incorporação do Valor .................................... 329

7.4 Fatores Explicativos da Essência Custos ................................................................. 331

7.4.1 Avaliação dos Pressupostos das Análises de Regressão Ordinal........................ 332

7.4.2 Análise dos Resultados das Análises de Regressão Ordinal .............................. 336

7.4.3 Resumo dos Resultados dos Fatores Explicativos da Essência Custos ............... 345 


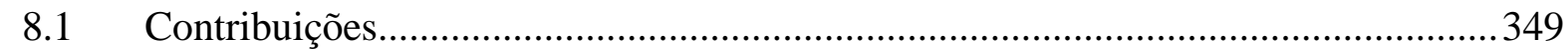

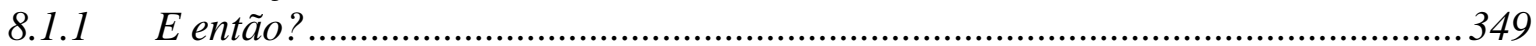

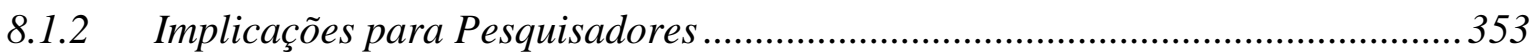

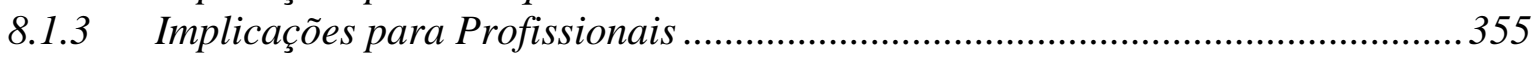

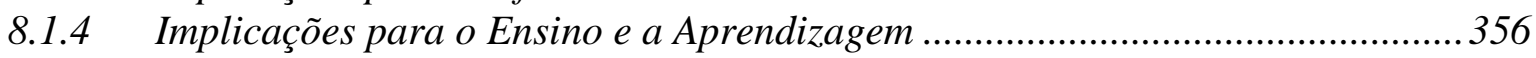

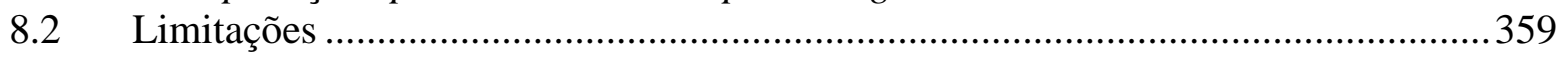

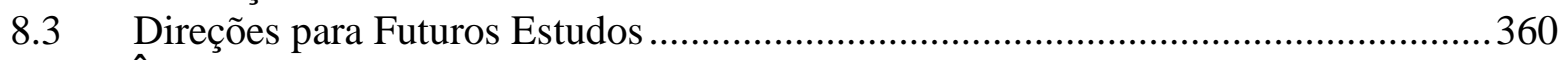

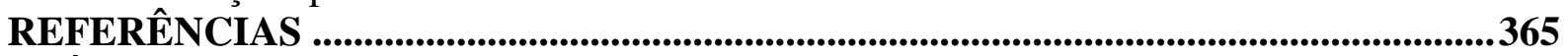

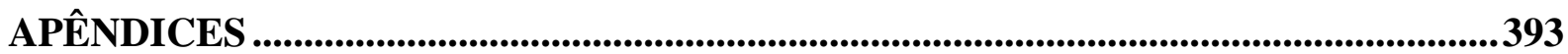

APÊNDICE A - Formulário da Segunda Fase do Pré-Teste ................................................393

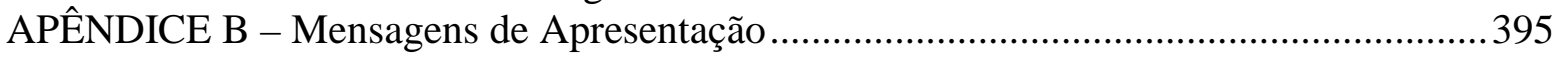

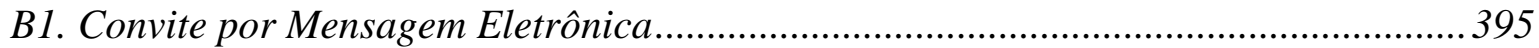

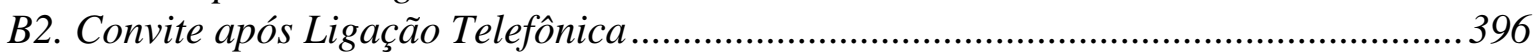

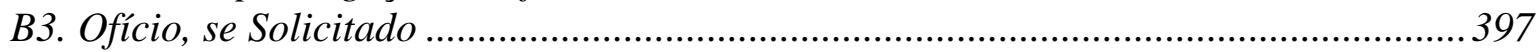

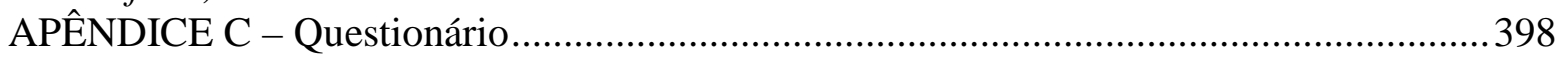

APÊNDICE D - Cabeçalhos dos Relatórios de Controle da Pesquisa ...................................403

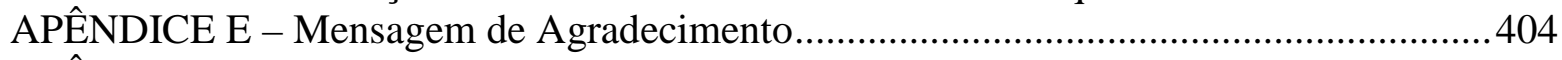

APÊNDICE F - Mensagem de Envio dos Resultados ....................................................... 405 



\section{INTRODUÇÃO}

\subsection{Precedentes}

"Tudo na vida tem preço" é o que afirma um conhecido ditado popular. Para que tudo tenha preço e esse ditado mostre-se verdadeiro, é preciso, logicamente, que os preços de tudo sejam estabelecidos. Raju e Zhang (2010) corroboram essa conclusão lógica e entendem que alguém, em algum momento e em algum lugar necessariamente precisa definir o preço de tudo o que é oferecido.

Duas disciplinas têm se dedicado a teorizar sobre o estabelecimento dos preços: economia e marketing (Skouras, Avlonitis, \& Indounas, 2005). A teoria econômica explica que os preços estabelecidos refletem a igualdade entre o custo marginal e a receita marginal, já a teoria de marketing recomenda que os preços estabelecidos espelhem o valor oferecido ao cliente e não os preços dos concorrentes ou os custos.

As pesquisas empíricas, todavia, têm sugerido que os preços não são estabelecidos em função da paridade entre o custo marginal e a receita marginal e tampouco em função do valor oferecido ao cliente. Estudos de toda parte do mundo têm reportado que, na realidade, a ampla maioria das empresas define seus preços com base nos custos, ou melhor, com base na combinação dos custos à margem. Dentre eles, destacam-se os amplamente citados R. I. Hall e Hitch (1939), Zeithaml, Parasuraman, e Berry (1985), Noble e Gruca (1999a), Avlonitis e Indounas (2005a) e Fabiani et al. (2005).

Em virtude dos achados desses estudos, gaps entre a teoria (da economia e do marketing) e a prática têm sido proclamados. Do lado econômico, R. I. Hall e Hitch (1939), por exemplo, defendem que as empresas não aderem à premissa marginalista, pois estabelecem seus preços sem sequer terem ciência dos seus custos marginais e das suas receitas marginais. Do lado do marketing, Hinterhuber (2008), como outro exemplo, sustenta que as empresas preterem informações do valor oferecido aos clientes para definirem os preços com base em informações da concorrência ou dos custos. 
Para o gap entre a teoria econômica e a prática há contra-argumentos. O argumento do instrumentalismo endossa a premissa marginalista ao esclarecer que o resultado da decisão é o que importa e não a decisão por si mesma. Com esse argumento, demonstra-se que os preços estabelecidos podem implicar a igualdade entre os custos marginais e as receitas marginais, mesmo que essas informações não sejam conhecidas, sequer avaliadas, no processo (Friedman, 1953).

$\mathrm{O}$ argumento do marginalismo implícito apoia a premissa marginalista ao aclarar que a mesma pode ser seguida de forma inconsciente. Com esse argumento, demonstra-se que as empresas podem tomar suas decisões de preços de acordo com a paridade entre os custos marginais e as receitas marginais, por mais que não estejam considerando essas informações conscientemente (Lucas, 2003).

O posicionamento de Edwards (1952) também enfraquece a proclamação do gap entre a teoria econômica e a prática. De acordo com o autor, a utilização da combinação dos custos à margem em nada corrói a teoria econômica, ao passo que ela refere-se meramente à fórmula matemática empregada para uma decisão que, invariavelmente, reflete a igualdade entre o custo marginal e a receita marginal. Langholm (1969) complementa e afirma que a teoria econômica nunca teve a intenção de servir como guia para a decisão empresarial e de descrever o que realmente acontece nos processos decisórios das empresas, uma vez que sua natureza é a de um aparato explanatório em alto nível de abstração.

Nesse sentido, pode-se entender que o gap entre a teoria econômica e a prática não existe quando as decisões de preços, independentemente da forma que são tomadas, vão ao encontro das postulações teóricas. Em outras palavras, pode-se dizer que não há qualquer diferença entre a teoria e a prática quando o uso da fórmula "custos mais margem" traz o mesmo resultado que a aplicação literal do cálculo marginalista traria (Lucas \& Rafferty, 2008).

Agora, se no final das contas os preços não refletem a igualdade entre o custo marginal e a receita marginal, há um problema porque a teoria não explica a que os preços correspondem. O gap existe, portanto, quando a teoria não é capaz de explanar, em um alto nível de abstração, o estabelecimento dos preços na prática e não quando a prática não condiz a uma aplicação literal dos cálculos marginalistas. 
Destarte, conclui-se que o gap entre a teoria econômica e a prática é indicado pela insuficiência da teoria, não pelo uso da fórmula "custos mais margem", tal como R. I. Hall e Hitch (1939) equivocadamente sugeriram. Sua superação envolve a reconstrução da teoria econômica, como proposto por Downward (1999, 2000) e Prado (2007), não a adequação da prática.

A figura é distinta para o gap entre a teoria de marketing e a prática. Além de não serem encontrados contra-argumentos, cada vez mais, localizam-se lamentações para a sua existência. Cressman Jr. (1999), por exemplo, lastima o fato de encontrar com facilidade empresas que colocam preços utópicos porque não definem seus preços com base no valor.

As evidências empíricas do estabelecimento dos preços com o uso da fórmula "custos mais margem" também são utilizadas para sustentar a existência do gap. No entanto, cumpre esclarecer que a teoria de marketing, apesar de recomendar fortemente a definição dos preços com base no valor, em nenhum momento impede que informações de custos sejam utilizadas. Assim, diferentemente do que autores como Cressman Jr. (1999), Ingenbleek (2007), Hinterhuber (2008) e Calabrese e Francesco (2014) defendem, não se entende como correta a afirmação que os preços não refletem o valor simplesmente por que informações de custos são utilizadas na sua definição. Por conseguinte, não se concorda que o gap entre a teoria de marketing e a prática seja da dimensão difundida.

Para começar, nota-se que as proclamações do gap partem da assunção equivocada que todas as empresas têm poder para formar preços, quando, na realidade, algumas precisam tomar os preços correntes no mercado. Ora, uma empresa somente tem poder para formar preços quando oferece produtos que são, em alguma extensão, diferenciados dos produtos ofertados pelas outras entidades (Banterle, Carraresi, \& Cavaliere, 2011).

Quando os produtos oferecidos assemelham-se aos produtos ofertados pelas demais entidades, o poder sobre a formação dos preços é limitado e a empresa é uma tomadora de preços (price taker), precisando tomar os preços colocados no mercado por seus concorrentes (Hofstrand, 2007). Daí, pode-se notar por que em algumas pesquisas empíricas o reflexo aos preços dos concorrentes é até mais frequente do que o preço formado a partir dos custos mais margem. 
A formação dos preços é, portanto, uma prerrogativa dos formadores de preços (price makers), como o próprio nome sugere (Hofstrand, 2007). Por lidarem com produtos diferenciados que não têm comparação direta com os produtos das demais empresas, os formadores têm condições de definir seus preços com base nos custos e no valor oferecido aos clientes sem precisarem colocar preços idênticos à concorrência.

Tanto os tomadores quanto os formadores de preços usam fórmulas para operacionalizar o cálculo dos preços (Edwards, 1952), sendo enfatizada, de acordo com Drury e Tayles (2006), aquela de custos mais margem. O uso da fórmula "custos mais margem" demonstra claramente que os custos são incorporados no estabelecimento dos preços, contudo, não indica que outros tipos de informações (como aquelas da concorrência e de valor) não são contemplados. Nada impede, por exemplo, que um preço estabelecido por meio da fórmula reflita o valor, já que a margem pode ser uma ponte de integração entre os custos e o valor (Indounas, 2006).

Diante do exposto, nota-se que as constatações empíricas da predominância do uso da fórmula “custos mais margem" não são suficientes para sustentar a existência do gap entre a teoria de marketing e a prática. Afinal, tal fórmula reflete a forma (mecânica de operacionalização do estabelecimento dos preços), mas não necessariamente a essência (base central do estabelecimento dos preços) do processo. Os tomadores e os formadores de preços podem muito bem usar a fórmula "custos mais margem" para simplificar o processo sem deixarem de colocar preços consoantes à concorrência e ao valor oferecido aos clientes, respectivamente.

\subsection{Problema e Objetivos}

O gap entre a teoria econômica e a prática não é da dimensão que os estudos, como R. I. Hall e Hitch (1939), defendem ser. Afinal, os contra-argumentos do instrumentalismo e do marginalismo implícito mostram que os preços podem ser definidos a partir da fórmula “custos mais margem” sem que os pressupostos econômicos sejam corroídos.

Da mesma forma, o gap entre a teoria de marketing e a prática não é necessariamente do tamanho que os estudos, como Cressman Jr. (1999), Ingenbleek (2007), Hinterhuber (2008) e Calabrese e Francesco (2014), afirmam ser. Diferentemente do que acontece com o gap 
econômico, entretanto, faltam argumentos contundentes que minimizem o tamanho do gap ao demonstrarem que o estabelecimento dos preços baseado na fórmula "custos mais margem" revela a forma, não a essência, do processo.

No uso da combinação "custos mais margem”, os custos relevantes dos produtos são extraídos do sistema de custos e formam a base da definição dos preços (Drury \& Tayles, 2006). Sobre essa base é colocada uma margem que, dependendo das circunstâncias, pode ser um elemento conector dos custos à concorrência, nos tomadores de preços, ou dos custos ao valor, nos formadores de preços.

Logo, apropriar-se de evidências do uso de tal fórmula não ratifica, por si só, a existência do gap entre a teoria de marketing e a prática. Tal gap pode existir, sim, mas sua evidenciação depende da demonstração que os custos são a essência do processo. Em outras palavras, a existência do gap somente é comprovada com a exposição de que os preços são definidos como uma função exclusiva dos custos.

Nesse sentido, à luz desses novos argumentos, vale averiguar se há empresas que são escravas dos custos no estabelecimento dos preços. Se forem encontradas empresas nessa condição, confirma-se que o gap entre a teoria de marketing e a prática existe, muito embora em extensão inferior àquela comumente defendida.

A razão pela qual existem empresas que se sujeitam exclusivamente aos custos na definição dos preços não está clara para os estudiosos do tema (Ingenbleek, 2007). Trabalhos (e.g., Ingenbleek, Debruyne, Frambach, \& Verhallen, 2003; Fabiani et al., 2005; Guilding, Drury, \& Tayles, 2005; Al-Hussari, 2006; Hinterhuber, 2008; Liozu, Hinterhuber, Perelli, \& Boland, 2012; Ingenbleek \& van der Lans, 2013; Töytäri, Rajala, \& Alejandro, 2015) já foram desenvolvidos para investigar fatores associados ao embasamento em diferentes tipos de informações (incluindo os custos), mas não chegaram a um consenso.

Destarte, percebe-se que há uma lacuna no entendimento do que faz existir o gap entre a teoria de marketing e a prática. Afinal, não se tem uma compreensão razoável sobre os motivos relacionados ao estabelecimento dos preços cuja essência é marcada pelos custos. A falta de segregação entre os tomadores e os formadores de preços bem como a ênfase na 
forma, não na essência, prejudicaram a análise da realidade encontrada nos estudos prévios e inibiram essa compreensão.

O preenchimento de tal lacuna, embora seja importante em todos os setores de empresas, é especialmente relevante no setor industrial por três principais motivos. Primeiramente, o setor industrial tem condições expressivas de apresentar empresas oferecendo produtos diferenciados e, portanto, de possuir mais formadores de preços do que os demais setores.

Em segundo lugar, as indústrias tendem a apresentar uma gama maior e mais complexa de possibilidades para a fórmula "custos mais margem" do que os setores de comércio e serviço. Por exemplo, os custos fixos que as empresas industriais possuem tendem a ser muito maiores do que os custos fixos dos comércios e das empresas de serviços, o que as expõe a uma maior discricionariedade na escolha da base de custos considerada para os preços (e.g., custo variável, custo total etc.).

Finalmente, em terceiro lugar, os gestores de empresas industriais são aqueles que mais vêem o estabelecimento dos preços como uma "dor de cabeça". Segundo Lancioni (2005), essa "dor de cabeça" decorre, sobretudo, da falta de entendimento das implicações das decisões de preços, não raramente bastante complexas no contexto industrial.

Compreender essa realidade em empresas industriais localizadas no Brasil é ainda mais relevante. O Brasil, além de ser um país emergente, diferente dos demais países desenvolvidos normalmente investigados (Estados Unidos, países da Europa), tem uma importância expressiva na economia mundial.

Ainda que exposto a uma crise econômica, não se pode deixar de reconhecer que o Brasil é membro do grupo dos países emergentes formado por Brasil, ㄸússia, Índia, China e África do Sul - South Africa (BRICS) e é o maior país da América Latina. Além disso, de acordo com ranking levantado a partir de dados do Instituto Brasileiro de Geografia e Estatística (IBGE) e do Fundo Monetário Internacional (FMI), no ano-base 2015, o Brasil ocupava o $9^{\circ}$ lugar entre as maiores economias do planeta (F. Nakagawa, 2016). Apesar dessa sua importância, faltam estudos que abordem empiricamente com profundidade a determinação dos preços em nível nacional. 
Esta tese busca, portanto, investigar em empresas industriais localizadas no Brasil os fatores que explicam a real existência do gap entre a teoria de marketing e a prática. Em outras palavras, esta tese visa averiguar os fatores que explicam o estabelecimento dos preços em que a fórmula "custos mais margem" designa não só a forma, mas também a essência do estabelecimento dos preços. Convertendo a situação problema para a forma interrogativa, tal como Kerlinger (1980) sugere, chega-se à seguinte questão de pesquisa: Nas empresas industriais localizadas no Brasil, quais fatores explicam o estabelecimento dos preços marcado pela essência custos?

Agora que a questão deste estudo já foi apresentada, é possível partir para a formulação dos objetivos da pesquisa. Segundo Gil (2008), a determinação de objetivos da pesquisa é uma tarefa importante porque indica o ponto de partida e a direção a seguir.

Gil (2008) também aclara que os objetivos de uma pesquisa podem ser gerais e específicos. Os objetivos gerais são aqueles que designam de maneira simplificada a direção que a pesquisa deve seguir, enquanto que os objetivos específicos são aqueles que efetivamente permitem que se parta para a investigação diante dessa direção. Os objetivos específicos também podem ser vistos como uma redefinição, um esclarecimento e uma delimitação do objetivo geral.

Diante do exposto e considerando a questão proposta, esta pesquisa definiu o seguinte objetivo geral: Investigar os fatores que explicam o estabelecimento dos preços marcado pela essência custos nas empresas industriais localizadas no Brasil.

Em outras palavras, pode-se dizer que, nesta tese, toda a análise da literatura e toda a construção do desenho da pesquisa empírica seguem a direção comum de investigar os fatores que explicam o estabelecimento dos preços marcado pela essência custos. Para que o seguimento dessa direção comum seja viabilizado, colocaram-se os seguintes objetivos específicos:

a) pesquisar a presença de formadores e de tomadores de preços nas empresas industriais localizadas no Brasil; 
b) comparar os formadores aos tomadores de preços no que se refere à dificuldade de obtenção de informações dos preços da concorrência;

c) confrontar as informações usadas nos formadores de preços com as informações usadas nos tomadores de preços;

d) examinar a forma do processo de estabelecimento dos preços nos formadores e nos tomadores de preços;

e) investigar a essência do processo de estabelecimento dos preços nos formadores e nos tomadores de preços; e

f) averiguar os fatores explicativos da essência custos nos formadores e nos tomadores de preços.

\subsection{Tese e Hipóteses}

Ao atender aos objetivos da pesquisa, pretende-se ratificar a tese proposta no estudo. Ora, de acordo com G. Martins e Theóphilo (2009), a tese refere-se não somente a uma publicação científica que cumpre requisitos para tal classificação, mas também a uma proposição formulada com o intuito de ser defendida em público.

Este trabalho sustenta a tese que a utilização da fórmula "custos mais margem" não conflita com a incorporação de informações da concorrência e do valor. Como Japiassu e Marcondes (2001) descrevem, "na dialética, a tese é o primeiro momento positivo, ao qual se contrapõe uma antítese, gerando um conflito a ser resolvido em uma síntese”. Logo, a tese aqui proposta configura o primeiro momento do trabalho em que se propõe explicitamente a afirmativa de que a forma custos mais margem não conflita com a essência concorrência nem com a essência valor. Todos os elementos apresentados neste trabalho são reunidos (sintetizados) não só para responder a questão de pesquisa como também para confirmar essa proposição.

Afinal, o trabalho consolida teorias e levanta dados empíricos sobre a forma e a essência do estabelecimento dos preços que, reunidos, permitem descobrir os fatores que explicam o estabelecimento dos preços marcado pela essência custos (e, inversamente, pela não essência custos) e, assim, responder a questão de pesquisa. De forma específica, com a resposta à questão, são identificados nas empresas aderentes da combinação “custos mais margem” tanto 
os fatores que fazem com que a essência do processo seja marcada pelos custos quanto os fatores que afastam a essência custos e permitem a incorporação de outros tipos de informação.

Essa identificação pode propiciar a resolução do conflito intencionalmente trazido se demonstrar que o uso da fórmula não inibe as empresas de incorporarem na margem o tipo de informação desejada: informações dos preços da concorrência nos tomadores de preços e informações do valor nos formadores de preços. Ou seja, essa identificação pode confirmar que o desprezo de informações alheias aos custos no estabelecimento dos preços não é uma consequência lógica da aplicação da fórmula “custos mais margem”, mas, sim, uma opção daquelas empresas que propositalmente optam por ater-se ao uso dos custos.

As hipóteses da pesquisa foram elaboradas para sustentar essa defesa e demonstrar tanto os fatores que explicam o fato de a combinação "custos mais margem" ser a forma e a essência dos preços quanto os fatores que explicam o fato de a combinação ser a forma, mas não necessariamente a essência dos preços. Na seção 6.5, os argumentos que ampararam a elaboração das hipóteses são apresentados com detalhes, cabendo nesta seção resumir as defesas centrais que sustentaram as expectativas com relação à essência custos.

No que se refere ao impacto positivo sobre a essência custos, espera-se que as inúmeras dificuldades para implantar e manter processos de preços pautados no valor (Hinterhuber, 2008; Töytäri et al., 2015) incentivem as empresas a contentarem-se com o embasamento único nos custos (Hipótese 6).

Ademais, de acordo com DiMaggio e Powell (1983), as pressões isomórficas coercitivas, normativas e miméticas forçam uma unidade na população a se assemelhar às demais unidades da população, o que pode originar um ciclo vicioso de estímulo à essência custos (Hipótese 7).

O uso dos custos totais deixa a deliberação do preço restrita a uma faixa de variação da margem bastante limitada, o que inibe a incorporação do valor. Uma situação diferente é encontrada, segundo Indounas (2006), quando os custos variáveis são usados e viabilizam a 
inclusão de características específicas dos produtos e dos clientes nos preços mediante a margem de contribuição (Hipótese 10).

Com relação específica aos formadores de preços, presume-se que a diferenciação explica positivamente a essência custos. Isso considerando que as empresas que ofertam produtos realmente diferenciados não têm as mesmas restrições que Gatignon e Xuereb (1997) relataram para as empresas que oferecem produtos sem atributos diferentes (restrições de não poderem sustentar altos preços para justificar ineficiências de custos) (Hipótese 1). Tem-se também a expectativa que os líderes de mercado, por influenciarem as demais empresas (Kotler \& Keller, 2012) e terem alto poder sobre a formação dos preços, embasem-se fortemente nos custos para determinar os preços (Guilding et al., 2005) (Hipótese 3).

Já no que se refere ao impacto negativo sobre a essência custos, conjectura-se o efeito do grande porte. Essa conjectura parte dos resultados das pesquisas empíricas e da alegação de Hinterhuber (2016) sobre o domínio da ideia de que as empresas de pequeno porte são as que mais definem os preços com base exclusiva nos custos (Hipótese 2).

Como Farres (2012) alerta que no ambiente de business-to-business (B2B) as empresas clientes tomam suas decisões de compras embasadas em fatores objetivos (e.g., atributos específicos dos produtos), espera-se que a atuação nesse ambiente também afaste dos custos a essência dos preços. Afinal, se as empresas pautarem-se unicamente nos custos, elas não vão conseguir evidenciar aos clientes de forma prática a relação entre o preço e os atributos de fato oferecidos (Hipótese 8).

Ademais, segundo van Bruggen, Smidts, e Wierenga (2001), os acertos e desacertos cometidos ao longo do tempo expandem o contexto funcional dos tomadores de decisões e ampliam as situações prévias consideradas por eles nas deliberações. Logo, presume-se que a experiência é outro fator que afasta a essência custos da decisão dos preços (Hipótese 9).

Com relação específica aos formadores de preços, diante da argumentação de Ingenbleek e van der Lans (2013), espera-se que a estratégia de preço premium, por requerer preços elevados correspondentes à qualidade elevada, peça a incorporação do valor a fim de identificar tetos viáveis, afastando dos custos a essência dos preços (Hipótese 4). 
Já com relação específica aos tomadores de preços, espera-se que a intensidade da concorrência estimule comportamentos oportunistas dos concorrentes (Nagle \& Hogan, 2007; Ingenbleek et al., 2003) e force a busca pela eficiência das empresas na colocação de preços similares aos deles (Hipótese 5).

A Figura 1 ilustra as dez hipóteses elaboradas nesta pesquisa.

Figura 1 - Hipóteses da pesquisa
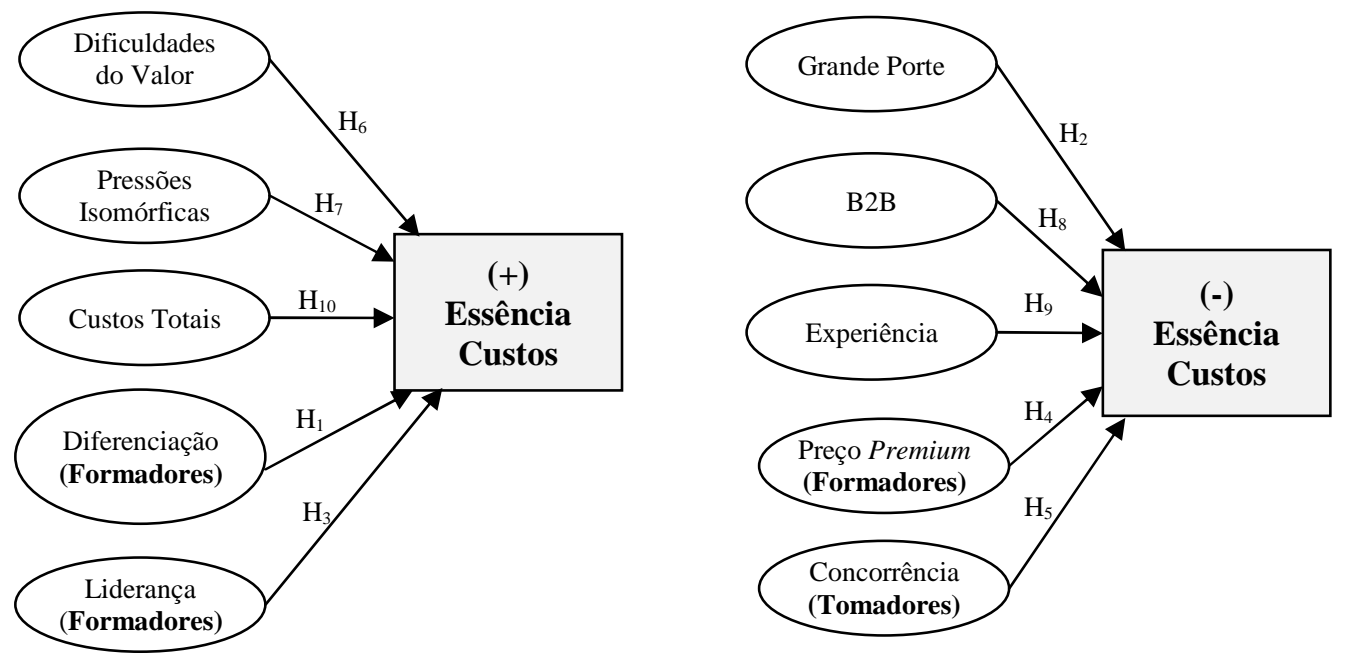

Fonte: Elaboração própria

\section{$1.4 \quad$ Potenciais Contribuições}

No caminho percorrido para responder o problema de pesquisa e comprovar a tese proposta, surgem as contribuições deste estudo. Elas são aplicáveis tanto ao campo teórico quanto ao campo prático.

Primeiramente, sob o prisma teórico, esta tese organiza e resume, num mesmo trabalho, as duas vertentes teóricas sobre o estabelecimento dos preços. Assim, ela permite visualizar as semelhanças e as dessemelhanças entre as teorias e favorece o entendimento de quando uma e outra mais bem se aplicam. A tese demonstra que o cunho da economia é a explicação, enquanto que o cunho de marketing é a orientação.

Uma segunda contribuição teórica decorre da consolidação de vasta gama de estudos empíricos sobre o tema. Por mais que outras pesquisas já tenham trazido revisões de 
numerosos trabalhos (e.g., Ingenbleek, 2007), esta tese expõe detalhes específicos sobre o processo de definição dos preços. Além disso, não se pode deixar de mencionar que ela exibe estudos recentes e apresenta trabalhos de locais do mundo cujas revisões prévias costumaram desprezar.

Esta tese também contribui com a teoria ao discutir e fomentar um novo olhar para os gaps entre as teorias e a prática do estabelecimento dos preços. Ela demonstra tanto pontos que fortalecem quanto pontos que enfraquecem os gaps e, alem disso, sugere uma nova estrutura para avaliar a existência do gap entre a teoria de marketing e a prática.

Finalmente, do ponto de vista teórico, a visão crítica empregada na discussão dos fatores explicativos da determinação dos preços escrava dos custos promove a identificação de inconsistências até então despercebidas na literatura e possibilita descobrir fatores relevantes ainda não relacionados. A ratificação empírica dessas inconsistências e dos novos fatores permite expandir e aperfeiçoar a literatura do tema.

Do ponto de vista prático, esta tese contribui ao demonstrar que a fórmula "custos mais margem" não inibe o uso de outros tipos de informação. Dessa forma, os profissionais passam a compreender que a operacionalização do processo mediante uma fórmula simples não impede que informações sobre o valor oferecido ao cliente e sobre a concorrência sejam consideradas.

Ao evidenciar os fatores que explicam a essência custos, esta tese oferece mais contribuições práticas. Afinal, ela possibilita que os profissionais identifiquem os motivos relacionados à execução de seus processos de determinada maneira e sejam capazes de notar potenciais melhorias.

\subsection{Justificativas e Delimitações}

Antes de elencar os atributos que fazem com que este estudo justifique-se, vale esclarecer por que ela pode ser considerada uma tese. Nesse sentido, primeiramente relacionam-se as principais características das teses para que sua presença neste trabalho possa ser evidenciada. 
Demo (2000) explica que uma pesquisa não precisa necessariamente construir um conhecimento novo para ser considerada tese, mas deve, pelo menos, implicar uma interpretação própria do arcabouço teórico em análise. Em uma tese não basta que os autores e as teorias sejam revisados. É preciso que eles sejam desconstruídos literalmente, analisados a fundo, confrontados com rigor para que, a partir daí, seja possível alguma formulação própria. Ou seja, em uma tese não se pode passar nem ao lado nem por cima, mas, sim, por dentro das teorias e dos autores.

Theóphilo (2004) acrescenta que a tese não é destinada a ensinar, pois o momento é de desafiar e expandir o conhecimento, não de congelá-lo. G. Martins e Theóphilo (2009) são mais específicos e detalham que a tese deve pelo menos atender a dois requisitos fundamentais:

a) demonstração, por parte do autor do trabalho, de ser um estudioso capaz de avançar a disciplina a que se dedica; e

b) originalidade, no sentido de conhecer profundamente um assunto de forma a descobrir algo que ainda não foi dito pelos demais estudiosos.

Ora, nesta tese não se tem o objetivo de meramente descrever o que já está difundido e plenamente aceito na literatura que versa sobre o estabelecimento dos preços. O propósito de revisar a literatura já consolidada sobre o tema não é de simples exposição, mas, sim, de formação de uma base conceitual sobre o assunto para que um posicionamento crítico possa ser emitido, demonstrando aspectos merecedores de reavaliação e levantando aspectos que ainda não foram abordados.

No que se refere à originalidade, G. Martins e Theóphilo (2009) advertem que a descoberta promovida por estudos das ciências sociais não se referem, obviamente, ao mesmo tipo das descobertas alcançadas nas ciências naturais. Eco (2010) especifica que as descobertas não precisam ser invenções revolucionárias no campo humanista. Uma tese das ciências humanas deve oferecer resultados que, embora modestos, não sejam ignorados por estudiosos do ramo por trazerem algo novo sobre o assunto. Castro (1977) acrescenta que os resultados originais são aqueles que, além de novos, têm a capacidade de surpreender os demais pesquisadores. 
Nesta tese, a originalidade centra-se em dois pontos. O primeiro ponto refere-se ao recorte de pesquisa diferenciado. Esta tese pode surpreender ao defender que o uso da fórmula "custos mais margem" não conflita necessariamente com o estabelecimento dos preços com base na concorrência e no valor. Partindo dessa defesa, o segundo e principal ponto de originalidade decorre da investigação sobre os fatores explicativos da essência custos do estabelecimento dos preços. O presente estudo aborda o tema mediante uma perspectiva mais ampla que prioriza a essência, não a forma. Tal perspectiva abre a possibilidade de refutar achados de pesquisas anteriores que, até então, eram aceitos sem discussão.

Agora que já se mostrou por que a presente pesquisa caracteriza-se como uma tese, pode-se passar à relação dos atributos que justificam sua realização. De acordo com Castro (1977), uma pesquisa é justificada quando possui conjuntamente os elementos originalidade, importância e viabilidade. Como a originalidade já foi abordada, discorre-se na sequência somente sobre a importância e a viabilidade.

Para Castro (1977), uma tese contém o elemento importância quando seu tema está ligado a uma questão crucial que afeta segmento substancial da sociedade e/ou é relacionado a uma questão teórica que merece atenção continuada na literatura especializada. Nesse sentido, cumpre salientar que, segundo Kohli e Suri (2011), o estabelecimento dos preços é um elemento chave na gestão de qualquer empresa, afinal, ele não requer nem investimentos nem recursos significativos (tais como as propagandas, por exemplo, requerem) e é provavelmente a alavanca mais acessível para gerenciar a lucratividade. Logo, pode-se inferir que a investigação dos fatores que impedem a melhor configuração do processo e que dificultam a obtenção do melhor lucro é um tema polarizador de atenção.

Ademais, vale destacar que o estabelecimento dos preços é um tema que faz jus à atenção continuada na literatura, pois ele modifica-se e aprimora-se com o tempo, como reflexo das mudanças nos negócios das empresas. Assim, pesquisas que exploraram o tema em décadas e anos passados precisam ser revisitadas para que a manutenção da sua validade seja avaliada. Esta tese promove uma releitura do tema e o sistematiza, sendo, portanto, assim como Eco (2010) sugere, útil para os demais pesquisadores. 
Na concepção de Castro (1977), a viabilidade é dentre os três elementos de relevância, aquele mais tangível em uma tese. Dispondo de prazos, de recursos financeiros, de competência, de disponibilidade potencial de informações e conhecendo o estado da teoria existente, o autor tem condições de determinar se é possível ou não realizar a pesquisa. Considerando que a sentença final da viabilidade é expressa pela conclusão da pesquisa, há de se afirmar que a presente tese apresentou-se viável.

Vale mencionar que a viabilidade é mais bem alcançada quando a pesquisa é delimitada, conforme defende Gil (2008). Eco (2010) menciona que quanto mais se restringe o campo do estudo, com mais segurança se trabalha. A delimitação da pesquisa é, portanto, necessária para a realização de reflexões e de análises detalhadas, originais e rigorosas.

O estudo, quando não é delimitado, acaba conduzindo a resultados genéricos que trazem nada além de repetições (G. Martins \& Theóphilo, 2009). Nesse sentido, vale esclarecer as principais delimitações colocadas nesta tese para viabilizar um recorte restrito à investigação dos fatores explicativos da definição dos preços marcada pela essência custos.

No que se refere à base conceitual, destaca-se que a tese está estruturada para discutir a forma e a essência do processo de estabelecimento dos preços. Embora os debates sobre políticas, estratégias e táticas de preços, bem como sobre o alinhamento entre elas, sejam importantes e também mereçam estudos, sua inclusão detalhada nesta tese não contribuiria com a resolução do problema da pesquisa.

Já no que se refere à parte empírica desta tese, é salutar ressaltar que a construção das hipóteses e o consequente levantamento dos fatores delimitam-se a explicações que possuem um mínimo embasamento teórico. Isso acontece porque, tal como Demo (1995) explica, não é possível colocar uma pergunta (ou uma hipótese) se nada se sabe da resposta, já que nessa condição não se teria o que perguntar. Ou seja, a delimitação aqui explicitada deriva da abordagem positivista da pesquisa, que enfatiza não somente as realidades observáveis, mas também a expressão lógica do discurso científico (G. Martins \& Theóphilo, 2009).

Por fim, ainda no que concerne à parte empírica da pesquisa, vale salientar que não é viável investigar todas as entidades industriais localizadas no Brasil. A fim de viabilizar o estudo, 
delimitações à população da pesquisa foram estabelecidas. A seção 6.2 esclarece detalhes dos motivos que levaram a essas delimitações.

\subsection{Estrutura da Tese}

Além da introdução, o presente trabalho está estruturado com mais sete capítulos, dispostos de acordo com o encadeamento do assunto. Nesta introdução, apresentaram-se os precedentes, o problema, os objetivos, a tese, as hipóteses, as potenciais contribuições, as justificativas e as delimitações da pesquisa.

Os capítulos 2, 3, 4 e 5 compreendem a revisão e a análise crítica da literatura e subsidiam a aplicação da pesquisa empírica. O capítulo 2 discorre sobre as duas vertentes teóricas que abordam o estabelecimento dos preços (economia e marketing). O capítulo 3 reporta os resultados apresentados nas principais pesquisas sobre o tema, assim como em pesquisas pouco citadas do Brasil e de outras partes do mundo. O capítulo 4 traça um paralelo entre os capítulos 2 e 3, debatendo se há ou não gaps entre a teoria e a prática. $\mathrm{O}$ capítulo 5 relaciona as potenciais causas para a definição dos preços que tem os custos como essência.

O capítulo 6 demonstra os métodos que este estudo aplicou para testar as hipóteses, comprovar a tese proposta e responder a questão de pesquisa. Ele apresenta especificidades da população e da amostra, explicita a elaboração do questionário e dos constructos, evidencia as técnicas de análise estatística, externa os motivos que induziram a essas escolhas e manifesta os aspectos de validade e de confiabilidade. Além disso, ele desenvolve as hipóteses do estudo, tendo como base a análise de literatura realizada nos capítulos anteriores.

O capítulo 7 apresenta e discute os resultados obtidos na pesquisa, alinhando as evidências empíricas à teoria retratada nos capítulos 2, 3, 4 e 5. Por fim, o capítulo 8 retoma os principais achados e exibe as conclusões e considerações finais do estudo. Ele traz a resposta à questão de pesquisa, a comprovação da tese, as implicações e limitações do estudo.

A Figura 2 resume o papel de cada um dos oito capítulos na estrutura da tese. 
Figura 2 - Estrutura da tese

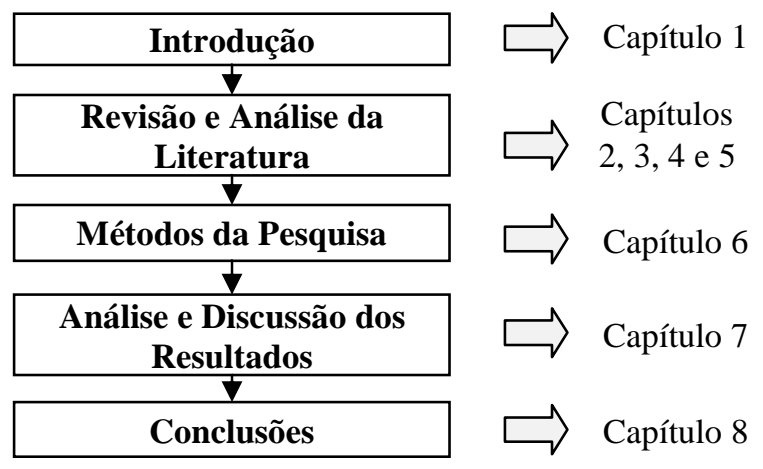

Fonte: Elaboração própria

Vale esclarecer que há ainda os apêndices com o formulário de pré-teste, as mensagens de apresentação remetidas ao público alvo da pesquisa, o questionário usado como instrumento de pesquisa, os cabeçalhos dos relatórios usados no controle da pesquisa, as mensagens de agradecimento e os arquivos de resultados (mensagem e relatório) enviados aos respondentes. 


\section{ESTABELECIMENTO DOS PREÇOS NA TEORIA}

Monroe (2003) é enfático e defende que o estabelecimento dos preços é vital em todas as empresas. Kohli e Suri (2011) reforçam o argumento e frisam que apenas as decisões certas conduzem ao lucro. E, tais decisões estão sempre presentes, afinal, como Raju e Zhang (2010) bem colocam, todos os preços precisam ser definidos por alguém, em algum momento e em algum lugar. Assim, sendo um fenômeno reconhecidamente importante, não é difícil entender por que o estabelecimento dos preços atraiu os olhares de diversos estudiosos e tornou-se objeto de desenvolvimento de teorias.

De acordo com Kerlinger (1980), as teorias são conjuntos de constructos, definições e proposições relacionados entre si que apresentam uma visão sistemática de fenômenos. Para G. Martins e Theóphilo (2009), a função mais importante das teorias é explicar, ou seja, dizernos "por quê? como? quando?" os fenômenos ocorrem.

No contexto do estabelecimento dos preços, a economia e o marketing são as duas disciplinas que mais se dedicam a teorizar. Cada qual propõe diferentes teorias para o tema, já que suas origens, missões, centralidades e, sobretudo, suas evoluções doutrinárias são distintas (Skouras et al., 2005). Portanto, na sequência, são apresentados os principais aspectos tanto da teoria da economia quanto da teoria do marketing.

\subsection{Teoria da Economia}

Uma ampla proporção da literatura econômica é voltada à explicação do estabelecimento dos preços, tanto que o termo teoria dos preços é sinônimo do termo microeconomia (Rizzieri, 2013). Harper (1966) frisa que o foco da economia está na análise abstrata do estabelecimento dos preços e não no oferecimento de guias práticos a serem aplicados pelas empresas. Nessa análise abstrata, são elucidadas as variáveis que explicam o estabelecimento dos preços em empresas das mais variadas estruturas de mercado. 


\subsubsection{Conceitos Centrais}

O principal problema abordado pela teoria dos preços refere-se ao fato que os desejos humanos excedem os recursos disponíveis (W. D. Maxwell, 1970). Do lado da demanda, os homens buscam apropriar-se da quantidade de produtos que maximiza sua satisfação. Do lado da oferta, as empresas esforçam-se para combinar os fatores de produção, dada a sua limitação orçamentária, de uma forma capaz de maximizar o nível de lucro. Como os desejos humanos são ilimitados, mas a disponibilidade dos recursos requerida para seu atendimento é limitada, há a necessidade de um denominador comum que iguale a quantidade demandada à quantidade ofertada. Esse denominador comum é o preço (Garófalo, 2004).

A quantidade demandada de um produto refere-se a quanto (desse produto) os compradores desejam e podem comprar. Embora muitos fatores influenciem essa quantidade, o preço do produto é o principal determinante. A quantidade demandada diminui quando o preço aumenta; a quantidade demandada aumenta quando o preço diminui. Ou seja, a quantidade demandada é negativamente relacionada com o preço (Mankiw, 2014).

Quando a quantidade demandada de um produto responde substancialmente a mudanças no preço, a demanda é denominada elástica e quando a quantidade demandada pouco responde a alterações nos preços, a demanda é denominada inelástica (Frank \& Bernanke, 2012). A elasticidade-preço da demanda é calculada pela divisão da variação percentual da quantidade demandada pela variação percentual do preço, como mostrado na Equação 1.

Elasticidade preço da demanda $=\frac{\text { Variação percentual da quantidade demandada }}{\text { Variação percentual do preço }}$

A demanda é considerada elástica quando o resultado dessa equação corresponde a um número maior do que 1 , de tal forma que a quantidade demandada varia proporcionalmente mais do que o preço varia. A demanda é considerada inelástica quando a elasticidade é menor do que 1 , de tal forma que a quantidade demandada varia proporcionalmente menos do que o preço varia. A demanda é considerada de elasticidade unitária quando sua elasticidade é igual a 1 , de tal forma que a quantidade demandada varia da mesma maneira que o preço varia (Montoro Filho, 2013). 
Conhecido, de modo sucinto, o lado da demanda, pode-se passar agora ao outro lado do mercado, isto é, à oferta. A quantidade ofertada de um produto refere-se a quanto (desse produto) os vendedores estão dispostos a vender e podem vender. Embora muitos fatores influenciem essa quantidade, o preço do produto novamente entra como o principal determinante. A quantidade ofertada aumenta quando o preço aumenta (a venda do produto torna-se mais lucrativa); a quantidade ofertada diminui quando o preço diminui (a venda do produto torna-se menos lucrativa). Ou seja, a quantidade ofertada é positivamente relacionada com o preço (Mankiw, 2014).

A dimensão das alterações no preço é mostrada pela elasticidade-preço da oferta. Tal elasticidade é uma medida do quanto a quantidade ofertada de um produto responde a variações no preço. Quando a quantidade ofertada de um produto responde substancialmente a mudanças no preço, a oferta é denominada elástica e quando a quantidade ofertada pouco responde a alterações nos preços, a oferta é denominada inelástica (Montoro Filho, 2013). A elasticidade-preço da oferta é calculada pela divisão da variação percentual da quantidade ofertada pela variação percentual do preço, como mostrado na Equação 2.

Elasticidade preço da of erta $=\frac{\text { Variação percentual da quantidade ofertada }}{\text { Variação percentual do preço }}$

A oferta é considerada elástica quando o resultado dessa equação corresponde a um número maior do que 1, de tal forma que a quantidade ofertada varia proporcionalmente mais do que o preço varia. A oferta é considerada inelástica quando a elasticidade é menor do que 1 , de tal forma que a quantidade ofertada varia proporcionalmente menos do que o preço varia. A oferta é considerada de elasticidade unitária quando sua elasticidade é igual a 1, de tal forma que a quantidade ofertada varia de modo exatamente igual à variação do preço (Montoro Filho, 2013).

Agora que os principais conceitos de oferta e de demanda já foram resumidos, é possível trazer mais especificamente que, na teoria econômica, o estabelecimento dos preços é explicado como uma função do encontro dessas duas variáveis (demanda e oferta). Nessa teoria, os preços são estabelecidos em função do equilíbrio, que se refere à situação na qual o preço atinge o nível em que a quantidade ofertada é igual à quantidade demandada. O preço que iguala a quantidade ofertada à quantidade demandada é denominado preço de equilíbrio e 
a quantidade nesse preço de equilíbrio é chamada quantidade de equilíbrio (Frank \& Bernanke, 2012; Montoro Filho, 2013; Mankiw, 2014). A Figura 3 ilustra esses conceitos.

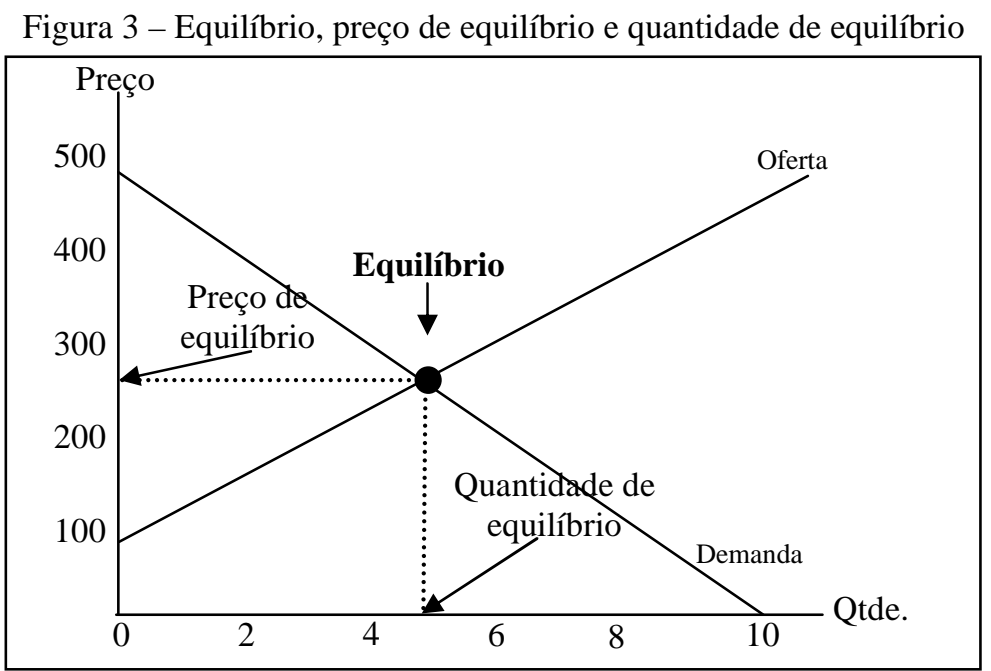

Fonte: Adaptada de Mankiw (2014, p. 75)

Ao preço de equilíbrio, a quantidade de produtos que os compradores desejam e podem comprar é exatamente igual à quantidade que os vendedores desejam e podem vender. A esse preço, o mercado todo está satisfeito, já que os compradores compram tudo aquilo que desejam comprar e os vendedores vendem tudo aquilo que desejam vender (Mankiw, 2014).

Defende-se que o equilíbrio de mercado é alcançado naturalmente, de acordo com as ações dos compradores e dos vendedores. Afinal, se o preço do mercado for colocado acima do preço do equilíbrio, há um excesso de oferta, pois a quantidade ofertada é maior do que a quantidade demandada. Esse excesso de oferta faz com que os vendedores não consigam vender todo o seu estoque e estimula a redução dos preços. Com a redução dos preços, a quantidade demandada aumenta, a quantidade ofertada diminui e o preço de equilíbrio é alcançado (Frank \& Bernanke, 2012).

Por outro lado, se o preço do mercado for colocado abaixo do preço de equilíbrio, há um excesso de demanda, pois a quantidade demandada é maior do que a quantidade ofertada. Esse excesso faz com que muitos compradores disputem a compra dos produtos e estimula os vendedores a aumentar o preço. Com o aumento dos preços, a quantidade demandada diminui, a quantidade ofertada aumenta e o preço de equilíbrio é alcançado (Frank \& Bernanke, 2012). 
Uma vez que o mercado atinge o equilíbrio, todos os compradores e vendedores ficam satisfeitos e não existe pressão nem para cima nem para baixo dos preços. Na maioria dos mercados livres, o excesso de oferta e/ou o excesso de demanda são apenas temporários porque os preços acabam se movendo naturalmente aos níveis de equilíbrio. O fenômeno de ajuste do preço de qualquer produto para trazer o equilíbrio entre a quantidade demandada e a quantidade ofertada é conhecido como lei da oferta e da demanda (Mankiw, 2014).

\subsubsection{Explicações}

O fato de a oferta e a demanda agirem natural e conjuntamente não significa que decisões, diretas ou indiretas, sobre o estabelecimento dos preços são dispensáveis. Segundo a teoria dos preços, deliberações são, sim, necessárias para que os vendedores consigam assegurar a maximização do lucro (Frank \& Bernanke, 2012).

A teoria econômica tradicionalmente assume que os agentes têm condições de maximizar o lucro porque dispõem de racionalidade otimizadora, colocam metas distintas e claras e possuem informações perfeitas e ilimitadas sobre si mesmos e sobre o ambiente (Prado, 2007). Em outras palavras, ela assume que os tomadores de decisão são perfeitamente racionais em todos os momentos e têm informações ilimitadas que lhes dão condições de fazer deliberações que conduzam à maximização do lucro. Nela, as empresas são tidas como mecanismos de entrada e de saída de recursos e, especificamente, os custos são definidos como valor de entrada e as receitas como valor de saída. A diferença entre as entradas e as saídas representa o lucro que deve ser maximizado (Mankiw, 2014).

Mais especificamente, o lucro é apurado como o resultado da subtração do custo total da receita total $($ lucro $=$ receita total - custo total). A receita total é o montante que uma empresa recebe ou tem a receber pela venda de sua produção e o custo total é o montante que a empresa paga ou tem a pagar pelos insumos usados na sua produção. Além dos conceitos de receita total e de custo total, vale destacar os conceitos de receita marginal e de custo marginal. A receita marginal refere-se à variação da receita total decorrente da venda de uma

unidade adicional. O custo marginal refere-se ao aumento do custo total decorrente da produção de uma unidade adicional (Mankiw, 2014). 
As empresas competitivas decidem a quantidade que vão ofertar para que o lucro seja o maior possível (receita total maior que custo total). A quantidade que maximiza o lucro pode ser encontrada no ponto em que o acréscimo da produção de uma unidade deixa de gerar receitas que excedem os custos. Esse ponto é marcado pela igualdade entre a receita marginal e o custo marginal de cada unidade produzida. Enquanto a receita marginal for maior que o custo marginal, o aumento da quantidade de produção eleva o lucro. Agora quando a receita marginal for menor que o custo marginal, o aumento da quantidade passa a diminuir o lucro. Ou seja, o lucro está maximizado quando não há mais perspectivas de aumentá-lo com o aumento de produção (Mankiw, 2014).

Já as empresas monopolistas, além de decidirem sobre a quantidade, têm capacidade de influenciarem os preços dos seus produtos por serem as únicas produtoras em seu mercado. Nelas, o preço sempre é maior do que a receita marginal porque quando elas aumentam a produção em uma unidade, elas aumentam a quantidade ofertada no mercado e precisam reduzir o preço cobrado por unidade vendida (não só dessa unidade adicional, mas de todas). Essa redução de preços diminui a receita marginal advinda das unidades que já vinham sendo vendidas (Frank \& Bernanke, 2012).

De qualquer forma, a quantidade que maximiza o lucro nas empresas monopolistas também pode ser encontrada no ponto em que o acréscimo da produção de uma unidade deixa de gerar uma receita marginal que excede o custo marginal. Esse ponto novamente é marcado pela igualdade entre a receita marginal e o custo marginal de cada unidade produzida. Enquanto a receita marginal for maior que o custo marginal, a empresa deve expandir a produção. Quando a receita marginal for menor que o custo marginal, a empresa deve reduzir a produção (Frank \& Bernanke, 2012).

As empresas de oligopólio (homogêneo e diferenciado) e de competição monopolística lidam com situações específicas de tal sorte que, diferentemente daquelas de competição perfeita e de monopólio, não permitem que apenas uma solução geral seja admitida para a explicação do estabelecimento dos preços. Isso ocorre porque o comportamento dos concorrentes dessas empresas, que é variado, é de crucial importância nos potenciais resultados. Diversos modelos foram desenvolvidos, especialmente no contexto da teoria dos jogos, para postular as várias possíveis respostas dos concorrentes e as interações entre as empresas, mas um modelo com 
solução aplicável a toda e qualquer situação dos oligopólios e das competições monopolísticas ainda não existe (Skouras et al., 2005).

Considerando os graus de complexidade e de especificidade que traria a apresentação dos diversos modelos econômicos de estabelecimento dos preços no oligopólio e na competição monopolística e tendo em vista o escopo pretendido nesta tese, este estudo não entra em detalhes do tópico. Ressalta-se, entretanto, que para as empresas oligopolistas e de competição monopolística o ponto de maximização do lucro também é o ponto em que a receita marginal se iguala ao custo marginal e que, portanto, o preço colocado deve estar nesse ponto. Ademais, da mesma forma que no monopólio, o preço supera a receita marginal (Skouras et al., 2005).

Em resumo, vale trazer que a economia explica que os preços estabelecidos necessariamente refletem a igualdade entre o custo marginal e a receita marginal. Toda a teoria dos preços, para as diversas estruturas de mercado, apresenta explicações detalhadas que, na essência, demonstram que os preços colocados são aqueles nos quais os custos marginais são equivalentes às receitas marginais das empresas.

\subsection{Teoria do Marketing}

No marketing, o foco da teoria desloca-se da análise abstrata e passa ao oferecimento de guias para as empresas. Por essa razão, a teoria de marketing deixa de explicar como o estabelecimento dos preços é para sugerir como ele deve ser (Skouras et al., 2005).

\subsubsection{Conceitos Centrais}

Na teoria do marketing, o conceito conhecido como "prática de determinação dos preços" (price-setting practice) é fundamental para entender como os preços devem ser estabelecidos. De acordo com Diamantopoulos e Mattews (1994) e com Ingenbleek (2007), a "descoberta" desse conceito pode ser atribuída a R. I. Hall e Hitch (1939). Esses foram os autores que reconheceram que as empresas não estabeleciam os preços da forma mecânica explicada pela teoria econômica, mas empreitavam atividades que conduziam à definição dos preços. 
Ingenbleek et al. (2003) definem a prática de determinação dos preços como o conjunto das atividades (de coleta, compartilhamento, interpretação e uso de diferentes tipos de informações) executadas para estabelecimento dos preços. A prática de determinação dos preços pode ser marcada por diferentes métodos, como mostra a Figura 4.

Figura 4 - Diferentes métodos na prática de determinação dos preços

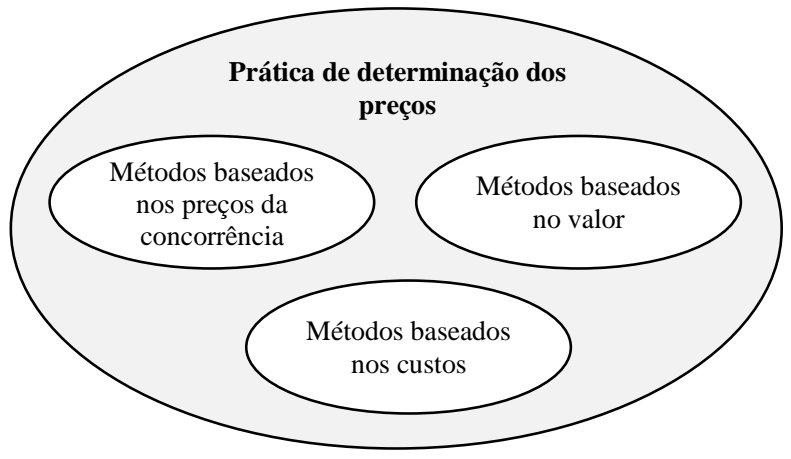

Fonte: Elaboração própria

Os métodos de determinação dos preços (também referenciados como técnicas e procedimentos de determinação dos preços) referem-se às atividades em que um tipo específico de informação é coletado, compartilhado, interpretado e usado visando à deliberação dos preços (Ingenbleek et al., 2003), como mostra a Figura 5.

Figura 5 - Métodos de determinação dos preços

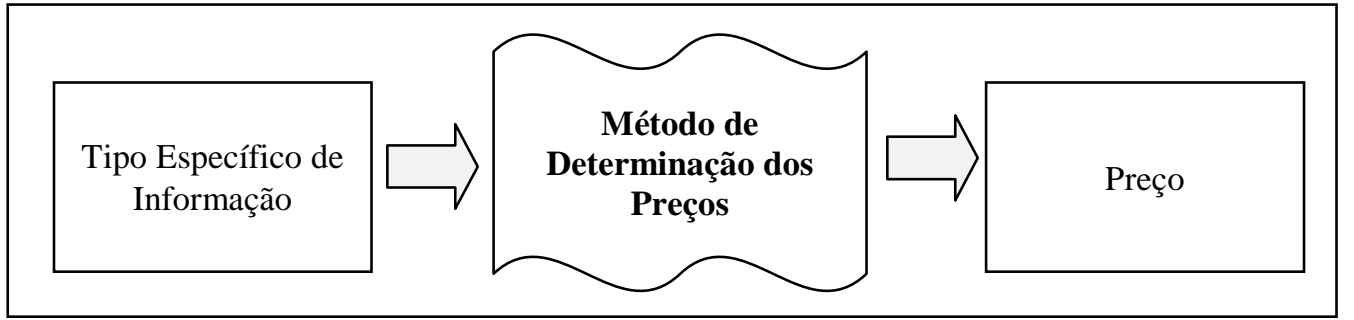

Fonte: Elaboração própria

Indounas (2009), com base na revisão de literatura, concluiu que, no marketing, os métodos de determinação dos preços são normalmente agrupados em três amplas abordagens:

a) abordagem do preço baseado na concorrência;

b) abordagem do preço baseado no valor (também denominada como com base no cliente ou ainda com base no valor para o cliente); e

c) abordagem do preço baseado nos custos. 
Exemplos dos inúmeros trabalhos que, em linha à conclusão de Indounas (2009), classificam os métodos nessas três abordagens incluem: Shapiro e Jackson (1978), Cunningham e Hornby (1993), G. E. Smith (1995), Shipley e Jobber (2001), Ingenbleek et al. (2003), Avlonitis e Indounas (2005a, 2006a), Collins e Parsa (2006), Hinterhuber (2008), Raju e Zhang (2010), Hinterhuber e Liozu (2012), Liozu, Hinterhuber, Boland, e Perelli (2012) e Calabrese e Francesco (2014). A seguir, cada uma dessas três abordagens é sucintamente explanada.

\subsubsection{1 $\quad$ Abordagem do Preço Baseado na Concorrência}

$\mathrm{Na}$ abordagem do preço baseado na concorrência, como o próprio nome sugere, as empresas estabelecem seus preços a partir de informações dos preços colocados pelos concorrentes (Hinterhuber, 2008), como ilustra a Figura 6.

Figura 6 - Abordagem do preço baseado na concorrência

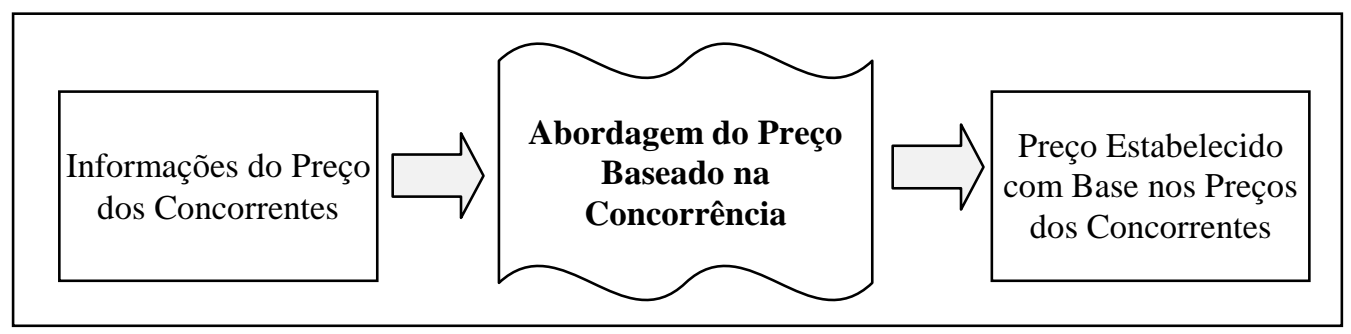

Fonte: Elaboração própria

Observa-se que a principal informação coletada, compartilhada, interpretada e usada nessa abordagem refere-se ao preço dos concorrentes. De acordo com Nagle e Hogan (2007) e Hinterhuber (2008), tal preço pode ser tanto aquele diretamente observado (e.g., o preço de tabela) quanto aquele específico (e.g., preço estimado considerando os descontos específicos concedidos a cada cliente). Dutta, Zbaracki, e Bergen (2003) destacam a relevância de estimar o preço específico dos concorrentes (considerando os descontos concedidos), já que é bem provável encontrar concorrentes que fixam um preço elevado para que o mesmo seja copiado, mas depois acordam descontos e abatimentos significativos com cada um dos seus clientes.

Garda (1991) inclusive argumenta que, para os concorrentes, a maior vantagem da concessão de descontos é sua invisibilidade. Os descontos, quando são efetivamente concedidos pelos concorrentes, podem passar despercebidos e dificultarem a ciência do preço cobrado por transação. Essa realidade não é surpreendente para Cressman Jr. (1999), já que, para ele, o 
altruísmo até pode existir no ambiente de negócios, mas certamente não vai ser direcionado em benevolência dos concorrentes.

Nagle e Hogan (2007) explicam que a coleta dos preços dos concorrentes (sejam os tabelados, sejam os específicos) requer um processo formalizado, já que tal informação, mesmo que seja pública, não é fornecida em listas pela concorrência. Por vezes, tempo e dinheiro consideráveis precisam ser investidos para que eles sejam coletados mediante tarefas de consulta (em sites, divulgações etc.), atuação de funcionários como clientes dos concorrentes (sobretudo em lojas de varejo, agências de viagens e hotéis) e incentivos para os clientes alertarem quanto à concessão de descontos nos concorrentes (S. Anderson \& Guilding, 2006).

Roll (2009) defende que para as informações coletadas serem devidamente compartilhadas, interpretadas e usadas, é preciso formar e, sobretudo, constantemente atualizar um banco de dados. Segundo o autor, isso é necessário porque os preços coletados nunca são do exato momento. No mínimo, eles são de um momento imediatamente anterior, já que não é possível conhecer instantaneamente os preços dos rivais (Shipley \& Jobber, 2001), principalmente em mercados altamente competitivos, nos quais os concorrentes buscam o máximo possível esconder seus preços (Nagle \& Hogan, 2007).

O uso das informações de preços dos concorrentes, de acordo com Avlonitis e Indounas (2005a), pode acontecer de quatro diferentes maneiras. Tais maneiras caracterizam os diferentes métodos da abordagem do preço baseado na concorrência, conforme segue:

a) preço similar ao preço corrente no mercado (colocado pelos concorrentes);

b) preço similar ao preço dominante no mercado (normalmente quando há um líder que estabelece o preço dominante e é copiado pelo restante das empresas do mercado);

c) preço acima do preço dos concorrentes; e

d) preço abaixo do preço dos concorrentes.

Nos dois primeiros métodos, a empresa basicamente determina o seu preço seguindo o preço coletado dos seus concorrentes e/ou do líder de mercado. Para Hinterhuber (2008), a principal desvantagem desses dois métodos é o fato que eles em nada consideram o lado dos clientes. Pode ser que os concorrentes e/ou o líder estejam cobrando por seus produtos menos do que 
os clientes julgam que eles valem e a empresa, ao meramente copiar os preços, incorra no mesmo erro e cobre dos clientes menos do que eles estariam dispostos a pagar.

G. E. Smith (1995) acrescenta a desvantagem que a colocação dos preços nesses dois métodos tende a enfatizar a reação aos preços e deixar de lado a gestão dos preços. Urbany (2001) ressalta que essa ênfase, além de normalmente prejudicar a lucratividade, ocasiona mais três graves efeitos negativos:

a) qualquer ganho na fatia de mercado tem vida curta;

b) clientes sensíveis a preço tornam-se ainda mais sensíveis a preço; e

c) o bom preço oferecido aos clientes menos sensíveis os torna mais sensíveis a preço.

Apesar dessas desvantagens, vale mencionar que a empresa, quando oferece um produto exatamente igual aos produtos dos concorrentes e/ou do líder e não detém poder com relação aos preços, pouco ganharia ao considerar o lado dos clientes. Nessa situação, o preço inevitavelmente deveria assemelhar-se ao preço corrente no mercado, estando ele consistente ou não ao valor do produto.

Afinal, como nenhum cliente dispõe-se a pagar por um produto mais do que paga pelos produtos iguais das demais empresas (Ingenbleek \& van der Lans, 2013), se o preço fixado for superior ao preço do mercado, o volume de vendas necessário à sobrevivência da empresa tende a não ser atingido (R. V. Santos, 1995). Além disso, ao aplicar esses métodos, a empresa foca sua atenção no que os concorrentes estão fazendo, o que pode fazer com que ela localize oportunidades internas de melhoria.

Já nos dois últimos métodos, a empresa determina o seu preço baseando-se nos preços dos concorrentes e/ou no líder de mercado, mas ajustando-os para cima ou para baixo, dependendo da comparação entre o valor dos produtos. Quando o valor oferecido pelo produto é maior do que o valor oferecido pelos produtos similares dos concorrentes, o preço pode ser ajustado para um patamar maior do que aquele do preço corrente no mercado; já quando o valor oferecido pelo produto é menor do que o valor oferecido pelos produtos similares dos concorrentes, o preço precisa ser ajustado para um patamar menor do que aquele do preço corrente no mercado. 
Para Collins e Parsa (2006), todos os métodos da abordagem do preço baseado na concorrência carregam o problema de poderem induzir a preços que proporcionam margens pequenas (ou até mesmo negativas), por não considerarem os custos. Essas margens pequenas ou negativas podem fazer com que nem sequer os custos variáveis sejam cobertos e, assim, prejudicar a continuidade da empresa (R. V. Santos, 1995).

Nesta tese, discorda-se que esse problema seja causado pela definição de preços baseados na concorrência. Afinal, por mais que, para Nagle e Hogan (2007), o preço mais lucrativo não seja aquele que segue a concorrência, há empresas que não têm autonomia para repassar seus custos nos preços e precisam copiar os preços dos seus concorrentes. Nessas empresas, tal como R. C. Skinner (1970) postula, o preço já é uma variável dada que os métodos da abordagem baseada na concorrência simplesmente revelam. Isto é, os métodos simplesmente mostram o preço que precisa ser tomado e a eventual margem pequena ou negativa resulta dos altos custos frente a esse preço necessário. $\mathrm{O}$ aumento da margem até é possível, desde que os custos (não os preços) sejam inteligentemente gerenciados (Marques, 2012).

\subsubsection{2 $\quad$ Abordagem do Preço Baseado no Valor}

$\mathrm{Na}$ abordagem do preço baseado no valor, como o nome indica, as empresas estabelecem seus preços a partir de informações do valor que os produtos oferecem para os clientes (Hinterhuber, 2008), como ilustrado na Figura 7.

Figura 7 - Abordagem do preço baseado no valor

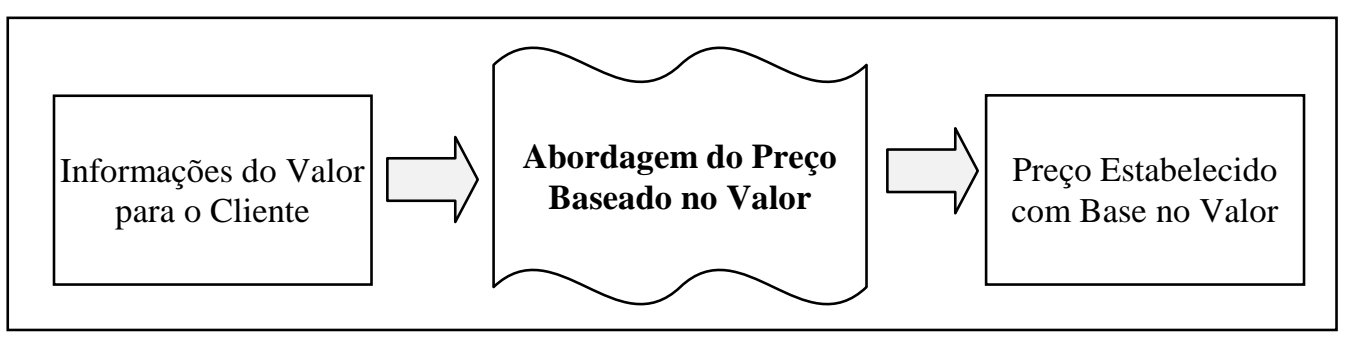

Fonte: Elaboração própria

Logo, o primeiro conceito que merece ser aclarado refere-se ao valor para o cliente. Diferentes definições teóricas são encontradas para o termo, sendo que a maior parte delas tem em comum o fato de expressar as trocas compensatórias entre os benefícios recebidos e 
os custos incorridos pelos clientes na aquisição e na utilização de um produto (Munnukka \& Järvi, 2012).

Woodruff (1997), por exemplo, defende que o valor para o cliente é um conceito que envolve o balanceamento entre tudo o que os clientes recebem num produto (e.g., qualidade, benefícios, utilidades) e tudo o que eles sacrificam para ter e manter esse produto (e.g., preço). O valor para o cliente é positivo quando ele proporciona mais benefícios do que sacrifícios e negativo quando proporciona mais sacrifícios do que benefícios.

Posto em uma estruturação lógica, o valor para o cliente pode ser visto como resultado da subtração do custo total para o cliente (que se refere ao conjunto de sacrifícios que o cliente tem para avaliar, obter, utilizar e descartar um produto, incluindo seu preço) do benefício total para o cliente (que se refere ao valor monetário do conjunto de benefícios econômicos, funcionais e psicológicos que o cliente obtém de um produto), conforme evidencia a Figura 8.

Figura 8 - Estruturação lógica do valor para o cliente

\begin{tabular}{|c|c|}
\hline $\begin{array}{l}\text { Benefício Total para o Cliente } \\
\text { (-) Custo Total para o Cliente }\end{array}$ & $\begin{array}{l}\text { (Benefícios Totais) } \\
\text { (Sacrifícios Totais) }\end{array}$ \\
\hline Valor para o Cliente & \\
\hline
\end{tabular}

Fonte: Elaboração própria

Nagle e Hogan (2007) esclarecem que dois conceitos específicos podem ser encontrados para o valor para o cliente: valor de uso e valor econômico total (também conhecido como valor de troca).

O valor de uso refere-se a toda utilidade que o produto oferece ao cliente. Ele é único para cada cliente e representa o proveito líquido total proporcionado pelo produto (similar ao conceito de utilidade de aquisição proposto por Thaler, 1985). Como ele reflete todo proveito que o produto, per si, proporciona, ele não é influenciado pela existência de alternativas (a existência de outros produtos não interfere na utilidade oferecida pelo produto, por exemplo, não interfere na quantidade que o equipamento é capaz de produzir).

Em algumas empresas, sobretudo industriais que atuam com o mercado organizacional, a estimativa do valor de uso é extremamente importante. Nessas empresas, a existência de 
alternativas é escassa porque a empresa oferece customizações específicas que passam por todos os estágios de desenvolvimento do produto (desenho, produção, entrega e manutenção etc.) e proporcionam um valor de uso único para cada cliente (Johansson \& Andersson, 2012).

Já o valor econômico total (denominado pelos economistas como valor de troca) incorpora a existência das alternativas e refere-se aos benefícios e sacrifícios (tangíveis e intangíveis) oferecidos pelo produto em relação aos benefícios e sacrifícios oferecidos pelas outras opções disponíveis (Galhanone, 2013). Nagle e Hogan (2007) explicam que seu cálculo demanda a soma do valor das melhores alternativas disponíveis para o cliente (valor de referência) ao valor de tudo aquilo que diferencia o produto dessas alternativas (valor da diferenciação), como ilustra a Figura 9. O valor da diferenciação pode ter elementos tanto positivos (benefícios) quanto negativos (sacrifícios).

Figura 9 - Valor econômico total: Valor de referência + valor da diferenciação

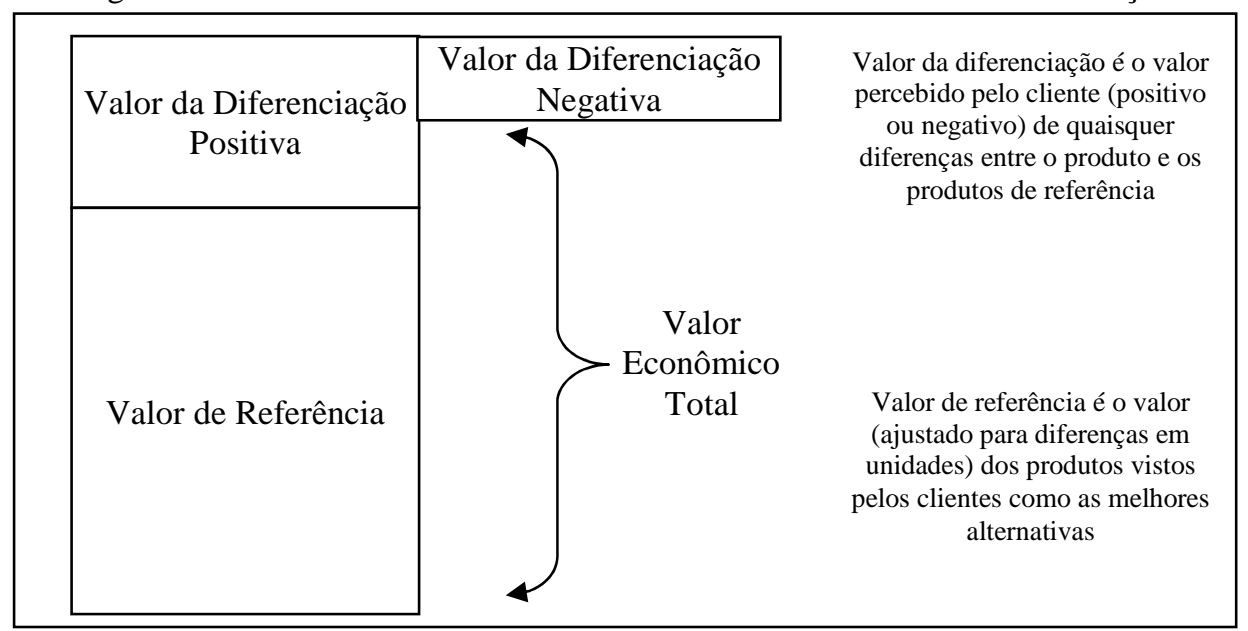

Fonte: Adaptada de Nagle \& Hogan (2007, p. 33)

O valor econômico total do produto varia entre os clientes porque os benefícios e os custos variam entre eles, dependendo das suas características. Por exemplo, um cliente com linhas de produtos amplas e fragmentadas e com limitado espaço para armazenamento tende a se beneficiar mais pelas entregas just-in-time do seu fornecedor do que um cliente que possui apenas uma linha de produto e dispõe de amplo espaço para guardar seus estoques (Hinterhuber, 2004).

Nagle e Hogan (2007) destacam que as diferenças mais expressivas são encontradas entre consumidores finais e clientes organizacionais. De modo geral, os consumidores finais 
valorizam aspectos subjetivos, enquanto que clientes organizacionais valorizam aspectos objetivos (e.g., aperfeiçoamento da produtividade, durabilidade, economia de combustível desempenho superior, maior confiabilidade, custos de manutenção reduzidos, custos de implantação menores, serviço mais rápido).

Os distintos usos feitos pelos diferentes clientes fazem com que não seja viável estimar um único valor econômico total. Ao invés disso, é recomendável estimar os diferentes valores que o produto tem para os diferentes clientes. Em grande parte das empresas, não é preciso estimar o valor econômico individual de cliente a cliente porque é possível encontrar grupos (segmentos de clientes) que possuem interesses comuns e fazem usos similares dos produtos (Hinterhuber, 2004).

Para calcular o valor econômico total de cada segmento de clientes, o produto alternativo considerado como referência não precisa ser necessariamente fisicamente parecido, mas precisa, pelo menos, ser enxergue pelos clientes como referência. Como vários produtos, não apenas um, podem realizar parte de funções similares ao produto, a estimativa do valor econômico total pode demandar a consideração de mais de um produto de referência (geralmente, os dois ou três principais). É importante frisar que esses produtos de referências devem depender da avaliação de o que o cliente, não a empresa, enxerga como melhor alternativa disponível (Hinterhuber, 2004).

Um ponto que merece ser aclarado refere-se ao valor do(s) produto(s) de referência. Para Forbis e Mehta (1981), o usufruto de todos os benefícios proporcionados por um produto de referência, durante o seu ciclo de vida, não é obtido sem que o cliente incorra em custos (life cycle costs). São esses custos na sua totalidade, e não somente o preço, que designam o valor a ser incorporado.

O produto diferencia-se do(s) produto(s) de referência em função de atributos intrínsecos ou extrínsecos. Os atributos intrínsecos são auto-orientados e referem-se a aspectos como estética, ética, espiritualidade e diversão. Já os atributos extrínsecos têm orientação externa e referem-se a aspectos tangíveis como eficiência, excelência, status e reputação (Holbrook, 1996). 
Nos clientes organizacionais, como há ampla predominância de valorização de atributos extrínsecos, o estudo dos seus modelos de negócios e das suas estratégias já indica de antemão os atributos que tendem a ser por eles priorizados. Os clientes organizacionais tendem a valorizar produtos que, ao serem usados no lugar dos produtos de referência, geram economia de tempo, dinheiro e/ou esforço, propiciam redução de custos (e.g., redução de custos de manutenção e de reposição de estoques, diminuição de investimentos etc.) e/ou melhoram as receitas que recebem dos seus clientes (e.g., maiores receitas pela colocação de processadores mais velozes - oferecidos pelo fornecedor - na venda aos consumidores finais) (Nagle \& Hogan, 2007).

Para identificar, os atributos que, na visão dos clientes, diferenciam o produto do(s) produto(s) de referência, Hinterhuber (2008) sugere a aplicação conjunta de vários procedimentos relacionados na sequência:

a) entrevistas com especialistas. Nessas entrevistas, deve-se solicitar que profissionais seniores da empresa emitam uma opinião consubstanciada sobre o que os clientes valorizam nos produtos em fase de testes. As opiniões dos diferentes profissionais devem exibir consenso, pois se o próprio pessoal interno expressar visões divergentes ou ambíguas sobre o que constitui valor para o cliente, não há uma base consistente para determinar o valor econômico total;

b) avaliações de valor em grupos focais. Clientes em grupos de 5-15 podem ser solicitados a avaliar a importância e o impacto dos conceitos de novos produtos. Tais grupos focais permitem que a voz do cliente seja ouvida;

c) análise conjunta (ou análise de tradeoff). A análise conjunta refere-se a um levantamento das avaliações dos clientes em respeito às potenciais ofertas de produtos. Cada oferta demonstrada deve consistir em um conjunto específico de atributos específicos. Os níveis desses atributos devem ser sistematicamente diferentes para cada oferta. Os respondentes são solicitados a revelar sua preferência de compra em relação a cada oferta na forma de um ranque;

d) avaliação do valor no uso do produto. Os clientes podem ser observados e entrevistados quando estiverem realmente usando os novos produtos. Essa avaliação permite identificar a real satisfação ou insatisfação do cliente (em termos de dimensão do produto) no dia-a-dia; e 
e) escalas de importância. Esse método pede que os clientes respondam a um questionário indicando a importância (e a satisfação) em relação ao conjunto de atributos dos produtos existentes e de um produto novo. As respostas a essas questões são usadas para estimar o que o cliente valoriza nos produtos já existentes e no novo produto. Níveis mais altos de importância são observados quando o cliente assinala respostas em faixas altas para o novo produto e em faixas baixas para os produtos já existentes.

Os principais atributos de diferenciação do produto devem ser mensurados monetariamente. Há situações em que essa mensuração é simples, pois o produto oferecido proporciona melhorias tangíveis e facilmente quantificáveis em relação ao(s) produto(s) de referência. Esse é o caso, por exemplo, de equipamentos industriais específicos para os quais tanto os clientes quanto os vendedores têm condições de estimar objetivamente em quanto serão reduzidas as falhas (e consequentes custos), em quanto diminuirão os custos de instalação e de manutenção etc. (Hinterhuber, 2004).

Nos casos em que o valor dos principais atributos não pode ser calculado objetivamente, pode-se recorrer a métodos para viabilizar sua identificação. As entrevistas com especialistas, grupos focais, análise conjuntas, avaliações do valor no uso do produto e escalas de importância podem novamente entrar em cena para que os atributos mais importantes, além de identificados, sejam valorados. Nagle e Hogan (2007) acrescentam o método das entrevistas em profundidade, em que os clientes oferecem respostas detalhadas de como usam os produtos. Essas respostas servem de base para inferência do valor dos atributos.

Como tanto o(s) produto(s) de referência (e consequentemente o valor de referência) quanto o valor da diferenciação tendem a variar entre os diferentes segmentos de clientes, é altamente provável que haja distintos valores econômicos totais para distintos segmentos (Gale \& Swire, 2012).

Hinterhuber (2004) oferece um exemplo que ilustra e facilita o entendimento do processo de identificação do valor econômico total em diferentes segmentos. Nesse exemplo, o autor relata que uma empresa de agronegócios buscou identificar o valor econômico total de Zenta, um inovador inseticida (a ser lançado na época) aplicável em plantações de frutas cítricas. 
Essa empresa chegou ao valor econômico de Zenta em cada um dos seus seis segmentos de clientes, ao identificar o produto de referência, o valor de referência, os atributos de diferenciação valorizados e o valor desses atributos. A Figura 10 ilustra essas identificações em dois dos seis segmentos.

Figura 10 - Valor econômico em diferentes segmentos

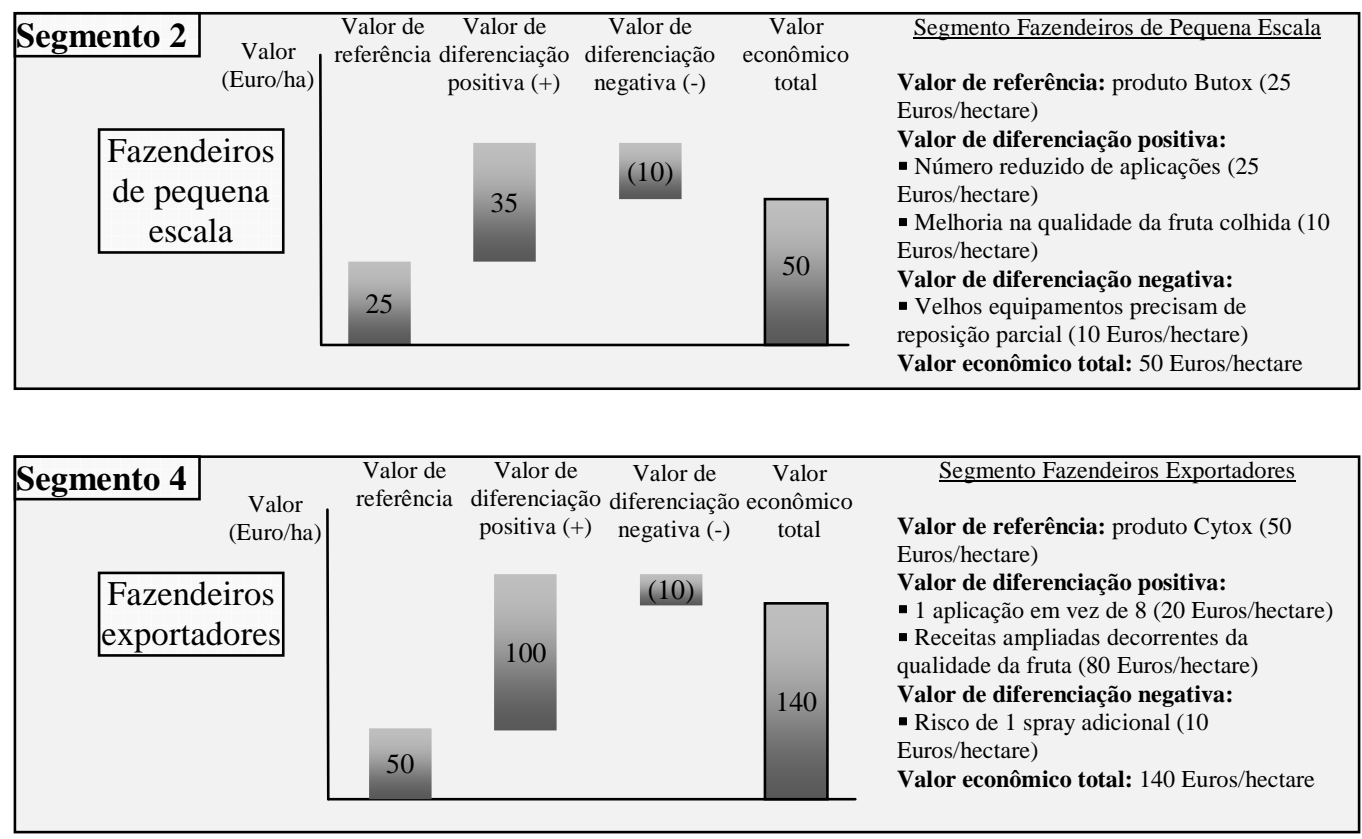

Fonte: Adaptada de Hinterhuber (2004, p. 771)

Para G. E. Smith e Nagle (2005), nem o valor econômico total nem mesmo o valor de uso são suficientes quando o assunto é valor para o cliente, uma vez que eles referem-se apenas ao valor que é oferecido aos clientes e não ao valor que é percebido ou acatado pelos clientes. Galhanone (2013) concorda com esse entendimento e adverte que os clientes, como não são seres totalmente racionais, não consideram necessariamente nas suas decisões todo o valor que o produto de fato proporciona. G. E. Smith e Nagle (2005) acrescentam, portanto, os conceitos do valor percebido e da disposição do pagamento.

O valor percebido, como o nome sugere, refere-se à parcela do valor do produto que já é percebida pelos clientes. Ele depende da avaliação global que os clientes têm do produto (Chang \& Dibb, 2012) e reflete o valor que os clientes já percebem (Whittaker, Ledden, \& Kalafatis, 2007). 
Já a disposição de pagamento refere-se à parcela do valor percebido que os clientes dispõemse a pagar, levando em conta a justiça que atribuem à determinada transação. A justiça atribuída às transações é influenciada por uma referência interna formada pelos clientes ao longo do tempo. Os clientes, por mais informados e convencidos que estejam do valor do produto, podem considerar que um preço excessivamente alto é injusto. Isso pode acontecer especialmente se os clientes entenderem que o vendedor tenta capturar a totalidade dos benefícios criados ao invés de compartilhar com eles esses benefícios (Hinterhuber, 2004).

A literatura sobre a justiça dos preços é ampla (ver, por exemplo, revisão de Ferguson, 2008) e subsidia-se fundamentalmente nos trabalhos desenvolvidos por Thaler (1985) e por Kahneman, Knetsch e Thaler (1986a, 1986b). Pelo escopo que esta tese tem, detalhes que fazem um preço ser considerado justo ou injusto não são trazidos. Destaca-se, contudo, que nessa literatura é salientado que os clientes preocupam-se com a justiça dos preços, têm ideias formadas a respeito de quando os preços são justos e injustos e tentam punir empresas que estabelecem preços injustos. Nela, há certo consenso que, no caso de produtos já lançados, os clientes consideram que um aumento de preço é justo quando é colocado para cobrir incrementos de custos do vendedor, mas injusto quando é posto para aumentar a margem do vendedor (M. C. Campbell, 1999; Codini, Saccani, \& Sicco, 2012).

Nagle e Hogan (2007) e Collins e Parsa (2006) concordam que o valor percebido e a disposição de pagamento devem ser considerados, mas criticam sua utilização em demasia, pois acreditam que um dos trabalhos das equipes de marketing é fazer com eles se aproximem do valor total (de uso ou econômico total) do produto. Segundo Hinterhuber (2008), a ampliação da percepção do valor e da disposição de pagamento pode ocorrer com atividades de comunicação do valor aos clientes.

Em suma, traz-se a Figura 11 que relaciona os quatro diferentes conceitos de valor. Nela, percebe-se que a cada conceito a parcela abarcada do valor oferecido é diminuída. 
Figura 11 - Quatro diferentes tipos do valor para o cliente

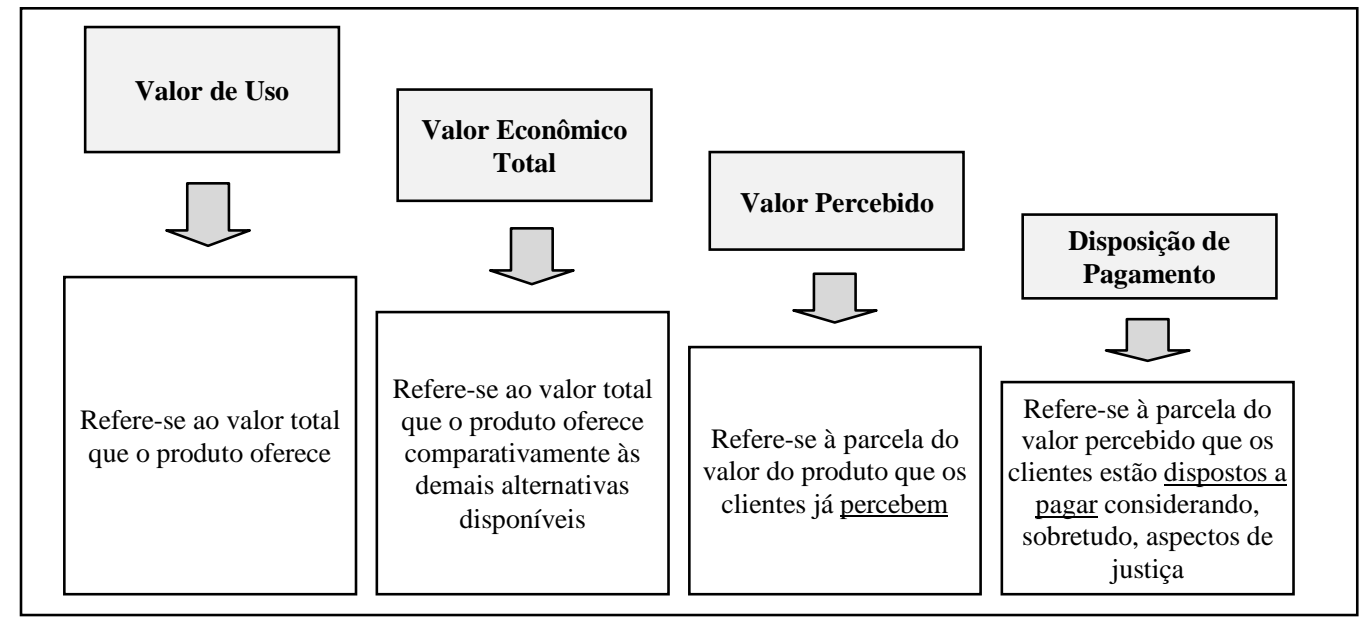

Fonte: Elaboração própria

Agora que o conceito do valor para o cliente já foi esclarecido, pode-se passar para a exposição dos métodos oferecidos pela abordagem do preço baseado no valor, ou seja, dos métodos que, para estabelecerem os preços, usam, em alguma extensão, informações de valor (Ingenbleek, 2007). Como existem quatro diferentes tipos de valor para os clientes, é possível minimamente encontrar quatro diferentes métodos, cada qual consoante a um conceito:

a) preço conforme a disposição de pagamento dos clientes;

b) preço conforme o valor percebido pelos clientes;

c) preço conforme o valor econômico total oferecido aos clientes; e

d) preço conforme o valor de uso dos clientes.

No primeiro método, a empresa basicamente determina o preço que os clientes estão previamente dispostos a pagar. Hinterhuber (2004) critica esse método e adverte que os profissionais responsáveis pelas deliberações dos preços não devem contentar-se em estabelecer preços que reflitam a disposição de pagamento. Ao invés disso, eles devem ao menos tentar fazer com que essa disposição aumente. Afinal, cobrar o montante que o cliente quer é cômodo, mas desperdiça a oportunidade de receber o quanto o produto realmente vale.

No segundo método, a empresa considera o valor percebido pelos clientes. Hinterhuber (2008) também critica esse método, pois defende que os profissionais responsáveis pelas deliberações dos preços, além de aumentarem a disposição de pagamento dos clientes, devem 
ampliar a percepção de valor dos clientes. Isto é, tais profissionais devem aproximar o valor percebido ao máximo do valor oferecido, mediante atividades de comunicação do valor.

Já no terceiro e no quarto método, a empresa determina o preço com base no valor que o produto oferece aos clientes (valor econômico total e valor de uso). Johansson e Andersson (2012) esclarecem que o método baseado no valor econômico total só é aplicável se houver ao menos um produto de referência. $\mathrm{Na}$ inexistência de produtos de referência, há apenas condições de consideração do valor de uso. Os autores esclarecem que, diante de customizações específicas, a consideração do valor econômico total fica difícil porque os produtos ganham características singulares, não encontradas em produtos de referência.

As aplicações do terceiro método e do quarto método tendem a ser enfatizadas quando os preços colocados têm um papel ativo na promoção dos produtos. De acordo com Piercy, Cravens, e Lane (2010), num papel ativo o preço é protagonista e tem influência significativa nas propagandas, nas vendas e em outros esforços promocionais. Como para empenhar esse papel ativo, a relação entre o preço e o valor oferecido ao cliente precisa ser divulgada, é necessário que esse valor, de alguma forma, oriente a determinação do preço.

Para Kotler (2000), a relação entre o preço e o valor oferecido não é necessariamente marcada por níveis semelhantes entre eles, já que podem existir situações em que a empresa intencionalmente opte por estabelecer e divulgar preços menores do que o valor do seu produto permitiria, por exemplo. De acordo com o autor, nove possíveis relações entre o nível de valor oferecido (qualidade) e o nível de preço podem ser encontradas, configurando as nove macroestratégias de preço existentes, como mostrado na Tabela 1.

Tabela 1 - Estratégias de preços

\begin{tabular}{|c|c|c|c|c|}
\hline & & \multicolumn{3}{|c|}{ PREÇO } \\
\hline & & ALTO & MÉDIO & BAIXO \\
\hline \multirow{3}{*}{ 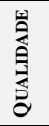 } & ALTA & Estratégia de preço premium & Estratégia de alto valor & Estratégia de supervalor \\
\hline & MÉDIA & Estratégia de preço excessivo & Estratégia de valor médio & Estratégia de valor bom \\
\hline & BAIXA & Estratégia de assalto ao cliente & Estratégia de falsa economia & Estratégia de economia \\
\hline
\end{tabular}

Fonte: Kotler (2000, p. 477)

Nagle e Hogan (2007) acrescentam que duas outras estratégias podem orientar a relação entre o preço e o valor oferecido aos clientes nos estágios iniciais de lançamento dos produtos. Elas são as estratégias de desnatamento (skim pricing) e de penetração (penetration pricing). 
A estratégia de desnatamento orienta a colocação inicial de preços altos para os produtos (próximos do valor oferecido), seguida de baixas ao longo do tempo. A estratégia de penetração, por sua vez, refere-se ao estabelecimento inicial de um preço baixo para atrair e manter uma grande base de clientes. Os preços de penetração não são necessariamente baratos, mas são baixos em relação ao valor total oferecido (Noble \& Gruca, 1999a; Nagle \& Hogan, 2007; Kotler \& Armstrong, 2007).

\subsubsection{3 $\quad$ Abordagem do Preço Baseado nos Custos}

$\mathrm{Na}$ abordagem do preço baseado nos custos, como a denominação indica, as empresas estabelecem seus preços a partir dos custos dos produtos (Hinterhuber, 2008), conforme demonstra a Figura 12.

Figura 12 - Abordagem do preço baseado nos custos

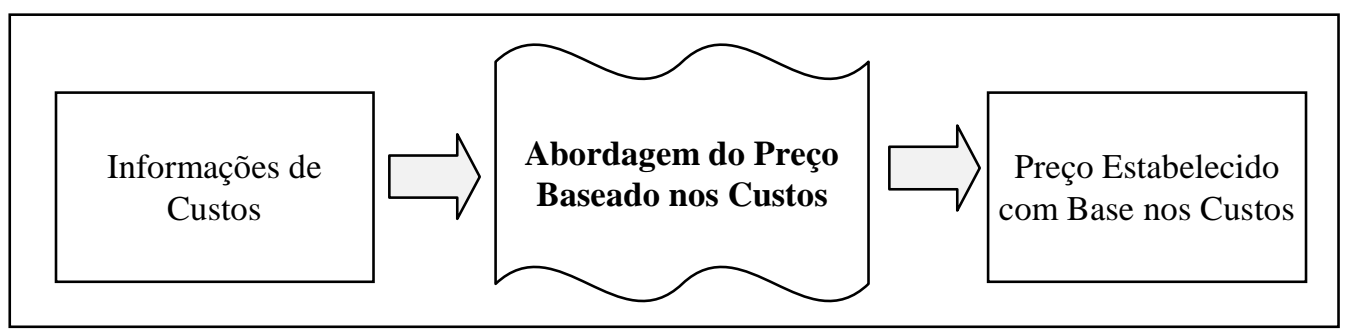

Fonte: Elaboração própria

De acordo com Collins e Parsa (2006), a aplicação de métodos dessa abordagem visa determinar preços capazes de não somente cobrir os custos, mas também de superá-los. Como a superação dos custos ocorre mediante o estabelecimento de uma margem, o entendimento das possíveis margens e dos possíveis custos é importante para a compreensão da abordagem, como ilustra a Figura 13. 
Figura 13 - Diferentes custos e diferentes margens

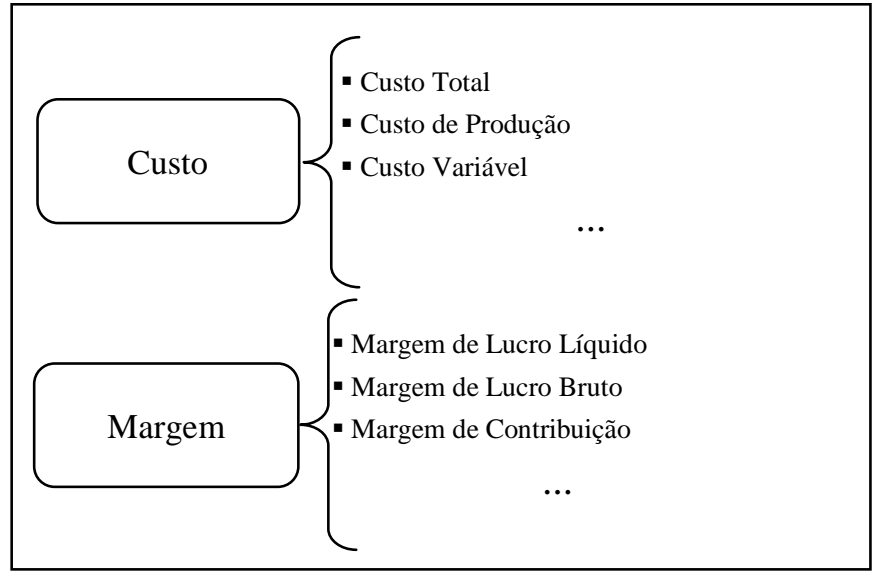

Fonte: Elaboração própria

Antes de iniciar a exposição dos diferentes tipos de custos e de margens, cumpre destacar a diferença, postulada na literatura contábil, entre custos e despesas. Iudícibus (2009) ajuda a enxergar essa diferença com a seguinte argumentação:

\footnotetext{
Despesa, em sentido restrito, representa a utilização ou o consumo de bens e serviços no processo de produzir receitas. . . . Quando bens ou serviços são consumidos na produção de bens que ainda não deixaram a empresa, incorporam-se ao custo do produto, não se caracterizando, ainda, a despesa ou o custo de período. (grifo original de Iudícibus, 2009, p. 153)
}

Dessa argumentação, depreende-se que, contabilmente, o consumo de recursos é classificado como custo, quando é aplicado na fabricação de produtos que permanecem na empresa; e como despesa, quando não é aplicado na produção. Há, portanto, principalmente no setor industrial, um lapso temporal entre a ocorrência dos custos e a sua caracterização como despesa, já que os custos são ocorridos no momento da fabricação do produto e a despesa na venda do produto (E. Martins \& Rocha, 2010).

Tanto os custos quanto as despesas podem ser classificados em função da sua relação com o volume de atividades ao longo do tempo. Essa classificação dá origem à segregação entre elementos variáveis e elementos fixos. Os custos e despesas variáveis englobam recursos cujo consumo varia de acordo com o volume de atividade (e.g., quilogramas de leite consumidos na fabricação de iogurte, comissão dos vendedores etc.). Os custos e despesas fixos, por sua vez, abrangem o consumo de recursos que, num dado intervalo de tempo, não sofre influência do volume de atividade (e.g, aluguel). Cumpre destacar que os custos e despesas fixos, mesmo sendo fixos, podem variar em função de outros fatores não relacionados ao volume 
(por exemplo, reajuste anual do contrato de aluguel) (E. Martins, 2010; Hansen \& Mowen, 2013).

As categorias de custos e despesas que compõem o custo do produto dependem do método de custeio adotado. Segundo E. Martins e Rocha (2010), a expressão método de custeio diz respeito à composição do custo de um evento, atividade, produto, atributo etc.. Os principais métodos de custeio reportados na literatura do tema são o custeio pleno, o custeio por absorção, o custeio variável e o custeio baseado em atividades (ABC).

O custeio pleno atribui ao custo do produto todos os custos de produção e também os gastos de administração geral da empresa. Ou seja, nesse custeio não são considerados somente os custos (variáveis e fixos) de produção, mas também todas as despesas comerciais, administrativas e financeiras (E. Martins \& Rocha, 2010).

Já no método de custeio por absorção, as despesas não integram o custo do produto. Nele, o custo é formado pelos custos de produção variáveis e fixos. E. Martins (2010) adverte que a maior desvantagem do método é o fato de ele implicar uma alocação de custos fixos que, para efeito gerencial, pode ser perniciosa. O montante atribuído a cada unidade pode variar expressivamente dependendo do volume de produção e do critério de rateio utilizado.

No método de custeio variável, o custo do produto é composto somente pelos custos variáveis. Todos os custos fixos, inclusive os identificáveis em relação aos produtos (por exemplo, aluguel de um galpão dedicado exclusivamente à fabricação de um determinado produto), são levados diretamente a resultado (despesa) (Garrison \& Noreen, 2001). Para apurar o resultado do produto, é comum também somar as despesas variáveis aos custos variáveis.

Finalmente, há o método do custeio baseado em atividades (ABC), que surgiu para contornar o problema da alocação de custos ao assumir que os recursos são consumidos por atividades. Mediante ele, tanto os custos fixos quanto as despesas fixas podem ser alocados ao custo do produto a partir de dois estágios baseados nas atividades. $\mathrm{O}$ primeiro estágio atribui os custos fixos, e eventualmente também as despesas fixas, às atividades de acordo com o consumo que 
cada atividade faz de recursos. O segundo estágio atribui os custos das atividades aos objetos de custos de acordo com o consumo que cada objeto faz das atividades (M. Nakagawa, 2001).

A Figura 14 ilustra a diferente composição dos custos de acordo com os diferentes métodos de custeio adotados. Ela está organizada em uma forma sequencial que parte do custeio que atribui menos custos e termina no custeio que atribui mais custos. $\mathrm{O} A B C$ não está ilustrado porque, dependendo da sua aplicação, mais ou menos elementos de custos podem ser alocados aos produtos e serviços. Na aplicação do ABC para apuração do custo para servir, por exemplo, as despesas decorrentes do atendimento aos clientes são alocadas (Guerreiro et al., 2008).

Figura 14 - Custos de acordo com métodos de custeio

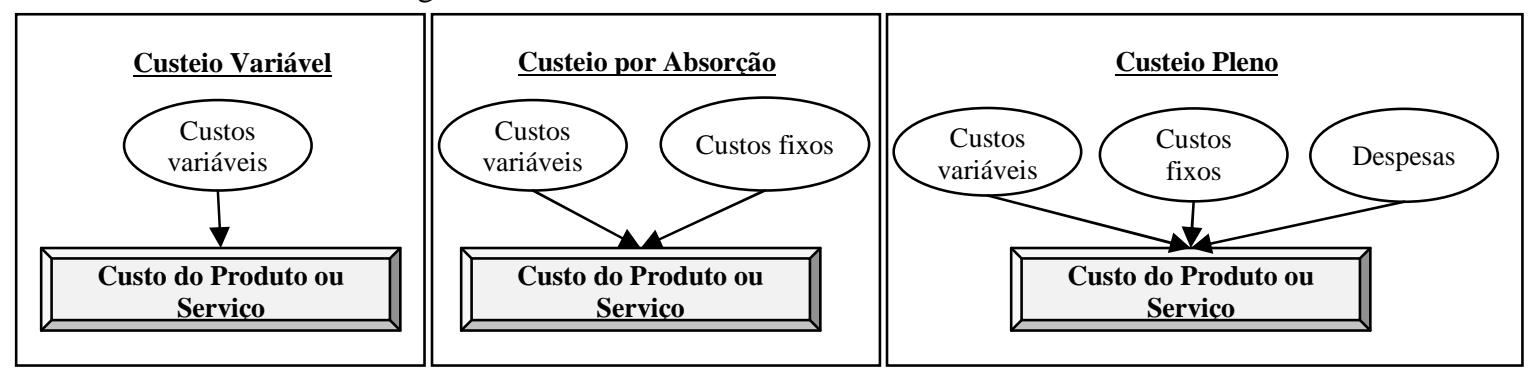

Fonte: Elaboração própria

Uma vez que os diferentes custos já foram abordados pode-se passar à discussão das variadas margens. E. Martins e Rocha (2010) esclarecem que cada método de custeio possui sua própria medida, ou parâmetro, para expressar o resultado individual de cada produto. Essa medida, denominada margem, além de gerar o lucro, destina-se a cobrir todos os custos e despesas ainda não contemplados no custo do produto.

A composição da margem depende, portanto, dos recursos considerados como custo do produto, como mostra a Tabela 2. Por exemplo, se o custeio variável é adotado, o custo abarca somente os integrantes variáveis e a margem estabelecida precisa ser capaz de cobrir todos os custos e despesas fixos e de gerar lucro. Por outro lado, se o custeio pleno é adotado, o custo incorpora todos os custos e despesas (fixos e variáveis) e a margem de lucro estabelecida precisa apenas gerar o lucro desejável (Guerreiro, Cornacchione Jr., \& Kassai, 2012). 
Tabela 2 - Custo e margem de acordo com o método de custeio

\begin{tabular}{|c|c|c|c|c|c|}
\hline $\begin{array}{c}\text { MÉTODO DE } \\
\text { CUSTEIO }\end{array}$ & $\begin{array}{l}\text { COMPOSIÇÃO DO } \\
\text { CUSTO DO } \\
\text { PRODUTO }\end{array}$ & $\begin{array}{c}\text { DIREÇÃO DO } \\
\text { AUMENTO NA } \\
\text { COMPOSIÇÃo DO } \\
\text { CUSTO }\end{array}$ & $\begin{array}{l}\text { MARGEM DE } \\
\text { LUCRO }\end{array}$ & $\begin{array}{c}\text { COMPOSIÇÃO DA } \\
\text { MARGEM DE LUCRO } \\
\text { (O QUE ELA DEVE } \\
\text { COBRIR) }\end{array}$ & $\begin{array}{c}\text { DIREÇÃO DO } \\
\text { AUMENTO NA } \\
\text { COMPOSIÇÃO DA } \\
\text { MARGEM }\end{array}$ \\
\hline Custeio Pleno & $\begin{array}{l}\text { Custos Totais + } \\
\text { Despesas Totais }\end{array}$ & \multirow[t]{3}{*}{4} & $\begin{array}{c}\text { Margem de Lucro } \\
\text { Líquido }\end{array}$ & Lucro Desejado & \multirow[t]{3}{*}{1} \\
\hline $\begin{array}{l}\text { Custeio por } \\
\text { Absorção }\end{array}$ & Custos Totais & & $\begin{array}{l}\text { Margem de Lucro } \\
\text { Bruto }\end{array}$ & $\begin{array}{c}\text { Despesas Totais + } \\
\text { Lucro Desejado }\end{array}$ & \\
\hline Custeio Variável & $\begin{array}{c}\text { Custos e Despesas } \\
\text { Variáveis }\end{array}$ & & $\begin{array}{l}\text { Margem de } \\
\text { Contribuição }\end{array}$ & $\begin{array}{c}\text { Custos Fixos }+ \\
\text { Despesas Fixas }+ \\
\text { Lucro Desejado }\end{array}$ & \\
\hline
\end{tabular}

Fonte: Adaptada de Guerreiro et al. (2012, p. 05)

Guerreiro, Bio, e Merschmann (2008) citam que as empresas tradicionalmente priorizam a margem de contribuição e a margem de lucro bruto. A margem de contribuição revela o montante que a empresa dispõe para cobrir todos os seus custos fixos, todas as suas despesas fixas e ainda gerar lucro. Já a margem de lucro bruto revela o montante que a empresa dispõe para cobrir o consumo de recursos classificados como despesa e ainda gerar lucro.

Gebert, Goldenberg, e Peters (1996) relatam que a utilização da margem de lucro líquido também pode ser encontrada com frequência. Tal margem revela o montante que a empresa dispõe para gerar lucro. Os autores, no entanto, criticam essa margem, pois entendem que as despesas que fazem parte da sua composição normalmente são rateadas com base no volume de vendas. Essa forma de rateio tende a fazer parecer que os produtos com menor volume de vendas são os mais lucrativos, uma vez que recebem menor proporção das despesas.

Outra margem que merece receber atenção, embora ainda não seja amplamente utilizada, é a margem de servir. Em termos de composição, ela situa-se entre a margem de lucro bruto e a margem de lucro líquido, pois, além de deduzir da receita os custos referentes à fabricação do produto (de acordo com o custeio adotado), ela subtrai as despesas relacionadas ao atendimento aos clientes (custo para servir). As despesas que fazem parte da sua composição são atribuídas com base no consumo dos clientes e dos produtos (Guerreiro et al., 2008). A Figura 15 ilustra um exemplo comparativo desses quatro tipos de margem. 
Figura 15 - Principais margens

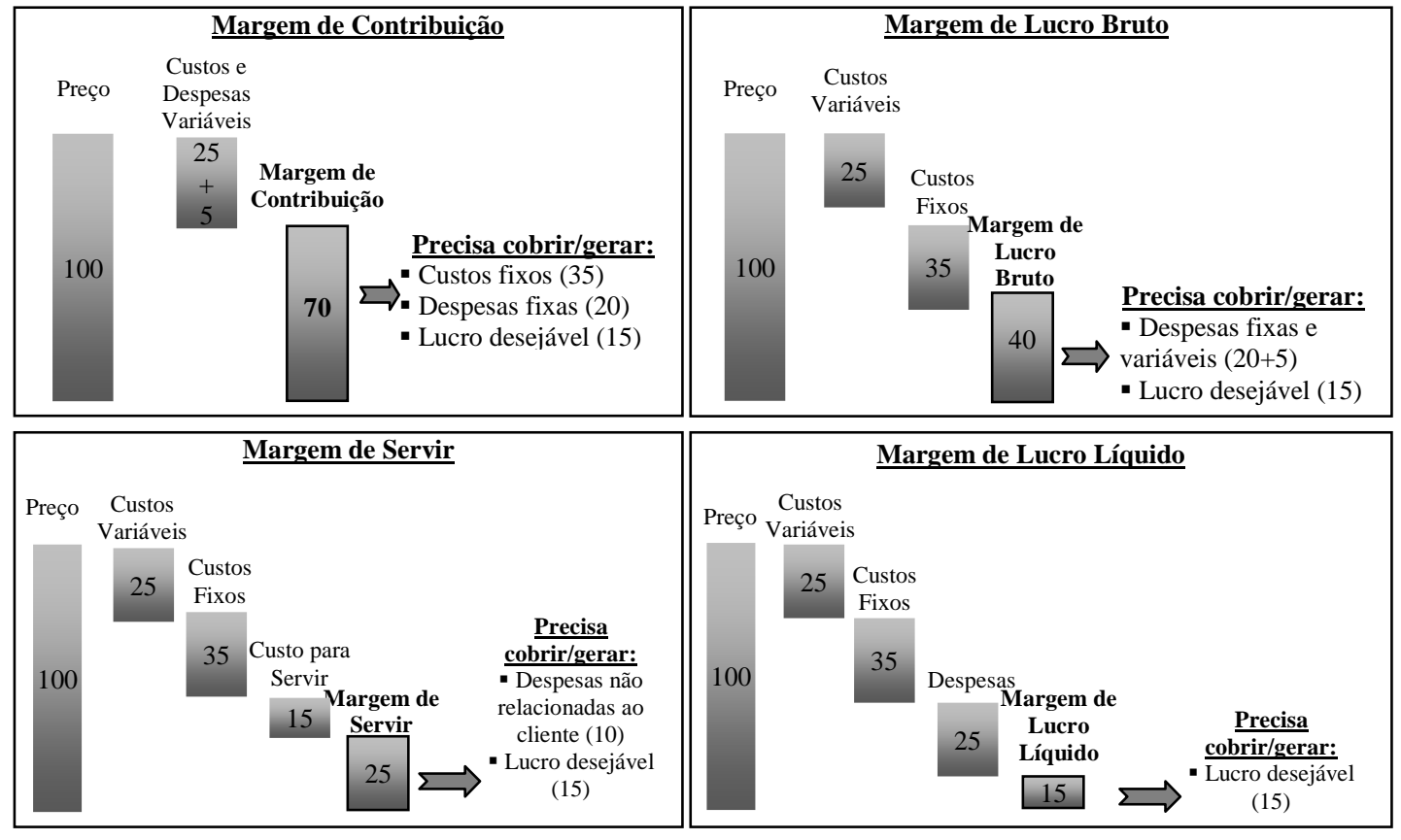

Fonte: Elaboração própria

Em resumo, quando a empresa seleciona o método de custeio ela decide não apenas o que compõe o custo dos produtos, mas também o que compõe a margem. Em outras palavras, a composição da margem, da mesma forma que o custo do produto, é consequência do método de custeio adotado. Tudo o que o método de custeio considera que não faz parte do custo do produto precisa ser coberto pela margem e, consequentemente, precisa fazer parte da sua composição.

Agora que já foram apresentados os principais tipos de custos e os principais tipos de margens, pode-se passar, finalmente, à discussão das diferentes formas de combinação. Na visão teórica do marketing, essas diferentes formas de combinação correspondem aos métodos da abordagem do preço baseado nos custos, que basicamente são:

a) preço conforme os custos mais margem (cost-plus ou markup); e

b) preço conforme o lucro alvo.

Como o próprio nome indica, no método do preço conforme os custos mais margem, o preço é estabelecido mediante a adição de uma margem ao custo do produto. Isto é, o preço é basicamente determinado depois que uma margem (percentual ou unitária) é somada ao custo 
do produto. Diante do método, os custos são o ponto de partida de toda e qualquer decisão de preços (Indounas, 2006).

Vale destacar que em alguns trabalhos estrangeiros propaga-se uma distinção entre os termos cost-plus e markup. Os estudos do governo da Alberta (2009) e de Indounas (2006) são exemplos. Neles, é trazido que o cost-plus é especialmente útil quando a empresa desconhece de antemão os custos dos seus produtos, afinal, ao invés de ela arriscar-se com estimativas, ela compactua com o cliente um preço resultante da soma de uma margem (previamente determinada) aos custos realmente incorridos. Tanto o vendedor quanto o comprador aceitam que um custo inicialmente desconhecido seja a base elementar do preço.

Já no markup, o preço é determinado com o simples acréscimo de uma margem aos custos. Esses custos não são reais, mas, sim, estimados com base em perspectivas da quantidade a ser vendida/produzida. Ou seja, o preço é determinado mediante a adição de uma margem aos custos, antes de esses custos serem de fato apurados (Alberta, 2009). A Figura 16 ilustra a ideia central defendida nessa distinção.

Figura 16 - Comparação entre markup e cost-plus

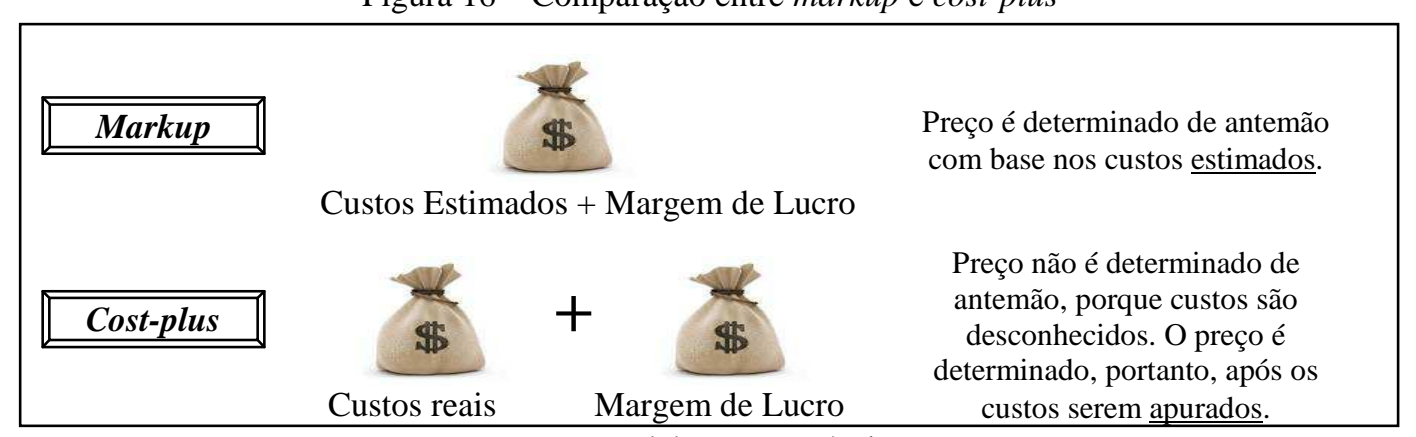

Fonte: Elaboração própria

Entretanto, a maior parte dos trabalhos não faz distinção entre os termos e quando menciona cost-plus ou markup refere-se à articulação de uma margem aos custos. Hample (1977), por exemplo, trata os termos como sinônimos (“markup or cost-plus pricing”). Shipley e Jobber (2001), como outro exemplo, usam o termo cost-plus quando se referem ao estabelecimento dos preços a partir da soma da margem ("predeterminate percentage profite markup") aos custos estimados. 
O outro método da abordagem do preço baseado nos custos é aquele em que o preço é estabelecido conforme o lucro alvo (target return pricing). A principal diferença entre este e o outro método (custos mais margem) é que ele parte do lucro global em direção ao lucro unitário (o outro parte do lucro unitário em direção ao lucro global) (Alberta, 2009). O racional do método é que a empresa, para ter condições de produzir e vender determinada quantidade de produtos, precisa invariavelmente investir capital (em custos, em despesas e em investimentos). Nele, o preço estabelecido visa propiciar o retorno global desejado pela empresa sobre seus investimentos.

Para ilustrar o método, Indounas (2006) trouxe o exemplo de uma empresa grega de tecnologia de informação que precisava investir um capital total de $€ 500.000$ para executar suas atividades. Como o retorno alvo dessa empresa era 15\%, o faturamento total deveria ser de $€ 575.000$ ( $€ 500.000+15 \%$ de $€ 500.000$ ). Com a produção e a venda estimada em 80.000 unidades, o preço final determinado para cada unidade foi $€ 7,19$ ( $€ 575.000 \div 80.000$ unidades).

É salutar mencionar que variantes ao investimento total de capital podem orientar a determinação dos preços no método. Por exemplo, Avlonitis e Indounas (2005a) expõem que, no lugar do investimento total, é possível colocar somente a parte investida no custo total. Se esse custo total for acrescido a uma taxa de retorno igual a $0 \%$ e for dividido pela quantidade estimada de produção/venda, identifica-se o preço em que o ponto de equilíbrio é atingindo (preço que faz com que as receitas totais sejam iguais aos custos totais, oferecendo um "lucro" alvo total igual a zero). Os autores também entendem que os custos variáveis totais podem ser colocados no lugar do investimento total para exibirem o preço em que a margem de contribuição iguala-se a zero.

De acordo com a variante adotada, um problema específico que pode ser encontrado no método do lucro alvo é assumir que todo o capital investido equivale a um custo, o que não é necessariamente verdadeiro. Grande parte do investimento pode estar concentrada em ativos que serão usados por diversos períodos e para os quais o custo de oportunidade correspondente, não o montante integral investido no ativo, mais bem representa o custo. R. V. Santos (1995) acrescenta que quando existem investimentos comuns a vários produtos o 
método do lucro alvo também implica o problema da arbitrariedade e pode originar rateios distorcidos sobre o capital empregado na fabricação ou na comercialização dos produtos.

Apesar desse problema, tanto o método do lucro alvo quanto o método dos custos mais margem têm a simplicidade como principal vantagem. De acordo com Cannon e Morgan (1990) e com Shipley e Jobber (2001), eles são fáceis e podem ser rapidamente compreendidos por gestores de qualquer nível. Além disso, eles mostram de uma forma não complexa qual preço é necessário para assegurar que todos os custos e/ou investimentos estejam cobertos (Tzokas, Hart, Argouslidis, \& Saren, 2000).

Entretanto, vale ressaltar que eles, justamente por serem simples de usar, podem fazer com que o papel de determinação dos preços seja delegado a gestores juniores, não a alta gerência. Esses gestores tendem a não ter uma visão estratégica nem um entendimento razoável do funcionamento do mercado, o que pode gerar um descasamento entre o preço determinado e a real postura competitiva da empresa (Shipley \& Jobber, 2001).

\subsubsection{Recomendações}

Nesta seção são apresentados trabalhos que, de alguma forma, exprimem recomendações sobre como os preços devem ser estabelecidos. A análise desses trabalhos permite observar que o marketing sugere que a definição dos preços seja norteada pelo valor, não pelos custos. Afinal, ao mesmo tempo em que foram localizados vários estudos aconselhando a determinação dos preços com base no valor, não foram encontrados estudos indicando processos guiados exclusivamente pelos custos.

Shapiro e Jackson (1978) foram uns dos primeiros autores a emitirem recomendações sobre o estabelecimento dos preços. Eles sugeriram o embasamento em informações de valor. O argumento dos autores centra-se no fato que quando os clientes compram um produto, eles promovem uma comparação complexa entre o preço e o valor no uso do produto. Ora, se os clientes pensam dessa maneira quando analisam uma compra, faz sentido que os definidores de preços também façam suas deliberações dessa maneira, isto é, estabelecendo os preços com base no valor que o produto oferece. 
Monroe (1979) também recomendou a definição dos preços a partir do valor logo na primeira edição do seu livro ("Pricing: making profitable decisions"). Em edições mais atuais, Monroe (2003) até propõe um modelo no qual assume que as empresas podem estabelecer qualquer preço que esteja entre um piso e um teto. O piso é designado pelos custos, enquanto que o teto é designado pelo valor.

Nagle, autor de outro dos principais livros de preços ("The strategy and tactics of pricing: a guide to profitable decision making", ou em português, "Estratégia e táticas de preços"), cuja primeira edição data de 1987, endossou as recomendações para o embasamento no valor. O autor argumentou que se os produtos e os preços não são coerentes aos desejos e às disposições dos clientes, perde-se a oportunidade de maximizar a diferença entre o valor criado e o custo incorrido. Portanto, ao invés de começar com o produto (e respectivos custos) e terminar com um preço, ele sugeriu começar com o valor e terminar com um produto (e respectivos custos) coerente aos desejos e disposições dos clientes (Nagle \& Hogan, 2007).

Kortge e Okonkwo (1993) também sugeriram o estabelecimento dos preços a partir de informações de valor, pois, segundo eles, inspirar-se somente nos custos, sem considerar o lado do cliente, não é mais suficiente em decisões críticas de preços. Os autores sugeriram um modelo de estabelecimento dos preços conforme o valor percebido (perceived-value pricing model).

Esse modelo, que é inspirado na faixa de satisfação da teoria da equidade, é usado para estabelecer uma faixa viável de preços em que tanto os clientes quanto os vendedores estejam satisfeitos, como ilustra a Figura 17. Os custos estabelecem o piso para a faixa (linha CD); a sensibilidade aos preços dos clientes estabelece o teto para a faixa (linha $\mathrm{AB}$ ). 
Figura 17 - Modelo de estabelecimento dos preços conforme o valor percebido

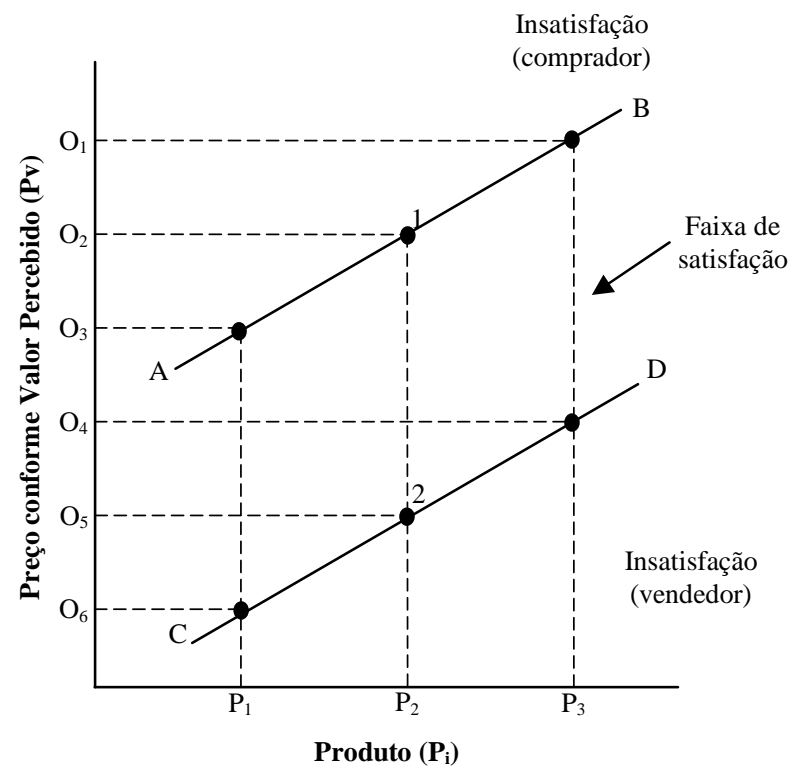

Fonte: Traduzida de Kortge \& Okonkwo (1993, p. 136)

G. E. Smith e Nagle (1994), na sequência, mais uma vez recomendaram preços estabelecidos conforme o valor. Eles defenderam que na definição dos preços deve-se, sim, identificar o quanto é preciso para cobrir os custos e gerar lucro, mas só isso não basta, uma vez que é preciso identificar se os clientes sentem-se motivados a comprar por esse tanto. Diante dessa defesa, os autores sugeriram um modelo integrado orientado pelo lucro, em que o preço estabelecido espelha o valor para o cliente, contribuindo com um lucro sustentável.

Nesse modelo, o valor é espelhado na margem de contribuição sobre os custos variáveis. Essa margem de contribuição não é uma decisão interna da empresa e tampouco reflete um mero desejo de lucro sobre os custos. Mais do que isso, ela reproduz o valor oferecido aos clientes, tanto que é incapaz de realizar "milagres". Afinal, como G. E. Smith e Nagle (1994) frisam, "não se pode esperar que a determinação dos preços conserte maus investimentos. Pode-se apenas esperar que ela capture integralmente a contribuição disponível” (p. 75). ${ }^{1}$

Em 1995, criticando os modelos de marketing embasados na teoria microeconômica, G. E. Smith complementou o trabalho elaborado em conjunto com Nagle em 1994 e sugeriu uma orientação estratégica para o estabelecimento dos preços. $\mathrm{O}$ autor reiterou que $\mathrm{o}$

\footnotetext{
${ }^{1}$ Pricing cannot be expected to fix bad investment decisions. It can only be expected to fully capture the contribution available.
} 
estabelecimento dos preços precisa integrar dados de valor a dados de custos, por meio de uma margem de contribuição que capture e comunique o valor para os clientes (G. E. Smith, 1995).

Kotler e Keller (2012), autores do livro "Marketing management”, cuja primeira edição data de 2000, foram mais dois autores que sugeriram a definição dos preços baseada no valor. Eles propuseram um modelo, denominado 3 Cs (clientes, concorrência e custos), que similarmente ao modelo de Monroe (2003) estabelece um piso e um teto para os preços, conforme ilustra a Figura 18. O teto é dado pela avaliação feita pelos clientes sobre as características únicas do produto e o piso é dado pelos custos. A concorrência (ou sua ausência) modera a aproximação do preço ao piso ou ao teto.

Figura 18 - Modelo dos 3Cs

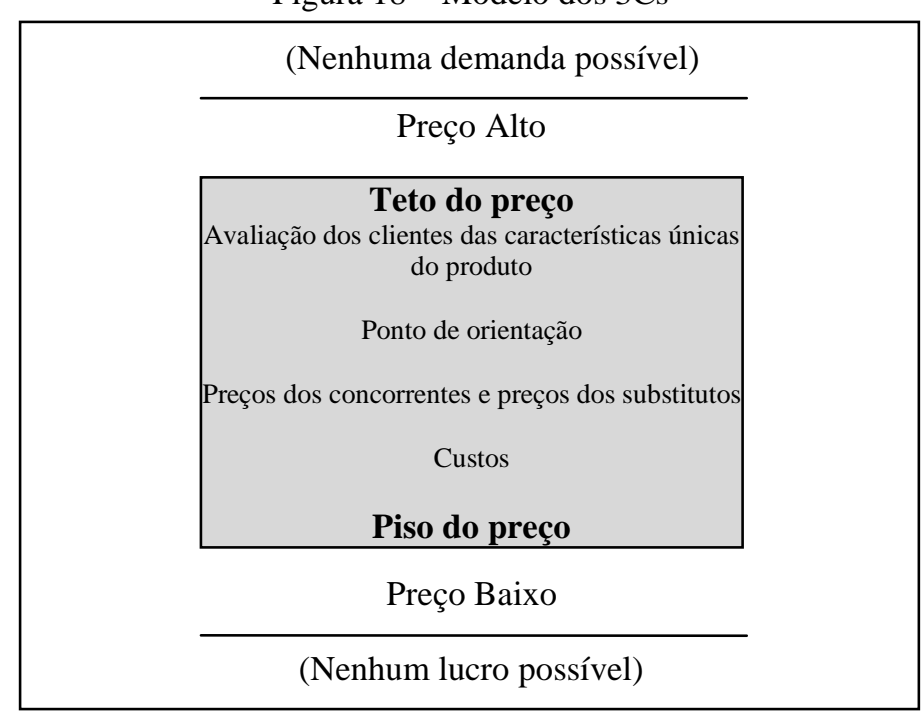

Fonte: Adaptada de Kotler \& Keller (2012, p. 395)

Shipley e Jobber (2001) também recomendaram o embasamento no valor. De acordo com os autores, não tem como estabelecer preços sem analisar o valor que os clientes percebem no produto e sem conhecer os preços que eles dispõem-se e têm capacidade a pagar. Eles propuseram um modelo (técnica integrada de determinação dos preços), como mostra a Figura 19, para incorporar tais tipos de considerações a partir de informações de custos (diretos no curto prazo, totais no longo prazo). 
Figura 19 - Técnica integrada de determinação dos preços

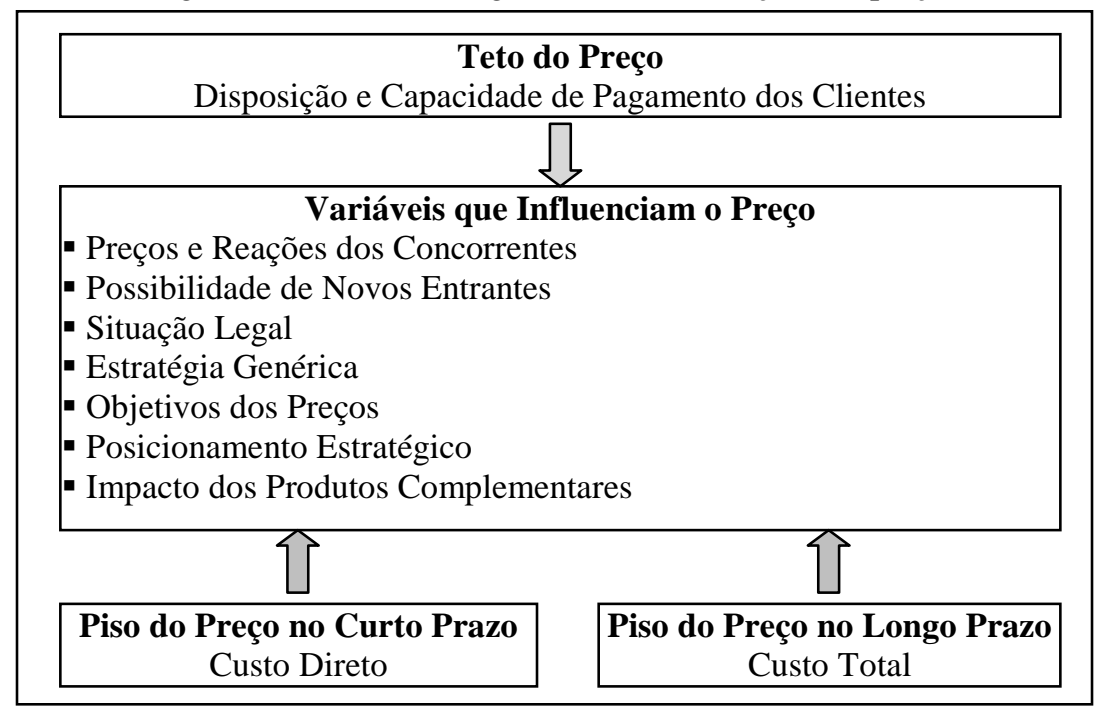

Fonte: Adaptada de Shipley \& Jobber (2001, p. 312)

Hinterhuber (2004) foi outro que indicou a definição dos preços a partir de informações de valor e sugeriu um modelo para o estabelecimento dos preços, dessa vez inspirado no triângulo estratégico originalmente desenvolvido por Ohmae (1982). Nesse modelo, o autor sugere que o preço espelhe o valor que o produto possui para os clientes, sem deixar de considerar aspectos inerentes aos custos e aos concorrentes, como mostra a Figura 20.

Figura 20 - Aplicação dos métodos na análise do triângulo estratégico

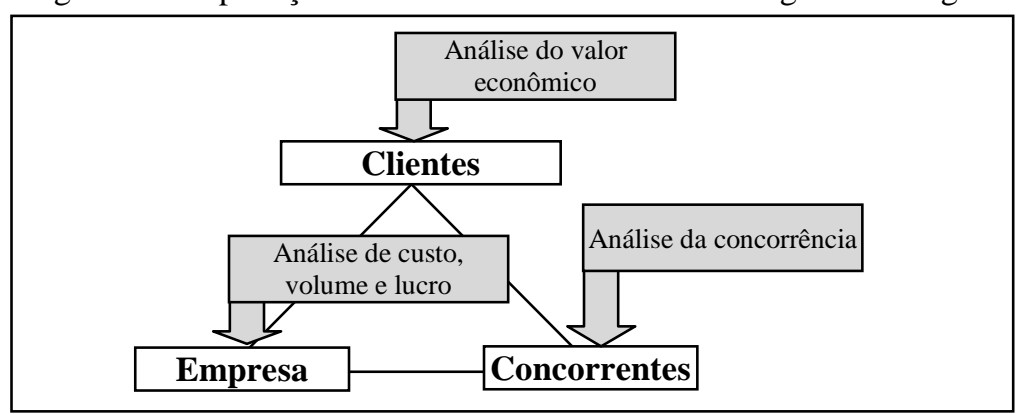

Fonte: Adaptada de Hinterhuber (2004, p. 768)

No modelo de Hinterhuber (2004), a primeira etapa do estabelecimento dos preços consiste na identificação do valor (valor econômico total, valor percebido pelos clientes e disposição de pagamento dos clientes) para que, com base nele, sejam levantadas estimativas dos volumes de vendas em pontos específicos de preços.

Na sequência, a atenção recai sobre a própria companhia e sobre a sua estrutura de custos e, portanto, a análise de custo, volume e lucro é aplicada para levantar os impactos dos 
diferentes preços na margem. A análise dos impactos decorrentes da concorrência nos preços aparece em seguida. Hinterhuber (2004) citou que é imprescindível, por exemplo, apreciar se a colocação do preço no patamar mais elevado não poderia ter como impacto negativo a atração da entrada de uma vasta gama de novos concorrentes (pelo nível alto do preço).

Ingenbleek (2007) também aconselhou o estabelecimento dos preços baseado no valor, afirmando, inclusive, que quanto maior fosse tal embasamento, maior seria o desempenho da empresa. Após realizar um estudo abrangente que revisou 53 pesquisas, o autor concluiu que estabelecer os preços exclusivamente com base nos custos não é uma boa escolha.

De acordo com Ingenbleek (2007), o preço final precisa espelhar o que o mercado pode suportar, ainda que informações de custos sejam usadas na sua formação. Ou seja, ele defendeu que o preço, por mais que possa ser estabelecido partindo de informações de custos, precisa derradeiramente basear-se em informações de valor e, por esse motivo, as margens precisam ser flexíveis.

Piercy et al. (2010) foram outros autores que recomendaram o preço fundamentado no valor. Depois de analisarem de forma estratégica a tomada de decisões de preços, os autores concluíram que quando os preços não são estabelecidos com base no valor, as empresas entram num ciclo vicioso que só prejudica seu desenvolvimento. Afinal, como elas são obrigadas a competir em função de preço elas não vêem quaisquer motivos para oferecer soluções de valor (preferem oferecer pouco valor, mas também cobrar pouco preço). Ao se comportarem repetidamente dessa maneira, elas sentem-se desmotivadas a investir na elaboração de produtos com valor e focam-se, basicamente, na elaboração de commodities.

Liozu e Hinterhuber (2012) também sugeriram a determinação dos preços a partir do valor. Ao compararem métodos das três abordagens de preços e investigarem os potenciais impactos de cada um deles em empresas industriais, os autores observaram que enquanto os métodos baseados nos custos e na concorrência induziam ao estabelecimento de um preço fortemente ancorado na intuição, os métodos baseados no valor conduziam a uma decisão de preço sustentada por pesquisas de mercado, análises científicas e recomendações de especialistas. Com isso, o estabelecimento dos preços baseado no valor reduzia substancialmente a chance 
de um preço não adequado ser definido e, além disso, estimulava as empresas a conhecerem e divulgarem todo o valor que seus produtos ofereciam.

Gale e Swire (2012) são outros autores que recomendaram o preço baseado no valor. Os autores sugeriram um mapeamento que apura o valor com base no preço e no desempenho comparativo (de acordo com a visão dos clientes) de produtos concorrentes. Nesse mapa, a informação do custo do produto e das possíveis margens pode ser incluída.

Calabrese e Francesco (2014) também sugeriram a definição dos preços a partir do valor. Eles propuseram o uso da técnica do guia de serviço (Service Blueprint). Nessa técnica, os levantamentos de custos não monetários, de atividades que adicionam valor, de pontos de contato e de momentos da verdade são essenciais para identificar e comunicar o valor. Calabrese e Francesco (2014) também apresentaram uma fórmula que, com base no valor previamente identificado, indica o preço a ser estabelecido. Eles mencionaram que o resultado dessa fórmula está restrito à condição de ser maior que os custos variáveis e fixos mais margem ou que o preço dos concorrentes.

Em suma, é possível observar que o marketing recomenda fortemente preços definidos em consonância ao valor. No início, os trabalhos teóricos enfatizavam a sugestão de modelos e mais recentemente eles têm focado na exposição da superioridade de preços embasados no valor e de meios que viabilizam a identificação do valor.

Cumpre mencionar que a teoria de marketing em nenhum momento impede que os custos e outros tipos de informações sejam considerados no processo, desde que o valor seja incorporado. O que, de fato, a teoria não indica e chega a postular como "pecados capitais" são as ações de fazer preço apenas em função da concorrência e de fazer preço apenas em função dos custos (Costa, Ferreira, \& Saraiva Júnior, 2010). 


\section{ESTABELECIMENTO DOS PREÇOS NA PRÁTICA}

Além de trabalhos teóricos, econômicos e de marketing, que recomendam como o estabelecimento dos preços deve ser, há trabalhos empíricos que revelam como o estabelecimento dos preços é na prática. De maneira geral, esses trabalhos empíricos entrevistam ou questionam uma quantidade significativa de empresas para identificar de que maneira as decisões de preços são tomadas no dia-a-dia.

Na sequência, são relacionados alguns desses trabalhos. Na primeira seção, são apresentados os trabalhos que tiveram mais impacto na construção do conhecimento sobre o tema, recebendo variadas citações. Depois, são arrolados trabalhos de menor impacto que, apesar de explorarem o estabelecimento dos preços na prática, não influenciaram significativamente a literatura mundial (receberam poucas citações). São incluídas a apresentação dos resultados de locais costumeiramente pouco abordados em pesquisas acadêmicas (e.g. África, Europa Oriental, Ásia etc.). Para complementar a revisão, são expostos os trabalhos brasileiros desenvolvidos sobre o assunto, ainda que sua publicação tenha sido restrita ao escopo local.

\subsection{Pesquisas Empíricas mais Citadas}

As pesquisas apresentadas nesta seção são normalmente reconhecidas como as principais pesquisas sobre o estabelecimento dos preços pela ampla utilização que tiveram no desenvolvimento do conhecimento empírico sobre o tema. Especificamente, são descritas nesta seção todas as pesquisas sobre preços, publicadas em inglês e localizadas em bases científicas (ProQuest, EBSCOhost, ScienceDirect, Scielo etc.), que receberam pelo menos 25 citações. Vale mencionar que esses dois critérios (publicação em inglês e disponibilidade em bases científicas) foram definidos para assegurar que as citações partissem de variados pontos do mundo e não se referissem apenas a uma extensa consideração do trabalho no contexto nacional.

São relatadas as constatações de 30 trabalhos, sendo 27 pesquisas individuais e 3 séries de estudos. As séries de estudos referem-se a pesquisas que partiram de um mesmo instrumento de investigação empírica e contemplam: uma série de 9 estudos de Avlonitis e Indounas; uma série de 2 estudos de Greenslade e Parker; e uma série de 3 estudos de Indounas. Cada um 
desses 30 trabalhos recebeu pelo menos 25 citações $^{2}$, conforme consulta realizada no Google Acadêmico em 12 de fevereiro de 2016 (Google, 2016). Na Tabela 3, pode-se verificar que há concentração de pesquisas que receberam entre 25 e 49 citações bem como de pesquisas que receberam mais de 100 citações.

Tabela 3 - Número de citações das pesquisas empíricas mais citadas
\begin{tabular}{c|c|c}
\hline DESCRIÇão & QUANTIDADE DE PESQUISAS & PERCENTUAL \\
\hline 25 a 49 citações & 11 & $37 \%$ \\
\hline 50 a 99 citações & 8 & $27 \%$ \\
\hline Mais de 100 & 11 & $37 \%$ \\
\hline TOTAL & $\mathbf{3 0}$ & $\mathbf{1 0 0 \%}$ \\
\hline
\end{tabular}

Vale mencionar que há uma pesquisa nacional (D. G. Machado \& Souza, 2006) que alcançou quantidade superior a 25 citações (53 citações), no entanto, ela não é apresentada nesta seção porque não pode ser considerada, globalmente, como uma das principais pesquisas sobre o estabelecimento dos preços (é apresentada na seção 3.3). O fato de não ter sido atendido o critério da publicação em inglês limitou o acesso ao texto e fez com que as citações fossem numerosas, mas oriundas de trabalhos brasileiros. Haveria imparcialidade se essa pesquisa fosse apresentada nesta seção enquanto que trabalhos publicados em outros idiomas, que talvez também tenham alcançado em seus países quantidade expressiva de citações, não fossem mencionados.

Para iniciar a apresentação, vale trazer o estudo de R. I. Hall e Hitch (1939), o primeiro a investigar o estabelecimento dos preços na prática. Depois de aplicarem um questionário a 38 empresas do Reino Unido (33 industriais, 3 comerciais e 2 construtoras), os autores concluíram que os preços eram, predominantemente, determinados com base nos custos.

R. I. Hall e Hitch (1939) constataram que as empresas, em vez de igualarem os custos marginais às receitas marginais, estabeleciam os preços somando os custos diretos aos custos indiretos (estes, incluídos por meio de um percentual) e a uma margem de lucro (frequentemente de 10\%). A conclusão foi que das 38 empresas analisadas, 30 (79\%) definiam os preços dessa forma.

\footnotetext{
${ }^{2}$ Pelo menos um estudo das séries de Avlonitis e Indounas, de Greenslade e Parker e de Indounas obteve quantidade de citações igual ou superior a 25. A quantidade de citações reportada na Tabela 13 refere-se à soma das citações de cada pesquisa.
} 
R. I. Hall e Hitch (1939) perceberam que a maior parte das empresas considerava que o preço determinado a partir do custo total mais margem era o preço "certo", isto é, o preço que "deveria" ser colocado. A margem de lucro somada aos custos variava para que esse preço "certo" ficasse coerente aos preços de produtos similares oferecidos pelos concorrentes.

Os autores também constataram que apenas 12 empresas eram reféns dos preços indicados pelo custo total (full cost) mais margem. 15 empresas cobravam o preço sugerido por essa soma em condições "normais", mas em certas situações, como crises e concorrência acirrada, optavam por cobrar preços diferentes. 3 empresas (todas têxteis) aderiam "a princípio" à definição dos preços com base no custo total mais margem, contudo, alteravam os preços por conta da crônica e severa depressão daquele momento no setor.

Cumpre mencionar que R. I. Hall e Hitch, apesar de terem sido os primeiros a alvoroçarem o estudo do estabelecimento dos preços, nunca mais publicaram sobre o tema. Conforme citado por Ingenbleek (2007), os autores migraram para diferentes campos. R. I. Hall tornou-se um economista keynesiano e, por longo tempo, foi um dos principais conselheiros do governo britânico em assuntos econômicos. Hitch retornou para os Estados Unidos e desenvolveu sua carreira em torno da pesquisa operacional. Quando, nos anos 1960, Hitch foi questionado onde estava o "Hitch do Hall e Hitch", ele respondeu que "aquilo foi em outra encarnação".

Na sequência, W. W. Haynes dedicou-se a investigar a realidade do estabelecimento dos preços nas pequenas empresas. $\mathrm{O}$ autor entrevistou gestores de 88 empresas de pequeno porte, sendo 26 varejistas, 6 atacadistas, 21 prestadoras de serviço, 28 industriais, 5 relacionadas à jardinagem e 2 mistas de varejo e serviço. Geograficamente, essas empresas estavam localizadas nos Estados Unidos, sobretudo no estado de Kentucky, mas também nos estados de Ohio e de Indiana, na costa leste e no extremo sul. Os principais achados foram publicados em um livro da universidade Kentucky em 1962 e sumarizados em um artigo em 1964.

Logo no início, o trabalho de W. W. Haynes (1964) surpreendeu por mencionar que os preços baseados nos custos eram a exceção e não a regra. $\mathrm{O}$ autor explicou que as empresas, apesar de aderirem à mecânica de custos mais margem, incorporavam aspectos da concorrência e dos clientes nos preços. 
Especificamente, W. W. Haynes (1964) constatou que não era comum cobrar cegamente os preços sugeridos pelos custos mais margem. O autor observou que o custo total somado à margem oferecia mais um ponto de referência aos preços do que indicava um montante fechado a ser cobrado. A maior parte das empresas que usava o custo total atuava com margens variáveis que se alteravam de acordo com as linhas de produtos e/ou com as circunstâncias. Nas empresas que somavam o custo total a uma margem pré-determinada, havia ajustes nos preços dependendo da situação competitiva e da demanda dos clientes.

Depois, o trabalho de R. C. Skinner (1970) buscou refinar o entendimento da definição dos preços tanto de empresas de pequeno porte quanto de empresas de grande porte. Ele foi elaborado com base em um questionário remetido no primeiro semestre de 1968 a todos os membros da Associação de Comércio de Merseyside (Merseyside Chamber of Commerce), localizada na Inglaterra. Cartas com o questionário foram enviadas para empresas associadas de variados portes de todos os setores industriais, exceto o de gás, eletricidade e água e o de administração e defesa pública. Das 1.903 cartas despachadas, 179 foram devolvidas com o questionário respondido.

R. C. Skinner (1970) concluiu que informações dos custos, dos preços dos concorrentes e da demanda dos clientes eram consideradas pela maioria das empresas como elementares para a definição dos preços, como mostra a Tabela 4.

Tabela 4 - Resultados da pesquisa de R. C. Skinner (1970)

\begin{tabular}{c|c|c}
\hline BASE DOS PREÇOS & QUANTIDADE & PERCENTUAL \\
\hline Custos estimados e margem de lucro & 144 & $97 \%$ \\
\hline Preços dos concorrentes & 134 & $90 \%$ \\
\hline Efeito do preço na demanda dos clientes & 120 & $81 \%$ \\
\hline
\end{tabular}

Fonte: Adaptada de R. C. Skinner (1970, pp. 215-216)

Ademais, o autor identificou que $70 \%$ das empresas (121) estabeleciam os preços especificamente com base nos custos mais margem. O autor também observou que, dentre essas empresas, 68\% (80) não aplicavam o mesmo percentual de margem para todos os produtos e pedidos. Dessas 80 empresas, $81 \%$ variavam a margem em função dos preços dos concorrentes, $53 \%$ em função dos clientes e $26 \%$ em função de variáveis internas, como capacidade ociosa e nível de estoques. 
Um resultado intrigante, de acordo com R. C. Skinner (1970), foi que, dentre as empresas que estabeleciam os preços com base nos custos mais margem, $80 \%$ definiam um percentual de margem destinado não só a proporcionar lucro, mas também a cobrir custos fixos. O autor ressalvou, entretanto, que esse resultado não é de todo válido, pois, diante de algumas entrevistas telefônicas, ele constatou que muitos respondentes entenderam que a questão visava identificar se os preços buscavam recuperar os custos fixos, independentemente de essa recuperação ocorrer pela margem ou diretamente pelo custo unitário. Na mesma linha desse achado, R. C. Skinner (1970) observou que era grande o número de empresas que considerava o custo variável separadamente do custo fixo para estabelecer os preços: $69 \%$.

Em seguida, a pesquisa de Atkin e Skinner (1975) expandiu o estudo desenvolvido isoladamente pelo segundo autor (R. C. Skinner, 1970). Ela foi desenvolvida mediante a aplicação de um questionário a empresas britânicas industriais de porte médio e grande. Os autores obtiveram 220 respostas e com elas concluíram que $90 \%$ das empresas investigadas usavam os custos mais margem para estabelecer os preços.

Os autores constataram, contudo, que, apesar de tamanho uso dos custos mais margem, só 59\% das empresas atinham-se exclusivamente à combinação: $41 \%$ das empresas modificavam os preços de acordo com outros tipos de considerações. Dentre esses tipos de considerações, destacavam-se os preços colocados pelos concorrentes $(81 \%)$ e as supostas reações dos clientes (31\%).

Na sequência, apareceu o trabalho desenvolvido por Gordon, Cooper, Falk, e Miller (1981). Ele foi realizado a partir de entrevistas pessoais com os principais responsáveis pelo estabelecimento dos preços de 44 empresas industriais localizadas nos Estados Unidos (22) e no Canadá (22). Os autores optaram por abranger empresas de quatro diferentes ramos (alimento, química, equipamentos de transporte e equipamentos pesados) a fim de avaliar se o tipo de produto (produzido em massa ou especializado), as condições ambientais, as características dos clientes e o tipo do mercado (oligopólio ou competição monopolística) afetavam as decisões de preços.

Gordon et al. (1981) concluíram que os custos mais margem imperavam no estabelecimento dos preços. Havia, todavia, empresas em que a decisão final era ditada pelos preços dos 
concorrentes, ainda que os custos mais margem fossem usados. Nessas empresas, a combinação "custos mais margem" era aplicada para avaliar se o produto poderia ou não ser vendido ao preço do mercado.

Os autores também verificaram que os preços eram mais estabelecidos com base nos custos quando os produtos eram diferenciados do que quando eram padronizados. Por outro lado, eles observaram que os preços eram mais estabelecidos com base no mercado quando as empresas não eram líderes e precisavam seguir os preços colocados por quem dominava o mercado.

Depois, o estudo de Piercy (1981) envolveu empresas industriais de médio porte (constantes no banco de dados da Kompass) que lidavam com exportações. O questionário do estudo foi enviado a 235 empresas localizadas no norte da Inglaterra do setor químico e do setor de maquinários industriais. 118 respostas foram obtidas.

$\mathrm{O}$ autor constatou que o estabelecimento dos preços era essencialmente uma função da concorrência, pois $35 \%$ das empresas colocavam o preço que julgavam que seria aceito no mercado, considerando o cenário competitivo, e $23 \%$ colocavam preços similares aos concorrentes. Somente $17 \%$ das empresas estabeleciam os preços adicionando uma margem de lucro ao custo total e $11 \%$ adicionando uma margem ao custo variável.

Com esses percentuais, Piercy (1981) sugeriu que a determinação dos preços em empresas exportadoras afastava-se da ênfase exagerada nos custos. Os resultados, entretanto, não são totalmente conclusivos, pois como o próprio Piercy reconheceu, o mero questionamento de qual era o principal método usado para definir os preços proporcionava uma mensuração um tanto quanto rude.

Em seguida, surgiu a pesquisa realizada por Govindarajan e Anthony (1983). Essa pesquisa visou identificar como as empresas usam informações de custos nas decisões de preços e implicou o envio de um questionário às 1.000 maiores firmas industriais norte-americanas, conforme classificação da revista Fortune. 505 respostas foram obtidas e subsidiaram a conclusão dos autores de que a ampla maioria das empresas estabelecia seus preços com base no custo total mais margem, como mostra a Tabela 5. 
Tabela 5 - Resultados da pesquisa de Govindarajan e Anthony (1983)

\begin{tabular}{|c|c|c|c|}
\hline BASE DOS PREÇOS & INFORMAÇÕES DE CUSTOS USADAS & QUANTIDADE & PERCENTUAL \\
\hline \multirow{4}{*}{$\begin{array}{c}\text { Preço Baseado no Custo } \\
\text { Total }\end{array}$} & $\begin{array}{l}\text { Custos e Despesas } \\
\text { (Variáveis e Fixos) }\end{array}$ & 208 & $41 \%$ \\
\hline & $\begin{array}{c}\text { Custos de Produção (Variáveis e Fixos) e } \\
\text { Despesas Variáveis }\end{array}$ & 41 & $8 \%$ \\
\hline & Custos de Produção (Variáveis e Fixos) & 168 & $33 \%$ \\
\hline & $\begin{array}{l}\text { Subtotal } \\
\end{array}$ & 417 & $82 \%$ \\
\hline \multirow{3}{*}{$\begin{array}{c}\text { Preço Baseado no Custo } \\
\text { Variável }\end{array}$} & Custos e Despesas Variáveis & 30 & $6 \%$ \\
\hline & Custos de Produção Variáveis & 54 & $11 \%$ \\
\hline & Subtotal & 84 & $17 \%$ \\
\hline Não respondeu à questão & Não respondeu à questão & 4 & $1 \%$ \\
\hline \multicolumn{2}{|r|}{ TOTAL } & 505 & $100 \%$ \\
\hline
\end{tabular}

Fonte: Adaptada de Govindarajan \& Anthony (1983, p. 31)

Vale mencionar que diversas críticas foram levantadas a esses achados (e.g., Bella, 1983; P. F. Smith, 1983; Owens, 1983; Bella, 1984). Uma dessas críticas (Owens, 1983) censurou as conclusões por elas terem sido pautadas em um questionário extremamente curto que somente indagava os tipos de custos considerados no estabelecimento dos preços.

De fato, não se pode negar que os resultados de Govindarajan e Anthony (1983) são restritos a demonstrar os tipos de custos usados para estabelecer os preços, sem revelar se outras variáveis, tais como a concorrência e o valor aos clientes, influenciavam os preços. Entretanto, essa restrição é mais uma delimitação do que uma limitação do estudo, pois nunca foi objetivo dos autores explicar aspectos alheios aos custos na determinação dos preços.

A seguir, despontou o estudo de Abratt e Pitt (1985) fundamentado na aplicação de um questionário a 21 empresas industriais da África do Sul (12 do setor de construção, 9 do setor químico). Essas 21 empresas, selecionadas aleatoriamente dentre todas as 17 companhias de construção e as 13 companhias químicas listadas na bolsa de Johanesburgo, responderam o questionário pessoalmente em entrevistas realizadas durante março de 1985.

Os autores concluíram que, na sua amostra, os preços eram fortemente baseados nos custos e nos concorrentes, sendo pouco influenciados pelo valor ao cliente. Especificamente, Abratt e Pitt (1985) observaram que os preços estabelecidos deveriam coincidir com os preços cobrados pelos concorrentes, ainda que fossem formados com base nos custos mais margem.

Um aspecto curioso constatado por Abratt e Pitt (1985) é que nem todas as empresas estabeleciam os preços exclusivamente com base no custo total (apenas 7). Conforme a 
Tabela 6 demonstra, das 21 empresas, 5 determinavam os preços com base unicamente nos custos variáveis e 9, dependendo da situação, determinavam os preços com base nos custos variáveis ou no custo total.

Tabela 6 - Resultados da pesquisa de Abratt e Pitt (1985)

\begin{tabular}{c|c|c|c|c}
\hline \multirow{2}{*}{ BaSE dos Preços } & \multicolumn{2}{|c|}{ SETOR DE CONSTRUÇÃO } & \multicolumn{2}{c}{ SETOR QUíMICO } \\
\cline { 2 - 5 } & QUANTIDADE & PERCENTUAL & QUANTIDADE & PERCENTUAL \\
\hline Preço com base no custo total & 4 & $33 \%$ & 3 & $33 \%$ \\
\hline Preço com base nos custos variáveis & 2 & $17 \%$ & 3 & $33 \%$ \\
\hline $\begin{array}{c}\text { Preço com base no custo total ou nos } \\
\text { custos variáveis, dependendo da } \\
\text { situação }\end{array}$ & 6 & $50 \%$ & 3 & $33 \%$ \\
\hline TotaL & $\mathbf{1 2}$ & $\mathbf{1 0 0 \%}$ & $\mathbf{9}$ & $\mathbf{1 0 0 \%}$ \\
\hline
\end{tabular}

Fonte: Adaptada de Abratt \& Pitt (1985, p. 304)

Logo após, apareceu o trabalho de Zeithaml, Parasuraman, e Berry (1985). Esse trabalho buscou comparar os problemas e as estratégias citados na literatura de marketing com aqueles de fato encontrados na prática. Ou seja, a pesquisa teve um escopo que transcendeu a mera investigação de como os preços eram estabelecidos. Os autores remeteram um questionário a uma amostra aleatória de 1.000 empresas dos Estados Unidos constantes no diretório "Dun and Bradstreet's Million Dollar" e obtiveram 323 respostas. As empresas participantes eram de variados portes e atuavam em variados ramos (industriais, comerciais e de serviço).

Os autores constataram que, na amostra investigada, os preços eram mais baseados nos custos do que baseados na concorrência e nos clientes. Especificamente, 63\% das empresas afirmaram definir os preços a partir dos custos, enquanto que $36 \%$ asseguraram determinar os preços de acordo com a concorrência e outros 36\% asseveraram estabelecer os preços conforme a disposição de pagamento dos clientes (múltiplos tipos de informação poderiam ser assinalados).

Vale mencionar que o trabalho de Zeithaml et al. (1985) é, dentre os apresentados nesta seção, aquele que recebeu o maior número de citações (3.056 citações). Apesar disso, não é comum considerá-lo como a principal referência sobre o estabelecimento dos preços, já que ele, diferentemente das outras pesquisas, não se dedica exclusivamente ao tema. $\mathrm{O}$ trabalho aborda variados problemas e estratégias de marketing, incluindo a definição dos preços, e acaba sendo citado em estudos que exploram quaisquer desses problemas e dessas estratégias. 
Depois, teve-se a pesquisa de Mills (1988), conduzida em 1986 com o envio de um questionário a 100 empresas industriais e a 100 empresas de serviços do Reino Unido. Essas 200 empresas foram selecionadas aleatoriamente em meio ao total das 7.500 maiores companhias britânicas, conforme o banco de dados, até então existente, da ELC International. 94 das 200 empresas contatadas devolveram o questionário com respostas completas.

O principal achado da pesquisa foi que a base elementar para o estabelecimento dos preços era a combinação "custos mais margem" (em 71\% das empresas industriais e em $68 \%$ das empresas de serviço). O custo predominantemente usado era o custo total (em $71 \%$ das empresas industriais e em $65 \%$ das empresas de serviço). A margem normalmente usada era a de lucro bruto na forma de um percentual sobre o preço de venda.

Apesar desse resultado, Mills (1988) constatou que os preços finais estabelecidos não eram necessariamente aqueles indicados pela combinação dos custos à margem e que informações do mercado, sobretudo referentes aos preços dos concorrentes, precisavam ser consideradas. Além disso, o autor percebeu que o custo variável era preferível ao custo total na definição de preços de pedidos especiais cuja fabricação complementava o uso da capacidade de produção.

Em seguida, apareceu o estudo de Morris e Fuller (1989) que teve o objetivo de investigar o estabelecimento de preços de serviços industriais. Ele foi realizado mediante o envio de uma carta personalizada a 268 empresas de contabilidade de Orlando (Flórida, Estados Unidos). 71 respostas completas foram obtidas de firmas de pequeno e de médio porte.

Os autores observaram que, para estabelecer os preços dos serviços contábeis, as empresas usavam fórmulas que abrangiam informações dos custos (não foi detalhado se os custos referiam-se ao custo total ou aos custos variáveis) e do lucro desejado. Vale destacar que em 81,7\% das empresas os preços variavam de acordo com o tipo do serviço oferecido, sobretudo em função da sensibilidade ao preço dos clientes e das condições atuais das demandas dos clientes. Poucas empresas $(2,8 \%)$ monitoravam os preços dos concorrentes, tendo em vista o alto grau de customização oferecido para os serviços.

Na sequência, surgiu o trabalho de Shipley e Bourdon (1990) que envolveu a remessa de questionários a 351 distribuidores britânicos de papel (listados no jornal Paper Facts and 
Figures) e a 261 distribuidores britânicos de produtos industriais (vinculados à Associação Nacional de Distribuidores Industriais). 192 respostas foram avaliadas porque 204 empresas responderam o questionário, mas 12 tiveram que ser eliminadas. A amostra, apesar de conter firmas de variados portes, abrangia principalmente pequenas e médias empresas.

Os autores concluíram que os distribuidores predominantemente baseavam-se nos custos para estabelecerem os preços, pois, conforme a Tabela 7 demonstra, eles combinavam a margem de contribuição aos custos variáveis.

Tabela 7 - Resultados da pesquisa de Shipley e Bourdon (1990)

\begin{tabular}{c|c|c|c}
\hline \multirow{2}{*}{ BASE DOS Preços } & TODOS & $\begin{array}{c}\text { PRODUTOS } \\
\text { INDUSTRIAIS }\end{array}$ & PAPEL \\
\cline { 2 - 4 } & PERCENTUAL & PERCENTUAL & PERCENTUAL \\
\hline $\begin{array}{c}\text { Margem de contribuição sobre os custos } \\
\text { variáveis }\end{array}$ & $57,5 \%$ & $53,8 \%$ & $60,4 \%$ \\
\hline Referência de preço dos concorrentes & $54,1 \%$ & $50,0 \%$ & $57,4 \%$ \\
\hline Custo total mais margem & $51,9 \%$ & $45,0 \%$ & $57,4 \%$ \\
\hline Disposição de pagamento dos clientes & $19,3 \%$ & $11,3 \%$ & $25,7 \%$ \\
\hline
\end{tabular}

Fonte: Adaptada de Shipley \& Bourdon (1990, p. 219)

A combinação dos custos variáveis à margem de contribuição ocorria com a finalidade de os preços serem os mais altos em condições favoráveis e os mais competitivos e atraentes em condições desfavoráveis. Afinal, com ela seria possível identificar preços viáveis, ainda que menores que o custo total, se as condições assim exigissem (Shipley \& Bourdon, 1990).

$\mathrm{Na}$ ampla maioria da amostra, a fórmula usada incorporava a referência de preço dos concorrentes, já que devido à oferta pouco diferenciada, poucas eram as condições de definir os próprios preços sem considerar os rivais. Parte da amostra também incorporava a disposição de pagamento dos clientes na fórmula.

Shipley e Bourdon (1990) também detectaram que a submissão aos custos não era absoluta mesmo nos casos em que a fórmula não incorporava referências externas e usava o custo total, não o custo variável. O preço baseado no custo total só era de fato cobrado quando as condições assim o permitissem. Nas outras circunstâncias, o preço indicado era apenas o ponto de partida, pois se ajustava às condições competitivas. 
Posteriormente, despontou a pesquisa de Cunningham e Hornby (1993), voltada especificamente às pequenas empresas. Os autores encaminharam cartas a 50 firmas de pequeno porte do Reino Unido, selecionadas aleatoriamente, solicitando a participação no trabalho. Dessas 50 empresas, 12 (5 industriais, 3 de serviço e 4 distribuidoras) aceitaram fazer parte dos estudos de caso.

Assim como W. W. Haynes (1964), os autores reconheceram que as pesquisas prévias vinham cometendo equívocos ao concluírem que as empresas estabeleciam os preços com base nos custos só por que consideravam informações desse tipo nas suas decisões. Para não incorrerem no mesmo erro, eles optaram por classificar uma empresa como "verdadeira" definidora de preço baseado no custo se:

a) o custo fosse o primeiro fator considerado no estabelecimento dos preços;

b) numa escala de 1 a 10, a importância de cobertura dos custos variáveis e fixos recebesse uma nota 9 ou 10 ; e

c) não fossem assinaladas mais do que duas situações em que os preços diferiram do preço indicado pelos custos mais margem.

Cunningham e Hornby (1993) observaram que 5 das 12 empresas (todas as industriais) usavam a informação do custo total no estabelecimento dos preços. Contudo, nenhuma foi classificada como "verdadeira" definidora de preço baseado no custo, já que nenhuma atendia a todas as três condições. Ou seja, os autores deram a entender que nessas 5 empresas o custo total não era a única variável considerada no estabelecimento dos preços.

Nas demais 7 empresas (não industriais) o custo total não era sequer avaliado. 4 empresas consideravam somente o custo variável e 3 empresas determinavam seus preços de uma forma totalmente independente dos custos. Em todas as 7, o valor aos clientes era de alguma forma incorporado, pois era apurado com relativa facilidade, tendo em vista a proximidade entre as pequenas empresas e seus clientes (locais).

Cunningham e Hornby (1993) relataram que a margem era o elemento que conectava os custos ao valor dos produtos. A ampla maioria das empresas indicou que as margens variavam dependendo do tamanho do pedido e do grau de diferenciação dos produtos. Quanto a esse 
último aspecto, os autores apresentaram a citação de um dos proprietários das pequenas empresas que expressava o desejo de diferenciar mais e mais os produtos, a fim de ampliar o controle sobre os preços e de torná-los mais flexíveis e coerentes ao valor.

Diante dessa citação, os autores deduziram (apressada e equivocadamente) que o estabelecimento dos preços com base no custo total era mais propício em produtos padrões com pouca diferenciação. Como conclusão geral, Cunningham e Hornby (1993) refutaram os estudos anteriores que relatavam a predominância do preço baseado no custo total, mas confirmaram a forte influência da combinação dos custos à margem nos preços. Eles sugeriram que em empresas industriais (uso do custo total) os preços eram mais baseados nos custos do que em empresas de serviço e em distribuidores (uso do custo variável). O mais interessante da pesquisa foi demonstrar que o preço poderia ser orientado pelo valor ao cliente, ainda que a sua fórmula contivesse o elemento custo.

Logo após, apareceu o trabalho de Shim e Sudit (1995) que reportou os resultados da dissertação de Shim, defendida em 1993, na qual 141 empresas industriais dos Estados Unidos responderam um questionário sobre o estabelecimento dos preços. A maior parte dessas empresas era multiprodutora e oferecia, em média, 75 tipos diferentes de produtos. $\mathrm{O}$ trabalho dos autores inspira-se na pesquisa de Govindarajan e Anthony (1983), mas transcende a mesma ao passo que aborda o uso de outras informações, além daquelas de custos, nas decisões de preços.

Os autores concluíram que $82 \%$ das empresas estabeleciam seus preços com base nos custos porque $69,5 \%$ delas usavam informações do custo total e $12,1 \%$ usavam informações do custo variável, como mostra a Tabela 8. 
Tabela 8 - Resultados da pesquisa de Shim e Sudit (1995)

\begin{tabular}{|c|c|c|c|}
\hline BASE DOS PREÇOS & INFORMAÇÕES USADAS & QUANTIDADE & PERCENTUAL \\
\hline \multirow{3}{*}{$\begin{array}{c}\text { Preço Baseado no Custo } \\
\text { Total }\end{array}$} & $\begin{array}{l}\text { Custos e Despesas } \\
\text { (Variáveis e Fixos) }\end{array}$ & 50 & $35,5 \%$ \\
\hline & $\begin{array}{l}\text { Custos de Produção (Variáveis e } \\
\text { Fixos) }\end{array}$ & 48 & $34,0 \%$ \\
\hline & Subtotal & 98 & $69,5 \%$ \\
\hline \multirow{3}{*}{$\begin{array}{c}\text { Preço Baseado no Custo } \\
\text { Variável }\end{array}$} & Custos e Despesas Variáveis & 9 & $6,4 \%$ \\
\hline & Custos de Produção Variáveis & 8 & $5,7 \%$ \\
\hline & Subtotal & 17 & $12,1 \%$ \\
\hline $\begin{array}{l}\text { Preço Baseado na } \\
\text { Concorrência }\end{array}$ & Preços dos Concorrentes & 25 & $17,7 \%$ \\
\hline Outra & Outra & 1 & $0,7 \%$ \\
\hline \multicolumn{2}{|c|}{ TOTAL } & 141 & $100,0 \%$ \\
\hline
\end{tabular}

Fonte: Adaptada de Shim \& Sudit (1995, p. 38)

Na sequência, S. Hall, Walsh, e Yates $(1997)^{3}$ reportaram os achados feitos pelo banco da Inglaterra, depois de um questionário ser enviado a aproximadamente 1.100 empresas de pequeno, médio e grande porte, de ramos industriais, comerciais e de serviço. Para esse questionário, foram obtidas 654 respostas.

Dentre os resultados apresentados, destaca-se que a maior parte dos respondentes afirmou que optava por estabelecer o preço mais alto que o mercado suportaria (39\%). Na sequência, apareciam as empresas que colocavam preços de acordo com os preços dos concorrentes (25\%) e de acordo com os custos mais margem (20\% para margem variável e $17 \%$ para margem constante). Apenas 5\% das empresas respondentes afirmaram definir os preços de acordo com informações dos clientes. Os autores chamaram a atenção às empresas construtoras, pois nelas a ordem era distinta, isto é, elas priorizavam a combinação dos custos à margem, ao invés de seguirem os preços dos concorrentes.

Ainda no mesmo ano, apareceu mais um trabalho sobre o estabelecimento dos preços, dessa vez conduzido por Myers (1997) e voltado a empresas exportadoras. Cumpre mencionar que, nessa década, a globalização ganhou força e motivou os pesquisadores a investigarem diversos aspectos das trocas comerciais entre países, incluindo a definição dos preços. Myers (1997), em específico, enviou um questionário (elaborado com base em entrevistas previamente realizadas) a empresas industriais dos Estados Unidos, cujos contatos foram

\footnotetext{
3 A pesquisa empírica também foi publicada em 2000, no periódico "Oxford Economic Papers". Logo, a contagem de citações articula ambas as publicações: S. Hall et al. (1997) e S. Hall, Walsh, e Yates (2000).
} 
localizados num banco de dados de exportadores daquele país. Das 1.840 empresas de variados portes contatadas, 369 enviaram o questionário completamente preenchido.

Myers (1997) observou que a maior parte da sua amostra usava os custos como base para os preços e dedicava pouco tempo e esforço a esse processo. De acordo com o autor, os preços eram estabelecidos a partir do acréscimo de um percentual aos custos fixos e variáveis porque poucas informações sobre o valor aos clientes e sobre os concorrentes eram coletadas.

Em consequência, muitos gestores apresentavam-se como insatisfeitos e relatavam que o mero embasamento nos custos conduzia a preços utópicos. Myers (1997) expôs o depoimento de um gestor de uma empresa exportadora de equipamentos biotecnológicos para a Europa que ilustrou essa insatisfação: "A área de Pesquisa e Desenvolvimento [da empresa] não tem ideia de quanto os nossos clientes estão dispostos ou são capazes de pagar por unidade, porém ela continua fazendo modificações desnecessárias e sofisticadas nos produtos que aumentam os custos de produção a uma extensão inviável de venda no nosso mercado" (p. 287). ${ }^{4}$

Assim, Myers (1997), apesar de não apresentar muitos detalhes, deu a entender que grande parte das empresas da sua amostra era escrava dos custos no estabelecimento dos preços. Os preços resultantes dos custos mais margem eram colocados, independentemente de serem ou não competitivos. Por isso, os gestores mostravam-se insatisfeitos e com severas dificuldades de concretizar vendas a preços ilusórios.

Logo depois, despontou o estudo de Carson, Gilmore, Cummins, O’Donnel, e Grant (1998), realizado por meio de entrevistas a gestores e a proprietários de 40 empresas de pequeno e médio porte da Irlanda do Norte. Variados ramos do serviço, do comércio e da indústria foram acessados, pois a amostra abrangia desde companhias que elaboravam vídeos publicitários até companhias que fabricavam equipamentos para produção de bebidas.

\footnotetext{
4 "R \& D has no idea what our customers are willing or able to spend per unit, yet they keep giving us fancy, unnecessary modifications that increase the production costs to such an extent that we just can't sell them in our market".
} 
A principal conclusão dos autores foi que o estabelecimento dos preços com base nos custos era o dominante, pois a maior parte das empresas definia os preços adicionando uma margem aos custos. No entanto, trechos das entrevistas revelaram que não só os custos, mas também os preços dos concorrentes impactavam os próprios preços, sendo as margens mais ou menos generosas dependendo da competição.

A maior parte das empresas tinha ciência dos preços dos concorrentes e sabia que, se desejasse cobrar mais do que eles, teria que oferecer um valor adicional aos clientes, na forma de um produto com mais qualidade, de uma entrega mais precisa etc.. Além disso, parte das empresas da amostra alterava o preço dos produtos dependendo dos clientes e enfatizava o uso dos custos variáveis (custos dos materiais).

Em seguida, surgiu o estudo de Noble e Gruca (1999a) que foi direcionado a empresas industriais norte-americanas oferecedoras de bens de capital duráveis e diferenciados no ambiente B2B. Nomes e endereços de contatos de 1.534 empresas dos Estados Unidos, de variados portes e de 15 diferentes segmentos, foram comprados da base de Dun e Bradstreet. Entre maio e junho de 1994, o questionário foi enviado por carta para 1.021 empresas (foram excluídas empresas que não possuíam o contato do respondente alvo) contendo US\$ 1 de incentivo. 347 questionários foram recebidos, mas 77 tiveram que ser eliminados por estarem em branco, incompletos ou inutilizáveis, deixando à pesquisa um total de 270 respostas.

Noble e Gruca (1999a) concluíram que as decisões de preços eram fortemente baseadas nos custos, uma vez que 56\% das empresas (152) estabeleciam os preços no ponto em que obtinham uma margem específica sobre os custos.

$\mathrm{Na}$ sequência, mais um estudo voltou-se ao estabelecimento dos preços em empresas exportadoras: Tzokas et al. (2000). Por meio do banco de dados Financial Analysis Made Easy (FAME), os autores identificaram 503 empresas de três setores industriais do Reino Unido que almejavam investigar (setores químico, de metais e de plástico). Em junho de 1997, enviaram a elas um questionário, obtendo 178 respostas.

Tzokas et al. (2000) concluíram que as empresas exportadoras do Reino Unido estabeleciam os preços predominantemente a partir dos custos mais margem. Em segundo lugar apareciam 
os preços definidos com base no valor percebido pelos clientes, em terceiro lugar apareciam os preços definidos com base nos preços dos concorrentes.

No ano seguinte, surgiu o trabalho de Mochtar e Arditi (2001). Focando na investigação sobre a definição dos preços em construtoras dos Estados Unidos, os autores enviaram um questionário aos presidentes das 400 principais empresas do país (de acordo com a edição de 25/05/1998 da revista Engineering News Record) e obtiveram 91 respostas.

Com as respostas, os autores concluíram que a ampla maioria das empresas estabelecia os preços a partir dos custos. Especificamente, 40,7\% das empresas estimavam detalhadamente os custos e colocavam uma margem sobre eles. Essa margem era definida com base nas preferências das firmas. As condições de mercado também eram consideradas para verificar se existiam ou não oportunidades para otimização dos custos e/ou se o preço intencionado seria ou não viável.

Na sequência, apareceu o trabalho de Ingenbleek et al. (2003). Os autores enviaram um questionário a 590 empresas industriais belgas constantes num banco de dados daquele país. 78 respostas foram obtidas, mas 1 teve que ser eliminada porque estava incompleta. Os ramos industriais envolvidos foram os de eletrônicos e de maquinários.

Diferentemente dos outros estudos, Ingenbleek et al. (2003) constataram que a base central para o estabelecimento dos preços estava nas informações de valor. Eles observaram que as informações da concorrência e de custos eram consideradas importantes, mas menos do que as informações de valor.

Logo depois, Amirault, Kwan, e Wilkinson $(2004 / 2005)^{5}$ publicaram um estudo cuja realização foi coordenada pelo banco central canadense. Economistas do banco entrevistaram pessoalmente representantes seniores de 170 empresas, de variados portes e ramos (industriais, comerciais e de serviço), e, assim, obtiveram a amostra da pesquisa.

\footnotetext{
${ }^{5}$ Para contagem das citações, também foi considerada a versão disponibilizada no site do Bank of Canada (Amirault, Kwan, \& Wilkinson, 2006).
} 
O trabalho focou mais na alteração do que na definição inicial dos preços, mas ainda assim discutiu sobre a importância das três diferentes abordagens de preços (custos, concorrência e valor). De acordo com os autores, a maior parte da amostra entendia definir seus preços com base nos custos e, inclusive, atribuía a não frequente alteração dos preços a também não frequente alteração nos custos de matérias-primas e de mão de obra.

Ainda no mesmo ano, teve início a primeira série de estudos apresentada nesta seção. Essa série foi elaborada por Avlonitis e Indounas, de 2004 a 2009, e é composta por nove pesquisas sobre o estabelecimento dos preços em empresas gregas de serviços (Avlonitis \& Indounas, 2004, 2005a, 2005b, 2006a, 2006b, 2007a, 2007b; Avlonitis, Indounas, \& Gounaris, 2005; Indounas \& Avlonitis, 2009).

Os autores optaram por incluir empresas de variados portes dos setores de serviços mais significativos na economia grega, no entanto excluíram o setor de educação por ele ter sido apontado como altamente regulado nas 26 entrevistas realizadas durante a fase inicial da série de estudos. Inicialmente, 1.495 empresas seriam contatadas, já que esse era o número de empresas nos setores de serviços almejados (de acordo com diretório de 2000 de um grupo denominado ICAP). Entretanto, os autores optaram por restringir a população e incluir apenas empresas com faturamento superior a 1,5 milhões de euros em 1999, o que abrangia 558 empresas, dentre as quais 464 com endereços ativos para envio dos questionários. Para os questionários remetidos, foram recebidas 170 respostas válidas.

Em cada um dos nove estudos, Avlonitis e Indounas apresentaram objetivos diferentes. No estudo de 2004, eles buscaram identificar a relação entre a estrutura de mercado e os objetivos de preços. No estudo de 2005a, eles estabeleceram a meta de identificar a relação entre os objetivos de preços e os métodos aplicados. No estudo de 2005b, eles exploraram a relação entre os objetivos de preços e as políticas de preços seguidas. No estudo de 2005 junto com Gounaris, eles investigaram a relação entre os objetivos de preços e o estágio do ciclo de vida das empresas. No estudo de 2006a, eles exploraram a relação das características do serviço, da organização e do ambiente com os métodos aplicados. No estudo de 2006b, eles investigaram a relação entre as políticas de preços e as informações analisadas. No estudo de 2007a, eles averiguaram a relação das características do serviço, da organização e do ambiente com as políticas de preços. No estudo de 2007 b, eles investigaram a relação entre os objetivos de 
preços e as informações analisadas. No estudo de 2009, com a ordem de autoria invertida (Indounas \& Avlonitis, 2009), eles exploraram a relação das características da organização e do ambiente com os objetivos de preços.

Ainda que cada estudo tenha oferecido resultados específicos de relações entre diferentes variáveis, uma conclusão geral apresentada foi referente ao predomínio do estabelecimento dos preços com base nos custos mais margem $(58,2 \%)$, seguido de perto pela colocação de preços conforme os preços dos concorrentes $(55,3 \%)$, conforme a Tabela 9 evidencia.

Tabela 9 - Resultados da primeira série de estudos de Avlonitis e Indounas

\begin{tabular}{|c|c|c|}
\hline BASE DOS PREÇOS & QUANTIDADE & Percentual \\
\hline \multicolumn{3}{|l|}{ Abordagem do Preço Baseado nos Custos } \\
\hline Custos mais margem & 99 & $58,2 \%$ \\
\hline Retorno alvo & 48 & $28,2 \%$ \\
\hline Análise do ponto de equilíbrio & 41 & $24,1 \%$ \\
\hline Custo variável mais margem de contribuição & 13 & $7,6 \%$ \\
\hline Custo marginal & 3 & $1,8 \%$ \\
\hline $\begin{array}{c}\text { SUBTOTAL } \\
\end{array}$ & 204 & \\
\hline \multicolumn{3}{|l|}{ Abordagem do Preço Baseado na Concorrência } \\
\hline Preços dos concorrentes & 94 & $55,3 \%$ \\
\hline Preço inferior aos preços dos concorrentes & 24 & $14,1 \%$ \\
\hline Preço superior aos preços dos concorrentes & 16 & $9,4 \%$ \\
\hline Preço dominante no mercado & 47 & $27,6 \%$ \\
\hline SUBTOTAL & 181 & \\
\hline \multicolumn{3}{|l|}{ Abordagem do Preço Baseado no Valor } \\
\hline Valor percebido pelos clientes & 40 & $23,5 \%$ \\
\hline Valor ao cliente & 39 & $22,9 \%$ \\
\hline Necessidades dos clientes & 46 & $27,1 \%$ \\
\hline SUBTOTAL & 125 & \\
\hline
\end{tabular}

Fonte: Adaptada de Avlonitis \& Indounas (2005a, p. 52)

Logo depois, Apel, Friberg, e Hallsten (2005) publicaram uma pesquisa desenvolvida na Suécia com o apoio de representantes do departamento nacional de estatística. Tais representantes foram os responsáveis por encaminhar o questionário a 1.285 empresas de pequeno, médio e grande porte de setores industriais e de serviço. Atuando em nome do banco central sueco, eles conseguiram a alta taxa de retorno de $48,7 \%$ e mais de 600 questionários preenchidos (a quantidade exata não foi divulgada).

O trabalho focou na alteração (não na definição inicial dos preços). Ainda assim, ele revelou que as principais causas para a alteração dos preços eram as mudanças nos preços dos concorrentes. Na sequência, apareciam as mudanças nos custos de componentes importados, as pressões de clientes considerados importantes, as mudanças na demanda, as mudanças nos 
custos internos e, finalmente, as mudanças em impostos e taxas. No que se refere especificamente à margem imposta sobre os custos, o trabalho também demonstrou que as empresas normalmente preferiam sua relativa constância, de tal forma que a proporção de aumento nos custos acabava sendo a mesma proporção de aumento nos preços.

No mesmo ano, surgiu o estudo de Fabiani et al. $(2005)^{6}$ que hoje está entre os três trabalhos mais citados sobre o tema. Nesse estudo, os autores sumarizaram levantamentos sobre o estabelecimento dos preços em nove países adotantes do euro como moeda (Alemanha, Áustria, Bélgica, Espanha, França, Holanda, Itália, Luxemburgo e Portugal). Esses levantamentos foram conduzidos entre 2003 e 2004, quando essas nações representavam 94\% do PIB gerado na zona do euro, e contemplaram respostas de 11.038 empresas. Na França e na Holanda, somente empresas industriais fizeram parte do estudo, mas nos demais países, empresas comerciais e de serviço também participaram. Os portes acessados foram variados.

Vale ressaltar que os nove levantamentos, além de poderem ser consultados de forma articulada e sumarizada no trabalho de Fabiani et al. (2005), podem ser extraídos individualmente na forma de working papers disponíveis na base de pesquisas do Banco Central Europeu ${ }^{7}$. Todos eles foram realizados de forma descentralizada pelo banco central de cada um dos nove países (direta ou indiretamente por meio de instituto de pesquisa).

Os levantamentos, apesar de apresentarem características peculiares no que se refere à forma de aplicação, ao tamanho da amostra e ao mercado objeto de pesquisa (Tabela 10), indagaram e observaram aspectos comuns do estabelecimento dos preços, o que viabilizou sua articulação no estudo de Fabiani et al. (2005).

\footnotetext{
${ }^{6}$ O trabalho também foi publicado em 2006 no periódico "International Journal of Central Banking”. Logo, a contagem de citações articula ambas as publicações: Fabiani et al. (2005) e Fabiani et al. (2006).

${ }^{7}$ Stahl (2005) referente à Alemanha; Kwapil, Baumgartner e Scharler (2005) referente à Áustria; Aucremanne e Druant (2005) referente à Bélgica; Álvarez e Hernando (2005) referente à Espanha; Loupias e Ricart (2004) referente à França; Hoeberichts e Stokman (2006) referente à Holanda; Fabiani, Gattulli e Sabbatini (2004) referente à Itália; Lünnemann e Mathä (2006) referente a Luxemburgo; e F. Martins (2005) referente a Portugal.
} 
Tabela 10 - Características dos levantamentos reportados por Fabiani et al. (2005)

\begin{tabular}{|c|c|c|c|c|c|c|}
\hline PAÍS & $\begin{array}{c}\text { PERÍODO DO } \\
\text { LEVANTAMENTO }\end{array}$ & $\begin{array}{c}\text { CONDUÇÃO DO } \\
\text { LEVANTAMENTO }\end{array}$ & $\begin{array}{c}\text { FORMA DA } \\
\text { APLICAÇÃO }\end{array}$ & AMOSTRA & $\begin{array}{c}\text { TAMANHO DA } \\
\text { AMOSTRA/TAXA } \\
\text { DE RESPOSTA } \\
\end{array}$ & $\begin{array}{c}\text { MERCADO } \\
\text { DE } \\
\text { REFERÊNCIA }\end{array}$ \\
\hline Bélgica & Fevereiro/2004 & $\begin{array}{c}\text { Banque } \\
\text { Nationale de } \\
\text { Belgique }\end{array}$ & Carta tradicional & $\begin{array}{c}\text { Amostra } \\
\text { existente no } \\
\text { levantamento } \\
\text { mensal do } \\
\text { Banque } \\
\text { Nationale de } \\
\text { Belgique } \\
\end{array}$ & $\approx 5.600 / 35 \%$ & $\begin{array}{l}\text { Mercado } \\
\text { principal }\end{array}$ \\
\hline Alemanha & Junho-Julho/2004 & $\begin{array}{l}\text { Instituto externo } \\
\text { (IFO) }\end{array}$ & Carta tradicional & $\begin{array}{c}\text { Amostra } \\
\text { existente no } \\
\text { levantamento } \\
\text { mensal do } \\
\text { IFO } \\
\end{array}$ & $\approx 2.740 / 46 \%$ & $\begin{array}{l}\text { Mercado } \\
\text { doméstico }\end{array}$ \\
\hline Espanha & $\begin{array}{c}\text { Maio- } \\
\text { Setembro/2004 }\end{array}$ & Companhia externa & $\begin{array}{l}\text { Carta tradicional } \\
\text { com prévio } \\
\text { contato por } \\
\text { telefone } \\
\text { (respostas por } \\
\text { carta, telefone, } \\
\text { fax e internet) } \\
\end{array}$ & $\begin{array}{c}\text { Amostra } \\
\text { definida pelo } \\
\text { Banco de } \\
\text { Espana }\end{array}$ & $\approx 3.000 / 69 \%$ & $\begin{array}{l}\text { Mercado } \\
\text { principal }\end{array}$ \\
\hline França & $\begin{array}{l}\text { Dezembro/2003 a } \\
\text { Fevereiro/2004 }\end{array}$ & $\begin{array}{c}\text { Banque de } \\
\text { France branches }\end{array}$ & $\begin{array}{c}\text { Carta tradicional } \\
\text { com prévio } \\
\text { contato por } \\
\text { telefone, } \\
\text { entrevista por } \\
\text { telefone, } \\
\text { entrevista pessoal } \\
\end{array}$ & $\begin{array}{c}\text { Amostra } \\
\text { existente no } \\
\text { levantamento } \\
\text { mensal do } \\
\text { Banque de } \\
\text { France } \\
\text { branches } \\
\end{array}$ & $\approx 4.300 / 38 \%$ & $\begin{array}{l}\text { Mercado } \\
\text { doméstico }\end{array}$ \\
\hline Itália & $\begin{array}{l}\text { Fevereiro- } \\
\text { Março/2003 }\end{array}$ & $\begin{array}{l}\text { Companhia externa } \\
\text { (poster s.r.I) }\end{array}$ & $\begin{array}{l}\text { Carta tradicional } \\
\text { com prévio } \\
\text { contato por } \\
\text { telefone (retorno } \\
\text { poderia ser por } \\
\text { fax) } \\
\end{array}$ & $\begin{array}{c}\text { Amostra } \\
\text { definida pelo } \\
\text { Banco da } \\
\text { Itália }\end{array}$ & $729 / 46 \%$ & $\begin{array}{l}\text { Mercado } \\
\text { principal }\end{array}$ \\
\hline Luxemburgo & $\begin{array}{c}\text { Agosto- } \\
\text { Novembro/2004 }\end{array}$ & $\begin{array}{l}\text { Banque centrale } \\
\text { du Luxembourg }\end{array}$ & Carta tradicional & $\begin{array}{c}\text { Amostra } \\
\text { definida pelo } \\
\text { Instituto } \\
\text { Nacional de } \\
\text { Estatística }\end{array}$ & $\approx 1.100 / 30 \%$ & $\begin{array}{l}\text { Mercado } \\
\text { doméstico }\end{array}$ \\
\hline Holanda & Maio/2004 & $\begin{array}{l}\text { Instituto externo } \\
\text { (TNS-NIPO) }\end{array}$ & Internet & $\begin{array}{c}\text { Painel de } \\
\text { empresários } \\
\text { com os níveis } \\
\text { mais altos de } \\
\text { gestão }\end{array}$ & $1.870 / 67 \%$ & $\begin{array}{c}\text { Não } \\
\text { especificado }\end{array}$ \\
\hline Áustria & $\begin{array}{c}\text { Janeiro- } \\
\text { Fevereiro/2004 }\end{array}$ & $\begin{array}{l}\text { Instituto austríaco } \\
\text { de pesquisas } \\
\text { econômicas } \\
\text { (WIFO) }\end{array}$ & Carta tradicional & $\begin{array}{c}\text { Amostra } \\
\text { existente no } \\
\text { levantamento } \\
\text { do ciclo de } \\
\text { negócios } \\
\text { austríaco } \\
\end{array}$ & $\approx 2.500 / 36 \%$ & $\begin{array}{l}\text { Mercado } \\
\text { principal }\end{array}$ \\
\hline Portugal & $\begin{array}{c}\text { Maio- } \\
\text { Setembro/2004 }\end{array}$ & Banco de Portugal & $\begin{array}{l}\text { Carta tradicional } \\
\text { (retorno em } \\
\text { papel, por email } \\
\text { ou por site) }\end{array}$ & $\begin{array}{l}\text { Amostra } \\
\text { existente no } \\
\text { banco de } \\
\text { dados do } \\
\text { Banco de } \\
\text { Portugal }\end{array}$ & $2.494 / 55 \%$ & $\begin{array}{c}\text { Não } \\
\text { especificado }\end{array}$ \\
\hline
\end{tabular}

Fonte: Fabiani et al. (2005, p. 37)

Dentre os diversos achados, Fabiani et al. (2005) ressaltaram a predominância do estabelecimento dos preços com base nos custos. Os autores trouxeram a Tabela 11 para apresentar os resultados apurados em cada país (exceto para Áustria e Luxemburgo) e para demonstrar que 54\% da amostra global (ponderada pelo Gross Domestic Product - GDP, ou 
seja, pelo Produto Interno Bruto - PIB) somavam os custos à margem e 27\% espelhavam os preços colocados pelos concorrentes.

Tabela 11 - Resultados da pesquisa de Fabiani et al. (2005)

\begin{tabular}{|c|c|c|c|c|c|c|c|c|c|c|c|c|c|c|}
\hline \multirow[b]{2}{*}{$\begin{array}{l}\text { BASE dOS } \\
\text { PREÇOS }\end{array}$} & \multicolumn{3}{|c|}{ BÉLGICA (\%) } & \multicolumn{3}{|c|}{ ALEMANHA (\%) } & \multirow[b]{2}{*}{$\begin{array}{c}\text { ESPANHA } \\
(\%)\end{array}$} & \multirow[b]{2}{*}{$\begin{array}{l}\text { FRANÇA } \\
(\%)\end{array}$} & \multirow[b]{2}{*}{$\begin{array}{l}\text { ITÁLIAA } \\
(\%)\end{array}$} & \multicolumn{3}{|c|}{ HOLANDA } & \multirow[b]{2}{*}{$\begin{array}{c}\text { PORTUGAL } \\
(\%)\end{array}$} & \multirow{2}{*}{$\begin{array}{c}\text { ZONA } \\
\text { DO } \\
\text { EURO } \\
(\%)\end{array}$} \\
\hline & Total & $\begin{array}{c}\text { Margem } \\
\text { Constante }\end{array}$ & $\begin{array}{l}\text { Margem } \\
\text { Variável }\end{array}$ & Total & $\begin{array}{c}\text { Margem } \\
\text { Constante }\end{array}$ & $\begin{array}{l}\text { Margem } \\
\text { Variável }\end{array}$ & & & & $\begin{array}{c}\text { Total } \\
(\%)\end{array}$ & $\begin{array}{c}\text { Margem } \\
\text { Constante } \\
(\%)\end{array}$ & $\begin{array}{c}\text { Margem } \\
\text { Variável } \\
(\%\end{array}$ & & \\
\hline $\begin{array}{c}\text { Custos mais } \\
\text { Margem }\end{array}$ & $46 \%$ & $13 \%$ & $33 \%$ & $73 \%$ & $4 \%$ & $69 \%$ & $52 \%$ & $40 \%$ & $42 \%$ & $56 \%$ & $27 \%$ & $30 \%$ & $65 \%$ & $54 \%$ \\
\hline $\begin{array}{c}\text { Preço dos } \\
\text { Concorrentes }\end{array}$ & $36 \%$ & & & $17 \%$ & & & $27 \%$ & $38 \%$ & $32 \%$ & $22 \%$ & & & $13 \%$ & $27 \%$ \\
\hline Outro & $18 \%$ & & & $10 \%$ & & & $21 \%$ & $22 \%$ & $26 \%$ & $21 \%$ & & & $23 \%$ & $18 \%$ \\
\hline
\end{tabular}

Fonte: Fabiani et al. (2005, p. 14)

É importante, contudo, ressaltar que esses resultados estão sujeitos a críticas, sobretudo, porque os questionários de alguns países (e.g., o aplicado na Espanha) limitavam a escolha do respondente ao estabelecimento dos preços com base nos custos mais margem ou com base nos preços dos concorrentes, tornando sua dominância óbvia (não havia outra opção a ser assinalada).

Outro ponto interessante de mencionar é que todos os levantamentos que investigaram se a margem colocada sobre os custos era constante ou variável (Bélgica, Alemanha e Holanda) constataram que a segunda situação era, de longe, a mais comum. Na Alemanha, por exemplo, enquanto somente $4 \%$ das empresas definiam os preços em função de uma margem única e constante colocada sobre os custos, $69 \%$ das empresas tomavam os custos como referência, mas variavam a margem levando em conta condições competitivas e do mercado.

Ainda em 2005, despontou mais um estudo sobre o estabelecimento dos preços: Forman e Hunt (2005) investigaram o tema em empresas industriais dos Estados Unidos que lidavam com exportações. Os autores enviaram questionários a 1.044 empresas e, após eliminarem respostas com negativas de participação e com respostas incompletas, conseguiram trabalhar com 135 questionários completos.

Os autores constataram que a combinação dos custos à margem estava entre as formas predominantes de estabelecer os preços (embora não tenham divulgado o percentual). Eles também asseguraram que o uso da combinação estava positivamente associado à confiança nos dados internos (não nos dados externos) para a determinação dos preços. 
Findando o ano de 2005, surgiu a pesquisa de Guilding et al. (2005) fundamentada na aplicação de um questionário a empresas do Reino Unido e da Austrália. No Reino Unido, o questionário foi encaminhado a 631 empresas com fins lucrativos que empregavam dois ou mais membros do Instituto de Contadores Gerenciais (Chartered Institute of Management Accountants - CIMA) com mais de cinco anos de experiência. 187 empresas, do total de 631, devolveram o questionário preenchido. Na Austrália, o questionário seria encaminhado para todas as 300 maiores empresas, conforme o banco de dados do Shareholder, mas como 20 não tiveram os contatos identificados, ele foi remetido a 280 companhias. 90 respostas foram obtidas. No fim, as empresas componentes da amostra eram de variados portes e de variados ramos da indústria, do comércio e do serviço de ambos os locais.

Guilding et al. (2005) constataram que aproximadamente $65 \%$ das empresas tinham os preços estabelecidos por meio da soma de uma margem aos custos e, além disso, consideravam tal soma importante (ou muito importante) para o processo.

Logo na sequência, apareceu o trabalho de Drury e Tayles (2006) que se voltou à investigação de empresas do Reino Unido de variados portes e setores. Um questionário foi remetido às 631 empresas com fins lucrativos que atuavam com dois ou mais membros do CIMA detentores de mais de cinco anos de experiência. 350 respostas foram obtidas, mas apenas 187 continham o questionário completo e puderam compor a análise dos resultados.

Observa-se, portanto, que o questionário usado neste trabalho é o mesmo usado em Guilding et al. (2005). Apesar disso, os resultados apresentados diferem um pouco daqueles (já mostrados) porque não incluem as respostas das empresas australianas. Por exemplo, Drury e Tayles (2006) apuraram que 60\% das empresas (112), não 65\%, estabeleciam os preços somando uma margem aos custos.

Nesse trabalho, Drury e Tayles (2006) também constataram que as informações de custos usadas para serem somadas à margem e indicarem os preços eram diferentes daquelas informações usadas para analisar a lucratividade dos produtos nos casos em que os preços eram ditados pelo mercado. Como a Tabela 12 evidencia, enquanto a utilização dos custos variáveis $(52 \%)$ prevalecia nas situações em que o preço era tomado, a utilização dos custos totais $(77 \%)$ prevalecia nas situações em que o preço era formado. 
Tabela 12 - Resultados da pesquisa de Drury e Tayles (2006)

\begin{tabular}{c|c|c}
\hline INFORMAÇões DE CUSTOS USADAS & $\begin{array}{c}\text { ANÁLISE DE } \\
\text { LUCRATIVIDADE } \\
\text { (PERCENTUAL) }\end{array}$ & $\begin{array}{c}\text { FORMAÇÃO DOS PREÇOS } \\
\text { (PERCENTUAL) }\end{array}$ \\
\hline $\begin{array}{c}\text { Custos variáveis apenas } \\
\text { Custos diretos somados aos custos indiretos passíveis de } \\
\text { apuração por causa e efeito }\end{array}$ & $6 \%$ & $16 \%$ \\
\hline $\begin{array}{c}\text { Custos diretos somados a todos os custos indiretos } \\
\text { (passíveis de apuração por causa e efeito e } \\
\text { arbitrariamente alocados) }\end{array}$ & $42 \%$ & $\mathbf{7 7 \%}$ \\
\hline
\end{tabular}

Fonte: Adaptada de Drury \& Tayles (2006, p. 416)

Os autores também observaram que nem sempre os custos tinham um papel crucial nas decisões de preços. Em algumas situações, os custos, tanto os variáveis quanto os totais, representavam apenas uma das diversas informações que influenciavam as deliberações. Isto é, a utilização dos custos não significava necessariamente que os preços eram estabelecidos com base exclusiva nos custos, pois outros tipos de informações (e.g., preços dos concorrentes) poderiam sobrepor-se a eles.

Anos depois, surgiu mais uma série de estudos. Desta vez, Greenslade e Parker $\left(2008,2012^{8}\right)$ divulgaram em duas pesquisas os resultados mais atualizados de um novo levantamento conduzido pelo banco da Inglaterra. 2.331 empresas industriais, comerciais e de serviço de pequeno, médio e grande porte foram contatadas, sendo que 693 responderam um questionário e passaram a compor a amostra do estudo.

Um ponto interessante reportado no artigo de 2008 é que, apesar de a maior parte das empresas (52\%) ter condições de identificar com facilidade os preços dos concorrentes, parcela significativa relatava dificuldades $(40 \%)$ ou mesmo impossibilidade $(7 \%)$ de coletar tal tipo de informação. Ainda assim, como divulga o artigo de 2012, a quantidade mais expressiva de empresas (68\%) pautava seus preços nos preços dos concorrentes. Somente na sequência, apareciam os preços estabelecidos a partir dos custos mais margem: $58 \%$ a partir de uma margem variável e $44 \%$ a partir de uma margem constante.

Ainda no mesmo ano, teve início mais uma série de estudos coordenada por Indounas. Depois de obter uma nova base amostral, a partir do encaminhamento de um novo questionário a uma amostra aleatória de 600 empresas de variados portes dos ramos de transporte e de tecnologia

\footnotetext{
${ }^{8}$ Para contagem das citações, também foi considerada a versão disponibilizada no site do Bank of England (Greenslade \& Parker, 2010).
} 
de informação, o autor publicou mais três pesquisas. Foram obtidas 177 respostas, 129 de empresas de transporte e 48 de empresas de tecnologia de informação (Indounas, 2008; Indounas, 2009; Indounas \& Avlonitis, 2011).

No estudo de 2008, Indounas, investigou a relação entre os objetivos de preços e os fatores que conduziam a um comportamento não ético de definição de preços. No estudo de 2009, Indounas averiguou a relação do desempenho dos preços com os objetivos, os métodos e as políticas de preços, bem como com as informações usadas no estabelecimento dos preços. No estudo de 2011, com Avlonitis, Indounas pesquisou a relação entre as estratégias de preços e as características de serviço, da estrutura corporativa, dos clientes e da concorrência.

Os três estudos, apesar de terem revelado resultados específicos sobre as diferentes associações entre as variáveis, relataram, novamente, o predomínio do estabelecimento dos preços a partir dos custos. Indounas (2009) concluiu que a soma dos custos à margem era a principal forma de determinar os preços (na escala de 1 a 5 , essa forma obteve média de 3,72 ) seguida pela colocação de preços similares aos preços dos concorrentes (média de 3,65).

Vale mencionar que, recentemente, Indounas deu início a uma nova série de estudos. Nos artigos já publicados dessa série (Indounas, 2014; Indounas, 2015), o autor ainda não reportou resultados específicos sobre as formas de estabelecimento dos preços. Contudo, conhecendo a estratégia de pesquisa do autor, sabe-se que os questionários provavelmente indagaram esse aspecto e que, portanto, futuros estudos possivelmente atualizarão as constatações das pesquisas anteriores.

Os dois artigos publicados são praticamente iguais: colocam os mesmos objetivos, apresentam as mesmas hipóteses, chegam às mesmas conclusões e, aparentemente, usam as mesmas respostas aos questionários. A única diferença entre os estudos é a quantidade de ramos acessados. Ao que parece, Indounas optou por divulgar seus resultados duas vezes, uma mais expandida e outra restrita a menos ramos, conforme exposto na sequência.

No trabalho de 2014, Indounas investigou associações entre as variáveis contextuais e a existência de uma precificação estratégica e entre a existência de uma precificação estratégica e o desempenho das empresas. Sua pesquisa abrangeu os sete principais segmentos de 
serviços industriais na Grécia (logística, serviços financeiros, tecnologia da informação, serviços profissionais, linhas áreas, hotéis e manutenção de navios). Pautando-se no banco de dados da ICAP, Indounas identificou que 2.346 firmas poderiam fazer parte da pesquisa, mas optou por enviar o questionário aleatoriamente a apenas 1.500 empresas, das quais recebeu 301 respostas completas.

No estudo de 2015, o autor investigou as mesmas relações. Só que, dessa vez, selecionou aleatoriamente somente empresas dos quatro principais ramos gregos de serviços industriais (logística, serviços financeiros, tecnologia da informação e serviços profissionais). Dos 800 questionários enviados aleatoriamente, 154 foram recebidos completamente preenchidos e utilizados na análise dos dados.

Assim, com essa expectativa de que em breve serão publicados novos estudos sobre o tema, encerra-se a revisão. Entretanto, antes de finalizar a seção, vale apresentar a Tabela 13 para sumarizar as conclusões centrais de cada artigo e, dessa forma, identificar qual foi a constatação geral das pesquisas empíricas mais citadas. 
Tabela 13 - Sumário dos resultados das pesquisas empíricas mais citadas

\begin{tabular}{|c|c|c|c|c|c|c|}
\hline ESTUDO & LOCAL & AMOSTRA & PORTE & RAMO & $\begin{array}{l}\text { PRINCIPAL CONCLUSÃO } \\
\end{array}$ & CITAÇÕES \\
\hline $\begin{array}{l}\text { R. I. Hall e } \\
\text { Hitch (1939) }\end{array}$ & Reino Unido & 38 & $\begin{array}{l}\text { Não } \\
\text { mencionado }\end{array}$ & $\begin{array}{l}\text { Indústria e } \\
\text { comércio }\end{array}$ & $\begin{array}{l}\text { A maior parte das empresas estabelece os } \\
\text { preços a partir da combinação “custos mais } \\
\text { margem". Dependendo dos preços dos } \\
\text { concorrentes e das condições competitivas, } \\
\text { a margem é modificada. }\end{array}$ & 1.247 \\
\hline $\begin{array}{l}\text { W. W. Haynes } \\
\text { (1964) }\end{array}$ & $\begin{array}{l}\text { Estados } \\
\text { Unidos }\end{array}$ & 88 & $\begin{array}{l}\text { Pequenas } \\
\text { empresas }\end{array}$ & $\begin{array}{l}\text { Indústria, } \\
\text { comércio e } \\
\text { serviço }\end{array}$ & \begin{tabular}{|c|} 
A maior parte das empresas estabelece os \\
preços a partir da combinação "custos mais \\
margem". Entretanto, os preços baseados \\
estritamente na combinação são exceção e \\
não regra. As margens normalmente são \\
variáveis e incorporam aspectos referentes \\
à concorrência e aos clientes. \\
\end{tabular} & 25 \\
\hline $\begin{array}{l}\text { R. C. Skinner } \\
\text { (1970) }\end{array}$ & Inglaterra & 179 & $\begin{array}{l}\text { Variados } \\
\text { portes }\end{array}$ & Indústria & $\begin{array}{l}\text { A maior parte das empresas estabelece os } \\
\text { preços a partir da combinação “custos mais } \\
\text { margem”. O percentual da margem não é o } \\
\text { mesmo para todos os produtos e pedidos, } \\
\text { variando, sobretudo, em função dos preços } \\
\text { dos concorrentes. }\end{array}$ & 75 \\
\hline $\begin{array}{c}\text { Atkin e } \\
\text { Skinner (1975) }\end{array}$ & $\begin{array}{l}\text { Grã- } \\
\text { Bretanha }\end{array}$ & 220 & $\begin{array}{l}\text { Médias e } \\
\text { grandes } \\
\text { empresas }\end{array}$ & Indústria & $\begin{array}{c}\text { A maior parte das empresas estabelece os } \\
\text { preços a partir da combinação “custos mais } \\
\text { margem”. Os preços formados a partir dos } \\
\text { custos podem ser modificados dependendo } \\
\text { dos preços dos concorrentes e da suposta } \\
\text { reação dos clientes. } \\
\end{array}$ & 39 \\
\hline $\begin{array}{l}\text { Gordon et al. } \\
\quad(1981)\end{array}$ & $\begin{array}{l}\text { Estados } \\
\text { Unidos e } \\
\text { Canadá }\end{array}$ & 44 & $\begin{array}{l}\text { Não } \\
\text { mencionado }\end{array}$ & Indústria & $\begin{array}{c}\text { A maior parte das empresas estabelece os } \\
\text { preços a partir da combinação “custos mais } \\
\text { margem”. Entretanto, os preços dos } \\
\text { concorrentes podem ditar o preço final. } \\
\end{array}$ & 34 \\
\hline Piercy (1981) & Inglaterra & 118 & $\begin{array}{l}\text { Médias } \\
\text { empresas }\end{array}$ & $\begin{array}{l}\text { Indústria - } \\
\text { Exportação }\end{array}$ & $\begin{array}{l}\text { A maior parte das empresas estabelece os } \\
\text { preços com base nos preços dos concorrentes. } \\
\text { Ainda assim, há empresas que estabelecem os } \\
\text { preços a partir da combinação "custos mais } \\
\text { margem". }\end{array}$ & 123 \\
\hline $\begin{array}{l}\text { Govindarajan e } \\
\text { Anthony } \\
\text { (1983) }\end{array}$ & $\begin{array}{l}\text { Estados } \\
\text { Unidos }\end{array}$ & 505 & $\begin{array}{l}\text { Grandes } \\
\text { empresas }\end{array}$ & Indústria & $\begin{array}{l}\text { A maior parte das empresas estabelece os } \\
\text { preços com base nos custos totais. }\end{array}$ & 155 \\
\hline $\begin{array}{l}\text { Abratt e Pitt } \\
\quad(1985)\end{array}$ & $\begin{array}{l}\text { África do } \\
\text { Sul }\end{array}$ & 21 & $\begin{array}{l}\text { Não } \\
\text { mencionado }\end{array}$ & $\begin{array}{l}\text { Indústria e } \\
\text { engenharia }\end{array}$ & $\begin{array}{l}\text { A maior parte das empresas estabelece os } \\
\text { preços a partir da combinação “custos mais } \\
\text { margem". Entretanto, os preços precisam } \\
\text { assemelhar-se aos preços dos concorrentes. }\end{array}$ & 67 \\
\hline $\begin{array}{l}\text { Zeithaml et al. } \\
\quad(1985)\end{array}$ & $\begin{array}{l}\text { Estados } \\
\text { Unidos }\end{array}$ & 323 & $\begin{array}{l}\text { Variados } \\
\text { portes }\end{array}$ & $\begin{array}{l}\text { Indústria, } \\
\text { comércio e } \\
\text { serviço }\end{array}$ & $\begin{array}{c}\text { A maior parte das empresas estabelece os } \\
\text { preços a partir da combinação "custos mais } \\
\text { margem". }\end{array}$ & 3.056 \\
\hline Mills (1988) & Reino Unido & 94 & $\begin{array}{l}\text { Grandes } \\
\text { empresas }\end{array}$ & $\begin{array}{l}\text { Indústria e } \\
\text { serviço }\end{array}$ & $\begin{array}{c}\text { A maior parte das empresas estabelece os } \\
\text { preços a partir da combinação "custos mais } \\
\text { margem". Os preços são influenciados } \\
\text { pelos preços dos concorrentes. } \\
\end{array}$ & 33 \\
\hline $\begin{array}{l}\text { Morris e Fuller } \\
\quad(1989)\end{array}$ & $\begin{array}{l}\text { Estados } \\
\text { Unidos }\end{array}$ & 71 & $\begin{array}{l}\text { Pequenas e } \\
\text { médias } \\
\text { empresas }\end{array}$ & Serviço & $\begin{array}{l}\text { A maior parte das empresas estabelece os } \\
\text { preços a partir da combinação “custos mais } \\
\text { margem". Os preços variam de acordo com } \\
\text { o serviço oferecido. }\end{array}$ & 92 \\
\hline $\begin{array}{l}\text { Shipley e } \\
\text { Bourdon } \\
\text { (1990) }\end{array}$ & $\begin{array}{c}\text { Grã- } \\
\text { Bretanha }\end{array}$ & 192 & $\begin{array}{l}\text { Variados } \\
\text { portes }\end{array}$ & Indústria & \begin{tabular}{|c|}
$\begin{array}{c}\text { A maior parte das empresas estabelece os } \\
\text { preços a partir da combinação “custos mais } \\
\text { margem”. A fórmula usada incorporava o } \\
\text { preço dos concorrentes. }\end{array}$ \\
\end{tabular} & 35 \\
\hline $\begin{array}{l}\text { Cunningham e } \\
\text { Hornby (1993) }\end{array}$ & Reino Unido & 12 & $\begin{array}{l}\text { Pequenas } \\
\text { empresas }\end{array}$ & $\begin{array}{l}\text { Indústria, } \\
\text { comércio e } \\
\text { serviço }\end{array}$ & $\begin{array}{l}\text { A maior parte das empresas estabelece os } \\
\text { preços a partir da combinação “custos mais } \\
\text { margem”. Entretanto, os preços não se } \\
\text { atém exclusivamente a essa combinação e } \\
\text { variam de acordo com a diferenciação dos } \\
\text { produtos. } \\
\end{array}$ & 38 \\
\hline $\begin{array}{l}\text { Shim e Sudit } \\
\quad(1995)\end{array}$ & $\begin{array}{l}\text { Estados } \\
\text { Unidos }\end{array}$ & 141 & $\begin{array}{l}\text { Variados } \\
\text { portes }\end{array}$ & Indústria & $\begin{array}{l}\text { A maior parte das empresas estabelece os } \\
\text { preços a partir da combinação "custos mais } \\
\text { margem". }\end{array}$ & 126 \\
\hline
\end{tabular}




\begin{tabular}{|c|c|c|c|c|c|c|}
\hline ESTUDO & LOCAL & AMOSTRA & PORTE & RAMO & $\begin{array}{l}\text { PRINCIPAL CONCLUSÃO } \\
\end{array}$ & CITAÇÕES \\
\hline $\begin{array}{l}\text { S. Hall et al. } \\
\text { (1997) }\end{array}$ & Reino Unido & 654 & $\begin{array}{c}\text { Variados } \\
\text { portes }\end{array}$ & $\begin{array}{l}\text { Indústria, } \\
\text { comércio e } \\
\text { serviço }\end{array}$ & $\begin{array}{l}\text { A maior parte das empresas estabelece os } \\
\text { preços máximos que o mercado suporta. } \\
\text { Ainda assim, há empresas que estabelecem os } \\
\text { preços com base nos preços dos concorrentes } \\
\text { e a partir da combinação "custos mais } \\
\text { margem". }\end{array}$ & 314 \\
\hline Myers (1997) & $\begin{array}{l}\text { Estados } \\
\text { Unidos }\end{array}$ & 369 & $\begin{array}{l}\text { Variados } \\
\text { portes }\end{array}$ & $\begin{array}{l}\text { Indústria - } \\
\text { Exportação }\end{array}$ & $\begin{array}{l}\text { A maior parte das empresas estabelece os } \\
\text { preços a partir da combinação “custos mais } \\
\text { margem". O embasamento exclusivo na } \\
\text { combinação conduz a preços utópicos. }\end{array}$ & 47 \\
\hline $\begin{array}{c}\text { Carson et al. } \\
\quad(1998)\end{array}$ & $\begin{array}{l}\text { Irlanda do } \\
\text { Norte }\end{array}$ & 40 & $\begin{array}{l}\text { Pequenas e } \\
\text { médias } \\
\text { empresas }\end{array}$ & $\begin{array}{l}\text { Indústria, } \\
\text { comércio e } \\
\text { serviço }\end{array}$ & $\begin{array}{l}\text { A maior parte das empresas estabelece os } \\
\text { preços a partir da combinação “custos mais } \\
\text { margem". Entretanto, as margens eram } \\
\text { mais ou menos generosas dependendo da } \\
\text { competição. } \\
\end{array}$ & 72 \\
\hline $\begin{array}{l}\text { Noble e Gruca } \\
\quad(1999 a)\end{array}$ & $\begin{array}{l}\text { Estados } \\
\text { Unidos }\end{array}$ & 270 & $\begin{array}{l}\text { Variados } \\
\text { portes }\end{array}$ & Indústria & $\begin{array}{c}\text { A maior parte das empresas estabelece os } \\
\text { preços a partir da combinação “custos mais } \\
\text { margem”. }\end{array}$ & 240 \\
\hline $\begin{array}{c}\text { Tzokas et al. } \\
\text { (2000) }\end{array}$ & Reino Unido & 178 & $\begin{array}{c}\text { Não } \\
\text { mencionado }\end{array}$ & $\begin{array}{l}\text { Indústria - } \\
\text { Exportação }\end{array}$ & $\begin{array}{l}\text { A maior parte das empresas estabelece os } \\
\text { preços a partir da combinação “custos mais } \\
\text { margem". }\end{array}$ & 63 \\
\hline $\begin{array}{c}\text { Mochtar e } \\
\text { Arditi (2001) }\end{array}$ & $\begin{array}{l}\text { Estados } \\
\text { Unidos }\end{array}$ & 91 & $\begin{array}{c}\text { Não } \\
\text { mencionado }\end{array}$ & Engenharia & $\begin{array}{l}\text { A maior parte das empresas estabelece os } \\
\text { preços a partir da combinação “custos mais } \\
\text { margem”. As condições de mercado são } \\
\text { incorporadas para evidenciar } \\
\text { oportunidades de otimização dos custos } \\
\text { e/ou a viabilidade do preço intencionado. }\end{array}$ & 58 \\
\hline $\begin{array}{l}\text { Ingenbleek et } \\
\text { al. (2003) }\end{array}$ & Bélgica & 77 & $\begin{array}{c}\text { Não } \\
\text { mencionado }\end{array}$ & Indústria & $\begin{array}{c}\text { A maior parte das empresas estabelece os } \\
\text { preços a partir de informações de valor. Ainda } \\
\text { assim, informações da concorrência e de } \\
\text { custos também são importantes para o } \\
\text { processo. }\end{array}$ & 99 \\
\hline $\begin{array}{c}\text { Amirault et al. } \\
(2004 / 2005)\end{array}$ & Canadá & 170 & $\begin{array}{l}\text { Variados } \\
\text { portes }\end{array}$ & $\begin{array}{c}\text { Indústria, } \\
\text { comércio e } \\
\text { serviço }\end{array}$ & $\begin{array}{c}\text { A maior parte das empresas estabelece os } \\
\text { preços a partir da combinação “custos mais } \\
\text { margem”. }\end{array}$ & 121 \\
\hline $\begin{array}{l}\text { Avlonitis e } \\
\text { Indounas } \\
\text { (série de } 9 \\
\text { estudos) } \\
\end{array}$ & Grécia & 170 & $\begin{array}{l}\text { Variados } \\
\text { portes }\end{array}$ & Serviço & $\begin{array}{c}\text { A maior parte das empresas estabelece os } \\
\text { preços a partir da combinação "custos mais } \\
\text { margem". }\end{array}$ & 279 \\
\hline $\begin{array}{l}\text { Apel et al. } \\
\text { (2005) }\end{array}$ & Suécia & $\begin{array}{l}\text { Mais de } \\
600 \\
\text { (número } \\
\text { exato não } \\
\text { mencionado) }\end{array}$ & $\begin{array}{l}\text { Variados } \\
\text { portes }\end{array}$ & $\begin{array}{l}\text { Indústria e } \\
\text { serviço }\end{array}$ & $\begin{array}{l}\text { A maior parte das empresas delibera } \\
\text { alterações nos preços de acordo com } \\
\text { mudanças nos preços dos concorrentes. } \\
\text { Alterações nos preços em função de } \\
\text { mudanças nos custos aparecem na sequência. }\end{array}$ & 154 \\
\hline $\begin{array}{l}\text { Fabiani et al. } \\
\qquad(2005)\end{array}$ & Europa & 11.038 & $\begin{array}{c}\text { Variados } \\
\text { portes }\end{array}$ & $\begin{array}{l}\text { Indústria, } \\
\text { comércio e } \\
\text { serviço }\end{array}$ & $\begin{array}{l}\text { A maior parte das empresas estabelece os } \\
\text { preços a partir da combinação “custos mais } \\
\text { margem". Em alguns locais, a margem } \\
\text { varia levando em conta condições } \\
\text { competitivas e do mercado. }\end{array}$ & 363 \\
\hline $\begin{array}{l}\text { Forman e Hunt } \\
\qquad(2005)\end{array}$ & $\begin{array}{c}\text { Estados } \\
\text { Unidos }\end{array}$ & 135 & $\begin{array}{c}\text { Não } \\
\text { mencionado }\end{array}$ & $\begin{array}{l}\text { Indústria - } \\
\text { Exportação }\end{array}$ & $\begin{array}{c}\text { A combinação "custos mais margem" está } \\
\text { entre as formas predominantes de } \\
\text { estabelecimento dos preços. }\end{array}$ & 59 \\
\hline $\begin{array}{l}\text { Guilding et al. } \\
\qquad(2005)\end{array}$ & $\begin{array}{l}\text { Reino Unido } \\
\text { e Austrália }\end{array}$ & $\begin{array}{c}277 \\
(187+90)\end{array}$ & $\begin{array}{l}\text { Variados } \\
\text { portes }\end{array}$ & $\begin{array}{l}\text { Indústria, } \\
\text { comércio e } \\
\text { serviço }\end{array}$ & $\begin{array}{c}\text { A maior parte das empresas estabelece os } \\
\text { preços a partir da combinação “custos mais } \\
\text { margem”. }\end{array}$ & 36 \\
\hline $\begin{array}{c}\text { Drury e Tayles } \\
\quad(2006)\end{array}$ & Reino Unido & 187 & $\begin{array}{l}\text { Variados } \\
\text { portes }\end{array}$ & $\begin{array}{l}\text { Indústria, } \\
\text { comércio e } \\
\text { serviço }\end{array}$ & $\begin{array}{l}\text { A maior parte das empresas estabelece os } \\
\text { preços a partir da combinação “custos mais } \\
\text { margem". Entretanto, os preços finais não } \\
\text { eram necessariamente o resultado dessa } \\
\text { combinação e podiam ser influenciados por } \\
\text { outros tipos de informações. }\end{array}$ & 28 \\
\hline $\begin{array}{l}\text { Greenslade e } \\
\text { Parker } \\
\text { (série de } 2 \\
\text { estudos) }\end{array}$ & Reino Unido & 693 & $\begin{array}{l}\text { Variados } \\
\text { portes }\end{array}$ & $\begin{array}{l}\text { Indústria, } \\
\text { comércio e } \\
\text { serviço }\end{array}$ & $\begin{array}{l}\text { A maior parte das empresas estabelece os } \\
\text { preços com base nos preços dos concorrentes. } \\
\text { Ainda assim, há empresas que estabelecem os } \\
\text { preços a partir da combinação "custos mais } \\
\text { margem". }\end{array}$ & 39 \\
\hline $\begin{array}{l}\text { Indounas } \\
\text { (série de } 3 \\
\text { estudos) }\end{array}$ & Grécia & 177 & $\begin{array}{c}\text { Variados } \\
\text { portes }\end{array}$ & Serviço & $\begin{array}{l}\text { A maior parte das empresas estabelece os } \\
\text { preços a partir da combinação “custos mais } \\
\text { margem". }\end{array}$ & 46 \\
\hline
\end{tabular}


Pode-se observar que, de fato, predomina a constatação de que a maior parte das empresas estabelece os preços a partir dos custos mais margem. Nas 30 investigações relacionadas nesta seção, essa foi a conclusão de 25 , ou seja, de $83,3 \%$ (conforme negrito e sombreamento cinza na Tabela 13). Até mesmo os 5 estudos que não chegaram a esse entendimento, relataram que os custos eram usados nas deliberações de preços, ainda que não fossem a informação mais importante.

É fundamental, no entanto, ressaltar que na maioria dos estudos os autores fizeram questão de frisar que os custos, apesar de serem a principal base para os preços, não indicavam isoladamente a decisão. Muitos foram os relatos de que a margem estava sujeita a informações alheias aos custos, sobretudo dos preços dos concorrentes e do valor. Em outras palavras, pode-se dizer que os autores demonstraram que os custos representavam a forma, mas não obrigatoriamente a essência do estabelecimento dos preços. Esse é um ponto central desta tese e será, portanto, retomado posteriormente (seção 4.2.4).

Outro aspecto que merece ser alertado é que o entendimento sobre a definição dos preços ancora-se, sobretudo, nos resultados de estudos realizados na Europa Ocidental e na América Anglo-Saxônica (sobretudo, Grã-Bretanha e Estados Unidos), como mostra a Tabela 14.

Tabela 14 - Sumário dos locais investigados nas pesquisas empíricas mais citadas

\begin{tabular}{c|c|c|c}
\hline REGIÃo GEOGRÁFICA & LOCALIDADE & QUANTIDADE & PERCENTUAL \\
\hline \multirow{2}{*}{ Europa Ocidental } & Grã-Bretanha & $\mathbf{1 2}$ & $38 \%$ \\
\cline { 2 - 4 } & Outros & 6 & $19 \%$ \\
\hline \multirow{2}{*}{ América Anglo-Saxônica } & Estados Unidos & $\mathbf{1 0}$ & $31 \%$ \\
\cline { 2 - 4 } & Outros & 2 & $6 \%$ \\
\hline Oceania & Austrália & 1 & $3 \%$ \\
\hline África & África do Sul & 1 & $3 \%$ \\
\hline \multicolumn{2}{r|}{ TOTAL } & $\mathbf{3 0}$ & $\mathbf{1 0 0 \%}$ \\
\hline
\end{tabular}

Ora, ao enfatizarem a Europa Ocidental e a América Anglo-Saxônica, os estudos mais citados sobre estabelecimento dos preços deixaram de abordar a realidade existente em outros pontos do mundo, como ilustra a Figura 21. O pior é que a realidade constatada nesses locais, extremamente desenvolvidos, pode não corresponder à realidade encontrada em outros lugares, principalmente se esses lugares referirem-se a países em desenvolvimento. Por esse

9 A soma das linhas dá 32, não 30, pois dois trabalhos (Gordon et al., 1981; Guilding et al., 2005) estão apresentados em duas linhas, já que abordaram dois países (Estados Unidos e Canadá; Reino Unido e Austrália). 
motivo, a fim de expandir o entendimento sobre o tema, decidiu-se incluir a próxima seção com trabalhos menos citados e verificar se seus resultados, independentemente da localização, coincidem com os dos trabalhos mais citados.

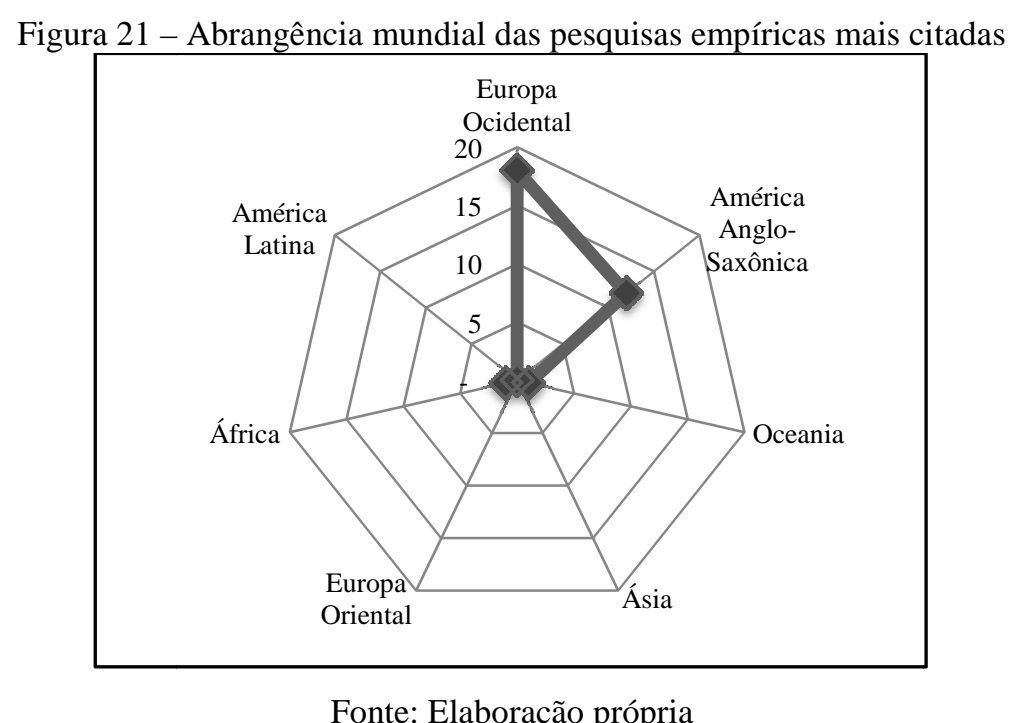

\subsection{Pesquisas Empíricas Menos Citadas}

Para que o escopo da revisão desta tese pudesse contemplar a maior variedade possível de pesquisas empíricas, optou-se por também apresentar, nesta seção, aquelas pesquisas sobre estabelecimento dos preços, publicadas em inglês e disponíveis em bases científicas (ProQuest, EBSCOhost, ScienceDirect, Scielo etc.), que receberam menos do que 25 citações.

Foram identificadas mais 28 pesquisas que, de alguma forma, reportaram a realidade empírica do estabelecimento dos preços. Nesta seção são apresentadas 27 dessas pesquisas, pois uma refere-se ao Brasil, objeto de estudo da próxima seção. Dessas 27 pesquisas, 17 divulgaram a realidade da América Latina (exceto Brasil), da África, da Europa Oriental, da Ásia e da Oceania. As 10 restantes ainda concentraram-se no eixo América Anglo-Saxônica - Europa Ocidental.

Para a América Latina, foram poucos os estudos localizados sobre o tema. Os achados limitam-se a quatro, sendo um do Brasil (A. X. V. Braga, Souza, Kronbauer, \& Braga, 2012) e três de outros países: um da Guiana (Murray, 2013), um de Trinidad e Tobago (Mahabir, 
Primus, Cox, Jagessar, \& Neptun, $2013^{10}$ ) e um do Uruguai (Borraz, Licandro, \& Sola, 2013). Há também estudos da Colômbia (Julio \& Zárate, 2008; Iregui Bohórquez, Melo Becerra, \& Ramírez Giraldo, 2011; Iregui Bohórquez, Melo Becerra, \& Ramírez Giraldo, 2012), no entanto, eles não são aqui apresentados porque não se voltaram a demonstrar como é o estabelecimento dos preços na prática. Eles focaram na exploração das mudanças de preços e da relação entre os preços e os salários.

Vale mencionar que o único estudo brasileiro em inglês sobre estabelecimento dos preços disponível em bases científicas é A. X. V. Braga et al. (2012). Apesar de reportar resultados do Brasil, que é um país da América Latina, optou-se por apresentá-lo na próxima seção (3.3) junto aos demais estudos nacionais.

Murray (2013) explorou o estabelecimento dos preços na Guiana, especificamente na cidade de Nova Amsterdam. A autora distribuiu pessoalmente questionários para 47 empresas comerciais selecionadas aleatoriamente dentre as 76 localizadas nas ruas almejadas. 31 respostas foram obtidas e serviram como fonte para Murray (2013) afirmar que os preços eram fundamentalmente definidos a partir dos custos.

A autora também concluiu que em $45,2 \%$ das firmas a margem era colocada sobre os custos totais dos produtos (custo do bem mais as despesas fixas); em 32,3\% das empresas a margem era colocada sobre os custos estimados; em 19,4\%, a margem era adicionada somente aos custos variáveis.

Já Mahabir et al. (2013) desenvolveram uma pesquisa sobre o estabelecimento dos preços em Trinidad e Tobago. Depois de contatarem 196 empresas de variados portes e ramos (empresas industriais de alimentos, industriais de outros setores, de construção e de outros serviços), os autores conseguiram obter 63 respostas. Nesse trabalho, eles preferiram expor as variáveis consideradas para alteração dos preços a expor as variáveis abordadas na definição inicial dos preços.

\footnotetext{
${ }^{10}$ Para contagem das citações, também foi considerada a versão disponibilizada no site do Central Bank of Trinidad \& Tobago (Mahabir, Primus, Cox, Jagessar, \& Neptun, 2012).
} 
Com a investigação, Mahabir et al. (2013) constataram que os custos de matéria-prima, os custos com o pessoal e os custos financeiros eram as principais variáveis usadas para deliberar preços. Eles também observaram que, no geral, as empresas variavam, caso a caso, os preços entre os clientes.

O estudo de Borraz et al. (2013), por sua vez, apoiou-se num levantamento conduzido pelo Instituto Nacional de Estadística (INE) como apoio ao Banco Central del Uruguay (BCU). Nesse levantamento, um questionário foi enviado para 630 empresas uruguaias de variados portes de todos os setores (com exceção do setor público). Ao final, 363 questionários preenchidos foram recebidos.

O principal achado foi que a maioria das empresas (mais de 50\%) definia os preços a partir dos custos mais margem. Em todos os setores investigados, os autores constataram essa realidade, exceto no setor de transportes em que os preços eram regulados pelo governo. Um ponto interessante detectado pelos autores é que, dentre as empresas industriais, aquelas que produziam equipamentos pesados eram as que mais definiam os preços a partir dos custos mais margem. Já nas empresas industriais produtoras de alimentos e de madeira, importantes commodities uruguaias, o impacto dos preços internacionais era maior do que o da combinação dos custos à margem.

Dessa forma, nota-se que os resultados das três pesquisas da América Latina (sem contar o trabalho do Brasil, apresentado na próxima seção) coincidem entre si e com os resultados dos principais estudos sobre o tema, já que evidenciam a predominância do uso dos custos na definição dos preços (Murray, 2013; Mahabir et al., 2013; Borraz et al., 2013). No entanto, não se pode deixar de alertar que esses três trabalhos, além de serem poucos, são restritos aos locais investigados e, portanto, não podem ser usados para generalização das conclusões sobre o tema nesse ponto do globo.

Para a África, foram localizados apenas mais três estudos (além daquele de Abratt \& Pitt, 1985, já apresentado na seção dos principais estudos). Dois estudos discorreram sobre a realidade observada na África do Sul (Morris \& Schurink, 1993; Govender, 2000) e outro sobre a realidade encontrada nos países Burkina Faso e Côte d'Ivoire (Bassett, 2014). Encontrou-se também um estudo sobre Lesotho, um país no sul do continente, que não é aqui 
apresentado por delimitar-se a explorar as alterações dos preços (frequência, período de incidência etc.) sem explorar o processo, em si, do estabelecimento dos preços (Nchake, Edwards, \& Rankin, 2015).

Morris e Schurink (1993) propuseram-se a investigar o estabelecimento dos preços nas grandes empresas da África do Sul, instigados pelo fato que, naquele momento, elas enfrentavam um ambiente turbulento em decorrência do cenário político, social e econômico do país. Eles aplicaram um questionário a gestores de empresas industriais do ambiente B2B que participaram de um seminário de marketing industrial promovido por uma renomada escola de negócios sul-africana. Ao todo, eles obtiveram respostas de 70 empresas, dentre as quais 42 constavam na lista das 300 maiores companhias do país africano.

Os autores concluíram que na África do Sul os preços eram mais baseados no mercado do que nos custos, ainda que a consideração dos custos também fosse notória. Não se entende, todavia, como os autores chegaram a essa conclusão, uma vez que a assertiva que obteve maior concordância referia-se aos custos mais margem (não ao mercado), conforme a Tabela 15 demonstra.

Tabela 15 - Resultados de Morris e Schurink (1993)

\begin{tabular}{l|c|c}
\hline \multicolumn{1}{c|}{ ASSERTIVAS } & MÉDIA & $\begin{array}{c}\text { DESVIO } \\
\text { PADRÃO }\end{array}$ \\
\hline PREÇO BASEADO NOS CUSTOS & & 1,45 \\
\hline Nós adicionamos um markup ao custo unitário & 2,93 & 1,52 \\
\hline $\begin{array}{l}\text { Nós calculamos a margem em Rand (moeda sul-africana) desejada para cada } \\
\text { unidade vendida }\end{array}$ & 2,98 & $\mathbf{1 , 6 3}$ \\
\hline Nós usamos uma fórmula de custos mais margem & $\mathbf{3 , 2 7}$ & 1,10 \\
\hline $\begin{array}{l}\text { Nós definimos os preços para recuperarmos rapidamente os investimentos no } \\
\text { desenvolvimento do produto }\end{array}$ & 1,77 & 1,14 \\
\hline Os custos têm um papel importante & 2,98 & 1,00 \\
\hline As considerações de impostos têm um papel importante & 0,86 & \\
\hline PREÇO BASEADO NO MERCADo & & 1,02 \\
\hline A concorrência tem um papel importante & 2,71 & 1,11 \\
\hline Os preços são alterados em paralelo às alterações das outras empresas na indústria & 2,64 & 1,25 \\
\hline Nós colocamos preços semelhantes aos nossos concorrentes & 2,96 & 1,31 \\
\hline Nós não competimos com base nos preços & 3,25 & 1,39 \\
\hline Nós definimos os preços para alcançarmos uma fatia de mercado almejada & 3,20 & 1,38 \\
\hline Os preços refletem o valor que um dado cliente está recebendo & 2,74 & 1,36 \\
\hline O fator principal para definir os preços é a disposição de pagamento do cliente & 2,44 & 1,13 \\
\hline A demanda do cliente tem um papel importante & 2,84 & \\
\hline Fone: Mor &
\end{tabular}

Fonte: Morris e Schurink (1993, p. 35) 
Depois, Govender (2000) focou na averiguação dos tipos de custos usados no estabelecimento dos preços. Para tanto, ele enviou um questionário a uma amostra de 266 empresas industriais de variados portes localizadas na região metropolitana de Durban (África do Sul), constantes numa lista (de 798 empresas) mantida pelo centro de pesquisa de mercado da University of South Africa (UNISA). Ele obteve 110 respostas.

O autor constatou a dominância do custo total, usado no estabelecimento dos preços por $74,6 \%$ das empresas respondentes: $38,2 \%$ usavam os custos totais de produção e $36,4 \%$ usavam os custos de produção mais despesas. O custo variável era usado por apenas $25,4 \%$ da amostra: $12,7 \%$ usavam o custo variável de produção e $12,7 \%$ usavam todos os elementos variáveis (custos mais despesas). Govender (2000) também observou que a escolha do tipo de custo usado estava associada a vários fatores, conforme ilustra a Tabela 16.

Tabela 16 - Resultados de Govender (2000)

\begin{tabular}{c|c|c}
\hline FATORES & USO DO CUSTO TOTAL & USO DO CUSTO VARIÁVEL \\
\hline Tamanho da Empresa & Grandes empresas & Pequenas empresas \\
\hline Tipo do Produto & Produtos customizados & Produtos padronizados \\
\hline Ciclo de Vida do Produto & Estágio da introdução e da maturidade & Estágio do crescimento e do declínio \\
\hline Custos Fixos & Custos fixos materiais & Custos fixos imateriais \\
\hline Objetivos da Empresa & $\begin{array}{c}\text { Objetivo de maximização do lucro e de } \\
\text { obtenção de um retorno alvo }\end{array}$ & Objetivos gerenciais \\
\hline
\end{tabular}

Ainda na África, percebeu-se que o pesquisador Bassett da universidade americana de Illinois tem dedicado especial atenção à formação de preços de algodão no oeste do continente, elaborando uma série de estudos sobre o tema. Nesta tese, optou-se por mostrar o estudo de 2014, no qual o autor debruçou-se especificamente na investigação dos países de Burkina Faso e Côte d'Ivoire. Nesse trabalho, ele entrevistou representantes de empresas de algodão e do ministério da agricultura em Côte d'Ivoire e analisou documentos e descrições de jornais em Burkina Faso.

Bassett (2014) revelou que em ambos os países o preço do algodão era fortemente regulado, sendo estabelecido por associações interprofissionais, ligadas de alguma forma ao governo. Em Burkina Faso, o preço era definido por meio de uma fórmula denominada "mecanismo de suavização" (le mécanisme de lissage), desenvolvida por consultores franceses em 2006, que envolve informações referentes exclusivamente ao mercado (e.g., média dos preços em anos anteriores, cotação da taxa US\$-euro etc.). 
Em Côte d'Ivoire, o preço era definido por uma fórmula popularmente conhecida como COWI (COWI é o nome de empresa de consultoria), desenvolvida por consultores franceses em 2009, que também envolve apenas informações de mercado. Nesse último país, os custos eram indiretamente considerados, ao passo que um dos componentes da fórmula (o percentual das receitas de algodão dedicado aos produtores) variava dependendo das declarações dos custos nos processos de produção de algodão à capacidade completa (50.000 toneladas).

Não é surpreendente observar que no contexto da produção de algodão na África a mecânica dos custos mais margem não era a predominante. Afinal, em meio a commodities, não há poder para formar preços individualmente e a relevância está em informações de mercado.

Pode-se assim constatar que a quantidade de estudos sobre a definição dos preços em países africanos é muito pequena para viabilizar a compreensão da realidade dominante no continente, ainda mais que consenso não foi encontrado. Foi apenas possível perceber que a combinação “custos mais margem”, detectada em alguns setores por Abratt e Pitt (1985), por Morris e Schurink (1993) e por Govender (2000), não estava presente em meio a commodities (Bassett, 2014).

Para a Europa Oriental, também foram poucas as pesquisas encontradas sobre o estabelecimento dos preços. Localizaram-se apenas estudos sobre o estabelecimento dos preços na Turquia (Sahinöz \& Saraçoglu, 2008), na República Tcheca (Babecký, Dybczak, Galuščák, 2008) e na Romênia (Copaciu, Neagu, \& Braun-Erdei, 2010). Vale mencionar que há também estudos sobre a Eslováquia (Coricelli \& Horváth, 2010), a Lituânia (Virbickas, 2009; Virbickas, 2010) e a Letônia (Beņkovskis, Fadejeva, \& Kalnbērziṇa, 2011; Beṇkovskis, Fadejeva, \& Kalnbērziņa, 2012) que, apesar de discutirem sobre decisões de preços, não são apresentados nesta seção. Tais estudos estão fora do escopo da tese por se restringirem exclusivamente a alterações nos preços e não abordarem o uso dos diferentes tipos de informações (custos, concorrentes, clientes).

O estudo da Turquia (Sahinöz \& Saraçoglu, 2008) foi conduzido pelo banco central local e envolveu a remessa de um questionário para 3.606 empresas industriais de variados portes. 999 respostas foram obtidas e serviram de base às conclusões do estudo. 
Os autores concluíram que a maior parte das empresas turcas $(50,6 \%)$ entendia atuar em um oligopólio. Elas acreditavam, portanto, ter a possibilidade de conspirar com as outras firmas para alcançar o máximo lucro possível ou de atuar com um posicionamento estratégico que, com acordos ou não, conduziria os preços a patamares elevados.

No que se refere à operacionalização do estabelecimento dos preços, os autores ofereceram possibilidades limitadas de respostas: apenas custos mais margem constante, custos mais margem variável e preço regulado. A combinação "custos mais margem variável” foi a mais assinalada (47,6\% das empresas), seguida pela combinação "custos mais margem constante" $(27,2 \%)$ e pelos preços regulados $(5,8 \%)$. Apesar da ampla dominância dos custos mais margem, não se pode concluir que o uso dos custos seja de fato elementar para definir os preços, já que não existiam outras possibilidades de respostas. Além disso, faltou Sahinöz e Saraçoglu (2008) revelarem os fatores que norteavam a variação da margem.

O estudo da República Tcheca (Babecký et al., 2008) também foi coordenado pelo banco central local (CNB - Czech National Bank). Para operacionalizá-lo, divisões regionais do banco enviaram um questionário a uma amostra aleatória de 1.591 empresas, de variados portes (constantes no banco de dados do departamento de estatística), de ramos industriais, comerciais e de serviço. Ao todo foram obtidas 399 respostas.

A principal conclusão reportada por Babecký et al. (2008) foi que na República Tcheca duas principais formas de estabelecimento dos preços imperavam: preços de acordo com os preços dos concorrentes (38\% da amostra) e custos mais margem (37\%). Na sequência, mas distantes, apareciam a obediência às definições da matriz (14\%) e a consideração de informações dos clientes (11\%).

O estudo da Romênia (Copaciu et al., 2010) foi mais um conduzido com o apoio do banco central local. Ele foi viabilizado mediante o envio de um questionário a 1.901 empresas industriais e de serviço de variados portes. 377 empresas responderam o questionário.

Os autores identificaram que a maior parte das empresas (50\%) equiparava seus preços aos preços correntes no mercado. A definição dos preços por meio da soma de uma margem aos custos (43\%) ocupava o segundo lugar. Segundo Copaciu et al. (2010), as empresas de grande 
porte eram as que mais aderiam à mecânica de custos mais margem no estabelecimento dos preços (74\% das empresas desse tipo), enquanto que as empresas de pequeno porte eram as que menos aderiam, por priorizarem a colocação de preços coerentes ao mercado.

Copaciu et al. (2010) também constataram que embora a maior parte das empresas cobrasse o mesmo preço para todos os clientes, havia firmas que variavam os preços dependendo da quantidade adquirida e companhias que variavam os preços dependendo de outros fatores (não especificados).

Constata-se, portanto, que as evidências apresentadas pelos três estudos da Europa Oriental não coincidem, nem entre si nem com as conclusões dos principais estudos sobre o tema. Afinal, Sahinöz e Saraçoglu (2008) foram os únicos que apuraram o uso predominante dos custos, já que Copaciu et al. (2010) apuraram o uso predominante do preço corrente do mercado e Babecký et al. (2008) apuraram o uso praticamente equivalente dos dois tipos de informações.

Para a Ásia, a escassez de estudos também é notória. Foram localizados somente quatro estudos, dois sobre o leste asiático e dois sobre o Oriente Médio. Especificamente para o leste asiático, foram identificadas pesquisas sobre Cingapura (Chia \& Noble, 1999) e sobre o Japão (S. Nakagawa, Hattori, \& Takagawa, 2000). Vale mencionar que há também o estudo de Howard e Herbig (1996), no entanto, ele não é aqui relatado por não ser de fato empírico, mas, sim, relatar a percepção que os autores têm sobre o estabelecimento dos preços no Japão.

A pesquisa de Chia e Noble (1999) assemelha-se ao estudo de Noble e Gruca (1999a), tanto nos objetivos quanto nos métodos empregados. Entretanto, ela tira o foco dos Estados Unidos e volta-se à Ásia, especificamente à Cingapura. Questionários foram remetidos a 700 empresas, produtoras de bens duráveis no ambiente B2B. Os dados de contato foram extraídos de duas fontes: uma listagem de 2.500 empresas participantes de um programa na universidade local e uma versão do The Green Book, guia de compras na internet das empresas industriais de Cingapura. 75 respostas foram obtidas no começo de 1997. 
Os achados de Chia e Noble (1999) também são similares aos de Noble e Gruca (1999a). Eles indicaram a ampla predominância (42\%) da soma de uma margem aos custos na determinação dos preços.

A pesquisa de S. Nakagawa et al. (2000) foi coordenada pelo Banco Central do Japão. Os autores enviaram questionários para 1.206 empresas listadas na bolsa de valores de Tóquio, sobretudo de setores industriais, mas também de atacado, de varejo, de construção, de transporte, de comunicação e de outros setores. Eles obtiveram 630 respostas.

Os autores concluíram que os preços japoneses eram definidos principalmente em função do mercado: 35,6\% das empresas optavam por colocar preços correspondentes ao limite máximo acatado pelo mercado, 22,2\% das empresas estabeleciam os preços de acordo com a importância da sua fatia de mercado e 18,9\% das empresas definiam os preços a partir de imposições dos clientes. Apenas $18,4 \%$ das firmas estabeleciam seus preços a partir dos custos. Nessas firmas, os custos diretos eram adicionados a uma margem percentual fixa visando alcançar o lucro desejado por unidade.

Destarte, nota-se mais uma situação em que as constatações não convergem entre si e tampouco com os principais estudos sobre o tema. Ora, o pouco uso dos custos no estabelecimento dos preços observado no Japão diverge do uso predominante dos custos constatado em Cingapura e, consequentemente, contrasta com a conclusão dos principais estudos. S. Nakagawa et al. (2000) enfatizam a validade dos seus achados, pois asseguram que num ambiente como o Japão a competição é tão intensa que seria difícil estabelecer preços de acordo com a fórmula "custos diretos mais margem fixa de lucro". Em ambientes assim, as empresas não têm escolha e precisam tomar os preços.

Para o lado oposto da Ásia, os outros dois trabalhos localizados referem-se ao Paquistão. O primeiro estudo, de Malik, Satti, e Saghir (2010), foi elaborado com o apoio do Instituto de Desenvolvimento Econômico do Paquistão, já o segundo, de Choudhary, Faheem, Hanif, Naeem, e Pasha (2012), foi desenvolvido com o apoio do Banco Central do Paquistão.

No estudo de Malik et al. (2010), empresas de pequeno (com pelo menos 10 empregados), médio e grande porte cadastradas na junta comercial e industrial de quatro cidades da 
província de Punjab (Faisalabad, Gujrat, Gujranwala, e Sialkot) foram selecionadas para responder o questionário. Vale mencionar que os autores buscaram empresas que, independentemente do ramo, estivessem envolvidas no processo produtivo, seja de produtos ou de serviços. Ao todo, eles conseguiram a participação de 343 empresas.

Malik et al. (2010) detectaram que a forma predominante de estabelecer os preços era a combinação dos custos à margem: 62,39\% das firmas investigadas definiam os preços dessa maneira. Na sequência, apareciam os preços definidos em conformidade com os preços prevalecentes no mercado $(41,15 \%)$ e de acordo com os preços do principal concorrente $(30,97 \%)$. Eles também perceberam que as empresas de médio e principalmente as de grande porte priorizavam a combinação dos custos à margem, enquanto que as pequenas empresas priorizavam os preços prevalecentes no mercado.

Os autores ainda notaram que a maioria das empresas não definia necessariamente o mesmo preço para todos os clientes: $52 \%$ dos respondentes afirmaram variar os preços entre os clientes. As principais causas para essa variação concentravam-se na quantidade adquirida, na situação específica e em acordos contratuais.

O estudo de Choudhary et al. (2012) foi mais completo, ao passo que buscou abranger empresas formais, industriais e de serviço, de várias cidades paquistanesas localizadas nas províncias de Punjab e de Sindh (as cidades das outras duas províncias do país - Balochistan e Khyber-Pakhtun Khwa - foram evitadas por segurança). Ao todo, 1.189 empresas formais foram entrevistadas.

Os autores constataram que $47 \%$ das empresas definiam os preços a partir de uma margem, constante ou variável, colocada sobre os custos, enquanto que $37 \%$ das empresas determinavam os preços em função dos preços dos concorrentes. Eles também notaram que na linguagem local markup era o termo comumente usado para expressar a margem.

Os dois estudos sobre o Oriente Médio, portanto, coincidem entre si e com os principais estudos sobre o tema, uma vez que revelam a predominância do uso dos custos na definição dos preços. Ainda assim, as evidências são restritas a um único país (Paquistão), impedindo sua generalização a toda a localidade. 
Assim, pode-se constatar que a Ásia como um todo é mais um continente no qual ainda não se tem uma compreensão sobre o real panorama local. Afinal, quatro é uma quantidade pequena de estudos, ainda mais quando falta consenso. Ora, S. Nakagawa et al. (2000) garantiram o pouco uso dos custos na definição dos preços, o que contradiz as pesquisas de Chia e Noble (1999), de Malik et al. (2010) e de Choudhary et al. (2012).

Passando para a Oceania, além do trabalho de Guilding et al. (2005) sobre a Austrália, já reportado na seção dos principais estudos, encontraram-se mais quatro pesquisas: mais duas sobre a Austrália e duas sobre a Nova Zelândia.

Park, Rayner, e D’Arcy (2010) publicaram os resultados obtidos num estudo coordenado pelo banco central australiano sobre o estabelecimento dos preços na Austrália. Nesse estudo, cerca de 700 empresas de pequeno, médio e grande porte, de ramos industriais, comerciais e de serviço responderam um questionário (número exato de respondentes não foi divulgado).

A principal constatação dos autores foi de que a maior parte das empresas definia os preços de acordo com os custos mais margem (49\%). Interessante pontuar que, desse total, mais empresas afirmaram usar uma margem que variava de acordo com as condições da demanda (26\%) do que uma margem fixa (23\%). Depois da combinação dos custos à margem apareciam os preços estabelecidos de acordo com as condições gerais do mercado (25\%) e com os preços dos concorrentes (11\%). Ainda havia 5\% de empresas em que os preços eram determinados pelos clientes e $4 \%$ em que os preços eram definidos de acordo com o nível da demanda.

Os autores também observaram que a forma de definir os preços distinguia-se bastante dependendo do ramo e da competição a que as empresas estavam expostas. Em níveis elevados de competição a prioridade no estabelecimento dos preços concentrava-se em informações de mercado, enquanto que em níveis baixos concentrava-se nos custos. No que se refere aos ramos, Park et al. (2010) notaram que empresas de agricultura, de mineração e de turismo priorizavam a consideração de informações de mercado. Por outro lado, empresas de construção, de transporte e de estocagem enfatizavam a combinação dos custos à margem. 
Carnegie, Tuck, e West (2011) dedicaram-se a explorar os preços estabelecidos pelo governo local australiano. Os autores enviaram um questionário aos gestores financeiros das 562 entidades governamentais existentes nos 6 estados australianos e no território do norte (Northern Territory) e obtiveram 162 respostas.

Partindo de 5 possíveis cenários de preços (propostos em um estudo anterior), eles identificaram que a maior parte das entidades governamentais visava a recuperação dos custos com os preços, como mostra a Tabela 17.

Tabela 17 - Resultados de Carnegie et al. (2011)

\begin{tabular}{c|c}
\hline BASE DOS PREÇOS & PERCENTUAL \\
\hline Preços mandatórios (definidos pelo governo) & $19,11 \%$ \\
\hline Preços conformes à Política Nacional de Competição & $11,00 \%$ \\
\hline Preços para recuperar os custos & $29,50 \%$ \\
\hline Preços para recuperar os custos e assegurar uma margem & $18,80 \%$ \\
\hline Preços viabilizados por subsídios & $21,60 \%$ \\
\hline
\end{tabular}

Fonte: Carnegie et al. (2011, p. 197)

Carnegie et al. (2011) também constataram uma diversidade considerável na forma que as entidades investigadas operacionalizavam a determinação dos preços. Diante dessa diversidade, eles propuseram uma fórmula para sumarizar, em linhas gerais, o processo: preço $=$ custos + margem - subsídio. A fórmula foi bem aceita por $91 \%$ dos respondentes .

Cumpre mencionar que os custos totais não eram comumente utilizados. As entidades preferiam usar os custos diretos e os custos indiretos administrativos. A depreciação dos ativos imobilizados assim como os custos indiretos gerais e as despesas financeiras não eram frequentemente considerados para estabelecer os preços. As principais justificativas apresentadas para a exclusão desses custos estavam na dificuldade da sua mensuração, na tendência de eles não serem conhecidos e na circunstância, não rara, em que os custos excediam os preços.

Indounas e Roth (2012), por sua vez, investigaram na Nova Zelândia a relação entre as variáveis contextuais e a precificação estratégica e também o efeito da precificação estratégica na colocação dos preços. Questionários foram encaminhados a 810 empresas dos quatro principais ramos de serviço daquele país: logística/transporte, serviços financeiros, tecnologia de informação e serviços profissionais. 120 respostas completas foram obtidas. 
Os autores não reportaram detalhes, mas asseguraram que as definições de preços baseadas na concorrência e no valor predominavam sobre aquela baseada nos custos. Ainda assim, a combinação “custos mais margem” estava presente nas empresas neozelandesas.

Parker (2014), por parte do banco central local, também investigou a realidade neozelandesa. A população, composta por empresas que deveriam constar no levantamento de operações empresariais (Business Operations Survey) conduzido pelo departamento nacional de estatística, chegou a 35.307 firmas. Uma parcela estratificada dessa população recebeu o questionário, sendo obtido um total de 5.369 respostas. Vale mencionar que essas respostas vinham de empresas de pequeno, médio e grande porte de variados ramos da indústria, do comércio e de serviço.

O autor constatou que o estabelecimento dominante dos preços pautava-se na combinação dos custos à margem. Tal forma de definição dos preços era empregada por mais da metade das empresas investigadas, seguida pelo estabelecimento dos preços de acordo com os concorrentes (pouco menos de um terço das empresas) e conforme regras pré-definidas (cerca de um décimo da amostra).

Parker (2014) também observou que a forma de determinar os preços variava bastante entre os segmentos. Em empresas do setor primário (e.g., agricultura, pesca, mineração), a definição dos preços de acordo com os preços dos concorrentes praticamente igualava-se à definição dos preços a partir da combinação dos custos a margem, enquanto que em empresas da indústria e do comércio, a combinação "custos mais margem” estava bem a frente do embasamento nos preços dos concorrentes.

Dessa forma, observa-se que também na Oceania as evidências apresentadas foram poucas e controversas, afinal Indounas e Roth (2012) categoricamente não concordaram com as constatações dos outros estudos sobre a predominância do uso dos custos na definição dos preços. Logo, eis aí mais uma situação na qual as constatações empíricas não podem ser utilizadas para a generalização da realidade no continente. 
Para encerrar a seção, cumpre agora apresentar os trabalhos menos citados sobre o estabelecimento dos preços na América Anglo-Saxônica e na Europa Ocidental para verificar se seus resultados coincidem com aqueles dos estudos mais citados já reportados.

Para a América Anglo-Saxônica, foram localizados mais 3 estudos (Lazer, 1957; Bruegelmann, Haessly, Wolfangel, \& Schiff, 1985; Goetz, 1985). Vale mencionar que, além deles, há um trabalho sobre os Estados Unidos (Blinder, 1991) que não é apresentado nesta tese, ainda que seja uma referência recorrente em pesquisas sobre o tema. Essa não apresentação decorre do fato que tal estudo delimitou-se a explorar as teorias que explicam as alterações dos preços, sem detalhar os diferentes tipos de informações usados no processo.

Em junho de 1956, Lazer defendeu seu trabalho de doutorado (Doctoral Dissertation) sobre a definição de preços em empresas industriais têxteis do oeste canadense e, em 1957, ele publicou um artigo sumarizando os resultados dessa dissertação. Lazer entrevistou representantes de 22 empresas, de variados portes, todas envolvidas na produção em massa de roupas, isto é, na confecção de roupas sem customizações.

Lazer (1957) reportou que na sua amostra o estabelecimento dos preços recebia mais atenção do que qualquer outro elemento promocional do marketing. O grande número de pequenos produtores, a similaridade das roupas por eles produzidas, a voracidade da concorrência e a facilidade de entrar no mercado ressaltavam o papel significativo dos preços.

O autor também mencionou que o estabelecimento dos preços era basicamente uma função de custos mais margem. As empresas por ele entrevistadas estimavam os custos diretos das roupas a serem lançadas (com base na experiência das roupas anteriormente confeccionadas) e somavam a eles um percentual fixo a fim de cobrir todos os custos e despesas indiretos. $\mathrm{Na}$ sequência, o montante até então apurado, que equivalia ao custo total, era somado a um percentual, agora referente à margem, para assegurar a obtenção do lucro.

Lazer (1957) advertiu que o resultado sugerido pelos custos mais margem não correspondia necessariamente ao preço de fato cobrado. As empresas precisavam comparar esse resultado aos preços colocados pelos concorrentes para itens similares. No caso de discrepâncias, três decisões (isolada ou conjuntamente) eram tomadas: 
a) alterações eram feitas para ajustar o resultado aos preços dos concorrentes;

b) o processo de confecção das roupas era alterado para diminuir os custos; e

c) a margem colocada sobre os custos era diminuída.

Depois de o preço sugerido já estar semelhante aos preços dos concorrentes, as empresas somavam ou subtraíam mais um percentual de acordo com o tipo do cliente atendido. Em algumas empresas, esse percentual fazia o preço proposto para clientes por correspondência ser até $15 \%$ mais caro do que o preço proposto para clientes atacadistas. Uma amostra de clientes avaliava os preços propostos e exprimia suas percepções com relação a eles. Com base nessas percepções, ajustes finais aos preços propostos eram promovidos e indicavam, finalmente, o preço a ser cobrado.

Ou seja, os resultados de Lazer (1957) indicaram que os preços não eram estabelecidos de acordo com um resultado fechado da fórmula "custos mais margem”. A fórmula indicava um ponto de referência que poderia ser modificado, dependendo da concorrência e das percepções dos clientes.

O estudo de Bruegelmann et al. (1985) focou na investigação dos tipos de custos usados no estabelecimento dos preços. Para tanto, os autores entrevistaram profissionais de 11 empresas industriais dos Estados Unidos, sendo 8 oriundas da base da Fortune das 500 maiores empresas e 3 do círculo de conhecimento pessoal dos autores.

Bruegelmann et al. (1985) identificaram que o uso do custo variável era mais frequente do que se costumava pensar. Eles concluíram que a utilização dos diferentes custos não era uma questão de "branco ou preto" como se habituava defender, pois as empresas entrevistadas ora aderiam aos custos totais ora aos custos variáveis. O que acontecia, segundo os autores, era que dependendo das circunstâncias, um ou outro tipo de custo era priorizado.

Os autores observaram inicialmente que a maior parte das empresas (6 das 11) estabelecia os preços a partir dos custos totais, mas, ainda assim, quase metade da amostra (5 das 11) priorizava o custo variável nas decisões. Em situações específicas, todavia, essa condição era invertida e a utilização do custo variável predominava. Por exemplo, oito das onze empresas entrevistadas assumiram usar o custo variável para conseguirem responder à competição no 
mercado. Outro exemplo era o de uma das empresas que passava a utilizar o custo variável na precificação de mix de produtos.

Já Goetz (1985) voltou seu trabalho a pequenas empresas de lavanderia e de limpeza a seco (dry-cleaning) dos Estados Unidos. Ele enviou um questionário a uma amostra aleatória de 450 empresas dentre as 5.000 constantes num banco de dados do setor. 103 respostas foram obtidas.

Um ponto interessante do trabalho é que o autor buscou separar sua amostra em líderes de preços (price leader) e seguidores de preços (price follower), ainda que tenha feito pouco uso dessa segregação. A única distinção que o autor demonstrou foi que a maior parte dos seguidores colocava preços em torno dos preços médios existentes no mercado, enquanto que a maior parte dos líderes definia preços superiores a essa média, conforme a Tabela 18 evidencia. $\mathrm{Na}$ amostra, $78 \%$ das empresas consideravam-se líderes e $22 \%$ consideravam-se seguidoras.

Tabela 18 - Resultados de Goetz (1985)

\begin{tabular}{|c|c|c|c|}
\hline Posicionamento & $\begin{array}{c}\text { PREÇOS NA MÉDIA } \\
\text { DO MERCADO } \\
\text { (PERCENTUAL) } \\
\end{array}$ & $\begin{array}{c}\text { PREÇOS SUPERIORES À } \\
\text { MÉDIA DO MERCADO } \\
\text { (PERCENTUAL) } \\
\end{array}$ & $\begin{array}{c}\text { PREÇOS INFERIORES À } \\
\text { MÉDIA DO MERCADO } \\
\text { (PERCENTUAL) } \\
\end{array}$ \\
\hline Líderes de preços & $27 \%$ & $63 \%$ & $10 \%$ \\
\hline Seguidores de preços & $57 \%$ & $19 \%$ & $23 \%$ \\
\hline
\end{tabular}

Fonte: Adaptada de Goetz (1985, p. 64)

Goetz (1985) constatou que na sua amostra imperava o estabelecimento dos preços a partir dos custos (43\%). Empresas que usavam exclusivamente informações de mercado apareciam na sequência (39\%) seguidas por empresas que definiam os preços com base nos dois tipos de informação (18\%).

Assim, nota-se que os resultados das pesquisas realizadas no escopo da América AngloSaxônica, sim, coincidem entre si e com os achados dos principais trabalhos, ao passo que sugerem que os custos são a base elementar usada pelas empresas na definição dos preços. Essa percepção não surpreende, pois os principais estudos referem-se em grande parte a esse local e, mais do que isso, em sua totalidade (todos os 11 principais estudos) asseguram a predominância da combinação dos custos à margem. 
Para a Europa Ocidental, foram encontrados mais 7 estudos sobre o estabelecimento dos preços. Na sequência, expõem-se os principais achados desses trabalhos, que se referem à Grã-Bretanha (Shipley, 1983; Hankinson, 1995), à Noruega (Langbraaten, Nordbø, \& Wulfsberg, 2008), à Irlanda (Keeney, Lawless, \& Murphy, 2010), à Holanda (Ingenbleek \& van der Lans, 2013), à França (Carricano, 2014) e à Grécia (Nicolitsas, 2015 ${ }^{11}$ ). Há também uma pesquisa sobre a Finlândia (Freystätter, 2003) que não é descrita nesta tese por delimitarse a elaborar um modelo teórico e aplicá-lo com dados finlandeses, sem investigar as informações de fato utilizadas no estabelecimento dos preços.

O trabalho de Shipley (1983) envolveu a remessa de cartas a empresas industriais britânicas, de variados portes, constantes na base de dados do diretório KOMPASS. 728 respostas válidas foram obtidas. O objetivo do trabalho foi investigar o estabelecimento dos preços em um ambiente econômico desfavorável, tal como era o da Grã-Bretanha em 1979, ano de coleta dos dados.

O autor constatou que, mesmo em condições adversas, o estabelecimento dos preços com base nos custos era o dominante, uma vez que 59\% dos respondentes afirmaram somar os custos à margem com essa finalidade. Shipley (1983) percebeu, contudo, que a maior parte das empresas $(45,4 \%)$ reavaliava a margem a ser somada aos custos sempre que constatava uma necessidade de revisão. Ademais, o autor observou que não eram poucas as empresas $(64,1 \%)$ que se dispunham a cobrar preços menores do que o custo total, desde que eles fossem maiores que os custos variáveis, se as condições exigissem isso.

Na sequência, Hankinson (1995) voltou-se a uma região britânica específica: sul do Wessex, na Inglaterra. Durante o período de 1990 a 1995, o autor conduziu entrevistas pessoais estruturadas com uma amostra de 50 empresas de engenharia com até 100 empregados.

Hankinson (1995) constatou que, por mais que os custos totais não fossem calculados de maneira precisa, $82 \%$ da amostra definia os preços a partir da sua soma a uma margem de lucro arbitrária. Apesar disso, o autor identificou que apenas $28 \%$ da amostra fiava-se exclusivamente nos resultados da combinação "custos mais margem”, sem modificá-los

\footnotetext{
${ }^{11}$ Para contagem das citações, também foi considerada a versão disponibilizada no site do Bank of Greece (Nicolitsas, 2013).
} 
diante de considerações externas (e.g., tendências de mercado, inflação, recessão etc.) e de considerações internas (e.g., problemas técnicos na planta, cargos etc.).

Na Noruega, com coordenação do banco central norueguês, um questionário foi encaminhado a mais de 3.000 empresas de pequeno, médio e grande porte de setores industriais, comerciais e de serviço. 725 empresas o responderam e passaram a compor a amostra da pesquisa (Langbraaten et al., 2008).

A principal revelação do estudo foi que a maior parte da amostra (75\%) dependia dos preços dos concorrentes para definir seus próprios preços. No entanto, muitas aderiam concomitantemente à mecânica dos custos mais margem, tanto que $67 \%$ das empresas assumiram seu uso. Os autores constataram que o uso dos custos mais margem sobrepunha-se ao uso dos preços dos concorrentes em empresas que tinham relações de longo prazo com os clientes. Eles explicaram que isso tendia a acontecer por que o poder para estabelecer os preços era maior quando havia proximidade com os clientes.

$\mathrm{Na}$ Irlanda, o banco central local coordenou o envio de um questionário a empresas constantes no banco de dados "Kompass". Essas empresas poderiam ser industriais, de construção, de distribuição ou de serviços e poderiam ter qualquer porte. Aproximadamente $25 \%$ das empresas aceitaram participar, rendendo à pesquisa um total de 985 respostas. Dentre os resultados, destacam-se aqueles que demonstraram a forma que as empresas irlandesas estabeleciam os preços, conforme mostra a Tabela 19 (Keeney et al., 2010).

Tabela 19 - Resultados de Keeney et al. (2010)

\begin{tabular}{c|c}
\hline BASE DOS PREÇOS & PERCENTUAL \\
\hline Custos mais margem & $44 \%$ \\
\hline Preços dos principais concorrentes & $33 \%$ \\
\hline Preço regulado ou definido pela matriz & $11 \%$ \\
\hline Preço definido pelos clientes & $6 \%$ \\
\hline Outra forma & $6 \%$ \\
\hline ToTAL & $\mathbf{1 0 0 \%}$ \\
\hline
\end{tabular}

Fonte: Adaptada de Keeney et al. (2010, p. 06)

Nota-se a predominância da combinação "custos mais margem" (44\%), seguida pela ampla aderência à equiparação aos preços dos concorrentes (33\%). Um ponto ressaltado pelos autores foi que nas grandes empresas a situação era diferente. Afinal, muitas empresas de grande porte tinham que seguir definições da matriz e não tinham autonomia para formar os 
preços a partir dos custos mais margem. Outro ponto destacado foi que em empresas industriais e de construção a proporção de empresas que usava os custos mais margem era maior do que em empresas de distribuição e de serviços.

Keeney et al. (2010) também observaram que nos mercados em que a concorrência era intensa, havia uma maior equiparação aos preços dos concorrentes do que nos mercados em que a concorrência não era intensa (onde era priorizada a formação própria dos preços mediante a soma dos custos à margem).

O trabalho de Ingenbleek e van der Lans (2013) investigou empresas holandesas de pequeno e médio porte. Os setores envolvidos foram o industrial e o de serviços industriais. Das 600 empresas que receberam o questionário por e-mail, 108 responderam. 13 respostas incompletas tiveram que ser eliminadas, deixando 95 questionários para a análise de dados.

Desta vez com van der Lans e na Holanda, Ingenbleek chegou a resultados muito parecidos com os que obteve em 2003, com outros autores, na Bélgica. Os autores detectaram que as informações de valor continuavam consideradas centrais para o estabelecimento dos preços. Na sequência, apareciam as informações de custos e da concorrência.

A pesquisa de Carricano (2014) foi focada nas maiores empresas industriais francesas. Entre abril e junho de 2007, 588 empresas (identificadas no banco de dados Expansion 1000, que contém informações sobre as maiores empresas da França) foram convidadas (por telefone) a participar da pesquisa. Dentre todas as empresas contatadas, 98 aceitaram o convite e responderam o questionário.

Os resultados apresentados por Carricano (2014) mais uma vez sugeriram que as empresas preferiam estabelecer os preços somando uma margem aos custos. Conforme a Tabela 20 demonstra, 27,6\% das empresas definiam seus preços dessa maneira, seguidas de perto por $24,5 \%$ das empresas que estabeleciam os preços conforme os preços dos concorrentes. 
Tabela 20 - Resultados de Carricano (2014)

\begin{tabular}{c|c|c|c}
\hline RANKING & BASE DOS PREÇOS & QUANTIDADE & PERCENTUAL \\
\hline 1 & Custos mais Margem & 27 & $27,6 \%$ \\
\hline 2 & Preços dos Concorrentes & 24 & $24,5 \%$ \\
\hline 3 & De Acordo com Estratégia de Liderança & 15 & $15,3 \%$ \\
\hline 4 & De Acordo com Estratégia de Penetração & 12 & $12,2 \%$ \\
\hline 4 & De Acordo com Estratégia de Desnatação & 12 & $12,2 \%$ \\
\hline 6 & De Acordo com Estratégia Oportunista & 8 & $8,2 \%$ \\
\hline & TOTAL & $\mathbf{9 8}$ & $\mathbf{1 0 0 , 0 \%}$ \\
\hline
\end{tabular}

Fonte: Adaptada de Carricano (2014, p. 166)

Finalmente, na Grécia, Nicolitsas (2015) reportou pesquisa desenvolvida sob coordenação do banco da Grécia (Bank of Greece). Nela, um questionário foi encaminhado a 6.700 empresas, selecionadas a partir da estratificação de uma população de 25.000 firmas (limitadas ou sociedades anônimas) de todos os setores, com exceção dos não lucrativos, primários, de construção, de serviços financeiros e de imobiliária. 444 respostas foram obtidas e corresponderam à amostra final investigada na pesquisa.

Como principal achado, destaca-se a constatação de que a maior parte das empresas investigadas estabelecia os preços em função dos preços dos concorrentes $(41,3 \%)$. Na sequência apareciam os preços definidos a partir da combinação dos custos à margem $(35,6 \%)$, os preços regulados $(12,9 \%)$ e os preços determinados pelos clientes $(10,1 \%)$.

Interessante pontuar que essa distribuição diferia muito entre os setores, tanto que em empresas industriais, atacadistas e de serviços industriais a ordem era invertida e a combinação dos custos à margem sobrepunha-se ao embasamento nos preços dos concorrentes. No setor de vendas de automóveis nem os custos nem os concorrentes eram a principal fonte para a decisão dos preços, devido a fortes imposições das matrizes às subsidiárias. Com relação ao tamanho, a ordem se invertia apenas para empresas que tinham de 50 a 199 empregados, nas quais a combinação dos custos à margem era mais adotada do que os preços dos concorrentes.

É possível constatar que a Europa Ocidental não tem o mesmo consenso que a América Anglo-Saxônica. Afinal, 3 das 6 pesquisas acrescentadas nesta seção corroboraram a constatação central dos principais estudos (predominância dos custos mais margem no estabelecimento dos preços), mas a outra metade das pesquisas chegou à conclusão diferente (predominância do embasamento nos preços dos concorrentes ou no valor). Essa constatação 
replica aquela encontrada nos estudos mais citados, pois nem todos os trabalhos europeus mais citados demonstraram a ampla aderência aos custos para definição dos preços (todos os 5 trabalhos mais citados que chegaram a outras conclusões são da Europa Ocidental).

Destarte, finalizada a apresentação dos trabalhos menos citados sobre o estabelecimento dos preços, pode-se caminhar para a conclusão da seção. Para tanto, inicialmente apresenta-se a Tabela 21, que sumariza os resultados centrais de cada estudo.

Tabela 21 - Sumário dos resultados das pesquisas empíricas menos citadas

\begin{tabular}{|c|c|c|c|c|c|c|}
\hline ESTUDO & LOCAL & AMOSTRA & PORTE & RAMO & PRINCIPAl CONCluSÃo & Citações \\
\hline \multicolumn{7}{|c|}{ AMÉRICA LATINA (EXCETO BRASIL) } \\
\hline Murray (2013) & Guiana & 31 & $\begin{array}{c}\text { Não } \\
\text { mencionado }\end{array}$ & Comércio & $\begin{array}{l}\text { A maior parte das empresas estabelece os preços } \\
\text { a partir da combinação "custos mais margem". }\end{array}$ & - \\
\hline $\begin{array}{l}\text { Mahabir et al. } \\
\quad(2013)\end{array}$ & $\begin{array}{l}\text { Trinidad e } \\
\text { Tobago }\end{array}$ & 63 & $\begin{array}{l}\text { Variados } \\
\text { portes }\end{array}$ & $\begin{array}{l}\text { Indústria, } \\
\text { engenharia } \\
\text { e serviço }\end{array}$ & $\begin{array}{l}\text { A maior parte das empresas delibera alterações } \\
\text { nos preços de acordo com alterações nos custos } \\
\text { (matéria-prima, pessoal e custos financeiros). Os } \\
\text { preços variam entre os clientes. }\end{array}$ & - \\
\hline $\begin{array}{l}\text { Borraz et al. } \\
\quad(2013)\end{array}$ & Uruguai & 363 & $\begin{array}{l}\text { Variados } \\
\text { portes }\end{array}$ & $\begin{array}{l}\text { Indústria, } \\
\text { comércio e } \\
\text { serviço }\end{array}$ & $\begin{array}{l}\text { A maior parte das empresas estabelece os preços } \\
\text { a partir da combinação “custos mais margem". } \\
\text { Em empresas oferecedoras de commodities, } \\
\text { contudo, os preços internacionais sobrepõem-se à } \\
\text { combinação. }\end{array}$ & - \\
\hline \multicolumn{7}{|c|}{ ÁFRICA } \\
\hline $\begin{array}{l}\text { Morris e } \\
\text { Schurink } \\
(1993)\end{array}$ & $\begin{array}{l}\text { África do } \\
\quad \text { Sul }\end{array}$ & 70 & $\begin{array}{l}\text { Grandes } \\
\text { empresas }\end{array}$ & Indústria & $\begin{array}{l}\text { A maior parte das empresas estabelece os preços } \\
\text { mais com base no mercado do que com base nos } \\
\text { custos. }\end{array}$ & 18 \\
\hline $\begin{array}{l}\text { Govender } \\
(2000)\end{array}$ & $\begin{array}{l}\text { África do } \\
\text { Sul }\end{array}$ & 110 & $\begin{array}{l}\text { Variados } \\
\text { portes }\end{array}$ & Indústria & $\begin{array}{c}\text { A maior parte das empresas estabelece os preços } \\
\text { com base nos custos totais. }\end{array}$ & 2 \\
\hline Bassett (2014) & $\begin{array}{l}\text { Burkina } \\
\text { Faso e } \\
\text { Côte } \\
\text { d'Ivoire }\end{array}$ & $\begin{array}{c}\text { Não } \\
\text { mencionado }\end{array}$ & $\begin{array}{l}\text { Não } \\
\text { mencionado }\end{array}$ & Indústria & $\begin{array}{c}\text { A maior parte das empresas estabelece os preços a } \\
\text { partir de fórmulas pré-definidas que contemplam } \\
\text { informações de mercado. }\end{array}$ & 3 \\
\hline \multicolumn{7}{|c|}{ EUROPA ORIENTAL } \\
\hline $\begin{array}{l}\text { Sahinöz e } \\
\text { Saraçoglu } \\
\text { (2008) }\end{array}$ & Turquia & 999 & $\begin{array}{l}\text { Variados } \\
\text { portes }\end{array}$ & Indústria & $\begin{array}{l}\text { A maior parte das empresas estabelece os preços } \\
\text { a partir da combinação "custos mais margem". }\end{array}$ & 17 \\
\hline $\begin{array}{l}\text { Babecký et al. } \\
\text { (2008) }\end{array}$ & $\begin{array}{l}\text { República } \\
\text { Tcheca }\end{array}$ & 399 & $\begin{array}{l}\text { Variados } \\
\text { portes }\end{array}$ & $\begin{array}{l}\text { Indústria, } \\
\text { comércio e } \\
\text { serviço }\end{array}$ & $\begin{array}{l}\text { A maior parte das empresas estabelece os preços } \\
\text { com base nos preços dos concorrentes. Ainda assim, } \\
\text { há empresas que estabelecem os preços a partir da } \\
\text { combinação "custos mais margem". }\end{array}$ & 11 \\
\hline $\begin{array}{l}\text { Copaciu et al. } \\
\quad(2010)\end{array}$ & Romênia & 377 & $\begin{array}{l}\text { Variados } \\
\text { portes }\end{array}$ & $\begin{array}{l}\text { Indústria e } \\
\text { serviço }\end{array}$ & $\begin{array}{l}\text { A maior parte das empresas estabelece os preços } \\
\text { com base nos preços dos concorrentes. Ainda assim, } \\
\text { há empresas que estabelecem os preços a partir da } \\
\text { combinação "custos mais margem". }\end{array}$ & 23 \\
\hline \multicolumn{7}{|c|}{ ( } \\
\hline $\begin{array}{c}\text { Chia e Noble } \\
\text { (1999) }\end{array}$ & Cingapura & 75 & $\begin{array}{c}\text { Não } \\
\text { mencionado }\end{array}$ & Indústria & $\begin{array}{l}\text { A maior parte das empresas estabelece os preços } \\
\text { a partir da combinação "custos mais margem". }\end{array}$ & 7 \\
\hline $\begin{array}{l}\text { S. Nakagawa } \\
\text { et al. (2000) }\end{array}$ & Japão & 630 & $\begin{array}{l}\text { Não } \\
\text { mencionado }\end{array}$ & $\begin{array}{l}\text { Indústria, } \\
\text { comércio, } \\
\text { serviço e } \\
\text { engenharia }\end{array}$ & $\begin{array}{l}\text { A maior parte das empresas estabelece os preços a } \\
\text { partir de informações do mercado. Ainda assim, há } \\
\text { empresas que estabelecem os preços a partir da } \\
\text { combinação "custos mais margem". }\end{array}$ & 20 \\
\hline $\begin{array}{l}\text { Malik et al. } \\
\quad(2010)\end{array}$ & Paquistão & 343 & $\begin{array}{l}\text { Variados } \\
\text { portes }\end{array}$ & $\begin{array}{l}\text { Indústria, } \\
\text { comércio e } \\
\text { serviço }\end{array}$ & $\begin{array}{l}\text { A maior parte das empresas estabelece os preços } \\
\text { a partir da combinação "custos mais margem". } \\
\text { Entretanto, os preços definidos podem ser } \\
\text { alterados dependendo da quantidade adquirida, } \\
\text { da situação específica e de acordos contratuais } \\
\text { com os clientes. }\end{array}$ & 4 \\
\hline $\begin{array}{l}\text { Choudhary et } \\
\text { al. (2012) }\end{array}$ & Paquistão & 1.189 & $\begin{array}{l}\text { Variados } \\
\text { portes }\end{array}$ & $\begin{array}{c}\text { Indústria e } \\
\text { serviço }\end{array}$ & $\begin{array}{l}\text { A maior parte das empresas estabelece os preços } \\
\text { a partir da combinação "custos mais margem". }\end{array}$ & - \\
\hline
\end{tabular}




\begin{tabular}{|c|c|c|c|c|c|c|}
\hline ESTUDO & LOCAL & AMOSTRA & PORTE & RAMO & Principal Conclusão & CiTAÇõES \\
\hline \multicolumn{7}{|c|}{ OCEANIA } \\
\hline $\begin{array}{l}\text { Park et al. } \\
\quad(2010)\end{array}$ & Austrália & $\begin{array}{l}\text { Aproximada } \\
\text { mente } 700 \\
\text { (número } \\
\text { exato não } \\
\text { mencionado) }\end{array}$ & $\begin{array}{l}\text { Variados } \\
\text { portes }\end{array}$ & $\begin{array}{l}\text { Indústria, } \\
\text { comércio, } \\
\text { serviço e } \\
\text { engenharia }\end{array}$ & $\begin{array}{c}\text { A maior parte das empresas estabelece os preços } \\
\text { a partir da combinação "custos mais margem". A } \\
\text { margem varia de acordo com as condições da } \\
\text { demanda. }\end{array}$ & 8 \\
\hline $\begin{array}{l}\text { Carnegie et al. } \\
\qquad(2011)\end{array}$ & Austrália & 162 & $\begin{array}{l}\text { Não } \\
\text { mencionado }\end{array}$ & Governo & $\begin{array}{l}\text { A maior parte das empresas estabelece os preços } \\
\text { a partir da combinação "custos mais margem". } \\
\text { No entanto, por serem entidades governamentais, } \\
\text { a fórmula aparece de uma forma diferente: } \\
\text { deduzida dos subsídios. }\end{array}$ & 6 \\
\hline $\begin{array}{l}\text { Indounas e } \\
\text { Roth (2012) }\end{array}$ & $\begin{array}{l}\text { Nova } \\
\text { Zelândia }\end{array}$ & 120 & $\begin{array}{l}\text { Variados } \\
\text { portes }\end{array}$ & Serviço & $\begin{array}{l}\text { A maior parte das empresas estabelece os preços a } \\
\text { partir de informações de valor e da concorrência. } \\
\text { Ainda assim, informações de custos também são } \\
\text { importantes para o processo. }\end{array}$ & 1 \\
\hline Parker (2014) & $\begin{array}{l}\text { Nova } \\
\text { Zelândia }\end{array}$ & 5.369 & $\begin{array}{l}\text { Variados } \\
\text { portes }\end{array}$ & $\begin{array}{l}\text { Indústria, } \\
\text { comércio e } \\
\text { serviço }\end{array}$ & $\begin{array}{l}\text { A maior parte das empresas estabelece os preços } \\
\text { a partir da combinação “custos mais margem". }\end{array}$ & 2 \\
\hline \multicolumn{7}{|c|}{ AMÉRICA ANGLO-SAXÔNICA } \\
\hline Lazer (1957) & Canadá & 22 & $\begin{array}{l}\text { Variados } \\
\text { portes }\end{array}$ & Indústria & $\begin{array}{l}\text { A maior parte das empresas estabelece os preços } \\
\text { a partir da combinação “custos mais margem”. } \\
\text { Os preços são ajustados aos preços dos } \\
\text { concorrentes e às percepções dos clientes. }\end{array}$ & 13 \\
\hline $\begin{array}{l}\text { Bruegelmann } \\
\text { et al. (1985) }\end{array}$ & $\begin{array}{l}\text { Estados } \\
\text { Unidos }\end{array}$ & 11 & $\begin{array}{c}\text { Não } \\
\text { mencionado }\end{array}$ & Indústria & $\begin{array}{l}\text { A maior parte das empresas estabelece os preços } \\
\text { com base nos custos totais. }\end{array}$ & 11 \\
\hline Goetz (1985) & $\begin{array}{l}\text { Estados } \\
\text { Unidos }\end{array}$ & 103 & $\begin{array}{l}\text { Pequenas } \\
\text { empresas }\end{array}$ & Serviço & $\begin{array}{l}\text { A maior parte das empresas estabelece os preços } \\
\text { a partir da combinação “custos mais margem”. }\end{array}$ & 24 \\
\hline \multicolumn{7}{|c|}{ EUROPA OCIDENTAL } \\
\hline Shipley (1983) & $\begin{array}{l}\text { Grã- } \\
\text { Bretanha }\end{array}$ & 728 & $\begin{array}{l}\text { Variados } \\
\text { portes }\end{array}$ & Indústria & $\begin{array}{c}\text { A maior parte das empresas estabelece os preços } \\
\text { a partir da combinação "custos mais margem". A } \\
\text { margem pode ser modificada e os custos podem } \\
\text { não ser totais. }\end{array}$ & 24 \\
\hline $\begin{array}{l}\text { Hankinson } \\
\text { (1995) }\end{array}$ & $\begin{array}{l}\text { Grã- } \\
\text { Bretanha }\end{array}$ & 50 & $\begin{array}{l}\text { Pequenas e } \\
\text { médias } \\
\text { empresas }\end{array}$ & Engenharia & $\begin{array}{l}\text { A maior parte das empresas estabelece os preços } \\
\text { a partir da combinação “custos mais margem”. O } \\
\text { resultado pode ser alterado em função de } \\
\text { considerações externas e internas. }\end{array}$ & 11 \\
\hline $\begin{array}{l}\text { Langbraaten et } \\
\quad \text { al. (2008) }\end{array}$ & Noruega & 725 & $\begin{array}{l}\text { Variados } \\
\text { portes }\end{array}$ & $\begin{array}{l}\text { Indústria, } \\
\text { comércio e } \\
\text { serviço }\end{array}$ & $\begin{array}{l}\text { A maior parte das empresas estabelece os preços } \\
\text { com base nos preços dos concorrentes. Ainda assim, } \\
\text { há empresas que estabelecem os preços a partir da } \\
\text { combinação "custos mais margem". }\end{array}$ & 6 \\
\hline $\begin{array}{l}\text { Keeney et al. } \\
\quad(2010)\end{array}$ & Irlanda & 985 & $\begin{array}{l}\text { Variados } \\
\text { portes }\end{array}$ & $\begin{array}{l}\text { Indústria, } \\
\text { comércio, } \\
\text { serviço e } \\
\text { engenharia }\end{array}$ & $\begin{array}{l}\text { A maior parte das empresas estabelece os preços } \\
\text { a partir da combinação “custos mais margem". }\end{array}$ & 3 \\
\hline $\begin{array}{l}\text { Ingenbleek e } \\
\text { van der Lans } \\
\quad(2013)\end{array}$ & Holanda & 95 & $\begin{array}{l}\text { Pequenas e } \\
\text { médias } \\
\text { empresas }\end{array}$ & $\begin{array}{l}\text { Indústria e } \\
\text { serviço }\end{array}$ & $\begin{array}{l}\text { A maior parte das empresas estabelece os preços a } \\
\text { partir de informações de valor. Ainda assim, } \\
\text { informações da concorrência e de custos também são } \\
\text { importantes para o processo. }\end{array}$ & 19 \\
\hline $\begin{array}{l}\text { Carricano } \\
(2014)\end{array}$ & França & 98 & $\begin{array}{c}\text { Grandes } \\
\text { empresas }\end{array}$ & Indústria & $\begin{array}{l}\text { A maior parte das empresas estabelece os preços } \\
\text { a partir da combinação "custos mais margem". }\end{array}$ & 4 \\
\hline $\begin{array}{l}\text { Nicolitsas } \\
(2015)\end{array}$ & Grécia & 444 & $\begin{array}{l}\text { Variados } \\
\text { portes }\end{array}$ & $\begin{array}{l}\text { Indústria, } \\
\text { comércio, } \\
\text { serviço e } \\
\text { engenharia }\end{array}$ & $\begin{array}{l}\text { A maior parte das empresas estabelece os preços } \\
\text { com base nos preços dos concorrentes. Ainda assim, } \\
\text { há empresas que estabelecem os preços a partir da } \\
\text { combinação "custos mais margem". }\end{array}$ & 5 \\
\hline
\end{tabular}

Primeiramente, pode-se perceber que o foco na Europa Ocidental permaneceu entre os estudos menos citados, já que um quarto dos trabalhos encontrados nesta etapa (7) referiu-se a esse local. Ademais, mais da metade (15) das pesquisas acrescentadas continuou discutindo a realidade encontrada em países desenvolvidos. De fato, poucos (12) foram os estudos que se debruçaram a investigar a realidade de pontos menos desenvolvidos. Quando se articula os estudos menos citados aos mais citados, nota-se ainda mais essa concentração (Tabela 22). 
Tabela 22 - Sumário dos locais investigados nas pesquisas empíricas (mais e menos citadas)

\begin{tabular}{c|c|c|c}
\hline REGIÃo GeOGRÁFICA & QUANTIDADE & PERCENTUAL & PERCENTUAL ACUMULADO \\
\hline Europa Ocidental & 25 & $42 \%$ & $42 \%$ \\
\hline América Anglo-Saxônica & 14 & $25 \%$ & $67 \%$ \\
\hline Oceania & 5 & $9 \%$ & $75 \%$ \\
\hline Ásia & 4 & $7 \%$ & $82 \%$ \\
\hline África & 4 & $7 \%$ & $89 \%$ \\
\hline Europa Oriental & 3 & $5 \%$ & $95 \%$ \\
\hline América Latina (exceto Brasil) & 3 & $5 \%$ & \\
\hline
\end{tabular}

A Figura 22 ilustra graficamente essa concentração e revela que o que se sabe sobre o estabelecimento dos preços refere-se, sem dúvidas, a locais desenvolvidos.

Figura 22 - Abrangência mundial das pesquisas empíricas (mais e menos citadas)

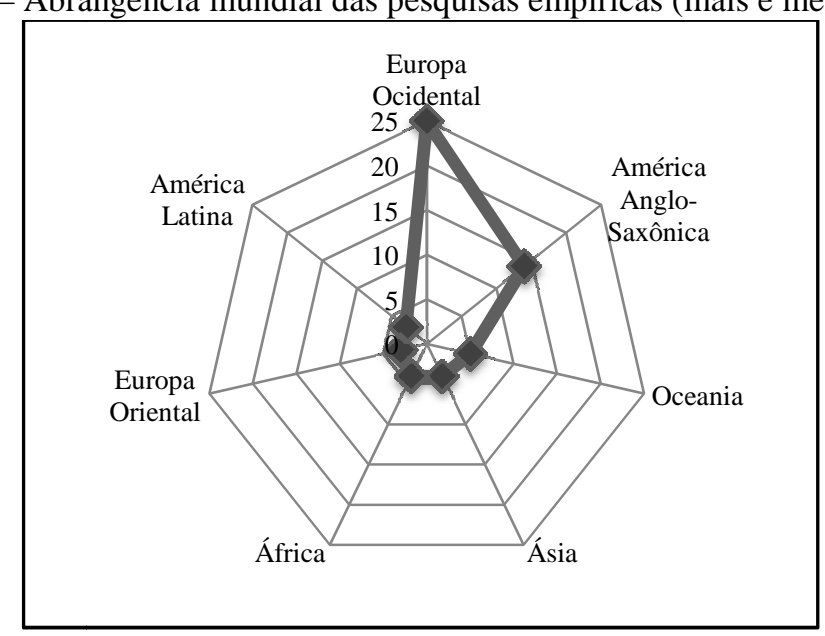

Fonte: Elaboração própria

Em segundo lugar, nota-se que a conclusão central das pesquisas menos citadas é semelhante à conclusão dos estudos mais citados, pois defende que o estabelecimento dos preços ocorre fundamentalmente mediante a combinação dos custos à margem (vide negrito e sombreamento cinza na Tabela 21). Assim, observa-se que a ampla maioria dos 57 estudos empíricos internacionais (mais e menos citados) sobre o estabelecimento dos preços, tanto os mais quanto os menos citados, conclui que o mecanismo de custos mais margem é aquele que mais bem explica a forma que as empresas definem os preços (conclusão de 25 dos estudos mais citados e de 18 dos estudos menos citados), como ilustrado na Figura 23.

12 A soma das linhas dá 58 não 57, pois o trabalho de Guilding et al. (2005) está apresentado em duas linhas, já que abordou duas regiões geográficas (Europa Ocidental e Oceania). 


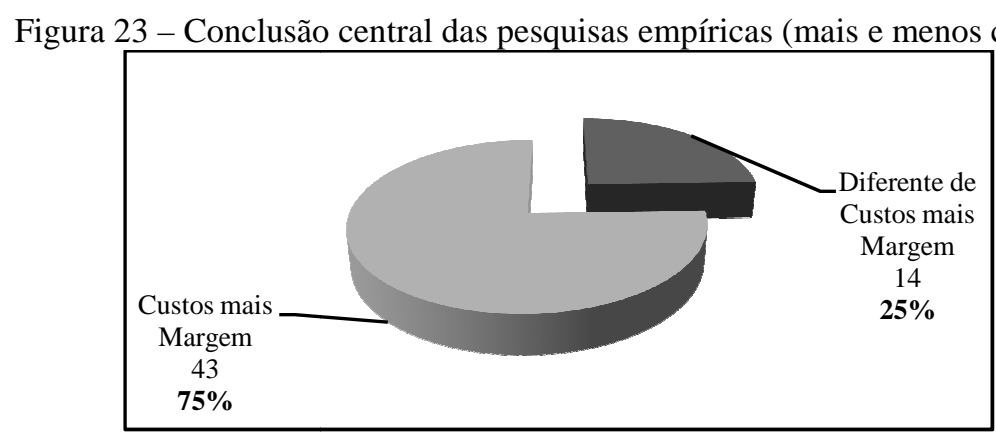

Fonte: Elaboração própria

Cabe novamente salientar que essa conclusão revela a forma, mas não necessariamente a essência do estabelecimento dos preços, afinal, vários estudos apresentados nessas duas seções demonstraram que a combinação dos custos à margem não indicava isoladamente a decisão a ser tomada. Por isso, cautela deve ser tomada quando as conclusões desses estudos forem usadas como base para afirmar que os preços não são definidos tal como postula a teoria, seja econômica ou de marketing.

\subsection{Pesquisas Empíricas Brasileiras}

Agora que já foram apresentados os estudos internacionais sobre o estabelecimento dos preços, vale voltar a atenção para a literatura nacional e investigar se seus achados assemelham-se ou não aos achados das pesquisas de outras partes do mundo. Cumpre mencionar que tais estudos foram localizados depois de serem realizadas buscas em sites de revistas e de congressos brasileiros. Procurou-se especialmente acessar os sites de revistas da área de Administração, Ciências Contábeis e Turismo classificadas até o extrato B5 pela Coordenação de Aperfeiçoamento de Pessoal de Nível Superior (CAPES, 2016) e dos eventos (da mesma área) que já foram classificados como E1 (CAPES, 2009).

Vale esclarecer que, a fim de manter a comparabilidade com as duas seções anteriores, as pesquisas aqui apresentadas delimitam-se àquelas elaboradas na forma de levantamento. Nas consultas realizadas, localizou-se na literatura nacional uma quantidade expressiva de trabalhos realizados como estudos de caso, com uma ou múltiplas empresas, mas optou-se por não reportá-los nesta seção já que eles expõem a realidade específica das organizações investigadas e não da realidade dominante no contexto brasileiro. 
O primeiro estudo brasileiro localizado foi o de Mello (2000). Tal estudo resumiu a dissertação de mestrado do autor (defendida em 1999), voltada a indústrias alimentícias localizadas no Rio Grande do Sul. O questionário da pesquisa, inspirado no instrumento usado por R. I. Hall e Hitch (1939), foi remetido para 24 empresas de pequeno porte do município gaúcho de Santa Maria e para 23 empresas de grande porte localizadas em qualquer município gaúcho. Para o primeiro grupo foram obtidas 14 respostas, para o segundo, 9.

Mello (2000) reportou que, para o grupo de empresas que investigou no Brasil, os preços também eram estabelecidos prioritariamente a partir da soma de uma margem aos custos, como a Tabela 23 demonstra. Apesar disso, o autor mencionou que a demanda e, sobretudo, os preços dos concorrentes tinham papel relevante na determinação dos preços. Ele citou o depoimento de um empresário que revelou "o mercado é que determina as margens. Como o mercado é de alto giro, as margens são pequenas, definir margens que não acontecem, não interessa" (p. 34).

Tabela 23 - Resultados de Mello (2000)

\begin{tabular}{c|c|c|c|c}
\hline \multirow{2}{*}{ BASE dOS PREÇOS } & \multicolumn{2}{|c|}{ SANTA MARIA } & \multicolumn{2}{c}{ DEMAIS MUNICÍPIOS } \\
\cline { 2 - 5 } & QUANTIDAdE & PERCENTUAL & QUANTIDADE & PERCENTUAL \\
\hline Custos mais margem & 10 & $71,4 \%$ & 5 & $55,6 \%$ \\
\hline Outra base & 4 & $28,6 \%$ & 4 & $44,4 \%$ \\
\hline TotaL & $\mathbf{1 4}$ & $\mathbf{1 0 0 , 0 \%}$ & $\mathbf{9}$ & $\mathbf{1 0 0 , 0 \%}$ \\
\hline
\end{tabular}

Fonte: Adaptada de Mello (2000, p. 33)

Na sequência, encontrou-se o trabalho de Barbosa (2003) que investigou o estabelecimento dos preços em indústrias de diversos ramos e de diversos portes. $\mathrm{O}$ questionário do trabalho foi remetido mediante duas estratégias. A primeira foi a realização de entrevistas pessoais a empresas do Pernambuco constantes no cadastro de 1999 do Sindicato da Indústria da Construção Civil de Pernambuco (Sinduscon/PE) e/ou na lista telefônica comercial da região metropolitana do Recife e do Arquipélago de Fernando de Noronha do ano de 2001

A segunda foi o envio de mensagens eletrônicas a representantes de 1.434 empresas de todo o país, constantes na revista Noticiários de Equipamentos Industriais (NEI) - Edição Especial Top Five do ano de 2000/2001, a profissionais que participaram do VII Congresso Brasileiro de Custos e/ou a profissionais alunos dos cursos de especialização da Universidade Federal do Rio Grande do Sul (UFRGS) e de pós-graduação da Universidade Federal de Pernambuco (UFPE). 
53 respostas foram obtidas a partir da primeira estratégia e 31 a partir da segunda estratégia. Como 3 questionários tiveram que ser excluídos, por não se referirem a empresas industriais, a análise de dados ateve-se a 81 respostas.

Ao questionar a fórmula usada para estabelecer os preços, Barbosa (2003) constatou que a maioria das empresas combinava informações de custos a informações de mercado. Somente na sequência, apareciam as empresas que se embasavam exclusivamente nos custos, conforme traz a Tabela 24.

Tabela 24 - Resultados de Barbosa (2003)

\begin{tabular}{c|cc}
\hline RANKING & BASE DOS PREÇOS & QUANTIDADE \\
\hline 1 & Combinando informação de custos e de mercado & 40 \\
\hline 2 & Usando uma fórmula que leva em conta custos, impostos e lucro & 26 \\
\hline 3 & Combinando informações de custos com a margem & 19 \\
\hline 4 & É negociado caso a caso & 12 \\
\hline 5 & Não calcula, observa o mercado & 9 \\
\hline 6 & Aplicando um índice sobre custos & 7 \\
\hline & ToTAL & $\mathbf{1 1 3}$ \\
\hline
\end{tabular}

Fonte: Adaptada de Barbosa (2003, p. 10)

Barbosa (2003) também observou que as empresas enfatizavam o uso do custo total (apurado com base no custeio por absorção) ao invés do custo variável, mas, ainda assim, definiam preços coerentes àqueles disponíveis no mercado.

Para o ano seguinte, encontrou-se o estudo de Rosadas e Macedo (2004). Esse estudo buscou averiguar o processo de estabelecimento dos preços em empresas de pequeno porte que atuavam com a comercialização de materiais de construção em bairros do subúrbio carioca. Os autores conseguiram obter respostas de 37 empresas, dentre as 51 que almejavam.

Como principais achados, Rosadas e Macedo (2004) destacaram a nítida predominância dos custos mais margem na definição dos preços. Eles constataram que 64,86\% das empresas definiam os preços a partir dos custos (preços de compra) mais margem, enquanto que apenas $18,92 \%$ definiam os preços com base nos preços do mercado e 16,22\% com base numa combinação desses dois tipos de informação.

Rosadas e Macedo (2004) também mencionaram que nas empresas em que os preços de venda eram determinados a partir dos custos mais margem, a margem era formada pela crença 
de que um determinado preço final era adequado ou por informações advindas dos fornecedores (vendedores) dos produtos. A margem colocada ia de $8 \%$ até $40 \%$. Já nas empresas em que os preços baseavam-se no mercado, a definição era pautada pela percepção do cliente em relação ao preço e por pesquisas (por telefone ou pessoalmente) dos preços propostos pelos principais concorrentes.

Em seguida, encontrou-se a pesquisa de L. P. Silva e Santos (2005) focada na definição dos preços em indústrias que atendiam três condições: atuavam com exportações de equipamentos médico-hospitalares e odontológicos; eram de pequeno porte; e eram localizadas na região de Ribeirão Preto. A pesquisa foi marcada pelo envio de questionários a 11 empresas, dentre as quais 4 responderam e passaram a compor a amostra.

Os autores constataram que os custos eram a principal base para a definição dos preços. Especificamente, eles observaram que sobre os custos era colocada uma margem simples, espelhando o lucro desejado. L. P. Silva e Santos (2005) também notaram que ênfase era dada aos custos apurados pelo custeio pleno. No que se refere à forma que a margem era constituída bem como ao seu percentual, não houve investigação por parte dos autores.

Depois, localizou-se a pesquisa de Dias, Carvalho, e Cogan (2006) sobre a definição dos preços em lojas do setor do vestuário no Shopping Center Rio Sul (na cidade do Rio de Janeiro). Os autores selecionaram aleatoriamente 28 empresas dentre as 141 de vestuário existentes no referido Shopping e procuraram entrevistar seus gestores. Eles conseguiram obter a participação de 19 dessas 28 empresas.

Como principal achado, Dias et al. (2006) detectaram que todas as empresas determinavam o preço da mesma maneira, isto é, todas somavam uma margem ao custo do produto. Eles relataram que a simplicidade da combinação dos custos à margem aliada ao atendimento das expectativas de retorno dos lojistas explicava o censo encontrado.

Para o mesmo ano, também foi encontrado o estudo de D. G. Machado e Souza (2006) ${ }^{13}$ que sumarizou os resultados da dissertação de mestrado da autora (defendida em 2005). Essa

\footnotetext{
${ }^{13} \mathrm{O}$ estudo havia sido anteriormente publicado no IX Congresso Internacional de Custos (D. G. Machado \& Souza, 2005).
} 
dissertação envolveu empresas industriais conserveiras de médio e grande porte localizadas no Rio Grande do Sul e cadastradas na Federação das Indústrias daquele estado. Das 11 empresas cadastradas, 9 participaram da pesquisa.

A autora identificou que $100 \%$ das empresas calculavam os preços a partir dos custos mais margem. No entanto, apenas 33\% cobravam necessariamente o preço calculado porque não dependiam dos preços dos concorrentes, tinham clientes extremamente fiéis, ofereciam produtos de alta qualidade e ofertavam um prazo de pagamento interessante. Nas demais empresas (67\%), o preço calculado originalmente era considerado apenas como uma referência ou ponto de partida para a negociação. $89 \%$ das empresas indicaram reduzir a margem quando ela orientasse a preços superiores aos preços dos concorrentes.

Ainda para o mesmo ano, foi encontrado o trabalho de M. A. V. Machado, Machado, e Holanda (2006) investigando a deliberação dos preços em hotéis de João Pessoa. Os autores buscaram entrevistar os gestores de todos os 46 hotéis (de variados portes) sediados na capital paraibana e cadastrados na Secretaria de Turismo do Estado da Paraíba, no entanto, apenas conseguiram assegurar a participação de 31 deles.

Como achados, M. A. V. Machado et al. (2006) destacaram que a maior parte dos hotéis (71\%) definia seus preços com base em uma combinação de informações de custos e de mercado. Na sequência apareciam os hotéis que estabeleciam os preços pautados unicamente nos custos $(12,9 \%)$ ou unicamente no mercado $(9,7 \%)$. Os autores também ressaltaram que $64,5 \%$ dos hotéis consideravam as informações de custos muito úteis para as decisões de preços e que $54,8 \%$ dos hotéis priorizavam o uso dos custos totais (contra $25,8 \%$ que priorizavam os custos variáveis).

Logo na sequência, localizou-se a pesquisa de Almeida e Santos (2007) ${ }^{14}$ que analisou as práticas de contabilidade de custos em indústrias paranaenses. Os autores enviaram questionários para 30 indústrias paranaenses que constavam entre as trezentas maiores do Sul do Brasil em 2004, de acordo com a Revista Expressão 2005 da Fundação Getúlio Vargas. Como eles obtiveram apenas 10 respostas, eles optaram por incluir mais 4 empresas que,

\footnotetext{
${ }^{14} \mathrm{O}$ estudo havia sido anteriormente publicado no XIII Congresso Brasileiro de Custos (A. R. Santos \& Almeida, 2006).
} 
apesar de não estarem na lista da revista, tinham reconhecimento no contexto regional, nacional e mesmo internacional. No total, trabalharam com uma amostra de 14 empresas.

Como mostra a Tabela 25, Almeida e Santos (2007) detectaram que as indústrias paranaenses priorizavam informações de mercado, sobretudo de elasticidade e de economia, na definição dos preços. Informações de custos apareciam na sequência, ao passo que os conceitos de custeio variável e de margem de contribuição eram levados em consideração no processo.

Tabela 25 - Resultados de Almeida e Santos (2007)

\begin{tabular}{c|cc}
\hline QUESTõES & QUANTIDADE & PERCENTUAL \\
\hline Informações sobre o mercado (elasticidade, na economia) são levadas em consideração? & 13 & $93 \%$ \\
\hline Conceitos de custeio variável e margem de contribuição são levados em consideração? & 12 & $86 \%$ \\
\hline São utilizadas informações do método de custeio utilizado pela indústria? & 11 & $79 \%$ \\
\hline A margem de contribuição marginal dos produtos é considerada? & 10 & $71 \%$ \\
\hline $\begin{array}{c}\text { Utiliza-se o Target Costing (Custo-meta) para a partir do preço de mercado atingir o custo- } \\
\text { meta? }\end{array}$ & 7 & $50 \%$ \\
\hline Utiliza-se do Método de Custeio ABC para redução de custos e despesas? & 3 & $21 \%$ \\
\hline Target Costing (Custo-meta) combinado com o ABC são utilizados? & 2 & $14 \%$ \\
\hline
\end{tabular}

Fonte: Adaptada de Almeida e Santos (2007, pp. 31-32)

Continuando a exploração de 2007, identificou-se o estudo de Callado, Machado, Callado, Machado, e Almeida (2007) ${ }^{15}$ focado na averiguação de como as empresas agroindustriais da Paraíba definiam os preços. Os autores enviaram um questionário para as 118 empresas cadastradas na Federação das Indústrias do Estado da Paraíba (FIEP-PB) e conseguiram obter 20 respostas.

Callado et al. (2007) detectaram que a ampla maioria das empresas agroindustriais paraibanas (70\%) estabelecia os preços sobrepondo uma margem aos custos de fabricação. Na sequência, apareciam os preços formados caso a caso com cada cliente (20\%) e os preços definidos com a sobreposição de uma margem unicamente ao custo das matérias primas (5\%).

Explorando 2007 ainda, localizou-se a pesquisa de Cogan, Cabral, Castro, e Bispo (2007) que investigou a formação do preço de venda das micro e pequenas empresas dos municípios de Guapimirim e Teresópolis, no estado do Rio de Janeiro. Os autores aplicaram um questionário a 19 empresas (7 de Guapimirim e 12 de Teresópolis), sendo todas comerciais (entretanto 1 também era indústria e 4 também eram prestadoras de serviço).

\footnotetext{
${ }^{15} \mathrm{O}$ estudo havia sido anteriormente publicado no $5^{\circ}$ Congresso USP de Controladoria e Contabilidade (Callado, Machado, Callado, \& Machado, 2005).
} 
A constatação central do estudo foi de que a maioria das empresas definia os preços a partir dos custos mais margem (36\%). Na sequência apareciam os preços de acordo com os preços da concorrência (32\%), com os custos de compras mais despesas (18\%) e com os custos de compras apenas (14\%). Curioso pontuar que os autores não obtiveram resultados homogêneos nas duas cidades investigadas.

Cogan et al. (2007) também investigaram a fonte usada para deliberar a margem e constataram que $65 \%$ dos respondentes definiam a margem a partir da sua própria experiência. Na sequência, apareceram os respondentes que faziam essa definição com base em relatórios contábeis (17\%), no mercado (9\%) e no conselho de outros profissionais da empresa, como do contador (9\%).

Para o mesmo ano, também se encontrou o estudo de Lima, Ferrarezi, e Smith (2007), voltado à exploração do papel dos custos no estabelecimento dos preços em indústrias metalúrgicas de Franca, cidade do interior paulista. Os autores buscaram entrevistar gestores das 36 empresas do segmento de máquinas associadas ao Sindicato dos Metalúrgicos de Franca, mas conseguiram concluir apenas 15 entrevistas. As empresas participantes da pesquisa eram de micro e de pequeno porte.

Lima et al. (2007) não averiguaram se, no estabelecimento dos preços, as empresas utilizavam outros tipos de informações além daquelas de custos, mas observaram que ênfase era dada às informações de custos apuradas pelos métodos de custeio pleno ou por absorção (60\% das empresas usavam informações apuradas por esses custeios).

Na sequência, foi encontrado o trabalho de Hamann, Pereira, Barreto Junior, Nascimento Júnior, e Silva (2010) sobre o estabelecimento dos preços em empresas agroindustriais familiares da região de Planaltina, no Distrito Federal. Os autores aplicaram um questionário a produtores familiares da referida região e, com base nas respostas recebidas, realizaram sua pesquisa. Eles não mencionaram a quantidade de empresas para as quais o questionário foi encaminhado e tampouco quantas respostas foram obtidas. Os autores apenas relataram que, de acordo com a associação local dos Empreendimentos de Assistência Técnica e Extensão Rural (EMATER), os núcleos rurais em Planaltina, Tabatinga e Taquara eram compostos por 621 agroindústrias familiares. 
Hamann et al. (2010) concluíram que, para definirem os preços, as agroindústrias familiares de Planaltina enfatizavam as informações de preços de mercado (59\%). Em segundo lugar, apareciam as empresas que determinavam os preços com base nos custos (29\%) e com base na deliberação de cooperativas (12\%). Os autores também observaram que a margem era definida principalmente como uma função dos gastos (41\%), ou seja, aparentemente para cobrir todos os gastos.

Ainda averiguando 2010, localizou-se o estudo de D. G. Machado, Fiorentin, e Scarpin (2010), voltado a indústrias metalúrgicas de médio e grande porte de Santa Catarina. Com base no banco de associados da Federação das Indústrias do Estado de Santa Catarina (FIESC) do período de 2009/2010, os autores identificaram 65 empresas aptas a participar do estudo. Após o questionário ser enviado eletronicamente e ligações telefônicas terem sido realizadas, os autores conseguiram obter respostas de 15 empresas.

D. G. Machado et al. (2010) identificaram que os custos dos produtos compunham a informação considerada pelas empresas como a mais importante no estabelecimento dos preços. No entanto, os preços calculados com base neles, antes de serem de fato cobrados, eram comparados aos preços do mercado. Caso o preço indicado pelo cálculo fosse maior que os preços dos concorrentes, as empresas revisavam os custos.

Os autores também detectaram que na maior parte das empresas $(86,68 \%)$ o custo usado no estabelecimento dos preços incluía todos os custos de produção, os impostos sobre vendas e as despesas com vendas. A margem de lucro bruto incidia normalmente na forma percentual.

Logo depois, identificou-se a pesquisa de Alves, Varotto, e Gonçalves (2012) ${ }^{16}$ sobre a definição dos preços em empresas paulistanas de varejo. Os autores organizaram 6 equipes de pesquisa, cada qual contendo de 4 a 8 integrantes, orientando-as a entregar um questionário a todos os centros comerciais de bairros localizados na zona sul da cidade de São Paulo. Ao todo, 2.368 estabelecimentos foram visitados, dos quais 437 aceitaram responder o instrumento. 137 questionários foram descartados por possuírem algum tipo de erro, o que fez com que a amostra fosse formada por 300 empresas varejistas de diversos portes, sobretudo

\footnotetext{
${ }^{16} \mathrm{O}$ estudo havia sido anteriormente publicado na REMark - Revista Brasileira de Marketing (Alves, Varotto, \& Gonçalves, 2011).
} 
de micro porte. Os segmentos abrangidos foram variados, mas quase metade da amostra referia-se a empresas de varejo de vestuário.

Alves et al. (2012) focaram na exploração dos objetivos e dos métodos de preços aplicados pelas empresas varejistas paulistanas. Eles segregaram os métodos como baseados nos custos, nas expectativas dos clientes e nas condições concorrenciais do mercado e chegaram à conclusão de que aqueles baseados nos custos eram empregados com mais frequência. Afirmaram que a simplicidade desses métodos poderia explicar essa frequência.

Entretanto, vale esclarecer que os autores trouxeram essas conclusões sem de fato investigarem os tipos de informações usados no processo de definição dos preços, ou seja, trouxeram essa argumentação com base exclusivamente na classificação que haviam feito dos métodos (por exemplo, classificaram que preços premium caracterizavam a aplicação de métodos baseados nos custos). Logo, cautela deve ser tomada na interpretação dos resultados.

Ainda explorando 2012, encontrou-se a pesquisa de A. X. V. Braga et al. (2012) ${ }^{17}$, que é a única pesquisa nacional em inglês disponível nas bases científicas. Esse estudo investigou o estabelecimento dos preços em indústrias conserveiras de pequeno e médio porte da região de Pelotas (Rio Grande do Sul). Seu universo era constituído por 13 empresas, conforme cadastro de 2008 do Sindicato das Indústrias de Conservas de Pelotas e Região, mas os autores optaram por restringir a amostra às 8 empresas que tinham apresentado, em 2008, um faturamento mínimo de R\$ 12 milhões ao executarem atividades de conserva. Os autores entrevistaram gestores dessas 8 empresas.

Os autores detectaram que 6 empresas (75\%) estabeleciam os preços somando uma margem aos custos. As outras 2 empresas $(25 \%)$ definiam os preços de acordo com a média do mercado. A. X. V. Braga et al. (2012) ressaltaram que mesmo nos casos em que o preço era tomado do mercado, os custos mais margem podiam ser usados para avaliar a lucratividade. Os autores também observaram que o uso do custo total era priorizado por 5 empresas, enquanto que o uso do custo variável era priorizado por 3 empresas.

\footnotetext{
17 O estudo havia sido anteriormente publicado no XVI Congresso Brasileiro de Custos (D. P. G. Braga, Kronbauer, Braga, \& Ott, 2009) e na revista Contabilidade, Gestão e Governança (D. P. G. Braga, Braga, \& Souza, 2010).
} 
Para o mesmo ano, localizou-se a pesquisa de Canever, Lunkes, Schnorrenberger, e Gasparetto $(2012)^{18}$ que investigou o estabelecimento dos preços nas maiores empresas industriais de Santa Catarina. Questionários foram enviados para o endereço eletrônico das 100 maiores empresas do estado (por número de empregados) constantes na base de dados da FIESC. 12 respostas foram obtidas.

Os autores concluíram que a maior parte das empresas da amostra (67\%) definia os preços a partir do que nomearam como "métodos mistos", isto é, a partir do uso combinado de informações de custos, da concorrência e do valor. Na sequência, apareciam empresas que determinavam os preços exclusivamente com base nos custos (16,5\%) e as empresas que unicamente tomavam o preço no mercado (16,5\%). Canever et al. (2012) também constataram que as empresas enfatizavam o uso do custo apurado pelo custeio por absorção.

Para o ano seguinte, localizou-se o trabalho de Dallabona, Melz, Santos, e Nunes (2013) que se debruçou a analisar a formação do preço de honorários nos escritórios de contabilidade cadastrados na Prefeitura Municipal de Tangará da Serra (Mato Grosso). Do total de 40 escritórios cadastrados, 28 responderam o questionário aplicado pelos autores.

A conclusão central dos autores foi que o tempo consumido na realização do trabalho (e consequentemente seus custos) era a principal informação considerada para definir os preços dos honorários contábeis. Na sequência, apareciam informações que influenciavam tanto os custos quanto o valor, como o grau de dificuldade e as características do serviço. A Tabela 26 reproduz as dez principais informações constatadas por Dallabona et al. (2013).

Tabela 26 - Resultados de Dallabona et al. (2013)

\begin{tabular}{|c|c|c|c|c|c|c|c|}
\hline ASSERTIVAS & $\mathbf{0}$ & 1 & 2 & 3 & 4 & 5 & PONTUAÇÃO \\
\hline O tempo que será consumido para a realização do trabalho & 0 & 0 & 0 & 3 & 12 & 13 & 122 \\
\hline A relevância, o vulto, a complexidade e a dificuldade do serviço a executar & 0 & 1 & 1 & 5 & 4 & 17 & 119 \\
\hline Características do serviço a ser prestado & 0 & 0 & 1 & 5 & 9 & 13 & 118 \\
\hline Habilidade e experiência que o trabalho exige & 1 & 1 & 0 & 5 & 6 & 15 & 115 \\
\hline A peculiaridade de tratar-se de cliente eventual habitual ou permanente & 0 & 2 & 4 & 4 & 7 & 11 & 105 \\
\hline O resultado lícito favorável que para o contratante advirá com o serviço prestado & 2 & 0 & 3 & 6 & 7 & 10 & 102 \\
\hline $\begin{array}{l}\text { Salários pagos aos funcionários } \\
\end{array}$ & 2 & 1 & 2 & 4 & 13 & 6 & 99 \\
\hline Margem de lucro pretendida & 3 & 0 & 3 & 6 & 8 & 8 & 96 \\
\hline Gastos gerais da empresa contábil & 3 & 0 & 4 & 6 & 6 & 9 & 95 \\
\hline A possibilidade de ficar impedido da realização de outros serviços & 3 & 2 & 1 & 5 & 9 & 8 & 95 \\
\hline
\end{tabular}

Fonte: Adaptada de Dallabona et al. (2013, p. 21)

18 O estudo havia sido anteriormente publicado no XVII Congresso Brasileiro de Custos (Canever, Schnorrenberger, \& Gasparetto, 2010). 
Ainda investigando 2013, identificou-se o estudo de Queiroz, Conceição, Silva, Santos, e Cabral (2013) ${ }^{19}$ sobre a definição de preços em microempresas de artigos turísticos. Os autores buscaram aplicar um questionário a empresas de artesanato localizadas no Mercado Central de Fortaleza e na Praça Estrela (que fica na ilha de São Vicente, cidade de Mindelo, Cabo Verde). Ao todo, eles obtiveram 30 respostas, sendo 15 referentes à Fortaleza e 15 referentes à Mindelo.

Queiroz, Conceição, Silva, Santos, e Cabral (2013) observaram que em ambas as cidades imperava o estabelecimento dos preços a partir de algum mecanismo de custos mais margem. Em Fortaleza, os preços eram definidos principalmente com base no custo de aquisição da mercadoria mais margem (46\%), enquanto que em Mindelo eles eram estabelecidos, sobretudo, em função do custo de produção total médio mais margem. Em posição bastante afastada aparecia o embasamento nos preços dos concorrentes (7\% das empresas de Fortaleza e $13 \%$ das empresas de Mindelo).

Os autores explicaram que a diferença da base de custo usada nas duas cidades (custo de aquisição em Fortaleza e custo de produção em Mindelo) devia-se ao fato de que na capital cearense a maioria das empresas não era fabricante dos produtos, mas, sim, revendedora, diferentemente de Mindelo, onde grande parte dos lojistas fabricava seus próprios produtos.

Queiroz, Conceição, Silva, Santos, e Cabral (2013) também constataram que aspectos como a redução e o aumento da demanda, a alteração nos preços dos concorrentes e a nacionalidade dos clientes (preços mais elevados para clientes internacionais) podiam, em algumas circunstâncias, modificar os preços colocados.

Na sequência, identificou-se a pesquisa de Kruger, Mazzioni, Glustak, e Zanin (2014) que investigou o papel da Contabilidade na gestão (e também na definição dos preços) dos estabelecimentos rurais localizados no município de Erval Grande (Rio Grande do Sul). De acordo com Associação Rio-grandense da Empresa de Assistência Técnica e Extensão Rural (EMATER), havia 850 propriedades rurais no município, dentre as quais 150 foram

\footnotetext{
${ }^{19} \mathrm{O}$ estudo também foi publicado na Revista da Micro e Pequena Empresa, Campo Limpo Paulista (Queiroz, Conceição, Santos, Cabral, \& Pessoa, 2013). Essa versão, que recebeu uma citação, não é a relatada nesta tese porque a revista não consta na relação de periódicos classificados pela CAPES.
} 
selecionadas aleatoriamente e participaram da pesquisa. Havia propriedades de variados portes, mas a maioria delas era de pequeno porte.

Os autores concluíram que os preços eram estabelecidos basicamente a partir de informações do mercado, especialmente referentes ao preço oferecido pela cooperativa (ou pela empresa compradora) e ao preço do mercado.

Depois, finalmente, encontrou-se o estudo de L. F. Rocha e Leal (2015) sobre a definição dos preços em pequenas empresas de Uberlândia (Minas Gerais) vinculadas ao programa Empreender. Os autores enviaram mensagens eletrônicas e estiveram em reuniões presenciais com empresas dos segmentos (núcleos) que almejavam a participação. Das 103 empresas contatadas, 48 aceitaram participar da pesquisa e responderam o questionário.

Como achados, L. F. Rocha e Leal (2015) destacaram o uso conjunto de informações do preço de mercado e dos custos na definição dos preços $(60,4 \%)$ e a pequena utilização de uma margem de lucro única $(12,5 \%)$.

Com esse estudo finaliza-se esta seção e conclui-se que no Brasil também há pesquisas sobre o estabelecimento dos preços na prática. Essas pesquisas, por mais que na sua maioria não estejam em inglês nem disponíveis em bases científicas globais (o que pode explicar a baixa quantidade de citações), permitem que qualquer interessado verifique o que já se constatou sobre o tema no país. A Tabela 27 sumariza os resultados dessas pesquisas e, além disso, demonstra que os trabalhos brasileiros, com exceção de D. G. Machado e Souza (2006), ainda são pouco citados (consulta realizada no Google Acadêmico em 08 de agosto de 2016). 
Tabela 27 - Sumário dos resultados das pesquisas empíricas brasileiras

\begin{tabular}{|c|c|c|c|c|c|c|}
\hline ESTUDO & LOCAL & AMOSTRA & PORTE & RAMO & $\begin{array}{c}\text { PRINCIPAL CONCLUSÃo } \\
\end{array}$ & CITAÇÕES \\
\hline $\begin{array}{l}\text { Mello } \\
(2000)\end{array}$ & $\begin{array}{l}\text { Rio Grande } \\
\text { do Sul }\end{array}$ & 23 & $\begin{array}{l}\text { Pequenas e } \\
\text { grandes } \\
\text { empresas }\end{array}$ & Indústria & $\begin{array}{l}\text { A maior parte das empresas estabelece os preços } \\
\text { a partir da combinação "custos mais margem”. } \\
\text { Entretanto, as margens normalmente incorporam } \\
\text { aspectos referentes à concorrência e aos clientes. }\end{array}$ & 1 \\
\hline $\begin{array}{c}\text { Barbosa } \\
(2003)\end{array}$ & $\begin{array}{l}\text { Ênfase na } \\
\text { região } \\
\text { metropolitana } \\
\text { do Recife } \\
\quad(\mathrm{PE})\end{array}$ & 81 & $\begin{array}{l}\text { Variados } \\
\text { portes }\end{array}$ & $\begin{array}{l}\text { Indústria e } \\
\text { construção }\end{array}$ & $\begin{array}{l}\text { A maior parte das empresas estabelece os preços a } \\
\text { partir do uso de informações de custos e de mercado. }\end{array}$ & - \\
\hline $\begin{array}{l}\text { Rosadas e } \\
\text { Macedo } \\
(2004)\end{array}$ & $\begin{array}{c}\text { Rio de } \\
\text { Janeiro (RJ) }\end{array}$ & 37 & $\begin{array}{l}\text { Pequenas } \\
\text { empresas }\end{array}$ & Comércio & $\begin{array}{l}\text { A maior parte das empresas estabelece os preços } \\
\text { a partir da combinação “custos mais margem”. } \\
\text { Informações advindas dos fornecedores são } \\
\text { utilizadas para definição das margens. }\end{array}$ & 2 \\
\hline $\begin{array}{l}\text { L. P. Silva } \\
\text { e Santos } \\
(2005) \\
\end{array}$ & $\begin{array}{l}\text { Ribeirão } \\
\text { Preto (SP) }\end{array}$ & 4 & $\begin{array}{l}\text { Pequenas } \\
\text { empresas }\end{array}$ & Indústria & $\begin{array}{l}\text { A maior parte das empresas estabelece os preços } \\
\text { a partir da combinação “custos mais margem”. }\end{array}$ & 1 \\
\hline $\begin{array}{l}\text { Dias et al. } \\
(2006)\end{array}$ & $\begin{array}{c}\text { Rio de } \\
\text { Janeiro (RJ) }\end{array}$ & 19 & $\begin{array}{c}\text { Não } \\
\text { mencionado }\end{array}$ & Comércio & $\begin{array}{c}\text { Todas as empresas estabelecem os preços a partir } \\
\text { da combinação "custos mais margem". }\end{array}$ & - \\
\hline $\begin{array}{l}\text { D. G. } \\
\text { Machado e } \\
\text { Souza } \\
(2006)\end{array}$ & $\begin{array}{l}\text { Rio Grande } \\
\text { do Sul }\end{array}$ & 9 & $\begin{array}{l}\text { Médias e } \\
\text { grandes } \\
\text { empresas }\end{array}$ & Indústria & $\begin{array}{c}\text { Todas as empresas estabelecem os preços a partir } \\
\text { da combinação "custos mais margem". } \\
\text { Entretanto, os preços baseados estritamente na } \\
\text { combinação são exceção e não regra e, } \\
\text { dependendo dos preços dos concorrentes, a } \\
\text { margem é modificada. }\end{array}$ & 53 \\
\hline $\begin{array}{l}\text { M. A. V } \\
\text { Machado et } \\
\text { al. (2006) }\end{array}$ & $\begin{array}{l}\text { João Pessoa } \\
\text { (PB) }\end{array}$ & 31 & $\begin{array}{l}\text { Variados } \\
\text { portes }\end{array}$ & Serviços & $\begin{array}{l}\text { A maior parte das empresas estabelece os preços a } \\
\text { partir do uso de informações de custos e de mercado. }\end{array}$ & 6 \\
\hline $\begin{array}{l}\text { Almeida e } \\
\text { Santos } \\
(2007)\end{array}$ & Paraná & 14 & $\begin{array}{l}\text { Médias e } \\
\text { grandes } \\
\text { empresas }\end{array}$ & Indústria & $\begin{array}{l}\text { A maior parte das empresas estabelece os preços a } \\
\text { partir de informações do mercado. Ainda assim, as } \\
\text { empresas usam informações de custos no processo } \\
\text { de definição dos preços. }\end{array}$ & 3 \\
\hline $\begin{array}{l}\text { Callado et } \\
\text { al. (2007) }\end{array}$ & Paraíba & 20 & $\begin{array}{c}\text { Não } \\
\text { mencionado }\end{array}$ & Indústria & $\begin{array}{l}\text { A maior parte das empresas estabelece os preços } \\
\text { a partir da combinação “custos mais margem”. }\end{array}$ & 9 \\
\hline $\begin{array}{l}\text { Cogan et al. } \\
\text { (2007) }\end{array}$ & $\begin{array}{l}\text { Guapimirim e } \\
\text { Teresópolis } \\
\text { (RJ) }\end{array}$ & 19 & $\begin{array}{c}\text { Micro e } \\
\text { pequenas } \\
\text { empresas }\end{array}$ & Comércio & $\begin{array}{l}\text { A maior parte das empresas estabelece os preços } \\
\text { a partir da combinação “custos mais margem”. }\end{array}$ & 1 \\
\hline $\begin{array}{l}\text { Lima et al. } \\
\quad(2007)\end{array}$ & Franca (SP) & 15 & $\begin{array}{l}\text { Micro e } \\
\text { pequenas } \\
\text { empresas }\end{array}$ & Indústria & $\begin{array}{l}\text { A maior parte das empresas estabelece os preços } \\
\text { com base em custos apurados pelos custeio pleno } \\
\text { ou por absorção. }\end{array}$ & $\begin{array}{l}\text { Não } \\
\text { localizado }\end{array}$ \\
\hline $\begin{array}{l}\text { Hamann et } \\
\text { al. }(2010)\end{array}$ & $\begin{array}{l}\text { Planaltina } \\
\text { (DF) }\end{array}$ & $\begin{array}{c}\text { Não } \\
\text { mencionado }\end{array}$ & $\begin{array}{l}\text { Pequenas } \\
\text { empresas }\end{array}$ & Indústria & $\begin{array}{l}\text { A maior parte das empresas estabelece os preços a } \\
\text { partir dos preços de mercado. }\end{array}$ & - \\
\hline $\begin{array}{l}\text { D. G. } \\
\text { Machado et } \\
\text { al. }(2010)\end{array}$ & $\begin{array}{c}\text { Santa } \\
\text { Catarina }\end{array}$ & 15 & $\begin{array}{l}\text { Médias e } \\
\text { grandes } \\
\text { empresas }\end{array}$ & Indústria & $\begin{array}{l}\text { A maior parte das empresas estabelece os preços } \\
\text { a partir da combinação “custos mais margem". } \\
\text { Entretanto, os preços calculados com base na } \\
\text { combinação, antes de serem de fato cobrados, são } \\
\text { comparados aos preços do mercado. }\end{array}$ & $\begin{array}{l}\text { Não } \\
\text { localizado }\end{array}$ \\
\hline $\begin{array}{l}\text { Alves et al. } \\
\text { (2012) }\end{array}$ & $\begin{array}{l}\text { São Paulo } \\
\quad(\text { SP) }\end{array}$ & 300 & $\begin{array}{l}\text { Variados } \\
\text { portes }\end{array}$ & Comércio & $\begin{array}{l}\text { A maior parte das empresas estabelece os preços a } \\
\text { partir do que os autores classificaram como } \\
\text { "estratégias baseadas nos custos", entretanto, tais } \\
\text { "estratégias" não configuram necessariamente } \\
\text { embasamento nos custos. }\end{array}$ & 7 \\
\hline $\begin{array}{l}\text { A. X. V. } \\
\text { Braga et al. } \\
\quad(2012)\end{array}$ & Pelotas (RS) & 8 & $\begin{array}{l}\text { Pequenas e } \\
\text { médias } \\
\text { empresas }\end{array}$ & Indústria & $\begin{array}{l}\text { A maior parte das empresas estabelece os preços } \\
\text { a partir da combinação “custos mais margem”. } \\
\text { Em alguns casos a combinação é usada apenas } \\
\text { para avaliação da lucratividade, pois o preço } \\
\text { precisa ser tomado do mercado. }\end{array}$ & 7 \\
\hline $\begin{array}{l}\text { Canever et } \\
\text { al. }(2012)\end{array}$ & $\begin{array}{c}\text { Santa } \\
\text { Catarina }\end{array}$ & 12 & $\begin{array}{c}\text { Grandes } \\
\text { empresas }\end{array}$ & Indústria & $\begin{array}{l}\text { A maior parte das empresas estabelece os preços a } \\
\text { partir do uso de informações de custos, da } \\
\text { concorrência e do valor. }\end{array}$ & 2 \\
\hline
\end{tabular}




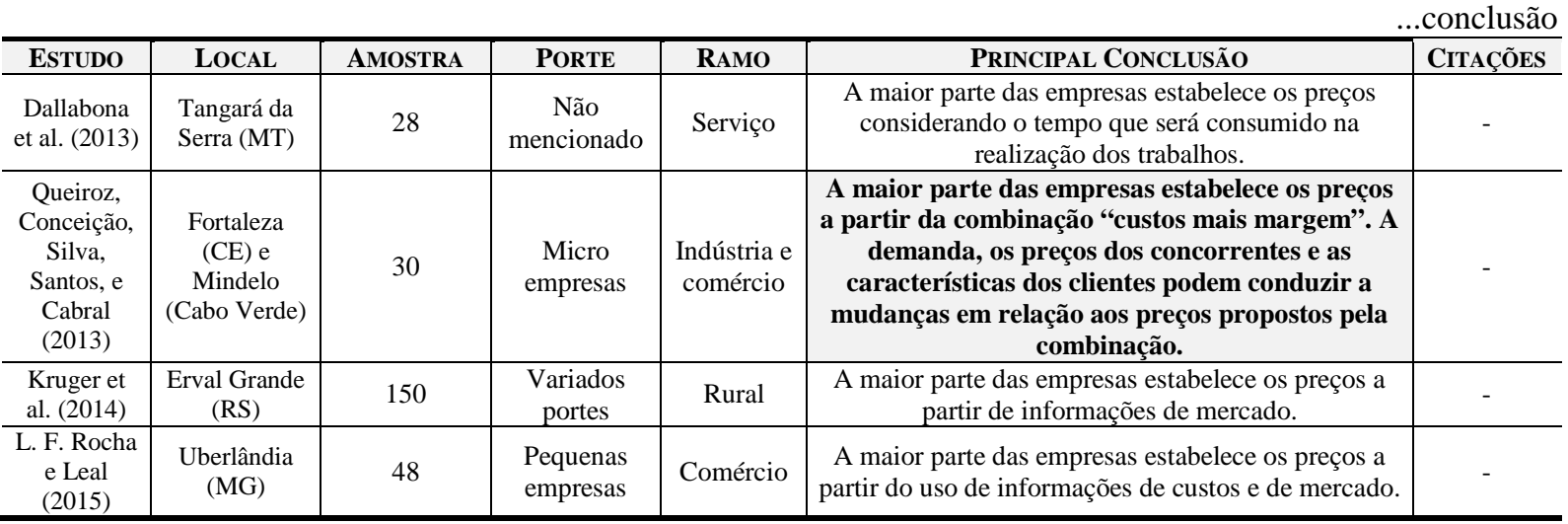

Com esse resumo, pode-se primeiramente perceber que todos os trabalhos brasileiros localizados, sem exceção, têm uma característica diferente da maior parte dos trabalhos publicados em outros países: eles abordam regiões geográficas bastante restritas, ao invés de explorarem a realidade do país como um todo. As conclusões apresentadas ou se referem à realidade constatada em empresas de uma determinada cidade ou demonstram os achados de empresas de diferentes cidades de um único estado. Barbosa (2003) até aplicou um questionário sem a restrição de região, contudo acabou tendo que completar a pesquisa com entrevistas limitadas a empresas da região metropolitana do Recife (Pernambuco).

Com a ciência dessa restrição, é possível perceber que as pesquisas costumam investigar empresas da região sudeste e sul do país e que poucos são os estudos que se dedicaram a explorar as outras regiões, conforme a Figura 24 demonstra. Especificamente, constatou-se que $70 \%$ dos trabalhos concentraram-se no eixo sudeste-sul e que somente $30 \%$ dos trabalhos investigaram empresas do nordeste e do centro-oeste. Nenhum trabalho com empresas da região norte foi encontrado.

Figura 24 - Abrangência regional das pesquisas empíricas brasileiras

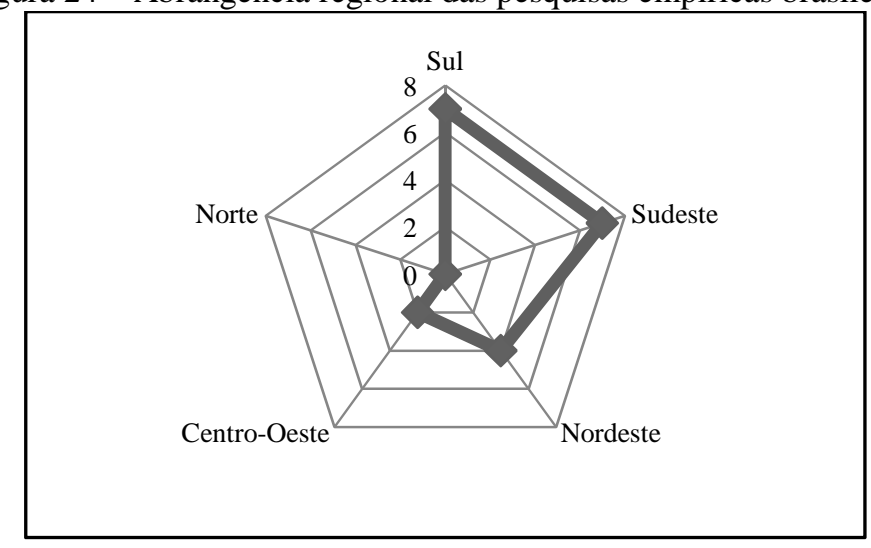

Fonte: Elaboração própria 
Em segundo lugar, pode-se constatar que no Brasil também se chega à conclusão que os preços são estabelecidos mediante a combinação dos custos à margem, como revelou o negrito e o sombreamento cinza na Tabela 27 e conforme ilustra a Figura 25. No entanto, cumpre mencionar que a proporção de trabalhos brasileiros que chegaram a essa conclusão é bem menor do que a proporção encontrada nos outros pontos do globo (55\% contra $75 \%$ ).

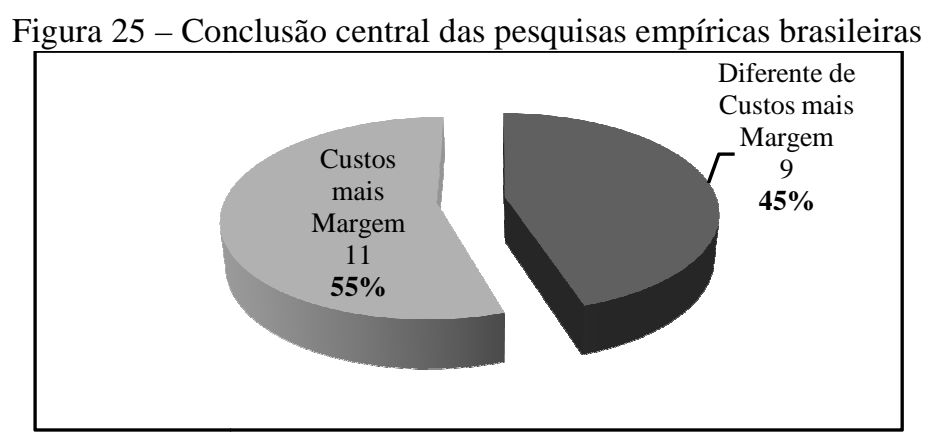

Fonte: Elaboração própria

\subsection{Sumário sobre o Estabelecimento dos Preços na Prática}

Para concluir este capítulo, vale sumarizar e revelar os principais pontos de tudo o que foi nele apresentado. De início, vale mencionar que se constatou que os estudos sobre o tema são bastante centralizados na Europa Ocidental e na América Anglo-Saxônica. De todos os trabalhos empíricos internacionais revisados no capítulo, 67\% dedicaram-se a abordar a realidade desses locais. O Brasil encontra-se numa posição de pouco destaque e apenas um estudo teria sido apresentado no capítulo, se não tivessem sido incluídas pesquisas em português e/ou exclusivamente locais (divulgadas unicamente nos sites das revistas em que foram publicadas e/ou dos eventos em que foram apresentadas).

Feita essa ressalva, pode-se partir para a conclusão central dos trabalhos revisados. Independentemente do local investigado, a maior parte das pesquisas detectou que os preços são definidos a partir da combinação "custos mais margem". Essa foi a conclusão de $75 \%$ dos estudos internacionais e de $55 \%$ dos estudos brasileiros.

Diante dessa constatação, não é difícil compreender por que na literatura normalmente é afirmado que os custos são a principal base para o estabelecimento dos preços. O problema é que nessa literatura usualmente assume-se implicitamente que os custos isoladamente 
conduzem à decisão dos preços, o que não foi a conclusão da maioria dos estudos, tanto nacionais quanto internacionais.

Ora, os estudos mostraram, sim, que a combinação dos custos à margem imperava no estabelecimento dos preços, mas também evidenciaram que essa combinação raramente conduzia sozinha à decisão. Afinal, o que grande parte dos estudos revelou foi que informações da concorrência e/ou do valor oferecido eram acopladas aos custos para definição dos preços. Inclusive, em vários trabalhos mostrou-se que eram os preços dos concorrentes que ditavam a escolha final, ainda que a combinação dos custos à margem fosse usada.

Assim, como a Figura 26 mostra, pode-se concluir que pesquisas de todos os cantos do planeta não concluíram necessariamente que os preços eram embasados exclusivamente nos custos, mas, sim, que a combinação "custos mais margem" era a principal forma usada pelas empresas para estabelecer os preços.

Figura 26 - Prática do estabelecimento dos preços segundo pesquisas empíricas

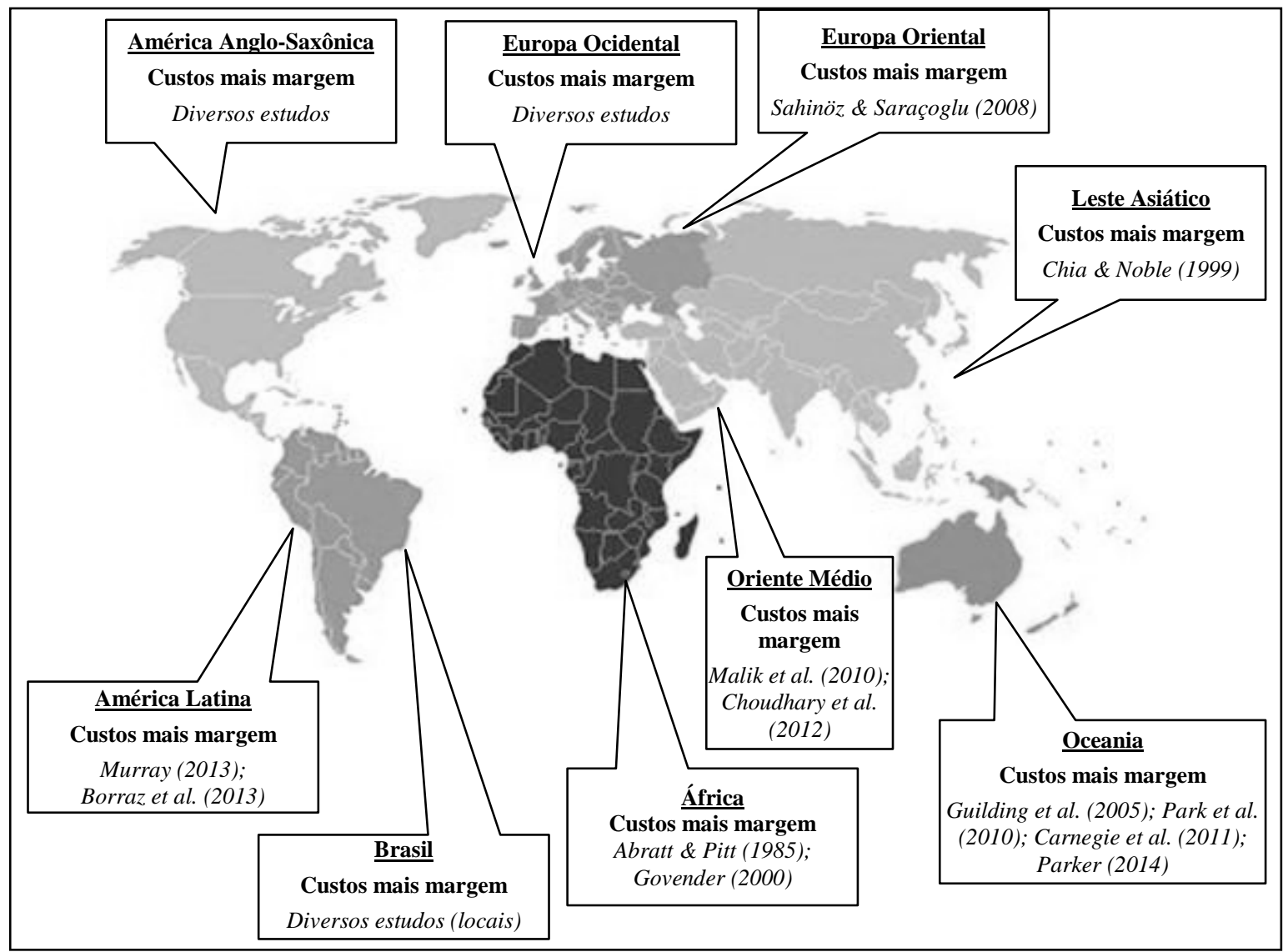

Fonte: Elaboração própria a partir de mapa de zonu.com (2009) 
Diante dessas conclusões, o próximo capítulo traça um paralelo entre a prática retratada neste capítulo e as visões teóricas de economia e de marketing mostradas no capítulo anterior. Com base nesse paralelo, abre-se a discussão sobre a existência ou não de gaps entre as duas perspectivas (teórica versus prática). 


\section{GAPS ENTRE TEORIA E PRÁTICA}

Como os resultados dos estudos empíricos indicam que a combinação dos custos à margem é utilizada para estabelecer os preços, é comum encontrar defesas na literatura que sustentam que a prática diverge das recomendações teóricas. Ou seja, há argumentações que dão a entender que, na realidade, os preços definidos nem promovem a igualdade entre o custo e a receita marginal nem espelham o valor ao cliente, e que há, portanto, gaps entre a teoria e a prática, conforme ilustrado na Figura 27.

Figura 27 - Supostos gaps entre a teoria e a prática de estabelecimento dos preços

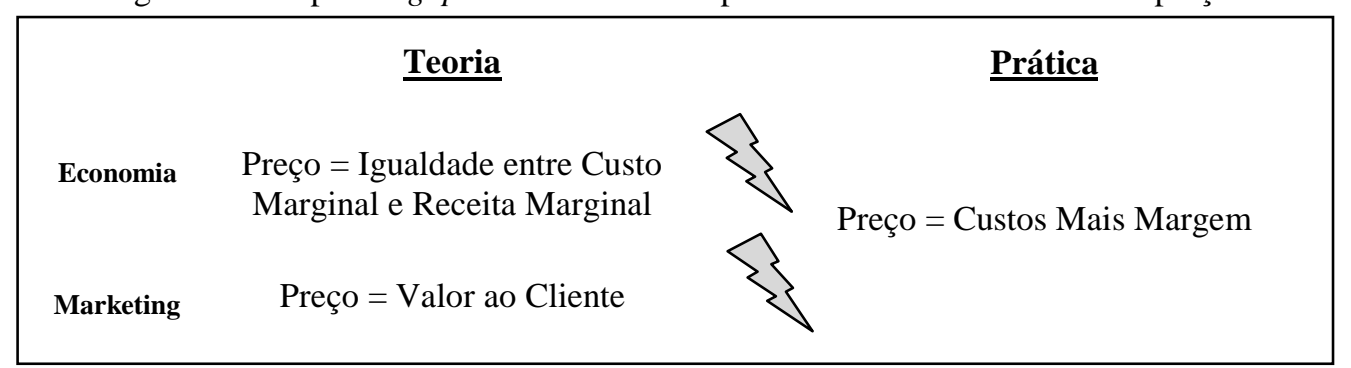

Fonte: Elaboração própria

Na sequência, esses dois supostos gaps são expostos e a pertinência das suas existências é avaliada.

\subsection{Os Gaps}

\subsubsection{Gap entre a Teoria Econômica e a Prática}

O estudo de R. I. Hall e Hitch (1939), justamente por ter sido o primeiro a expor o estabelecimento dos preços na prática, foi o pioneiro a sugerir a existência de um gap entre a teoria econômica e a real definição dos preços.

R. I. Hall e Hitch (1939) defenderam que a teoria econômica não era aplicada pelas empresas, uma vez que os custos marginais raramente eram usados para estabelecer os preços. No seu lugar, as empresas davam preferência à utilização do custo total. Segundo os autores, as empresas julgavam que a formação dos preços com base no custo total era justa para a competição, já que era uma tradição seguida por todos. Além disso, os autores apresentaram outras razões associadas a não aplicação da teoria econômica na prática: 
a) os produtores não podem conhecer suas curvas de demanda e de receita marginal porque eles não têm ciência das preferências dos clientes e, normalmente, são oligopolistas, não sabendo, as reações que os concorrentes teriam se eles alterassem os preços;

b) embora os produtores não saibam o que os concorrentes fariam se eles cortassem os preços, eles têm medo que eles também cortem os preços;

c) embora os produtores não saibam o que os concorrentes fariam se eles aumentassem os preços, eles têm medo que eles não aumentem os preços na mesma extensão ou que sequer aumentem os preços;

d) os preços não são reduzidos em decorrência de um acordo real ou tácito entre os produtores por causa da convicção que a elasticidade da demanda para o grupo dos produtos é insuficiente para arcar com essa redução;

e) se os preços são baseados no custo total, eles não são aumentados em decorrência de um acordo real ou tácito entre os produtores porque se sabe que o aumento, embora possa ser viável no curto prazo, estimula novos entrantes no mercado que forçam o preço para baixo no longo prazo; e

f) mudanças nos preços geralmente são custosas, irritantes para os vendedores, e desgostadas pelos comerciantes e clientes.

Em suma, R. I. Hall e Hitch (1939) sugeriram que a igualdade entre a receita marginal e o custo marginal não era aplicada na prática porque a maior parte das empresas não fazia qualquer esforço para estimar seus custos marginais e as elasticidades da sua demanda. As empresas que faziam (um pequeno) esforço consideravam que esse tipo de informação tinha pouca ou nenhuma relevância no estabelecimento dos preços. Além disso, a curva de receita marginal não era conhecida pelas empresas, exceto por aquelas da competição perfeita, em que a curva refere-se exatamente ao preço do mercado. O problema é que, para Harper (1966), a competição perfeita, no seu estrito senso, nunca existiu e nunca vai existir. Assim, na prática, nenhuma empresa conhecia com exatidão sua curva de receita marginal.

Outros estudos vieram mostrar que o princípio básico que antecede essa igualdade também não era aplicado na prática. De acordo com Avlonitis e Indounas (2005a) e Keil, Reibstein, e Wittink (2001), alcançar o objetivo de maximização do lucro não é viável porque nem a racionalidade nem a disponibilidade de informações são ilimitadas. Ou seja, as empresas até 
podem desejar maximizar o lucro, mas normalmente não dispõem de todas as informações que gostariam e/ou precisariam e seus gestores têm um comportamento que não é perfeitamente racional.

Ora, se os tomadores de decisão não são suficientes racionais e não dispõem de todas as informações que necessitam, as deliberações de preços tendem a se afastar da solução otimizadora que maximiza o lucro. Se a solução não é necessariamente aquela que maximiza o lucro, ela não é obrigatoriamente aquela em que o custo marginal iguala-se à receita marginal, como resume a Figura 28.

Figura 28 - Críticas à aplicação prática da teoria econômica

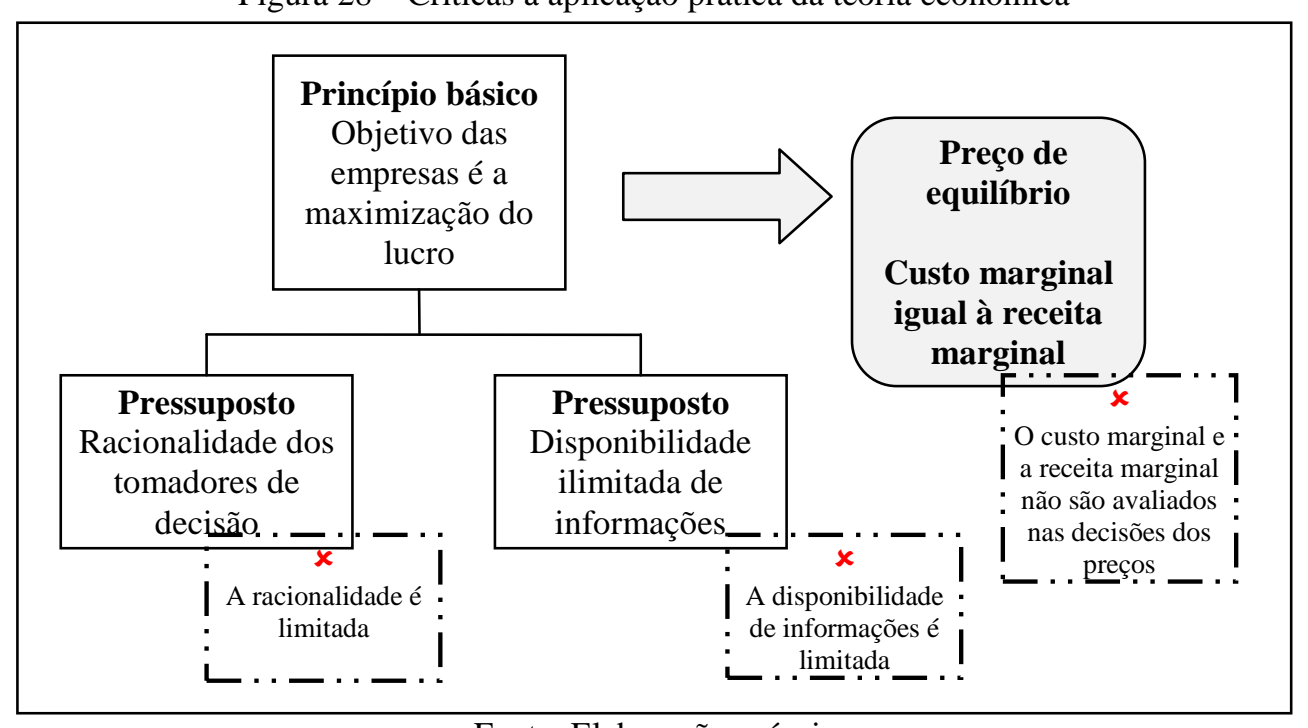

Fonte: Elaboração própria

R. I. Hall e Hitch (1939) eram economistas. Entretanto, isso não significa que todos os economistas estavam de acordo com os comentários deles, tanto que aqueles mais ortodoxos logo os rebateram e defenderam que o gap promulgado não existia. Os argumentos do instrumentalismo e do marginalismo implícito foram usados para mostrar como isso poderia acontecer se, na prática, a combinação "custo total mais margem" (e não a igualdade entre o custo e a receita marginal) era usada para indicar os preços.

O argumento do instrumentalismo pauta-se, sobretudo, em trabalho de Friedman (1953) e defende que o resultado da decisão é o que importa e não a decisão por si mesma. Especificamente, o autor sustenta que uma teoria não pode ser testada pelo realismo de suas assunções, pois mesmo que todas suas assunções fossem falsas, o que importa é se ela é, ou 
não, suficientemente boa para o propósito que tem. Ou seja, o instrumentalismo defende que o relevante na comprovação de uma teoria é a extensão de predição satisfatória dos resultados, independentemente da forma que essa predição é realizada.

Fazendo analogia a um experiente jogador do bilhar, pode-se trazer que, assim como não importa saber o que motivou tal jogador a tomar a decisão de tacar a bola de determinada maneira (experiência, observação de demais jogadores, estudos trigonométricos etc.), não importa saber o que motivou a empresa a estabelecer os preços de determinada maneira. $\mathrm{O}$ que realmente importa é saber que, independentemente do caminho percorrido, as decisões de preços tomadas são consoantes às preconizadas pela teoria econômica.

Afinal, é possível que com a experiência determinada empresa tenha descoberto que o preço mais lucrativo é aquele obtido com a adição de certa margem (e.g., de 20\%) aos custos de determinado produto e tome a decisão de fixá-la. Esse preço pode ser exatamente igual àquele que seria colocado caso a decisão fosse conscientemente guiada pela meta de equiparar a receita marginal ao custo marginal (Lucas, 2003).

$\mathrm{O}$ argumento do marginalismo implícito, por sua vez, traz que as empresas tendem, sim, a igualar o custo marginal à receita marginal, mas inconscientemente. Da mesma forma que os experientes jogadores de bilhar fazem suas tacadas de acordo com teoremas de geometria, sem estarem pensando neles, as empresas tomam suas decisões de preço de acordo com a premissa marginalista, sem estarem pensando nela (Lucas, 2003). Ademais, segundo Edwards (1952), o preço indicado pela combinação dos custos à margem dificilmente é colocado com a mera consideração dos custos, sem que haja incorporação do lado da demanda e das exigências do mercado.

Em resumo, pode-se concluir que os argumentos do instrumentalismo e do marginalismo implícito dão a entender que não existe qualquer gap entre a teoria econômica e a prática. Eles sugerem que as decisões de preços, por mais que não sejam tomadas racionalmente com base na igualdade entre o custo marginal e a receita marginal, trazem resultados que, no geral, assemelham-se aos resultados recomendados pela teoria econômica. Como frisado por Edwards (1952), a combinação do custo total à margem nada mais é do que uma fórmula 
matemática usada pelos tomadores de decisão para justificar um preço que já era pressentido e que, invariavelmente, já seria colocado.

Ademais, de acordo com Langholm (1969), a teoria dos preços nunca teve a intenção de servir como guia para a decisão empresarial e tampouco de descrever o que realmente acontece nas firmas, já que ela tem a natureza de um aparato explanatório em alto nível de abstração. A teoria econômica foi desenvolvida, não para oferecer passos para estabelecer os preços, mas, sim, para inferir deduções generalizadas que explicam os efeitos agregados do comportamento empresarial. Recentemente, Ray e Gramlich (2016) retomaram o tema e, por meio de proposições quantitativas, argumentaram que o estabelecimento dos preços a partir dos custos totais mais margem converge ao preço ótimo econômico.

Em outras palavras, pode-se dizer que a teoria econômica explana os fins, não os meios, do estabelecimento dos preços. Por essa razão, não há gap entre a teoria e a prática quando os preços definidos, independentemente da forma de cálculo, coincidem com os preços teoricamente sugeridos. Agora, quando os preços definidos deixam de coincidir com os preços teoricamente admissíveis, existe, sim, um gap entre a teoria e a prática.

Esse gap sempre deriva de inconsistências teóricas e nunca da prática. Como o próprio Friedman (1953) defende ao sustentar o argumento do instrumentalismo, o resultado da decisão é o que importa para a teoria econômica e não a decisão por si mesma. A teoria econômica deve ser capaz de apresentar princípios e pressupostos que expliquem as decisões dos preços, sem importar como tais decisões são tomadas. Isto é, ela deve conseguir explicar por que os preços definidos foram aqueles, não fazendo qualquer diferença se eles foram guiados pelos custos mais margem, pelos preços dos concorrentes ou pelo valor aos clientes.

Nesse sentido, pode-se defender que para evidenciar esse gap não adianta mostrar que a prática não acontece da forma explicada pela teoria econômica, como R. I. Hall e Hitch (1939) fizeram, já que os preços definidos podem ser similares àqueles teoricamente recomendados (custo marginal igual receita marginal) independentemente da prática. $\mathrm{O}$ caminho deve ser o inverso: para evidenciar a existência do gap deve-se mostrar que a teoria econômica não é mais hábil a explicar os preços, ou seja, que os princípios e pressupostos vigentes não mais explanam os preços definidos na prática, como mostra a Figura 29. 
Figura 29 - Gap entre teoria econômica e prática

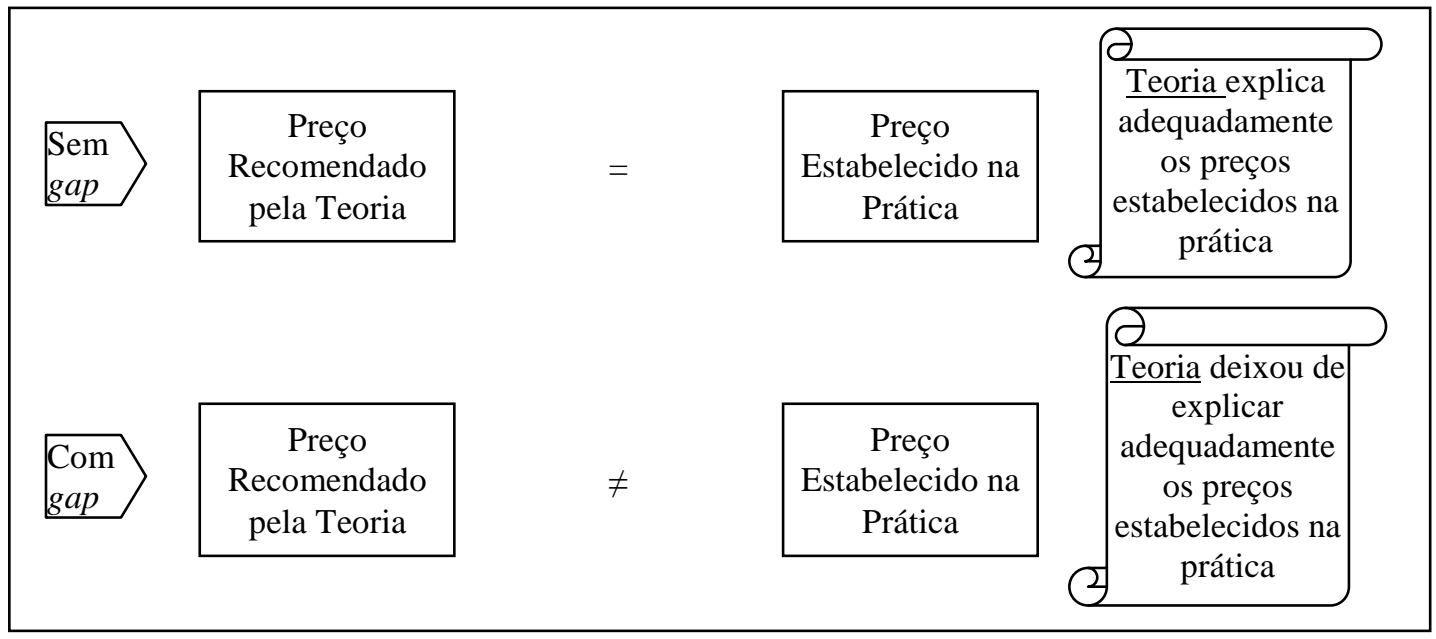

Fonte: Elaboração própria

Eiteman, de acordo com a revisão promovida por Ruggles (1952), já criticava em 1949 a teoria econômica, descrevendo-a como "irrealista e completamente inadequada" para explicar o estabelecimento dos preços. Hague (1967) acrescentava que, nessa teoria, o princípio básico do objetivo de maximização dos lucros vinha sendo usado como um artifício para evitar olhar, em detalhe, as decisões de preços.

Mais recentemente, os estudos de Downward (1999, 2000) e de Prado (2007) são exemplos de sugestões para a reconstrução da teoria econômica referente ao estabelecimento dos preços. Para Downward (1999, 2000), o principal problema da teoria econômica convencional está na imposição de uma forma única para todas as empresas determinarem os preços. Já segundo Prado (2007), o cunho normativo da microeconomia faz com que o estabelecimento dos preços seja abordado mediante um modelo simplificado (custo marginal igual à receita marginal) que se sustenta em um contexto pouco sofisticado.

Diante dessas conclusões, vale reforçar que os resultados dos estudos empíricos (reportados no capítulo anterior) não devem ser usados como argumento para a existência do gap entre a teoria econômica e a prática. Afinal, não é por que as empresas usam a combinação dos custos à margem que os preços por elas estabelecidos não coincidem, necessariamente, com os preços resultantes da aplicação da teoria econômica. $\mathrm{O}$ argumento correto deve evidenciar que a teoria econômica, na atual conjuntura, não é mais suficiente para explicar os preços estabelecidos, sem importar qual é a prática. 
Superadas as discussões sobre o gap entre a teoria econômica e a prática, pode-se passar à exposição de um novo gap, sugerido nos trabalhos mais contemporâneos: entre a teoria de marketing e a prática.

\subsubsection{Gap entre a Teoria de Marketing e a Prática}

Recentemente, tem-se encontrado pesquisas que indicam a existência de um gap entre a teoria de marketing e a prática. Essas pesquisas pautam suas argumentações nos resultados dos estudos empíricos que mostraram que as decisões de preços foram tomadas a partir da combinação dos custos à margem ou da colocação de preços similares aos preços dos concorrentes.

Cressman Jr. (1999), orientado principalmente pelos resultados de Noble e Gruca (1999a), concluiu que havia um gap entre a teoria de marketing e a prática porque o estabelecimento dos preços acontecia mediante a soma de uma margem aos custos. O autor demonstrou preocupação com essa realidade e argumentou que ela poderia afetar negativamente a eficácia das estratégias de marketing.

Ingenbleek (2007), após revisar vasta gama de estudos empíricos, também concluiu que existia um gap entre a teoria de marketing e a prática. Essa conclusão ancorou-se nos resultados empíricos por ele reportados que mostraram que a maior parte das empresas definia os preços a partir de informações de custos (custos mais margem).

Hinterhuber (2008) foi outro autor que concluiu sobre a existência de um gap entre a teoria de marketing e a prática. Após revisar quase duas dúzias de estudos empíricos, desenvolvidos entre 1983 e 2006 nos Estados Unidos, na Europa e na Ásia, e constatar que os preços eram estabelecidos com base nos preços da concorrência e nos custos, como demonstra a Figura 30, ele deduziu esse gap. 


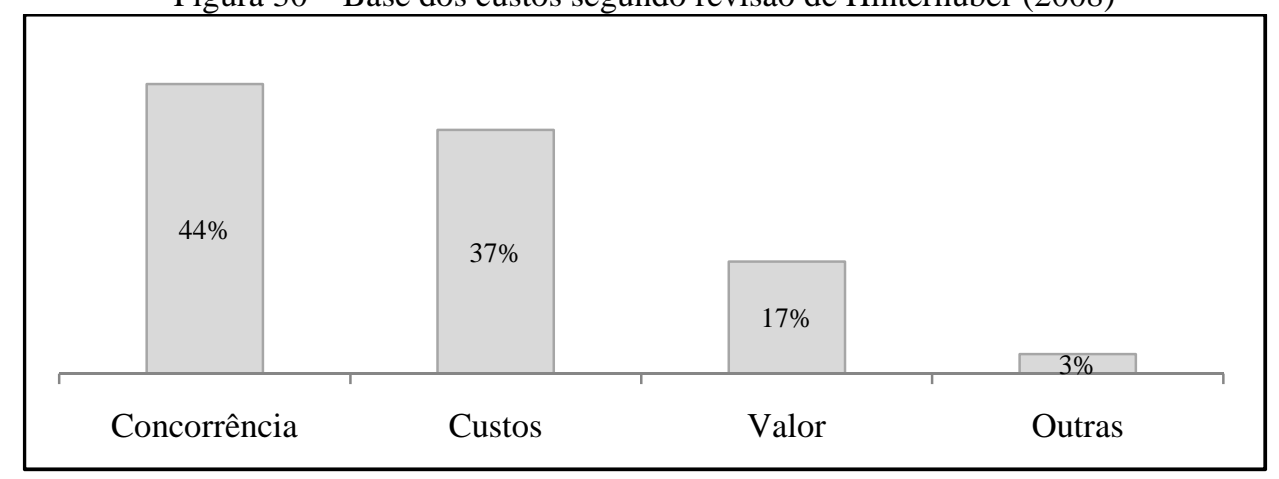

Fonte: Adaptada de Hinterhuber (2008, p. 43)

Calabrese e Francesco (2014) novamente concluíram que existia um gap entre a teoria de marketing e a prática. De acordo com a revisão de estudos empreitada pelos autores, permanecia a predominância da definição dos preços a partir de informações da concorrência e de custos.

Uma análise superficial dessas quatro pesquisas permite perceber que o gap entre a teoria de marketing e a prática é tido como existente quando os preços são definidos a partir dos custos ou dos preços da concorrência, já que a principal recomendação teórica do marketing é o embasamento no valor.

Vale lembrar que a teoria de marketing oferece guias que sugerem como as empresas devem estabelecer os preços, diferentemente da teoria econômica que oferta explicações abstratas de como os preços são determinados. Por essa razão, a existência do seu gap decorre de motivo inverso ao gap da economia: o gap deriva da prática, não de inconsistências teóricas.

As recomendações teóricas de marketing são prontamente substituídas quando há indicativos de que deixaram de orientar à melhor solução. Em outras palavras, as recomendações teóricas de marketing são alteradas quando se percebe que elas deixaram de ser as mais adequadas. Por exemplo, atualmente, o uso da disposição de pagamento dos clientes não é mais sugerido isoladamente (sem o uso conjunto com o valor percebido ou com o valor oferecido), embora em tempos atrás fosse considerado suficiente (Nagle \& Hogan, 2007).

Assim, quando as empresas optam por não estabelecer os preços de acordo com as recomendações teóricas, seja pela presença de barreiras e obstáculos (Ingenbleek, 2007; 
Hinterhuber, 2008; Töytäri et al., 2015), seja por mero desconhecimento das recomendações, há o gap entre a teoria e a prática. A Figura 31 resume esse entendimento.

Figura 31 - Gap entre teoria de marketing e prática

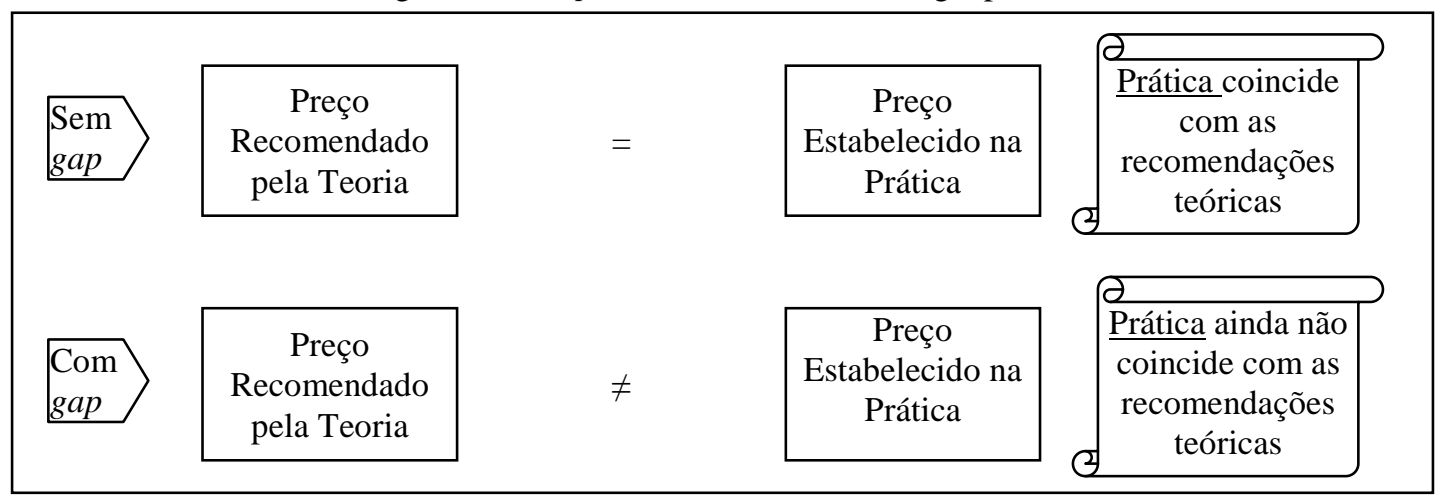

Fonte: Elaboração própria

Cumpre, contudo, rememorar que a teoria de marketing recomenda fortemente a definição de preços baseados no valor, mas, em nenhum momento impede o uso de diferentes tipos de informações (e.g., custos e concorrência). Por esse motivo, uma análise mais detida dos estudos de Cressman Jr. (1999), Ingenbleek (2007), Hinterhuber (2008) e Calabrese e Francesco (2014) permite questionar os argumentos dos autores. Afinal, não é correto concluir que os preços não são embasados no valor simplesmente por que são definidos a partir dos custos. Nada impede, por exemplo, que a combinação da margem aos custos seja a forma utilizada pelas empresas para operacionalizar o estabelecimento dos preços conforme o valor.

Diante do exposto, a próxima seção promove uma reavaliação do gap e evidencia que os argumentos até então apresentados para sustentá-lo podem ser contraditos.

\subsection{Reavaliação do Gap entre a Teoria de Marketing e a Prática}

Como a Figura 32 ilustra, a seção anterior demonstrou que a explicação trazida para a existência do gap entre a teoria econômica e a prática é diferente da explanação oferecida para a existência do gap entre a teoria de marketing e a prática. 
Figura 32 - Explicação para a existência dos gaps

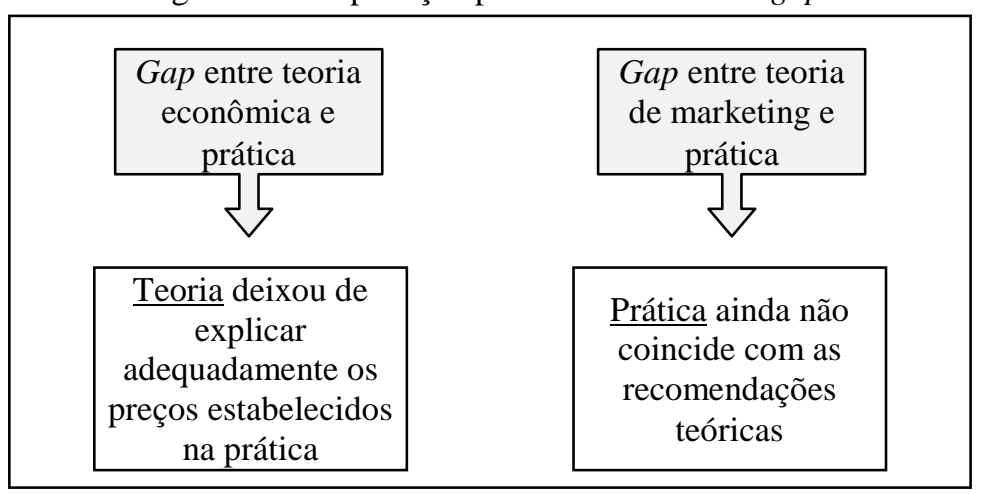

Fonte: Elaboração própria

Como esta tese é de natureza contábil, não cabe aprofundar aqui discussões da teoria econômica. Discussões desse tipo devem ser fomentadas em trabalhos da economia e promovidas por autores (economistas) com propriedade para discorrer sobre o assunto. Nos trabalhos de Downward (1999, 2000) e Prado (2007) podem ser encontrados exemplos dessas discussões. Nesta tese contábil, cumpre apenas enfatizar que se for constatado esse gap é por que a teoria econômica vigente deixou de explicar adequadamente os preços estabelecidos na prática sendo, portanto, necessário amparar-se em outra construção teórica.

A figura é diferente para o gap entre a teoria de marketing e a prática, já que tal gap é encontrado quando a prática não coincide com as recomendações teóricas, isto é, quando as empresas optam por estabelecer preços que não espelham o valor. Logo, é relevante para um estudo contábil averiguar se o uso dos custos mais margem impede a incorporação do valor e é, realmente, o grande responsável pela existência do gap (como sugerido nas pesquisas reportadas na seção 4.1).

Para que essa averiguação possa ser conduzida, propõe-se uma reorganização do entendimento sobre a definição dos preços na prática. Essa reorganização pauta-se em ideias e percepções que, apesar de conhecidas, não têm sido incorporadas na explicação das práticas empiricamente encontradas, como a Figura 33 ilustra. Com ela, conseguir-se-á perceber se os custos mais margem necessariamente conflitam com preços embasados no valor. 
Figura 33 - Reorganização do entendimento sobre a definição dos preços na prática

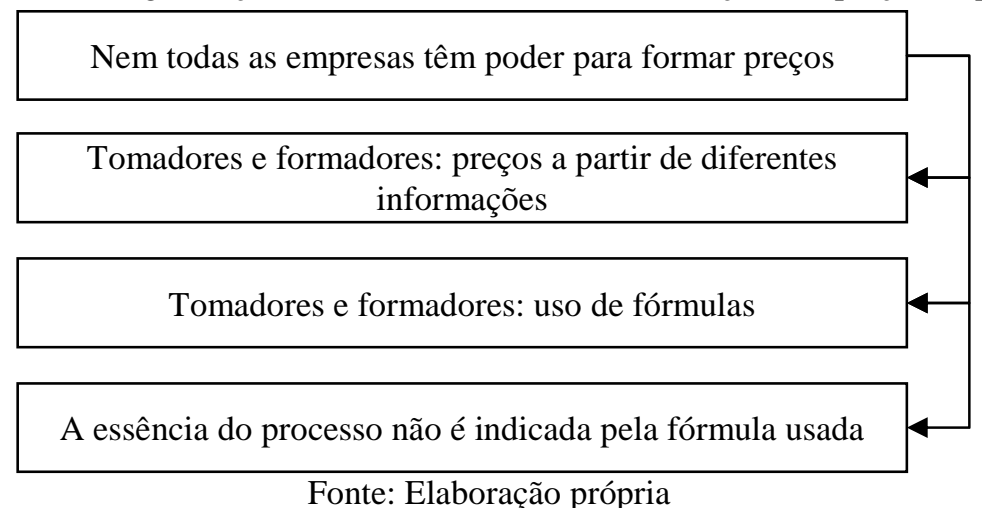

Vale ressaltar que a reorganização ilustrada na Figura 33 é uma das inovações trazidas neste trabalho. A partir de uma análise crítica da literatura sobre o estabelecimento dos preços, identificou-se que havia conceitos esparsos em diferentes áreas do conhecimento, cuja reunião poderia aprimorar o entendimento do processo. Por exemplo, a segregação das empresas em tomadoras e formadoras de preços, apesar de ser uma concepção básica da economia no estudo das estruturas de mercado, é, até então, relativamente pouco incorporada na literatura de marketing e da Contabilidade Gerencial.

Como outro exemplo, pode-se trazer o uso de diferentes informações, recorrentemente abordado na literatura de marketing, mas, até então, relativamente pouco explorado por autores da Contabilidade Gerencial (que enfatizam quase que exclusivamente o uso de informações de custos, reservando-se à discussão se tais informações devem ou não ser de custos totais) e por autores de economia (que enfatizam o uso de informações de custos e receitas, sobretudo, marginais).

Em outras palavras, pode-se defender que a reorganização proposta nesta tese busca lançar um olhar inovador e interdisciplinar para o estabelecimento dos preços, ou seja, busca trazer uma nova visão que permita enxergar e compreender o que estava ofuscado e passava despercebido.

\subsubsection{Nem Todas as Empresas Têm Poder para Formar Preços}

Pelo menos entre os economistas, existe uma noção clara de que nem todas as empresas têm poder para formar preços. Isto é, há a ciência que algumas empresas conseguem, sim, definir 
preços de acordo com as variáveis que consideram relevantes, enquanto que outras empresas precisam tomar o preço corrente no mercado, conforme explicado na sequência deste trabalho (Tishlias, 1984; Chand, 2009).

Tradicionalmente, explica-se essa situação em função do posicionamento na estrutura de mercado. Defende-se que enquanto os monopolistas dispõem de poder para formar os preços, as empresas da competição perfeita não têm condições de impactarem significativamente os preços do mercado e precisam acatá-los e tomá-los (Solberg, Stöttinger, \& Yaprak, 2006; Mankiw, 2014). Os oligopolistas ocupam uma posição intermediária, ao passo que algumas empresas são as líderes e definem o preço do mercado, enquanto que outras, normalmente menores, precisam acatar e tomar o preço definido pelos líderes (Tishlias, 1984).

O problema dessa visão tradicional é que, de acordo com Harper (1966), a estruturação de mercado (competição perfeita, monopólio, oligopólio) não descreve o "mundo real”. Segundo o autor, a competição perfeita, por exemplo, nunca existiu e nunca vai existir, uma vez que os produtos raramente são homogêneos e a diferenciação é normalmente a regra (mesmo que seja sutil, marcada por um produto igual disposto em embalagens com nomes de marcas distintas).

No entanto, não é por que a competição perfeita não existe no seu estrito senso, que não existem tomadores de preços. Afinal, uma concorrência voraz pode ser encontrada mesmo quando os produtos não são exatamente homogêneos. Por essa razão, Hofstrand (2007) sugeriu que se parta do grau de diferenciação dos produtos, ao invés da estruturação do mercado, para intuir se uma empresa é tomadora ou formadora de preços. Banterle et al. (2011) corroboraram essa sugestão, ao passo que detectaram empiricamente que o poder para estabelecer os preços é diretamente relacionado à capacidade de diferenciar os produtos.

Partindo da diferenciação, é possível perceber que quando a empresa oferta produtos similares aos produtos dos concorrentes, ela tem um grau de poder limitado sobre os preços porque, devido à semelhança, seus clientes priorizam o preço e não se importam se os produtos advêm dela ou de outro vendedor. Nessa situação, a empresa não tem escolha e precisa tomar o preço determinado pelo mercado como um todo. Já quando a empresa oferece produtos diferentes dos concorrentes, ela tem autonomia para variar seus preços porque, devido às características 
específicas, os clientes importam-se de qual vendedor advêm os produtos. Nessa situação, ela dispõe, em alguma extensão, de poder para formar preços (Hofstrand, 2007).

Incorporando esse conceito e categorizando as empresas em formadoras e em tomadoras de preços com base no grau de diferenciação dos produtos oferecidos, chega-se à segregação ilustrada na Figura 34.

Figura 34 - Tomadores e formadores de preços

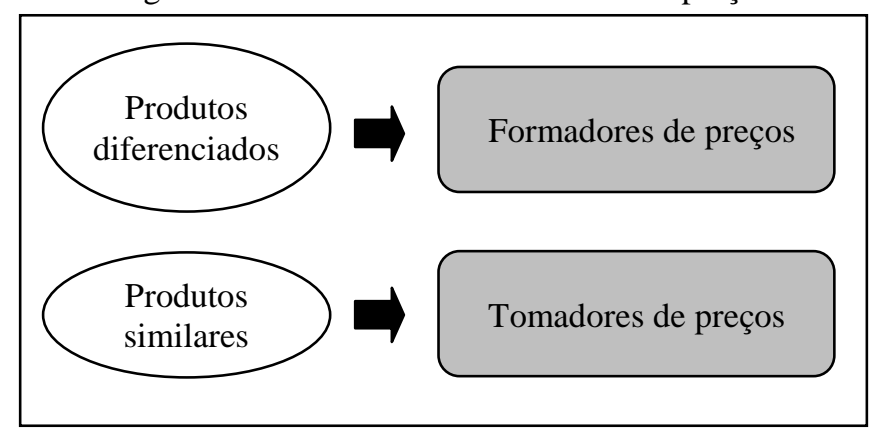

Fonte: Elaboração própria

A empresa é tomadora de preços quando os seus produtos têm versões iguais ou similares oferecidas pelos concorrentes. Como os produtos são parecidos, os preços também precisam ser e, assim, são determinados pelo mercado. Empresas que lidam com commodities (Harper, 1966; Hofstrand, 2007) e com produtos padronizados destinados ao consumo (S. Maxwell, 1998) são as principais tomadoras de preços.

As commodities são produtos exatamente iguais oferecidos por diferentes empresas. Dentre elas, destacam-se as matérias-primas (grãos, algodão, cobre, ferro), os combustíveis e certos tipos de instrumentos financeiros (Harper, 1966). Por exemplo, uma tonelada padrão de milho ofertada por um produtor é idêntica a uma tonelada padrão de milho ofertada por outro produtor, tanto que não há sequer a necessidade de o comprador manter as toneladas armazenadas separadamente. Como o produto é exatamente igual, o produtor de milho precisa cobrar o preço disponível no mercado do milho, uma vez que a origem do seu produto (produtor "X”, produtor "Y”) é indiferente para o comprador (Hofstrand, 2007).

Outro exemplo é a gasolina. Os postos, mesmos que ofereçam tipos de gasolina e/ou serviços associados que não são exatamente iguais aos ofertados pelos outros postos, precisam lidar 
com a visão da maioria dos compradores que "gasolina é gasolina" e que, portanto, o preço é o principal fator decisório para a aquisição (Harper, 1966).

Os produtos padronizados destinados ao consumo normalmente são produzidos em massa e, por essa razão, por mais que não sejam exatamente iguais, tendem a ser muito similares entre as empresas. Como os produtos são parecidos, os preços também precisam ser. Fratto (2006) relaciona o exemplo de artigos de vestuário padrões que, por falta de diferenciação, têm suas vendas norteadas principalmente pelo preço. Alimentos, bebidas, artigos de higiene e produtos de limpeza em suas versões simplificadas são outros exemplos de produtos que acabam tendo o preço determinado pelo mercado.

Vale destacar que, dependendo do produto, o mercado que define o preço transcende a esfera local e contempla a esfera global. M. Skinner (2003) traz como exemplo a situação da produção de grãos no Reino Unido, que é relativamente pouco importante quando comparada àquela de todo o mundo. Os produtores britânicos, por maiores que sejam localmente, são pequenos sob o prisma global, não possuindo condições de influenciar significativamente o mercado e precisando acatar o preço colocado pelos concorrentes globais.

Como o tomador de preços precisa acatar os preços do mercado, ele não tem, em tese, o que decidir sobre os preços. Um vendedor isoladamente não pode determinar um preço maior do que aquele corrente no mercado porque certamente perderá vendas, já que os compradores podem adquirir de outros vendedores a quantidade que desejarem ao preço corrente do mercado. Um vendedor isoladamente também não se interessa em cobrar menos do que o preço corrente do mercado, pois já consegue comercializar a quantidade que possui por aquele preço e quer evitar uma guerra de preços com seus concorrentes (Harper, 1966).

Simons (2012) defende que se não houver a submissão aos preços, só resta ao tomador de preços as piores opções de brigar ou desistir. As brigas pelo controle de preços normalmente acontecem com aqueles tomadores que julgam que são maiores do que realmente são. Eles adotam ações que, por vezes, até conseguem influenciar os preços por um pequeno período, mas, no fim, perdem dinheiro ou vão à falência, já que não é possível "enganar" todo o mercado por um longo tempo. 
Por exemplo, todos os produtores de grão de uma determinada área podem brigar pelo preço e recusarem-se a vender sua produção ao patamar corrente, provocando uma escassez local e aumentando o preço no curto prazo. Contudo, depois de certo tempo, produtores globais entram em cena e, ao ofertarem um produto similar àquele oferecido pelos produtores locais, eliminam a escassez e os preços retornam ao seu nível natural. Nessa situação, os produtores locais que não acatarem o preço terão que desistir do mercado (M. Skinner, 2003).

Shapiro (1998) acrescenta a opção de o tomador de preços migrar à condição de formador de preços. Na publicação “Be a Price Maker” (2004), esclarece-se que essa migração é possível se, com o tempo, o tomador de preços diferenciar consideravelmente seu produto.

Por exemplo, para deixar de ser uma tomadora de preços, a empresa canadense Inco Ltd. passou a produzir um metal único que se diferenciava e que possuía um valor maior do que o metal na sua simples forma de commodity. Em 1944, ela começou a se envolver na elaboração de produtos especiais a partir do níquel, oferecendo pela primeira vez o níquel na forma de pó em grande quantidade. Desde então, tal empresa migrou à condição de formadora de preços, uma vez que sua atuação deixou de centrar-se no segmento de metais na forma de commodity para centrar-se no segmento de metais diferenciados ("Special Products", 2002).

A diferenciação é, portanto, a característica elementar da empresa formadora de preços. De acordo com Hofstrand (2007), a empresa só tem poder para formar preços quando consegue fazer com que seus produtos sejam percebidos como diferentes dos produtos ofertados pelos concorrentes. Não importa se os produtos são realmente diferentes daqueles ofertados pelas outras empresas (e.g., em termos de qualidade, consistência de entrega etc.) ou somente vistos como diferentes (e.g., em função de reputação, status etc.).

É o caso, por exemplo, de instrumentos musicais elaborados por um produtor com reputação de prestígio. A diferenciação dos instrumentos musicais, física (por customização) ou meramente psicológica (pela reputação), faz com que o preço não seja visto pelos compradores como o principal fator decisório para a aquisição e permite que o produtor não se limite ao preço colocado pelos demais fabricantes e disponha de controle sobre os preços (Harper, 1966). 
Um aspecto merecedor de destaque, apesar de parecer óbvio, é que a diferenciação refere-se à distinção do próprio produto em relação aos produtos oferecidos pelas demais empresas. $\mathrm{Ou}$ seja, a diferenciação não se refere à distinção do produto em relação a produtos de outras categorias e tampouco decorre do surgimento de nichos de mercado.

Por exemplo, muitos produtores de leite orgânico acreditam que oferecem um produto diferenciado, quando isso não é verdade. Ora, o nicho de mercado de leite orgânico permite que a empresa ofereça produtos diferentes do leite comum e a coloca em um mercado mais restrito, no entanto ele não faz com que um produto diferenciado seja oferecido, afinal um leite orgânico comum é idêntico ao leite orgânico comum oferecido pelos demais produtores. A diferenciação só existe quando a diferença (real ou percebida) é específica do produto (Hofstrand, 2007).

O grau da diferenciação percebida pelos compradores e a importância por eles atribuída a essa diferenciação definem o grau de poder da empresa sobre os preços. Quanto mais os produtos forem percebidos como distintos e quanto mais a diferenciação for valorizada, mais poder sobre a formação dos preços a empresa tem (Oxenfeldt, 1961). Kotler e Keller (2012) esclarecem que o grau de diferenciação dos produtos pode advir de variados aspectos, dentre os quais destacam a forma, as características, a qualidade, a durabilidade, a confiabilidade, a facilidade de reparo, o estilo, o design e a customização.

Hofstrand (2007) esclarece que as percepções são tudo quando o assunto é diferenciação. Segundo o autor, um produto não precisa ser necessariamente melhor do que os demais produtos disponíveis no mercado, ele apenas precisa ser percebido pelos compradores como um produto melhor em qualquer aspecto. Inclusive, segundo o autor, grande parte da publicidade encontrada na atualidade é focada em convencer os clientes que o produto divulgado é melhor do que os demais produtos, mesmo quando ele não é de fato melhor.

$\mathrm{O}$ apelo às marcas é uma forma de fazer os clientes perceberem o produto como diferente. Uma marca forte é capaz de passar a percepção ao cliente que o produto tem características, qualidade e durabilidade melhores do que o produto de marcas menos fortes (Hinterhuber \& Hinterhuber, 2012). É por essa razão que os produtos oferecidos por empresas líderes de 
mercado são muitas vezes vistos como diferentes dos produtos oferecidos pelas empresas não líderes, ainda que a diferença entre eles seja praticamente nula.

Vale ressaltar que o poder sobre os preços não é definitivo. Da mesma forma que os tomadores de preços conseguem detê-lo caso seus produtos passem a ser diferenciados, os formadores de preços podem perdê-lo caso seus produtos deixem de ser diferenciados. Para D’Aveni (2009), não são raros casos de produtos diferenciados que se deparam com a perda da diferenciação. O autor cita o depoimento de Steve Heyer, antigo presidente (Chief Operating Officer - CEO) da Starwood Hotels \& Resorts Worldwide e antigo gestor operacional (Chief Operating Officer - COO) da Coca-Cola: "Tudo se 'comoditiza' com o tempo. Os limites e os pontos de diferença são deteriorados pela competição. As facetas dos diamantes são arruinadas e deixam você com um pedaço de vidro. É fácil imitar e difícil inovar" 20 (D’Aveni, 2009, p. 01).

De acordo com D’Aveni (2009), hoje as empresas estão sujeitas ao que ele denomina de armadilha de commodity (commodity trap), na qual qualquer produto, por mais diferenciado que seja, "comoditiza"-se, isto é, transforma-se numa espécie de commodity, amplamente disponível e similar a produtos oferecidos por outras empresas. Como a manutenção do poder sobre os preços depende da preservação da diferenciação, não resta outra solução aos formadores a não ser conter a armadilha de commodity.

\subsubsection{1 $\quad \underline{\text { Tomadores e Formadores de Preços nas Pesquisas Empíricas }}$}

$\mathrm{O}$ argumento central para o gap entre a teoria de marketing e a prática sustenta que as empresas não escolhem o valor como base elementar do estabelecimento dos preços (e.g., Hinterhuber, 2008). O problema é que não são todas as empresas que podem escolher como determinar seus preços. Os tomadores precisam tomar o preço do mercado e não têm opção: seus preços precisam assemelhar-se aos preços dos concorrentes.

\footnotetext{
20 "Everything commoditizes over time. The edges and points of difference get worn off by competition. The facets of diamonds are worn away and you are left with a piece of glass. It is easy to imitate and hard to innovate".
} 
No geral, as pesquisas empíricas não reconhecem que nem todas as empresas têm poder para formar preços e, por isso, sugerem equivocadamente que o estabelecimento de preços similares aos concorrentes é uma escolha (não uma necessidade). Em outras palavras, ao investigarem as companhias sem segregação, as pesquisas sugerem implicitamente que todas poderiam formar preços e que nenhuma teria a necessidade de tomar o preço do mercado. As exceções encontradas são as pesquisas de Goetz (1985), Fabiani et al. (2005), Guilding et al. (2005) e Drury e Tayles (2006) que, ao menos, mencionam formalmente a existência dos tomadores de preços.

Goetz (1985) apenas separa sua amostra em formadores e tomadores de preços e constata que são os primeiros que conseguem estabelecer preços superiores à média do mercado. Fabiani et al. (2005), por sua vez, sugerem que em um ambiente extremamente competitivo as empresas são essencialmente tomadoras de preços, mas não abordam o assunto de forma mais detida e tampouco segregam a amostra em tomadores e formadores de preços. Guilding et al. (2005) e Drury e Tayles (2006) expandem a averiguação do tema. Os autores relatam que os tomadores têm um poder mínimo para deliberarem sobre os preços e precisam decidir sobre os produtos/serviços a vender aos preços ditados pelo mercado. No estudo de 2005, os autores até buscaram segregar a amostra em tomadores e formadores de preços, mas, como eles mesmos reconheceram, não foram venturosos ao considerar que apenas o tamanho da empresa definia o enquadramento.

Em suma, pelas pesquisas empíricas revisadas, pode-se observar que a investigação da presença de tomadores e de formadores de preços é escassa, além de ser bastante limitada. Por isso, pode-se considerar como fatídico o argumento que a "escolha" pela colocação de preços consoantes àqueles da concorrência sustenta o gap entre a teoria de marketing e a prática. Afinal, para os tomadores de preços não há o que escolher.

\subsubsection{Tomadores e Formadores: Preços a partir de Diferentes Informações}

Os preços dos tomadores precisam refletir os preços do mercado. Essa situação é distinta daquela dos formadores, que, por oferecerem produtos diferenciados, não possuem substitutos diretos e, consequentemente, não têm preços do mercado a espelhar. 
Nos tomadores de preços, conforme já mencionado, a submissão ao preço do mercado é a opção mais sensata (Simons, 2012). No entanto, essa submissão não implica o uso exclusivo de informações da concorrência. Afinal, os tomadores têm acesso a dados externos (i.e., há disponibilidade dos preços de produtos similares oferecidos pelos concorrentes; valor), mas também têm acesso a dados internos (i.e., há ciência dos custos do produto), como ilustra a Figura 35.

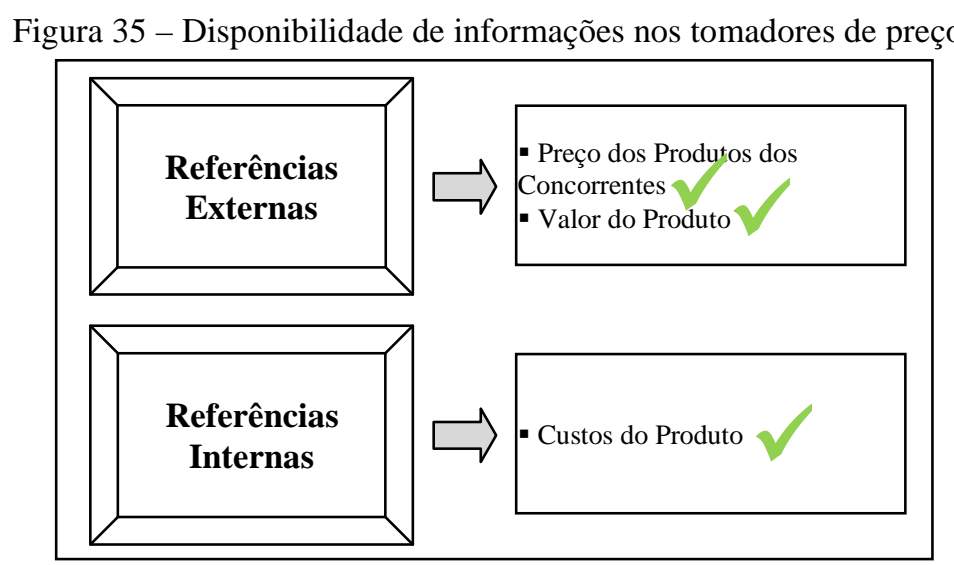

Fonte: Elaboração própria

Quando os preços estabelecidos limitam-se a informações da concorrência, eles não levam em conta se o preço corrente no mercado é economicamente interessante e viável, trazendo riscos e fazendo com que oportunidades sejam perdidas. Pois bem, por mais que os tomadores não possam decidir incisivamente sobre os preços (precisam tomá-los do mercado), eles podem, sim, decidir sobre a gestão da empresa, o que inclui deliberações atuais e futuras referentes à produção, às vendas e à promoção dos produtos.

Strickland (2007) esclarece que a ausência de poder não configura uma justificativa para displicência em relação às decisões de preços. Afinal, embora forças externas sejam de fato responsáveis pelos preços, a operação interna é a responsável pela eficiência diante dos preços. Assim, ainda que os tomadores não tenham condições de aumentarem o lucro mediante elevação de preços, eles têm condições de aumentá-lo de outras formas (Abel, 1978). E mais, ainda que eles tenham que determinar um preço que necessariamente reflita os preços dos concorrentes, eles não são obrigados a amargar prejuízos permanecendo num mercado que para eles não é lucrativo (Avlonitis \& Indounas, 2006a). 
Os tomadores de preços devem dedicar todos os seus esforços para que seus custos assumam patamares consoantes ao preço aceitável, já que, conforme Mises (1995) frisa, o mais insignificante desvio, seja intencional ou causado por erro, mau julgamento ou ineficiência, restringe os lucros. Um desvio mais acentuado resulta em perdas, reduzindo ou absorvendo inteiramente a riqueza. Destarte, os tomadores de preços devem buscar reduzir os custos o quanto puderem (obviamente sem prejudicar a qualidade do produto), já que eventuais ineficiências ou erros não poderão ser repassados aos clientes embutidos no preço (preço é dado pelo mercado).

Por esse motivo, de acordo com May (1970), é tão comum (entre os tomadores) a definição dos preços a partir dos custos mais margem. Com essa combinação os tomadores conseguem concomitantemente determinar preços coerentes aos preços do mercado (por intermédio da margem) e analisar a lucratividade do produto, isto é, aferir se o produto é ou não lucrativo. Drury e Tayles (2006) esclarecem que quando as empresas são tomadoras de preços e a combinação "custos mais margem” é usada, é possível analisar a lucratividade relativa dos diferentes produtos e serviços e, dessa maneira, identificar quais ações podem melhorá-la.

E. Martins e Rocha (2010) corroboram essa argumentação ao defenderem que, sem o conhecimento dos custos, os tomadores de preços não têm sequer condições de definir metas para as margens e, consequentemente, não conseguem conduzir a contento seus processos de avaliação de desempenho e de gestão.

Nos tomadores de preços, informações de valor também podem ser incorporadas mesmo que os preços sejam estabelecidos a partir dos preços dos concorrentes ou dos custos mais margem. Dependendo de comparações entre o valor oferecido pela empresa e pelos concorrentes, podem haver ajustes tanto positivos quanto negativos nos preços (Avlonitis \& Indounas, 2006a).

Segundo Carson et al. (1998), para os tomadores de preços ajustarem positivamente os preços, eles devem oferecer aos clientes mais valor do que os concorrentes oferecem. Ademais, os clientes devem perceber e estar dispostos a pagar por esse valor adicional oferecido. Por exemplo, por mais que determinada empresa comercialize um produto parecido com o produto do concorrente, ela pode em algumas circunstâncias estabelecer um preço 
ligeiramente superior se oferecer um atendimento mais cortês e uma entrega mais tempestiva. Esses oferecimentos adicionais, ainda que não sejam capazes de diferenciar a empresa a ponto de torná-la uma formadora de preços, permitem estabelecer preços levemente superiores.

Por outro lado, os tomadores de preços devem ajustar negativamente os preços se oferecerem menos valor do que os concorrentes oferecem (Ingenbleek et al., 2003). Se os clientes entenderem que os produtos dos concorrentes têm um valor ligeiramente superior (seja pelas características dos produtos, seja pelos serviços associados prestados), não resta outra opção a não ser cobrar preços menores do que os concorrentes.

Já nos formadores de preços a figura é diferente, pois os produtos são percebidos pelos clientes como diferenciados. Diante dessa situação, não é fácil identificar se há concorrentes oferecendo opções que os clientes percebem como tão diferenciadas e menos fácil ainda é identificar os preços colocados por eles.

Dutta et al. (2003) reportaram o exemplo da dificuldade de obter informações a respeito dos preços dos concorrentes em uma grande empresa do tipo formadora de preços. Nessa empresa, havia mais de 8.000 códigos de produtos a serem precificados e era necessário identificar, para cada um deles, os produtos dos concorrentes, se existentes, que poderiam ser considerados como funcionalmente equivalentes. Como os concorrentes simplesmente não distribuíam (e normalmente não distribuem) listas de preços, também era necessário conseguir o apoio de clientes com os quais a empresa mantinha um estreito relacionamento para obter os preços aproximados dos produtos considerados razoavelmente equivalentes.

Diante da extrema dificuldade, em alguns casos da total impossibilidade, de identificação dos preços dos concorrentes, os formadores precisam estabelecer os preços a partir de referências internas e do valor, conforme ilustra a Figura 36. 
Figura 36 - Disponibilidade de informações nos formadores de preços

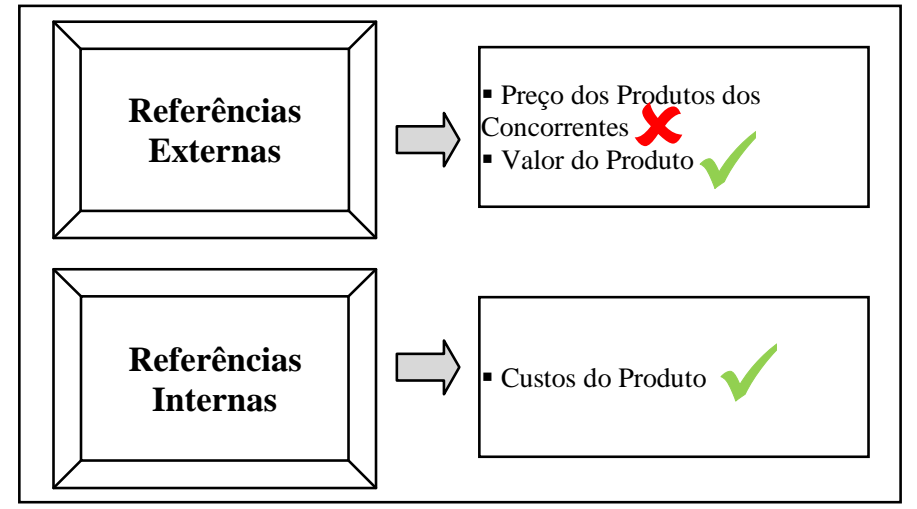

Fonte: Elaboração própria

Nagle e Hogan (2007) advertem que "não se pode precificar eficazmente sem compreender os custos" (p. 168) e Oxenfeldt (1961) e R. V. Santos (1995) esclarecem que isso acontece porque nenhuma empresa consegue sobreviver se vender seus produtos, de forma contínua, abaixo dos custos. Por isso é tão comum entre os formadores a definição dos preços a partir dos custos mais margem.

O debate sobre quais tipos de custos devem ser incluídos para determinar os preços é antigo e extenso (e.g., Lere, 1979; Tishlias, 1984; Christensen \& Demski, 1997; Noreen \& Burgstahler, 1997; Balakrishnan \& Sivaramakrishnan, 2002; Hsu, 2006), mas ainda não trouxe consenso. Há argumentos prós e contras à inclusão dos custos fixos e das despesas.

Sem se ater, neste momento, a essa discussão, é possível perceber que, inicialmente, os formadores de preços vão buscar cobrir integralmente seus custos e despesas, independentemente de eles serem considerados ou não como diretamente relacionados ao produto. Afinal, adotando-se uma visão reducionista, percebe-se que os preços são compostos basicamente por dois elementos: custos e margem. As parcelas de custos e de despesas não consideradas como diretamente relacionadas aos produtos são cobertas indiretamente mediante a margem (Guerreiro et al., 2012), como evidencia a Tabela 28.

Tabela $28-$ Preço $=$ custos + margem

\begin{tabular}{c|c}
\hline COMPOSIÇÃo Do CUSTO & COMPOSIÇÃo DA MARGEM (O QUE ELA DEVE COBRIR) \\
\hline Custos Totais + Despesas Totais & Lucro Desejado \\
\hline Custos Totais & Despesas Totais + Lucro Desejado \\
\hline Custos e Despesas Variáveis & Custos Fixos + Despesas Fixas + Lucro Desejado \\
\hline
\end{tabular}

Fonte: Adaptada de Guerreiro et al. (2012, p. 05) 
O fato de formar os preços a partir dos custos mais margem não significa, contudo, que informações de valor não podem ser incorporadas. De acordo com Hofstrand (2007), não é nem um pouco recomendável definir os preços sem considerar o valor oferecido e percebido pelos clientes e a disposição de pagamento dos mesmos. Afinal, não só os formadores como também os tomadores de preços (oferecedores de uma típica commodity) podem cobrar o preço que quiserem visando alcançar um lucro extraordinário. Mas será que eles vão encontrar algum cliente disposto a comprar o produto a um preço utópico? Certamente, não. Ora, por mais que os formadores tenham poder para estabelecer os preços que quiserem, eles não têm poder para impelir os clientes a comprarem seus produtos a qualquer preço.

R. C. Skinner (1970) explica que não tem como a percepção e a disposição de pagamento dos clientes não interferirem nos preços. De nada adianta à empresa colocar um preço que cubra seus custos e proporcione uma vultosa margem se ela não encontrar nenhum cliente disposto ou com condições de pagar esse preço. Por outro lado, também, não é interessante à empresa estabelecer um preço que cubra seus custos e proporcione uma razoável margem, se os clientes enxergam um valor muito maior para o produto.

Nesse contexto, parece razoável afirmar que a discricionariedade na determinação dos preços também é limitada nos formadores, ainda que seus limites não sejam tão estritos como as restrições das referências de mercado dos tomadores de preços. Todavia, vale destacar que a incorporação do valor não implica somente preços mais baixos, pois ela também pode implicar preços mais elevados (Carlson, 2005).

Noble e Gruca (1999b) citam que, do ponto de vista de marketing, o produto, a praça e a promoção visam criar e oferecer valor para o cliente, enquanto que o preço visa capturar o valor. Infortunadamente, segundo Horkan (2003), não raras são as circunstâncias em que as empresas esquecem-se de capturar esse valor e contentam-se em meramente cobrir os custos e obter um lucro satisfatório.

O executivo Washkewicz ilustra essa situação ao expor o caso da empresa que presidiu (Parker Hannifin Corp.). Tal empresa determinava o preço de todos os seus produtos com base nos custos acrescidos a uma margem (pré-definida) e, assim, ignorava todos os benefícios exclusivos que oferecia e repassava aos clientes toda eficiência de custos que tinha. 
Ora, não é por que ela conseguia fabricar um produto diferenciado de forma eficiente (a baixo custo) que ela devia necessariamente colocar um preço baixo (inferior ao valor percebido pelo cliente e à sua disposição de pagamento). Depois que mudou essa prática e começou a incorporar informações de valor, a Parker Hannifin Corp. passou a colocar preços mais coerentes, ampliando seus montantes por vezes em mais de 25\% (Aeppel, 2007).

\subsubsection{Diferentes Formas de Definição dos Preços nas Pesquisas Empíricas}

A principal diferença entre o estabelecimento dos preços nos tomadores e nos formadores de preços está nas informações da concorrência. Enquanto elas devem ser consideradas nos tomadores para que os preços não destoem dos concorrentes, elas raramente são coletadas com facilidade pelos formadores. Assim, a demonstração das pesquisas empíricas que grande parte das empresas ancora-se nos preços dos concorrentes para estabelecer os preços revela a ampla presença de tomadores na amostra e não o desprezo das informações do valor.

Como, no geral, as pesquisas não segregam as empresas em tomadoras e formadoras de preços, elas simplesmente sugerem que o estabelecimento dos preços com base na concorrência é sinônimo do desprezo de informações de valor. Mesmas as pesquisas relacionadas na seção 4.2.1.1, que segregam os tomadores dos formadores de preços, discorrem de uma forma extremamente limitada sobre as distinções na definição dos preços.

Goetz (1985) somente menciona que os tomadores colocam preços em torno da média do mercado enquanto que os formadores estabelecem preços maiores do que a média do mercado. Fabiani et al. (2005), por sua vez, apenas frisam que os tomadores não estabelecem os preços com base na combinação "custos mais margem”. Cabe, entretanto, ressaltar que Fabiani et al. (2005) não expuseram com clareza os atributos que usaram para segregar os tomadores dos formadores de preços e tampouco as diferenças entre eles no processo de estabelecimento dos preços.

Guilding et al. (2005) assim como Drury e Tayles (2006) também distinguem levemente o estabelecimento dos preços nos tomadores e nos formadores de preços. Os autores argumentam que as informações de custos são um importante input para definir os preços nos formadores, mas pouco expressivas nos tomadores, já que eles precisam colocar o preço dado 
pelo mercado. Os achados empíricos, no entanto, não confirmaram esses argumentos, sobretudo porque o enquadramento foi indevidamente inferido pelo tamanho das empresas.

Os demais estudos, apesar de não promoverem a segregação entre os tomadores e os formadores de preços, relacionam indícios que sugerem a existência de diferentes padrões no estabelecimento dos preços. Afinal, não foram poucas as conclusões que demonstraram que enquanto algumas empresas definiam os preços em função dos custos mais margem, outras determinavam os preços em função da concorrência. Tem-se, portanto, uma alta probabilidade de composições mistas das amostras (formadores e tomadores de preços) em que os diferentes padrões encontrados seriam função desse enquadramento. Entretanto, os dados divulgados nos estudos não foram suficientes para ra/retificar essa percepção.

Em suma, pelas pesquisas empíricas revisadas, pode-se constatar que a averiguação específica do estabelecimento dos preços em tomadores e em formadores de preços também é escassa e limitada. Por esse motivo, pode-se considerar novamente como fatídico o argumento que a colocação de preços similares aos da concorrência apoia o gap entre a teoria de marketing e a prática. Afinal, os tomadores necessitam definir preços que não destoam do preço do mercado ainda que não correspondam ao valor oferecido ao cliente.

\subsubsection{Tomadores e Formadores: Uso de Fórmulas}

Agora que já foi demonstrado o principal ponto de diferença entre os tomadores e os formadores de preços (uso distinto das informações da concorrência), cumpre apresentar o ponto de similaridade entre eles: o uso de fórmulas no estabelecimento dos preços.

Essa similaridade existe porque, como Edwards (1952) menciona, todas as empresas costumam empregar fórmulas matemáticas para estabelecer os preços. Afinal, o uso de fórmulas permite não só calcular os preços, mas também justificar os preços que inevitavelmente devem ser postos. Assim, enquanto as fórmulas usadas possibilitam definir preços (aceitáveis pelos clientes) que gerem um lucro sustentável nos formadores, elas possibilitam a tomada do preço do mercado nos tomadores. 
Avlonitis e Indounas (2006a) mencionam que algumas fórmulas são bastante simples e que outras são sofisticadas. As fórmulas mais comuns nos tomadores são aquelas que têm os preços dos concorrentes como base. De acordo com Avlonitis e Indounas (2005a), destacamse: "preço de venda = preço dos concorrentes no mercado" e "preço de venda = preço dos concorrentes no mercado +/- ajustes". Segundo Drury e Tayles (2006), pode também ser encontrado o uso de fórmulas que tomam os custos como base.

J. O. Silva (1997), por exemplo, ilustrou a utilização dos custos mais margem no mercado do ouro, no qual as mineradoras lidam com uma commodity e tipicamente são tomadoras de preços. O preço é estabelecido pelo mercado e a combinação dos custos à margem serve para operacionalizar a colocação do preço aceitável. O autor reporta uma comparação feita entre os países que esclarece essa situação ao demonstrar que o preço de venda precisa ser o mesmo independentemente do custo (Tabela 29), sendo a margem ajustada.

Tabela 29 - Comparação da margem no mercado do ouro

\begin{tabular}{c|c|c|c|c|c}
\hline ITENS & ÁFrICA Do SUL & AUSTRÁLIA & BRASIL & CANADÁ & $\begin{array}{c}\text { ESTADOS } \\
\text { UNIDOS }\end{array}$ \\
\hline $\begin{array}{c}\text { Preço de Venda (US\$/onça } \\
\text { troy) }\end{array}$ & US\$ 387 & US\$ 387 & US\$ 387 & US\$ 387 & US\$ 387 \\
\hline Custo Total (US\$onça troy) & US\$ 334 & US\$ 358 & US\$ 315 & US\$ 282 & US\$ 300 \\
\hline Margem (US\$/onça troy) & US\$ 53 & US\$ 29 & US\$ 72 & US\$ 105 & US\$ 87 \\
\hline Margem (Percentual) & $16 \%$ & $8 \%$ & $23 \%$ & $37 \%$ & $29 \%$ \\
\hline
\end{tabular}
Fonte: J. O. Silva (1997, p. 05)

Já nos formadores, segundo Drury e Tayles (2006), as fórmulas costumam ter os custos como base. Tais fórmulas tendem a orientar a decisão, per si, dos preços. Assim, a Figura 37 compara as principais bases das fórmulas nas empresas dos dois enquadramentos.

Figura 37 - Base da fórmula nos tomadores e nos formadores de preços

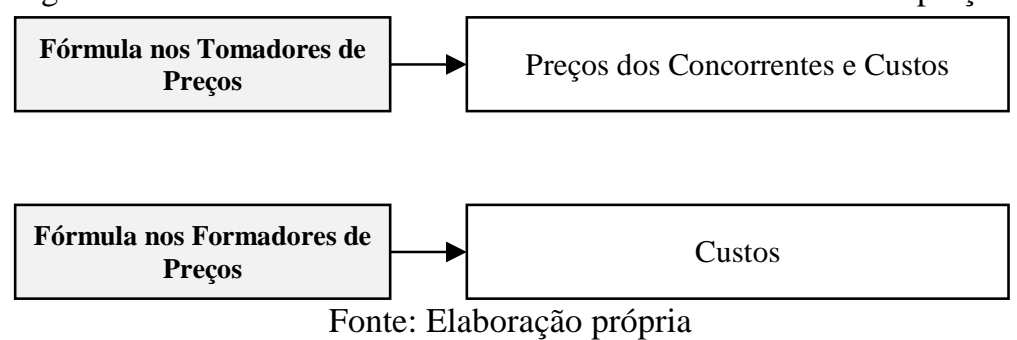

Constata-se, portanto, que a fórmula "custos mais margem" pode estar presente nos tomadores de preços e tende a estar presente nos formadores de preços. Assim, não é difícil entender por que há tempos Wentz (1966) reconheceu a ampla utilização da fórmula pelas 
empresas e por que a maioria das pesquisas empíricas (ver seções 3.1, 3.2 e 3.3) ratificou esse reconhecimento.

A fórmula "custos mais margem", como o próprio nome sugere, é composta por dois elementos: os custos e a margem. Como evidenciado na Tabela 30, independentemente do método de custeio adotado, são esses os dois elementos que estão presentes na fórmula. O que se altera, dependendo do método de custeio, é o que é considerado como custo do produto e o que a margem, além de gerar lucro, almeja cobrir.

Tabela 30 - Fórmulas do preço: Custos + margem

\begin{tabular}{|c|c|c|c|c|}
\hline MÉtodo de Custeio & $\begin{array}{c}\text { FóRMULA DO } \\
\text { PREÇO }\end{array}$ & $\begin{array}{c}\text { FóRMULA DOS } \\
\text { CUSTOS }\end{array}$ & FóRMULA da MARGEM & FóRMUla do PREÇO \\
\hline Custeio Pleno & $\mathrm{pv}=\mathrm{cp}+\mathrm{ma}$ & $\mathrm{cp}=\mathrm{cv}+\mathrm{cf}+\mathrm{dv}+\mathrm{df}$ & $\mathrm{ma}=\mathrm{ld}$ & $p v=(\underbrace{c v+c f+d v+d f}_{c p})+\underbrace{(l d)}_{m a}$ \\
\hline Custeio por Absorção & $\mathrm{pv}=\mathrm{cp}+\mathrm{ma}$ & $\mathrm{cp}=\mathrm{cv}+\mathrm{cf}$ & $m a=d v+d f+l d$ & $\mathrm{pv}=(\underbrace{\mathrm{cv}+\mathrm{cf}}_{\mathrm{cp}})+\underbrace{\mathrm{dv}+\mathrm{df}+\mathrm{ld})}_{\mathrm{ma}}$ \\
\hline Custeio Variável & $\mathrm{pv}=\mathrm{cp}+\mathrm{ma}$ & $\mathrm{cp}=\mathrm{cv}+\mathrm{dv}$ & $\mathrm{ma}=\mathrm{cf}+\mathrm{df}+\mathrm{ld}$ & $\mathrm{pv}=\underbrace{(\mathrm{cv}+\mathrm{dv})}_{\mathrm{cp}}+\underbrace{\mathrm{cf}+\mathrm{df}+\mathrm{ld})}_{\mathrm{ma}}$ \\
\hline
\end{tabular}

Nota $. \mathrm{pv}=$ preço de venda, $\mathrm{cp}=$ custos do produto, $\mathrm{ma}=$ margem desejada, $\mathrm{cv}=$ custo variável, $\mathrm{cf}=$ custo fixo, $\mathrm{dv}=$ despesa variável, $\mathrm{df}=$ despesa fixa, ld = lucro desejado

Guerreiro et al. (2012) explicam que a margem pode ser adicionada aos custos de diferentes maneiras, destacando: um percentual sobre o preço de venda; um montante (em unidades monetárias, no Brasil, em reais) somado aos custos; e um montante horário somado aos custos. A seguir, um exemplo ilustrativo apresentado pelos autores é reproduzido para ilustrar o emprego da fórmula diante dessas três possibilidades.

Nesse exemplo, uma empresa que adota o custeio variável é abordada. Nela, o único custo variável é o custo incorrido pela aquisição dos materiais diretos. Esse custo é de R $\$ 72,75$, porque os materiais são adquiridos por $\mathrm{R} \$ 100,00$, mas nesse valor há impostos recuperáveis embutidos: o ICMS $(18 \%$ - R\$ 18,00), o PIS $(1,65 \%$ - R\$ 1,65$)$ e a COFINS $(7,6 \%$ - R\$ 7,60). A empresa demora 3 horas para elaborar cada unidade de produto e no preço de venda incidem as seguintes despesas variáveis: $5,00 \%$ de comissão e fretes, $18,00 \%$ de ICMS, 1,65\% de PIS, 7,60\% de COFINS. Por fins didáticos, a empresa é isenta de IPI.

Quando a margem é colocada na forma de um percentual sobre o preço de venda, o uso da fórmula simplesmente pede que esse percentual seja somado aos percentuais das despesas 
variáveis. No caso de ela ser de $25,00 \%$, o percentual total chega a 57,25 (18,00\% do ICMS, $1,65 \%$ do PIS, $7,60 \%$ do COFINS, $5,00 \%$ da comissão de vendas e fretes e $25,00 \%$ da margem). Com esse percentual apurado, basta aplicar uma regra de três para definir o preço de venda. Se $42,75 \%(100,00 \%$ - 57,25\%) corresponde a $\mathrm{R} \$ 72,75$, então $100 \%$ corresponde a $\mathrm{R} \$ 170,17$. A Figura 38 demonstra a composição desses $\mathrm{R} \$ 170,17$.

Figura 38 - Margem como um percentual sobre o preço de venda

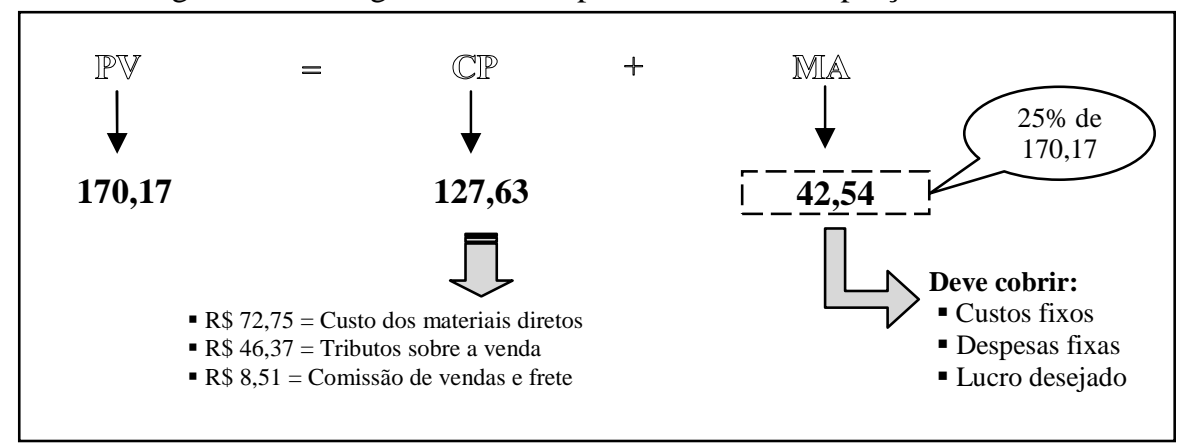

Fonte: Elaboração própria a partir de dados de Guerreiro et al. (2012)

Quando a margem é designada como um montante em reais, o uso da fórmula simplesmente pede que esse montante seja somado aos custos. Entretanto, não se pode olvidar que os impostos (ICMS: 18\%, PIS: 1,65\% e COFINS: 7,6\%) e as despesas variáveis (comissões de vendas e fretes: $5 \%$ ) sobre o preço de venda compõem esses custos. Como eles correspondem a $32,25 \%$ do preço de venda $(18 \%$ do ICMS $+1,65 \%$ do PIS $+7,6 \%$ da COFINS $+5 \%$ das comissões de vendas e frete), sabe-se que os demais componentes representam $67,75 \%$ do preço de venda (100\% - 32,25\%). Se a margem colocada é de $\mathrm{R} \$ 42,54,67,75 \%$ corresponde a $\mathrm{R} \$ 115,29(\mathrm{R} \$ 72,75+42,54)$ e, consequentemente, $100 \%$ corresponde a $\mathrm{R} \$ 170,17$. A Figura 39 ilustra a composição desses R \$ 170,17.

Figura 39 - Margem como um montante em reais

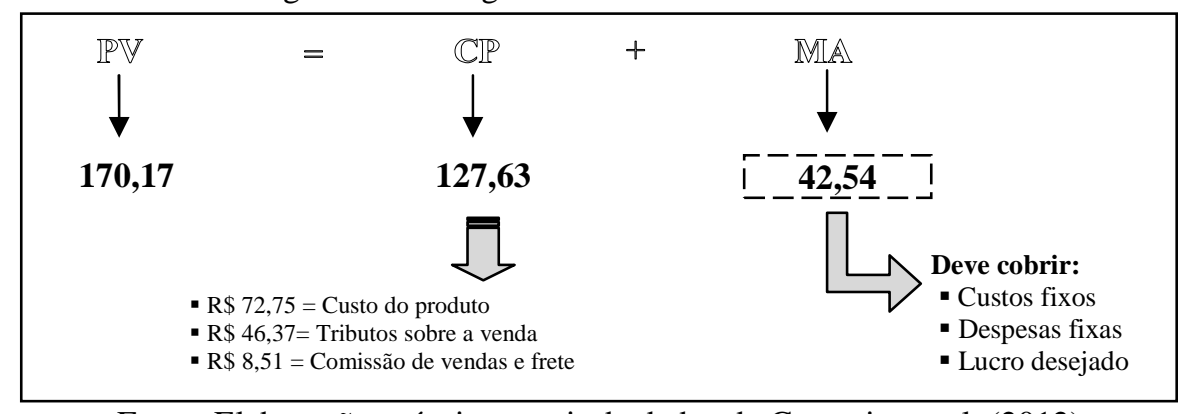

Fonte: Elaboração própria a partir de dados de Guerreiro et al. (2012)

Quando a margem é designada como um montante horário em reais, o uso da fórmula 
simplesmente pede que esse montante seja multiplicado pelas horas consumidas para produção e somado aos custos. No caso de a margem horária ser $\mathrm{R} \$ 14,18$, ela deve ser multiplicada pelas três horas de produção $(\mathrm{R} \$ 42,54)$ e somada aos custos. Se $67,75 \%$ do preço de venda $(100 \%$ - 32,25\% referente aos tributos e às despesas variáveis) corresponde a $\mathrm{R} \$ 115,29(\mathrm{R} \$ 72,75+42,54), 100 \%$ do preço de venda corresponde a $\mathrm{R} \$ 170,17$. A Figura 40 ilustra a composição desses R \$ 170,17.

Figura 40 - Margem como um montante horário em reais

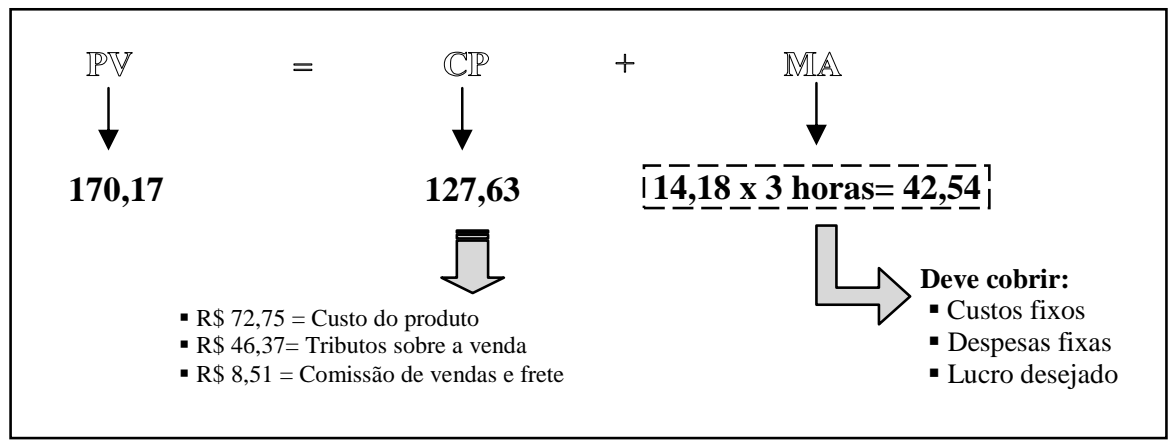

Fonte: Elaboração própria a partir de dados de Guerreiro et al. (2012)

Nota-se, portanto, que a operacionalização da fórmula "custos mais margem" é bastante simples, qualquer que seja a modalidade da margem selecionada. A aplicação da regra de três materializa um conceito clássico conhecido como markup multiplicador, que se refere a um índice pelo qual o custo unitário do produto é multiplicado.

A complicação do uso da fórmula está na definição da margem, seja ela em percentual ou em montantes reais. Como Guerreiro et al. (2012) frisam, a empresa, apesar de em tese poder colocar a margem que quiser (e.g., 5\%, 20\%, 50\%, 100\%, 300\% etc.), deve estar ciente do quão factível é a sua incorporação. De nada adianta estabelecer uma margem extremamente atraente (e.g., 300\%) que iniba as vendas por fazer o preço destoar do preço de produtos similares oferecidos pelos concorrentes, se existentes, ou do real valor oferecido aos clientes.

Por exemplo, um tomador de preços, ainda que tenha calculado o preço de venda de $\mathrm{R} \$$ 170,17 em função do objetivo de alcançar 25\% de margem (ou R $\$ 42,54$ ou $\mathrm{R} \$ 14,18$ por hora), pode identificar que o preço de mercado é R \$ 140,00. Nessa situação, para igualar seu preço a esse patamar, ele deve alterar a margem para 15,8\% ( $\mathrm{R}$ 140,00 do preço - $\mathrm{R} \$ 72,75$ do custo do produto $-\mathrm{R} \$ 45,15$ de impostos e despesas variáveis = $\mathrm{R} \$ 22,10$ de lucro). 
Mesmo um formador de preços que não possui produtos similares oferecidos pelos concorrentes não pode definir a margem arbitrariamente, sem ser sustentado por informações coerentes (Ingenbleek, 2007). Guerreiro et al. (2012), corroborando esse entendimento, defendem que a margem deve ser inspirada em um conjunto de informações, tais como, o histórico das margens na empresa, as margens dos produtos mais lucrativos, a média das margens na empresa, a estrutura de custos da empresa, a capacidade de produção, a tecnologia envolvida, o potencial volume de vendas, a potencial frequência de vendas e, sobretudo, a importância do produto para os clientes.

\subsubsection{Uso de Fórmulas nas Pesquisas Empíricas}

As fórmulas usadas pelos tomadores e pelos formadores de preços simplesmente indicam como o estabelecimento dos preços é operacionalizado. Isto é, elas demonstram a forma, não a essência, do processo.

As pesquisas empíricas enfatizam a investigação desse aspecto, diferentemente do que aconteceu nos dois tópicos anteriores. Pode-se até dizer que algumas optam por analisá-lo em demasia, ao invés de averiguarem com mais profundidade a essência do estabelecimento dos preços, ponto que seria mais relevante para o real entendimento do processo.

A ampla maioria das pesquisas revela o uso da fórmula "custos mais margem" (revisitar e Tabelas 13, 21 e 27). As evidências, ainda que tenham sido posteriormente utilizadas para argumentar o estabelecimento dos preços com base nos custos, apenas demonstram que essa é a principal fórmula usada no processo.

R. I. Hall e Hitch (1939) foram os pioneiros a expor que a definição dos preços ocorria fundamentalmente mediante o uso da fórmula "custos mais margem". Segundo os autores, nessa fórmula as empresas normalmente tomavam o custo direto como base, adicionavam um percentual referente aos custos indiretos e somavam uma margem convencional (usualmente de $10 \%$ ) a esses custos.

Lazer (1957), logo depois, apresentou uma reflexão para explicar por que o uso da fórmula seria tão frequente. Segundo o autor, os preços devem ser determinados de alguma forma e a 
simplicidade e a facilidade do uso dos custos mais margem tornaram a fórmula bastante atraente. Mesmo que ela não indique resultados que possam ser exatamente colocados (diante das condições do mercado), ela oferece uma noção para os preços, sujeita a modificações.

Nesta seção, não cabe reapresentar os achados de todas as pesquisas, mas, sim, reafirmar que o uso da fórmula "custos mais margem" imperava nas empresas investigadas. A maior parte das pesquisas demonstrou explicitamente que essa fórmula estava presente no processo de estabelecimento dos preços.

Em suma, pode-se concluir que é extensa a investigação sobre as fórmulas usadas no estabelecimento dos preços. Os resultados demonstram que o uso da fórmula "custos mais margem" predomina nas empresas e que o uso de fórmulas baseadas nos preços dos concorrentes aparece em segundo lugar. No entanto, esses resultados não são suficientes para apoiar o gap entre a teoria de marketing e a prática, ao passo que eles evidenciam somente a forma do estabelecimento dos preços, sem revelar se, na essência, há ou não um embasamento no valor.

\subsubsection{A Essência do Processo Não é Indicada pela Fórmula Usada}

Chega-se agora em um ponto crítico da tese. Enquanto as três seções anteriores expuseram aspectos intuitivos, apesar de não plenamente difundidos, esta seção discute um tópico que envolve ideias paradoxais. O objetivo central desta seção é demonstrar que o tipo da fórmula não indica necessariamente a essência do estabelecimento dos preços. Afinal, não é por que as empresas, tomadoras e formadoras de preços, fazem uso da fórmula "custos mais margem" que elas estabelecem os preços unicamente com base nos custos.

Nos tomadores de preços, a combinação "custos mais margem" pode ser empregada para operacionalizar o estabelecimento dos preços, ainda que os preços finais precisem equipararse aos preços do mercado (Lere, 1979; Drury \& Tayles, 2006). Para tanto, há duas opções: ou a margem já espelha os preços dos concorrentes (eventualmente ajustados por diferenças no valor), o que possibilita a determinação dos preços em uma única etapa, ou a margem é arbitrária, mas o resultado é alterado para equiparar-se aos preços dos concorrentes, o que deixa o processo com duas etapas. 
Nos formadores, o emprego da combinação "custos mais margem”, além de viabilizar a colocação de preços que assegurem a cobertura dos custos e a geração do lucro desejado, pode operacionalizar o estabelecimento dos preços baseado no valor, por intermédio da margem (Indounas, 2006).

Para dar início à discussão, cumpre reproduzir um argumento frisado por Edwards (1952):

O estabelecimento dos preços não é uma operação científica, nem o resultado de uma fórmula matemática bem definida. Uma fórmula matemática ou uma estimativa de custo podem ser empregadas para se chegar a um preço de venda como base de discussão.$^{21}$. (p. 304)

Desse argumento, depreende-se que a definição dos preços transcende a simples mecânica da aplicação de fórmulas. Afinal, como J. B. Haynes e Wilkens (1974) relatam, dificilmente e só "por acidente" um preço embasado exclusivamente nos custos totais mais uma margem arbitrária constante conduz à maximização do lucro. Segundo os autores, números fechados não são capazes de incorporar as condições de mercado, o peso de um determinado cliente ou mesmo a importância de um determinado produto.

Foxall $(1972$, 1980) reforça essa ideia. O autor argumenta que as informações de custos dificilmente são as responsáveis isoladas pelo processo de determinação dos preços. Ele defende que as empresas, embora tomem a decisão aplicando uma fórmula que tenha os custos como base, geralmente usam margens flexíveis que permitem incorporar outras informações (i.e., concorrência e/ou valor). O autor considera um grande equívoco afirmar que os preços são embasados nos custos só por que a fórmula “custos mais margem” é usada.

No estudo de 1972, Foxall argumenta que suas conclusões poderiam ser diferentes se ele não tivesse investigado com profundidade a realidade das 17 empresas entrevistadas e tivesse se contentado com a confirmação, em praticamente todas as empresas, da presença de cálculos de custos mais margem. Se essa confirmação fosse considerada suficiente, ele inferiria, erroneamente, que os custos eram a essência dos preços, mas como ele foi mais a fundo, ele averiguou que os custos não tinham o principal papel. Afinal, os preços variavam de acordo

21 Price-fixing is not a scientific operation, nor is it the result of a well defined mathematical formula. A mathematical formula or a cost estimate may be employed for arriving at a selling price as a basis of discussion. 
com os clientes, com a sazonalidade e de região a região. Nenhuma das empresas tinha margens invariáveis e a maior parte delas promovia regularmente revisões.

De acordo com Foxall (1972), duas causas são responsáveis pelo disparate de alegar que a essência dos preços está nos custos simplesmente porque a fórmula "custos mais margem" é empregada. A primeira causa é que há, sim, algumas empresas que aderem estritamente à fórmula e definem os preços como uma função exclusiva dos custos, ignorando outros tipos de informação. O problema é que apenas a minoria das empresas atua dessa forma.

O segundo e principal motivo resulta dos métodos empregados nas pesquisas que buscam identificar o processo de estabelecimento dos preços. Como tais pesquisas são ancoradas em entrevistas e questionários, os respondentes, ao serem questionados sobre seus procedimentos de preços, são conduzidos a afirmar que fazem uso dos custos mais margem. O problema é que, nessa fórmula, informações da concorrência e/ou dos clientes podem estar incorporadas (na margem), o que faz com que o resultado não seja uma mera função dos custos (Foxall, 1972).

Vale ressaltar que, antes de Foxall (1972), outros autores também já tinham indicado essas causas. Para a primeira causa, Edwards (1952), por exemplo, já havia apontado que independentemente da fórmula ser usada, "o fator decisivo no estabelecimento dos preços é o preço que o cliente está disposto, ou pode ser induzido, a pagar" ${ }^{22}$ (p. 304). De acordo com o autor, os custos exercem um papel importante na determinação dos preços, mas estão longe de ser seu único determinante. Wentz (1966), corroborando esse apontamento, já tinha defendido que o papel dos custos costuma ser limitado na definição dos preços.

Cavusgil (1988) já tinha argumentado que os preços eram mais ou menos embasados nos custos dependendo dos tipos de custos incluídos na fórmula. De acordo com o autor, quando os custos totais não são a base da fórmula, as empresas têm condições de variar significativamente a margem entre os produtos e os clientes. Dessa forma, elas conseguem colocar preços baixos e competitivos em mercados que, de outra forma, lhe pareceriam proibitivos ou impenetráveis. É o caso, por exemplo, de exportadores que conseguem vender

\footnotetext{
22 The deciding factor in price-fixing is the price which the customer is willing, or can be induced, to pay.
} 
externamente a preços menores do que no mercado doméstico. Na mesma linha, Indounas (2006) já tinha defendido que a essência afasta-se dos custos quando os custos variáveis são considerados e propiciam flexibilidade para variar a margem entre os produtos e os clientes.

Para a segunda causa, Machlup (1946), como outro exemplo, já havia criticado a conclusão de R. I. Hall e Hitch (1939) de que os preços eram formados com base exclusiva nos custos. De acordo com o autor, os achados de que as margens colocadas para cada produto eram diferentes e variavam ao longo do tempo contrastavam com essa conclusão, ao passo que evidenciavam que outros dados além dos custos eram incorporados. Pearce (1956) atribuiu parte da culpa dessa situação aos gestores, pois acredita que eles mesmos tendem a explicar que os preços são estabelecidos com base em cálculos de custos. Já W. W. Haynes (1964) lamentou que na literatura do assunto costuma-se chegar muito rapidamente à conclusão de que os preços são orientados pelos custos em decorrência do mero uso da fórmula "custos mais margem".

Em suma, pode-se trazer que não é por que a fórmula "custos mais margem" é empregada que os custos são a essência do processo. Dependendo do uso feito, a fórmula é apenas a forma

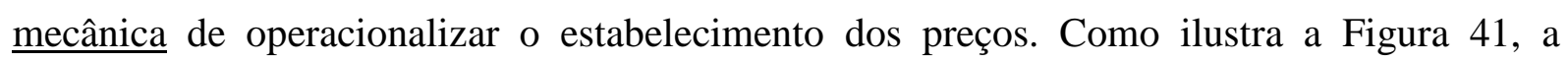
essência custos é encontrada somente quando a margem é arbitrária e deixa de conectar os custos a outros tipos de informações. Quando a margem conecta informações de custos a informações dos preços da concorrência (tomadores) e de valor (formadores), tem-se a forma, mas não a essência custos.

Figura 41 - Margem como elemento caracterizador da essência custos

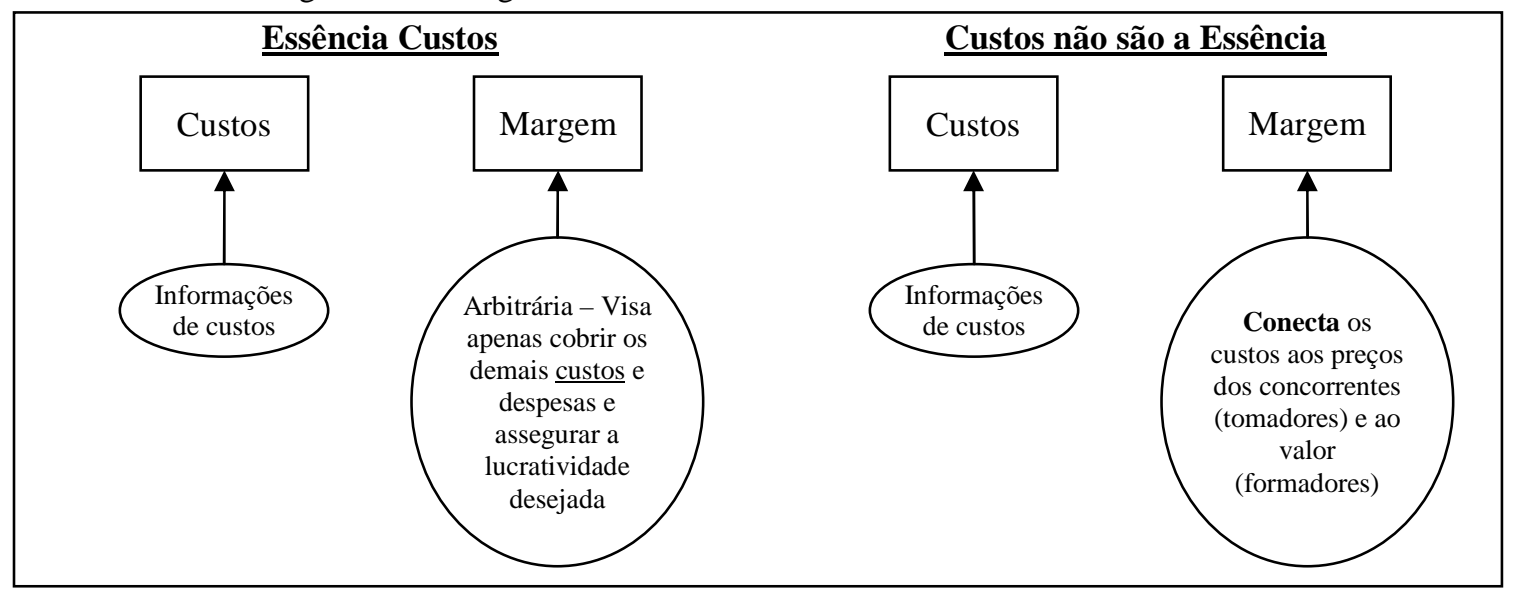

Fonte: Elaboração própria 
Nos tomadores, a essência custos traz a necessidade de uma etapa adicional ao processo de definição dos preços (comparação do resultado da fórmula aos preços correntes do mercado, eventualmente ajustados pelo valor), uma vez que os preços colocados devem necessariamente ser similares aos preços dos concorrentes. Lazer (1957), Atkin e Skinner (1975), Gordon et al. (1981), Mills (1988), Hankinson (1995), Drury e Tayles (2006), D. G.

Machado e Souza (2006), D. G. Machado et al. (2010) e Queiroz, Conceição, Silva, Santos, e Cabral (2013), por exemplo, mostraram que há empresas (supostamente tomadoras de preços) que definem os preços a partir dos custos mais margem, mas usam o resultado dessa combinação como mera referência, já que precisam colocar os preços ditados pelo mercado.

Nos formadores, por sua vez, a ausência de referências de mercado faz com que o preço sugerido pela combinação "custos mais margem” já seja o preço final colocado, e, por esse motivo, a essência custos origina preços destoantes do valor (maiores ou menores do que o valor), por vezes utópicos (Myers, 1997).

\subsubsection{Essência do Preço nas Pesquisas Empíricas}

O uso da fórmula "custos mais margem" não é sinônimo do estabelecimento dos preços baseado exclusivamente nos custos. Tanto tomadores quanto formadores de preços podem empregar a fórmula sem que os custos sejam a essência do processo.

Parte das pesquisas revisadas, ao mesmo tempo em que relatou que os preços eram definidos a partir dos custos mais margem, demonstrou impactos da concorrência e do valor na decisão da margem. Exemplos de estudos que evidenciaram que as margens eram, em algumas circunstâncias, variáveis visando espelhar os preços colocados pelos concorrentes no mercado ou o valor incluem: R. I. Hall e Hitch (1939), W. W. Haynes (1964), R. C. Skinner (1970), Shipley (1983), Abratt e Pitt (1985), Morris e Fuller (1989), Shipley e Bourdon (1990), Cunningham e Hornby (1993), Carson et al. (1998), Mello (2000), Mochtar e Arditi (2001), Fabiani et al. (2005) e Park et al. (2010).

Entretanto, não foram todos os trabalhos que trouxeram indícios para analisar se a fórmula guiava ao estabelecimento dos preços ancorada exclusivamente nos custos ou viabilizava a operacionalização de preços pautados no valor ou na concorrência. Assim, não se pode inferir 
ao certo se os achados dos estudos apresentaram apenas a forma ou também a essência do estabelecimento dos preços. Owens (1983), inclusive, critica o trabalho de Govindarajan e Anthony (1983) pelo fato de seus resultados serem evasivos e não demonstrarem se o elemento margem refletia ou não a situação do mercado.

\subsubsection{Em resumo}

Esta seção demonstrou a fraqueza dos argumentos trazidos para sustentar o gap entre a teoria de marketing e a prática. Ela mostrou que o estabelecimento dos preços a partir da fórmula “custos mais margem” não significa necessariamente um desprezo das informações de valor.

Primeiramente, evidenciou-se que nem todas as empresas têm poder para formar preços e que, por consequência, a não incorporação do valor não é necessariamente uma escolha. Os tomadores de preços, como o nome sugere, precisam tomar os preços do mercado. Destarte, não se pode dizer que eles preterem informações de valor, pois precisam colocar preços similares aos concorrentes.

Por mais que os tomadores queiram colocar preços correspondentes ao valor, eles estão restritos aos preços do mercado, já que a colocação de preços superiores a esse patamar incentiva os clientes a comprarem dos concorrentes e a colocação de preços inferiores a esse patamar fomenta guerras de preços (Harper, 1966). Em outras palavras, argumentou-se que os preços dos tomadores precisam equiparar-se aos preços da concorrência (ajustados ou não pelo valor), independentemente da forma adotada no processo (Hofstrand, 2007).

Por intermédio da margem, os tomadores conseguem determinar preços coerentes ao mercado de uma forma simplificada. O problema está quando a combinação "custos mais margem" é empregada de uma forma restrita, com uma margem arbitrária que não conecta as informações de custos às informações da concorrência. Por mais que nessa situação a definição dos preços conte com uma etapa adicional, na qual o resultado da fórmula é comparado aos preços da concorrência, tem-se aí um gap entre a teoria de marketing e a prática. Afinal, nessa circunstância o processo afasta-se do valor não por conta da necessidade da colocação de preços similares aos concorrentes, mas, sim, pela utilização de uma combinação arbitrária dos custos à margem. 
Já os formadores de preços têm condições de decidir se definem seus preços com base nos custos ou com base no valor. A colocação de preços a partir dos preços dos concorrentes normalmente não lhes é viável, pois as características diferenciadas oferecidas dificultam a identificação dos produtos dos concorrentes e dos seus respectivos preços.

A constatação da ampla utilização dos custos mais margem não indica, contudo, que a escolha dominante é a dos preços baseados nos custos. Ela apenas indica que a forma de operacionalizar o cálculo do preço toma como base os custos. Em outras palavras, não é por que os formadores definem seus preços mediante essa combinação que eles são guiados exclusivamente pelos custos. Afinal, eles podem usar a margem como elemento integrador entre os custos e o valor, colocando preços que espelham o valor, ainda que tenham sido calculados pela fórmula “custos mais margem” (Indounas, 2006).

Conclui-se, portanto, que o gap não existe para os tomadores que usam a fórmula "custos mais margem" para atender a necessidade de definir preços similares aos concorrentes e tampouco para os formadores que usam a fórmula "custos mais margem" para operacionalizar a colocação de preços consoantes ao valor. O gap entre a teoria de marketing e a prática apenas é encontrado quando a fórmula "custos mais margem" é empregada para determinar preços guiados exclusivamente pelos custos, como ilustra a Figura 42, ou seja, quando não é usada para conectar os custos aos demais tipos de informações.

Figura 42 - Reavaliação do gap entre a teoria de marketing e a prática

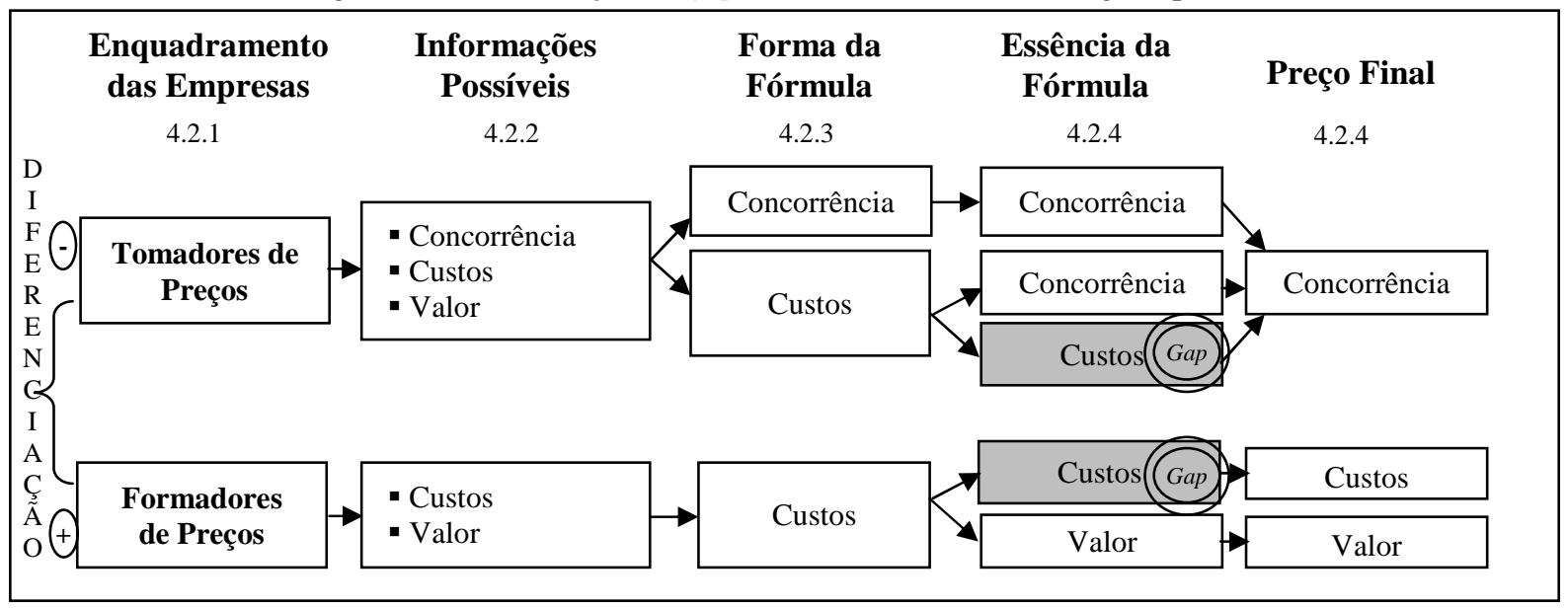

Fonte: Elaboração própria 


\section{O PORQUÊ DA ESSÊNCIA CUSTOS}

No capítulo anterior argumentou-se que a extensão do gap entre a teoria de marketing e a prática é bem menor do que se costuma afirmar. Afinal, estabelecer preços similares aos concorrentes não é uma escolha dos tomadores de preços e usar a fórmula "custos mais margem" não é sinônimo de desprezo do valor. Entretanto, defendeu-se que tal gap, ainda que não seja tão extenso, de fato existe, já que há, sim, empresas que empregam a combinação exclusivamente guiadas pelos custos.

As críticas ao estabelecimento dos preços orientado exclusivamente pelos custos não são poucas. A principal delas menciona que não tem como a concorrência e/ou a disposição e a disponibilidade de pagamento dos clientes não interferirem nos preços (R. C. Skinner, 1970). De nada adianta as empresas colocarem preços que cubram os custos e proporcionem uma vultosa margem se elas não encontrarem nenhum cliente que pague esses preços.

Segundo Cressman Jr. (1999), os custos, embora sejam criticamente importantes para a determinação dos preços, não devem definir o processo isoladamente, pois podem induzir à colocação de preços utópicos. Por exemplo, quando o valor entregue por um produto é muito menor do que o seu custo, o preço baseado nos custos torna-se inviável já que os clientes não aceitam pagar mais do que o produto realmente vale só por que as empresas gastaram mais do que deveriam para produzi-lo. Por outro lado, também não é interessante às empresas estabelecerem preços que cubram os custos e proporcionem uma razoável margem de lucro, se os clientes enxergam um valor muito maior para o produto.

Outra crítica menciona que o embasamento único nos custos impede que as empresas aproveitem oportunidades. Se as empresas ainda têm capacidade de produção ociosa e há clientes dispostos a pagar preços que superem o custo variável dos produtos, não há por que se ater: melhor do que obter nada é obter recursos adicionais que pelo menos ajudem a cobrir os custos fixos e as despesas fixas que são irreversíveis (Shipley \& Jobber, 2001).

Assim, não parecem existir motivos plausíveis que justifiquem o ainda encontro de empresas que estabelecem os preços em função única dos custos. Ingenbleek (2007) corrobora essa 
defesa e acrescenta que, mesmo entre os pesquisadores do assunto, não há consenso sobre o que faz essa situação perseverar.

Nesse sentido, esta seção dedica-se a explorar os fatores que explicam a excessiva ênfase colocada sobre os custos no estabelecimento dos preços. Em outras palavras, esta seção destina-se a levantar os fatores explicativos da essência custos.

Para iniciar a discussão, promove-se uma revisão crítica de estudos que previamente investigaram os fatores associados à ênfase posta em cada tipo de informação. Vale destacar que a revisão crítica de trabalhos anteriores é importante porque, além de organizar o entendimento vigente sobre o assunto, fomenta a identificação de lacunas ainda não preenchidas. Depois da revisão e diante das lacunas localizadas, relacionam-se aspectos não explorados nos estudos prévios e propõem-se fatores ainda não apresentados.

\subsection{Revisão Crítica de Fatores Sugeridos nos Estudos Prévios}

\subsubsection{Estudo de Ingenbleek et al. (2003)}

Um dos objetivos do estudo de Ingenbleek et al. (2003) foi investigar as condições em que o embasamento nos diferentes tipos de informações era mais efetivo para a definição dos preços (por mais bem contribuir com o desempenho - lucro, fatia de mercado etc. - alcançado pelos novos produtos). Ora, ao distinguir as condições que interferiam na efetividade, o estudo acabou indiretamente relacionando condições que explicavam a ênfase no uso das informações (já que as empresas tendem a enfatizar o uso das informações que lhe são mais efetivas).

Para alcançar esse e os demais objetivos do estudo, Ingenbleek et al. (2003) adotaram a perspectiva contingencial. As contingências abordadas pelos autores foram: a vantagem relativa do produto, a intensidade da concorrência e a vantagem relativa de um produto simultânea à intensidade da concorrência.

Seis hipóteses foram elaboradas para presumir a relação entre as contingências e a efetividade do uso das informações, como mostra a Tabela 31. Nela, percebe-se, por exemplo, que foi 
previsto um relacionamento negativo entre a vantagem relativa do produto e o embasamento nos custos. A expectativa dos autores era que quanto menos superioridade (na qualidade, na inovação, no atendimento de expectativas) o produto tivesse em relação aos produtos oferecidos pelos concorrentes, $\underline{\text { mais }}$ efetivo seria o embasamento em informações de custos. Por outro lado, quanto mais superioridade o produto tivesse em relação aos produtos oferecidos pelos concorrentes, $\underline{\text { mais }}$ efetivo seria o embasamento em informações de valor.

Tabela 31 - Hipóteses do estudo de Ingenbleek et al. (2003)

\begin{tabular}{|c|c|c|c|}
\hline \multirow{2}{*}{ CONTINGÊNCIA } & \multicolumn{3}{|c|}{ EFETIVIDADE } \\
\hline & VALOR & CONCORRÊNCIA & Custos \\
\hline Vantagem relativa do produto & + & - & - \\
\hline Intensidade da concorrência & - & Sem hipótese & + \\
\hline $\begin{array}{l}\text { Vantagem relativa do produto simultânea à intensidade da } \\
\text { concorrência }\end{array}$ & $\begin{array}{c}\text { Sem } \\
\text { hipótese }\end{array}$ & - & $\begin{array}{c}\text { Sem } \\
\text { hipótese }\end{array}$ \\
\hline
\end{tabular}

Fonte: Adaptada de Ingenbleek et al. (2003, p. 293)

Para testar essas hipóteses com as 77 respostas válidas recebidas, Ingenbleek et al. (2003) aplicaram a análise de regressão moderada. Com essa análise, os autores puderam, entre outros feitos, testar se as variáveis moderadoras (vantagem relativa do produto, intensidade da concorrência e ambas) modificavam a relação entre as variáveis independentes (embasamento no valor, na concorrência e nos custos) e a variável dependente (desempenho do novo produto). A Tabela 32 mostra os resultados alcançados.

Tabela 32 - Resultados do estudo de Ingenbleek et al. (2003)

\begin{tabular}{|c|c|c|c|c|c|c|}
\hline \multirow{3}{*}{ CONTINGÊNCIA } & \multicolumn{6}{|c|}{ EFETIVIDADE } \\
\hline & \multicolumn{2}{|c|}{ VALOR } & \multicolumn{2}{|c|}{ CONCORRÊNCIA } & \multicolumn{2}{|c|}{ Custos } \\
\hline & PREVISTOO & OBSERVADO & PReVisto & OBSERVADO & Previsto & OBSERVADO \\
\hline $\begin{array}{l}\text { Vantagem relativa do } \\
\text { produto }\end{array}$ & + & + & - & - & - & $\begin{array}{c}- \\
\text { (não significativo) }\end{array}$ \\
\hline $\begin{array}{c}\text { Intensidade da } \\
\text { concorrência }\end{array}$ & - & - & Se & pótese & + & + \\
\hline $\begin{array}{l}\text { Vantagem relativa do } \\
\text { produto simultânea à } \\
\text { intensidade da } \\
\text { concorrência }\end{array}$ & \multicolumn{2}{|c|}{ Sem hipótese } & - & - & \multicolumn{2}{|c|}{ Sem hipótese } \\
\hline
\end{tabular}

Fonte: Elaborada a partir de dados de Ingenbleek et al. (2003)

Observa-se que todas as expectativas previstas pelos autores foram confirmadas. Foi ratificado que quando a vantagem relativa do produto era maior, o embasamento no valor era mais efetivo e o embasamento nos custos era menos efetivo (embora esta última relação não seja estatisticamente significativa). Foi confirmado também que quando a intensidade da concorrência era maior, o embasamento nos custos era mais efetivo e o embasamento no valor era menos efetivo. Ademais, foi assegurado que quando tanto a vantagem relativa do produto 
quanto a intensidade da concorrência eram maiores, o embasamento na concorrência, curiosamente, era menos efetivo. Apesar da coincidência entre os resultados e as expectativas, notam-se pontos contraditórios no estudo.

Primeiramente, não parece ter sentido a agregação das variáveis contingenciais tal como proposta pelos autores: vantagem relativa do produto simultânea à intensidade da concorrência. Conforme já abordado, quanto mais diferenciado o produto for, menos concorrentes diretos a empresa tende a ter, uma vez que poucos produtos similares são oferecidos pela outras empresas. Ou seja, o mais usual é que a vantagem relativa do produto esteja em pólo oposto à intensidade da concorrência.

Dessa agregação surge um segundo ponto contraditório, tanto nas expectativas quanto nos resultados do trabalho: a afirmação de que quanto maior fosse a vantagem relativa do produto simultânea à intensidade da concorrência menor seria a efetividade do embasamento na concorrência. Ora, em situações normais, não seria plausível a uma empresa tomadora de preços exposta à ardorosa competição simplesmente ignorar os preços dos seus concorrentes.

Daí nota-se por que faz falta a segregação das empresas em tomadoras e formadoras de preços. As empresas que ofertam produtos com vantagem relativa (diferenciados) tendem a ser formadoras de preços e, como tais, têm poder para formar preços. Muitas vezes elas não têm sequer concorrentes diretos oferecendo produtos semelhantes que possam ser usados como base aos preços. Por essa razão, independentemente da competitividade do ambiente em que elas atuam, a efetividade do embasamento na concorrência tende a ser menor nelas do que naquelas empresas que não trazem produtos com vantagem relativa (tomadoras de preços).

Os resultados do estudo de Ingenbleek et al. (2003) foram consistentes com as expectativas justamente por esse motivo: a efetividade do uso de informações da concorrência é necessariamente menor nos formadores do que nos tomadores de preços (os segundos precisam desse tipo de informação para estabelecer os preços).

Outro ponto que merece ser mencionado é que a análise da regressão moderada mostrou que quanto mais intensa era a concorrência, mais efetivo era o embasamento nos custos. Fabiani et al. (2005), no entanto, apresentaram conclusão oposta (ver próxima seção 5.1.2) à conclusão 
de Ingenbleek et al. (2003): de acordo com os autores, a base custos seria maior quanto menos intenso fosse o nível da concorrência.

Novamente a avaliação isolada das variáveis (em ambos os estudos), sem considerar o enquadramento da empresa, pode ser a responsável por esses resultados opostos (um dos estudos pode ter trabalhado com uma amostra dominada por tomadores, outro pode ter trabalhado com uma amostra balanceada).

Por exemplo, pode ser que o estudo de Ingenbleek et al. (2003) tenha na amostra a predominância de tomadores de preços e, portanto, indique que tomadores expostos a concorrência mais intensa têm mais efetividade no embasamento nos custos. Já o estudo de Fabiani et al. (2005) pode ter uma amostra balanceada e, portanto, indicar que os tomadores (expostos a maior concorrência) usam menos informações de custos do que os formadores (expostos a menor concorrência). Essas observações são apenas conjecturas, já que, pelos dados disponibilizados nos estudos, não é possível inferir como de fato as amostras estavam distribuídas.

Finalmente, vale esclarecer que os resultados referentes ao embasamento nos custos reportados por Ingenbleek et al. (2003) também podem estar enviesados. Os autores inferiram tal embasamento ao constatarem a utilização de informações de custos variáveis, de ponto de equilíbrio, de investimentos e de custos fixos. O uso dessas informações, todavia, podia configurar meramente a forma do processo, no qual a essência poderia ser marcada pelo valor ou pela concorrência.

\subsubsection{Estudo de Fabiani et al. (2005)}

Uma dentre as doze proposições do estudo de Fabiani et al. (2005) defendeu que quanto mais baixa fosse a intensidade da concorrência mais frequente seria o estabelecimento dos preços conforme os custos mais margem (proposição $\mathrm{n}^{\circ}$ 4). Os dados empíricos obtidos das 11.038 empresas questionadas ratificaram essa proposição, como demonstra a Figura 43. 
Figura 43 - Custos mais margem diante da intensidade da concorrência

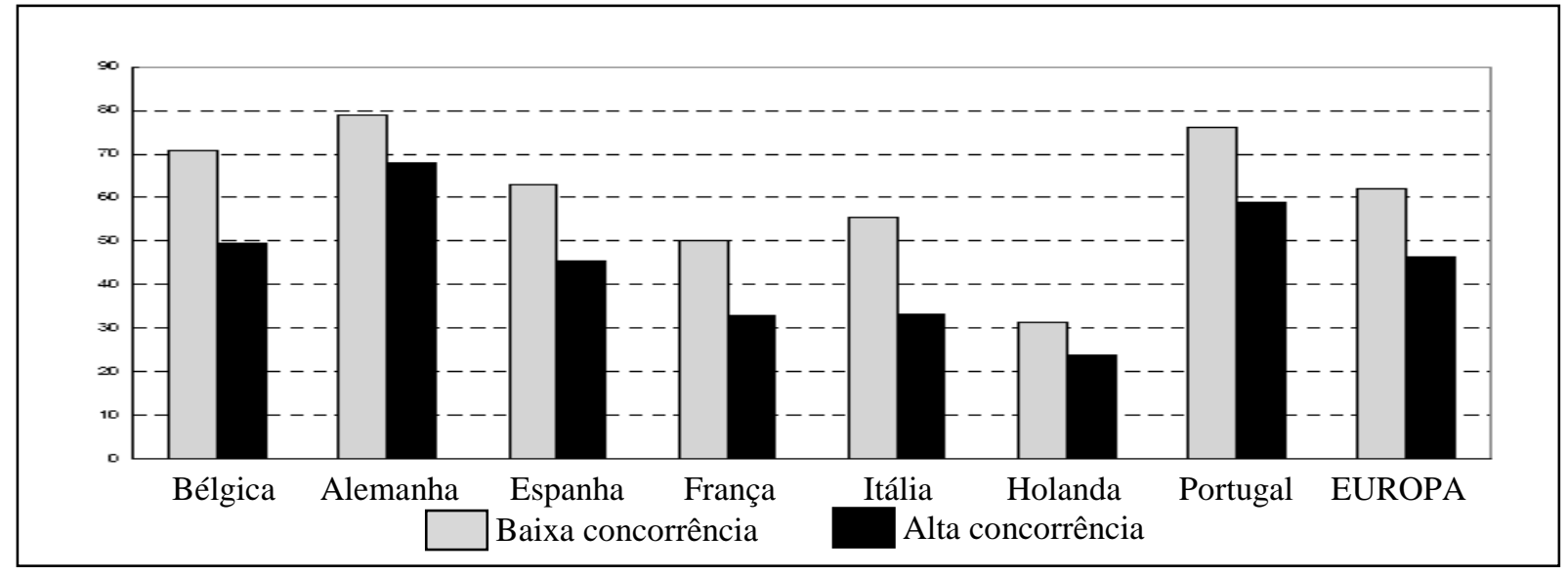

Fonte: Traduzida de Fabiani et al. (2005, p. 15)

O problema dessa conclusão é que ela pode estar omitindo a verdadeira causa para a maior ou menor frequência no estabelecimento dos preços conforme os custos mais margem (enquadramento da empresa como tomadora ou como formadora de preços). O fato de a intensidade da concorrência ser pequena tende a decorrer do oferecimento de um produto diferenciado.

Nessa situação, a empresa tende a ser formadora de preços e, por essa razão (não pela intensidade da concorrência), forma os preços partindo de referências internas, o que explica a aderência à fórmula "custos mais margem". Já o fato de a intensidade da concorrência ser elevada tende a decorrer do oferecimento de um produto não diferenciado. Nessa condição, a empresa tende a ser tomadora de preços e, por esse motivo (não pela intensidade da concorrência), tem que tomar os preços de mercado e usar menos as informações de custos.

Cumpre finalmente esclarecer que Fabiani et al. (2005) ativeram-se à investigação da forma, não da essência, da definição dos preços. Ou seja, eles investigaram se a fórmula "custos mais margem" estava ou não presente, o que não indicava necessariamente a essência do processo. Os autores demonstraram que não raramente as margens eram variáveis, mas não detalharam como elas eram deliberadas (i.e., não evidenciaram se as margens eram definidas a partir de informações de preços dos concorrentes ou do valor).

Dessa forma, assim como aconteceu no estudo de Ingenbleek et al. (2003), o estudo de Fabiani et al. (2005) deixou de realmente revelar, os fatores explicativos da maior e da menor essência custos no estabelecimento dos preços. 


\subsubsection{Estudo de Guilding et al. (2005)}

O estudo de Guilding et al. (2005) teve o objetivo de desenvolver e de testar hipóteses sobre as condições que interferiam no grau de importância atribuído aos custos mais margem no estabelecimento dos preços. Para atingir os objetivos do estudo, Guilding et al. (2005), da mesma forma que Ingenbleek et al. (2003), adotaram a perspectiva contingencial. Eles assumiram que três fatores contingenciais explicavam a importância imputada aos custos mais margem: intensidade da concorrência, tamanho da empresa (proxy para o enquadramento) e setor.

Três hipóteses foram elaboradas para conjecturar a relação entre os fatores contingenciais e a importância atribuída aos custos mais margem, conforme evidencia a Tabela 33. A primeira hipótese assumia que a intensidade da concorrência seria positivamente relacionada à importância (similar à conclusão de Ingenbleek et al. 2003, oposta à conclusão de Fabiani et al., 2005). A segunda hipótese propunha que o tamanho da empresa seria positivamente relacionado à importância. Por fim, a terceira hipótese sugeria que companhias do setor industrial atribuiriam baixa importância aos custos mais margem.

Tabela 33 - Hipóteses do estudo de Guilding et al. (2005)

\begin{tabular}{c|c}
\hline CONTINGÊNCIA & IMPORTÂNCIA ATRIBUÍDA AOS CUSTOS MAIS MARGEM \\
\hline Intensidade da concorrência & + \\
\hline Tamanho da empresa & + \\
\hline Setor (industrial) & - \\
\hline
\end{tabular}

Fonte: Elaborada a partir de dados de Guilding et al. (2005)

A análise de regressão exposta na Equação 3 foi aplicada para testar essas três hipóteses.

$Y=b_{1}+b_{2} C O N C+b_{3} T A M+b_{4} I N D+b_{5} P A I S+\varepsilon$

Em que:

$Y=$ importância atribuída ao cost-plus

CONC $=$ intensidade da concorrência

$T A M=$ tamanho da empresa

$I N D=$ setor industrial, variável dummy igual a 1 se a empresa fosse industrial ou igual a 0 se a empresa não fosse industrial 
$P A I S=$ variável dummy igual a 1 se a empresa fosse localizada no Reino Unido ou igual a 0 se a empresa fosse localizada na Austrália

$\varepsilon=$ erro

A Tabela 34 mostra a comparação entre os resultados alcançados com a análise de regressão e as previsões de relações sugeridas nas hipóteses.

Tabela 34 - Resultados do estudo de Guilding et al. (2005)

\begin{tabular}{|c|c|c|}
\hline \multirow{2}{*}{ CONTINGÊNCIA } & \multicolumn{2}{|c|}{ IMPORTÂNCIA ATRIBUÍDA AOS CUSTOS MAIS MARGEM } \\
\hline & Previsto & OBSERVADO \\
\hline Intensidade da concorrência & + & + \\
\hline Tamanho da empresa & + & $\begin{array}{c}+ \\
\text { (Não significativo) }\end{array}$ \\
\hline Setor (industrial) & - & - \\
\hline
\end{tabular}

Fonte: Elaborada a partir de dados de Guilding et al. (2005)

Observa-se que as hipóteses relativas à intensidade da concorrência e ao setor industrial foram ratificadas pelos dados empíricos. Já o resultado relacionado ao tamanho da empresa, embora coincida com a previsão da hipótese, não obteve significância estatística.

Nesse ponto, vale esclarecer que apesar de haver coerência entre todas as situações esperadas e todas as situações encontradas, notam-se quatro aspectos controversos no estudo. Primeiramente, no que diz respeito à relação entre a intensidade da concorrência e a importância atribuída aos custos mais margem, acredita-se que Guilding et al. (2005) cometeram a mesma falta de Ingenbleek et al. (2003), pois abordaram a variável do grau de competição isoladamente para indicar que os custos são priorizados diante de forte competição. A avaliação isolada da variável pode ter enviesado os resultados por comparar indistintamente o estabelecimento dos preços em tomadores e em formadores de preços.

Em segundo lugar, julga-se que o estudo Guilding et al. (2005) não foi venturoso ao considerar que apenas o tamanho da empresa define o seu enquadramento como tomadora ou como formadora de preços. Conforme se discutiu na seção 4.2.1, a extensão de diferenciação do produto oferecido, mais do que o tamanho da empresa, é responsável por determinar o enquadramento da companhia. Tanto que nada impede que empresas de grande porte que ofertam commodities sejam tomadoras de preços e que microempresas que oferecem produtos altamente diferenciados sejam formadoras de preços. Não é, portanto, surpreendente verificar 
que não foi estatisticamente conclusivo o resultado empírico para a relação entre o tamanho da empresa e a importância atribuída aos custos mais margem.

Os autores justificaram que a não conclusão dessa relação deveu-se à ausência da investigação adicional da fatia de mercado da empresa, pois, segundo eles, poderia acontecer de uma companhia ser grande por atuar com vários produtos, mas cada qual ter vendas correspondentes à pequena parcela do mercado. Guilding et al. (2005) propuseram que futuros estudos corrigissem a associação presumida e investigassem a existência de relação entre as fatias de mercado detidas (posição no mercado) e a importância conferida aos custos.

Não se entende que tal alteração melhoraria a proxy ao enquadramento, já que a diferenciação do produto é o que realmente define o poder sobre a formação dos preços (Hofstrand, 2007). É claro que há uma maior possibilidade de que as empresas com amplas fatias de mercado sejam formadoras de preços (usualmente em decorrência da diferenciação por marca), mas, pode, sim, existir empresas pequenas com fatias de mercado modestas que possuem poder na formação dos preços (e.g., microempresas desenvolvedoras de máquinas altamente customizadas). Logo, a alteração proposta por Guilding et al. (2005) não promoveria a fidedigna segregação entre tomadores e formadores de preços e novamente enviesaria os resultados.

Em terceiro lugar, no que se refere ao setor da empresa, não se concorda com a argumentação dos autores de que empresas do setor de serviços enfatizam a consideração de informações de custos porque têm mais condições de oferecerem um produto sem substitutos perfeitos. Afinal, existem, sim, empresas de serviço que oferecem um produto (serviço) único, mas também existem empresas que oferecem um produto muito similar aos concorrentes (e.g., serviços padrões de limpeza, de vigilância etc.).

Não se concorda também com a argumentação de que empresas do setor industrial simplesmente atribuiriam pouca importância aos custos mais margem porque, devido aos seus vastos custos indiretos, não teriam informações precisas de custos. Ora, o custo considerado não precisa necessariamente contemplar a parcela de custos fixos. 
Por fim, em quarto lugar, vale esclarecer que esse estudo, ao invés de mostrar a essência do processo, evidenciou se o resultado da fórmula "custos mais margem" era ou não determinante no estabelecimento dos preços. Ora, ao investigar a importância relativa da fórmula na definição do preço de venda final, Guilding et al. (2005) observaram se a forma adotada no processo indicava ou não a decisão derradeira, mas em nenhum momento averiguaram se o valor ou os preços da concorrência estavam ou não incorporados no elemento margem.

\subsubsection{Estudo de Al-Hussari (2006)}

O estudo de Al-Hussari (2006) foi uma tese de doutorado orientada pelo professor Drury. Talvez por isso, um dos seus objetivos seja tão parecido com o objetivo central do trabalho de Guilding, Drury e Tayles (2005): examinar a relação existente entre fatores contextuais/contingenciais e a importância atribuída aos custos mais margem. Para alcançar esse objetivo, o autor elaborou sete hipóteses específicas, como evidencia a Tabela 35.

Tabela 35 - Hipóteses do estudo de Al-Hussari (2006)

\begin{tabular}{c|c}
\hline CONTINGÊNCIA & $\begin{array}{c}\text { IMPORTÂNCIA ATRIBUÍDA } \\
\text { AOS CUSTOS MAIS } \\
\text { MARGEM }\end{array}$ \\
\hline Fatia de mercado & - \\
\hline Customização & + \\
\hline Influência na determinação dos preços & + \\
\hline Estratégia de diferenciação & + \\
\hline Intensidade da concorrência & + \\
\hline Importância atribuída às informações de custos & + \\
\hline Tamanho da empresa & \\
\hline Fonte: Elaborada a partir de dados de Al-Hussari (2006)
\end{tabular}

É curioso mencionar que dois fatores (intensidade da concorrência e tamanho da empresa) já constavam no estudo elaborado pelo orientador de Al-Hussari (2006) (Guilding et al., 2005), entretanto, um deles (intensidade da concorrência) estava na direção inversa (positivo no estudo anterior, negativo no novo estudo).

A fim de testar as hipóteses, Al-Hussari (2006) escolheu para a população da sua pesquisa empresas industriais e de serviço, de grande porte, localizadas no Reino Unido que tivessem profissionais cadastrados no CIMA. De todas as empresas que se enquadravam nessas condições, ele selecionou 1.000, priorizando a seleção de firmas com mais de 200 
empregados, dentre os quais dois ou mais deveriam ser membros do CIMA. Ele também enfatizou o ramo de alimentos, que deveria compor $25 \%$ da amostra. Para as 1.000 requisições encaminhadas, o pesquisador obteve 152 respostas. Com as respostas recebidas, o autor pode avaliar as relações e chegou aos resultados demonstrados na Tabela 36 (nem todos os resultados foram estatisticamente significativos).

Tabela 36 - Resultados do estudo de Al-Hussari (2006)

\begin{tabular}{c|c|c}
\hline \multirow{2}{*}{ CONTINGÊNCIA } & \multicolumn{2}{|c}{ IMPORTÂNCIA ATRIBUÍDA AOS CUSTOS MAIS MARGEM } \\
\cline { 2 - 3 } & PREVISTO & OBSERVADO \\
\hline Fatia de mercado & - & - \\
\hline Customização & + & + \\
\hline Influência na determinação dos preços & + & + \\
\hline Estratégia de diferenciação & + & - \\
\hline Intensidade da concorrência & - & + \\
\hline Importância atribuída às informações de custos & + & - \\
\hline Tamanho da empresa & + & + \\
\hline
\end{tabular}

Fonte: Elaborada a partir de dados de Al-Hussari (2006)

Para esses resultados, nota-se dois pontos de inconsistências com relação aos demais estudos. O primeiro refere-se à customização, pois a relação positiva observada contrasta com a relação negativa observada por Ingenbleek et al. (2003) para a vantagem relativa do produto. O segundo, outra vez, refere-se à intensidade da concorrência. No estudo de Al-Hussari (2006), a relação negativa não coincide com a relação anteriormente observada pelo próprio orientador do autor (Guilding et al. , 2005) nem com o achado de Ingenbleek et al. (2003).

Assim, mais uma vez, nota-se que a não segregação das empresas em tomadoras e formadoras de preços prejudicou a interpretação dos resultados. Al-Hussari (2006) até avaliou se as empresas tinham ou não poder de definir preços, mas não separou as empresas de acordo com essas informações, comparando inapropriadamente a importância atribuída aos custos mais margem pelos tomadores de preços àquela designada pelos formadores de preços. Ora, as empresas formadoras de preços (com produtos customizados) tendem a atribuir mais importância aos custos mais margem do que as empresas tomadoras de preços, mas isso em nada surpreende, já que o relevante seria investigar a realidade dos formadores com produtos mais e menos customizados. O mesmo acontece, novamente, com a intensidade da concorrência. 


\subsubsection{Estudo de Hinterhuber (2008)}

O trabalho de Hinterhuber (2008) buscou identificar por que os preços baseados na concorrência e nos custos (supostamente) tomavam o lugar dos preços baseados no valor. Especificamente, o autor dedicou-se a investigar as razões para raramente encontrar o embasamento no valor.

Para viabilizar a investigação, o autor empregou um método empírico de dois estágios. No primeiro estágio, qualitativo, ele averiguou se as informações de valor estavam ou não presentes no estabelecimento dos preços empreendido por executivos participantes de workshops sobre o tema. No segundo estágio, quantitativo, ele elaborou um questionário e o direcionou a 126 gestores (de alto nível) participantes de workshops conduzidos na Alemanha, na Áustria, na China e nos Estados Unidos. 81 respostas válidas foram recebidas.

Com as análises quantitativas, Hinterhuber (2008) chegou à conclusão que cinco eram as principais dificuldades inibidoras do embasamento no valor, conforme demonstrado na Figura 44.

Figura 44 - Inibidores do embasamento no valor segundo Hinterhuber (2008)

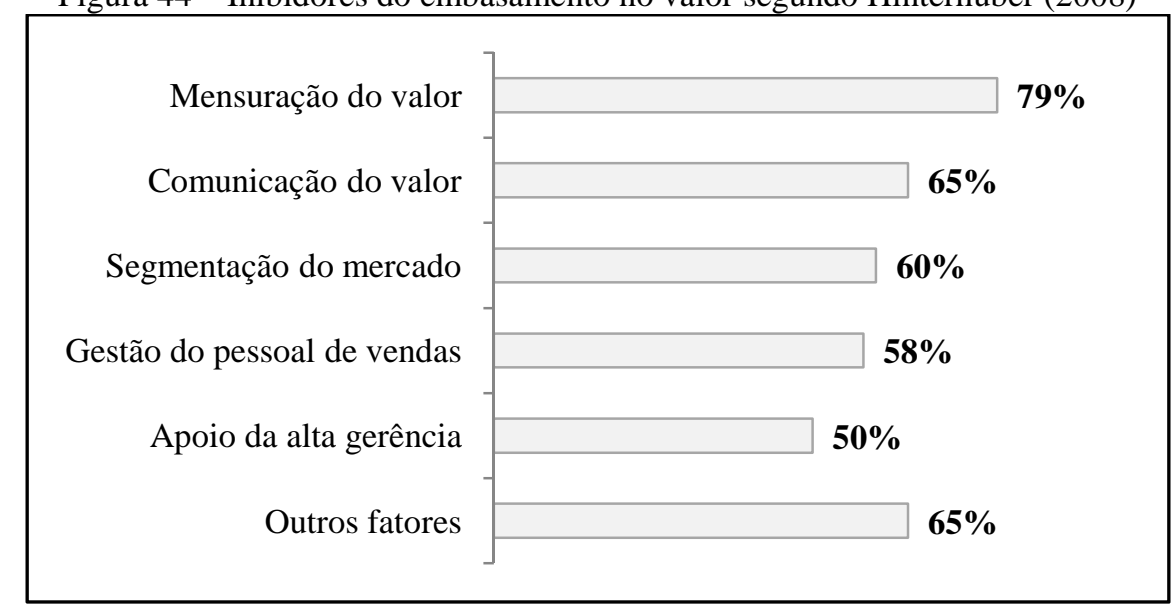

Fonte: Traduzida de Hinterhuber (2008, p. 45)

A dificuldade de mensurar o valor, mais do que inibir, impede a incorporação do valor, já que, conforme o autor frisa, "se a própria empresa não conhece o valor dos seus produtos ou dos 
seus serviços, como ela pode cobrar os clientes com base no valor?"23 (Hinterhuber, 2008, p. 44). O problema é que as informações de valor não estão naturalmente disponíveis e tampouco são elaboradas com facilidade. Diversos procedimentos precisam ser conjunta e continuamente executados para coletar e interpretar informações a fim de identificar, ao menos razoavelmente, o valor oferecido aos clientes.

No que se refere à coleta, vale destacar que a combinação de diferentes procedimentos é necessária para que a empresa estime um número confiável para o valor. No que se refere à interpretação, cumpre destacar que as informações coletadas não são objetivas. Por mais que diversos procedimentos sejam realizados simultaneamente para triangular e validar as evidências obtidas, a subjetividade domina já que os clientes avaliados podem expressar ou não a realidade, intencionalmente ou não.

A dificuldade de comunicar o valor, por sua vez, desmotiva a incorporação do valor. Hinterhuber (2008) salienta que, com a abundância de propagandas, está cada vez mais difícil atrair a atenção dos clientes. Os clientes, ao se depararem com inúmeras propagandas televisivas, impressas e na forma de "spam" na internet, acabam formando uma visão negativa do marketing e não respondem a ele da forma esperada. A indiferença dos clientes incentiva as empresas a não identificar e a não comunicar o valor e, consequentemente, a não implantar processos em que os preços sejam estabelecidos com base no valor.

A dificuldade de segmentar o mercado também desestimula o embasamento no valor. Empresas que atuam com produtos pouco diferenciados não encontram motivação em lançar uma linha diferenciada e a cobrar preços de acordo com o valor oferecido pelos produtos. A não segmentação faz com que elas optem por não arriscar e por colocar preços similares para todas as suas linhas (ou por não lançar produtos que estariam fora do seu escopo central).

A dificuldade de gerenciar o pessoal de vendas é outra que incentiva as empresas a não se pautarem no valor. A pressão por resultados faz com que o pessoal de vendas conceda descontos significativos, anulando o diferencial proposto e aproximando os preços das

\footnotetext{
${ }^{23}$ If the company itself does not know the value of its products or services to customers, how does it know what to charge customers for value?
} 
versões mais básicas disponíveis no mercado. Diante dessa situação, as empresas escolhem colocar preços já similares aos concorrentes, sem incorporar as diferenças no valor.

A dificuldade de conquistar o apoio da alta gerência é mais uma que desmotiva a colocação de preços a partir do valor. Afinal, de nada adianta propor inicialmente um preço alto orientado pelo valor se, depois, as pressões por vendas de amplos volumes fazem com que esse preço tenha que ser cortado e assemelhe-se aos preços dos concorrentes.

Em suma, observa-se que Hinterhuber (2008) focou numa apresentação descritiva das dificuldades reportadas pelos respondentes. O problema é que análises estatísticas não foram realizadas para ratificar se, de fato, havia diferença entre o embasamento no valor em empresas expostas e não expostas às dificuldades. Além disso, nada garante que as empresas classificadas pelo autor como embasadas nos custos (meramente pelo uso de fórmulas partindo dos custos) não tivessem o preço em essência definido pelo valor, por intermédio do elemento margem.

Outro problema do estudo foi, novamente, a não segregação das empresas em tomadoras e formadoras de preços. Ora, as três últimas dificuldades são potencializadas em tomadoras de preços, nas quais existem preços dos concorrentes que podem ser usados como referência. Logo, mais uma vez, o enquadramento (e não as dificuldades) poderia ser o real motivo que conduzia à ênfase na concorrência, ao invés de guiar à ênfase no valor.

\subsubsection{Estudo de Liozu, Hinterhuber, Perelli, e Boland (2012)}

A pesquisa de Liozu, Hinterhuber, Perelli, e Boland (2012) visou averiguar a mudança transformacional necessária à definição dos preços conforme o valor. Para atingir esse objetivo, os autores entrevistaram 44 gestores de 15 empresas industriais de pequeno e médio porte dos Estados Unidos. Essas empresas eram localizadas em 10 diferentes estados norteamericanos e atuavam na elaboração de materiais de construção, de produtos de transporte e de produtos de resina e plástico. 
Os autores constataram que normalmente uma mudança transformacional profunda, longa e dolorida era requerida para definir os preços conforme o valor. O "DNA" do estabelecimento dos preços precisava sofrer uma "mutação" e deixar de estar impregnado pelos custos. O sucesso dessa "mutação" dependia que a empresa estivesse aberta a reestruturar seus processos e a constantemente aprender com seus acertos e erros.

Nesse sentido, embora Liozu, Hinterhuber, Perelli, e Boland (2012) não mencionem explicitamente, percebe-se que a instituição de um novo "DNA" e a estruturação dos novos processos não eram gratuitas (Liozu \& Hinterhuber, 2013). Assim, é possível inferir que as empresas poderiam preteri-las se entendessem que seus benefícios eram menores do que seus custos.

\subsubsection{Estudo de Ingenbleek e Van der Lans (2013)}

Ingenbleek e van der Lans (2013) dedicaram-se a investigar um fator específico relacionado à aplicação dos métodos das três abordagens: a estratégia de preço. De acordo com eles, precisava-se demonstrar o quão equivocado é considerar o termo estratégias de preço como sinônimo ao termo práticas de determinação dos preços.

Os autores esclareceram que enquanto a estratégia define o meio pelo qual a empresa busca alcançar seus objetivos de preços, a prática operacionaliza o estabelecimento dos preços. Para eles, a diferença entre os conceitos pode ser facilmente percebida ao comparar sua visibilidade no mercado. As práticas são conhecidas somente dentro das fronteiras organizacionais (ao passo que somente os empregados da empresa sabem de que forma o estabelecimento dos preços é operacionalizado). Já as estratégias de preço são observáveis no mercado (os clientes, concorrentes e demais stakeholders têm noção de qual estratégia a empresa adota, pois conseguem comparar o nível de preço cobrado ao nível de valor qualidade oferecida).

Ingenbleek e van der Lans (2013) asseguraram que as práticas e as estratégias, apesar de não se referirem ao mesmo conceito, tendem a estar relacionadas. Segundo os autores, são as

\footnotetext{
${ }^{24}$ Sigla significa “desoxyribonucleic acid” ou, em português, "ácido desoxirribonucleico"
} 
práticas que colocam em ação os planos estabelecidos pelas estratégias, ou seja, são as práticas que possibilitam que os preços determinados sejam realmente coerentes à estratégia. Por exemplo, estratégias que colocam altos níveis de preço (e.g., estratégias de preços premium) tendem a estar associadas à ênfase na aplicação de métodos da abordagem baseada no valor, já que o êxito no elevado preço carece do entendimento das percepções dos clientes em relação ao produto.

Diante desse contexto, Ingenbleek e van der Lans (2013) estabeleceram os objetivos de conjecturar as possíveis relações entre as práticas de determinação dos preços e as estratégias de preço, divididas em três possíveis situações: lançamento de novos produtos, manutenção ou alteração da competitividade dos preços e linhas de produtos. Para testar tais relações empiricamente, eles propuseram oito hipóteses (a nona hipótese refere-se a outro aspecto), como mostra a Tabela 37.

Tabela 37 - Hipóteses do estudo de Ingenbleek e van der Lans (2013)

\begin{tabular}{|c|c|c|c|c|}
\hline \multirow{2}{*}{$\begin{array}{l}\text { SITUAÇÃO DA } \\
\text { ESTRATÉGIA }\end{array}$} & \multirow{2}{*}{ ESTRATÉGIA } & \multicolumn{3}{|c|}{ ABORDAGEM } \\
\hline & & VALOR & CONCORRÊNCIA & Custos \\
\hline \multirow{2}{*}{$\begin{array}{l}\text { Estratégia de Preço } \\
\text { no Lançamento de } \\
\text { Novos Produtos } \\
\text { (Determinação Inicial } \\
\text { dos Preços) }\end{array}$} & Preços de Desnatação (Price Skimming) & + & Sem hipótese & $\begin{array}{c}\text { Sem } \\
\text { hipótese }\end{array}$ \\
\hline & $\begin{array}{c}\text { Preços Conforme a Curva de } \\
\text { Experiência (Experience Curve Pricing) }\end{array}$ & $\begin{array}{l}\text { Sem } \\
\text { hipótese }\end{array}$ & + & $\begin{array}{c}\text { Sem } \\
\text { hipótese }\end{array}$ \\
\hline \multirow{3}{*}{$\begin{array}{c}\text { Estratégia de } \\
\text { Competitividade dos } \\
\text { Preços (Revisão dos } \\
\text { Preços) }\end{array}$} & $\begin{array}{l}\text { Liderança de Preços (Leader Pricing) ou } \\
\text { Preços Premium (Premium pricing) }\end{array}$ & + & Sem hipótese & $\begin{array}{c}\text { Sem } \\
\text { hipótese }\end{array}$ \\
\hline & $\begin{array}{c}\text { Nível de Preços Baixo (Low-Price } \\
\text { Supplier) }\end{array}$ & $\begin{array}{c}\text { Sem } \\
\text { hipótese }\end{array}$ & Sem hipótese & + \\
\hline & Preços de Paridade (Parity Pricing) & $\begin{array}{c}\text { Sem } \\
\text { hipótese }\end{array}$ & + & $\begin{array}{c}\text { Sem } \\
\text { hipótese }\end{array}$ \\
\hline \multirow{3}{*}{$\begin{array}{l}\text { Estratégia de Preço de } \\
\text { Linhas de Produtos }\end{array}$} & $\begin{array}{c}\text { Preços de Pacotes de Produtos (Price } \\
\text { Bundling) }\end{array}$ & + & Sem hipótese & $\begin{array}{c}\text { Sem } \\
\text { hipótese }\end{array}$ \\
\hline & $\begin{array}{c}\text { Preços de Valor para o Cliente } \\
\text { (Customer Value Price Strategy) } \\
\text { (uma versão do produto a preços mais } \\
\text { baixos) }\end{array}$ & $\begin{array}{l}\text { Sem } \\
\text { hipótese }\end{array}$ & Sem hipótese & + \\
\hline & $\begin{array}{l}\text { Preços de Produtos Complementares } \\
\text { (Complementary Product Pricing) }\end{array}$ & $\begin{array}{c}\text { Sem } \\
\text { hipótese }\end{array}$ & + & $\begin{array}{c}\text { Sem } \\
\text { hipótese }\end{array}$ \\
\hline
\end{tabular}

Fonte: Elaborada a partir de dados de Ingenbleek e van der Lans (2013)

Usando um total de 95 respostas válidas, Ingenbleek e van der Lans (2013) identificaram, antes de tudo, que era expressivo o número de empresas sem estratégias de preço $(26 \%$ da amostra). Entretanto, esse número elevado não é surpreendente, afinal, Harper (1966) já havia advertido que os tomadores não têm motivos para desenhar uma estratégia de preço. $\mathrm{O}$ poder que eles têm para decidir sobre os preços é nulo e, portanto, não lhes resta outra opção além 
de tomar o preço corrente no mercado (não lhes adiantaria estabelecer uma estratégia porque o preço não poderia destoar do preço corrente no mercado). Ingenbleek e van der Lans (2013) não puderam perceber essa realidade porque não segregaram a amostra em tomadores e formadores de preços.

Para reportar especificamente a relação entre as práticas e as estratégias de preço, os autores empreitaram análises da variância (ANOVA) a cada situação e a cada prática separadamente. Testes de diferenças de médias (Least Significant Difference - LSD) revelavam se, estatisticamente, eram ou não significativas as diferenças entre as empresas que adotavam e as empresas que não adotavam a estratégia objeto da hipótese (com relação à aplicação de métodos da abordagem objeto da hipótese). Por exemplo, na primeira hipótese, foi testado se a diferença entre as empresas que adotavam e as empresas que não adotavam a estratégia de desnatação era significativa com relação à aplicação de métodos da abordagem baseada no valor. A Tabela 38 mostra os resultados alcançados pelos autores para essa e para as demais sete hipóteses.

Tabela 38 - Resultados do estudo de Ingenbleek e van der Lans (2013)

\begin{tabular}{c|c|c|c}
\hline \multicolumn{2}{c|}{ RELAÇÕES ESPERADAS } & \multirow{2}{*}{ RESULTADOS } & $\begin{array}{c}\text { SINAL DA } \\
\text { RELAÇÃo }\end{array}$ \\
\hline ESTRATÉGIA & ABORDAGEM & Aceita & + \\
\hline Preços de Desnatação & Valor & Parcialmente Aceita & + \\
\hline Preços Conforme a Curva de Experiência & Concorrência & Aceita & + \\
\hline Niderança de Preços ou Preços Premium & Valor & Rejeitada & + \\
\hline Preços de Paridade & Custos & Aceita & + \\
\hline Preços de Pacotes de Produtos & Concorrência & Rejeitada & + \\
\hline Preços de Valor para o Cliente & Valor & Rejeitada & + \\
\hline Preços de Produtos Complementares & Custos & Rejeitada & + \\
\hline
\end{tabular}

Fonte: Elaborada a partir de dados de Ingenbleek e van der Lans (2013, p. 42)

É possível observar que as duas hipóteses que buscavam explanar a relação entre a estratégia adotada e a aplicação de métodos da abordagem baseada nos custos foram rejeitadas. De acordo com Ingenbleek e van der Lans (2013), essas rejeições explicavam-se porque todas as empresas, independentemente da estratégia adotada, aplicavam em extensões relativamente altas tais métodos. Entretanto, na realidade, o que os autores possivelmente constataram foi um amplo uso da fórmula "custos mais margem" e não, necessariamente, um amplo embasamento nos custos para estabelecer os preços. 
Além disso, ao analisar os resultados mais detidamente, especialmente aqueles relativos à situação de manutenção ou de alteração da competitividade dos preços (vide Figura 45), observa-se que há, sim, situações em que as informações de custos parecem ser menos enfatizadas: quando não há uma estratégia de preço ou quando a "estratégia" é estabelecer preços compatíveis aos concorrentes.

Figura 45 - Estratégia e informações segundo Ingenbleek e van der Lans (2013)

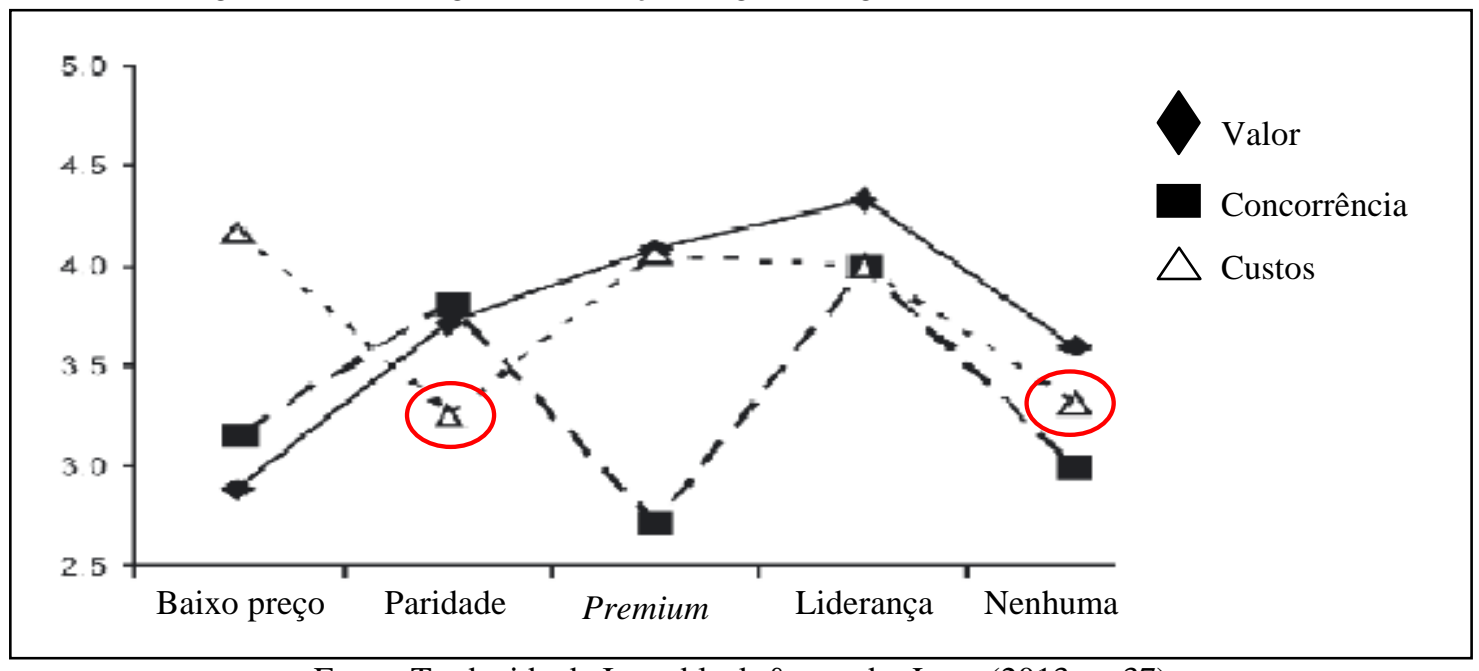

Fonte: Traduzida de Ingenbleek \& van der Lans (2013, p. 37)

Ora, estabelecer preços compatíveis aos concorrentes não é uma opção estratégica, mas, sim, uma necessidade dos tomadores de preços, já que eles não têm outra escolha além de definir o preço corrente no mercado (tanto que a hipótese relacionada à "estratégia" de preços de paridade foi aceita e indicou a expressiva aplicação de métodos da abordagem baseada na concorrência). Da mesma forma, conforme já abordado, as empresas que não têm uma estratégia de preço tendem a ser tomadoras de preços. Ou seja, os pontos mais baixos para o suposto embasamento nos custos foram justamente observados nas empresas que seriam tomadoras de preços.

É também possível observar nos dados empíricos (rever Figura 45) uma tendência que não foi explorada por Ingenbleek e van der Lans (2013). Essa tendência ratifica novamente o impacto que o enquadramento tem: enquanto as empresas que adotavam a "estratégia" de paridade (que são possivelmente as tomadoras de preços) aplicavam consideravelmente métodos da abordagem baseada na concorrência, as empresas que de fato possuíam estratégias de preço, sobretudo de preços premium (que são possivelmente as formadoras de preços) pouco aplicavam os métodos da referida abordagem. 
Destarte, pode-se entender que o estudo de Ingenbleek e van der Lans (2013) é outro em que os resultados foram comprometidos pela ausência de segregação entre tomadores e formadores de preços.

\subsubsection{Estudo de Töytäri et al. (2015)}

Mais recentemente, Töytäri et al. (2015) trouxeram um novo estudo para identificar as barreiras à definição dos preços baseada no valor no contexto específico do ambiente B2B. Para alcançar esse objetivo, eles realizaram um estudo de caso com nove empresas, aparentemente formadoras de preços, já que ofereciam equipamentos diferenciados. A conclusão geral foi que três eram as principais barreiras:

a) a dificuldade de identificar e de influenciar o valor desejado pelo cliente;

b) a dificuldade de mensurar e de comunicar o valor; e

c) a dificuldade de capturar parte do valor criado nas negociações entre empresas.

A dificuldade de identificar e de influenciar o valor desejado pelo cliente do ambiente B2B, de acordo com Töytäri et al. (2015), decorre do usual comportamento dos compradores de guiar as escolhas unicamente pelo preço proposto, sem abrir espaço a ofertas de maior valor, cujo preço é, obviamente, maior. Os compradores são mais acostumados a avaliar inicialmente diferenças de preços, sendo pouco receptivos ao valor. Os autores esclarecem que isso acontece em decorrência de conflitos de interesses nas áreas da empresa compradora, uma vez que os responsáveis pelas compras são avaliados pelo baixo preço e não pelo valor que propiciam.

A dificuldade de mensurar e de comunicar o valor é a mesma reportada por Hinterhuber (2008). Diante dela, a operacionalização do processo é prejudicada. Töytäri et al. (2015) explicaram que acessar os dados necessários à mensuração do valor é um desafio grande em empresas industriais. A comunicação desse valor, da mesma forma, enfrenta a relutância e mesmo um "fingimento de ignorância" dos compradores industriais.

A dificuldade de capturar parte do valor criado é o desafio final, pois não é fácil convencer os clientes que o preço formado com base no valor é justo. A costumeira consideração que o 
preço certo é ancorado nos custos e o risco de todo o potencial de valor não ser de fato aproveitado inibem a captura do valor. Ademais, nem sempre as empresas têm o poder de barganha para conseguir cobrar dos clientes o preço correspondente ao valor.

Destarte, observa-se que o estudo oferece insights para entender o que inibe, em formadores de preços do ambiente B2B, o estabelecimento dos preços baseado no valor. Entretanto, assim como Hinterhuber (2008), Töytäri et al. (2015) detiveram-se a apresentar descritivamente as barreiras para o embasamento no valor, sem empreender análises estatísticas para comprovar se, de fato, havia diferenças em empresas expostas e não expostas a essas barreiras.

\subsubsection{Sumário dos Estudos}

Nesta seção, sintetizam-se na Tabela 39 os resultados encontrados nos estudos anteriores. Tal síntese tem o objetivo de facilitar a incorporação dos fatores nesta tese e em eventuais trabalhos futuros sobre o tema.

Tabela 39 - Sumário dos resultados dos estudos anteriores

\begin{tabular}{|c|c|c|}
\hline ESTUDOS & INVESTIGAÇÃO & FATORES IDENTIFICADOS \\
\hline Ingenbleek et al. (2003) & $\begin{array}{l}\text { Fatores explicativos da efetividade dos três tipos } \\
\text { de informações (custos, valor, concorrência) }\end{array}$ & $\begin{array}{l}\text { - Vantagem relativa do produto } \\
\text { - Intensidade da concorrência } \\
\text { - Vantagem relativa do produto simultânea à intensidade } \\
\text { da concorrência }\end{array}$ \\
\hline Fabiani et al. (2005) & $\begin{array}{l}\text { Fatores explicativos do estabelecimento dos } \\
\text { preços conforme os custos mais margem }\end{array}$ & - Intensidade da concorrência \\
\hline Guilding et al. (2005) & $\begin{array}{l}\text { Fatores explicativos da importância atribuída } \\
\text { aos custos mais margem }\end{array}$ & $\begin{array}{l}\text { - Intensidade da concorrência } \\
\text { - Tamanho da empresa (sugerida substituição pela fatia de } \\
\text { mercado possuída) } \\
\text { - Setor }\end{array}$ \\
\hline Al-Hussari (2006) & $\begin{array}{c}\text { Fatores contextuais/contingenciais explicativos } \\
\text { da importância atribuída aos custos mais } \\
\text { margem }\end{array}$ & $\begin{array}{l}\text { - Fatia de mercado } \\
\text { - Customização } \\
\text { - Influência na determinação dos preços } \\
\text { - Estratégia de diferenciação } \\
\text { - Intensidade da concorrência } \\
\text { - Importância atribuída às informações de custos } \\
\text { - Tamanho da empresa }\end{array}$ \\
\hline Hinterhuber (2008) & $\begin{array}{l}\text { Fatores explicativos do não estabelecimento dos } \\
\text { preços conforme o valor }\end{array}$ & $\begin{array}{l}\text { - Dificuldade de mensurar o valor } \\
\text { - Dificuldade de comunicar o valor } \\
\text { - Dificuldade de segmentar o mercado } \\
\text { - Dificuldade de gerenciar o pessoal de vendas } \\
\text { - Dificuldade de conquistar o apoio da alta gerência }\end{array}$ \\
\hline $\begin{array}{l}\text { Liozu, Hinterhuber, Perelli, } \\
\quad \text { e Boland (2012) }\end{array}$ & $\begin{array}{l}\text { Fatores explicativos da não mudança para o } \\
\text { embasamento no valor }\end{array}$ & $\begin{array}{l}\text { - Custo de implantar métodos de valor (modificar o } \\
\text { "DNA" do estabelecimento dos preços) } \\
\text { - Custo de manter os novos processos }\end{array}$ \\
\hline $\begin{array}{l}\text { Ingenbleek e van der Lans } \\
\text { (2013) }\end{array}$ & $\begin{array}{l}\text { Associação entre as estratégias de preço e a } \\
\text { aplicação de métodos das três abordagens }\end{array}$ & - Estratégia de preço \\
\hline Töytäri et al. (2015) & $\begin{array}{l}\text { Fatores explicativos do não estabelecimento dos } \\
\text { preços conforme o valor no ambiente B2B }\end{array}$ & $\begin{array}{l}\text { - Dificuldade de identificar e de influenciar o valor } \\
\text { desejado pelo cliente } \\
\text { - Dificuldade de mensurar e de comunicar o valor } \\
\text { - Dificuldade de capturar parte do valor criado }\end{array}$ \\
\hline
\end{tabular}


Com esse resumo, é possível observar que, intencional ou ocasionalmente, os pesquisadores do tema não tem por hábito contestar os estudos anteriores e revisitar empiricamente os fatores por eles relacionados. Nota-se que nos trabalhos sobre estabelecimento dos preços os autores preferem levantar novos fatores, ao invés de avaliarem se os fatores já arrolados previamente de fato correspondem à atual realidade. Como a ciência está sempre em devir (Japiassu, 1992; G. Martins \& Theóphilo, 2009), esse comportamento tende a prejudicar a evolução do conhecimento sobre o assunto.

O único fator explicativo investigado recorrentemente é a intensidade da concorrência. Vale, entretanto, ressaltar que a explicação desse fator, apesar de ser recorrente, não é consensualmente abordada na literatura. Por exemplo, enquanto Ingenbleek et al. (2003) e Guilding et al. (2005) indicam que quanto mais intensa é a concorrência mais efetivos/importantes são os métodos baseados em informações de custos, Fabiani et al. (2005) e Al-Hussari (2006), que foi orientado por Drury, sugerem que quanto menos intensa é a concorrência mais os métodos baseados em informações de custos são usados.

Um ponto fraco encontrado nos estudos é o fato de nenhum deles, infortunadamente, segregar apropriadamente as empresas da amostra em tomadoras e formadoras de preços, o que prejudicou a interpretação dos resultados. O problema geral da não segregação foi fazer com que a realidade das formadoras de preços fosse equivocadamente comparada à realidade das tomadoras de preços.

Diante da não segregação, os estudos podem ter mal interpretado a verdadeira causa das diferenças expressivas (enquadramento como tomador e como formador) e ocultado o real impacto dos fatores abordados. Por exemplo, os formadores de preços oferecem produtos diferenciados, enquanto que os tomadores oferecem produtos não diferenciados. Ao não separar as empresas, contrasta-se a ênfase em informações de valor colocada por tomadores àquela colocada por formadores de preços e deixa-se de investigar o que realmente importa: examinar se formadores com produtos mais diferenciados enfatizam mais as informações de custos do que formadores com produtos menos diferenciados.

Outro ponto fraco comum nos estudos objetos de revisão está na conclusão do embasamento nos custos. No geral, o simples fato de usar a fórmula "custos mais margem" foi tomado 
como sinônimo do desprezo de informações de valor. Contudo, como se mostrou na seção 4.2.4, o elemento margem pode refletir o valor e, assim, a essência da fórmula pode não ser, necessariamente, os custos.

Em suma, pode-se afirmar que as conclusões apresentadas nos estudos prévios merecem ser reavaliadas. Primeiramente, é preciso focar os esforços na investigação segregada dos formadores e tomadores de preços. Em segundo lugar, é preciso investigar as situações em que os custos são de fato a essência, excluindo as circunstâncias em que o uso da fórmula "custos mais margem" operacionaliza o embasamento nos preços da concorrência (tomadores) ou no valor (formadores).

\subsection{Fatores Adicionais}

Além de reavaliar as conclusões reportadas nos trabalhos anteriores, vale investigar se há ou não outros fatores, ainda não diretamente investigados, explicativos do estabelecimento dos preços com essência custos. Nesse sentido, esta seção propõe o acréscimo de novos fatores que, ao menos teoricamente, parecem explanar essa situação (a comprovação ou a refutação empírica desses fatores é promovida pelas hipóteses de pesquisa).

Foram selecionados quatro fatores para os quais se encontrou na literatura do tema ao menos um indício sugerindo que sua presença poderia estimular ou afastar a essência custos. Especificamente, as pressões isomórficas foram adicionadas porque elas fazem com que as empresas deixem de adotar práticas que realmente reflitam suas necessidades para adotar práticas bem-aceitas externamente. Ora, a resistência a mudanças nas práticas de preços são citadas em trabalhos como possível explicação para o excessivo embasamento nos custos (e.g., Hinterhuber, 2008; Liozu \& Hinterhuber, 2013).

Já o ambiente de atuação foi incluído em virtude da defesa de Farres (2012) que o direcionamento dos produtos aos consumidores finais ou a outras empresas interfere no estabelecimento dos preços. A experiência, por sua vez, foi adicionada tomando como base os argumentos de que as decisões de preços podem ser por ela influenciadas (e.g., Rusetski, 2014). 
Finalmente, o uso dos custos totais na fórmula "custos mais margem" foi adicionado considerando que as críticas ao uso dos custos no estabelecimento dos preços (e.g., Christensen \& Demski, 1997; Noreen \& Burgstahler, 1997; Balakrishnan \& Sivaramakrishnan, 2002; Hsu, 2006) concentram-se na utilização da completude dos custos.

\subsubsection{Pressões Isomórficas}

O estabelecimento dos preços orientado exclusivamente pelos custos pode ser explicado pela existência de pressões isomórficas, já que tais pressões incitam as empresas a adotar procedimentos similares, ou seja, fazem as empresas ter comportamentos semelhantes, sejam eles ou não os mais adequados. As pressões isomórficas são abordadas dentro do contexto do isomorfismo.

DiMaggio e Powell (1983) citam que o isomorfismo refere-se ao processo que força uma unidade na população a se assemelhar a outras unidades que lidam com as mesmas condições ambientais. Van der Steen (2005), por sua vez, defende que o isomorfismo institucional explica por que as organizações, especificamente, tendem a adotar procedimentos similares. Normalmente, pressões de três tipos diferentes são relacionadas para o isomorfismo: coercitivas, normativas e miméticas (e.g., DiMaggio \& Powell, 1983; van der Steen, 2005).

As pressões coercitivas originam-se de influências políticas e reguladoras, sobretudo de imposições de órgãos reguladores ou governamentais. Já as pressões normativas decorrem da profissionalização e são originadas, principalmente, por normas da sociedade e de entidades que, de alguma forma, interferem nas profissões das organizações. As pressões miméticas, por sua vez, resultam da adoção de respostas padrões para incerteza, mediante cópias de processos utilizados em outras organizações (DiMaggio \& Powell, 1983; Scapens, 2006).

As pressões isomórficas (coercitivas, normativas e miméticas), ao explicarem por que as organizações adotam procedimentos similares, podem ser uma fonte adicional no entendimento de por que uma empresa estabelece seus preços de determinada maneira. Destarte, são relacionadas na sequência as pressões que podem ser potencialmente encontradas na definição dos preços. 


\subsubsection{1 $\quad \underline{\text { Pressões Coercitivas }}$}

O isomorfismo coercitivo resulta de pressões exercidas sobre a organização por entidades das quais ela depende. Essas pressões derivam do exercício de poderes políticos, econômicos e ideológicos sob a forma de coerção e de persuasão (DiMaggio \& Powell, 1983). Rezende (2009) sumariza que as organizações tendem a se assemelhar em decorrência do isomorfismo coercitivo pela força do "medo".

DiMaggio e Powell (1983) revelam que as pressões coercitivas podem ser tanto formais quanto informais. No caso das pressões formais, destacam-se imposições de órgãos reguladores sobre o estabelecimento dos preços. Esse é o caso, por exemplo, das imposições da Agência Nacional de Energia Elétrica (ANEEL) sobre as concessionárias de energia elétrica (Tancini, 2013).

Já no caso de pressões informais, destacam-se as imposições das matrizes sobre as subsidiárias. Granlund e Lukka (1998), ao investigarem as razões para a convergência de certas práticas contábeis, afirmaram que tais imposições esclareciam o porquê das características de inúmeras práticas gerenciais.

Malmi (1999), por exemplo, constatou que as deliberações das matrizes explicavam por que as inovações da Contabilidade Gerencial assemelhavam-se entre as empresas. Guler, Guillén, e Macpherson (2002), como outro exemplo, observaram que as imposições das matrizes esclareciam as similaridades no número de certificados da International Organization for Standardization (ISO) 9000 possuídos pelas organizações. Já Schulz, Schröder, Guerreiro, e Souza (2014) concluíram que as definições das matrizes explicavam a similaridade das organizações no que se referia à complexidade da Contabilidade de Custos.

Nesse sentido, parece razoável supor que a alta direção das matrizes também pode impor condições que designam o estabelecimento dos preços nas subsidiárias. Eventualmente, a alta direção pode exigir um processo marcado pela consideração excessiva dos custos pois, como citado por Hinterhuber (2008), ela normalmente não incentiva o estabelecimento dos preços com base no valor. 


\subsubsection{Pressões Normativas}

O isomorfismo normativo decorre de pressões da profissionalização, sendo ele, de acordo com DiMaggio e Powell (1983), resultado do esforço coletivo que membros de determinadas funções têm para determinar as condições e os métodos de trabalho. Rezende (2009) explica que como as pressões normativas têm uma característica de recomendação (não de imposição), elas não implicam punições objetivas no caso de não serem cumpridas. Logo, a semelhança das organizações delas derivada decorre de "precaução".

DiMaggio e Powell (1983) esclarecem que há duas principais fontes do isomorfismo normativo na profissionalização. A primeira refere-se à educação profissional e a segunda refere-se à consolidação de grupos de profissionais.

No que diz respeito à educação profissional, DiMaggio e Powell (1983) ressaltam que os cursos universitários e os cursos de treinamentos profissionais são importantes desenvolvedores e difusores de normas profissionais. De acordo com Van der Steen (2005), as universidades e os centros de treinamento criam e divulgam padrões normativos semelhantes. Os profissionais normalmente incorporam esses padrões, pois são avaliados mediante a comparação do seu comportamento àquele comportamento padronizado esperado.

Além disso, Granlund e Lukka (1998) relatam que as diferentes instituições de ensino, embora apresentem certas particularidades, usualmente compartilham e difundem conceitos similares, ao passo que normalmente aplicam os mesmos livros-texto e usam os mesmos materiais (e.g., aplicam os mesmos estudos de caso).

A consolidação de grupos profissionais, de acordo com DiMaggio e Powell (1983), também culmina em pressões normativas, pois promove o contato e o compartilhamento de ideias entre indivíduos que ocupam posições similares em distintas organizações. Granlund e Lukka (1998) acrescentam que o contato promovido nos grupos profissionais, tais como conselhos de classe (e.g., Conselho Regional de Contabilidade para contadores, Conselho Regional de Medicina para médicos, Ordem dos Advogados do Brasil para advogados etc.), colabora com a difusão das tendências e das práticas profissionais. 
No contexto do estabelecimento dos preços, destacam-se as similaridades nos cursos que se debruçam à exposição do tema (S. Maxwell, 1998). Nesse sentido, é plausível assumir que a educação profissional exerce pressões normativas, ao passo que os cursos sugerem como os preços devem ser definidos. Como não raramente as sugestões incluem a fórmula "custos mais margem", os profissionais podem ser tentados a tomar decisões exclusivamente nela embasados.

Já as pressões de grupos profissionais não tendem a ser intensas no Brasil, uma vez que associações de profissionais de preços não são tão difundidas como em outros pontos do mundo. Nos Estados Unidos, por exemplo, há até a Sociedade de Profissionais de Preços (Professional Pricing Society - PPS), conforme citado por Carricano, Trinquecoste, e Mondejar (2010).

\subsubsection{3 $\quad$ Pressões Miméticas}

O isomorfismo mimético decorre da incerteza, uma vez que ela fomenta a imitação e incentiva as organizações a tomarem outras entidades como modelo (DiMaggio \& Powell, 1983). Rezende (2009) entende que as práticas implantadas por força do isomorfismo mimético são percebidas como vantajosas por pouparem esforços (implicam mera cópia das práticas e modelos implantados por outras entidades). Logo, o autor resume que a semelhança das organizações decorrente das pressões miméticas origina-se da "dúvida". Ora, na dúvida de que prática adotar, as organizações optam por copiar as outras entidades, sobretudo aquelas de sucesso e com boa reputação (Granlund \& Lukka, 1998).

DiMaggio e Powell (1983) esclarecem que a elaboração e a aplicação de modelos são respostas à incerteza que originam pressões miméticas. De acordo com os autores, os modelos podem ser rapidamente difundidos, tanto de modo explícito, mediante a aplicação de orientações pré-formatadas, quanto de modo indireto, mediante a cópia informal de empresas de sucesso.

No que se refere à aplicação de orientações pré-formatadas, Granlund e Lukka (1998) explicam que é usual os consultores oferecerem "soluções" gerais para as questões e para os problemas gerenciais mais comuns. Para questões e problemas habituais, os consultores 
geralmente não oferecem orientações específicas que se refiram à realidade da empresa, pois entregam um pacote padronizado de soluções.

Assim, pode acontecer de a formatação proposta pela consultoria para o estabelecimento dos preços ser uma mera cópia do formato a que ela está acostumada, ainda que esse formato não seja o mais adequado. Pode também acontecer de a proposta da consultoria priorizar eventuais acordos existentes entre ela e fabricantes de softwares. Afinal, de acordo com Davidson e Simonetto (2005), não são raras as circunstâncias em que os fabricantes de softwares combinam compartilhamento de receitas com consultorias que fazem os clientes adquirirem seus sistemas.

Ao adquirirem sistemas pré-formatados (sugeridos pela consultoria), as empresas expõem-se fortemente a pressões isomórficas miméticas, pois os sistemas já definem a forma de elaboração e de análise da informação (Brandau, Endenich, Trapp, \& Hoffjan, 2013). A facilidade de lidar com informações de custos e de incorporá-las nos sistemas tende, portanto, a estimular o embasamento nos custos. Waller, Shapiro, e Sevcik (1999) argumentam que essa facilidade emana da atuação com informações que já estão disponíveis, previamente elaboradas para outras finalidades.

Finalmente, no que se refere à difusão indireta (não explícita) dos modelos, DiMaggio e Powell (1983) argumentam que a rotatividade dos empregados favorece a cópia das práticas. A transferência dos empregados permite que práticas aplicadas em ocupações anteriores sejam importadas, ainda que elas não sejam as mais adequadas. Nesse sentido, pode-se formar um ciclo vicioso que impulsiona a essência custos em distintas empresas. Além disso, a consideração de que a definição dos preços amparada nos custos é a que conduz a preços mais justos e não é antiética (Indounas, 2008) pode incentivar ainda mais o empregado a difundi-la.

\subsubsection{Síntese das Pressões Isomórficas}

Esta seção resume os três blocos anteriores e ilustra (Figura 46) de que forma as pressões isomórficas podem explicar o estabelecimento dos preços. 
Figura 46 - Pressões isomórficas no estabelecimento dos preços

\begin{tabular}{|c|c|c|}
\hline & Pressões Isomórficas & \\
\hline $\begin{array}{l}\text { Pressões Coercitivas } \\
\text { (Medo) } \\
\text { - Imposições de } \\
\text { reguladores; } \\
\text { - Imposições da matriz às } \\
\text { subsidiárias. }\end{array}$ & $\begin{array}{l}\text { Pressões Normativas } \\
\text { (Precaução) } \\
\text { - Orientações decorrentes } \\
\text { da educação profissional; } \\
\text { - Orientações de grupos } \\
\text { profissionais. }\end{array}$ & $\begin{array}{l}\text { Pressões Miméticas } \\
\text { (Dúvida) } \\
\text { - Aplicação de } \\
\text { orientações pré- } \\
\text { formatadas; } \\
\text { - Imitação das outras } \\
\text { organizações. }\end{array}$ \\
\hline
\end{tabular}

Fonte: Elaboração própria

Vale mencionar que a existência de qualquer uma dessas pressões isomórficas pode fazer a essência custos não só se colocar, mas também se perpetuar ao longo do tempo. Isso porque, de acordo com Urbany (2001), uma tendência dominante em muitos contextos (especialmente no estabelecimento dos preços) é o viés do status quo: os tomadores de decisão têm uma forte preferência de manter os estados das suas atuais decisões e de optar pela inércia.

\subsubsection{Ambiente de Atuação}

A essência custos do estabelecimento dos preços também pode estar relacionada ao ambiente de atuação das empresas, já que, de acordo com Farres (2012), as deliberações variam consideravelmente nos diferentes ambientes.

Tradicionalmente, o ambiente de atuação vem sendo separado em dois grandes grupos: ambiente business-to-business (B2B) e ambiente business-to-consumer (B2C) (Wilson, 2000; Ford, Gadde, Hakansson, \& Snehota, 2003; Cova \& Salle, 2008; Kuusela, Närvänen, Saarijärvi, \& Yrjölä, 2014). No ambiente B2B, as empresas ofertam seus produtos a outras empresas (daí o nome do ambiente "de empresa para empresa"), enquanto que no ambiente B2C, as empresas ofertam seus produtos aos consumidores finais (daí o nome do ambiente “de empresa para consumidor").

O problema dessa classificação tradicional é que as empresas que vendem produtos tipicamente de consumo por intermédio de outras empresas são consideradas como atuantes no B2B. Gummesson (2014) cita o exemplo de indústrias de alimentos. Tais indústrias são consideradas do B2B porque, apesar de terem produtos destinados aos consumidores finais, 
usualmente vendem para atacadistas e para varejistas (e esses revendem os produtos aos consumidores finais). Cravens e Glover (1995), por sua vez, citam o exemplo das indústrias farmacêuticas, que dificilmente vendem produtos de forma direta para os consumidores finais, no entanto, têm grande parte da produção a eles destinada.

Logo, uma classificação alternativa menos restrita pode ser encontrada se a destinação final do produto tomar o lugar da consideração do tipo de empresa com que a negociação direta é realizada, como mostra a Figura 47.

Figura 47 - Ambientes de atuação

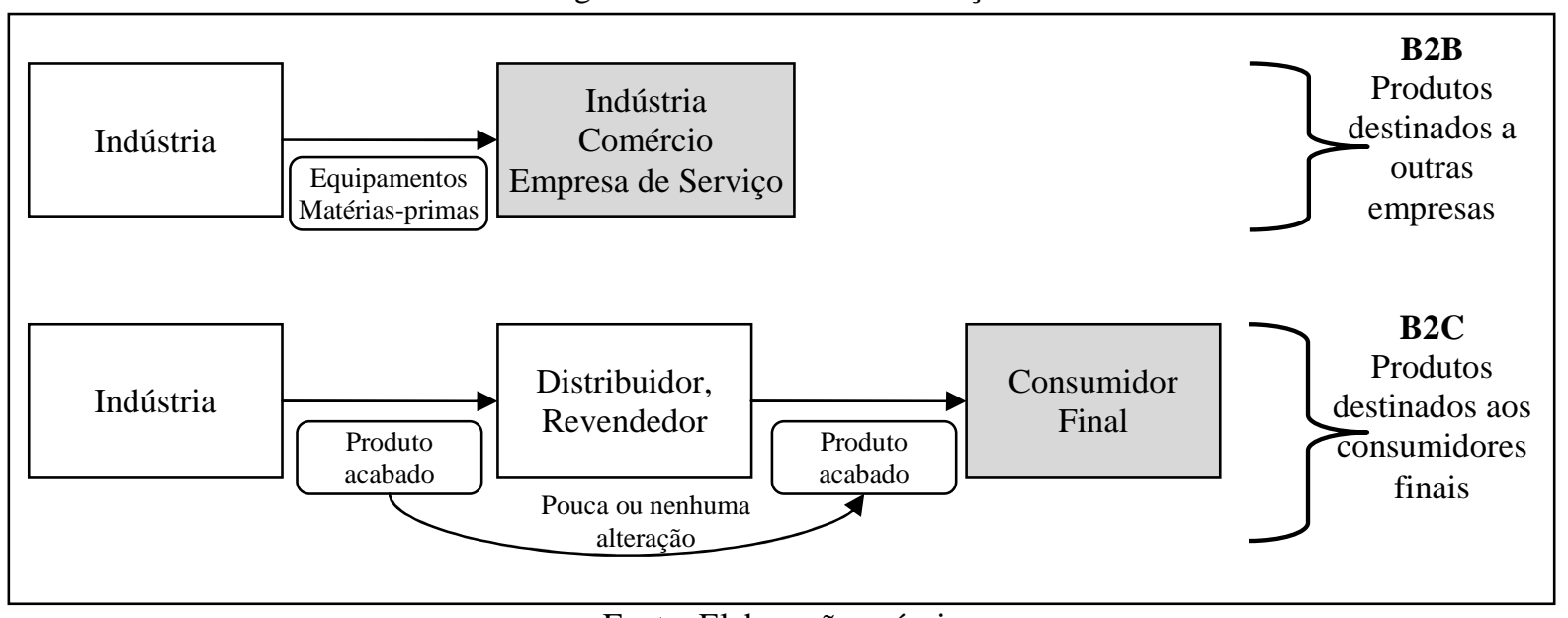

Fonte: Elaboração própria

Farres (2012) argumenta que as decisões de compra tendem a ser objetivas e baseadas em fatos quando os produtos são destinados a outras empresas, mas tendem a ser subjetivas quando os produtos são destinados aos consumidores finais. Por essa razão, as especificações particulares do produto, ainda que sejam a prioridade na definição dos preços de empresas do primeiro ambiente, não são necessariamente a prioridade de empresas do segundo ambiente. Conforme Barback (1979) e Laric (1980) há tempos frisam, os compradores corporativos normalmente são mais especialistas e fazem análises mais sofisticadas do que os compradores consumidores.

Nesse sentido, a avaliação do valor específico oferecido pelos produtos pode ser mais relevante nas empresas que lidam com outras organizações do que nas empresas que lidam com os consumidores finais. Afinal, nas últimas empresas, a marca usualmente sobrepõe-se a 
outros aspectos e, com o apoio de propagandas, pode ser incorporada de forma uniforme entre os produtos (Farres, 2012).

\subsubsection{Experiência no Estabelecimento dos Preços}

O estabelecimento dos preços embasado nos custos pode também resultar da falta de experiência dos profissionais responsáveis pelo processo. Ora, a experiência influencia o modo que os tomadores de decisão percebem os problemas e define a base comparativa acessada nas deliberações.

Como Van Bruggen et al. (2001) explicam, as pessoas tomam decisões com base em hipóteses sobre como "o mundo funciona", sendo que evidências coletadas ao longo da sua experiência afetam o modo de testá-las e de revisá-las. As empresas, sendo formadas por pessoas, acabam sendo afetadas pela experiência constituída nas suas áreas.

De acordo com Van Bruggen et al. (2001), a experiência tende a ampliar o escopo do problema percebido pelos tomadores de decisão. A forma que um problema é percebido depende mais do contexto funcional dos tomadores de decisão do que da própria característica do problema.

Os autores citam que estudos anteriores constataram, por exemplo, que o mesmo problema empresarial era percebido como um problema de marketing por profissionais de marketing, como um problema financeiro por profissionais financeiros e como um problema logístico por profissionais logísticos. Com experiência, o contexto funcional dos tomadores de decisão é ampliado (deixa de ser restrito à sua formação), o que permite uma percepção do problema menos limitada e mais holística.

Ademais, a experiência tende a aprimorar a base comparativa usada pelos tomadores de decisões. Van Bruggen et al. (2001) esclarecem que as similaridades existentes entre os objetos de decisão e as situações previamente vividas são analisadas nas deliberações numa espécie de "ancoragem". Hoch e Schkade (1996) observaram, por exemplo, que, ao elaborarem previsões, os tomadores de decisões fazem pequenos ajustes a situações similares 
vivenciadas que estão em sua memória. Quanto mais experiência eles têm, mais situações similares eles guardam na memória e mais possibilidades de solução eles possuem.

Vale mencionar que a teoria dos altos escalões também reconhece o papel da experiência nas deliberações. Hambrick (2007) argumenta que a personalidade, os valores e as experiências dos executivos influenciam fortemente as interpretações e, consequentemente, afetam as escolhas.

Nesse sentido, quanto mais experiência um profissional tiver no estabelecimento dos preços, mais aprimoradas tendem a ser suas deliberações. Carson et al. (1998) exemplificam que não é raro encontrar empresas, especialmente de pequeno porte, que melhoram sua habilidade na definição dos preços com a experiência adquirida ao longo dos anos. O processo de tentativas e erros, por mais intuitivo que seja, acaba refinando a prática e orientando as informações que devem ser consideradas.

Diante desse contexto, Cavusgil (1988) e Solberg et al. (2006) argumentam que enquanto os profissionais mais experientes tendem tipicamente a ir além dos custos e a estabelecer os preços de uma maneira sofisticada, os profissionais menos experientes tentam limitar o risco financeiro e estabelecem os preços em função exclusiva dos custos. Isso acontece porque a tarefa de incorporar o valor nos preços, assegurando a cobertura de custos e a obtenção de lucro, não é trivial. Iyer, Xiao, Sharma, e Nicholson (2015) também frisam que a experiência no estabelecimento dos preços faz com que os profissionais refinem suas deliberações e tornem-se capazes de adotar modelos mais complexos.

\subsubsection{Custos Totais na Fórmula “Custos mais Margem”}

As características da fórmula "custos mais margem" podem também explicar a aderência aos custos no estabelecimento dos preços. Nesse sentido vale ressaltar que Indounas (2006) é forte defensor do uso dos custos variáveis, pois, segundo o autor, com eles a fórmula torna-se simplesmente uma mecânica matemática que permite simultaneamente incorporar informações de custos, da concorrência e, sobretudo, do valor. 
Ora, quando os custos totais são considerados, há a inclusão de elementos fixos que, além de não serem derivados dos produtos em análise, deixam as empresas com uma faixa restrita para a variação da margem. Tornam-se praticamente nulas as possibilidades de alterar as margens sobre um patamar expressivo como os custos totais (e.g., uma variação de 5\% numa base de custos totais de $\mathrm{R} \$ 100.000$ é muito mais material do que uma variação de $5 \%$ numa base de custos variáveis de $\mathrm{R} \$ 40.000)$.

Quando somente os custos variáveis são considerados, amplia-se a faixa que a margem pode variar. A margem deixa de ser colocada sobre os custos totais e, assim, mostra o quanto a venda de cada unidade de produto de fato contribui com a cobertura dos custos (despesas e custos fixos) e com a geração de lucro (Indounas, 2006). Por incidir numa base menor (custos variáveis), aumenta-se a possibilidade de adequar a margem aos produtos e aos clientes. A maior possibilidade de variação favorece a determinação de preços de acordo com a política de negócios e viabiliza a conexão dos custos ao valor, afinal, como Cunningham e Hornby (1993) mostram, a margem colocada sobre os custos é capaz de incorporar considerações acerca dos clientes.

Vale mencionar que não são poucas as defesas em prol dos custos variáveis e contra os custos totais para o estabelecimento dos preços. Sizer (1966) relata o problema de os custos fixos terem que ser alocados com base em um volume de vendas que pode variar dependendo do preço colocado. Christensen e Demski (1997) argumentam que é inadequado considerar custos totais para qualquer tomada de decisões no nível de produtos individuais.

Noreen e Burgstahler (1997), de forma mais específica, demonstram que a determinação de preços com base nos custos totais em empresas multiprodutoras coloca uma restrição no relacionamento entre os preços dos produtos. Essa restrição pode impedir a empresa de atingir lucros satisfatórios, mesmo quando seria possível alcançá-los, e pode originar perdas econômicas (Balakrishnan \& Sivaramakrishnan, 2002).

Balakrishnan e Sivaramakrishnan (2002) são contrários à alocação dos custos fixos para qualquer deliberação, incluindo o estabelecimento dos preços. Suas principais críticas fundamentam-se no fato que os custos fixos são decorrentes de escolhas passadas e, portanto, já são custos irrecuperáveis (também chamados de custos afundados - sunk costs). Como os 
custos irrecuperáveis são irrelevantes para a tomada de decisões, alocá-los não melhora a qualidade das deliberações.

Nesse sentido, pode-se arguir que quando as empresas definem os preços a partir dos custos variáveis elas distanciam a essência do processo dos custos. Agora, quando os preços são determinados a partir dos custos totais, a essência do processo tende a estar nos custos.

\subsection{Em Resumo}

As ausências de consenso observadas (e.g., conclusões diferentes sobre o impacto da intensidade da concorrência) na revisão dos trabalhos prévios demonstraram um problema grave na construção do conhecimento sobre o tema: não consideração do saber existente. Ora, como Japiassu (1992) adverte, o conhecimento é um processo e não um estado. Sendo um processo, o conhecimento apresenta-se em devir e, para evoluir, passa constantemente de estágios menores para estágios maiores.

Quando o saber prévio não é considerado, a evolução de estágios menores para estágios maiores é inibida. Os estudos "sem passado" dedicam-se a construir, a partir de um patamar zero, um conhecimento que já existe, ao invés de acrescentarem dimensões (que ainda não existem) na literatura.

É isso o que está acontecendo com os estudos que buscaram identificar, de alguma forma, os fatores explicativos do processo de estabelecimento dos preços. Tais estudos têm ignorado os resultados já observados em pesquisas anteriores e sugerido novas explicações que julgam pertinentes. Com isso, chega-se a uma série de fatores esparsos (e algumas vezes inconsistentes), sem se saber, de fato, como tal série comporta-se em conjunto.

Diante do exposto, busca-se nesta tese corrigir esse problema, organizando e consolidando os fatores (fatores previamente identificados e fatores adicionais) em uma estrutura única. Essa organização e essa consolidação (vide Tabela 40) colaboram com a evolução do conhecimento do assunto, ao passo que acrescentam na literatura a exposição conjunta de variadas perspectivas. 
Tabela 40 - Relação de fatores

\begin{tabular}{|c|c|}
\hline FATORES & $\begin{array}{c}\text { ESTUDOS QUE ABORDARAM OS FATORES } \\
\end{array}$ \\
\hline Diferenciação & $\begin{array}{c}\text { Ingenbleek et al. (2003) (correlata à vantagem relativa do produto); Al- } \\
\text { Hussari (2006) (correlata à customização) }\end{array}$ \\
\hline Tamanho da Empresa & Guilding et al. (2005); Al-Hussari (2006) \\
\hline $\begin{array}{l}\text { Posição da Empresa no } \\
\text { Mercado }\end{array}$ & $\begin{array}{l}\text { Sugestão de Guilding et al. (2005) em substituição ao tamanho; Al-Hussari } \\
\text { (2006) (mediante avaliação da fatia de mercado e da influência na } \\
\text { determinação dos preços) }\end{array}$ \\
\hline Estratégia de Preço & $\begin{array}{c}\text { Ingenbleek e van der Lans (2013); Al-Hussari (2006) (especificamente a } \\
\text { estratégia de diferenciação) }\end{array}$ \\
\hline Intensidade da Concorrência & $\begin{array}{l}\text { Ingenbleek et al. (2003); Fabiani et al. (2005); Guilding et al. (2005); Al- } \\
\text { Hussari (2006) }\end{array}$ \\
\hline Dificuldades de Definir & $\begin{array}{l}\text { Al-Hussari (2006) (considerando que a importância atribuída às informações } \\
\text { de custos pode desestimular o uso de outros tipos de informações); }\end{array}$ \\
\hline Preços conforme o Valor & $\begin{array}{l}\text { Hinterhuber (2008); Liozu, Hinterhuber, Perelli, \& Boland (2012); Töytäri et } \\
\text { al. (2015) }\end{array}$ \\
\hline Pressões Isomórficas & Original desta tese \\
\hline Ambiente de Atuação & Original desta tese \\
\hline $\begin{array}{c}\text { Experiência no } \\
\text { Estabelecimento dos Preços }\end{array}$ & Original desta tese \\
\hline $\begin{array}{l}\text { Custos Totais na Fórmula } \\
\text { "Custos mais Margem" }\end{array}$ & Original desta tese \\
\hline
\end{tabular}




\section{MÉTODOS DA PESQUISA}

O conhecimento científico distingue-se do conhecimento vulgar em um fundamental aspecto: ele segue aplicações de métodos. Sem os métodos científicos, os seres humanos não teriam condições de comprovar novas descobertas e tampouco teriam poder de ação e controle sobre fatos e objetos. Ou seja, sem os métodos científicos, os seres humanos não teriam condições de desenvolver a ciência (G. Martins \& Theóphilo, 2009).

Para G. Martins e Theóphilo (2009), o método científico refere-se à maneira de construir boa ciência, nada mais nada menos. Os métodos científicos não oferecem um conjunto de regras exaustivas e infalíveis para realizar as investigações, já que tais tipos de receitas não existem, mas orientam o caminho a ser percorrido para chegar a um fim ou objetivo científico.

Nesse sentido, a demonstração do caminho percorrido no desenvolvimento desta tese é a meta deste capítulo. Destaques são trazidos ao perfil do participante, à população e à amostra da pesquisa; à coleta de dados; à elaboração das definições constitutivas e dos constructos; à formulação das hipóteses; às técnicas de análises dos dados; e à operacionalização da pesquisa.

\subsection{Perfil do Participante}

A decisão do perfil desejado para os participantes desta pesquisa subsidiou-se na análise das potenciais condições de oferecimento de informações relevantes e fidedignas sobre o estabelecimento dos preços.

Abratt e Pitt (1985) identificaram que, tradicionalmente, os profissionais responsáveis pela determinação dos preços vêm dos departamentos de vendas e de marketing. Depois, aparecem os diretores gerais da empresa, seguidos de profissionais dos departamentos financeiros e de produção, respectivamente. Mais recentemente, Carricano et al. (2010) citaram que grande parte das empresas já possui gestores de preços (pricing managers), cuja responsabilidade é estabelecer os preços oficiais. Segundo os autores, a profissão de gestor de preços existe nos Estados Unidos pelo menos desde os anos 1990. Ela está normalmente vinculada ao 
departamento de marketing, mas também pode ter vínculos com a direção geral, com o departamento financeiro e com o departamento de vendas.

Como não há estudos que mostram se a profissão de gestor de preços já está difundida no Brasil, optou-se nesta tese por definir, empresa a empresa, se o participante da pesquisa seria esse profissional ou, alternativamente, algum profissional do departamento de vendas, do departamento de marketing, do departamento financeiro, do departamento de produção ou o diretor geral. Especificamente, decidiu-se que os participantes seriam os profissionais com a melhor condição de oferecer informações relevantes e confiáveis sobre o tema estudado, independentemente da sua área de atuação na empresa.

Ingenbleek et al. (2003) adotaram estratégia semelhante ao deixarem em aberto a definição dos profissionais que participariam do seu estudo. Embora os autores tenham remetido o instrumento de pesquisa aos gestores de marketing, eles pediram que o mesmo fosse internamente direcionado ao profissional responsável pela determinação dos preços (caso eles não fossem esse profissional). Avlonitis e Indounas também optaram por não definir de antemão os profissionais que participariam da pesquisa nas duas coletas de dados que fizeram ( $1^{\text {a }}$ série de estudos: Avlonitis \& Indounas, 2004, 2005a, 2005b, 2006a, 2006b, 2007a, 2007b; Avlonitis et al., 2005; Indounas \& Avlonitis, 2009; $2^{\mathrm{a}}$ série de estudos: Indounas, 2008, 2009; Indounas \& Avlonitis, 2011).

\subsection{População e Amostra da Pesquisa}

Considerando o problema e os objetivos desta tese, entende-se que todos aqueles que atuam com o estabelecimento dos preços nas empresas industriais no Brasil são os potenciais informantes para este estudo. Cumpre rememorar que o setor industrial foi selecionado para esta pesquisa por três motivos:

a) é o setor com mais condições de apresentar empresas ofertando produtos diferenciados e, portanto, de possuir tanto formadores quanto tomadores de preços;

b) é o setor que apresenta a maior e mais complexa gama de possibilidades para a fórmula "custos mais margem", já que tanto os custos variáveis quanto os custos fixos tendem a ser expressivos; e 
c) é o setor no qual os gestores mais vêem o estabelecimento dos preços como uma "dor de cabeça" em decorrência das bastantes complexas implicações das decisões.

Questionar os responsáveis pela determinação dos preços de todas as empresas industriais no Brasil não seria uma tarefa viável. Afinal, o número total de estabelecimentos industriais que deveriam ser contatados (considerando apenas subsetores de indústria de transformação, agropecuária, construção civil e indústria extrativa) excederia 900.000. Esse número foi constatado mediante cálculo a partir de dados divulgados pela Federação das Indústrias do Estado de São Paulo (FIESP, 2016) referentes à Relação Anual de Informações Sociais (RAIS) do Ministério do Trabalho e Emprego (MTE) de 2014.

Destarte, optou-se nesta pesquisa, assim como ocorre na maior parte das investigações científicas, por delimitar o universo de estudo e atuar com grupos restritos que poderiam ser, de fato, acessados. Os grupos restritos que podem ser acessados compõem a população de um estudo.

G. Martins e Theóphilo (2009) esclarecem que a população refere-se ao conjunto de indivíduos ou objetos que apresentam determinadas características comuns para o estudo. Nesta pesquisa, definiu-se que essa população deveria ser formada por profissionais de empresas industriais de renome localizadas no Brasil, pois espera-se que nessas empresas as decisões (incluindo as de preços) sejam estruturadas.

Para identificar quais são as empresas industriais de renome no Brasil, optou-se por consultar dois bancos de dados: da revista Exame Melhores e Maiores, que anualmente relaciona as melhores e maiores empresas brasileiras (não financeiras) de acordo com análises das demonstrações contábeis e de diversos indicadores; e da revista NEI, que anualmente publica a edição especial Top Five e relaciona os cinco fornecedores industriais de diferentes categorias preferidos pelos leitores da revista (inclusive de pequeno e médio porte). As edições das publicações consideradas foram as dos anos 2014 e 2015.

Cumpre esclarecer que a revista Exame Melhores e Maiores relaciona não só as maiores empresas industriais, mas também as maiores empresas comerciais e de serviço. Contudo, como o setor investigado nesta pesquisa é o industrial, somente as maiores empresas de ramos 
industriais fazem parte da população. A revista Exame também considera que o setor de energia faz parte do setor industrial, entretanto, nesta tese, optou-se por excluí-lo pelo fato de ele estar exposto a uma determinação de preços fortemente normatizada pela ANEEL e, em certas ocasiões, mais prestar serviços do que produzir um bem.

A revista NEI também não relaciona apenas empresas industriais, uma vez que, além de fabricantes, ela arrola distribuidores, representantes e prestadores de serviços. Nesta tese, como o setor investigado é o industrial, restringiu-se a população aos fabricantes.

Na sequência, são apresentados detalhes sobre a composição da população a partir dessas duas fontes de informações. Iniciando o trabalho com o banco de dados da revista Exame Melhores e Maiores, constatou-se que o total de empresas industriais constantes nas edições de 2014 e/ou 2015 era 903. Notou-se que, dentre essas 903 empresas, várias faziam partes de grupos e compartilhavam com outras companhias os mesmos telefones e os mesmos responsáveis, ainda que tivessem razões sociais e Cadastros Nacionais das Pessoas Jurídicas (CNPJ) distintos.

Optou-se, portanto, pela identificação dos grupos existentes (a partir de comparações das razões sociais, dos sites, dos emails, dos telefones de contato e até mesmo de informações obtidas durante as ligações telefônicas) para evitar o acionamento duplicado dos mesmos profissionais. Apurou-se que 269 empresas faziam parte de 99 grupos, o que culminou na eliminação de 170 acionamentos individuais (269-99) e revelou que, na realidade, 733 empresas (903 - 170) oriundas da revista Exame Melhores e Maiores deveriam fazer parte da população do estudo.

Em seguida, trabalhou-se com os dados coletados da revista NEI. Tal revista divulga para diversas categorias de produtos as cinco empresas preferidas pelos leitores. Em alguns casos (quando não há uma citação mínima de sete preferências), a quantidade pode ser inferior a cinco. Na edição de 2014 foi identificada a exposição de um total de 2.074 empresas preferidas distribuídas ao longo de 438 categorias (embora a revista cite 437 categorias), enquanto que na edição de 2015 foi identificada a exposição de um total de 1.967 empresas preferidas distribuídas ao longo de 418 categorias. 
Do total geral de 4.041 (2.074 + 1.967), foram eliminadas empresas que não eram fabricantes e foi anulado o efeito de replicação de empresas preferidas em mais de uma categoria, citadas em ambos os anos e/ou participantes de grupos empresariais (identificação de grupos a partir de comparações dos nomes, dos sites, dos emails, dos telefones de contato e até mesmo de informações obtidas durante as ligações telefônicas). Assim, foram identificadas as 936 outras empresas a serem contatadas.

Finalmente, cruzaram-se os dois bancos de dados para verificar se havia empresas que apareciam em ambos. Notou-se que, sim, 53 empresas apareciam tanto na revista Exame Melhores e Maiores quanto na revista NEI. A consideração duplicada dessas empresas foi eliminada e, desse modo, identificou-se as 1.616 empresas componentes da população da pesquisa, conforme resumido na Tabela 41.

Tabela 41 - População da pesquisa

\begin{tabular}{c|c}
\hline BANCO DE DADOS & NúMERO TOTAL DE EMPRESAS \\
\hline Exame Melhores e Maiores (apenas) & 680 \\
\hline NEI (apenas) & 883 \\
\hline Exame Melhores e Maiores e NEI & 53 \\
\hline ToTAL & $\mathbf{1 . 6 1 6}$ \\
\hline
\end{tabular}

Vale mencionar que, na eliminação da duplicidade de registros (Exame Melhores e Maiores; NEI), tomou-se o cuidado de manter os dados de contatos das duas bases. Preservaram-se tanto os telefones e endereços eletrônicos cadastrados na Revista Exame Melhores e Maiores quanto aqueles cadastrados na revista NEI.

Cumpre revelar também que os dados de contato foram incrementados, utilizando os telefones e endereços eletrônicos disponíveis em bancos de trabalhos conduzidos por esta pesquisadora. Infortunadamente, nem todas as empresas já haviam sido consultadas previamente, mas ainda assim conseguiu-se adicionar telefones e/ou endereços eletrônicos de 281 dentre as 1.616 empresas.

A população da pesquisa foi acessada mediante uma amostra, que nada mais é do que um subconjunto da população. G. Martins e Theóphilo (2009) explicam que, geralmente, as pesquisas são viabilizadas por meio de amostras, pois nem sempre é possível obter as informações de todos os elementos da população. Limitações de tempo, de custo e as 
vantagens do uso das técnicas estatísticas de inferência justificam as amostragens. Entretanto, claro deve estar que, como a representatividade da amostra depende do seu tamanho e de outras considerações metodológicas, é imprescindível acercar-se de cuidados para assegurar a melhor representação possível de toda a população.

A amostra utilizada nesta tese classifica-se como não probabilística já que sua obtenção ocorreu de forma não aleatória. As probabilidades de cada elemento da população fazer parte da pesquisa acabaram não sendo iguais (Fávero, Belfiore, Chan, \& Silva, 2009) porque a amostra foi composta pelas empresas que espontaneamente aceitavam participar do estudo.

Vale destacar que Castro (1977) argumenta que a não aleatoriedade não é necessariamente uma restrição à pesquisa e que amostras desse tipo podem fornecer informações extremamente importantes e úteis. Segundo o autor, a amostra aleatória não é de todo importante quando o que se busca é identificar relação entre variáveis.

Nesta tese, a amostra foi formada por profissionais de 380 empresas que responderam o instrumento de pesquisa. Ao todo, recebeu-se 395 questionários preenchidos, no entanto 15 tiveram que ser eliminados pelos seguintes motivos:

a) 4 eliminações ocorreram porque não se teve segurança sobre os dados respondidos (respondentes não revelaram nome, email e nome da empresa);

b) 1 eliminação aconteceu porque se percebeu que o respondente não foi sincero e simplesmente assinalou a resposta intermediária $3 \mathrm{em}$ todas as 49 assertivas que faziam uso da escala Likert. Não se entende o motivo pelo qual o respondente teve esse comportamento, já que a participação era voluntária e seria preferível assumir a não disposição em responder a fazer parte da pesquisa preenchendo dados inverídicos;

c) 1 eliminação sucedeu porque a pessoa contatada, ao invés de repassar o questionário ao potencial respondente (conforme tinha sido combinado na ligação), optou por preenchê-lo isoladamente sem ser o perfil esperado na pesquisa (era a recepcionista);

d) 4 eliminações ocorreram porque o respondente deixou de preencher, pelo menos, 95\% do questionário; 
e) 3 eliminações aconteceram porque se obteve mais de uma resposta do mesmo grupo empresarial; e

f) 2 eliminações sucederam porque procederam de empresas que não faziam parte da população da pesquisa (os respondentes tomaram conhecimento da realização da pesquisa e dispuseram-se, gentilmente, a participar).

Para apurar a taxa de resposta a que correspondem os 380 questionários recebidos, deve-se primeiramente extinguir da população as empresas que recusaram formalmente a participação na pesquisa, bem como as empresas que estão fora do escopo da pesquisa, que foram encerradas e que, em março de 2016, estavam na lista de investigados pela Operação Lava Jato. Cumpre mencionar que a Operação Lava Jato refere-se à operação deflagrada pela Polícia Federal no dia 17 de março de 2014 para investigar a prática de crimes financeiros e o desvio de recursos públicos (Polícia Federal, 2017).

Ao todo, 183 empresas se manifestaram formalmente (por email ou por telefone) contrárias à participação na pesquisa. As principais alegações apresentadas para a recusa foram: a falta de autorização e/ou restrições da área de compliance (34\%); consideração de que a empresa não teria o perfil desejado para a pesquisa (por ser uma típica tomadora de preços, por ser pequena etc.) (18\%); falta de interesse (13\%); posicionamento de não participar em pesquisas acadêmicas (11\%); falta de tempo (8\%); entendimento que as decisões de preços são tomadas pela matriz (6\%); posicionamento de não fornecer informações tais como as solicitadas na pesquisa (5\%); falta de conhecimento do processo e ausência de disposição a ajudar a encontrar o profissional que dispusesse desse conhecimento (4\%); e falecimento do proprietário no decorrer da pesquisa $(1 \%)$.

Ao longo da pesquisa, com informações obtidas nas ligações telefônicas, nos emails retornados e/ou em consultas aos sites, detectou-se que 44 empresas deveriam ser eliminadas porque, em verdade, não correspondiam ao ramo industrial. Essas empresas não faziam parte do escopo do estudo uma vez que eram comerciais, distribuidoras e/ou prestadoras de serviço.

Também mediante informações obtidas nas ligações telefônicas, nos emails retornados e/ou em consultas aos sites, constatou-se que 9 empresas haviam sido encerradas ou estavam com atividades suspensas porque tinham entrado em recuperação judicial. 
Optou-se ainda por remover do escopo do estudo empresas que estivessem publicamente investigadas pela Operação Lava Jato. Essas empresas foram identificadas em listas divulgadas pela imprensa, tal como por Mendonça (2014). Dentre as 24 empresas relacionadas nessas listas, sendo 23 fornecedoras mais a Petrobrás, 19 constavam na população da pesquisa e foram eliminadas. Essa decisão foi tomada por dois motivos. Primeiramente, percebeu-se a não viabilidade de acesso (essas empresas, no geral, dificultavam a transferência de ligações telefônicas). Em segundo lugar, julgou-se preferível não incluir no estudo empresas suspeitas de terem seus processos, o que inclui a precificação, permeados à corrupção.

Por fim, há que se deduzir aquelas empresas que fazem parte da população da pesquisa, responderam o questionário, mas tiveram as respostas eliminadas. Esse total corresponde a 6 (1 eliminação pela não sinceridade; 1 eliminação pelo respondente não ter o perfil desejado; 4 eliminações pelo questionário estar incompleto). As outras 9 eliminações não devem ser subtraídas, uma vez que: não se sabe se 4 realmente constam na população (não se sabe quais são as empresas); já se tem a resposta de outro profissional de 3 empresas; e 2 empresas, de fato, não fazem parte da população da pesquisa.

A Tabela 42 sumariza as supressões realizadas para chegar ao número da população ajustada da pesquisa.

Tabela 42 - População ajustada

\begin{tabular}{|c|c|c|c|c|c|c|c|}
\hline $\begin{array}{c}\text { BANCO } \\
\text { DE } \\
\text { DADOS }\end{array}$ & $\begin{array}{c}\text { POPULAÇÃO } \\
\text { DA } \\
\text { PESQUISA }\end{array}$ & $\begin{array}{c}\text { NÚMERO DE } \\
\text { EMPRESAS QUE } \\
\text { RECUSARAM A } \\
\text { PARTICIPAÇÃO }\end{array}$ & $\begin{array}{c}\text { NÚMERO } \\
\text { DE } \\
\text { EMPRESAS } \\
\text { FORA DO } \\
\text { ESCOPO } \\
\end{array}$ & $\begin{array}{c}\text { NÚMERO DE } \\
\text { EMPRESAS } \\
\text { ENCERRADAS } \\
\text { OU SUSPENSAS }\end{array}$ & $\begin{array}{l}\text { NÚMERO DE } \\
\text { EMPRESAS } \\
\text { ENVOLVIDAS } \\
\text { NA LAVA } \\
\text { JATO } \\
\end{array}$ & $\begin{array}{c}\text { NÚMERO DE } \\
\text { EMPRESAS COM } \\
\text { QUESTIONÁRIOS } \\
\text { ELIMINADOS }\end{array}$ & $\begin{array}{c}\text { PoPUlaÇão } \\
\text { AJUSTADa }\end{array}$ \\
\hline $\begin{array}{c}\text { Exame } \\
\text { Melhores } \\
\mathrm{e} \\
\text { Maiores } \\
\text { (apenas) }\end{array}$ & 680 & (85) & (11) & (6) & (17) & (2) & 559 \\
\hline $\begin{array}{c}\text { NEI } \\
\text { (apenas) }\end{array}$ & 883 & (87) & (33) & (3) & - & (4) & 756 \\
\hline $\begin{array}{c}\text { Exame } \\
\text { Melhores } \\
\mathrm{e} \\
\text { Maiores } \\
\underline{\mathrm{e}} \text { NEI } \\
\end{array}$ & 53 & (11) & - & - & (2) & - & 40 \\
\hline TOTAL & 1.616 & $(183)$ & (44) & (9) & (19) & (6) & 1.355 \\
\hline
\end{tabular}


Com a população ajustada é possível apurar a taxa de resposta deste estudo. Conforme a Tabela 43 demonstra, a taxa de resposta global do estudo é de $28 \%$, sendo que um percentual maior foi encontrado para as empresas oriundas do banco de dados da Exame Melhores e Maiores (30\%) do que para as empresas oriundas do banco de dados da NEI (27\%).

Tabela 43 - Taxa de resposta

\begin{tabular}{c|c|c|c}
\hline BANCO DE DADOS & POPULAÇÃo AJUSTADA & $\begin{array}{c}\text { NÚMERO DE } \\
\text { RESPOSTAS VÁLIDAS }\end{array}$ & TAXA DE RESPOSTA \\
\hline $\begin{array}{c}\text { Exame Melhores e Maiores } \\
\text { (apenas) }\end{array}$ & 559 & 167 & $30 \%$ \\
\hline NEI (apenas) & 756 & 201 & $27 \%$ \\
\hline Exame Melhores e Maiores e NEI & 40 & 12 & $30 \%$ \\
\hline ToTAL & $\mathbf{1 . 3 5 5}$ & $\mathbf{3 8 0}$ & $\mathbf{2 8 \%}$ \\
\hline
\end{tabular}

Vale mencionar que das 975 empresas (1.355 - 980) que não responderam à pesquisadora, 933 simplesmente não se manifestaram após o contato telefônico e o envio reiterado de mensagens. As demais 42 empresas não foram contatadas de forma individualizadas, apenas acionadas por mensagens grupais direcionadas ao contato cadastrado no banco de dados. Não foi possível concluir a ligação telefônica (telefones inválidos ou nos quais as chamadas nunca eram atendidas, incluindo, geralmente, ligações complementares a números localizados nos sites) e tampouco localizar o email do potencial respondente dessas 42 empresas.

Cumpre mencionar que dentre os 380 questionários válidos apenas 8 (2\%) ficaram com alguma resposta em branco pelo não atendimento à solicitação de complementação e/ou pela impossibilidade de identificação da informação. 7 questionários ficaram sem 1 resposta e 1 questionário ficou sem 2 respostas. Logo, teve-se um total de 9 missings, como mostra a Tabela 44. Para proceder às análises estatísticas, esses 9 missings foram substituídos pela moda ou média das respostas obtidas nas respectivas questões.

Tabela $44-$ Missings da pesquisa

\begin{tabular}{|c|c|c|}
\hline QUESTÃO & $\begin{array}{l}\text { QUANTIDADE DE } \\
\text { MISSINGS }\end{array}$ & SUBSTITUIÇÃo \\
\hline Tempo de experiência do profissional & 4 & Média \\
\hline Nível de concordância - Temos muitos clientes & 1 & Moda \\
\hline Intensidade de uso - Impostos sobre vendas & 1 & Moda \\
\hline Intensidade de uso - Estratégia de preço dos concorrentes & 1 & Moda \\
\hline $\begin{array}{c}\text { Nível de concordância - A margem colocada sobre os custos é definida } \\
\text { isoladamente pelo departamento financeiro }\end{array}$ & 1 & Moda \\
\hline Liderança no segmento & 1 & Moda \\
\hline TOTAL & 9 & \\
\hline
\end{tabular}




\subsection{Coleta de Dados}

Nesta tese, os dados foram coletados diretamente da amostra e, portanto, são classificados como dados primários. A coleta dos dados ocorreu mediante um levantamento (survey), que é, segundo G. Martins e Theóphilo (2009), uma estratégia de pesquisa apropriada quando se deseja responder questões envolvendo análise de fatos e descrições.

Como os levantamentos são marcados pelo estudo dos fenômenos que ocorrem naturalmente, ao menos três assunções epistemológicas devem ser pressupostas para suscitar sua escolha como estratégia de pesquisa. De acordo com Nazari, Kline, e Herremans (2006), a primeira assunção consiste em acreditar que os respondentes são a fonte mais confiável à informação buscada e que essa informação refere-se a situações que compreendem crenças, atitudes, valores, opiniões e/ou intenções dos indivíduos. A segunda assunção sentencia que as percepções subjetivas, alvos do levantamento, são realmente importantes, partindo da pressuposição que as pessoas agem em consonância às percepções. A terceira refere-se às consequências das percepções e ostenta que as mesmas influenciam o comportamento e que o comportamento impacta a realidade.

\subsubsection{Questionário}

O levantamento desta pesquisa foi viabilizado com a aplicação de um questionário, que é um importante e popular instrumento de coleta de dados em pesquisas sociais. Especificamente, o questionário compreende um conjunto ordenado e consistente de perguntas a respeito de variáveis e de situações que se deseja medir ou descrever. Ele assume uma versão por escrito (impressa ou digital) e normalmente é respondido pelos participantes sem o pesquisador estar presente. Seu encaminhamento é direcionado a potenciais informantes, previamente selecionados (G. Martins \& Theóphilo, 2009).

De acordo com Hoque (2006), no encaminhamento do questionário, deve-se assegurar aos potenciais informantes que os direitos éticos de voluntariedade, anonimato e confidencialidade serão preservados. Nesse sentido, uma carta de apresentação foi remetida com o questionário para demonstrar aos participantes a conservação desses direitos (encontrada no Apêndice B desta tese). 
O questionário (que se encontra no Apêndice C) trouxe 8 questões centrais. Sua divisão interna originou os seguintes blocos:

a) bloco 1 - caracterização geral do principal segmento. O objetivo desse bloco foi caracterizar a empresa respondente, tomando como base seu principal segmento;

b) bloco 2 - informações e fórmulas usadas no estabelecimento dos preços. O objetivo desse bloco foi identificar as informações usadas no estabelecimento dos preços, bem como levantar as fórmulas usadas no processo;

c) bloco 3 - custos mais margem. O objetivo desse bloco foi investigar características específicas da fórmula "custos mais margem” usada, principalmente para averiguar se os custos são ou não a essência do estabelecimento dos preços;

d) bloco 4 - fatores relacionados ao estabelecimento dos preços. O objetivo desse bloco foi identificar parte dos potenciais fatores explicativos da essência custos do estabelecimento dos preços; e

e) bloco 5 - conclusão do questionário. O objetivo desse bloco foi indagar questões relativas à caracterização do respondente (nome, empresa, endereço de email, departamento e cargo de atuação, tempo de experiência) e à eventual área dedicada ao estabelecimento dos preços (na existência dessa área, investigou-se há quanto tempo ela foi instituída). Além disso, almejou-se descobrir o tamanho da empresa, a ocupação (ou não) da posição de liderança e o ambiente de atuação (produtos ofertados).

Vale esclarecer que, tal como Günther (2003) sugere, a sequência das questões foi definida com a intenção de construir uma "conversa com objetivo" entre a pesquisadora e os respondentes. Para tanto, direcionou-se do mais geral para o mais específico; do menos delicado para o mais delicado.

Günther (2003) recomenda que as perguntas iniciais sirvam menos para obter informação do respondente e mais para estabelecer um relacionamento de confiança. Segundo o autor, após conseguir convencer um potencial respondente a dar sua atenção pelo argumento de que o estudo trata de assunto de interesse dele, não convém começar a interação por perguntas burocráticas e, às vezes, até delicadas. Em outras palavras, se o participante concorda em 
responder a pesquisa por considerar a temática interessante, a primeira pergunta (e as seguintes) deve tratar dessa temática.

Nesse sentido, optou-se por iniciar o questionário já com questões sobre o estabelecimento dos preços e por terminá-lo com questões sobre informações demográficas. Ainda que Sangster (1993) entenda que as questões demográficas estejam imunes aos efeitos de ordem, julgou-se que seu posicionamento no final seria o que mais bem atenderia às recomendações de Günther (2003).

Finalmente, é salutar aclarar que as perguntas que compõem o questionário são fechadas, com exceção daquelas referentes ao nome do respondente, ao nome da empresa, ao endereço de email do respondente, ao tempo de atuação no estabelecimento dos preços, ao tempo de existência da área de estabelecimento dos preços e aos principais produtos vendidos. Elas classificam-se em três diferentes tipos: dicotômica, de múltipla escolha e com o uso da escala Likert.

As perguntas dicotômicas, como o próprio nome sugere, oferecem ao respondente a possibilidade de escolher somente entre duas opções (e.g., sim ou não). Já as perguntas de múltipla escolha trazem aos respondentes várias alternativas de resposta (e.g., o preço é estabelecido a partir dos custos mais margem, o preço é estabelecido a partir dos preços dos concorrentes (+/-) ajustes etc.). Por fim, as perguntas que fazem uso da escala Likert trazem um conjunto de itens apresentados em forma de afirmações, ante aos quais os respondentes externam sua reação, escolhendo um dos pontos da escala (G. Martins \& Theóphilo, 2009).

No que se refere especificamente à escala Likert, cumpre destacar que números diferentes de pontos podem ser encontrados. Campell (1988) defende que conforme aumenta o número de pontos, a complexidade de escolha do respondente também aumenta. Preston e Colman (2000), por sua vez, advertem que números de pontos muito baixos, como dois, três ou quatro, prejudicam a confiabilidade e a consistência interna do questionário.

Weijters, Cabooter, e Schillewaert (2010) destacam que há inúmeras discussões sobre a quantidade ótima de pontos, segundo uma diversidade de teorias, e que ainda não há consenso sobre o tópico. Contudo, de acordo com o resultado do estudo que desenvolveram, eles 
sugerem, ainda que não conclusivamente, que cinco é a quantidade ideal de pontos quando o questionário é aplicado com o objetivo de estimar relações entre variáveis (por meio de correlações e regressões, por exemplo). Ademais, com uma escala de cinco pontos, tem-se o ponto neutro e, com ele, respondentes de posições intermediárias não são obrigados a escolher uma posição polar que não representa sua verdadeira percepção (Schuman \& Presser, 1981).

Diante do exposto, nesta tese optou-se pela escala Likert de 5 pontos. Entretanto, vale ressaltar que nas pesquisas sobre preços, não há unanimidade nas escalas adotadas. Por exemplo, Ingenbleek et al. (2003) usaram a escala Likert de 10 pontos, Guilding et al. (2005) e Ingenbleek e van der Lans (2013) usaram a escala Likert de 5 pontos, Liozu e Hinterhuber (2013) usaram a escala Likert de 7 pontos. Ou seja, nesse exemplo, enquanto dois estudos fizeram uso de quantidades médias de pontos (Guilding et al., 2005; Ingenbleek e van der Lans, 2013), dois fizeram uso de quantidades elevadas de pontos (Liozu \& Hinterhuber, 2013; Ingenbleek et al., 2003). Enquanto um usou uma escala sem ponto neutro (Ingenbleek et al., 2003), os outros três usaram escalas com ponto neutro (Guilding et al., 2005; Ingenbleek e van der Lans, 2013; Liozu \& Hinterhuber, 2013).

Não há unanimidade sequer quando os mesmos autores são envolvidos. Por exemplo, na $1^{\text {a }}$ série de estudos, Avlonitis e Indounas (Avlonitis \& Indounas, 2004, 2005a, 2005b, 2006a, 2006b, 2007a, 2007b; Avlonitis et al., 2005; Indounas \& Avlonitis, 2009), usaram a escala binária, mas na $2^{\text {a }}$ série de estudos (Indounas, 2008, 2009; Indounas \& Avlonitis, 2011) usaram a escala Likert de 5 pontos.

\subsubsection{Validade e Confiabilidade dos Dados}

G. Martins e Theóphilo (2009) advertem que é preciso atentar para os critérios de significância e de precisão dos instrumentos de medidas ao avaliar e quantificar dados. Esses critérios são demonstrados pela validade, ou validez, e pela confiabilidade, ou fidedignidade.

\subsubsection{1 $\quad \underline{\text { Validade }}$}

O critério da validade refere-se à capacidade de medir o que realmente foi proposto medir. A questão fundamental para admitir sua existência é dada pela resposta à seguinte pergunta 
“Será que se está medindo o que se crê que deve ser medido?". Se a resposta a essa pergunta for positiva, a medida é válida, se não, não é. G. Martins e Theóphilo (2009) esclarecem que a validade total de um instrumento é verificada pela soma das validades de conteúdo, de critério e de constructo.

A validade de conteúdo demonstra que o instrumento de pesquisa abrange o domínio específico que pretende medir. Em outras palavras, ela evidencia que a medição de fato representa o conceito que se pretende medir. Para assegurá-la, o instrumento de pesquisa deve conter todos os itens do domínio do conteúdo investigado. Nesta tese, assim como sugerem G. Martins e Theóphilo (2009), o domínio foi inteiramente descrito antes, e não depois, da construção do instrumento de pesquisa para propiciar mais garantia sobre esse tipo de validade. Toda a escrita do referencial teórico, a formulação dos constructos e a elaboração das hipóteses foram realizadas antes de o questionário ser definido.

A validade de critério, também chamada validade empírica, estabelece a validade de um instrumento de medição comparando-o com algum critério externo. Especificamente, a validade de critério, que se refere à capacidade do instrumento em diagnosticar a situação existente e em distinguir indivíduos sabidamente diferentes, denomina-se validade simultânea. (G. Martins \& Theóphilo, 2009).

Para assegurar a validade simultânea, um pré-teste do questionário foi realizado. De acordo com Gil (2008), o pré-teste não visa capturar os aspectos que constituem os objetivos do levantamento e tampouco pode trazer resultados referentes a esses objetivos. O pré-teste está centrado na avaliação dos instrumentos e visa garantir que os mesmos meçam exatamente o que pretendem medir. Nesta tese, o pré-teste foi dividido em três etapas.

Na primeira fase, uma avaliação preliminar do questionário foi solicitada a três pesquisadores com experiência no desenvolvimento de instrumentos de pesquisa e na realização de pesquisas de campo (dois da área de "Controladoria e Contabilidade Gerencial" e uma da área de "Educação e Pesquisa em Contabilidade"). A avaliação crítica e as sugestões oferecidas nessa etapa foram consideradas e serviram como base à implantação de melhorias no questionário. Diante dessas melhorias, passou-se à segunda fase do pré-teste. 
Na segunda etapa, pediu-se que dois consultores envolvidos especificamente na formulação de orientações para a determinação dos preços avaliassem criticamente o questionário. Nessa avaliação, como o Apêndice A demonstra, os consultores sugeriram melhorias para o questionário e analisaram: se os termos utilizados nas perguntas eram de compreensão dos respondentes; se as perguntas eram entendidas como deveriam ser; se as opções de respostas às perguntas fechadas estavam completas; se a sequência das perguntas estava correta; se não havia objeções na obtenção das respostas; se a forma de apresentar a pergunta não estava causando viés; se o questionário era preenchido com facilidade; e o tempo consumido para completar o preenchimento (Mattar, 1997).

Com essa análise, detectou-se que, a fim de não desestimular a participação dos respondentes, seria necessário cortar a quantidade de questões, simplificar os enunciados e incluir algumas assertivas. Com essas alterações, uma nova versão do questionário foi formulada e sujeita à validação final na terceira etapa do pré-teste.

A terceira fase foi marcada pela avaliação do questionário por dezesseis dos reais respondentes. Pediu-se que tais profissionais notificassem eventuais obstáculos no preenchimento do instrumento, relatassem o seu entendimento sobre a compreensibilidade do questionário e informassem o tempo consumido no processo. Quinze dos respondentes deram seu feedback eletronicamente (internet ou email) e uma das respondentes, além de dar seu feedback por email, aceitou participar de uma conferência telefônica na qual expôs mais detidamente sua percepção sobre o questionário e revelou aspectos merecedores de discussão aprofundada na posterior análise dos resultados.

Nessa etapa, observou-se, primeiramente, que o tempo consumido no preenchimento do questionário não era excessivo. A média encontrada foi de 16,625 minutos, sendo 8 minutos o tempo mínimo e 30 minutos o tempo máximo. A moda foi de 15 minutos. Notou-se também que a grande maioria dos respondentes (91\%) não encontrou problemas no entendimento e no preenchimento no questionário. Assim, não se detectou a necessidade de alterar profundamente o instrumento de pesquisa, mas, sim, de apenas promover pequenas melhorias. 
Vale mencionar que como as modificações foram bastante específicas e o conteúdo, per si, do questionário permaneceu inalterado, decidiu-se por não descartar as 16 respostas obtidas, utilizando-as também na análise dos dados.

A validade simultânea também foi preservada com a constatação de que a parcela da população acessada de fato corresponde à realidade vivenciada pela população como um todo. Ora, se a parcela que respondeu ao questionário difere substancialmente da parcela que não o respondeu, a obtenção de resultados conclusivos não é factível. Logo, para obter os resultados conclusivos desejados e diagnosticar a real situação encontrada, é preciso comparar se as respostas dos participantes da pesquisa assemelham-se às respostas dos não participantes (Armstrong \& Overton, 1977).

Entretanto, se os não participantes não responderam à pesquisadora, suas respostas obviamente não estão disponíveis e a comparação direta com os participantes não é viável. Para resolver esse impasse, existem abordagens que oferecem alternativas para operacionalizar a comparação e viabilizar a apuração do viés da não resposta. Neste trabalho, assim como no de Schoenherr, Modi, Talluri, e Hult (2014), duas abordagens são seguidas.

A primeira abordagem inspira-se em Armstrong e Overton (1977) e assume que os sujeitos que respondem menos prontamente ao questionário assemelham-se aos não respondentes. Cumpre destacar que o "menos prontamente" refere-se à demora de mais tempo no oferecimento das respostas e/ou à necessidade de mais insistência (reiterações, por exemplo) para obter as respostas.

Nesta tese, para seguir essa abordagem, os participantes foram divididos em dois grupos: um composto pelos 163 profissionais que responderam prontamente ao questionário (somente um contato telefônico e/ou eletrônico) e outro pelos 217 respondentes tardios para os quais foi necessária mais de uma solicitação de resposta. A Figura 48 ilustra a divisão da amostra nesses dois grupos. 
Figura 48 - Distribuição da amostra por número de reiterações

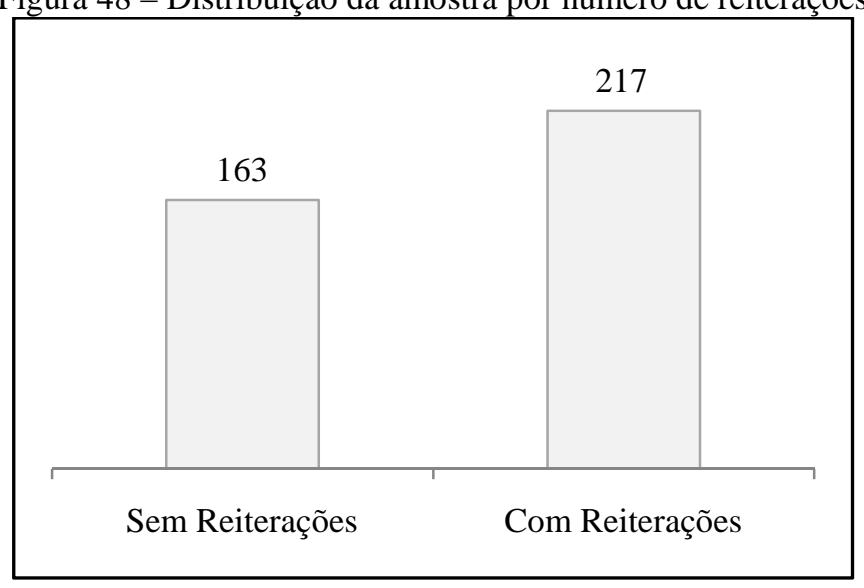

Fonte: Dados da pesquisa

As respostas às 49 assertivas respondidas com uso da escala Likert foram comparadas entre os dois grupos. Especificamente, as respostas assinaladas pelo grupo que não foi reiterado para as assertivas das questões 1, 2, 5, 6, 7 e 8 foram confrontadas com as respostas assinaladas pelo grupo que foi reiterado. As questões 3 e 4 não foram comparadas, pois não implicaram o uso da escala Likert.

Primeiramente, com o uso do SPSS, analisou-se a normalidade das variáveis com o teste estatístico de Kolmogorov-Smirnov. Considerando um nível de significância de 0,05, nenhuma variável de nenhum grupo foi constatada como normal (p-valores inferiores a 0,05). O não atendimento ao pressuposto da normalidade indicou a necessidade de se recorrer a testes não paramétricos. Dado o contexto de comparação (grupos independentes, variáveis ordinais), escolheu-se o teste de Mann-Whitney (Fávero et al., 2009). Os resultados são expressos na Tabela 45.

Tabela 45 - Resultados do teste Mann-Whitney para $1^{\text {a }}$ análise do viés da não resposta

\begin{tabular}{c|c|c}
\hline HIPóTESE NULA & P-VALOR & DECISÃo \\
\hline A distribuição da Questão 1a é a mesma entre as categorias do grupo & 0,708 & Não rejeitar a hipótese nula \\
\hline A distribuição da Questão 1b é a mesma entre as categorias do grupo & 0,159 & Não rejeitar a hipótese nula \\
\hline A distribução da Questão 1c é a mesma entre as categorias do grupo & 0,545 & Não rejeitar a hipótese nula \\
\hline A distribuição da Questão 1d é a mesma entre as categorias do grupo & 0,392 & Não rejeitar a hipótese nula \\
\hline A distribuição da Questão 1e é a mesma entre as categorias do grupo & 0,298 & Não rejeitar a hipótese nula \\
\hline A distribuição da Questão 1f é a mesma entre as categorias do grupo & 0,051 & Não rejeitar a hipótese nula \\
\hline A distribuição da Questão 1g é a mesma entre as categorias do grupo & 0,377 & Não rejeitar a hipótese nula \\
\hline A distribuição da Questão 1h é a mesma entre as categorias do grupo & 0,199 & Não rejeitar a hipótese nula \\
\hline A distribuição da Questão 1i é a mesma entre as categorias do grupo & 0,086 & Não rejeitar a hipótese nula \\
\hline A distribuição da Questão 1j é a mesma entre as categorias do grupo & 0,661 & Não rejeitar a hipótese nula \\
\hline A distribuição da Questão 1k é a mesma entre as categorias do grupo & 0,837 & Não rejeitar a hipótese nula \\
\hline A distribuição da Questão 11 é a mesma entre as categorias do grupo & 0,267 & Não rejeitar a hipótese nula \\
\hline
\end{tabular}




\begin{tabular}{|c|c|c|}
\hline HIPÓTESE NULA & P-VALOR & DECISÃO \\
\hline A distribuição da Questão 2a é a mesma entre as categorias do grupo & 0,568 & Não rejeitar a hipótese nula \\
\hline A distribuição da Questão 2b é a mesma entre as categorias do grupo & 0,575 & Não rejeitar a hipótese nula \\
\hline A distribuição da Questão 2c é a mesma entre as categorias do grupo & 0,353 & Não rejeitar a hipótese nula \\
\hline A distribuição da Questão 2d é a mesma entre as categorias do grupo & $0,012^{* *}$ & Não rejeitar a hipótese nula \\
\hline A distribuição da Questão 2e é a mesma entre as categorias do grupo & $0,045^{* *}$ & Não rejeitar a hipótese nula \\
\hline A distribuição da Questão 2f é a mesma entre as categorias do grupo & $0,009^{* * * *}$ & Rejeitar a hipótese nula \\
\hline A distribuição da Questão $2 \mathrm{~g}$ é a mesma entre as categorias do grupo & 0,833 & Não rejeitar a hipótese nula \\
\hline A distribuição da Questão $2 \mathrm{~h}$ é a mesma entre as categorias do grupo & 0,811 & Não rejeitar a hipótese nula \\
\hline A distribuição da Questão $2 \mathrm{i}$ é a mesma entre as categorias do grupo & 0,816 & Não rejeitar a hipótese nula \\
\hline A distribuição da Questão $2 \mathrm{j}$ é a mesma entre as categorias do grupo & 0,377 & Não rejeitar a hipótese nula \\
\hline A distribuição da Questão 2k é a mesma entre as categorias do grupo & 0,410 & Não rejeitar a hipótese nula \\
\hline A distribuição da Questão 21 é a mesma entre as categorias do grupo & 0,449 & Não rejeitar a hipótese nula \\
\hline A distribuição da Questão $2 \mathrm{~m}$ é a mesma entre as categorias do grupo & 0,770 & Não rejeitar a hipótese nula \\
\hline A distribuição da Questão 2n é a mesma entre as categorias do grupo & 0,611 & Não rejeitar a hipótese nula \\
\hline A distribuição da Questão 2o é a mesma entre as categorias do grupo & 0,695 & Não rejeitar a hipótese nula \\
\hline A distribuição da Questão 5a é a mesma entre as categorias do grupo & 0,916 & Não rejeitar a hipótese nula \\
\hline A distribuição da Questão 5b é a mesma entre as categorias do grupo & 0,269 & Não rejeitar a hipótese nula \\
\hline A distribuição da Questão 6a é a mesma entre as categorias do grupo & 0,546 & Não rejeitar a hipótese nula \\
\hline A distribuição da Questão 6b é a mesma entre as categorias do grupo & 0,640 & Não rejeitar a hipótese nula \\
\hline A distribuição da Questão 6c é a mesma entre as categorias do grupo & 0,098 & Não rejeitar a hipótese nula \\
\hline A distribuição da Questão 6d é a mesma entre as categorias do grupo & 0,480 & Não rejeitar a hipótese nula \\
\hline A distribuição da Questão 6e é a mesma entre as categorias do grupo & 0,227 & Não rejeitar a hipótese nula \\
\hline A distribuição da Questão $6 \mathrm{f}$ é a mesma entre as categorias do grupo & 0,180 & Não rejeitar a hipótese nula \\
\hline A distribuição da Questão 6g é a mesma entre as categorias do grupo & 0,783 & Não rejeitar a hipótese nula \\
\hline A distribuição da Questão 6h é a mesma entre as categorias do grupo & $\mathbf{0 , 0 0 0} 0^{* * * *}$ & Rejeitar a hipótese nula \\
\hline A distribuição da Questão 7a é a mesma entre as categorias do grupo & 0,094 & Não rejeitar a hipótese nula \\
\hline A distribuição da Questão 7b é a mesma entre as categorias do grupo & 0,541 & Não rejeitar a hipótese nula \\
\hline A distribuição da Questão 7c é a mesma entre as categorias do grupo & 0,757 & Não rejeitar a hipótese nula \\
\hline A distribuição da Questão 7d é a mesma entre as categorias do grupo & 0,485 & Não rejeitar a hipótese nula \\
\hline A distribuição da Questão 7e é a mesma entre as categorias do grupo & 0,600 & Não rejeitar a hipótese nula \\
\hline A distribuição da Questão 7f é a mesma entre as categorias do grupo & 0,491 & Não rejeitar a hipótese nula \\
\hline A distribuição da Questão 8a é a mesma entre as categorias do grupo & 0,235 & Não rejeitar a hipótese nula \\
\hline A distribuição da Questão 8b é a mesma entre as categorias do grupo & 0,187 & Não rejeitar a hipótese nula \\
\hline A distribuição da Questão 8c é a mesma entre as categorias do grupo & 0,369 & Não rejeitar a hipótese nula \\
\hline A distribuição da Questão 8 d é a mesma entre as categorias do grupo & 0,080 & Não rejeitar a hipótese nula \\
\hline A distribuição da Questão 8e é a mesma entre as categorias do grupo & 0,286 & Não rejeitar a hipótese nula \\
\hline A distribuição da Questão $8 \mathrm{f}$ é a mesma entre as categorias do grupo & 0,841 & Não rejeitar a hipótese nula \\
\hline
\end{tabular}
Nota. $* * p<0,05 * * * p<0,01$

Pode-se perceber que não há, no geral, distinção entre os participantes que prontamente responderam o questionário (respondentes) e os participantes que responderam após reiterações (equivalentes aos não respondentes). A um nível de significância de 0,01, diferenças estatisticamente significativas apenas foram observadas nas questões $2 \mathrm{f}$ e $6 \mathrm{~h}$, nas quais as médias para os respondentes e não respondentes foram, respectivamente, 4,3 e 4,1 (questão 2f) e 3,9 e 3,4 (questão 6h). A um nível de significância de 0,05, diferenças estatisticamente significativas também foram encontradas nas questões $2 \mathrm{~d}$ e $2 \mathrm{e}$, nas quais as médias para os respondentes e não respondentes foram, respectivamente, 4,0 e 3,7 (questão 2d) e 3,0 e 3,3 (questão 2e).

Com os resultados de somente 4 (dentre as 49) questões apresentando diferenças estatísticas significativas entre os grupos, é razoável afirmar que não há evidências do viés da não 
resposta na amostra desta pesquisa, o que traz um primeiro indício de validade no que tange à população efetivamente acessada.

Para ratificar a não presença do viés de não resposta, usou-se também uma segunda abordagem, inspirada em Schoenherr et al. (2014). Essa abordagem compara dados disponíveis dos respondentes a dados disponíveis dos não respondentes. Nesta tese, optou-se por comparar 4 dados econômico-financeiros dos anos base 2013 e 2014: receita líquida, lucro líquido, patrimônio líquido e ativo total. Vale destacar que essa comparação foi parcial e restringiu-se às empresas oriundas do banco de dados da Exame Melhores e Maiores, pois não há divulgação de informações desse tipo para as empresas oriundas do banco de dados da NEI.

Cumpre mencionar que esses dados foram selecionados porque, dentre aqueles prontamente disponíveis no banco da Exame Melhores e Maiores, são aqueles que mais revelam, sob diferentes perspectivas, a grandeza das empresas (em termos de faturamento, de resultado, de patrimônio e de ativo) e, consequentemente, a maior ou menor tendência de estruturação das decisões. Dependendo do objetivo do trabalho, diferentes dados poderiam ser escolhidos, como, por exemplo, capital circulante líquido (CCL) e índice de liquidez em pesquisas interessadas em investigar temas relacionados à disponibilidade financeira.

No banco da Exame Melhores e Maiores, foi possível localizar os dados econômicofinanceiros almejados de 731 empresas (empresas individuais, ainda que para o fim da pesquisa tivessem sido articuladas em grupos de pesquisa). Para os respondentes, foram encontrados dados de 173 empresas individuais (referentes a 150 participantes). Para os não respondentes, foram encontrados dados de 558 empresas individuais (referentes a 461 não participantes).

Com o uso do SPSS, analisou-se a normalidade das 8 variáveis a partir do teste estatístico de Kolmogorov-Smirnov. Considerando um nível de significância de 0,05, nenhuma variável de nenhum grupo foi constatada como normal (p-valores inferiores a 0,05 ). $\mathrm{O}$ não atendimento ao pressuposto da normalidade indicou, mais uma vez, a necessidade de recorrer a testes não paramétricos. O teste de Mann-Whitney foi novamente selecionado (Fávero et al., 2009) e seus resultados são apresentados na Tabela 46. 
Tabela 46 - Resultados do teste Mann-Whitney para $2^{\mathrm{a}}$ análise do viés da não resposta

\begin{tabular}{|c|c|c|}
\hline Hipótese Nula & $\begin{array}{c}\text { Mann- } \\
\text { Whitney U: } \\
\text { p-valor }\end{array}$ & Decisão \\
\hline A distribuição da Receita Líquida de 2014 é a mesma entre as categorias do grupo & 0,534 & Não rejeitar a hipótese nula \\
\hline A distribuição do Lucro Líquido de 2014 é a mesma entre as categorias do grupo & 0,699 & Não rejeitar a hipótese nula \\
\hline A distribuição do Patrimônio Líquido de 2014 é a mesma entre as categorias do grupo & 0,927 & Não rejeitar a hipótese nula \\
\hline A distribuição do Ativo Total de 2014 é a mesma entre as categorias do grupo & 0,727 & Não rejeitar a hipótese nula \\
\hline A distribuição da Receita Líquida de 2013 é a mesma entre as categorias do grupo & 0,220 & Não rejeitar a hipótese nula \\
\hline A distribuição do Lucro Líquido de 2013 é a mesma entre as categorias do grupo & 0,865 & Não rejeitar a hipótese nula \\
\hline A distribuição do Patrimônio Líquido de 2013 é a mesma entre as categorias do grupo & 0,948 & Não rejeitar a hipótese nula \\
\hline A distribuição do Ativo Total de 2013 é a mesma entre as categorias do grupo & 0,831 & Não rejeitar a hipótese nula \\
\hline
\end{tabular}

É possível constatar que não há qualquer distinção entre os respondentes e os não respondentes. Nenhuma diferença estatisticamente significativa foi encontrada entre a receita líquida, o lucro líquido, o patrimônio líquido e o ativo total dos anos base 2013 e 2014 dos respondentes e dos não respondentes. Esses resultados permitem, mais uma vez, inferir que não há o viés da não resposta na amostra desta pesquisa.

Para finalizar a exposição da validade desta tese, cumpre esclarecer os aspectos inerentes à validade de constructo. De acordo com G. Martins e Theóphilo (2009), a validade do constructo é dada pela resposta à seguinte questão: "em que medida o constructo de um conceito social de fato reflete seu verdadeiro significado teórico?”. Ou seja, ela refere-se ao grau que o instrumento relaciona-se consistentemente com medições assemelhadas derivadas da mesma teoria.

A validade do constructo é estabelecida pelos vários estudos que integram a teoria, sendo dificilmente estabelecida com uma única pesquisa. Afinal, com o acúmulo de resultados das pesquisas, os investigadores descobrem limitações e criam novas medidas para corrigir possíveis problemas, o que faz com que haja um aprimoramento contínuo das medidas e uma compreensão mais completa das variáveis subjacentes àquelas estudadas.

Todos os constructos desta pesquisa foram determinados sustentados pelo arcabouço teórico do tema. Nenhum constructo foi elaborado sem que estudos anteriores fossem consultados e servissem como base à sua formação. Todas variáveis foram instituídas mediante relação consistente com variáveis assemelhadas derivadas da mesma teoria. 


\subsubsection{Confiabilidade}

A confiabilidade refere-se à confiança que uma medida inspira e relaciona-se à coerência e à constância dos resultados. Especificamente, a confiabilidade de um instrumento de medição diz respeito ao grau em que sua repetida aplicação, ao mesmo sujeito ou objeto, produz resultados iguais. De maneira ampla, um instrumento é confiável quando fornece uma medida estável da variável em estudo (G. Martins \& Theóphilo, 2009). A confiabilidade de um instrumento de medidas pode ser determinada mediante a aplicação de diversas técnicas e procedimentos, sendo que, nesta tese, optou-se pelo cálculo do alfa de Cronbach.

O cálculo do alfa de Cronbach faz com que uma única aplicação do instrumento de coleta de dados seja suficiente para aferição da confiabilidade. Tal cálculo implica a mensuração de todas as correlações entre o escore de cada item e o escore total dos demais itens. As correlações e o próprio valor do alfa são reveladores porque fornecem informações sobre cada item individual. Itens que não estão correlacionados com os demais podem ser eliminados da medida para aumentar o alfa e, consequentemente, a confiabilidade do instrumento (G. Martins \& Theóphilo, 2009).

O alfa de Cronbach varia numa escala de 0 a 1 (ou de 0 a 100\%) e estima o quão uniformemente os itens contribuem para a soma não ponderada do instrumento. $\mathrm{O}$ alfa pode ser interpretado como o coeficiente médio de todas as estimativas de consistência interna que seriam obtidas se todas as divisões possíveis da escala fossem feitas. Quanto mais elevadas forem as correlações entre os itens, maior é a homogeneidade dos itens e maior é a confiança que eles medem a mesma dimensão ou o mesmo constructo teórico. Em outras palavras, pode-se dizer que quanto menor é a variabilidade de um mesmo item numa amostra de sujeitos, menor é o erro de medida associado a esse instrumento (Maroco \& Garcia-Marques, 2006).

De modo geral, um instrumento ou teste é classificado como tendo confiabilidade apropriada quando o alfa é pelo menos 0,70. Contudo, em alguns cenários de investigação das ciências sociais, um alfa de 0,60 é considerado aceitável desde que os resultados obtidos com o instrumento sejam interpretados com precaução e tenham em conta o contexto do cálculo do índice (Maroco \& Garcia-Marques, 2006). 
$\mathrm{O}$ alfa de Cronbach do questionário da presente pesquisa, calculado com o uso do SPSS a partir das 49 assertivas de escala Likert, é de 0,794. Esse valor é superior ao limite préestabelecido de 0,70 e, portanto, indica a confiabilidade do instrumento.

\subsection{Definições Constitutivas e Construtos}

A coleta de dados visou promover a comparação entre as observações empíricas e a literatura retratada ao longo do estudo. Esse tipo de comparação está presente em teses classificadas como teórico-empíricas, que constituem o caminho mais trilhado na evolução da ciência e na expansão do conhecimento. As teses teórico-empíricas tornam possível comparar a realidade à teoria e trazem contribuições respeitáveis, mesmo que modestas, à ciência (Castro, 1977).

G. Martins \& Theóphilo (2009) esclarecem que essa comparação ancora-se em explicações claras, precisas e não ambíguas do fenômeno sob investigação. Essas explicações são promovidas mediante definições, que, segundo Kerlinger (1980), podem ser de dois tipos: constitutivas e operacionais.

As definições constitutivas, também chamadas definições conceituais, definem palavras com outras palavras. Essas definições são importantes, mas insuficientes cientificamente, pois trazem imprecisões que podem comprometer a clareza e a precisão dos resultados por não expressarem o fenômeno investigado. Os cientistas, além de pensarem constitutivamente, pensam operacionalmente e usam a definição operacional como ponte entre os conceitos e as observações. As definições operacionais especificam as atividades e operações necessárias para medir um conceito e atribuem significado a um constructo (Kerlinger, 1980).

O constructo possui um significado construído intencionalmente a partir de um determinado marco teórico e deve ser definido de tal forma que permita a sua delimitação e a sua tradução para proposições particulares e mensuráveis. O constructo pode ser entendido como a operacionalização de abstrações que os cientistas consideram nas teorias. Ele é uma definição operacional robusta que busca representar empiricamente um conceito dentro de um específico quadro teórico (G. Martins \& Theóphilo, 2009). 
Nesse sentido, este estudo, além de apresentar as definições constitutivas que os conceitos abordados naturalmente possuem, relaciona os constructos elaborados para a sua representação empírica.

Todas as variáveis que compõem os constructos são inspiradas em estudos anteriores. Vale, no entanto, esclarecer que nenhuma delas replica literalmente as variáveis encontradas nas pesquisas prévias. Escolheu-se formular variáveis específicas, ao invés de seguir integralmente as opções previamente disponíveis, para facilitar o processo de entendimento dos respondentes. Por exemplo, acredita-se que os respondentes conseguem perceber com mais facilidade se no estabelecimento dos preços consideram a "capacidade de pagamento dos clientes" do que a "disposição do cliente em pagar os benefícios únicos dos produtos/serviços".

\subsubsection{Constructos Referentes ao Estabelecimento dos Preços}

\subsubsection{Enquadramento da Empresa}

Nesta tese, o enquadramento abordado restringe-se àquele aplicável ao estabelecimento dos preços, uma vez que uma empresa pode ser classificada em função de inúmeras características (e.g., em função do porte - micro, pequena, média ou grande; em função do segmento automotivo, alimentos etc.). Por essa razão, a definição constitutiva do enquadramento é aqui dada como a categorização da empresa em função da sua detenção (ou não) de poder no estabelecimento dos preços, isto é, da sua classificação como formadora ou como tomadora de preços.

Guilding et al. (2005) já buscaram acessar esse conceito de forma indireta, mediante proxy do tamanho da companhia. Entretanto, considerando toda a discussão já promovida no capítulo 5, entende-se que o acesso ao conceito não deve partir da mesma proxy, cuja validade é questionável, já que nada impede que grandes empresas oferecedoras de commodities sejam tomadoras de preços e pequenas empresas de produtos únicos sejam formadoras de preços. Neste estudo, alternativamente, infere-se o enquadramento a partir de três variáveis definidas para investigar se há ou não decisão a ser tomada com relação aos preços. 
A primeira variável, alinhada às constatações de Harper (1966), Hofstrand (2007) e D’ Aveni (2009) de que as empresas de commodities ofertam produtos idênticos aos concorrentes, averigua o ambiente de atuação das empresas (AMB). Considera-se que as empresas de commodities, por oferecerem produtos iguais aos produtos da concorrência, não têm o que deliberar sobre os preços e precisam necessariamente tomar os preços disponíveis no mercado. Em outras palavras, argumenta-se que as empresas atuantes no ambiente de commodities são invariavelmente tomadoras de preços.

A segunda variável investiga a diferenciação que os clientes percebem (DIP) para os produtos ofertados no ambiente B2C. Essa variável foi definida a partir da arguição de S. Maxwell (1998) de que as decisões de preços no mercado de consumo normalmente são guiadas coletivamente pela competição, tendo em vista a similaridade dos produtos. Ou seja, o argumento do autor implica que empresas do B2C oferecedoras de produtos percebidos como idênticos não têm o que decidir sobre os preços e devem tomar os preços disponíveis no mercado. Exceções são apenas encontradas em empresas do B2C que oferecem produtos nitidamente reconhecidos como diferenciados, nas quais pode haver poder da empresa em relação aos preços (Harper, 1966; Hofstrand, 2007; Hinterhuber \& Hinterhuber, 2012; Kotler \& Keller, 2012).

A terceira variável, com base no trabalho de Al-Hussari (2006), analisa de forma direta se, independentemente do ambiente, há poder para definição dos preços ou necessidade de colocação de preços exatamente iguais aos concorrentes (EXA). Al-Hussari (2006) argumenta que apenas podem ser consideradas formadoras de preços aquelas empresas com condições de influenciar os preços, isto é, aquelas empresas sem necessidade de seguir os preços colocados pelos demais participantes do mercado. Em outras palavras, somente podem ser consideradas formadoras de preços as empresas que não têm, de fato, a expressa necessidade de colocar preços idênticos aos concorrente, sejam elas do ambiente B2C (que ofertam produtos percebidos como diferenciados), do ambiente B2B ou de engenharia e construção.

A Tabela 47 mostra as questões elaboradas para acessar empiricamente o enquadramento da empresa. As questões que pediam demonstrar concordância usaram uma escala Likert de 5 pontos (extremos: $1=$ discordo totalmente e $5=$ concordo totalmente). 
Tabela 47 - Variáveis referentes ao enquadramento da empresa

\begin{tabular}{c|c|c|c}
\hline VARIÁVEL & ASSERTIVA & $\begin{array}{c}\text { No DA } \\
\text { QUESTÃo }\end{array}$ & $\begin{array}{c}\text { PRINCIPAIS FONTES DE } \\
\text { INSPIRAÇÃo }\end{array}$ \\
\hline AMB & Quais são os três principais produtos vendidos \\
pela empresa? & $\begin{array}{c}\text { Questão de } \\
\text { conclusão }\end{array}$ & Harper (1966); S. Maxwell \\
DIP & $\begin{array}{c}\text { Os clientes consideram que nossos produtos são } \\
\text { diferentes dos produtos oferecidos pelos nossos } \\
\text { concorrentes }\end{array}$ & $1 \mathrm{~b}$ & $\begin{array}{c}\text { Hofstrand, (2007); D’Aveni } \\
\text { (2009); Hinterhuber \& }\end{array}$ \\
\hline EXA & $\begin{array}{c}\text { Como nossos produtos são diferenciados, não } \\
\text { precisamos colocar preços exatamente iguais } \\
\text { aos preços dos nossos concorrentes }\end{array}$ & $1 \mathrm{~g}$ & $\begin{array}{c}\text { Hinter Keller (2012) } \\
\text { \& Kotler }\end{array}$ \\
\hline
\end{tabular}

A Figura 49 facilita o entendimento de como as empresas foram enquadradas a partir das respostas a essas três questões. Com as três variáveis combinadas, foi elaborada uma nova variável dummy (ENQ), na qual as duas opções eram: formadores de preços e tomadores de preços.

Figura 49 - Operacionalização do enquadramento das empresas

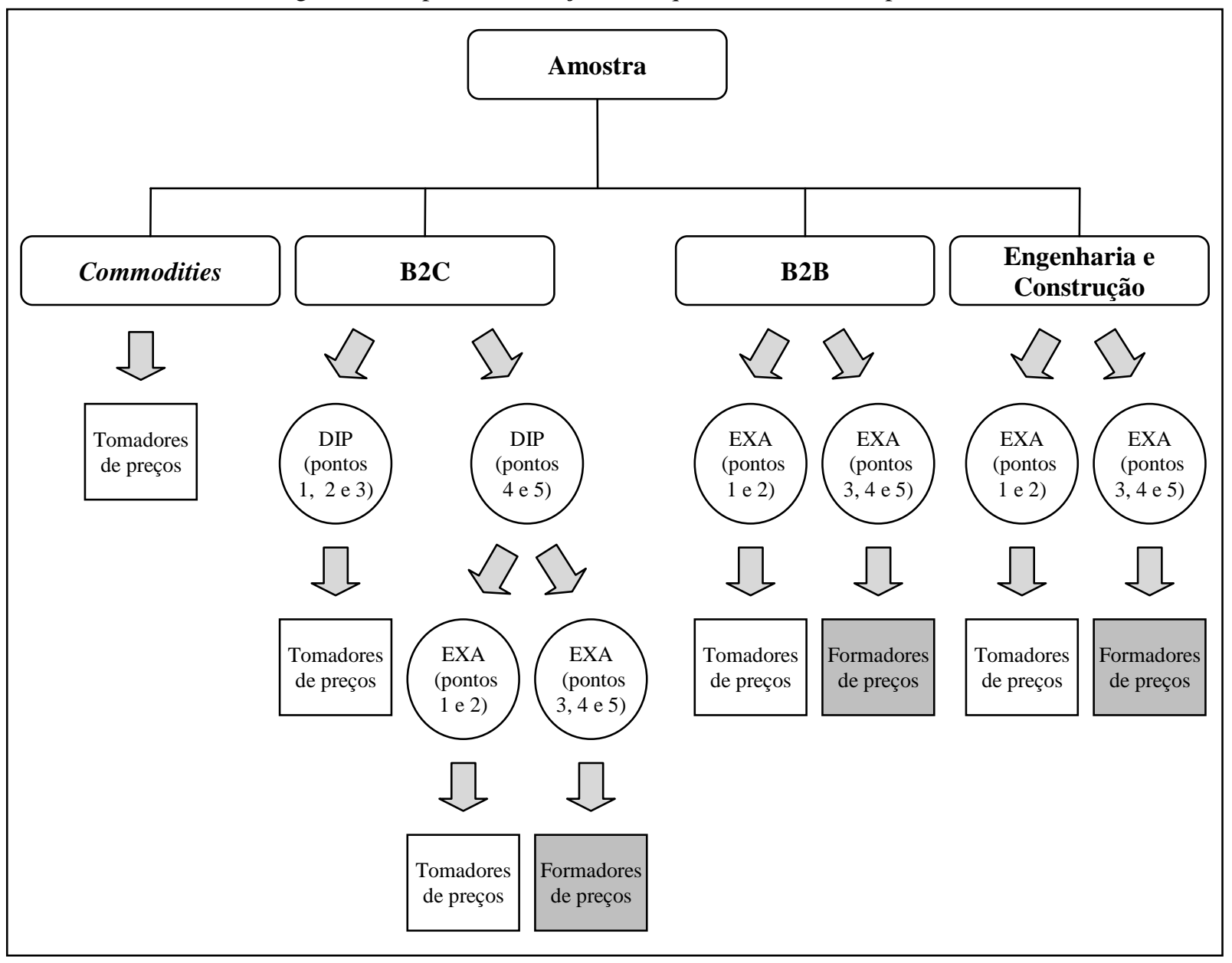

Fonte: Elaboração própria 


\subsubsection{Dificuldade de Uso das Informações da Concorrência}

A dificuldade de uso das informações da concorrência pode ser definitivamente constituída como a não facilidade em definir os preços a partir de informações dos preços dos concorrentes. Os formadores de preços, embora tenham poder para definir os preços, dificilmente conseguem usar tais tipos de informação, enquanto que os tomadores de preços, sim, conseguem capturar os preços disponíveis no mercado e usá-los como base ao estabelecimento dos preços (Drury \& Tayles, 2006).

Nagle e Hogan (2007) esclarecem que, embora possa haver várias potenciais fontes de dados sobre os preços dos concorrentes, coletar esses dados (por exemplo, de sites, catálogos etc.) e convertê-los em informações úteis requer um processo específico que não é implantado se dificuldades não forem transcendidas (DIF_1).

Morris e Fuller (1989) evidenciaram que quando os produtos ofertados são altamente diferenciados, as dificuldades para monitorar os preços dos concorrentes são maiores. Dutta et al. (2003) também ilustraram o quão inviável é identificar os preços cobrados por inúmeros concorrentes oferecendo produtos não idênticos. Roll (2009), por sua vez, destacou que em algumas condições é extremamente difícil ter informações precisas, tempestivas e disponíveis a todos sobre os concorrentes. Quanto mais dificuldades forem encontradas, mais necessário vai ser o amparo em outros tipos de informações (DIF_2).

Para acessar esse constructo, foram apresentadas assertivas que verificaram se existiam ou não dificuldades de obter informações da concorrência. Os respondentes deveriam manifestar sua concordância com relação às assertivas diante da escala Likert de 5 pontos (extremos: $1=$ discordo totalmente e $5=$ concordo totalmente). A Tabela 48 demonstra as assertivas, os números das questões correspondentes e as principais fontes de inspiração consultadas. 
Tabela 48 - Variáveis referentes à dificuldade de uso das informações da concorrência

\begin{tabular}{|c|c|c|c|}
\hline VARIÁVEL & ASSERTIVA & $\begin{array}{c}\text { No DA } \\
\text { QUESTÃo }\end{array}$ & $\begin{array}{c}\text { PRINCIPAIS FONTES DE } \\
\text { INSPIRAÇÃO }\end{array}$ \\
\hline DAC_1 & $\begin{array}{l}\text { Temos dificuldade em identificar os preços } \\
\text { cobrados pelos nossos concorrentes (é } \\
\text { escassa a divulgação prévia dos preços em } \\
\text { sites, catálogos etc.) }\end{array}$ & $1 \mathrm{~h}$ & \multirow{2}{*}{$\begin{array}{l}\text { Morris \& Fuller (1989); Dutta et al. } \\
\text { (2003); Drury \& Tayles (2006); } \\
\text { Nagle \&Hogan (2007); Roll (2009) }\end{array}$} \\
\hline DAC_2 & $\begin{array}{l}\text { A dificuldade de obtenção dos preços dos } \\
\text { concorrentes explica nossa necessidade de } \\
\text { usar informações alternativas no } \\
\text { estabelecimento dos preços }\end{array}$ & $1 \mathrm{i}$ & \\
\hline
\end{tabular}

\subsubsection{Informações Usadas}

As informações coletadas, compartilhadas, interpretadas e, principalmente, utilizadas no processo de estabelecimento dos preços são a definição constitutiva desse constructo (Ingenbleek et al., 2003; Avlonitis \& Indounas, 2006a).

É praxe nos trabalhos questionar os tipos de informações usadas como base às decisões de preços (e.g., Ingenbleek et al., 2003; Avlonitis \& Indounas, 2006a; Ingenbleek \& van der Lans, 2013; Liozu \& Hinterhuber, 2013). Esta tese, em linha a esses trabalhos, promoveu o questionamento da intensidade de uso dos três principais tipos de informações (custos - ACU; valor - AVA; e concorrência - ACO), bem como de outras informações eventualmente encontradas, conforme mostra a Tabela 49. As respostas deveriam enquadrar-se na escala Likert de 5 pontos (extremos: 1 = baixa intensidade de uso e $5=$ alta intensidade de uso).

Tabela 49 - Variáveis referentes às informações usadas

\begin{tabular}{|c|c|c|c|}
\hline VARIÁVEL & ASSERTIVA & $\begin{array}{c}\mathbf{N}^{\circ} \text { DA } \\
\text { QUESTÃO } \\
\end{array}$ & $\begin{array}{l}\text { PRINCIPAIS FONTES DE } \\
\text { INSPIRAÇÃO }\end{array}$ \\
\hline \multicolumn{3}{|c|}{ Informações de Custos } & \multirow{12}{*}{$\begin{array}{c}\text { Ingenbleek et al., (2003); } \\
\text { Avlonitis \& Indounas } \\
\text { (2006a); Ingenbleek \& } \\
\text { van der Lans (2013); } \\
\text { Liozu \& Hinterhuber } \\
\text { (2013) }\end{array}$} \\
\hline ACU_1 & Custos variáveis/diretos dos produtos & $2 \mathrm{a}$ & \\
\hline ACU_2 & Custos fixos de fabricação dos produtos & $2 \mathrm{~b}$ & \\
\hline ACU_3 & Impostos sobre vendas & $2 \mathrm{c}$ & \\
\hline ACU_4 & Despesas (administrativas, comerciais e financeiras) & $2 \mathrm{~d}$ & \\
\hline ACU_5 & $\begin{array}{l}\text { Valores dos investimentos (em maquinários, instalações } \\
\text { etc.) }\end{array}$ & $2 \mathrm{e}$ & \\
\hline ACU_6 & $\begin{array}{l}\text { Margem desejada para os produtos (margem de } \\
\text { contribuição, de lucro bruto ou de lucro líquido) }\end{array}$ & $2 \mathrm{f}$ & \\
\hline \multicolumn{3}{|c|}{ Informações de Valor } & \\
\hline AVA_1 & Necessidades e interesses dos clientes & $2 \mathrm{~g}$ & \\
\hline AVA_2 & Capacidade de pagamento dos clientes & $2 \mathrm{~h}$ & \\
\hline AVA_3 & Percepções dos clientes em relação aos produtos & $2 \mathrm{i}$ & \\
\hline AVA_4 & $\begin{array}{l}\text { Comparação entre os benefícios oferecidos e os custos } \\
\text { trazidos aos clientes pelos produtos }\end{array}$ & $2 \mathrm{j}$ & \\
\hline
\end{tabular}




\begin{tabular}{|c|c|c|c|}
\hline VARIÁVEL & ASSERTIVA & $\begin{array}{c}\mathbf{N}^{\circ} \text { DA } \\
\text { QUESTÃO }\end{array}$ & $\begin{array}{l}\text { PRINCIPAIS FONTES DE } \\
\text { INSPIRAÇÃO } \\
\end{array}$ \\
\hline \multicolumn{3}{|c|}{ Informações da Concorrência } & \multirow{7}{*}{$\begin{array}{l}\text { Ingenbleek et al., (2003); } \\
\text { Avlonitis \& Indounas } \\
\text { (2006a); Ingenbleek \& } \\
\text { van der Lans (2013); } \\
\text { Liozu \& Hinterhuber } \\
\text { (2013) }\end{array}$} \\
\hline ACO_1 & $\begin{array}{l}\text { Preços de produtos concorrentes que são iguais aos nossos } \\
\text { produtos }\end{array}$ & $2 \mathrm{k}$ & \\
\hline ACO_2 & $\begin{array}{l}\text { Preços de produtos concorrentes que são similares aos } \\
\text { nossos produtos }\end{array}$ & 21 & \\
\hline ACO_3 & Nível de preço dos concorrentes & $2 \mathrm{~m}$ & \\
\hline ACO_4 & Estratégia de preço dos concorrentes & $2 n$ & \\
\hline \multicolumn{3}{|c|}{$\begin{array}{c}\text { Outros Tipos de Informações } \\
\end{array}$} & \\
\hline AOU & $\begin{array}{l}\text { Por exemplo, informações econômicas, políticas, } \\
\text { tecnológicas, regulatórias, ecológicas, sociais etc. }\end{array}$ & 20 & \\
\hline
\end{tabular}

\subsubsection{Forma do Estabelecimento dos Preços}

A forma do estabelecimento dos preços refere-se ao modo que a deliberação dos preços é operacionalizada. Essa forma tende a ser apoiada em uma abordagem, afinal, as empresas, por mais que se embasem em variadas perspectivas, acabam priorizando um tipo de informação para simplificarem o processo decisório (Marn \& Rosiello, 1992; G. E. Smith \& Nagle, 1994; Ingenbleek et al., 2003).

A maior parte dos trabalhos empíricos, dos mais antigos aos mais novos, dos menos citados aos mais citados (ver capítulo 3), já investigou esse aspecto do estabelecimento dos preços. Tomando como base esses estudos prévios, foi elaborada uma variável (FORMA) para indagar e identificar a forma predominantemente adotada na operacionalização da definição dos preços, como demonstra a Tabela 50.

Tabela 50 - Variável referente à forma do estabelecimento dos preços

\begin{tabular}{|c|c|c|c|}
\hline VARIÁVEL & ASSERTIVA & $\begin{array}{c}\text { No DA } \\
\text { QUESTÃo } \\
\end{array}$ & $\begin{array}{l}\text { PRINCIPAIS FONTES DE } \\
\text { INSPIRAÇÃO } \\
\end{array}$ \\
\hline FORMA & $\begin{array}{l}\text { Indique dentre as seguintes afirmações qual } \\
\text { demonstra a PRINCIPAL forma de } \\
\text { operacionalização do estabelecimento dos } \\
\text { preços: } \\
\text { •O preço é estabelecido a partir dos custos mais } \\
\text { margem (margem de contribuição, de lucro bruto ou de } \\
\text { lucro líquido); } \\
\text { •O preço é estabelecido a partir dos preços dos } \\
\text { concorrentes (+/-) ajustes; } \\
\text { •O preço é estabelecido com base no valor oferecido ao } \\
\text { cliente; } \\
\text { •O preço é estabelecido a partir de tentativa e erro; } \\
\bullet \text { O preço é estabelecido de outra forma (não descrita } \\
\text { nas quatro opções anteriores). }\end{array}$ & 3 & $\begin{array}{c}\text { Marn \& Rosiello (1992); G. E. } \\
\text { Smith \& Nagle (1994); Ingenbleek } \\
\text { et al. (2003) }\end{array}$ \\
\hline
\end{tabular}




\subsubsection{Essência do Estabelecimento dos Preços}

A essência do estabelecimento dos preços pode ser definida conceitualmente como a principal base de orientação à deliberação dos preços. Independentemente da forma, essa base pode ser ancorada nos custos, no valor ou na concorrência. Vale destacar que Drury e Tayles (2006) argumentam que os custos têm, de antemão, um papel relevante para definição dos preços, mas resta saber se esse papel é só forma ou também essência do estabelecimento dos preços.

Para identificar esse ponto e averiguar se os custos são ou não a essência do estabelecimento dos preços (ESC), investiga-se nesta tese o quanto a margem é ou não definida isoladamente pelo departamento financeiro e constante entre produtos e segmentos de clientes. Vale rememorar que a essência custos é encontrada quando a margem é arbitrária e não conecta os custos a outros tipos de informações. Quando a margem é variável e adaptável para promover a conexão entre os custos e as informações de valor ou da concorrência, os custos não configuram a essência, por mais que a combinação “custos mais margem” seja usada.

Defende-se que podem ser encontradas duas situações distintas da essência custos: uma nos formadores de preços outra nos tomadores de preços. Nos formadores de preços, a essência custos indica que os preços são formados unicamente a partir dos custos, sem que seja considerado o valor. Nos tomadores de preços, a essência custos indica que a combinação "custos mais margem" atém-se a informações de custos e traz inevitavelmente uma etapa adicional ao processo de estabelecimento dos preços (o preço proposto pela combinação deve ser comparado aos preços vigentes no mercado).

Já para examinar se o valor é ou não é incorporado no estabelecimento dos preços e, consequentemente, constitui a essência do processo (VNE), investiga-se o quanto as características específicas dos clientes e dos produtos são consideradas nas deliberações.

Cumpre mencionar que, diferentemente do que aconteceu com a forma, a maior parte dos estudos anteriores não explorou a essência do processo. Relativamente poucos foram os trabalhos que abordaram, mesmo que superficial e indiretamente, esse aspecto (e.g., R. I. Hall \& Hitch, 1939; W. W. Haynes, 1964; R. C. Skinner, 1970; Shipley, 1983; Abratt \& Pitt, 1985; 
Morris \& Fuller, 1989; Shipley \& Bourdon, 1990; Cunningham \& Hornby, 1993; Carson et al., 1998; Mello, 2000; Mochtar \& Arditi, 2001; Fabiani et al., 2005; Park et al., 2010).

A Tabela 51 sintetiza as assertivas apresentadas, os números das questões e as principais fontes de inspiração consultadas para acessar o constructo. Para todas as assertivas, os respondentes deveriam expressar sua concordância diante da escala Likert de 5 pontos (extremos: 1 = discordo totalmente e 5 = concordo totalmente).

Tabela 51 - Variáveis referentes à essência do estabelecimento dos preços

\begin{tabular}{|c|c|c|c|}
\hline VARIÁVEL & ASSERTIVA & $\begin{array}{c}\text { No DA }^{\circ} \\
\text { QUESTÃo }\end{array}$ & $\begin{array}{c}\text { PRINCIPAIS FONTES DE } \\
\text { INSPIRAÇÃO }\end{array}$ \\
\hline \multicolumn{3}{|c|}{$\begin{array}{l}\text { Essência Custos } \\
\end{array}$} & \multirow{8}{*}{$\begin{array}{l}\text { R. I. Hall \& Hitch (1939); W. W. } \\
\text { Haynes (1964); R. C. Skinner } \\
\text { (1970); Shipley (1983); Abratt \& } \\
\text { Pitt (1985); Morris \& Fuller } \\
\text { (1989); Shipley \& Bourdon } \\
\text { (1990); Cunningham \& Hornby } \\
\text { (1993); Carson et al. (1998); } \\
\text { Mello (2000); Mochtar \& Arditi } \\
\text { (2001); Fabiani et al. (2005); } \\
\text { Park et al. (2010) }\end{array}$} \\
\hline ESC_1 & $\begin{array}{c}\text { A margem colocada sobre os custos é } \\
\text { definida isoladamente pelo departamento } \\
\text { financeiro }\end{array}$ & $6 a$ & \\
\hline ESC_2 & $\begin{array}{l}\text { Todos os nossos produtos têm margens } \\
\text { parecidas }\end{array}$ & $6 f$ & \\
\hline ESC_3 & $\begin{array}{c}\text { Todos os nossos segmentos de clientes têm } \\
\text { margens parecidas }\end{array}$ & $6 g$ & \\
\hline \multicolumn{3}{|c|}{ Incorporação do Valor na Essência } & \\
\hline VNE_1 & $\begin{array}{l}\text { A definição da margem independe da } \\
\text { consideração de características específicas } \\
\text { dos produtos (por exemplo, a margem de } \\
\text { produtos simples é similar à margem de } \\
\text { produtos sofisticados) }\end{array}$ & $6 \mathrm{c}$ & \\
\hline VNE_2 & $\begin{array}{l}\text { A definição da margem independe da } \\
\text { consideração de características específicas } \\
\text { dos clientes, como porte e localidade }\end{array}$ & $6 \mathrm{~d}$ & \\
\hline VNE_3 & $\begin{array}{c}\text { A definição da margem independe da } \\
\text { consideração da importância que os clientes } \\
\text { vêem nos produtos }\end{array}$ & $6 e$ & \\
\hline
\end{tabular}

Nas análises de regressões ordinais, as variáveis ESC_1, ESC_2 e ESC_3 foram abordadas de forma conjunta a partir de análise de conglomerados executada com o objetivo de classificar as empresas ordinalmente em função da aderência à essência custos.

Foi realizada uma análise de conglomerados não hierárquica $K$-means para agrupar as empresas em função da essência custos. Nessa análise, buscou-se concentrar as empresas em 3 clusters, sendo o cluster 1 relativo à baixa essência custos; o cluster 2 relativo à moderada essência custos; e o cluster 3 relativo à alta essência custos. Para que os clusters ficassem dessa forma ordenados, estabeleceu-se que os centroides iniciais fossem 1 no cluster 1; 3 no cluster 2; 5 no cluster 3. 


\subsubsection{Problemas da Essência Custos}

Os problemas da essência custos referem-se às desvantagens trazidas ao processo de estabelecimento dos preços em decorrência de um embasamento rígido e fechado nos custos. Esses problemas têm sido levantados há tempos por pesquisadores de Marketing e de Contabilidade Gerencial.

Da área de Marketing, R. C. Skinner (1970) afirma que não tem como a disposição e a disponibilidade de pagamento dos clientes não interferirem nos preços, afinal, não adianta à empresa colocar um preço alto que cubra seus custos totais e proporcione uma elevada margem se ela não encontrar nenhum cliente disposto ou com condições de pagar esse preço (PRO_1). Tzokas et al. (2000) acrescentam que o embasamento único nos custos traz a desvantagem de tornar as empresas inflexíveis aos preços. Shipley e Jobber (2001) explicam que tal inflexibilidade pode impedir as empresas de alcançarem seus objetivos estratégicos, como, por exemplo, de entrar em novos segmentos (PRO_2).

De acordo com Shipley e Jobber (2001), os preços formados rigidamente com base nos custos também impedem que oportunidades esporádicas que requeiram adaptações nos preços sejam aproveitadas. Se a empresa ainda tem capacidade de produção ociosa e há um cliente que oferece a proposta de pagar um preço superior ao custo variável, não há por que se ater ao preço definido pelos custos totais. Afinal, melhor do que obter nada é obter recursos adicionais que, pelo menos, ajudem a cobrir os custos fixos e despesas fixas (irreversíveis) (PRO_3).

Da área de Contabilidade Gerencial, Christensen e Demski (1997) defendem que é inadequado usar os custos totais para o processo de tomada de decisões. Noreen e Burgstahler (1997) demonstram que a definição dos preços a partir dos custos totais coloca uma restrição no relacionamento entre os preços dos produtos. Essa restrição pode impedir a empresa de atingir lucros satisfatórios, mesmo quando seria possível alcançá-los. Balakrishnan e Sivaramakrishnan (2002) acrescentam que o emprego da combinação "custo total mais margem" em decisões táticas de preços origina perdas econômicas, ainda que os tomadores de decisão acreditem que ele seja a única forma de obter o lucro desejado (PRO_4). 
$\mathrm{Na}$ Tabela 52, são resumidas as assertivas apresentadas para acessar o constructo e revelados os números das questões e as principais fontes de inspiração consultadas. Diante de todas as perguntas, os respondentes deveriam expressar sua concordância na escala Likert de 5 pontos (extremos: 1 = discordo totalmente e 5 = concordo totalmente).

Tabela 52 - Variáveis referentes aos problemas da essência custos

\begin{tabular}{|c|c|c|c|}
\hline VARIÁVEL & ASSERTIVA & $\begin{array}{c}\text { No DA } \\
\text { QUESTÃo }\end{array}$ & $\begin{array}{c}\text { PRINCIPAIS FONTES DE } \\
\text { INSPIRAÇÃO }\end{array}$ \\
\hline PRO_1 & $\begin{array}{c}\text { Quando o preço resultante da fórmula não é } \\
\text { bem aceito no mercado, optamos por } \\
\text { descontinuar o produto }\end{array}$ & $7 d$ & \multirow{4}{*}{$\begin{array}{l}\text { R. C. Skinner (1970); Christensen } \\
\text { \& Demski (1997); Noreen \& } \\
\text { Burgstahler (1997); Tzokas et al. } \\
\text { (2000); Shipley \& Jobber (2001); } \\
\text { Balakrishnan \& Sivaramakrishnan } \\
\text { (2002) }\end{array}$} \\
\hline PRO_2 & $\begin{array}{c}\text { Nós desistimos de entrar em um segmento } \\
\text { no qual o preço aceitável pelos clientes é } \\
\text { inferior ao preço sugerido pela fórmula }\end{array}$ & $7 \mathrm{a}$ & \\
\hline PRO_3 & $\begin{array}{l}\text { Mesmo quando há capacidade ociosa de } \\
\text { produção, nós rejeitamos propostas de } \\
\text { preços inferiores ao resultado da fórmula }\end{array}$ & $7 b$ & \\
\hline PRO_4 & $\begin{array}{c}\text { Por assegurar a obtenção do lucro desejado, } \\
\text { o resultado da fórmula é mais importante do } \\
\text { que a informação do valor oferecido aos } \\
\text { clientes }\end{array}$ & $7 \mathrm{e}$ & \\
\hline
\end{tabular}

\subsubsection{Constructos Explicativos do Estabelecimento dos Preços}

\subsubsection{1 $\quad \underline{\text { Diferenciação }}$}

Como definição constitutiva à diferenciação, traz-se a fidedigna existência de atributos que distinguem determinado produto. De acordo com Kotler e Keller (2012), essa diferenciação pode ser função da forma, das características, da qualidade, da durabilidade, da confiabilidade, da facilidade de reparo, do estilo, do design e da customização do produto.

Segundo Holbrook (1996), os produtos podem ser diferenciados em função de atributos intrínsecos e/ou extrínsecos. Os atributos intrínsecos são auto-orientados e referem-se a aspectos como estética, ética, espiritualidade e diversão, enquanto que os atributos extrínsecos têm orientação externa e referem-se a aspectos tangíveis como eficiência, excelência, status e reputação (DIF).

A customização, embora não seja a única fonte de diferenciação, é especialmente importante porque faz com que o produto diferenciado torne-se único (Shipley \& Jobber, 2001). 
Narayandas (2005) enfatiza que no ambiente B2B quase todo cliente necessita da customização em alguma esfera, seja essa esfera o produto, a quantidade ou o preço (CMZ).

A Tabela 53 resume as assertivas oferecidas, os números da questões correspondentes e as principais fontes de referência consultadas para acessar o constructo da diferenciação. Mais uma vez, solicitou-se que os respondentes indicassem a extensão que concordavam com as assertivas com o uso da escala Likert de 5 pontos, com extremos do $1=$ discordo totalmente ao $5=$ concordo totalmente.

Tabela 53 - Variáveis referentes à diferenciação

\begin{tabular}{c|c|c|c}
\hline VARIÁVEL & ASSERTIVA & $\begin{array}{c}\text { No DA } \\
\text { QUESTÃo }\end{array}$ & $\begin{array}{c}\text { PRINCIPAIS FONTES } \\
\text { DE INSPIRAÇÃo }\end{array}$ \\
\hline DIF & $\begin{array}{c}\text { Os atributos e funcionalidades dos nossos produtos são } \\
\text { diferentes dos atributos e funcionalidades dos produtos } \\
\text { dos nossos concorrentes }\end{array}$ & $1 \mathrm{c}$ & $\begin{array}{c}\text { Holbrook (1996); } \\
\text { Shipley \& Jobber } \\
(2001) ; \text { Narayandas } \\
\text { (2005); Kotler \& } \\
\text { Keller (2012) }\end{array}$ \\
\hline & $\begin{array}{c}\text { Priorizamos a produção customizada, ou seja, } \\
\text { frequentemente atendemos a solicitações específicas dos } \\
\text { clientes na elaboração dos nossos produtos }\end{array}$ & 11 & \multicolumn{2}{|c}{} \\
\hline
\end{tabular}

$\mathrm{Na}$ análise de regressão ordinal dos formadores de preços, apenas foi incluída a variável DIF, que teve a escala invertida e reduzida para 3 pontos. Os pontos de discordância ( 1 e 2 ) foram agregados em um único ponto (ponto 3), os pontos de concordância (4 e 5) foram agregados em outro único ponto (ponto 1) e o ponto de neutralidade (3) transformou-se em ponto 2. Dessa maneira, a variável ficou assim ordinalmente classificada: maior concordância (1), neutralidade (2), menor concordância (3).

\subsubsection{2 $\quad \underline{\text { Tamanho da Empresa }}$}

O tamanho da empresa, como o próprio nome sugere, refere-se ao porte da firma. Normalmente, a classificação em função do tamanho da empresa ocorre a partir da receita auferida ou do número de empregados.

Guilding et al. (2005), embasados em estudos anteriores que constataram relação entre o tamanho da empresa e a sofisticação dos sistemas de contabilidade, argumentaram que o tamanho da empresa tende a ser associado à importância atribuída aos custos na definição dos preços, entretanto não obtiveram evidências que confirmaram essa argumentação. Os autores escolheram definir o tamanho com base na receita. 
Nesta tese, selecionou-se a opção do número de empregados (TAM), considerando o eventual receio dos respondentes em revelar qual havia sido a receita da sua companhia. Os números de empregados que representam cada porte foram extraídos do Serviço de Apoio às Micro e Pequenas Empresas de São Paulo (SEBRAE/SP, 2016). De acordo com esses números, indústrias com até 19 empregados são de micro porte; de 20 a 99 empregados são de pequeno porte; de 100 a 499 empregados são de médio porte; e com mais de 500 empregados são de grande porte. A Tabela 54 evidencia que a questão implicou a seleção de uma dessas opções.

Tabela 54 - Variável referente ao tamanho da empresa

\begin{tabular}{|c|c|c|c|}
\hline VARIÁVEL & AsSertiva & $\begin{array}{c}\mathbf{N}^{\circ} \text { DA } \\
\text { QUESTÃO }\end{array}$ & $\begin{array}{c}\text { PRINCIPAIS FONTES DE } \\
\text { INSPIRAÇÃOO }\end{array}$ \\
\hline TAM & $\begin{array}{l}\text { Aproximadamente, quantos empregados trabalham na } \\
\text { empresa? } \\
\text {-Até } 19 \text { empregados } \\
\text { - De } 20 \text { a } 99 \text { empregados } \\
\text { - De } 100 \text { a } 499 \text { empregados } \\
\text { - Mais de } 500 \text { empregados }\end{array}$ & $\begin{array}{c}\text { Questão } \\
\text { de } \\
\text { conclusão }\end{array}$ & $\begin{array}{l}\text { Guilding et al. (2005); } \\
\text { SEBRAE/SP (2016) }\end{array}$ \\
\hline
\end{tabular}

Nas análises de regressões ordinais, a variável TAM ficou codificada dessa forma: grandes empresas (mais de 500 empregados) receberam o código 0, médias empresas (de 100 a 499 empregados) receberam o código 1, pequenas empresas (de 20 a 99 empregados) receberam o código 2 e micro empresas (até 19 empregados) receberam o código 3.

\subsubsection{Posição de Liderança no Mercado}

A liderança no mercado pode ser constitutivamente definida como a ocupação do papel de líder no ambiente de atuação. Vale destacar que, conforme Kotler e Keller (2012) explicam, o papel de líder é um dos quatro papéis normalmente encontrados nos mercados (líderes de mercado, desafiadores de mercado, seguidores de mercado e ocupantes de nicho de mercado).

O líder de mercado é a empresa que possui a maior participação de vendas (LID) e, por esse motivo, seus produtos são usualmente vistos como diferenciados, o que tende a viabilizar a formação de preços (Kotler \& Keller, 2012).

A Tabela 55 demonstra que para acessar o constructo foi elaborada uma questão que permitia selecionar uma única resposta ( $\operatorname{sim}$ ou não). Ela também evidencia o número da questão correspondente à variável e a principal fonte de inspiração consultada para sua definição. 
Tabela 55 - Variável referente à posição de liderança no mercado

\begin{tabular}{c|c|c|c}
\hline VARIÁVEL & ASSERTIVA & $\begin{array}{c}\text { No DA }^{\circ} \\
\text { QUESTÃo }\end{array}$ & $\begin{array}{c}\text { PRINCIPAIS FONTES } \\
\text { DE INSPIRAÇÃo }\end{array}$ \\
\hline \multirow{2}{*}{ LID } & $\begin{array}{c}\text { No principal segmento, a sua empresa é a líder de } \\
\text { mercado (é a empresa com maior participação de } \\
\text { vendas)? }\end{array}$ & $\begin{array}{c}\text { Questão de } \\
\text { conclusão }\end{array}$ & $\begin{array}{c}\text { Kotler \& Keller } \\
(2012)\end{array}$ \\
\hline
\end{tabular}

$\mathrm{Na}$ análise de regressão ordinal dos formadores de preços, a variável LID ficou codificada com o código 0 para líderes e com o código 1 para não líderes.

\subsubsection{Estratégia de Preço Premium}

As estratégias de preço guiam e coordenam todas as decisões de preço de uma empresa (Morris \& Calantone, 1990) e podem ser definidas constitutivamente como o meio escolhido para atingir os objetivos diante das condições internas e externas (Noble \& Gruca, 1999a).

Há várias estratégias de preços, conforme exposto por Kotler (2000), mas nesta tese foi selecionada aquela referente ao preço premium (EST). Na estratégia de preços premium, a empresa opta por cobrar um preço alto, correspondente ou muito próximo ao valor oferecido pelo produto. Colvin (2009) relata que, nessa estratégia, preços baixos podem acabar com o conceito da marca. $\mathrm{O}$ autor exemplifica que se por conta de crises as bolsas da Hermès fossem temporariamente precificadas a US\$200, ao invés de US\$ 5.000, haveria uma mudança completa do significado da marca e extinguir-se-ia a diferenciação percebida pelos clientes.

Vale mencionar que a estratégia de preços premium foi escolhida nesta tese por se encontrar no extremo da relação entre preço e qualidade e, consequentemente, possibilitar que os níveis de concordância $(1=$ discordo totalmente a $5=$ concordo totalmente) revelassem o quanto a estratégia adotada pela empresa aproximava-se ou distanciava-se desse extremo. A Tabela 56 resume a assertiva oferecida bem como as principais fontes de referência consultadas.

Tabela 56 - Variável referente à estratégia de preços premium

\begin{tabular}{c|c|c|c}
\hline VARIÁVEL & ASSERTIVA & $\begin{array}{c}\text { No DA } \\
\text { QUESTÃo }\end{array}$ & $\begin{array}{c}\text { PRINCIPAIS FONTES } \\
\text { DE INSPIRAÇÃO }\end{array}$ \\
\hline \multirow{2}{*}{ EST } & O nível de preço dos nossos produtos é elevado (preço & & $\begin{array}{c}\text { Morris \& Calantone, } \\
(1990) ; \text { Noble \& }\end{array}$ \\
& premium) & if & $\begin{array}{c}\text { Gruca (1999a); } \\
\text { Kotler (2000); } \\
\end{array}$ \\
& & & Colvin (2009) \\
\hline
\end{tabular}


$\mathrm{Na}$ análise de regressão ordinal dos formadores de preços, a variável EST teve a escala invertida e reduzida para 3 pontos. Os pontos de discordância ( 1 e 2) foram agregados em um único ponto (ponto 3), os pontos de concordância (4 e 5) foram agregados em outro único ponto (ponto 1) e o ponto de neutralidade (3) transformou-se em ponto 2. Dessa maneira, a variável ficou assim ordinalmente classificada: maior concordância (1), neutralidade (2), menor concordância (3).

\subsubsection{Intensidade da Concorrência}

Na concepção de W. Rocha (1999), os concorrentes são todos aqueles que competem por clientes e por demais recursos. Contudo, como no contexto do estabelecimento dos preços destaca-se a competição por clientes, este trabalho delimita-se à exploração dos concorrentes por clientes.

A intensidade da concorrência é uma variável contingencial referente ao ambiente de atuação da empresa que, conforme a seção 5.1 mostrou, recorrentemente é trazida como explicação ao processo de estabelecimento dos preços (e.g., Ingenbleek et al., 2003; Fabiani et al., 2005; Guilding et al., 2005; Al-Hussari, 2006). Constitutivamente, ela pode ser definida como a magnitude da competição encontrada para determinado produto ou para determinado segmento.

Em ambientes de competição intensa, há uma constante disputa pela participação de mercado mediante cortes no preço, mesmo que se saiba que tais cortes - sejam explícitos ou implícitos - são um caminho que detona a lucratividade no longo prazo (Nagle \& Hogan, 2007). Como a intensidade da concorrência é maior quanto maior for o número de concorrentes brigando pela participação do mercado, houve a indagação sobre a existência de muitos concorrentes (INC).

A concorrência tende a ser intensificada com a capacidade de imitação dos rivais e, por esse motivo, incluiu-se uma assertiva referente a esse aspecto (COP). De acordo com Nagle e Hogan (2007) e Carricano (2014), a intensidade da concorrência é maior quando os concorrentes têm competência para copiar os produtos lançados, se tais produtos não forem protegidos por barreiras de entrada (e.g., patentes, direitos autorais) ou por direitos de exclusividade. 
A Tabela 57 resume as assertivas oferecidas bem como os números da questões correspondentes e as principais fontes de referência consultadas para sua elaboração. Ambas fizeram uso da escala Likert de 5 pontos, com extremos do $1=$ discordo totalmente ao $5=$ concordo totalmente.

Tabela 57 - Variáveis referentes à intensidade da concorrência

\begin{tabular}{|c|c|c|c|}
\hline VARIÁVEL & ASSERTIVA & $\begin{array}{c}\text { No DA }^{\circ} \\
\text { QUESTÃO }\end{array}$ & $\begin{array}{c}\text { PRINCIPAIS FONTES DE } \\
\text { INSPIRAÇÃO }\end{array}$ \\
\hline INC & $\begin{array}{l}\text { Muitas outras empresas atuam no nosso } \\
\text { segmento (temos muitos concorrentes) }\end{array}$ & $1 \mathrm{a}$ & \multirow{2}{*}{$\begin{array}{l}\text { Ingenbleek et al. (2003); } \\
\text { Fabiani et al. (2005); Guilding } \\
\text { et al. (2005); Al-Hussari, } \\
\text { (2006); Nagle \& Hogan } \\
\text { (2007); Carricano (2014) }\end{array}$} \\
\hline COP & $\begin{array}{l}\text { Nossos concorrentes conseguem copiar os nossos } \\
\text { produtos com facilidade }\end{array}$ & $1 \mathrm{e}$ & \\
\hline
\end{tabular}

$\mathrm{Na}$ análise de regressão ordinal dos tomadores de preços, as variáveis INC e COP tiveram a escala invertida e reduzida para 3 pontos. Os pontos de discordância ( 1 e 2) foram agregados em um único ponto (ponto 3), os pontos de concordância (4 e 5) foram agregados em outro único ponto (ponto 1) e o ponto de neutralidade (3) transformou-se em ponto 2. Dessa maneira, as variáveis ficaram assim ordinalmente classificadas: maior concordância (1), neutralidade (2), menor concordância (3).

\subsubsection{Dificuldades para Definir os Preços conforme o Valor}

Os obstáculos que impedem ou inibem a incorporação do valor no estabelecimento dos preços configuram a definição constitutiva do constructo. Eles podem estimular as empresas a estabelecerem os preços com base nos custos.

Nos trabalhos de Hinterhuber (2008) e de Töytäri et al. (2015) encontram-se relações relativamente extensas sobre essas principais dificuldades. Entretanto, nesta tese, a fim de não oferecer aos respondentes uma lista exaustiva de opções, buscou-se sumarizar e consolidar as principais dificuldades.

Primeiramente, foi relacionada a dificuldade relativa à percepção do custo de definir preços conforme o valor (PCV), ou seja, relativa ao entendimento que a empresa tem sobre os dispêndios necessários para instituir e manter a definição dos preços pautada no valor. Afinal, tal instituição e manutenção estão longe de serem gratuitas (Liozu \& Hinterhuber, 2013). 
Liozu, Hinterhuber, Perelli e Boland (2012) explicam que tanto a instituição de um "DNA" de preços pautado no valor quanto a estruturação de novos processos trazem benefícios. No entanto, não se pode olvidar que elas, evidentemente, também trazem custos, já que recursos precisam ser investidos para que o preço baseado no valor torne-se realidade.

Na sequência, foi relacionada a dificuldade que Hinterhuber (2008) elenca como o principal obstáculo para incorporação do valor no estabelecimento dos preços (FUV). Ela refere-se à dificuldade de calcular propriamente o valor oferecido aos clientes. Muitas vezes, os profissionais responsáveis pelo processo não estão preparados para fazer esses cálculos e/ou resistem a fazê-los porque estão com uma visão de formação de lucro equivocada.

Em seguida, trouxe-se a dificuldade da compreensão do processo (PRV), amparada na defesa de G. E. Smith e Nagle (1994) que, para definir os preços, não basta identificar o quanto é preciso para cobrir os custos e gerar lucro: é necessário identificar o quanto os clientes sentem-se motivados a comprar os produtos ao preço formado pela combinação entre esses custos e lucro. Indounas (2006) alerta que a ausência do entendimento dessa dinâmica pode conduzir a um desastre na formação do lucro.

Por exemplo, se for esperado um volume muito pequeno de vendas e de produção, o preço determinado tende a ser alto (seja por que o custo unitário acaba sendo alto ou por que a margem por unidade precisa ser alta para cobrir todos os custos e despesas fixos). O preço alto desestimula a aquisição dos produtos pelos clientes e, assim, o volume de vendas e de produção cai para um nível mais baixo do que era estimado. O volume mais baixo faz com que a revisão de preços sugira a colocação de um preço mais alto, que desestimula ainda mais a aquisição dos produtos e leva a níveis de vendas e de produção ainda mais baixos. Esse processo continua até que o volume caia a zero e que o preço tenda ao infinito.

Para R. C. Skinner (1970), é insano acreditar que os volumes de vendas podem ser estimados independentemente do preço. Logo, adotar uma postura inflexível e acreditar que um prejuízo estará presente na venda caso sejam aceitos preços inferiores ao resultado da combinação entre a margem e todos os custos e despesas (rateados por um volume ainda incerto), demonstra a falta de uma completa compreensão da dinâmica do processo. 
Finalmente, foi apresentada a dificuldade referente à disposição dos clientes em pagar pelo valor que lhes é oferecido (DIV). De acordo com Töytäri et al. (2015), especialmente no ambiente B2B, os clientes estão mais acostumados a negociar com base no preço do que com base no valor e, por isso, costumam resistir a escolhas em que o valor, mas também o preço, é maior.

A Tabela 58 demonstra as assertivas elaboradas assim como os números das questões a elas correspondentes e as principais fontes de referência consultadas para sua definição. Cumpre mencionar que, mais uma vez, as respostas deveriam ser enquadradas na escala Likert de 5 pontos, com extremos do $1=$ discordo totalmente ao $5=$ concordo totalmente.

Tabela 58 - Variáveis referentes às dificuldades para definir os preços conforme o valor

\begin{tabular}{|c|c|c|c|}
\hline VARIÁVEL & ASSERTIVA & $\begin{array}{c}\mathbf{N}^{\circ} \text { DA } \\
\text { QUESTÃO }\end{array}$ & $\begin{array}{l}\text { PRINCIPAIS FONTES } \\
\text { DE INSPIRAÇÃO }\end{array}$ \\
\hline PCV & $\begin{array}{l}\text { No nosso entendimento, são necessários investimentos e } \\
\text { gastos significativos para conseguirmos cobrar preços } \\
\text { conforme o valor oferecido aos clientes }\end{array}$ & $8 \mathrm{a}$ & \multirow{4}{*}{$\begin{array}{c}\text { R. C. Skinner } \\
\text { (1970); G. E. Smith, } \\
\text { \& Nagle (1994); } \\
\text { Indounas (2006); } \\
\text { Hinterhuber (2008); } \\
\text { Liozu, Hinterhuber, } \\
\text { Perelli, \& Boland } \\
\text { (2012); Liozu \& } \\
\text { Hinterhuber, (2013); } \\
\text { Töytäri et al. (2015) }\end{array}$} \\
\hline FUV & $\begin{array}{l}\text { Nossos funcionários não estão preparados para calcular } \\
\text { o valor oferecido aos clientes }\end{array}$ & $8 b$ & \\
\hline PRV & $\begin{array}{c}\text { Teremos prejuízo na venda, se aceitarmos que os } \\
\text { clientes paguem preços inferiores ao resultado da } \\
\text { combinação entre os custos e a margem }\end{array}$ & $7 \mathrm{c}$ & \\
\hline DIV & $\begin{array}{l}\text { Nossos clientes não estão dispostos a pagar preços que } \\
\text { correspondam integralmente ao valor a eles oferecido }\end{array}$ & $8 \mathrm{c}$ & \\
\hline
\end{tabular}

Nas análises de regressões ordinais, as variáveis PCV, FUV, PRV e DIV tiveram a escala invertida e reduzida para 3 pontos. Os pontos de discordância ( 1 e 2 ) foram agregados em um único ponto (ponto 3), os pontos de concordância (4 e 5) foram agregados em outro único ponto (ponto 1) e o ponto de neutralidade (3) transformou-se em ponto 2. Dessa maneira, as variáveis ficaram assim ordinalmente classificadas: maior concordância (1), neutralidade (2), menor concordância (3).

\subsubsection{Pressões Isomórficas}

As pressões isomórficas são constitutivamente definidas como as pressões que forçam uma unidade na população a se assemelhar a outras unidades que lidam com as mesmas condições ambientais (DiMaggio \& Powell, 1983). Mais especificamente, no contexto organizacional, as pressões isomórficas podem ser definidas como as pressões que forçam as organizações a adotarem procedimentos similares (Van der Steen, 2005). 
Como o isomorfismo institucional força a semelhança das unidades mediante diferentes pressões (coercitivas, normativas e miméticas) (DiMaggio \& Powell, 1983), colocam-se nesta tese questionamentos que investigam isoladamente a influência de cada uma delas no estabelecimento dos preços.

Entre as pressões coercitivas (ISC), relacionam-se as imposições da matriz sobre as subsidiárias e as imposições do governo e/ou de órgãos reguladores (Granlund \& Lukka, 1998; Malmi, 1999; Guler et al., 2002; Rezende, 2009; Schulz et al., 2014); entre as pressões normativas (ISN), apresentam-se as orientações decorrentes de cursos e as orientações de associações de profissionais (Granlund \& Lukka, 1998; S. Maxwell, 1998; Van der Steen, 2005; Rezende, 2009); e entre as pressões miméticas (ISM), colocam-se as aquisições de softwares em que os preços são definidos a partir dos custos (Granlund \& Lukka, 1998; Rezende, 2009; Brandau et al., 2013; Schulz et al., 2014).

As questões estabelecidas solicitaram que os respondentes assinalassem sua extensão de concordância. As respostas deveriam ser enquadradas na escala Likert de 5 pontos, com extremos do $1=$ discordo totalmente ao $5=$ concordo totalmente. A Tabela 59 resume as questões, seus números e as principais fontes.

Tabela 59 - Variáveis referentes às pressões isomórficas

\begin{tabular}{|c|c|c|c|}
\hline VARIÁVEL & ASSERTIVA & $\begin{array}{c}N^{\circ} \text { DA } \\
\text { QUESTÃo }\end{array}$ & $\begin{array}{l}\text { PRINCIPAIS FONTES DE } \\
\text { INSPIRAÇÃO }\end{array}$ \\
\hline ISC & $\begin{array}{l}\text { Há imposições da matriz, do governo e/ou de } \\
\text { órgãos reguladores que nos obrigam a formar os } \\
\text { preços a partir dos custos }\end{array}$ & $8 d$ & \multirow{3}{*}{$\begin{array}{c}\text { DiMaggio \& Powell (1983); } \\
\text { Granlund \& Lukka (1998); S } \\
\text { Maxwell (1998); Malmi } \\
\text { (1999); Guler et al. (2002); } \\
\text { Van der Steen (2005); } \\
\text { Rezende (2009); Brandau et } \\
\text { al. (2013); Schulz et al. } \\
\text { (2014) }\end{array}$} \\
\hline ISN & $\begin{array}{l}\text { Seguimos orientações de livros/estudos de casos } \\
\text { e/ou de associações de profissionais que sugerem a } \\
\text { formação de preços a partir dos custos }\end{array}$ & $8 \mathrm{e}$ & \\
\hline ISM & $\begin{array}{l}\text { Adquirimos um software no qual os preços são } \\
\text { necessariamente estabelecidos a partir dos custos }\end{array}$ & $8 f$ & \\
\hline
\end{tabular}

Nas análises de regressões ordinais, as variáveis ISC, ISN e ISM tiveram a escala invertida e reduzida para 3 pontos. Os pontos de discordância (1 e 2) foram agregados em um único ponto (ponto 3), os pontos de concordância (4 e 5) foram agregados em outro único ponto (ponto 1) e o ponto de neutralidade (3) transformou-se em ponto 2. Dessa maneira, as variáveis ficaram assim ordinalmente classificadas: maior concordância (1), neutralidade (2), menor concordância (3). 


\subsubsection{8 $\quad \underline{\text { Ambiente de Atuação }}$}

O ambiente de atuação é definido constitutivamente como o ambiente no qual a empresa oferece produtos e/ou serviços a seus clientes. Ele pode ser configurado como o ambiente no qual os produtos são destinados a outras empresas (B2B) ou no qual os produtos são destinados aos consumidores finais (B2C) (Cooke, 1986; Coviello \& Brodie, 2001). Optou-se ainda por apartar empresas oferecedoras de commodities e de engenharia e construção. Neste trabalho, os segmentos definidos por ambiente foram:

a) produtos destinados a outras empresas - automotivo; equipamentos; fertilizantes e defensivos; insumos para indústria de bens de consumo; materiais para construção; metalúrgico; papel, plástico e embalagens; peças e acessórios; químico; tecidos e confecções profissionais;

b) produtos destinados aos consumidores finais - alimentos; farmacêutico; produtos de higiene e limpeza; roupas e calçados; utensílios e aparelhos domésticos e de escritório;

c) commodities - açúcar e energia; agrícola e florestal; mineração; e

d) engenharia e construção - engenharia e construção.

Optou-se por identificar o ambiente de atuação (AMB) investigando o tipo de produto oferecido e, consequentemente, o tipo de ambiente atendido pelas empresas (Tabela 60).

Tabela 60 - Variável referente ao ambiente de atuação

\begin{tabular}{c|c|c|c}
\hline VARIÁVEL & QUESTÃo & $\begin{array}{c}\text { No DA } \\
\text { QUESTÃo }\end{array}$ & $\begin{array}{c}\text { PRINCIPAIS FONTES DE } \\
\text { INSPIRAÇÃo }\end{array}$ \\
\hline \multirow{2}{*}{ AMB } & Quais são os três principais produtos vendidos pela \\
empresa? & $\begin{array}{c}\text { Questão } \\
\text { de } \\
\text { conclusão }\end{array}$ & $\begin{array}{c}\text { Cooke (1986); Coviello } \\
\text { \& Brodie (2001) }\end{array}$ \\
\hline
\end{tabular}

Nas análises de regressões ordinais, a variável AMB ficou codificada com o código 0 para o ambiente no qual os produtos são destinados a outras empresas (B2B) e com o código 1 para os demais ambientes. 


\subsubsection{Experiência no Estabelecimento dos Preços}

A experiência no estabelecimento dos preços pode ser constitutivamente definida como a habilidade formada no exercício contínuo de definição dos preços. Ela influencia o modo que os tomadores de decisão percebem o problema e interfere na base comparativa acessada para chegar à deliberação (Van Bruggen et al., 2001; Hambrick, 2007).

Para operacionalizar sua mensuração, optou-se por seguir a usual apuração de tempo de exercício em determinada atividade (Myers, Griffith, Daugherty, \& Lusch, 2004), ou seja, do tempo de atuação no estabelecimento dos preços (EXP).

A Tabela 61 demonstra a variável elaborada, bem como a questão definida e as principais fontes de referência consultadas na tentativa de acessar empiricamente o conceito.

Tabela 61 - Variável referente à experiência no estabelecimento dos preços

\begin{tabular}{c|c|c|c}
\hline VARIÁVEL & ASSERTIVA & $\begin{array}{c}\mathbf{N}^{\circ} \text { DA } \\
\text { QUESTÃo }\end{array}$ & $\begin{array}{c}\text { PRINCIPAIS FONTES } \\
\text { DE INSPIRAÇÃO }\end{array}$ \\
\hline \multirow{3}{*}{ EXP } & $\begin{array}{c}\text { Há aproximadamente quanto tempo você (ou o principal } \\
\text { responsável pelo processo) atua no estabelecimento dos } \\
\text { preços? }\end{array}$ & $\begin{array}{c}\text { Questão de } \\
\text { conclusão }\end{array}$ & $\begin{array}{c}\text { Van Bruggen et al. } \\
(2001) ; \text { Myers et al. } \\
(2004) ; \text { Hambrick } \\
(2007)\end{array}$ \\
\hline
\end{tabular}

Nas análises de regressões ordinais, a variável EXP ficou representada pela quantidade de anos tal como informada pelo respondente (possibilidade de anos fracionados, como, por exemplo, 1,5 anos).

\subsubsection{Custos Totais na Fórmula "Custos mais Margem"}

Como o próprio nome sugere, os custos totais na fórmula "custos mais margem" referem-se ao tipo de custo selecionado como elemento de operacionalização da definição dos preços.

Conforme Guerreiro et al. (2012) explicam, os custos fixos e as despesas fixas podem aparecer na fórmula de duas maneiras: como componentes aos quais a margem é somada; ou, alternativamente, como elementos que a margem de contribuição busca cobrir. Críticas normalmente são colocadas à utilização de ambos como componentes da fórmula e defesas são lançadas ao uso de apenas os custos variáveis (Indounas, 2006). Vale, no entanto, 
mencionar que, por mais que não seja recomendada, a inclusão dos custos fixos (CFX) e das despesas fixas (DES) nos componentes da fórmula ainda predomina nas empresas, conforme se demonstrou no capítulo 3.

A Tabela 62 relaciona as variáveis e questões elaboradas, além de revelar as principais fontes de referência analisadas para acessar o constructo. Mais uma vez, as respostas deveriam ser enquadradas na escala Likert de 5 pontos, com extremos do $1=$ discordo totalmente ao $5=$ concordo totalmente.

Tabela 62 - Variáveis referentes aos custos totais na fórmula "custos mais margem"

\begin{tabular}{|c|c|c|c|}
\hline VARIÁVEL & ASSERTIVA & $\begin{array}{c}N^{\circ} \text { DA } \\
\text { QUESTÃO } \\
\end{array}$ & \begin{tabular}{|c} 
PRINCIPAIS FONTES \\
DE INSPIRAÇÃO
\end{tabular} \\
\hline CFX & $\begin{array}{c}\text { Todos os custos fixos de produção (por exemplo, } \\
\text { aluguel da fábrica, salário do supervisor etc.) devem } \\
\text { NECESSARIAMENTE ser incluídos nas fórmulas de } \\
\text { preços }\end{array}$ & $5 a$ & \multirow{2}{*}{$\begin{array}{l}\text { Indounas (2006); } \\
\text { Guerreiro et al. } \\
\quad(2012)\end{array}$} \\
\hline DES & $\begin{array}{c}\text { Todas as despesas fixas (administrativas, comerciais e } \\
\text { financeiras) devem NECESSARIAMENTE ser incluídas } \\
\text { nas fórmulas de preços }\end{array}$ & $5 b$ & \\
\hline
\end{tabular}

Nas análises de regressões ordinais, as variáveis CFX e DES tiveram a escala invertida e reduzida para 3 pontos. Os pontos de discordância (1 e 2) foram agregados em um único ponto (ponto 3), os pontos de concordância (4 e 5) foram agregados em outro único ponto (ponto 1) e o ponto de neutralidade (3) transformou-se em ponto 2. Dessa maneira, as variáveis ficaram assim ordinalmente classificadas: maior concordância (1), neutralidade (2), menor concordância (3).

\subsection{Hipóteses de Pesquisa}

Agora que os constructos já foram apresentados, pode-se passar à exposição das relações esperadas entre eles. Essas relações constituem as hipóteses de pesquisa. A principal diferença entre as hipóteses e os problemas de pesquisa é que enquanto as primeiras são sentenças afirmativas, os segundos são sentenças interrogativas. Por serem sentenças afirmativas, as hipóteses enunciam relações testáveis entre duas ou mais variáveis e permitem que o ser humano teste aspectos da realidade com um mínimo de distorção causada por predileções. Ora, as hipóteses, embora sejam construídas pelo ser humano, podem ser testadas e assim sua 
aceitação ou rejeição ocorre pela própria realidade e não por influências de crenças e valores do pesquisador (Kerlinger, 1980).

Outra virtude das hipóteses, segundo Kerlinger (1980), consiste no fato que as mesmas são uma forma de testar a validade do arcabouço teórico existente, uma vez que são dele deduzidas. G. Martins e Theóphilo (2009) corroboram esse entendimento, acrescentando que a aceitação ou a rejeição das hipóteses pode complementar significativamente a resposta à questão de pesquisa e o alcance dos objetivos de estudos, além de auxiliar fortemente na explicação do fenômeno em observação. Os autores ainda expressam que:

\footnotetext{
A abordagem metodológica hipotético-dedutiva - comum nos estudos da área de humanidades - pede o enunciado de hipóteses que no desenvolvimento do trabalho serão testadas e comprovadas através do suporte do referencial teórico e análises dos resultados de avaliações quantitativas e qualitativas das informações, dados e evidências conseguidas. (p. 31)
}

Esta seção, portanto, dedica-se ao desenvolvimento das hipóteses da pesquisa. Com base na revisão e na análise da literatura realizadas nos capítulos anteriores, são conjecturadas as associações previstas entre o estabelecimento dos preços orientado exclusivamente pelos custos e os dez fatores levantados.

\subsubsection{Hipótese 1 - Diferenciação}

Já se discutiu que uma empresa é tomadora de preços quando oferece produtos não percebidos como diferentes, uma vez que a semelhança faz com que os clientes não se importem em saber qual vendedor forneceu os produtos e priorizem o preço. Por outro lado, uma empresa é formadora de preços quando oferece produtos percebidos como diferentes porque as características peculiares fazem com que os clientes importem-se em saber qual vendedor forneceu os produtos (Hofstrand, 2007). Logo, a diferenciação está presente apenas nos formadores de preços e somente pode explicar a configuração do processo de estabelecimento dos preços em empresas desse enquadramento.

Hofstrand (2007) frisa que a diferenciação é uma questão de percepção. Nesse sentido, além de haver as situações em que a diferenciação percebida nos formadores de preços corresponde à real diferenciação do produto, podem ser encontradas ocorrências extremistas em que um produto é percebido como muito diferenciado quando na realidade não é (i.e., em decorrência 
de propagandas maciças da marca) ou em que um produto é muito diferenciado, mas ainda não é percebido como tal (i.e., falta os clientes conscientizarem-se do valor).

Nesse sentido, é possível inferir que o processo de estabelecer os preços não é interferido só pela diferenciação percebida (que designa o enquadramento), mas também pela diferenciação realmente encontrada. Afinal, como Oxenfeldt (1961) e Ingenbleek et al. (2003) advertem, quanto mais diferentes os produtos realmente forem e quanto mais valorizada a diferenciação for, mais a empresa consegue formar os preços. Em outras palavras, pode-se dizer que quando os produtos são realmente diferentes, o poder de formar preços tende a se perpetuar, o que não acontece necessariamente quando a diferenciação não passa de percepção.

Dessa forma, sabe-se que, embora tanto as empresas com produtos totalmente diferenciados quanto as empresas com produtos apenas percebidos como diferenciados sejam formadoras de preços, as primeiras possuem um poder mais sustentável do que as segundas.

De acordo com Gatignon e Xuereb (1997), as empresas que ofertam produtos comuns (pouco diferenciados) sabem que não podem manter preços altos para justificar ineficiências de custos, o que não acontece com as empresas que ofertam produtos com vários atributos diferentes. Essas empresas, diante do poder sustentável proporcionado pela diferenciação, vão buscar colocar preços que atendam a todos os seus almejos de cobertura de custos (eficientes ou não) e de lucratividade. Al-Hussari (2006) apresentou essa argumentação e obteve evidências que a suportou. Gordon et al. (1981) também haviam constatado empiricamente que os produtos diferenciados eram mais embasados nos custos do que os produtos padronizados.

Partindo dessas considerações, formula-se a Hipótese 1: A maior (menor) diferenciação explica a maior (menor) essência custos nos formadores de preços.

\subsubsection{Hipótese 2 - Tamanho da Empresa}

Carson et al. (1998) argumentam que as decisões de preços são menos estruturadas e mais simplificadas em organizações de pequeno porte do que em organizações de grande porte. 
Além disso, os autores relatam que há um quase consenso sobre o predomínio do uso dos custos mais margem em pequenas empresas.

Ao retomar os achados das pesquisas sobre o tema, consegue-se reforçar esse argumento. Hankinson (1995), por exemplo, detectou que os custos mais margem eram menos encontrados nas empresas de maior porte da sua amostra. Fabiani et al. (2005), da mesma forma, frisou que as nove pesquisas nacionais por eles sumarizadas indicaram que as pequenas empresas, mais do que as grandes empresas, tendiam a tomar suas decisões de preços pautadas pelos custos. Mais recentemente, Hinterhuber (2016) alegou que, embora não sejam poucas as grandes empresas que determinam os preços a partir dos custos, ainda prevalece a ideia de que são as pequenas empresas que mais definem os preços ancoradas nesse tipo de informação.

Guilding et al. (2005), assim como Al-Hussari (2006), seguindo a mesma lógica do seu orientador Drury (um dos autores de Guilding et al., 2005), discordaram e sugeriram que são as grandes empresas (não as pequenas) que tendem a atribuir mais importância aos custos mais margem. Seus resultados, todavia, não lhes deram razão ao passo que não obtiveram significância estatística e, além disso, o sinal observado por Al-Hussari (2006) foi oposto ao que era previsto (sinal positivo previsto; sinal negativo observado). Já Copaciu et al. (2010) e Malik et al. (2010) constataram que as empresas de grande porte priorizavam a combinação dos custos à margem, enquanto que as pequenas empresas priorizavam os preços prevalecentes no mercado, mas a não segregação entre formadores e tomadores de preços pode ter enviesado os resultados.

Destarte, percebe-se que ainda não se refutou o que a literatura costuma difundir, isto é, que, para deliberar sobre os preços, as pequenas empresas aderem mais aos custos do que as grandes empresas. O pequeno tamanho da empresa, por mais que não possa ser considerado como justificativa plausível, parece, sim, explicar as deliberações de preços mais simplistas, como aquelas baseadas nos custos que não incorporam o valor (Liozu \& Hinterhuber, 2013).Vale frisar que Indounas (2015) argumenta que em pequenas empresas, sejam formadoras ou tomadoras de preços, as decisões de preços tendem a ser menos organizadas e tomadas por gestores globais. 
A partir dessas arguições, propõe-se a Hipótese 2: O maior (menor) tamanho da empresa explica a menor (maior) essência custos nos formadores de preços e nos tomadores de preços.

\subsubsection{Hipótese 3-Posição de Liderança no Mercado}

Após chegarem a resultados não significativos com relação ao tamanho da empresa, Guilding et al. (2005) sugeriram que a posição no mercado poderia ajudar a entender a importância conferida aos custos no estabelecimento dos preços. Nesse sentido, vale mencionar que, de acordo com Kotler e Keller (2012), as empresas podem ocupar quatro posições no mercado: seguidoras de mercado, desafiadoras de mercado, ocupantes de nicho de mercado e líderes de mercado.

As empresas das duas primeiras categorias são tipicamente tomadoras de preços, já que encontram opções semelhantes oferecidas pelos concorrentes. Afinal, segundo Kotler e Keller (2012), os seguidores de mercado contentam-se em seguir os preços dos líderes, enquanto que os desafiadores de mercado, como o nome sugere, buscam desafiar os preços dos líderes de mercado.

Os formadores de preços normalmente concentram-se nas categorias de ocupantes de nicho de mercado ou de líderes de mercado. Os ocupantes de nicho de mercado têm um poder relativamente modesto sobre os preços, uma vez que a percepção da diferenciação restringe-se aos clientes do nicho de atuação. Já os líderes de mercado têm elevado poder sobre os preços porque seus produtos, pelo menos na mente da maior parte dos consumidores, são percebidos como altamente diferenciados.

Kotler e Keller (2012) frisam que os líderes de mercado influenciam as demais empresas do mercado. Diante dessa influência e da ausência de concorrência direta, eles podem sentir-se motivados a colocar os preços que mais bem atendam seus anseios de lucratividade. Por esse motivo, Guilding et al. (2005) argumentam que o papel dos custos na formação dos preços é potencializado em líderes de mercado. 
Considerando esse contexto, deduz-se a Hipótese 3: A posição de líder de mercado (não líder de mercado) explica a maior (menor) essência custos nos formadores de preços.

\subsubsection{Hipótese 4 - Estratégia de Preço Premium}

Conforme mostrado na seção 5.1.7, Ingenbleek e van der Lans (2013) já buscaram investigar a relação existente entre as estratégias e o processo de estabelecimento dos preços. Entretanto, os resultados do trabalho dos autores foram comprometidos porque não houve segregação entre os tomadores e os formadores de preços, olvidando-se o fato postulado por Harper (1966) que os tomadores não têm estratégias de preço.

Nesta tese, busca-se corrigir esse esquecimento e restringir o exame das estratégias de preço aos formadores de preços. Afinal, nos tomadores, o nível de preço não é uma escolha, mas, sim, uma necessidade frente aos preços correntes no mercado.

De acordo com Kotler (2000), uma das estratégias de preços extremistas é aquela de preços premium, em que tanto a qualidade quanto o nível de preço são altos. Ingenbleek e van der Lans (2013) constataram empiricamente que empresas com a estratégia de preços premium incorporavam mais o valor no estabelecimento dos preços do que empresas com outras estratégias. Segundo esses autores, o fato de a estratégia de preços premium requerer preços em níveis permanentemente elevados (condizentes com os níveis de qualidade elevados) carece que o teto do preço seja identificado e, consequentemente, pede que o valor oferecido aos clientes seja avaliado, afastando dos custos a essência do processo.

Diante dessas circunstâncias, propõe-se a Hipótese 4: A adoção de estratégias de preço premium explica a menor (maior) essência custos nos formadores de preços.

\subsubsection{Hipótese 5 - Intensidade da Concorrência}

Na seção 5.1, mostrou-se que a intensidade da concorrência é um fator recorrentemente apresentado para entendimento do estabelecimento dos preços. Apontou-se também que, infortunadamente, não há consenso nos trabalhos anteriores sobre o fator, uma vez que enquanto alguns estudos concluíram que ele estava associado ao maior embasamento nos 
custos (Ingenbleek et al., 2003; Guilding et al., 2005), outros indicaram que ele estava associado ao menor embasamento nos custos (Fabiani et al., 2005, Al-Hussari, 2006).

Nesta pesquisa, procura-se sanar essas contradições ao eliminar a comparação sem sentido da intensidade da concorrência nos tomadores e nos formadores de preços. Afinal, é evidente que os tomadores estão muito mais expostos à concorrência do que os formadores, tanto que eles, sim, possuem condições de identificar os preços colocados pelos concorrentes.

Nos formadores, os concorrentes existem, mas não é factível comparar os próprios preços com os preços da concorrência se não houver uma inteligência de mercado instalada, assim como ilustra o exemplo de Dutta et al. (2003). Argumenta-se, portanto, que a intensidade da concorrência é um fator que explica a definição dos preços nos tomadores de preços, não nos formadores.

Quanto mais os tomadores atuam em um mercado de competição intensa, mais eles têm que lidar com comportamentos oportunistas dos concorrentes, dentre os quais, ressaltam-se: concorrentes forçando a igualdade dos preços; concorrentes buscando ampliar a fatia de participação de mercado e derrubando os próprios preços (Nagle \& Hogan, 2007); e concorrentes oferecendo atributos adicionais nos produtos, sem deixar de cobrar o preço básico dos produtos (Ingenbleek et al., 2003).

Observa-se que os três comportamentos oportunistas exigem eficiência das empresas. Logo, não faz sentido para os tomadores de preços expostos à intensa concorrência atravancar o processo de definição dos preços com um forte embasamento nos custos, já que no final os preços, invariavelmente, devem espelhar os preços dos concorrentes. Nessas circunstâncias, é preferível que a combinação "custos mais margem”, por meio da margem, já indique preços coerentes à concorrência.

Por essa razão, infere-se que, diante da intensa concorrência, os tomadores apresentam processos mais concisos (já buscam conectar os custos aos preços dos concorrentes por intermédio da margem). Destarte, concorda-se com a defesa de Fabiani et al. (2005) e de AlHussari (2006) que o embasamento nos custos está mais presente quando a intensidade da concorrência é menor, não maior. 
Diante dessas constatações, formula-se a Hipótese 5: A maior (menor) intensidade da concorrência explica a menor (maior) essência custos nos tomadores de preços.

\subsubsection{Hipótese 6 - Dificuldades para Definir os Preços conforme o Valor}

Hinterhuber (2008) e Töytäri et al. (2015) sugerem que o valor não é incorporado no estabelecimento dos preços porque há dificuldades para a implantação e a manutenção de processos nele pautados. Ora, é evidente que, tanto nos tomadores quanto nos formadores de preços, os responsáveis pelo estabelecimento dos preços vão procurar alternativas para a definição dos preços se julgarem difícil a mensuração e a comunicação do valor e, além disso, não conseguirem segmentar apropriadamente o mercado, gerenciar o pessoal de vendas, conquistar o apoio da alta gerência, influenciar o valor desejado pelo cliente e capturar parte do valor criado (Hinterhuber, 2008; Töytäri et al., 2015).

Os custos inerentes à implantação e à manutenção de processos para incorporar o valor no estabelecimento dos preços desestimulam ainda mais sua aplicação. Afinal, como Liozu, Hinterhuber, Perelli e Boland (2012) advertem, para conseguir, verdadeiramente, aderir ao valor, as empresas precisam modificar seu "DNA" e manter perenemente novos procedimentos.

Por constatar as dificuldades e os elevados custos de estabelecer os preços conforme o valor, as empresas podem preferir desprezar esse tipo de informação e tomar suas decisões guiadas por mecanismos mais simples, como "custos mais margem”. Shipley e Jobber (2001) relatam que a combinação dos custos a uma margem arbitrariamente definida é fácil e rapidamente compreensível.

Seja nos formadores ou nos tomadores de preços, de acordo com Tzokas et al. (2000), não é complexo chegar aos preços que unicamente asseguram a cobertura de todos os custos (sejam eles viáveis ou não). Waller et al. (1999) inclusive defendem que é estridente a economia nesse tipo de decisão. Diferentemente da incorporação do valor, que requer investimentos substanciais, decidir os preços com base nos custos mais margem implica a atuação com informações que já estão disponíveis porque já foram elaboradas para outras finalidades. 
Diante desse contexto, propõe-se a Hipótese 6: As dificuldades para definir os preços conforme o valor explicam a maior (menor) essência custos nos formadores de preços e nos tomadores de preços.

\subsubsection{Hipótese 7 - Pressões Isomórficas}

O isomorfismo pode influenciar as escolhas sobre o estabelecimento dos preços, ao passo que pode forçar uma unidade na população a se assemelhar a outras unidades que lidam com as mesmas condições ambientais (DiMaggio \& Powell, 1983). De acordo com Van der Steen (2005), o isomorfismo institucional pode ser usado para entender o motivo pelo qual as organizações costumam adotar procedimentos similares.

Conforme a seção 5.2.1 demonstrou, diversas pressões isomórficas podem estar presentes no estabelecimento dos preços, merecendo destacar: imposições de reguladores; imposições da matriz às subsidiárias; orientações decorrentes da educação profissional; orientações de grupos profissionais; aplicação de orientações tradicionais e simplistas (pré-formatadas); e imitação das outras organizações (Granlund \& Lukka, 1998).

Muller (1997), por exemplo, constatou que um motivo para as empresas ainda ignorarem a incorporação de informações de valor era o ímpeto, por parte dos gestores, em adotar modelos tradicionais e simplistas pautados nos custos. Nesse sentido, conjectura-se que nos formadores e nos tomadores de preços pode haver uma maior aderência à essência custos, se houver: qualquer imposição da matriz ou do governo que obrigue os preços a serem definidos a partir dos custos; orientações de livros ou de associações profissionais que sugiram o estabelecimento dos preços a partir dos custos; e/ou uso de software pautado nos custos.

Vale, no entanto, destacar que da mesma forma que existem imposições, sugestões e softwares orientando a definição dos preços a partir dos custos, podem haver imposições, sugestões e softwares orientando o estabelecimento dos preços a partir de outros tipos de informações, sobretudo a partir de informações da concorrência nos tomadores de preços. 
De qualquer forma, frente às mais frequentes evidências de pressões para a determinação dos preços a partir dos custos, deduz-se a Hipótese 7: As pressões isomórficas explicam a maior (menor) essência custos nos formadores de preços e nos tomadores de preços.

\subsubsection{Hipótese 8-Ambiente de Atuação B2B}

Farres (2012) alerta que o estabelecimento dos preços é influenciado pelo ambiente de atuação das empresas e propõe a Figura 50 para defender que: quanto mais os produtos ofertados no ambiente aproximam-se da condição de commodities, menos o valor é considerado no processo; e que quanto mais os produtos ofertados no ambiente configuram-se como proposições de valor, mais o valor é incorporado. Como os produtos oferecidos por empresas do ambiente B2B normalmente implicam, em maior ou menor extensão, proposições de valor, nota-se uma primeira evidência do motivo pelo qual é importante considerar o valor e não se ater aos custos.

Figura 50 - Estabelecimento dos preços e ambiente de atuação

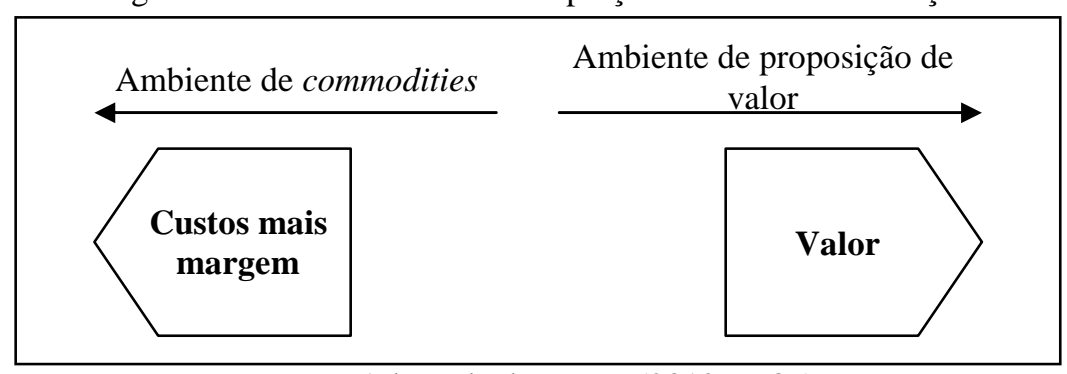

Fonte: Adaptada de Farres (2012, p. 36)

Nos formadores de preços do ambiente B2B, os produtos usualmente são desenhados conforme o desejo dos compradores, sobretudo quando se trata de maquinários e equipamentos (Narayandas, 2005). Como, nesse ambiente, o uso particular dos produtos determina o valor, as empresas podem sentir-se motivadas a identificar e demonstrar os benefícios singulares que oferecem e, assim, a incorporar o valor no estabelecimento dos preços, afastando o processo da essência custos.

Já nos tomadores de preços do ambiente B2B, os produtos ofertados, por mais que não sejam diferenciados, são de suma importância para os clientes, afinal, a quebra de equipamentos pode paralisar a produção e impedir que eles consigam atender a demanda a que se propunham. Por exemplo, a quebra do computador de um único consumidor não é um evento 
crítico, mas a quebra do mainframe de um banco é um evento crítico e requer suporte imediato para evitar que a vasta gama de consumidores do banco seja prejudicada (Cooke, 1986). Por esse motivo, tomadores do ambiente B2B, podem sentir-se motivados a demonstrar os benefícios que eles e seus concorrentes entregam e, desse modo, a incorporar o valor no estabelecimento dos preços, afastando o processo da essência custos.

Dessas exposições, pode-se depreender a Hipótese 8: A atuação no ambiente B2B explica a menor (maior) essência custos nos formadores de preços e nos tomadores de preços.

\subsubsection{Hipótese 9- Experiência no Estabelecimento dos Preços}

A experiência adquirida no estabelecimento dos preços tende a aprimorar o processo. Os acertos e desacertos percebidos ao longo do tempo expandem o contexto funcional dos tomadores de decisões e dilatam as situações prévias por eles consideradas nas deliberações (Van Bruggen et al., 2001).

Hambrick (2007) expõe que as experiências dos executivos influenciam fortemente suas interpretações e, consequentemente, afetam suas escolhas. Por esse motivo, talvez, Shipley e Jobber (2001) tenham percebido que gestores juniores, que não têm uma visão estratégica nem um entendimento razoável do funcionamento do mercado, tendem a aderir ao estabelecimento dos preços ancorado unicamente nos custos.

Liozu e Hinterhuber (2012), por sua vez, frisam que tempo é requerido para incorporar informações alheias aos custos no estabelecimento dos preços. A natureza transformacional do valor, por exemplo, carece de uma experimentação constante que avança o conhecimento e aperfeiçoa a determinação dos preços. Nesse sentido, quanto mais experiência o profissional responsável pelo processo tiver, mais provável é que ele tenha tentado e conseguido afastar os preços dos custos e aproximá-los do valor nos formadores de preços e da concorrência nos tomadores de preços.

Diante dessas considerações, elabora-se a Hipótese 9: A experiência explica a menor (maior) essência custos nos formadores de preços e nos tomadores de preços. 
6.5.10 Hipótese 10 - Custos Totais na Fórmula "Custos mais Margem”

Quando a fórmula "custos mais margem" tem os custos totais como elemento, as empresas vêem-se diante da necessidade de colocar preços capazes de, simultaneamente, cobrir todos os custos (variáveis, fixos e despesas) e proporcionar a margem de lucro desejada. Elas têm possibilidades remotas de cobrarem um preço distinto do indicado pela fórmula e, assim, são praticamente obrigadas a estabelecerem o único preço que assegura a cobertura de todos os custos e a obtenção da margem de lucro almejada (Guerreiro \& Amaral, 2016).

Nos formadores de preços, o uso dos custos totais é rígido, pois deixa as empresas com uma faixa muito restrita para a variação da margem. A limitação na faixa da variação da margem normalmente faz com que a empresa opte por um percentual único para todos os clientes (não raramente também para todos os produtos), o que impede que características específicas dos produtos e dos clientes impactem os preços. Ou seja, o uso dos custos totais inibe a incorporação do valor na definição dos preços (Indounas, 2006).

Já nos tomadores de preços, o uso dos custos totais também é rígido e, de acordo Cavusgil (1988), pode originar preços tão utópicos a ponto de impedir as empresas de serem competitivas no mercado de atuação. Ele implica numa ampla limitação para a variação da margem, impedindo que, em uma única etapa, os preços definidos já espelhem os preços da concorrência.

Uma situação diferente é encontrada, tanto nos formadores quanto nos tomadores de preços, quando os custos variáveis são usados. Com a utilização dos custos variáveis, amplia-se a faixa possível de alteração da margem de contribuição (Indounas, 2006), o que traz a possibilidade de incorporar o valor e os preços da concorrência na fórmula.

Destarte, propõe-se a Hipótese 10: O uso dos custos totais explica a maior (menor) essência custos nos formadores de preços e nos tomadores de preços.

\subsubsection{Sumário das Hipóteses de Pesquisa}


A Tabela 63 resume esta seção e relaciona todas as hipóteses elaboradas para identificar os fatores positiva e negativamente explicativos da essência custos, tanto nos tomadores quanto nos formadores de preços.

Tabela 63 - Resultados esperados nas hipóteses de pesquisa

\begin{tabular}{c|c|c}
\hline HIPóTESE & FATOR & SiNAL ESPERADO \\
\hline 1 & Diferenciação & $+($ F.) \\
\hline 2 & Tamanho da Empresa (Grande Porte) & - \\
\hline 3 & Posição de Liderança no Mercado & (F.) \\
\hline 4 & Estratégia de Preço Premium & $-($ T. $)$ \\
\hline 5 & Intensidade da Concorrência & + \\
\hline 6 & Dificuldades para Definir os Preços conforme o Valor & + \\
\hline 7 & Pressões Isomórficas & - \\
\hline 8 & Ambiente de Atuação B2B & + \\
\hline 9 & Experiência no Estabelecimento dos Preços & + \\
\hline 10 & Custos Totais na Fórmula "Custos mais Margem” & \\
\hline
\end{tabular}

Nota. (F.) Hipótese exclusiva para formadores de preços. (T.) Hipótese exclusiva para tomadores de preços.

A fim de facilitar a compreensão das hipóteses de pesquisa, traz-se a Figura 51 que ilustra as dez expectativas deste trabalho.

Figura 51 - Resultados esperados nas hipóteses de pesquisa
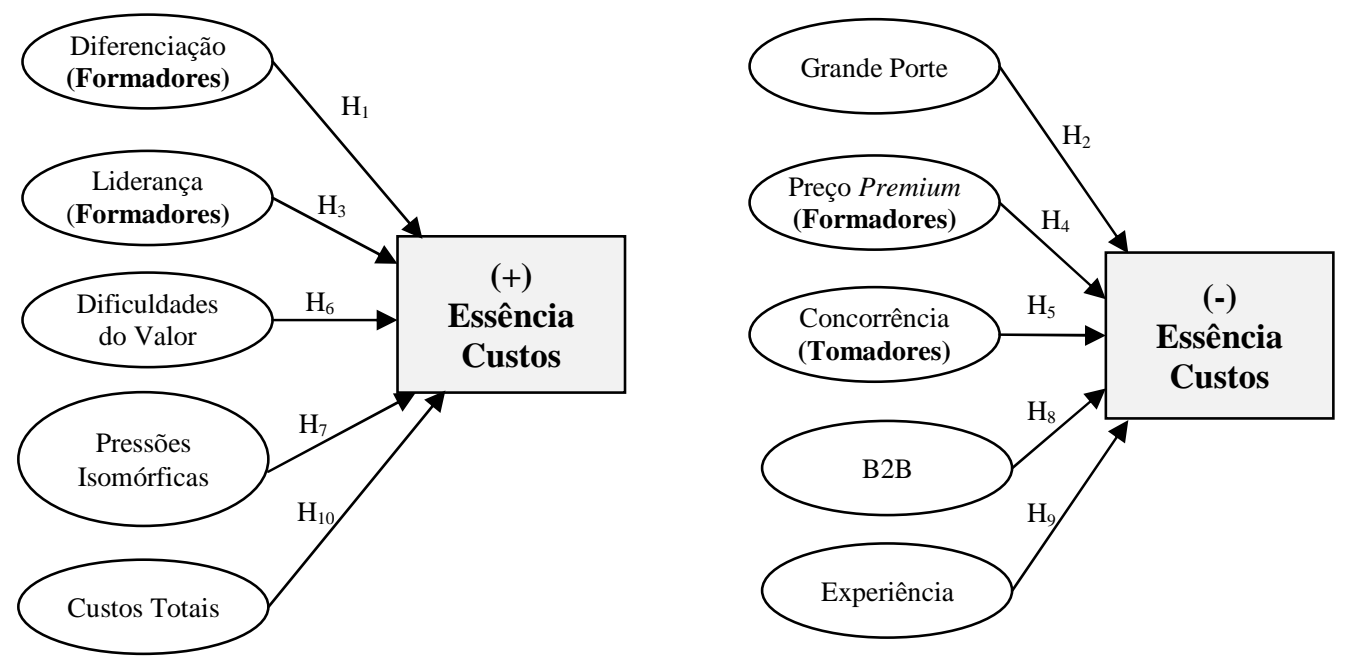

Fonte: Elaboração própria

6.6 Técnicas de Análise Estatística

Duas técnicas estatísticas foram selecionadas para atender os objetivos desta tese: a análise de correspondência (ANACOR) e a análise de regressão ordinal (ordinal regression). Os softwares utilizados foram o IBM SPSS Statistics (versão 19) e o Stata - Statistics/Data 
Analysis (14.2), licenciados para a Faculdade de Economia, Administração e Contabilidade da Universidade de São Paulo (FEA/USP) e disponíveis para uso nos laboratórios de informática dessa faculdade.

A ANACOR é uma técnica que examina relações de interdependência e embasa-se na associação entre objetos e atributos especificados pelo pesquisador, trazendo o benefício de representar linhas e colunas em um espaço conjunto (Hair, Anderson, Tatham, \& Black, 2009). De acordo com Fávero et al. (2009), ao exibir em um mapa perceptual as associações entre um conjunto de variáveis categóricas não métricas, a ANACOR viabiliza um exame visual de qualquer padrão ou estrutura nos dados.

A ANACOR foi escolhida para comparar os tomadores aos formadores de preços no que se refere à diferenciação, à dificuldade de uso das informações da concorrência e às informações usadas, bem como para confrontar os problemas da essência custos em empresas com menor e maior incorporação do valor.

Para operacionalizar as seis ANACOR referentes às relações entre o enquadramento e (1) a diferenciação, (2) a customização, (3) a dificuldade de uso das informações da concorrência, (4) o uso de informações de custos, (5) o uso de informações de valor e (6) o uso de informações da concorrência foram realizados basicamente dois procedimentos.

Primeiramente, foram criadas 6 planilhas nas quais foram tabuladas, lado a lado, por código da empresa, as informações do código do enquadramento (1 - formadores; 2 - tomadores commodities; 3 - demais tomadores), definido de acordo com o disposto na seção 6.4.1.1, e as informações referentes às variáveis investigadas, conforme detalhado na Tabela 64. Vale mencionar que as variáveis investigadas foram tabuladas tais como haviam sido respondidas, isto é, com o nível assinalado (1 dentre os 5 possíveis) para a concordância e para a intensidade do uso de informações. 
Tabela 64 - Tabulação para realização das 6 primeiras ANACOR

\begin{tabular}{c|c|c|c}
\hline PlaNiLHA & ANACOR & COLUNA NA PlaNILHA & VARIÁVEIS \\
\hline 1 & ANACOR 1 & DIF & DIF \\
\hline 1 & ANACOR 2 & CMZ & DAC_1, DAC_2 \\
\hline 2 & ANACOR 3 & DAC & ACU_1, ACU_2, ACU_3, ACU_4, ACU_5, \\
\hline 3 & ANACOR_6, \\
\hline 4 & ANACOR 5 & ACU & AVA_1, AVA_2, AVA_3, AVA_4 \\
\hline 5 & ANACOR 6 & AVA & ACO_1, ACO_2, ACO_3, ACO_4 \\
\hline 6 & ANACOR abortada & AOU & AOU \\
\hline
\end{tabular}

Em seguida, essas planilhas foram importadas no Stata para que, nesse software, a viabilidade de prosseguir com as ANACOR (teste qui-quadrado) pudesse ser a analisada e, se confirmada, todas as etapas das ANACOR pudessem ser conduzidas. Cumpre ressaltar que a ANACOR envolvendo a variável AOU foi abortada porque a realização do teste qui-quadrado trouxe resultados que sugeriram não dar continuidade à análise.

Já para operacionalizar a ANACOR referente à relação entre os problemas da essência custos encontrados em empresas com menor e maior incorporação do valor foram realizados três procedimentos.

Primeiramente, foi definido o nível de incorporação do valor das empresas, mediante análise de conglomerados não hierárquica K-means que buscou agrupar as empresas em função das variáveis VNE_1, VNE_2 e VNE_3. Nessa análise de conglomerados, optou-se por três agrupamentos, sendo o primeiro correlato à baixa incorporação do valor (modas das variáveis foram 1, 1 e 1), o segundo correlato à moderada incorporação do valor (modas das variáveis foram 1, 3 e 3 ) e o terceiro correlato à alta incorporação do valor (modas das variáveis foram $4,5$ e 5$)$.

Em seguida, foi criada 1 planilha na qual foram tabuladas, lado a lado, por código da empresa, as informações do nível de incorporação do valor (1 - baixa incorporação do valor; 2 moderada incorporação do valor; 3 - alta incorporação do valor) e as informações referentes aos problemas da essência custos, conforme detalhado na Tabela 65. Os problemas da essência custos foram tabulados tais como haviam sido respondidos, isto é, com o nível assinalado (1 dentre os 5 possíveis) para a concordância. 
Tabela 65 - Tabulação para realização da $7^{\text {a }}$ ANACOR

\begin{tabular}{c|c|c|c}
\hline Planilha & ANACOR & COLUNA Na Planilha & VARIÁVEIS \\
\hline 7 & ANACOR 7 & PRO & PRO_1, PRO_2, PRO_3, PRO_4 \\
\hline
\end{tabular}

Finalmente, essa planilha foi importada no Stata para que, nesse software, a viabilidade de dar continuidade à ANACOR (teste qui-quadrado) pudesse ser a analisada e, se confirmada, todas as etapas da ANACOR pudessem ser executadas.

A análise de regressão ordinal, por sua vez, foi selecionada para investigar os fatores explicativos da essência custos na definição dos preços, tanto nos formadores quanto nos tomadores de preços. Tal análise é não linear e tem uma variável dependente ordenada (Long \& Freese, 2006). Larasati, Yong, e Slevitch (2011) explicam que a análise de regressão ordinal pode ser considerada uma extensão da regressão logística. De acordo com os autores, ela é a técnica mais adequada para analisar o efeito de variáveis independentes em uma variável dependente que, por ser ordenada, não pode ser considerada nem como normal nem como intervalar.

Esse é o caso desta pesquisa, na qual a variável dependente é ordinal. Especificamente, a variável dependente essência custos pode apresentar três níveis, definidos a partir de análise de conglomerados não hierárquica $K$-means que agrupou as empresas em função das variáveis ESC_1, ESC_2 e ESC_3. Nessa análise de conglomerados, formaram-se três níveis da essência custos, sendo o primeiro correlato à baixa essência custos (modas das variáveis foram 1, 1 e 1), o segundo correlato à moderada essência custos (modas das variáveis foram 1, 3 e 3 ) e o terceiro correlato à alta essência custos (modas das variáveis foram 3, 3 e 3).

McCullagh e Nelder (1989) esclarecem que o modelo de regressão ordinal pode ser caracterizado da seguinte maneira:

$$
\operatorname{link}\left(\gamma_{j}\right)=\theta_{j}-\beta^{T} x
$$

Em que:

link corresponde à função selecionada (link function);

$\gamma_{\mathrm{j}}$ é a probabilidade cumulativa da j-ésima categoria;

$\theta j$ é o ponto de corte (threshold) para a j-ésima categoria;

$\beta$ é o conjunto de coeficientes da regressão para $\mathrm{x}$. 
Os autores explicam que o sinal negativo da equação é uma convenção adotada para assegurar que valores grandes de $\beta^{T} x$ conduzam a um aumento na probabilidade das categorias mais altas. Já Bender e Benner (2000) elucidam que, no caso de $\mathrm{m} \geq 2$ fatores explicativos, $\beta^{T} x$ refere-se à combinação linear $\beta_{1} x_{1}+\ldots+\beta_{\mathrm{m}} x_{\mathrm{m}}$ ). Assim, pode-se aprimorar a equação do modelo de regressão ordinal:

$\operatorname{link}\left(\gamma_{j}\right)=\theta_{j}-\left[\beta_{1} x_{1}+\ldots+\beta_{m} x_{m}\right]$

Em que:

link corresponde à função selecionada (link function);

$\gamma_{\mathrm{j}}$ é a probabilidade cumulativa da j-ésima categoria;

$\theta_{\mathrm{j}}$ é o ponto de corte (threshold) para a j-ésima categoria;

m é o número de fatores explicativos;

$\mathrm{x}_{1} \ldots \mathrm{x}_{\mathrm{m}}$ são os valores dos fatores explicativos;

$\beta_{1} \ldots \beta_{\mathrm{m}}$ são os coeficientes da regressão.

O'Connell (2006) clarifica que a função (link function) descreve o processo de "conexão" dos dados originais com o resultado transformado. No SPSS, cinco diferentes funções podem ser escolhidas para a análise de regressão ordinal, dependendo da distribuição das categorias, conforme a Tabela 66 evidencia.

Tabela 66 - Funções para a regressão ordinal no SPSS

\begin{tabular}{c|c|c}
\hline FUNÇão & FORMA & APLICAÇão \\
\hline Logit & $\log \left(\frac{\gamma}{1-\gamma}\right)$ & Categorias distribuídas proporcionalmente \\
\hline Log-log complementar & $\log (-\log (1-\gamma))$ & Categorias mais altas são as mais prováveis \\
\hline Log-log negativo & $-\log (-\log (\gamma))$ & Categorias mais baixas são as mais prováveis \\
\hline Probit & $\Phi^{-1}(\gamma)$ & Variável tem distribuição normal \\
\hline Cauchit (Cauchy inverso) & $\tan (\pi(\gamma-0,5))$ & Variável tem muitos valores extremos \\
\hline
\end{tabular}

Fonte: Elaborada a partir de consulta ao Tutorial do SPSS versão 19

No caso desta pesquisa, houve concentração da categoria mais baixa (baixa essência custos) tanto nos formadores quanto nos tomadores de preços, o que indicou a escolha da função loglog negativo (negative log-log) para os dois modelos de regressão ordinal. Logo, a equação que descreve o modelo com a função selecionada nesta tese é: 
$-\log \left(-\log \left(\gamma_{j}\right)\right)=\theta_{j}-\left[\beta_{1} x_{1}+\ldots+\beta_{m} x_{m}\right]$

Vale ressaltar que nesta tese há dois modelos de regressão ordinal, um para os formadores de preços outro para os tomadores de preços. A existência de dois modelos decorre das assunções previstas nas hipóteses da pesquisa, que atribuem fatores explicativos distintos para os formadores e tomadores de preços.

O modelo dos formadores de preços pode ser descrito da seguinte maneira:

$-\log \left(-\log \left(\gamma_{j}\right)\right)=\theta_{j}-\left[\beta_{1} \mathrm{DIF}+\beta_{2} \mathrm{TAM}+\beta_{3} \mathrm{LID}+\beta_{4} \mathrm{EST}+\beta_{5} \mathrm{PCV}+\beta_{6} \mathrm{FUV}+\beta_{7} \mathrm{PRV}+\beta_{8} \mathrm{DIV}+\beta_{9} \mathrm{ISC}+\right.$ $\left.\beta_{10} \mathrm{ISN}+\beta_{11} \mathrm{ISM}+\beta_{12} \mathrm{AMB}+\beta_{13} \mathrm{EXP}+\beta_{14} \mathrm{CFX}+\beta_{15} \mathrm{DES}\right]+\varepsilon$

Em que:

$\gamma_{\mathrm{j}}=$ probabilidade cumulativa da j-ésima categoria;

$\theta_{\mathrm{j}}=$ ponto de corte (threshold) para a j-ésima categoria;

DIF = Variável ordinal referente ao nível de diferenciação (3 níveis). Pontos de concordância (4 e 5) correspondentes ao nível 1; ponto de neutralidade (3) correspondente ao nível 2; e pontos de discordância (1 e 2) correspondentes ao nível 3;

TAM = Variável nominal referente ao tamanho da empresa. Grandes empresas correspondentes ao código 0; médias empresas correspondentes ao código 1; pequenas empresas correspondentes ao código 2; micro empresas correspondentes ao código 3;

LID = Variável nominal referente à liderança no mercado. Posição de liderança correspondente ao código 0; posição de não liderança correspondente ao código 1;

EST = Variável ordinal referente ao nível de adoção da estratégia de preço premium (3 níveis). Pontos de concordância (4 e 5) correspondentes ao nível 1; ponto de neutralidade (3) correspondente ao nível 2; e pontos de discordância (1 e 2) correspondentes ao nível 3;

PCV = Variável ordinal referente ao nível de percepção do custo dos processos de identificação e de mensuração do valor ( 3 níveis). Pontos de concordância (4 e 5) correspondentes ao nível 1; ponto de neutralidade (3) correspondente ao nível 2; e pontos de discordância (1 e 2) correspondentes ao nível 3;

FUV = Variável ordinal referente ao nível de falta de habilidade dos funcionários para identificar e mensurar o valor (3 níveis). Pontos de concordância (4 e 5) correspondentes ao nível 1; ponto de neutralidade (3) correspondente ao nível 2; e pontos de discordância (1 e 2) correspondentes ao nível 3;

PRV = Variável ordinal referente ao nível de percepção de que há prejuízos na colocação de preços inferiores ao resultado indicado pela combinação "custos mais margem" (3 níveis). Pontos de concordância (4 e 5) correspondentes ao nível 1; ponto de neutralidade (3) correspondente ao nível 2; e pontos de discordância (1 e 2) correspondentes ao nível 3; 
DIV = Variável ordinal referente ao nível de não disposição dos clientes em pagar o valor (3 níveis). Pontos de concordância (4 e 5) correspondentes ao nível 1; ponto de neutralidade (3) correspondente ao nível 2; e pontos de discordância (1 e 2) correspondentes ao nível 3;

ISC = Variável ordinal referente ao nível de isomorfismo coercitivo (3 níveis). Pontos de concordância (4 e 5) correspondentes ao nível 1; ponto de neutralidade (3) correspondente ao nível 2; e pontos de discordância (1 e 2) correspondentes ao nível 3;

ISN = Variável ordinal referente ao nível de isomorfismo normativo (3 níveis). Pontos de concordância (4 e 5) correspondentes ao nível 1; ponto de neutralidade (3) correspondente ao nível 2; e pontos de discordância (1 e 2) correspondentes ao nível 3;

ISM = Variável ordinal referente ao nível de isomorfismo mimético (3 níveis). Pontos de concordância (4 e 5) correspondentes ao nível 1; ponto de neutralidade (3) correspondente ao nível 2; e pontos de discordância (1 e 2) correspondentes ao nível 3;

AMB = Variável nominal referente ao ambiente de atuação. Ambiente B2B correspondente ao código 0; demais ambientes correspondentes ao código 1 ;

EXP = Variável contínua referente à experiência. Quantidade de anos de experiência informada pelo respondente;

CFX = Variável ordinal referente ao uso dos custos fixos no estabelecimento dos preços. Pontos de concordância (4 e 5) correspondentes ao nível 1; ponto de neutralidade (3) correspondente ao nível 2; e pontos de discordância (1 e 2) correspondentes ao nível 3;

DES = Variável ordinal referente ao uso das despesas fixas no estabelecimento dos preços. Pontos de concordância (4 e 5) correspondentes ao nível 1; ponto de neutralidade (3) correspondente ao nível 2; e pontos de discordância (1 e 2) correspondentes ao nível 3;

$\varepsilon=$ Erro do modelo.

O modelo que visa identificar os fatores explicativos da essência custos nos tomadores de preços, por sua vez, pode ser descrito do seguinte modo:

$$
\begin{aligned}
& -\log \left(-\log \left(\gamma_{j}\right)\right)=\theta_{j}-\left[\beta_{1} \mathrm{TAM}+\beta_{2} \mathrm{INC}+\beta_{3} \mathrm{COP}+\beta_{4} \mathrm{PCV}+\beta_{5} \mathrm{FUV}+\beta_{6} \mathrm{PRV}+\beta_{7} \mathrm{DIV}+\beta_{8} \mathrm{ISC}+\beta_{9} \mathrm{ISN}+\right. \\
& \left.\beta_{10} \mathrm{ISM}+\beta_{11} \mathrm{AMB}+\beta_{12} \mathrm{EXP}+\beta_{13} \mathrm{CFX}+\beta_{14} \mathrm{DES}\right]+\varepsilon
\end{aligned}
$$

Em que:

$\gamma_{\mathrm{j}}=$ probabilidade cumulativa da j-ésima categoria;

$\theta_{\mathrm{j}}=$ ponto de corte (threshold) para a j-ésima categoria;

TAM = Variável nominal referente ao tamanho da empresa. Grandes empresas correspondentes ao código 0; médias empresas correspondentes ao código 1; pequenas empresas correspondentes ao código 2; micro empresas correspondentes ao código 3; 
INC = Variável ordinal referente ao nível de quantidade dos concorrentes (3 níveis). Pontos de concordância (4 e 5) correspondentes ao nível 1; ponto de neutralidade (3) correspondente ao nível 2; e pontos de discordância (1 e 2) correspondentes ao nível 3;

COP = Variável ordinal referente ao nível de cópia dos concorrentes (3 níveis). Pontos de concordância (4 e 5) correspondentes ao nível 1; ponto de neutralidade (3) correspondente ao nível 2; e pontos de discordância (1 e 2) correspondentes ao nível 3;

PCV = Variável ordinal referente ao nível de percepção do custo dos processos de identificação e de mensuração do valor (3 níveis). Pontos de concordância (4 e 5) correspondentes ao nível 1; ponto de neutralidade (3) correspondente ao nível 2; e pontos de discordância (1 e 2) correspondentes ao nível 3;

FUV = Variável ordinal referente ao nível de falta de habilidade dos funcionários para identificar e mensurar o valor (3 níveis). Pontos de concordância (4 e 5) correspondentes ao nível 1; ponto de neutralidade (3) correspondente ao nível 2; e pontos de discordância (1 e 2) correspondentes ao nível 3;

PRV = Variável ordinal referente ao nível de percepção de que há prejuízos na colocação de preços inferiores ao resultado indicado pela combinação "custos mais margem” (3 níveis). Pontos de concordância (4 e 5) correspondentes ao nível 1; ponto de neutralidade (3) correspondente ao nível 2; e pontos de discordância (1 e 2) correspondentes ao nível 3;

DIV = Variável ordinal referente ao nível de não disposição dos clientes em pagar o valor (3 níveis). Pontos de concordância (4 e 5) correspondentes ao nível 1; ponto de neutralidade (3) correspondente ao nível 2; e pontos de discordância (1 e 2) correspondentes ao nível 3;

ISC = Variável ordinal referente ao nível de isomorfismo coercitivo (3 níveis). Pontos de concordância (4 e 5) correspondentes ao nível 1; ponto de neutralidade (3) correspondente ao nível 2; e pontos de discordância (1 e 2) correspondentes ao nível 3;

ISN = Variável ordinal referente ao nível de isomorfismo normativo (3 níveis). Pontos de concordância (4 e 5) correspondentes ao nível 1; ponto de neutralidade (3) correspondente ao nível 2; e pontos de discordância (1 e 2) correspondentes ao nível 3;

ISM = Variável ordinal referente ao nível de isomorfismo mimético (3 níveis). Pontos de concordância (4 e 5) correspondentes ao nível 1; ponto de neutralidade (3) correspondente ao nível 2; e pontos de discordância (1 e 2) correspondentes ao nível 3;

$\mathrm{AMB}=$ Variável nominal referente ao ambiente de atuação. Ambiente B2B correspondente ao código 0; demais ambientes correspondentes ao código 1;

EXP = Variável contínua referente à experiência. Quantidade de anos de experiência informada pelo respondente;

CFX = Variável ordinal referente ao uso dos custos fixos no estabelecimento dos preços. Pontos de concordância (4 e 5) correspondentes ao nível 1; ponto de neutralidade (3) correspondente ao nível 2; e pontos de discordância (1 e 2) correspondentes ao nível 3;

DES = Variável ordinal referente ao uso das despesas fixas no estabelecimento dos preços. Pontos de concordância (4 e 5) correspondentes ao nível 1; ponto de neutralidade (3) correspondente ao nível 2; e pontos de discordância (1 e 2) correspondentes ao nível 3;

$\varepsilon=$ Erro do modelo. 
A Figura 52 demonstra de que forma esses dois modelos de regressão ordinal incorporaram as definições constitutivas apresentadas na seção 6.4.

Figura 52 - Relação entre modelos de regressão ordinal e definições constitutivas

Modelo dos Formadores de Preços

\begin{tabular}{|l|}
\hline \multicolumn{1}{|c|}{ Definições Constituticativas } \\
\hline - Diferenciação \\
- Tamanho da empresa \\
- Posição de liderança no \\
mercado \\
- Estratégia de preço \\
premium \\
- (4) Dificuldades para \\
definir os preços conforme o \\
valor \\
- (3) Pressões isomórficas \\
- Ambiente de atuação \\
- Experiência no \\
estabelecimento dos preços \\
- (2) Custos totais na \\
fórmula “custos mais \\
margem" \\
\hline
\end{tabular}
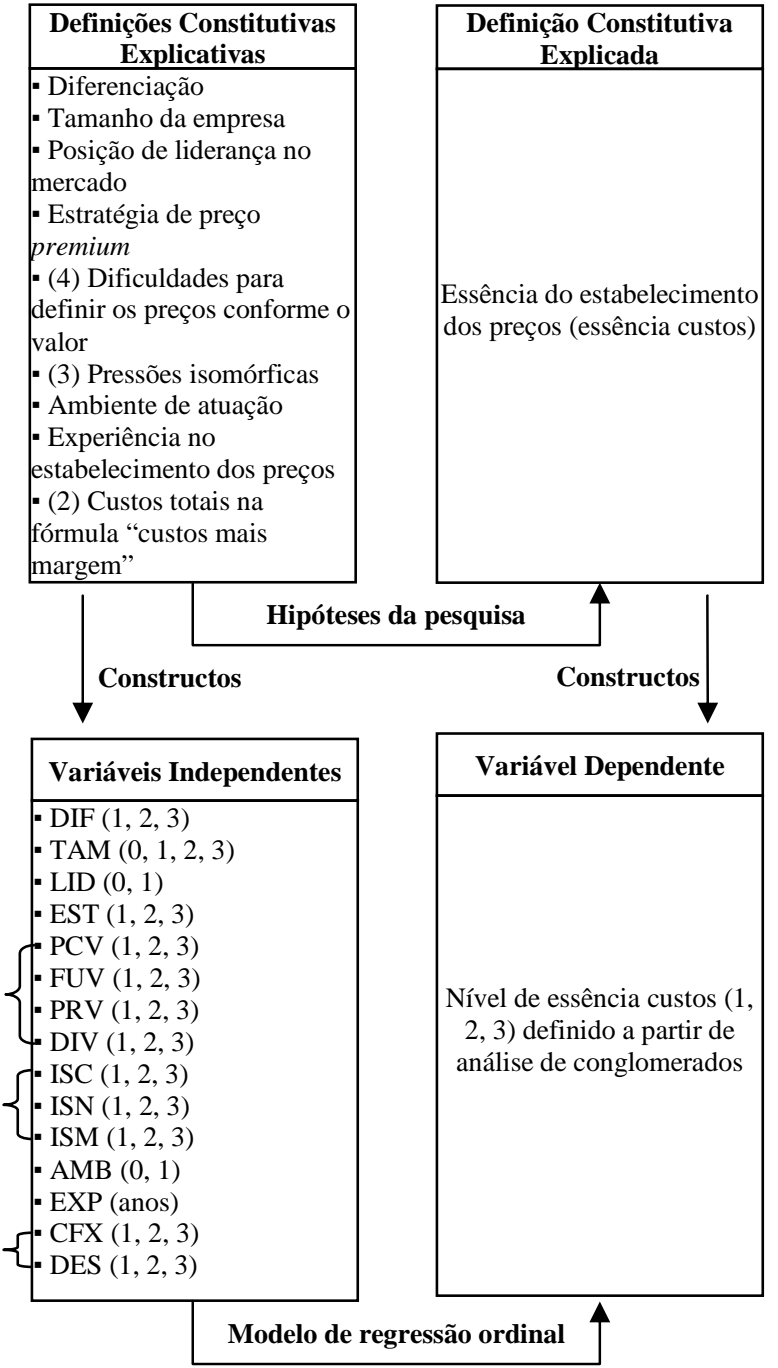

Modelo dos Tomadores de PReÇOS

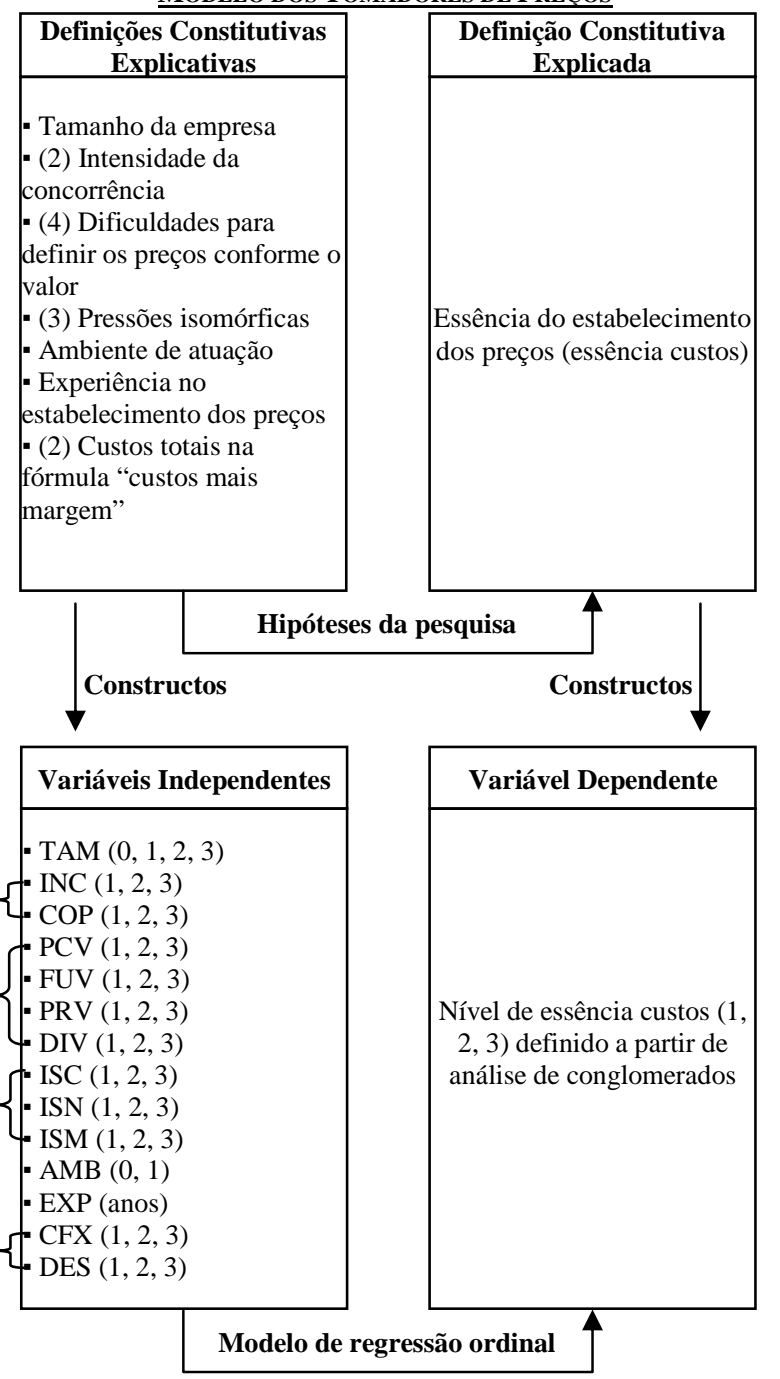

Fonte: Elaboração própria

\subsection{Operacionalização da Pesquisa}

Antes de encerrar o capítulo, vale revelar detalhes de como e quando os métodos nele reportados foram operacionalizados. Nesse sentido, um protocolo contendo os procedimentos realizados na pesquisa empírica é apresentado.

\subsubsection{Identificação e Organização dos Dados de Contato das Empresas}


O primeiro procedimento executado para operacionalizar a pesquisa empírica foi a solicitação da relação das empresas presentes nos bancos de dados das edições de 2014 e 2015 da revista Exame Melhores e Maiores e da revista NEI Top Five. Essa demanda foi direcionada aos responsáveis pela elaboração das revistas, isto é, para a Fundação Instituto de Pesquisas Contábeis, Atuariais e Financeiras (FIPECAFI) no caso da revista Exame Melhores e Maiores e para o departamento de marketing no caso da revista NEI Top Five.

Os responsáveis pela revista Exame Melhores e Maiores disponibilizaram prontamente todas as informações solicitadas. Vale mencionar que para eles foi requerida apenas a relação das empresas industriais (excluindo-se as empresas comerciais e de serviços) e também foi pedida a entrega de dados econômico-financeiros (e.g., vendas, lucro líquido, patrimônio líquido, ativo etc.) eventualmente disponíveis para as empresas relacionadas.

Já os responsáveis pela revista NEI comunicaram que as informações de e-mails, sites, nomes e contatos, embora fizessem parte dos seus bancos de dados, não poderiam ser entregues. Essas informações foram, portanto, coletadas e organizadas pela pesquisadora a partir das revistas digitais capturadas no site da revista.

O processo foi bastante trabalhoso e moroso porque os campos da revista NEI não são uniformes (por exemplo, ora dispostos na coluna direita, ora na coluna esquerda; ora apresentam mais de um dado na mesma linha, ora não etc.) e porque os dados são expressos de diferentes formas (por exemplo, ora abreviados, ora não; ora com a divisão da empresa responsável pela categoria, ora não etc.). A organização da revista por categorias (não por empresas) foi outro dificultador porque, além de replicar o número de coletas, trouxe a necessidade de rastrear os dados, um a um, para assegurar a elaboração de um banco com as informações combinadas de cada empresa (apresentadas ao longo das diferentes categorias).

As informações disponibilizadas (revista Exame Melhores e Maiores) ou coletadas (revista NEI) foram então articuladas. Tomou-se o cuidado de assegurar que nenhuma empresa (ou grupo de empresas) apareceria de forma repetida e de garantir que organizações fora do escopo do estudo (não industriais, não localizadas no Brasil) não fariam parte da população. Foram também acessados bancos de dados de trabalhos anteriores desta pesquisadora para 
acrescentar contatos (telefones e endereços eletrônicos) de profissionais das empresas já relacionadas (constantes na revista Exame Melhores e Maiores e/ou na revista NEI).

Foram elaborados três relatórios com os dados necessários para o contato inicial com as empresas. O primeiro relatório contemplava os dados oriundos do banco da revista Exame Melhores e Maiores, o segundo abrangia os dados coletados da revista NEI, o terceiro combinava os dois relatórios e oferecia campos em branco para realizar anotações durante o contato individualizado com as empresas. Esses três relatórios foram armazenados eletronicamente como documentos de pesquisa. As anotações realizadas durante o período de contato com as empresas também foram gravadas e constam armazenadas em meio eletrônico (salvas no terceiro relatório). Por questões de confidencialidade, somente os cabeçalhos desses três relatórios são publicados nesta tese (Apêndice D).

\subsubsection{Contato com a População da Pesquisa}

Os dados de contato até então relacionados normalmente não se referiam diretamente ao principal responsável pelo estabelecimento dos preços. No geral, eles correspondiam ao telefone e/ou ao endereço eletrônico da assessoria de imprensa, da recepção geral da empresa, dos profissionais contábeis (Revista Exame Melhores e Maiores) e das áreas de vendas (Revista NEI).

Foi realizado, portanto, um trabalho para identificar os principais responsáveis pelas decisões de preços de cada uma das empresas para, assim, convidá-los a participar da pesquisa. Decidiu-se que a primeira tentativa de identificação desses profissionais aconteceria por mensagem eletrônica.

Especificamente em 26 de fevereiro de 2016 e 01 de março de 2016, foi encaminhada uma mensagem eletrônica ao endereço de todos os emails relacionados nos relatórios de dados cadastrais. A carta de apresentação compunha o texto da mensagem, que tinha o questionário como anexo no formato Word (Apêndice C) e também como um link para participação online via internet (no site https://docs.google.com/forms/d/1cX1s1E7vHkV_139PPw6YyztSwhyR4d90jzEhG45W61M/ viewform?usp=send_form). O Apêndice B1 demonstra a versão mais recorrente da carta 
encaminhada (houve pequenos aprimoramentos em relação à versão enviada no primeiro dia). Vale esclarecer que a disponibilização do questionário em dois formatos decorreu da constatação de que a opção única na forma de link poderia inibir a participação de profissionais dispostos, mas sem acesso à internet no posto de trabalho.

Nessa mensagem eletrônica, foi solicitado que o destinatário ou participasse da pesquisa, caso fosse o principal responsável pelo estabelecimento dos preços, ou fizesse a gentileza de encaminhar o convite para que o principal responsável na sua empresa pudesse participar. Cumpre mencionar que foi nesse momento que aconteceu a terceira fase do pré-teste. Os primeiros profissionais identificados como sendo do público alvo da pesquisa, além de responderem ao questionário, avaliaram o instrumento. Em um bloco específico, eles analisaram a compreensibilidade e o processo de preenchimento do questionário e, além disso, revelaram o tempo consumido na atividade e ofereceram sugestões.

Nessa etapa, foram muito poucas as respostas positivas à mensagem eletrônica com o questionário preenchido (apenas 11 responderam espontaneamente antes de qualquer lembrete) ou com revelações espontâneas sobre quem era o profissional que deveria ser contatado por deliberar sobre os preços (somente 4). A maior parte dos destinatários simplesmente não respondeu à mensagem, sendo que vários destinatários também não receberam de fato a mensagem, pois em 443 empresas pelo menos um dos emails cadastrados tornou-se inválido. Assim, diante do exíguo apoio, optou-se por tempestivamente partir para outra forma de identificação dos principais responsáveis pelas decisões de preços: ligações telefônicas.

As ligações telefônicas seriam, inicialmente, direcionadas a todas as 1.616 empresas da população da pesquisa, excluindo-se aquelas que responderam o questionário antes de serem acionadas individualmente (66 ao todo, após reiterações, incluindo 1 que foi eliminada) e que negaram, por qualquer motivo (incluindo o não enquadramento ao escopo e o encerramento das atividades), a participação na pesquisa (19). Posteriormente, optou-se por eliminar as empresas envolvidas na operação Lava Jato da pesquisa o que eliminou 16 ligações (já que se chegou a telefonar para 3 das 19 empresas envolvidas constantes na população).

Ao longo da pesquisa, percebendo a dificuldade de entrar em contato telefônico diretamente 
com a alta gerência de empresas de portes muito grandes, decidiu-se acionar de antemão por email os diretores e/ou gerente comerciais, cujos nomes eram descobertos em consulta à internet e/ou a redes sociais profissionais. Dessa forma, conseguiu-se eliminar 342 ligações (substituídas por envios de mensagens eletrônicas diretas ao alto escalão).

As ligações foram direcionadas, portanto, a 1.173 empresas $(1.616-66$ - 19 - 16 - 342). Dentre todas essas empresas, não foi possível concluir os telefonemas com 57, uma vez que, inclusive em ligações direcionadas a números extras localizados nos sites, ninguém atendia, surgiam mensagens que o número era inválido, a ligação ficava muda etc.. Desses 57 insucessos, foi possível entrar em contato alternativo pelo site com 11 empresas e identificar que 3 estavam fora do escopo (não eram indústria) e que 1 estava encerrada. Ou seja, foi impossível contatar de modo individualizado apenas 42 empresas $(57-11-3-1)$.

Os telefonemas tiveram início em 10 de março de 2016 e perduraram até 30 de junho de 2016. Entrou-se em contato telefônico com 1.116 empresas (1.173 - 57) durante o expediente matutino (08:00 às 12:00) ao longo de 62 dias úteis. Aproximadamente, 248 horas da pesquisadora foram dedicadas exclusivamente às ligações, nas quais se tomou o cuidado de expor o objetivo da pesquisa e demonstrar como cada um dos acionados poderia contribuir de maneira ímpar com o estudo.

As ligações foram feitas aos números constantes nos relatórios de dados cadastrais, que, conforme já mencionado, normalmente não se referiam diretamente ao responsável pelo estabelecimento dos preços. Logo, falou-se, em média, com duas (telefonista e profissional da área) ou três (profissional contábil, telefonista e profissional da área) pessoas antes de se conseguir falar com esse responsável. O nome das pessoas contatadas e o resumo das conversações foram anotados em meio eletrônico e arquivados (cabeçalhos do registro disponíveis nos Apêndice D).

Em alguns casos, o principal responsável não atendia diretamente a ligação, mas permitia que passassem à pesquisadora o seu endereço de email. Em outros casos, o atendente não sabia prontamente quem seria esse principal responsável e passava à pesquisadora seu próprio email para que ele pudesse ter mais informações e condições de encaminhá-lo internamente. 
Nas ligações telefônicas, ficava acordado que seria enviada uma mensagem eletrônica com maiores explicações sobre a pesquisa e com o questionário (em Word e em link) a ser preenchido (Apêndice B2). Essa mensagem era expedida assim que o telefonema era encerrado. Isso aconteceu para todas as empresas contatadas, exceto àquelas que na ligação negaram, por qualquer motivo, a participação na pesquisa (191). Foram enviados, dessa forma, 925 (1.116 - 191) emails logo depois do desligamento das ligações. Todas as mensagens enviadas (bem como as respostas e negações recebidas) estão arquivadas em arquivo do tipo PST do Outlook.

Vale esclarecer que algumas empresas solicitaram o encaminhamento de um documento oficial (assinado) para participarem da pesquisa. Para atender a essas requisições, foi remetido eletronicamente o ofício disponível no Apêndice B3. Para 2 empresas, esse ofício também foi encaminhado por meio físico (pelos correios).

\subsubsection{Envio de Mensagem de Agradecimento}

Uma mensagem de agradecimento era enviada para os respondentes depois que os questionários preenchidos eram recebidos (teor da mensagem disponível no Apêndice E). No momento do agradecimento, uma breve conferência do questionário era realizada para verificar se alguma pergunta obrigatória havia ficado em branco e, consequentemente, carecia de complementação.

Foram necessários 29 complementos, sendo que 23 foram plenamente concluídos. Dos 6 restantes, 3 questionários foram mantidos no estudo porque o não preenchimento era ínfimo (apenas 1 questão em 2 questionários e 2 questões em 1 questionário) e 3 foram eliminados porque mais de 5\% do questionário havia ficado em branco (além disso, para 1 questionário, que acabou sendo eliminado, não se solicitou quaisquer complementos porque a respondente adiantou que não preencheu $100 \%$ da pesquisa).

Nos casos em que questões do bloco pessoal não eram respondidas ou eram preenchidas com termos vagos (por exemplo, "muito tempo" de experiência), buscava-se obter as informações na internet. Conseguiu-se assim complementar 5 respostas, mas 4 referentes ao tempo de 
experiência e 1 referente à posição de liderança acabaram tendo que ficar sem preenchimento (compõem os missings).

\subsubsection{Envio de Mensagem de Reiteração}

Quando se expirava o prazo definido para a participação na pesquisa, uma mensagem de reiteração era encaminhada. Para a maior parte dos respondentes (217) foi necessária ao menos uma reiteração. Conforme a Figura 53 ilustra, 124 profissionais participaram da pesquisa depois de 1 reiteração, 57 após 2 reiterações e 36 após 3 reiterações.

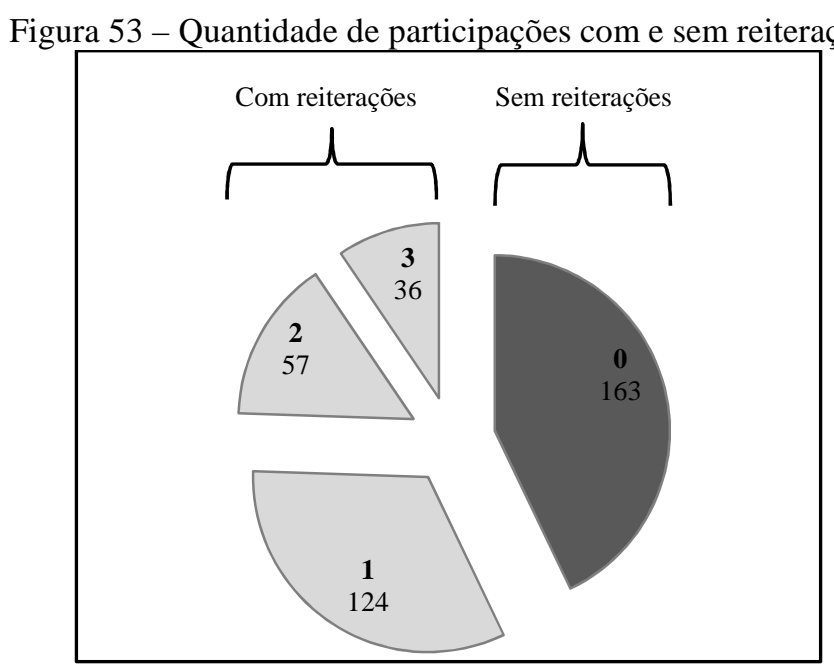

Fonte: Dados da pesquisa

Cumpre esclarecer que o anexo Word do questionário e o link eram reenviados na mensagem de reiteração, diante da possibilidade de exclusão da mensagem inicial. Foram encaminhadas até 3 mensagens de reiteração para cada participante nas datas relacionadas na Tabela 67.

Tabela 67 - Cronograma de reiterações

\begin{tabular}{c|c|c|c|c|c}
\hline ONDA & $\begin{array}{c}\text { No DA } \\
\text { REITERAÇão }\end{array}$ & DATA DA LIGAÇÃo & $\begin{array}{c}\text { PRAZO PREVIAMENTE } \\
\text { ACORDADO }\end{array}$ & $\begin{array}{c}\text { DATA DA } \\
\text { REITERAÇÃO }\end{array}$ & $\begin{array}{c}\text { NoVO } \\
\text { PRAZO }\end{array}$ \\
\hline 0 & 1 & Mensagens sem telefonema - 26/02-01/03/2016 & $14 / 03 / 2016$ & $14 / 03 / 2016$ & $23 / 03 / 2016$ \\
\hline 0 & 2 & Mensagens sem telefonema - 26/02-01/03/2016 & $23 / 03 / 2016$ & $28 / 03 / 2016$ & $18 / 04 / 2016$ \\
\hline 0 & 3 & Mensagens sem telefonema - 26/02-01/03/2016 & $18 / 04 / 2016$ & $25 / 04-05 / 05 / 2016$ & $23 / 05 / 2016$ \\
\hline 1 & 1 & $10 / 03 / 2016$ & $17 / 03 / 2016$ & $21 / 03 / 2016$ & $04 / 04 / 2016$ \\
\hline 1 & 2 & $10 / 03 / 2016$ & $04 / 04 / 2016$ & $04 / 04 / 2016$ & $18 / 04 / 2016$ \\
\hline 1 & 3 & $10 / 03 / 2016$ & $18 / 04 / 2016$ & $19 / 04 / 2016$ & $09 / 05 / 2016$ \\
\hline 2 & 1 & $14 / 03-16 / 03 / 2016$ & $23 / 03 / 2016$ & $22 / 03 / 2016$ & $04 / 04 / 2016$ \\
\hline 2 & 2 & $14 / 03-16 / 03 / 2016$ & $04 / 04 / 2016$ & $04 / 04 / 2016$ & $18 / 04 / 2016$ \\
\hline 2 & 3 & $14 / 03-16 / 03 / 2016$ & $18 / 04 / 2016$ & $19 / 04 / 2016$ & $09 / 05 / 2016$ \\
\hline 3 & 1 & $17 / 03-18 / 03 / 2016$ & $29 / 03 / 2016$ & $29 / 03 / 2016$ & $18 / 04 / 2016$ \\
\hline 3 & 2 & $17 / 03-18 / 03 / 2016$ & $18 / 04 / 2016$ & $19 / 04 / 2016$ & $09 / 05 / 2016$ \\
\hline 3 & 3 & $17 / 03-18 / 03 / 2016$ & $09 / 05 / 2016$ & $09 / 05 / 2016$ & $30 / 05 / 2016$ \\
\hline & & & & Continua...
\end{tabular}




\begin{tabular}{c|c|c|c|c|c}
\hline ONDA & $\begin{array}{c}\text { No DA } \\
\text { REITERAÇão }\end{array}$ & DATA DA LIGAÇão & $\begin{array}{c}\text { PRAZO PREVIAMENTE } \\
\text { ACORDADO }\end{array}$ & $\begin{array}{c}\text { DATA DA } \\
\text { REITERAÇÃO }\end{array}$ & $\begin{array}{c}\text { Novo } \\
\text { PRAZO }\end{array}$ \\
\hline 4 & 1 & $21 / 03-30 / 03 / 2016$ & $11 / 04 / 2016$ & $11 / 04 / 2016$ & $25 / 04 / 2016$ \\
\hline 4 & 2 & $21 / 03-30 / 03 / 2016$ & $25 / 04 / 2016$ & $25 / 04 / 2016$ & $16 / 05 / 2016$ \\
\hline 4 & 3 & $21 / 03-30 / 03 / 2016$ & $16 / 05 / 2016$ & $17 / 05 / 2016$ & $06 / 06 / 2016$ \\
\hline 5 & 1 & $31 / 03-09 / 04 / 2016$ & $18 / 04 / 2016$ & $18 / 04-19 / 04 / 2016$ & $09 / 05 / 2016$ \\
\hline 5 & 2 & $31 / 03-09 / 04 / 2016$ & $09 / 05 / 2016$ & $09 / 05 / 2016$ & $30 / 05 / 2016$ \\
\hline 5 & 3 & $31 / 03-09 / 04 / 2016$ & $30 / 05 / 2016$ & $30 / 05 / 2016$ & $20 / 06 / 2016$ \\
\hline 6 & 1 & $10 / 04-19 / 04 / 2016$ & $02 / 05 / 2016$ & $02 / 05 / 2016$ & $16 / 05 / 2016$ \\
\hline 6 & 2 & $10 / 04-19 / 04 / 2016$ & $16 / 05 / 2016$ & $17 / 05 / 2016$ & $30 / 05 / 2016$ \\
\hline 6 & 3 & $10 / 04-19 / 04 / 2016$ & $30 / 05 / 2016$ & $30 / 05 / 2016$ & $20 / 06 / 2016$ \\
\hline 7 & 1 & $20 / 04-30 / 04 / 2016$ & $16 / 05 / 2016$ & $17 / 05 / 2016$ & $30 / 05 / 2016$ \\
\hline 7 & 2 & $20 / 04-30 / 04 / 2016$ & $30 / 05 / 2016$ & $30 / 05 / 2016$ & $20 / 06 / 2016$ \\
\hline 7 & 3 & $20 / 04-30 / 04 / 2016$ & $20 / 06 / 2016$ & $20 / 06 / 2016$ & $11 / 07 / 2016$ \\
\hline 8 & 1 & $01 / 05-08 / 05 / 2016$ & $23 / 05 / 2016$ & $30 / 05 / 2016$ & $20 / 06 / 2016$ \\
\hline 8 & 2 & $01 / 05-08 / 05 / 2016$ & $20 / 06 / 2016$ & $20 / 06 / 2016$ & $11 / 07 / 2016$ \\
\hline 9 & 1 & $09 / 05-18 / 05 / 2016$ & $30 / 05 / 2016$ & $30 / 05 / 2016$ & $20 / 06 / 2016$ \\
\hline 9 & 2 & $09 / 05-18 / 05 / 2016$ & $20 / 06 / 2016$ & $20 / 06 / 2016$ & $11 / 07 / 2016$ \\
\hline 10 & 1 & $19 / 05-31 / 05 / 2016$ & $13 / 06 / 2016$ & $13 / 06 / 2016$ & $27 / 06 / 2016$ \\
\hline 10 & 2 & $19 / 05-31 / 05 / 2016$ & $27 / 06 / 2016$ & $29 / 06 / 2016$ & $12 / 07 / 2016$ \\
\hline 11 & 1 & $01 / 06-10 / 06 / 2016$ & $20 / 06 / 2016$ & $21 / 06 / 2016$ & $05 / 07 / 2016$ \\
\hline 11 & 2 & $01 / 06-10 / 06 / 2016$ & $05 / 07 / 2016$ & $05 / 07 / 2016$ & $12 / 07 / 2016$ \\
\hline 12 & 1 & $11-20 / 06 / 2016$ & $04 / 07 / 2016$ & $05 / 07 / 2016$ & $12 / 07 / 2016$ \\
\hline 13 & LEMBETE & $21 / 06-30 / 06 / 2016$ & $11 / 07 / 2016$ & $07 / 07 / 2016$ & $15 / 07 / 2016$ \\
\hline
\end{tabular}

\subsubsection{Entrega de Relatório Individualizado aos Respondentes}

Após o término da etapa de coleta (ligações, reiterações e agradecimentos), teve início a análise de dados. Sua primeira etapa abrangeu a elaboração de um relatório individualizado para cada respondente. Esse relatório, que foi entregue em 19 de agosto de 2016, apresentou, para cada questão, uma comparação entre as respostas oferecidas pelo participante e as respostas dominantes oferecidas pelas empresas do mesmo segmento, do mesmo ambiente e do mesmo porte que o participante, bem como pela amostra como um todo (Apêndice F).

Uma mensagem com link de acesso à versão eletrônica da tese (no sistema teses.usp) também será enviada aos respondentes depois de a defesa da tese ser concluída.

\subsection{Cronograma da Pesquisa}

A fim de posicionar no tempo o presente trabalho, vale revelar o seu cronograma, isto é, divulgar os meses em que cada uma das suas etapas foi iniciada e concluída.

Inicialmente, de julho/2015 a janeiro/2016, com base nas informações proporcionadas pela revista Exame Melhores e Maiores (FIPECAFI) e coletadas da revista NEI, a população da pesquisa foi identificada e os dados de contatos foram organizados. Partindo desses dados, em 
fevereiro/2016 teve início o envio de mensagens e em março/2016 teve início a realização de ligações solicitando a participação na pesquisa. Essas atividades aconteceram até junho/2016.

O envio de mensagens de agradecimento e de reiteração, por sua vez, começaram em março/2016 e terminaram em julho/2016. Finalmente, o envio do relatório individualizado a todos os respondentes aconteceu em agosto/2016. A Tabela 68 sumariza esse cronograma.

Tabela 68 - Cronograma da realização da pesquisa

\begin{tabular}{|c|c|c|}
\hline ETAPA & ATIVIDADE & PERÍODO \\
\hline 1 & Identificação e organização dos dados de contato das empresas & Julho/2015 - Janeiro/2016 \\
\hline 2 & Contato com a população da pesquisa & Fevereiro/2016 - Junho/2016 \\
\hline 3 & Envio de mensagem de agradecimento & Março/2016 - Julho/2016 \\
\hline 4 & Envio de mensagem de reiteração & Março/2016 - Julho/2016 \\
\hline 5 & Entrega de relatório individualizado aos respondentes & Agosto/2016 \\
\hline
\end{tabular}

\subsection{Resumo dos Métodos da Pesquisa}

Para concluir o capítulo, decidiu-se sumarizar o que foi nele abordado e também demonstrar que os métodos foram empregados para viabilizar a obtenção da resposta à questão de pesquisa, o atendimento aos objetivos da pesquisa e a ratificação da tese proposta. Para fazer essa síntese, elaborou-se a Figura 54. 
Figura 54 - Desenho da pesquisa
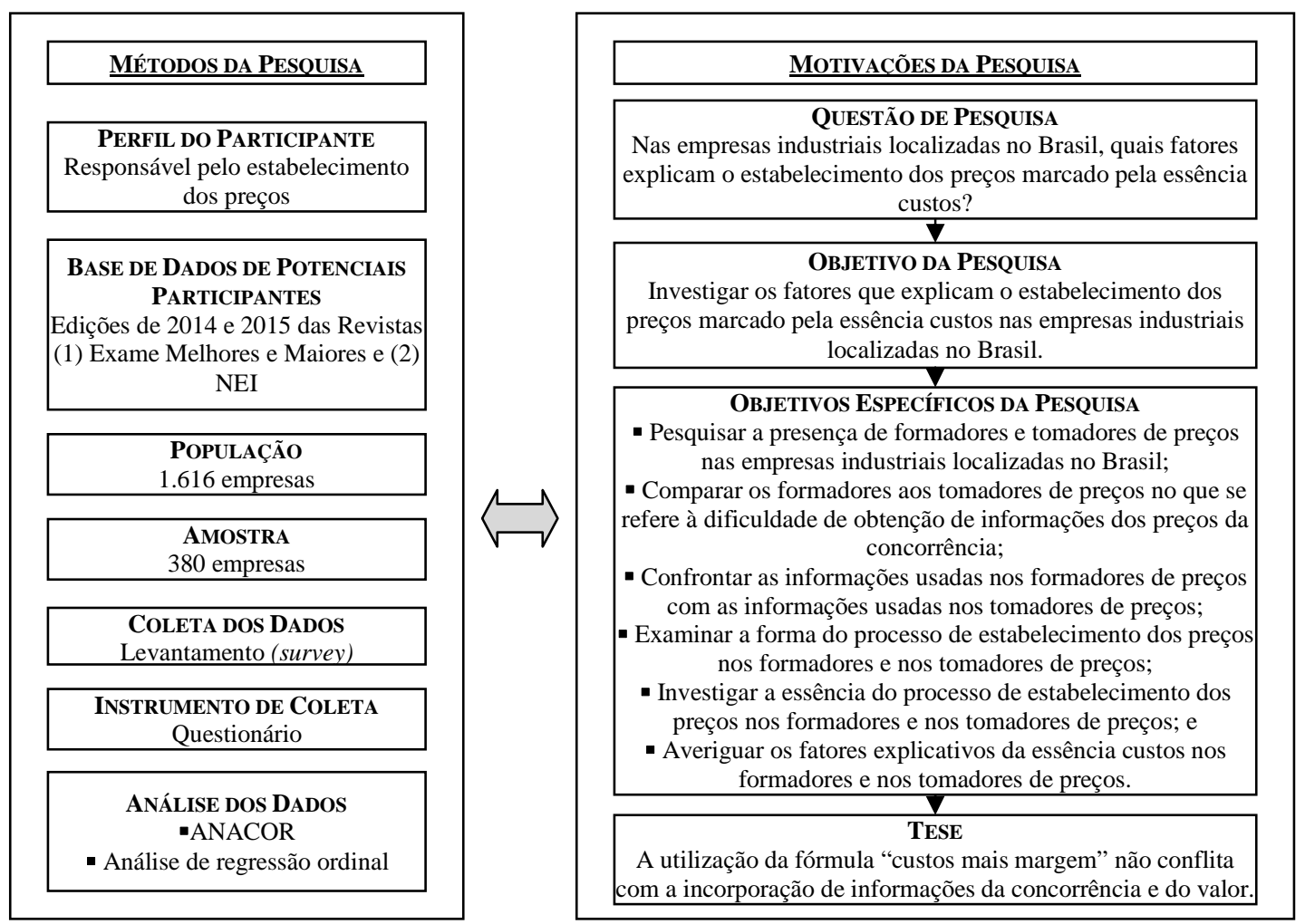

Fonte: Elaboração própria

Finalmente, vale esclarecer que, quanto à formatação, este estudo foi elaborado de acordo com os padrões da American Psychological Association - APA. A apresentação do trabalho atende as recomendações do manual da APA (2010) bem como do manual da Universidade de São Paulo - Sistema Integrado de Bibliotecas (SIBI/USP, 2016). Cumpre mencionar que houve o atendimento às diretrizes da SIBI/USP para pontos omissos no manual da APA ou divergentes entre os manuais. Por essa razão, por exemplo, as ilustrações estão identificadas na parte superior e com menção de fonte, ainda que sejam próprias ou oriundas dos dados da pesquisa. 


\section{ANÁLISE E DISCUSSÃO DOS RESULTADOS}

Este capítulo é o núcleo da tese, pois ele compara as observações empíricas à teoria reportada nos capítulos anteriores. Conforme a Figura 55 ilustra, sua apresentação divide-se em quatro blocos, cuja sequência prioriza a ascendência da interação entre a realidade e a literatura: descrição da amostra e dos respondentes; exploração do contexto empírico do estabelecimento dos preços; investigação da forma e da essência do estabelecimento dos preços; e análise dos fatores explicativos da essência do estabelecimento dos preços.

Figura 55 - Perspectivas de discussão dos resultados

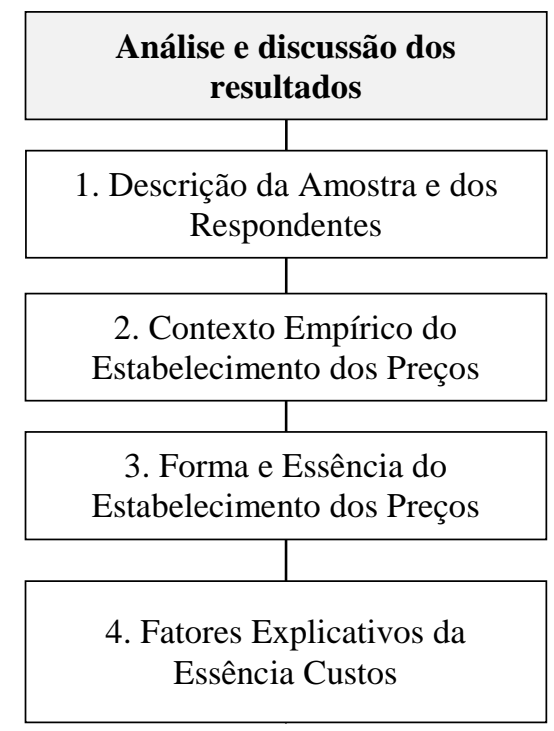

Fonte: Elaboração própria

\subsection{Descrição da Amostra e dos Respondentes}

\subsubsection{Características da Amostra}

Nesta seção são apresentadas as características das empresas da amostra a fim de revelar a origem que embasou os resultados encontrados na tese.

Em primeiro lugar, vale ressaltar que este estudo, diferentemente dos prévios trabalhos nacionais, buscou investigar o processo de estabelecimento dos preços no Brasil como um todo (não apenas em cidades, estados ou regiões específicas) e, de fato, conseguiu alcançar esse intento. 21 dos 27 estados brasileiros (incluindo o Distrito Federal) estão representados 
nesta pesquisa, sendo que há participantes de todas as regiões do país, como demonstra a Tabela 69.

Tabela 69 - Distribuição da amostra por localização

\begin{tabular}{|c|c|c|c|}
\hline REGIÃo & ESTADO & QUANTIDADE & Percentual \\
\hline \multirow{4}{*}{ Sudeste } & São Paulo & 236 & $62 \%$ \\
\hline & Minas Gerais & 29 & $8 \%$ \\
\hline & Rio de Janeiro & 7 & $2 \%$ \\
\hline & Espírito Santo & 1 & $0 \%$ \\
\hline \multicolumn{2}{|c|}{ Total Sudeste } & 273 & $72 \%$ \\
\hline \multirow{3}{*}{ Sul } & Rio Grande do Sul & 29 & $8 \%$ \\
\hline & Santa Catarina & 29 & $8 \%$ \\
\hline & Paraná & 19 & $5 \%$ \\
\hline \multicolumn{2}{|c|}{ Total Sul } & 77 & $20 \%$ \\
\hline \multirow{7}{*}{ Nordeste } & Bahia & 5 & $1 \%$ \\
\hline & Ceará & 5 & $1 \%$ \\
\hline & Pernambuco & 5 & $1 \%$ \\
\hline & Alagoas & 1 & $0 \%$ \\
\hline & Maranhão & 1 & $0 \%$ \\
\hline & Piauí & 1 & $0 \%$ \\
\hline & Rio Grande do Norte & 1 & $0 \%$ \\
\hline \multicolumn{2}{|c|}{ Total Nordeste } & 19 & $5 \%$ \\
\hline \multirow{4}{*}{ Centro-Oeste } & Goiás & 3 & $1 \%$ \\
\hline & Mato Grosso do Sul & 2 & $1 \%$ \\
\hline & Distrito Federal & 1 & $0 \%$ \\
\hline & Mato Grosso & 1 & $0 \%$ \\
\hline \multicolumn{2}{|c|}{ Total Centro-Oeste } & 7 & $2 \%$ \\
\hline \multirow{3}{*}{ Norte } & Pará & 2 & $1 \%$ \\
\hline & Amazonas & 1 & $0 \%$ \\
\hline & Tocantins & 1 & $0 \%$ \\
\hline \multicolumn{2}{|c|}{ Total Norte } & 4 & $1 \%$ \\
\hline \multicolumn{2}{|c|}{ TOTAL } & 380 & $100 \%$ \\
\hline
\end{tabular}

Nota-se que o peso da participação de empresas do sudeste (sobretudo de São Paulo) e do sul sobrepõe-se ao peso da participação de empresas das demais regiões. Essa sobreposição reflete a real concentração das empresas brasileiras pelo país, já que, como demonstrado na Figura 56, a amostra em muito se assemelha à população da pesquisa. Tanto na amostra quanto na população, encontra-se maior presença de empresas paulistas, seguidas de empresas de outros estados do sudeste e do sul. Nas demais regiões, destaques são encontrados em poucos estados específicos: Goiás (centro-oeste), Bahia, Ceará, Pernambuco (nordeste) e Pará (norte). 
Figura 56 - Localização da população e da amostra da pesquisa

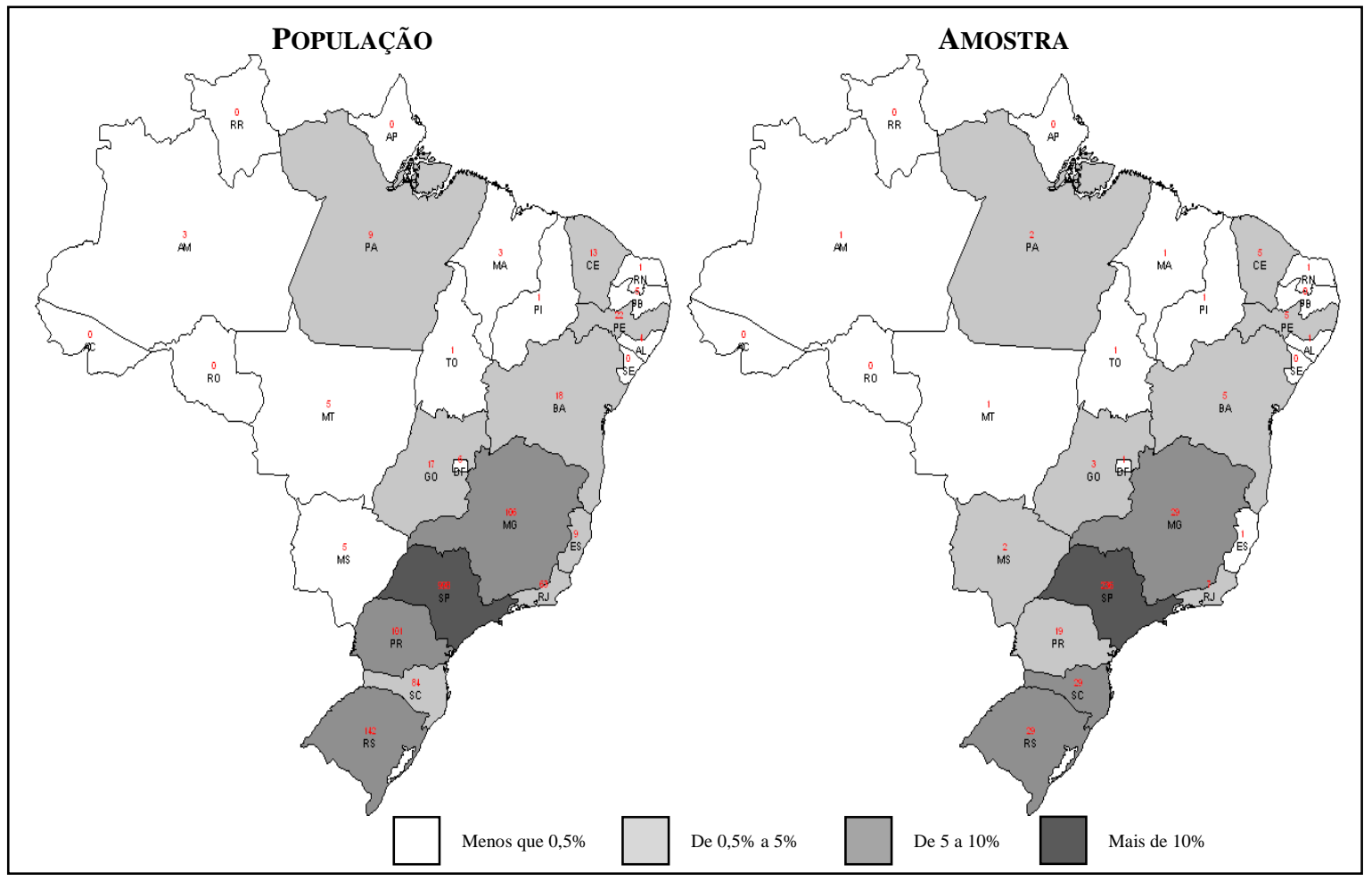

Fonte: Elaborada com a utilização do Gismaps Viewer - Versão de Avaliação

Pode-se perceber que a amostra é praticamente um espelho da população sendo que as únicas diferenças estão: na inversão de participação entre Paraná e Santa Catarina (há mais empresas paranaenses do que catarinenses, mas as empresas catarinenses participaram muito mais da pesquisa do que as paranaenses); na inexpressiva participação de empresas do Espírito Santo; e na participação ativa de empresas do Mato Grosso do Sul.

Outro ponto que merece ser apresentado refere-se ao porte das empresas participantes do estudo. Enquanto os trabalhos nacionais prévios sobre preços enfatizaram a investigação de portes específicos, esta tese procurou abranger empresas de variados tamanhos. A Tabela 70 demonstra a segregação da amostra por porte, segundo o critério de número de empregados (SEBRAE/SP, 2016).

Tabela 70 - Distribuição da amostra por porte

\begin{tabular}{|c|c|c|}
\hline PORTE & QUANTIDADE & Percentual \\
\hline Micro (Até 19 empregados) & 27 & $7 \%$ \\
\hline Pequena (De 20 a 99 empregados) & 91 & $24 \%$ \\
\hline Média (De 100 a 499 empregados) & 100 & $26 \%$ \\
\hline Grande (500 ou mais empregados) & 162 & $43 \%$ \\
\hline TOTAL & 380 & $100 \%$ \\
\hline
\end{tabular}


É possível constatar que na amostra, embora tenha a presença de empresas de todos os tamanhos, há uma concentração nos portes maiores (médio e grande), conforme a Figura 57 ilustra. Essa concentração mais uma vez espelha a composição da população da pesquisa, considerando que houve a utilização da base de dados da revista Exame Melhores e Maiores, na qual as maiores empresas brasileiras são relacionadas, em conjunto à base da NEI.

Figura 57 - Distribuição da amostra por porte

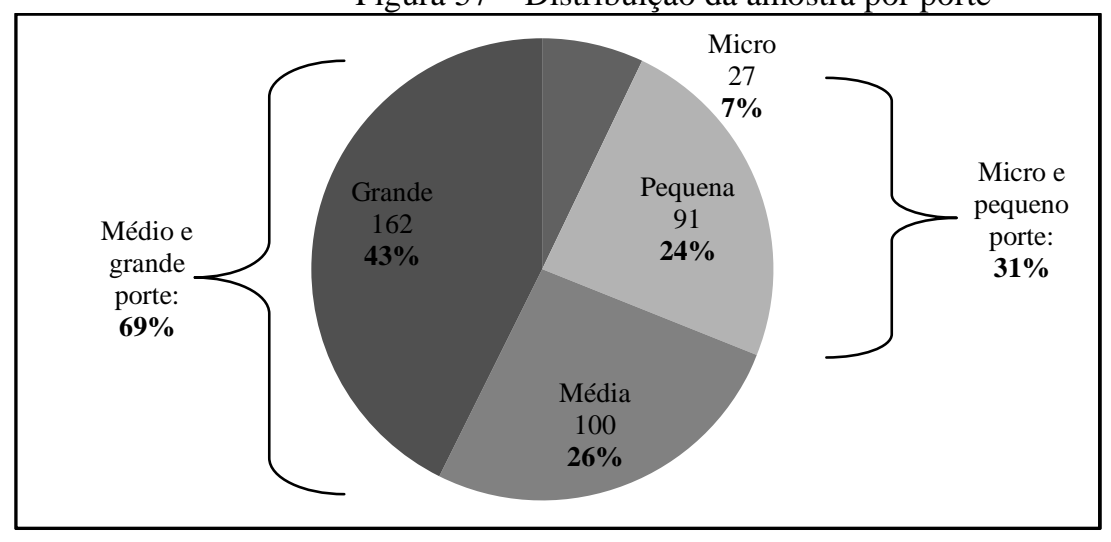

Fonte: Dados da pesquisa

A ampla maioria da amostra possui vários clientes. Como a Figura 58 demonstra, $72 \%$ da amostra concorda com a assertiva de que tem muitos clientes, enquanto que $10 \%$ discordam e $18 \%$ mostram-se indiferentes. Nota-se, portanto, que a amostra da pesquisa está predominantemente numa situação em que é fraca a dependência a um único cliente (ou a poucos clientes).

Figura 58 - Distribuição da amostra por quantidade de clientes

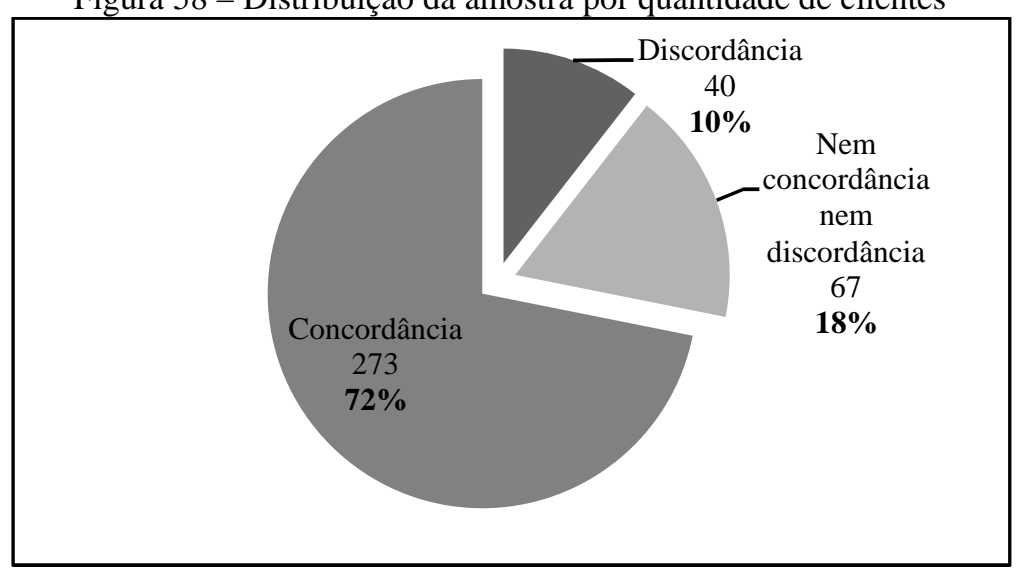

Fonte: Dados da pesquisa 
Cumpre também descrever a amostra no que se refere aos ambientes de atuação. Nesta tese, buscou-se abranger empresas dos mais variados ambientes, mas, naturalmente, há uma concentração de empresas do B2B, refletindo novamente a população da pesquisa. Isso acontece porque todas as empresas relacionadas no banco de dados da NEI atuavam no ambiente B2B e porque esse também era o ambiente predominante nas empresas industriais do banco de dados da Exame Melhores e Maiores. A Figura 59 evidencia essa concentração.

Figura 59 - Ambientes de atuação da amostra

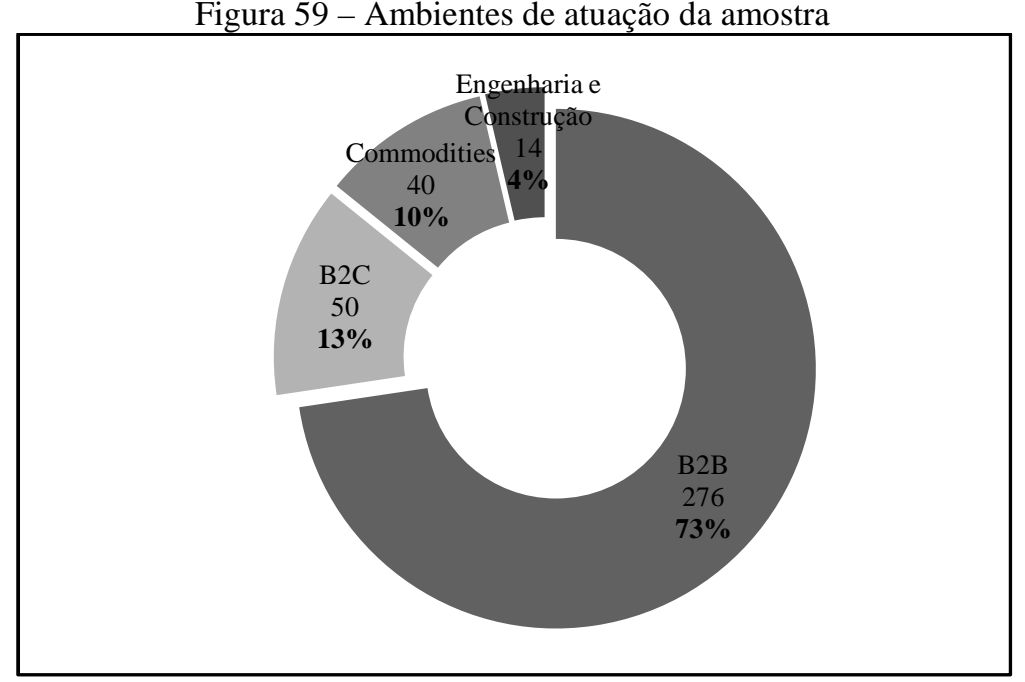

Fonte: Dados da pesquisa

Conforme a Tabela 71 expõe, para o ambiente B2B, há predomínio de empresas que produzem e vendem equipamentos (36\% da amostra). Para o ambiente $\mathrm{B} 2 \mathrm{C}$, há predomínio de empresas que elaboram e vendem alimentos (7\% da amostra). Já para o ambiente de commodities, há predomínio de empresas sucroalcooleiras (5\% da amostra).

Tabela 71 - Distribuição da amostra por segmento

\begin{tabular}{|c|c|c|}
\hline SEGMENTO & QUANTIDADE & Percentual \\
\hline B2B & 276 & $73 \%$ \\
\hline Equipamentos & 137 & $36 \%$ \\
\hline Peças e Acessórios & 65 & $17 \%$ \\
\hline Materiais para Construção & 18 & $5 \%$ \\
\hline Automotivo & 11 & $3 \%$ \\
\hline Tecidos e Confecções Profissionais & 11 & $3 \%$ \\
\hline Químico & 10 & $3 \%$ \\
\hline Papel, Plástico e Embalagens & 9 & $2 \%$ \\
\hline Fertilizantes e Defensivos & 8 & $2 \%$ \\
\hline Insumos para Indústria de Bens de Consumo & 4 & $1 \%$ \\
\hline Metalúrgico & 3 & $1 \%$ \\
\hline
\end{tabular}


..conclusão

\begin{tabular}{|c|c|c|}
\hline SEGMENTO & QUANTIDADE & Percentual \\
\hline B2C & 50 & $13 \%$ \\
\hline Alimentos & 27 & $7 \%$ \\
\hline Roupas e Calçados & 8 & $2 \%$ \\
\hline Farmacêutico & 6 & $2 \%$ \\
\hline Utensílios e Aparelhos Domésticos e de Escritório & 6 & $2 \%$ \\
\hline Produtos de Higiene e Limpeza & 3 & $1 \%$ \\
\hline Commodities & 40 & $10 \%$ \\
\hline Açúcar e Energia & 20 & $5 \%$ \\
\hline Agrícola e Florestal & 11 & $3 \%$ \\
\hline Mineração & 9 & $2 \%$ \\
\hline Engenharia e Construção & 14 & $4 \%$ \\
\hline Engenharia e Construção & 14 & $4 \%$ \\
\hline TOTAL & 380 & $100 \%$ \\
\hline
\end{tabular}

Sem fazer a segregação por ambiente, nota-se mais uma vez a ampla predominância dos produtores de equipamentos, os quais isoladamente correspondem a mais de um terço da amostra. Na sequência, aparece mais um segmento do B2B (peças e equipamentos) seguido de segmentos de outros ambientes: alimentos (B2C) e açúcar e energia (commodities). A Figura 60 expõe os detalhes dessa concentração amostral por segmentos.

Figura 60 - Distribuição da amostra por segmento

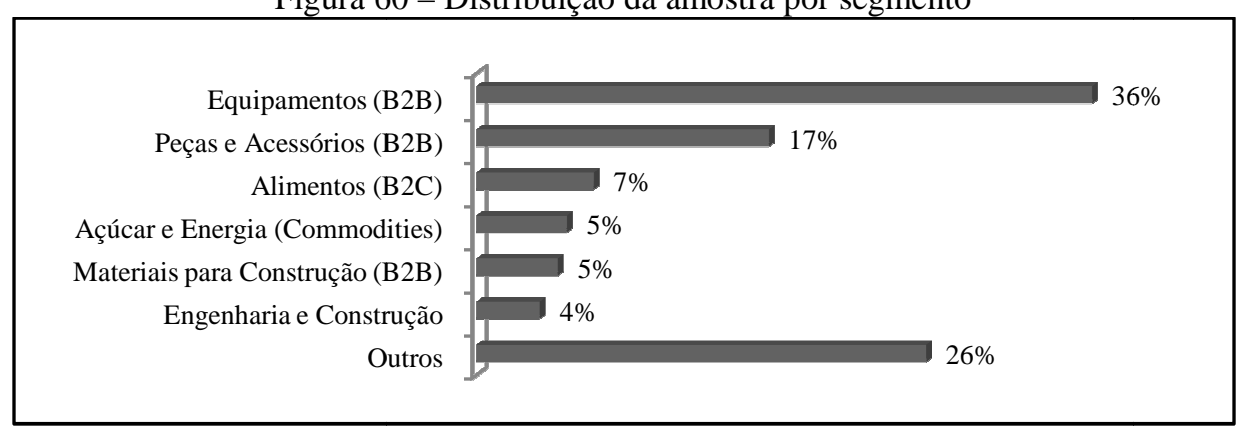

Fonte: Dados da pesquisa

Vale mencionar que, no geral, a maior parte das empresas da amostra total (56\%) não se considera a líder do seu segmento. A Tabela 72 detalha a quantidade e o percentual de empresas que se considera e que não se considera líder em cada segmento. Com esse detalhamento, percebe-se que as empresas de açúcar e energia são as que menos se enxergam como líderes (95\% contra 5\%). Já as empresas automotivas são as que mais se enxergam como líderes ( $82 \%$ contra 18\%). Cumpre esclarecer que 1 empresa de materiais para construção não respondeu a questão. 
Tabela 72 - Percepção de liderança por segmento

\begin{tabular}{|c|c|c|c|c|c|c|}
\hline \multirow{2}{*}{ AMbIENTE } & \multirow{2}{*}{ SEGMENTO } & \multicolumn{2}{|c|}{ NÃO LÍDER } & \multicolumn{2}{|c|}{ LÍDER } & \multirow{2}{*}{$\begin{array}{l}\text { TOTAL } \\
\text { GERAL }\end{array}$} \\
\hline & & QUANTIDADE & Percentual & QUANTIDADE & PERCENTUAL & \\
\hline \multirow{10}{*}{$\mathrm{B} 2 \mathrm{~B}$} & Equipamentos & 74 & $54 \%$ & 63 & $46 \%$ & 137 \\
\hline & Peças e Acessórios & 33 & $51 \%$ & 32 & $49 \%$ & 65 \\
\hline & Materiais para Construção & 9 & $53 \%$ & 8 & $47 \%$ & 17 \\
\hline & Automotivo & 2 & $18 \%$ & 9 & $82 \%$ & 11 \\
\hline & $\begin{array}{c}\text { Tecidos e Confecções } \\
\text { Profissionais } \\
\end{array}$ & 7 & $64 \%$ & 4 & $36 \%$ & 11 \\
\hline & Químico & 5 & $50 \%$ & 5 & $50 \%$ & 10 \\
\hline & Papel, Plástico e Embalagens & 4 & $44 \%$ & 5 & $56 \%$ & 9 \\
\hline & Fertilizantes e Defensivos & 8 & $100 \%$ & - & $0 \%$ & 8 \\
\hline & $\begin{array}{l}\text { Insumos para Indústria de Bens } \\
\text { de Consumo } \\
\end{array}$ & 3 & $75 \%$ & 1 & $25 \%$ & 4 \\
\hline & Metalúrgico & 1 & $33 \%$ & 2 & $67 \%$ & 3 \\
\hline & Total B2B & 146 & $53 \%$ & 129 & $47 \%$ & 275 \\
\hline \multirow{5}{*}{$\mathrm{B} 2 \mathrm{C}$} & Alimentos & 13 & $48 \%$ & 14 & $52 \%$ & 27 \\
\hline & Roupas e Calçados & 5 & $63 \%$ & 3 & $38 \%$ & 8 \\
\hline & Farmacêutico & 3 & $50 \%$ & 3 & $50 \%$ & 6 \\
\hline & $\begin{array}{c}\text { Utensílios e Aparelhos } \\
\text { Domésticos e de Escritório }\end{array}$ & 3 & $50 \%$ & 3 & $50 \%$ & 6 \\
\hline & Produtos de Higiene e Limpeza & 2 & $67 \%$ & 1 & $33 \%$ & 3 \\
\hline & Total B2C & 26 & $52 \%$ & 24 & $48 \%$ & 50 \\
\hline \multirow{3}{*}{ Commodities } & Açúcar e Energia & 19 & $95 \%$ & 1 & $5 \%$ & 20 \\
\hline & Agrícola e Florestal & 8 & $73 \%$ & 3 & $27 \%$ & 11 \\
\hline & Mineração & 4 & $44 \%$ & 5 & $56 \%$ & 9 \\
\hline \multicolumn{2}{|r|}{ Total Commodities } & 31 & $78 \%$ & 9 & $23 \%$ & 40 \\
\hline $\begin{array}{c}\text { Engenharia e } \\
\text { Construção }\end{array}$ & Engenharia e Construção & 8 & $57 \%$ & 6 & $43 \%$ & 14 \\
\hline \multicolumn{2}{|c|}{ Total Engenharia e Construção } & 8 & $57 \%$ & 6 & $43 \%$ & 14 \\
\hline & TOTAL GERAL & 211 & $56 \%$ & 168 & $44 \%$ & 379 \\
\hline
\end{tabular}

No que se refere ao nível de qualidade, cumpre destacar que a ampla maioria da amostra, especialmente os líderes de mercado, afirma oferecer produtos com qualidade superior aos concorrentes. 261 empresas concorda com essa assertiva contra 43 que discorda e 75 que nem concorda nem discorda. Como era de se esperar, os líderes oferecem produtos com qualidade superior aos concorrentes não líderes, havendo uma correlação de Pearson positiva $(0,227)$ e significativa ( $\mathrm{p}$-valor 0,000 ) entre a liderança e o nível de qualidade.

A Figura 61 compara, percentualmente, os não líderes aos líderes no que se refere ao nível de qualidade. Pode-se perceber que ambos concentram-se no oferecimento de produtos com alto nível de qualidade, entretanto, nos não líderes o percentual de empresas ofertando produtos com baixa e moderada qualidade é maior do que nos líderes. 
Figura 61 - Nível de qualidade ofertado por não líderes e líderes

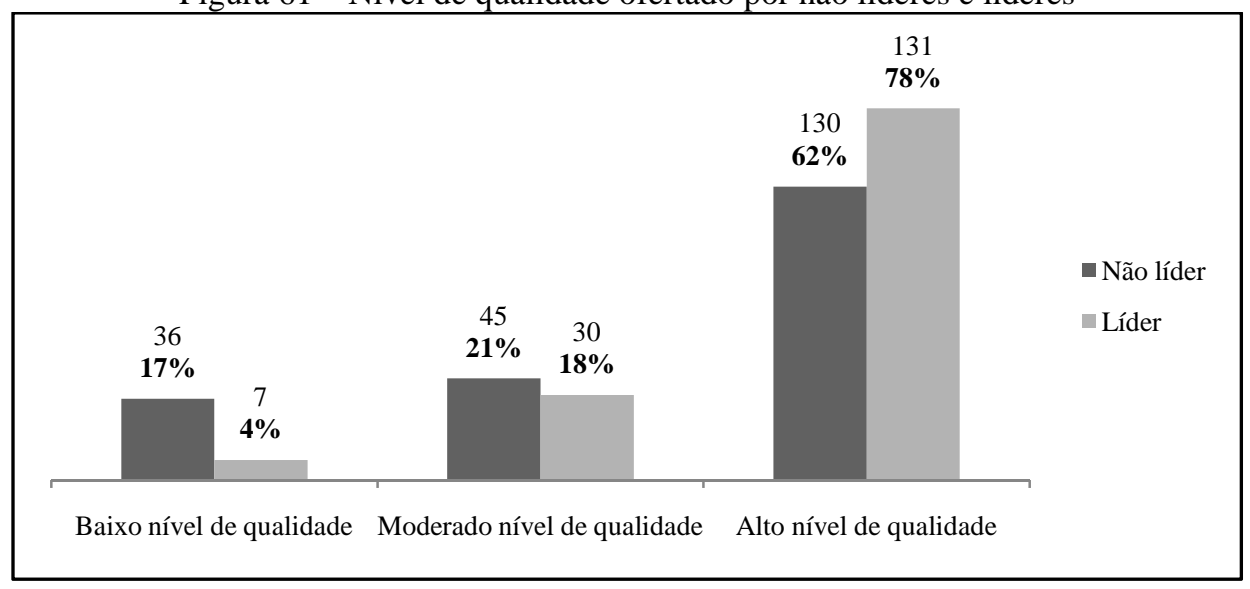

Fonte: Dados da pesquisa

Finalmente, vale mencionar que na ampla maioria da amostra existe uma área que, dentre outras atribuições, dedica-se ao gerenciamento de preços. Como a Tabela 73 evidencia, essa área é encontrada em $58 \%$ das empresas. O tempo médio que essa área está envolvida com os preços é de 20 anos, sendo 3 meses o menor tempo citado e 140 anos o maior tempo citado.

\begin{tabular}{c|c|c|c}
\multicolumn{3}{c|}{ Tabela 73 - Existência de área dedicada ao estabelecimento dos preços } \\
\hline ÁREA & QUANTIDADE & PERCENTUAL & $\begin{array}{c}\text { TEMPO MÉDIO } \\
\text { DE EXISTÊNCIA } \\
\text { (ANOS) }\end{array}$ \\
\hline Existência de área & 220 & $58 \%$ & 20 \\
\hline Inexistência de área & 160 & $42 \%$ & - \\
\hline TOTAL & $\mathbf{3 8 0}$ & $\mathbf{1 0 0 \%}$ & \\
\hline
\end{tabular}

\subsubsection{Características dos Respondentes}

Passando das características das empresas para as características específicas dos respondentes, vale mencionar que os principais responsáveis pela definição dos preços no Brasil são homens. Percebe-se uma desproporcionalidade muito grande no gênero responsável por essa deliberação já que $87 \%$ da amostra é formada pelo sexo masculino (329), enquanto que $13 \%$ é formada pelo sexo feminino (49). Em 3 empresas, mais de um profissional assinou ao questionário, sendo que em 2 havia respondentes dos dois sexos (em 1, os dois respondentes eram homens). A Figura 62 evidencia a distribuição da amostra pelo gênero dos respondentes. 
Figura 62 - Gênero dos respondentes

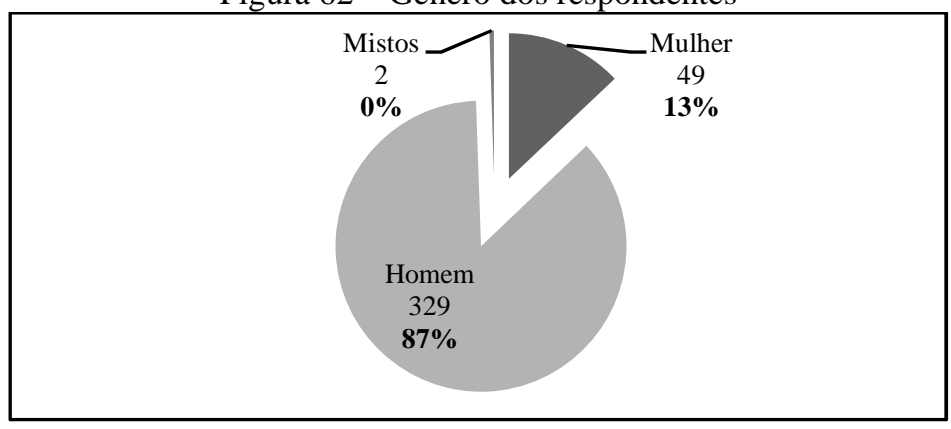

Fonte: Dados da pesquisa

Outra característica que merece ser salientada acerca dos responsáveis pela definição dos preços no Brasil refere-se à ocupação de função gerencial. Nesta tese, constatou-se que 87\% dos responsáveis pela definição dos preços (330) eram, em alguma extensão, gestores e que apenas 13\% (50) ocupavam funções somente técnicas. A Tabela 74 demonstra detalhes dessa constatação e evidencia que, no geral, os preços são definidos pelos gerentes ou diretores. Em algumas empresas a decisão é tomada diretamente pelos sócios e presidentes.

Tabela 74 - Função dos respondentes

\begin{tabular}{c|c|c|c}
\hline FuNÇão & QUANTIDADE & PERCENTUAL & $\begin{array}{c}\text { TEMPO MÉDIO DE } \\
\text { EXPERIÊNCIA } \\
\text { (ANOS) }\end{array}$ \\
\hline Gerencial & $\mathbf{3 3 0}$ & $\mathbf{8 7 \%}$ & $\mathbf{1 3 , 0}$ \\
\hline Gerente/Diretor & 257 & $68 \%$ & 13,5 \\
\hline Supervisor/Coordenador & 64 & $17 \%$ & 10,5 \\
\hline Sócio/Vice-presidente/Presidente & 6 & $2 \%$ & 19,0 \\
\hline Chefe/Gestor & 3 & $1 \%$ & 20,5 \\
\hline Técnica & $\mathbf{5 0}$ & $\mathbf{1 3 \%}$ & $\mathbf{7 , 0}$ \\
\hline Analista/Assessor/Consultor & 33 & $9 \%$ & 4,5 \\
\hline Auxiliar/Assistente & 4 & $1 \%$ & 12,5 \\
\hline Contador/Controller/Orçamentista & 3 & $1 \%$ & 13,0 \\
\hline Vendedor/Executivo de vendas & 3 & $1 \%$ & 12,5 \\
\hline Engenheiro & 2 & $1 \%$ & 11,0 \\
\hline Outro & 5 & $1 \%$ & \\
\hline
\end{tabular}

Pode-se também observar na Tabela 74, a ampla experiência dos profissionais na definição de preços. Os profissionais com funções gerenciais atuam no estabelecimento de preços, em média, há 13 anos enquanto que os profissionais técnicos têm, em média, 7 anos de experiência. Vale mencionar que o maior tempo de experiência assinalado foi 50 anos (por 2 profissionais) e que 4 profissionais não responderam à pergunta (nem foi possível identificar sua experiência). 
Com relação ao departamento de atuação, pode-se observar que no Brasil as deliberações de preços são concentradas no setor de vendas, já que mais de um terço dos respondentes (144) é vinculada a ele. $\mathrm{Na}$ sequência aparecem os departamentos financeiros (finanças, custos, contabilidade etc.), os departamentos específicos de preços, de marketing e de engenharia. Não é raro encontrar profissionais responsáveis pela definição dos preços que, por serem gestores, atuam em mais de um departamento ou atuam diretamente na diretoria. Como a Figura 63 evidencia, embora $78 \%$ dos profissionais sejam de um único departamento, 22\% são vinculados a mais de um setor ou à diretoria. As combinações mais comuns envolvem as áreas de vendas, marketing e preços.

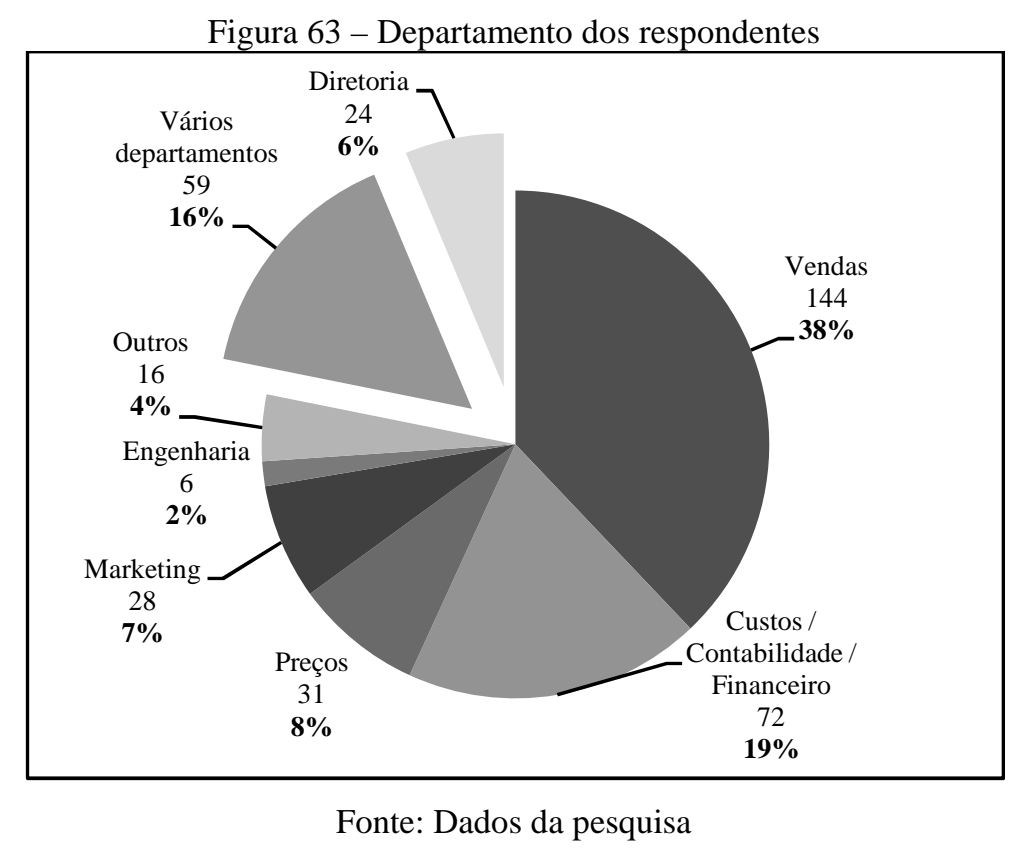

\subsection{Contexto Empírico do Estabelecimento dos Preços}

Para iniciar a seção e viabilizar a exploração do contexto empírico do estabelecimento dos preços, deve-se primeiramente segregar a amostra em tomadores e formadores de preços. Conforme a seção 6.4.1.1 explicou, essa separação é operacionalizada a partir de três variáveis: ambiente de atuação (AMB), diferenciação percebida (DIP) e necessidade de tomada dos preços dos concorrentes (EXA). Curiosamente, como a Tabela 75 demonstra, a amostra está proporcionalmente dividida entre formadores e tomadores de preços. 
Tabela 75 - Poder na definição dos preços

\begin{tabular}{c|c|c}
\hline ENQUADRAMENTO & QUANTIDADE & PERCENTUAL \\
\hline Formador de Preços & 192 & $51 \%$ \\
\hline Tomador de Preços & 188 & $49 \%$ \\
\hline TOTAL & $\mathbf{3 8 0}$ & $\mathbf{1 0 0 \%}$ \\
\hline
\end{tabular}

A Figura 64 ilustra como se chegou a essa distribuição, tendo como norte os parâmetros de operacionalização descritos na seção 6.4.1.1. Primeiramente, a amostra foi segregada de acordo com o ambiente de atuação, sendo que todas as empresas do ambiente de commodities foram imediatamente classificadas como tomadoras de preços. Na sequência, para empresas do ambiente B2C, houve análise das respostas assinaladas para a variável DIP, sendo que foram classificadas como tomadoras de preços todas as empresas que marcaram os pontos 1, 2 e 3, correlatos a não concordância de que os clientes consideram diferenciados os produtos ofertados. Finalmente, para as empresas remanescentes (ainda não classificadas como tomadoras de preços), foram analisadas as respostas marcadas para a variável EXA. Todas as empresas restantes que assinalaram os pontos 3, 4 e 5, correlatos a não necessidade de colocação de preços exatamente iguais aos concorrentes, foram classificadas como formadoras de preços enquanto que as demais foram enquadradas como tomadoras de preços.

Figura 64 - Enquadramento das empresas na amostra

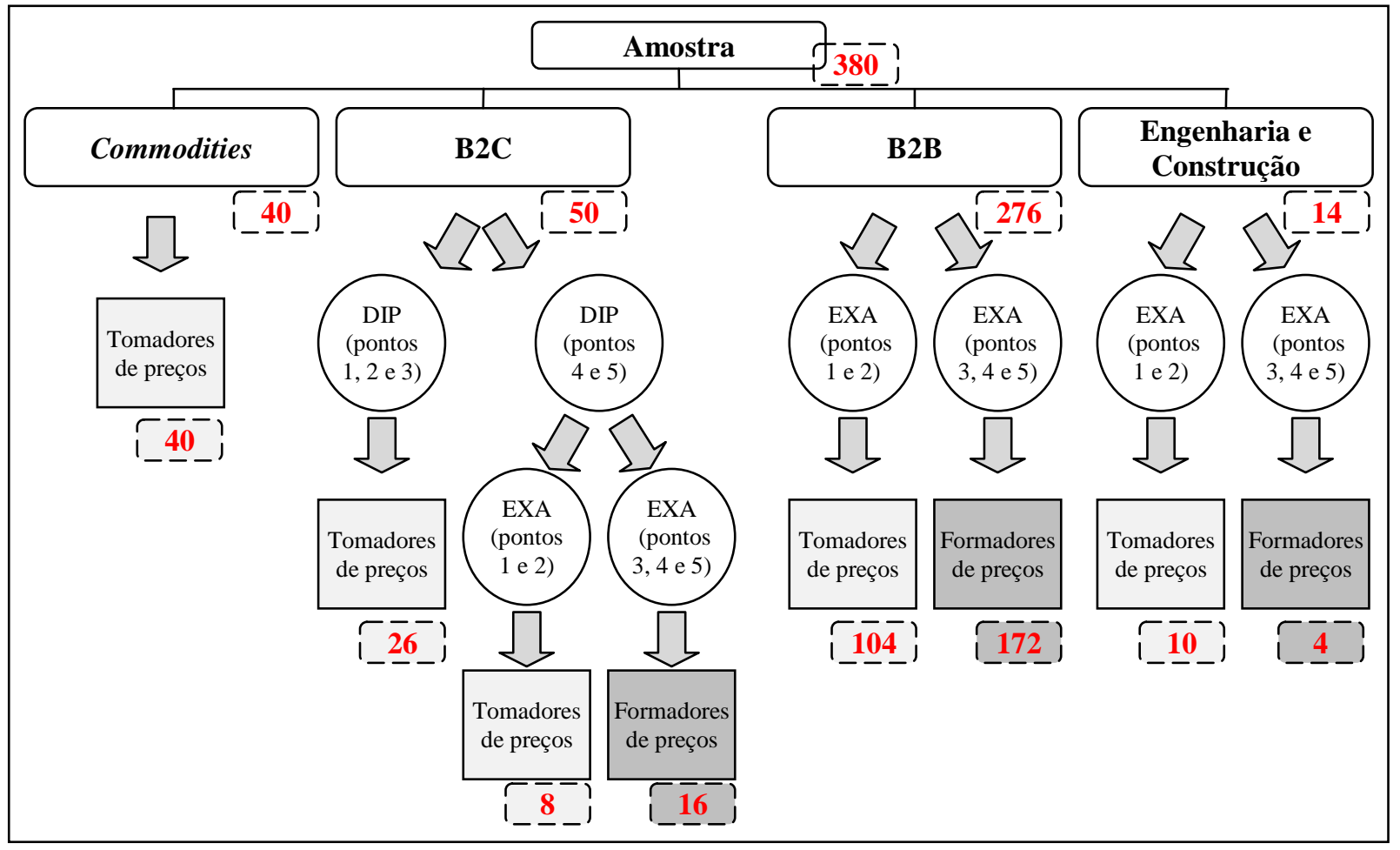

Fonte: Dados da pesquisa 
Com a amostra segregada, pode-se passar às análises do contexto empírico do estabelecimento dos preços, isto é, à investigação se, entre tomadores e formadores de preços, há distinção na diferenciação, na dificuldade de uso das informações da concorrência e nas informações usadas (Figura 65). Vale rememorar que a seção 4.2.1 discutiu, teoricamente, que os tomadores de preços tendem a oferecer produtos pouco diferenciados enquanto que os formadores de preços tendem a ofertar produtos diferenciados (alvo de investigação das ANACOR 1 e 2). Já a seção 4.2.2 debateu, teoricamente, a dificuldade encontrada pelos formadores de preços no uso de informações da concorrência (alvo de investigação da ANACOR 2) e, por consequência, os tipos de informações usadas por eles e pelos tomadores de preços (alvo de investigação das ANACOR 4, 5 e 6).

Figura 65 - Expectativas teóricas sobre o contexto empírico do estabelecimento

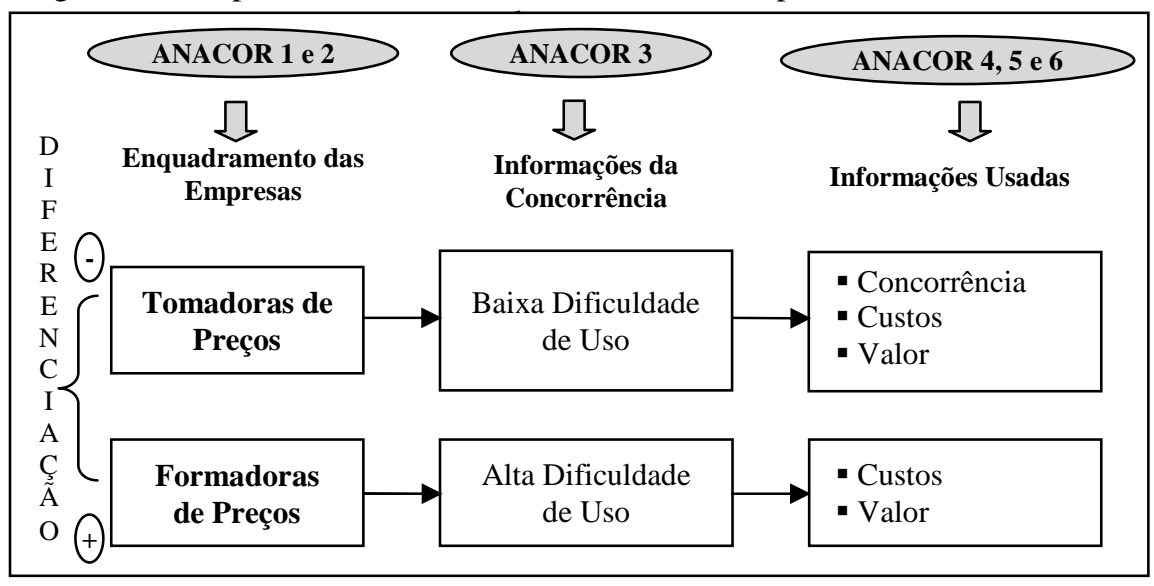

Fonte: Elaboração própria

O contexto empírico do estabelecimento dos preços é explorado com o uso de ANACOR que, de acordo com Hair et al. (2009), é uma técnica que examina relações de interdependência de variáveis não métricas. Ela é embasada na associação entre objetos e atributos especificados pelo pesquisador e traz o benefício de representar linhas e colunas em um espaço conjunto. Cumpre salientar que a interpretação dos resultados deve considerar que a ANACOR é uma técnica exploratória (Pestana \& Gageiro, 1998). Sua natureza é essencialmente descritiva e, portanto, não deve ser usada para inferir relações de causa e efeito (Fávero et al., 2009).

\subsubsection{Enquadramento e Diferenciação}

$\mathrm{Na}$ seção 4.2.1, foram levantados argumentos que nem todas as empresas têm poder para formar preços e que a diferenciação tende a estar associada a esse poder. Nesta parte da tese, 
portanto, busca-se empiricamente explorar a relação de interdependência entre o enquadramento e a diferenciação. Optou-se por evidenciar separadamente os tomadores de preços oferecedores de commodities dos demais tomadores de preços, considerando que os primeiros tendem a estar nas posições mais extremas. Decidiu-se também abordar a diferenciação segundo dois prismas: diferenciação e customização.

A primeira relação investigada nesta tese refere-se à diferenciação e o enquadramento como tomador ou formador de preços. Conforme mostra a Tabela 76, essa relação foi operacionalizada mediante análise do enquadramento e das respostas à questão 1c.

Tabela 76 - Enquadramento e diferenciação

\begin{tabular}{|c|c|c|}
\hline VARIÁVEL & ASSERTIVA & $\begin{array}{c}N^{\circ} \text { DA } \\
\text { QUESTÃO }\end{array}$ \\
\hline ENQ & Dummy formada a partir da combinação de AMB, DIP e EXA & N/A \\
\hline DIF & $\begin{array}{l}\text { Os atributos e funcionalidades dos nossos produtos são diferentes dos atributos e } \\
\text { funcionalidades dos produtos dos nossos concorrentes }\end{array}$ & $1 \mathrm{c}$ \\
\hline
\end{tabular}

Antes de proceder a ANACOR, costuma-se realizar o teste de Qui-Quadrado para verificar se há indícios que levam à rejeição de hipótese nula de independência das variáveis (Fávero et al., 2009). A Tabela 77 apresenta os resultados do referido teste.

Tabela 77 - Teste qui-quadrado: Enquadramento e diferenciação

\begin{tabular}{c|c|c|c}
\hline & VALOR & GRAUS DE LIBERDADE & P-VALOR \\
\hline Qui-Quadrado & 75,58 & 8 & $\mathbf{0 , 0 0 0}^{* * * *}$ \\
\hline Número de casos válidos & 380 & & \\
\hline
\end{tabular}

Nota. $* * * \mathrm{p}<0,01$

O teste Qui-Quadrado revela um p-valor de 0,000, que indica a não independência entre as variáveis e permite prosseguir com aplicação da ANACOR. O primeiro passo na aplicação da ANACOR está na elaboração da tabela de contingência (Tabela 78) na qual são relacionados os pontos da diferenciação (de 1 a 5) assinalados em cada enquadramento.

Tabela 78 - Tabela de contingência: Enquadramento e diferenciação

\begin{tabular}{c|c|c|c|c|c|c}
\hline \multirow{2}{*}{ ENQ } & \multicolumn{6}{|c}{ DIF } \\
\cline { 2 - 7 } & $\mathbf{1}$ & $\mathbf{2}$ & $\mathbf{3}$ & $\mathbf{4}$ & $\mathbf{5}$ & TOTAL \\
\hline Formadores & 8 & 28 & 58 & $\mathbf{6 6}$ & 32 & 192 \\
\hline Tomadores (Commodities) & $\mathbf{1 4}$ & 8 & 10 & 5 & 3 & 40 \\
\hline Tomadores (Demais) & 27 & $\mathbf{5 1}$ & 43 & 23 & 4 & 148 \\
\hline ToTAL & $\mathbf{4 9}$ & $\mathbf{8 7}$ & $\mathbf{1 1 1}$ & $\mathbf{9 4}$ & $\mathbf{3 9}$ & $\mathbf{3 8 0}$ \\
\hline
\end{tabular}


Em seguida, elaboram-se tabelas com os perfis das linhas e das colunas para identificar os cruzamentos entre as categorias. Os perfis das linhas indicam a proporção das linhas para cada célula da tabela de contingência com base nos totais marginais. Já os perfis das colunas indicam a proporção das colunas para cada célula da tabela de contingência com base nos totais marginais. Ambas as tabelas demonstram a margem, medida de influência de um objeto com base na frequência marginal (Fávero et al., 2009). A Tabela 79 traz os perfis das linhas.

Tabela 79 - Perfis das linhas: Enquadramento e diferenciação

\begin{tabular}{c|c|c|c|c|c|c}
\hline \multirow{2}{*}{ ENQ } & \multicolumn{6}{c}{ DIF } \\
\cline { 2 - 7 } & $\mathbf{1}$ & $\mathbf{2}$ & $\mathbf{3}$ & $\mathbf{4}$ & $\mathbf{5}$ & TOTAIS MARGINAIS \\
\hline Formadores & 0,042 & 0,146 & 0,302 & $\mathbf{0 , 3 4 4}$ & 0,167 & 1,000 \\
\hline Tomadores (Commodities) & $\mathbf{0 , 3 5 0}$ & 0,200 & 0,250 & 0,125 & 0,075 & 1,000 \\
\hline Tomadores (Demais) & 0,182 & $\mathbf{0 , 3 4 5}$ & 0,291 & 0,155 & 0,027 & 1,000 \\
\hline Massa & 0,129 & 0,229 & 0,292 & 0,247 & 0,103 & \\
\hline
\end{tabular}

Ao analisar os perfis das linhas, pode-se notar que nas empresas formadoras as maiores concentrações estão no oferecimento de produtos diferenciados (ponto 4) e que nas empresas tomadoras as maiores concentrações estão no oferecimento de produtos não diferenciados (ponto 1 nos tomadores oferecedores de commodities e ponto 2 nos demais tomadores). Esses já são os primeiros indícios de que há, sim, associação entre o enquadramento e a diferenciação: nos formadores de preços há predomínio da diferenciação (ponto 4) e nos tomadores de preços há predomínio de não diferenciação (pontos 1 e 2). Já a Tabela 80 apresenta os perfis das colunas.

Tabela 80 - Perfis das colunas: Enquadramento e diferenciação

\begin{tabular}{c|c|c|c|c|c|c}
\hline \multirow{2}{*}{ ENQ } & \multicolumn{7}{|c}{ DIF } \\
\cline { 2 - 7 } & $\mathbf{1}$ & $\mathbf{2}$ & $\mathbf{3}$ & $\mathbf{4}$ & $\mathbf{5}$ & MASSA \\
\hline Formadores & 0,163 & 0,322 & $\mathbf{0 , 5 2 3}$ & $\mathbf{0 , 7 0 2}$ & $\mathbf{0 , 8 2 1}$ & 0,505 \\
\hline Tomadores (Commodities) & 0,286 & 0,092 & 0,090 & 0,053 & 0,077 & 0,105 \\
\hline Tomadores (Demais) & $\mathbf{0 , 5 5 1}$ & $\mathbf{0 , 5 8 6}$ & 0,387 & 0,245 & 0,103 & 0,389 \\
\hline TOTAIS MARGINAIS & $\mathbf{1 , 0 0 0}$ & $\mathbf{1 , 0 0 0}$ & $\mathbf{1 , 0 0 0}$ & $\mathbf{1 , 0 0 0}$ & $\mathbf{1 , 0 0 0}$ & \\
\hline
\end{tabular}

A análise dos perfis das colunas permite perceber que os menores pontos (1 e 2) estão concentrados nos tomadores de preços e que os maiores pontos (3, 4 e 5) estão concentrados nos formadores de preços. Essa análise traz mais um indício de que há, sim, associação entre o enquadramento e a diferenciação: a presença da diferenciação predomina nos formadores de preços enquanto que sua ausência predomina nos tomadores de preços. 
A partir dos perfis das linhas e das colunas, pode-se executar os cálculos dos valores singulares e da inércia em cada dimensão. O número máximo de dimensões que pode ser estimado na ANACOR é um a menos do que o menor número de linhas ou de colunas (no caso da tese, 2: 3 linhas menos 1). A Tabela 81 apresenta os valores.

Tabela 81 - Valor singular e inércia: Enquadramento e diferenciação

\begin{tabular}{c|c|c|c}
\hline DIMENSÃo & VALOR SINGULAR & INÉRCIA & $\begin{array}{c}\text { PERCENTUAL DA } \\
\text { INÉRCIA }\end{array}$ \\
\hline 1 & 0,414 & 0,172 & $86 \%$ \\
\hline 2 & 0,165 & 0,027 & $14 \%$ \\
\hline TOTAL & & $\mathbf{0 , 1 9 9}$ & $\mathbf{1 0 0 \%}$ \\
\hline
\end{tabular}

Os valores singulares, também conhecidos como autovalores, indicam a contribuição relativa de cada dimensão na explicação das variâncias. A inércia também mede a variação explicada e está diretamente relacionada com o autovalor (Hair et al., 2009). A inércia total multiplicada pelo tamanho da amostra resulta no Qui-Quadrado (Fávero et al., 2009).

Por fim, foram apurados os escores linha e coluna, que correspondem às coordenadas dos pontos linhas e dos pontos colunas na representação espacial. Os escores das linhas, por exemplo, são calculados por meio do produto da matriz de perfil linha com o escore da coluna, dividido pelo valor singular para cada dimensão. Os dois escores dependem do método de normalização utilizado (Fávero et al., 2009).

Nesta tese, optou-se pelo método de normalização simétrica (symmetric normalization), em que a inércia é distribuída simetricamente pelos escores das linhas e das colunas. Esse método é usado quando o principal interesse é explorar as diferenças ou semelhanças entre as duas variáveis (Pestana \& Gageiro, 1998). A Tabela 82 evidencia os escores bem como as massas. 
Tabela 82 - Coordenadas de linhas e colunas: Enquadramento e diferenciação

\begin{tabular}{|c|c|c|c|c|}
\hline & \multirow{2}{*}{ Categorias } & \multicolumn{2}{|c|}{ COORDENADAS } & \multirow{2}{*}{ MASSA } \\
\hline & & DIMENSÃO 1 & DIMENSÃO 2 & \\
\hline \multirow{4}{*}{ ENQ } & Formadores & 0,635 & 0,036 & 0,505 \\
\hline & Tomadores (Commodities) & $(0,805)$ & 1,068 & 0,105 \\
\hline & Tomadores (Demais) & $(0,606)$ & $(0,335)$ & 0,389 \\
\hline & TOTAL & & & 1,000 \\
\hline \multirow{6}{*}{ DIF } & 1 & $(1,110)$ & 0,768 & 0,129 \\
\hline & 2 & $(0,542)$ & $(0,527)$ & 0,229 \\
\hline & 3 & 0,059 & $(0,090)$ & 0,292 \\
\hline & 4 & 0,614 & $(0,000)$ & 0,247 \\
\hline & 5 & 0,957 & 0,469 & 0,103 \\
\hline & TOTAL & & & 1,000 \\
\hline
\end{tabular}

A partir dessas coordenadas, é possível elaborar o mapa perceptual que ilustra a relação entre o enquadramento e a diferenciação (Figura 66). Nesse mapa, observa-se que, como esperado, empresas oferecedoras de produtos diferenciados (pontos 4 e 5) aproximam-se da condição de formadoras de preços e que empresas oferecedoras de produtos não diferenciados (pontos $1 \mathrm{e}$ 2) aproximam-se da condição de tomadoras de preços. Vale chamar a atenção aos tomadores oferecedores de commodities, nos quais a diferenciação é a mais baixa.

Figura 66 - Mapa perceptual: Enquadramento e diferenciação

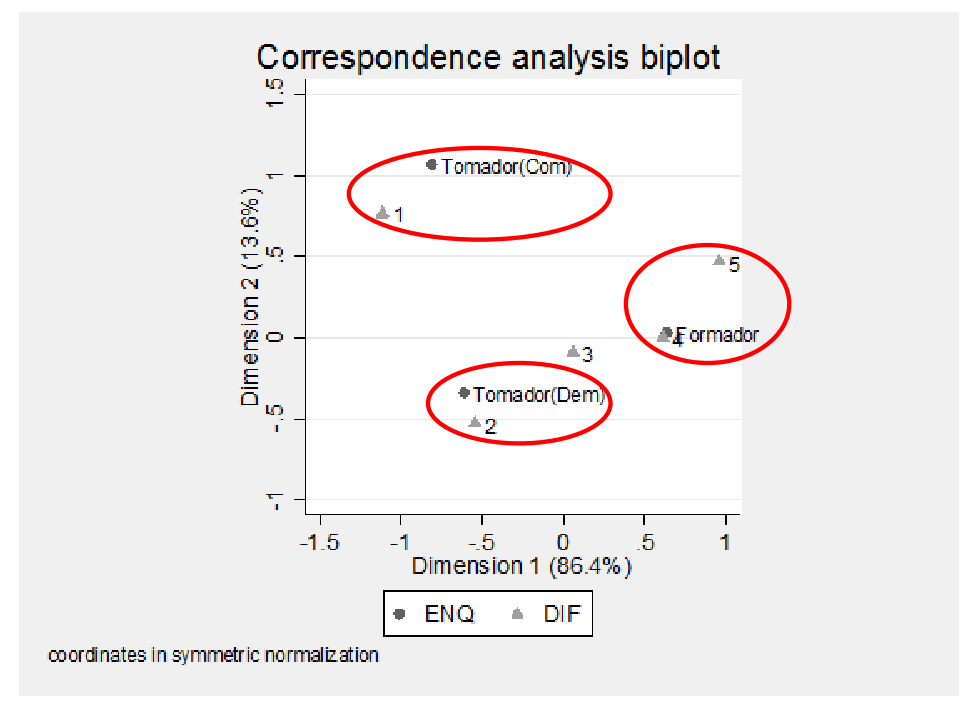

Fonte: Elaborada com a utilização do Stata

Para aprimorar o entendimento sobre a relação entre o enquadramento e a diferenciação, optou-se por explorá-la segundo mais um prisma: customização oferecida. A Tabela 83 evidencia como essa relação foi operacionalizada. 
Tabela 83 - Enquadramento e customização

\begin{tabular}{c|c|c}
\hline VARIÁVEL & QUESTÃo & $\begin{array}{c}\text { No DA } \\
\text { QUESTÃo }\end{array}$ \\
\hline ENQ & Dummy formada a partir da combinação de AMB, DIP e EXA & N/A \\
\hline CMZ & $\begin{array}{c}\text { Priorizamos a produção customizada, ou seja, frequentemente atendemos a solicitações } \\
\text { específicas dos clientes na elaboração dos nossos produtos }\end{array}$ & 11 \\
\hline
\end{tabular}

Realizaram-se os mesmos procedimentos da primeira ANACOR. Os resultados do teste QuiQuadrado indicaram que seria possível prosseguir com a ANACOR (valor 48,27; p-valor 0,000). Logo, foram elaboradas as tabelas de contingência, de perfis das linhas e de perfis das colunas. Foram também calculados os valores singulares, a inércia e as coordenadas de linha e coluna (método de normalização simétrica). A Tabela 84 sumariza os principais resultados.

Tabela 84 - Coordenadas de linhas e colunas: Enquadramento e customização

\begin{tabular}{c|c|c|c|c}
\hline \multirow{2}{*}{ CATEGORIAS } & \multicolumn{2}{c}{ COORDENADAS } & \multirow{2}{*}{ MASSA } \\
\cline { 2 - 5 } \multicolumn{2}{c|}{} & \multirow{2}{*}{ DIMENSÃO 1 } & \multirow{2}{*}{ DiMENSÃO 2 } & \\
\hline \multirow{4}{*}{ ENQ } & Formadores & 0,383 & 0,265 & 0,505 \\
\cline { 2 - 5 } & Tomadores (Commodities) & $(1,558)$ & 0,393 & 0,105 \\
\cline { 2 - 5 } & Tomadores (Demais) & $(0,076)$ & $(0,450)$ & 0,389 \\
\cline { 2 - 5 } & ToTAL & $(1,392)$ & 0,348 & 0,121 \\
\hline \multirow{5}{*}{ CMZ } & 1 & $(0,109)$ & $(0,744)$ & 0,171 \\
\cline { 2 - 5 } & 2 & $(0,180)$ & $(0,086)$ & 0,161 \\
\cline { 2 - 5 } & 3 & 0,272 & 0,102 & 0,203 \\
\cline { 2 - 5 } & 4 & 0,467 & 0,228 & 0,345 \\
\cline { 2 - 5 } & 5 & & & $\mathbf{1 , 0 0 0}$ \\
\hline
\end{tabular}

A partir dessas coordenadas, preparou-se o mapa perceptual para ilustrar a associação entre o enquadramento e a customização (Figura 67). Nesse mapa, vale destacar que os formadores de preços oferecem produtos customizados (pontos 4 e 5), enquanto que os tomadores de preços oferecem produtos padronizados (pontos 1 e 2 ). 
Figura 67 - Mapa perceptual: Enquadramento e customização

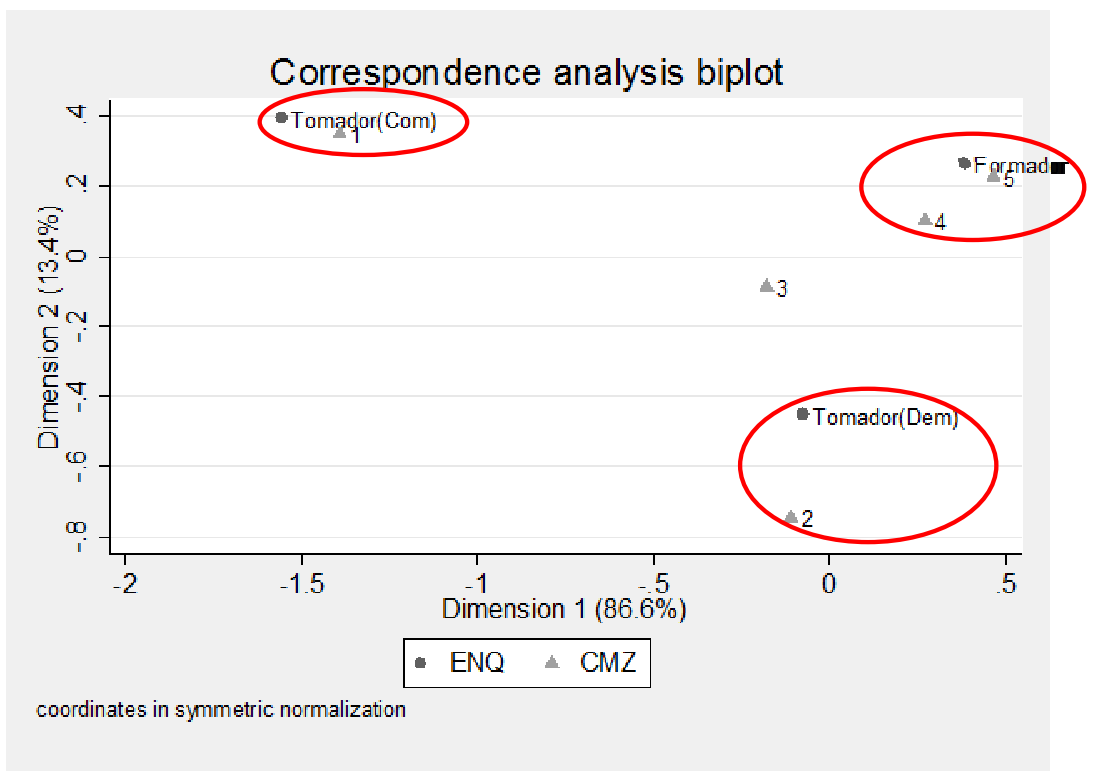

Fonte: Elaborada com a utilização do Stata

\subsubsection{Enquadramento e Dificuldade de Uso das Informações da Concorrência}

Visto que os tomadores e os formadores de preços são distintos entre si, pode-se passar à investigação do quão díspares são as condições que eles têm de usar informações dos preços dos concorrentes. Afinal, como argumentado na seção 4.2.2, enquanto os tomadores têm a possibilidade de usar os três tipos de informações (concorrência, custos e valor), os formadores, em decorrência da diferenciação ofertada, costumam ter dificuldades para identificar os preços dos concorrentes e precisam estabelecer os preços ancorados pelos custos e pelo valor.

Diante desse contexto, a fim de explorar a relação entre o enquadramento das empresas e a dificuldade de uso das informações da concorrência, procedeu-se à terceira ANACOR, cuja operacionalização está demonstrada na Tabela 85 .

Tabela 85 - Enquadramento e dificuldade de uso das informações da concorrência

\begin{tabular}{|c|c|c|}
\hline VARIÁVEL & QUESTÃo & $\begin{array}{c}\mathbf{N}^{\circ} \text { DA } \\
\text { QUESTÃo }\end{array}$ \\
\hline ENQ & Dummy formada a partir da combinação de AMB, DIP e EXA & N/A \\
\hline DAC_1 & $\begin{array}{l}\text { Temos dificuldade em identificar os preços cobrados pelos nossos concorrentes (é } \\
\text { escassa a divulgação prévia dos preços em sites, catálogos etc.) }\end{array}$ & $1 \mathrm{~h}$ \\
\hline DAC_2 & $\begin{array}{c}\text { A dificuldade de obtenção dos preços dos concorrentes explica nossa necessidade de } \\
\text { usar informações alternativas no estabelecimento dos preços }\end{array}$ & $1 \mathrm{i}$ \\
\hline
\end{tabular}


Os resultados do teste Qui-Quadrado (valor 58,02; p-valor 0,000) indicaram que seria possível prosseguir com a ANACOR. Foram, portanto, elaboradas as tabelas de contingência, de perfis das linhas e de perfis das colunas e calculados os valores singulares, a inércia e as coordenadas de linha e coluna (método de normalização simétrica). A Tabela 86 mostra os principais resultados.

Tabela 86 - Coordenadas: Enquadramento e dificuldade de uso das informações da concorrência

\begin{tabular}{|c|c|c|c|c|}
\hline & \multirow{2}{*}{ CATEgorias } & \multicolumn{2}{|c|}{ COORDENADAS } & \multirow{2}{*}{ MASSA } \\
\hline & & DIMENSÃO 1 & DIMENSÃO 2 & \\
\hline \multirow{4}{*}{ ENQ } & Formadores & 0,374 & 0,182 & 0,505 \\
\hline & Tomadores (Commodities) & $(1,343)$ & 0,355 & 0,105 \\
\hline & Tomadores (Demais) & $(0,122)$ & $(0,332)$ & 0,389 \\
\hline & TOTAL & & & 1,000 \\
\hline \multirow{6}{*}{ DAC } & 1 & $(0,885)$ & $(0,090)$ & 0,243 \\
\hline & 2 & 0,204 & 0,388 & 0,232 \\
\hline & 3 & 0,305 & $(0,255)$ & 0,200 \\
\hline & 4 & 0,509 & $(0,292)$ & 0,176 \\
\hline & 5 & 0,117 & 0,231 & 0,149 \\
\hline & TOTAL & & & 1,000 \\
\hline
\end{tabular}

A partir dessas coordenadas, confeccionou-se o mapa perceptual para evidenciar a relação entre o enquadramento e a dificuldade de uso das informações da concorrência (Figura 68). Nesse mapa, pode-se observar que os tomadores de preços oferecedores de commodities são os que menos têm dificuldade de usar esse tipo de informação (maior proximidade ao ponto 1). Já os formadores de preços encontram, sim, dificuldades (maior proximidade ao ponto 5).

Figura 68 - Mapa: Enquadramento e dificuldade de uso das informações da concorrência

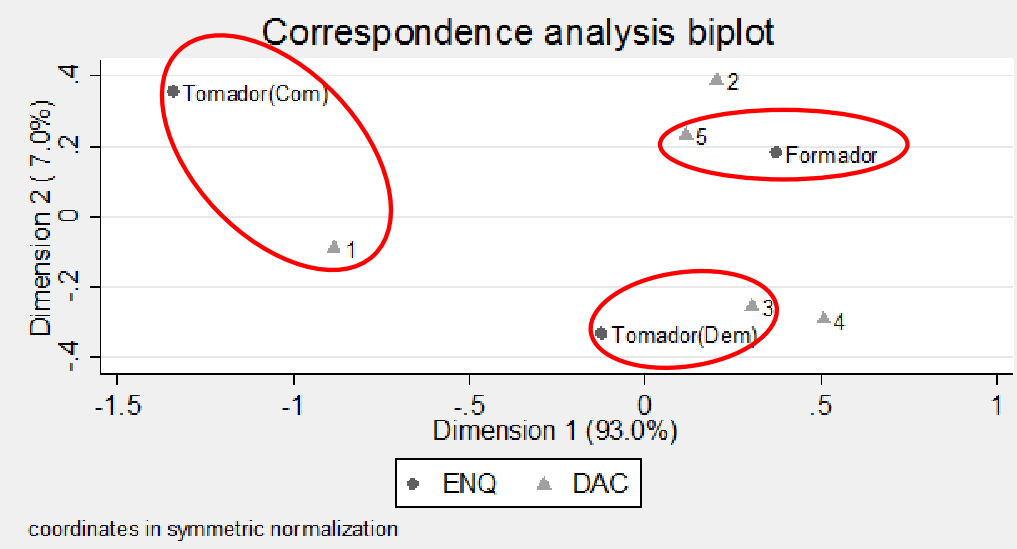

Fonte: Elaborada com a utilização do Stata 


\subsubsection{Enquadramento da Empresa e Informações Usadas}

Depois de identificadas as dificuldades de uso de informações da concorrência nos formadores de preços, pode-se partir para a exploração da intensidade de uso dessa e dos demais tipos de informação. Conforme se defendeu na seção 4.2.2, espera-se que os tomadores de preços priorizem o uso de informações da concorrência para conseguirem submeter seus preços ao mercado e que os formadores, diante das barreiras ao uso de informações sobre os preços dos concorrentes, priorizem as demais informações e formem seus preços a partir dos custos e do valor.

Primeiramente, vale apresentar a Tabela 87 para evidenciar as informações mais intensamente utilizadas por enquadramento. A quantidade reportada refere-se ao número de empresas que assinalou o uso altamente intenso (ponto 5) da informação. No caso de duas ou mais informações terem tido a mesma quantidade de marcações no ponto 5 , foi considerada a quantidade de marcações no ponto 4 como critério de desempate para definição do ranking. Em situações que o empate prevaleceu, foi considerada a quantidade de marcações no ponto 3 e assim sucessivamente. Em negrito estão as células referentes a informações de custos, em itálico estão as células referentes a informações de valor, sombreadas de cinza estão as células referentes a informações da concorrência, sublinhada está a célula referente a outros tipos de informações. 
Tabela 87 - Intensidade de uso de informações

\begin{tabular}{|c|c|c|c|c|c|c|}
\hline \multirow{2}{*}{ RANKING } & \multicolumn{2}{|l|}{ FORMAdORES DE PREÇOS } & \multicolumn{2}{|c|}{$\begin{array}{l}\text { TOMADORES DE PREÇOS } \\
\text { (COMMODITIES) }\end{array}$} & \multicolumn{2}{|c|}{ TOMADORES dE PREÇOS (DEMAIS) } \\
\hline & INFORMAÇÃO & QTDE. & INFORMAÇÃO & QTDE. & INFORMAÇÃO & QTDE. \\
\hline 1 & Impostos sobre vendas & 123 & $\begin{array}{c}\text { Custos variáveis/diretos dos } \\
\text { produtos }\end{array}$ & 21 & Impostos sobre vendas & 98 \\
\hline 2 & $\begin{array}{l}\text { Margem desejada para os } \\
\text { produtos (margem de } \\
\text { contribuição, de lucro bruto } \\
\text { ou de lucro líquido) }\end{array}$ & 122 & Impostos sobre vendas & 17 & $\begin{array}{l}\text { Custos variáveis/diretos } \\
\text { dos produtos }\end{array}$ & 91 \\
\hline 3 & $\begin{array}{c}\text { Custos variáveis/diretos dos } \\
\text { produtos }\end{array}$ & 108 & $\begin{array}{c}\text { Preços de produtos } \\
\text { concorrentes que são iguais } \\
\text { aos nossos produtos }\end{array}$ & 16 & $\begin{array}{l}\text { Custos fixos de fabricação } \\
\text { dos produtos }\end{array}$ & 82 \\
\hline 4 & $\begin{array}{l}\text { Custos fixos de fabricação } \\
\text { dos produtos }\end{array}$ & 93 & $\begin{array}{l}\text { Despesas (administrativas, } \\
\text { comerciais e financeiras) }\end{array}$ & 16 & $\begin{array}{l}\text { Margem desejada para os } \\
\text { produtos (margem de } \\
\text { contribuição, de lucro } \\
\text { bruto ou de lucro líquido) }\end{array}$ & 80 \\
\hline 5 & $\begin{array}{c}\text { Despesas (administrativas, } \\
\text { comerciais e financeiras) }\end{array}$ & 75 & $\begin{array}{c}\text { Custos fixos de fabricação } \\
\text { dos produtos } \\
\end{array}$ & 15 & $\begin{array}{c}\text { Despesas (administrativas, } \\
\text { comerciais e financeiras) }\end{array}$ & 66 \\
\hline 6 & $\begin{array}{c}\text { Necessidades e interesses dos } \\
\text { clientes }\end{array}$ & 64 & $\begin{array}{c}\text { Valores dos investimentos } \\
\text { (em maquinários, instalações } \\
\text { etc.) }\end{array}$ & 15 & $\begin{array}{l}\text { Nível de preço dos } \\
\text { concorrentes }\end{array}$ & 50 \\
\hline 7 & $\begin{array}{c}\text { Comparação entre os } \\
\text { benefícios oferecidos e os } \\
\text { custos trazidos aos clientes } \\
\text { pelos produtos }\end{array}$ & 56 & $\begin{array}{c}\text { Outros tipos de informações } \\
\text { (por exemplo, informações } \\
\text { econômicas, políticas, } \\
\text { tecnológicas, regulatórias, } \\
\text { ecológicas, sociais etc.) }\end{array}$ & $\underline{14}$ & $\begin{array}{l}\text { Capacidade de pagamento } \\
\text { dos clientes }\end{array}$ & 41 \\
\hline 8 & $\begin{array}{l}\text { Percepções dos clientes em } \\
\text { relação aos produtos }\end{array}$ & 52 & $\begin{array}{c}\text { Nível de preço dos } \\
\text { concorrentes }\end{array}$ & 13 & $\begin{array}{l}\text { Estratégia de preço dos } \\
\text { concorrentes }\end{array}$ & 40 \\
\hline 9 & $\begin{array}{c}\text { Capacidade de pagamento dos } \\
\text { clientes }\end{array}$ & 52 & $\begin{array}{c}\text { Capacidade de pagamento dos } \\
\text { clientes }\end{array}$ & 12 & $\begin{array}{c}\text { Necessidades e interesses } \\
\text { dos clientes }\end{array}$ & 39 \\
\hline 10 & $\begin{array}{c}\text { Valores dos investimentos } \\
\text { (em maquinários, instalações } \\
\text { etc.) }\end{array}$ & 48 & $\begin{array}{c}\text { Preços de produtos } \\
\text { concorrentes que são similares } \\
\text { aos nossos produtos }\end{array}$ & 10 & $\begin{array}{c}\text { Preços de produtos } \\
\text { concorrentes que são iguais } \\
\text { aos nossos produtos }\end{array}$ & 38 \\
\hline
\end{tabular}

Pode-se perceber que a intensidade de uso das informações de custos é alta em empresas de todos os enquadramentos, mas especialmente nos formadores de preços, nos quais seis dentre as dez informações usadas mais intensamente são dessa categoria (as cinco primeiras colocadas e a décima colocada são, nesta ordem: impostos sobre vendas, margem desejada para os produtos, custos variáveis/diretos dos produtos, custos fixos de fabricação dos produtos, despesas, valores dos investimentos).

Nos tomadores de preços que ofertam commodities, cinco das dez informações usadas com mais intensidade são informações de custos (as duas primeiras, a quarta, a quinta e a sexta colocadas são, nesta ordem: custos variáveis/diretos dos produtos, impostos sobre vendas, despesas, custos fixos de fabricação dos produtos, valores dos investimentos). Nos demais tomadores, cinco das dez informações usadas mais intensamente são de custos (as cinco primeiras colocadas são, nesta ordem: impostos sobre vendas, custos variáveis/diretos dos produtos, custos fixos de fabricação dos produtos, margem desejada para os produtos, despesas). 
Tanto nos formadores de preços quanto nos tomadores não oferecedores de commodities, a informação com o uso mais intenso refere-se aos impostos sobre vendas. Nos tomadores que ofertam commodities, os impostos também são usados intensamente ao passo que aparecem como a segunda informação mais utilizada. É importante ressaltar que os estudos prévios realizados nos demais países não tinham revelado um uso tão intenso dos impostos sobre vendas, o que pode indicar que a carga tributária nacional é tão elevada (comparada aos outros países) que faz com que esse tipo de informação ultrapasse a importância dada às outras informações.

Nota-se ainda que nos formadores de preços as informações de custos são mescladas com informações de valor (neles, nenhuma informação da concorrência aparece em meio às dez de uso mais intenso). Já nos tomadores de preços, as informações de custos são mescladas principalmente com informações da concorrência, mas também com informações de valor.

Para aprofundar a análise da relação entre o enquadramento das empresas e as informações usadas, buscou-se realizar mais uma ANACOR para cada tipo de informação. A Tabela 88 revela as variáveis consideradas para operacionalizar essas ANACOR.

Tabela 88 - Enquadramento e informações usadas

\begin{tabular}{c|c|c}
\hline VARIÁVEL & QUESTão & $\begin{array}{c}\text { No DA } \\
\text { QUESTÃo }\end{array}$ \\
\hline ENQ & Dummy formada a partir da combinação de AMB, DIP e EXA & N/A \\
\hline ACU_1 & Custos variáveis/diretos dos produtos & $2 \mathrm{a}$ \\
\hline ACU_2 & Custos fixos de fabricação dos produtos & $2 \mathrm{~b}$ \\
\hline ACU_3 & Impostos sobre vendas & $2 \mathrm{c}$ \\
\hline ACU_4 & Despesas (administrativas, comerciais e financeiras) & $2 \mathrm{~d}$ \\
\hline ACU_5 & Valores dos investimentos (em maquinários, instalações etc.) & $2 \mathrm{e}$ \\
\hline ACU_6 & Margem desejada para os produtos (margem de contribuição, de lucro bruto ou de lucro & $2 \mathrm{f}$ \\
\hline AVA_1 & Necessidades e interesses dos clientes & $2 \mathrm{~g}$ \\
\hline AVA_2 & Capacidade de pagamento dos clientes & $2 \mathrm{~h}$ \\
\hline AVA_3 & Percepções dos clientes em relação aos produtos & $2 \mathrm{i}$ \\
\hline AVA_4 & Comparação entre os benefícios oferecidos e os custos trazidos aos clientes pelos produtos & $2 \mathrm{j}$ \\
\hline ACO_1 & Preços de produtos concorrentes que são iguais aos nossos produtos & $2 \mathrm{k}$ \\
\hline ACO_2 & Preços de produtos concorrentes que são similares aos nossos produtos & $2 \mathrm{l}$ \\
\hline ACO_3 & Nível de preço dos concorrentes & $2 \mathrm{~m}$ \\
\hline ACO_4 & Estratégia de preço dos concorrentes & $2 \mathrm{n}$ \\
\hline AOU & Outros tipos de informações (por exemplo, informações econômicas, políticas, tecnológicas, & $2 \mathrm{o}$ \\
\hline
\end{tabular}

Antes de iniciar os procedimentos, foram realizados testes Qui-Quadrado. Os resultados dos três primeiros testes sugeriram avançar com as análises, já que os p-valores foram inferiores a 
0,01, como demonstra a Tabela 89. Já os resultados do último teste não foram enfáticos e implicaram o cancelamento da análise.

Tabela 89 - Testes qui-quadrado: Enquadramento e informações usadas

\begin{tabular}{c|c|c}
\hline ANACOR & VALOR & P-VALOR \\
\hline ENQ e ACU & 58,84 & $0,000^{* * * * *}$ \\
\hline ENQ e AVA & 62,51 & $0,000^{* * * * *}$ \\
\hline ENQ e ACO & 61,84 & $0,000^{* * * * *}$ \\
\hline ENQ e AOU & 12,61 & 0,126 \\
\hline
\end{tabular}

Nota. $* * * \mathrm{p}<0,01$

Para as três ANACOR que persistiram, mais uma vez, foram preparadas as tabelas de contingência, de perfis das linhas e de perfis das colunas e realizados cálculos dos valores singulares, da inércia e das coordenadas de linha e coluna (método de normalização simétrica). A Tabela 90 demonstra os principais resultados.

Tabela 90 - Coordenadas de linhas e colunas: Enquadramento e informações usadas

\begin{tabular}{|c|c|c|c|c|c|c|c|c|c|c|c|c|}
\hline \multirow{3}{*}{ Categorias } & \multicolumn{4}{|c|}{ ENQ E ACU } & \multicolumn{4}{|c|}{ ENQ E AVA } & \multicolumn{4}{|c|}{ ENQ E ACO } \\
\hline & \multirow{2}{*}{ VAR. } & \multicolumn{2}{|c|}{ COORD. } & \multirow{2}{*}{ MaSSA } & \multirow{2}{*}{ VAR. } & \multicolumn{2}{|c|}{ COORD. } & \multirow{2}{*}{ MaSSA } & \multirow{2}{*}{ VAR. } & \multicolumn{2}{|c|}{ COORD. } & \multirow{2}{*}{ MASSA } \\
\hline & & Dim. 1 & Dim. 2 & & & Dim. 1 & Dim. 2 & & & Dim. 1 & Dim. 2 & \\
\hline Formador & \multirow{4}{*}{ ENQ } & 0,205 & 0,174 & 0,505 & \multirow{4}{*}{ ENQ } & 0,417 & 0,068 & 0,505 & \multirow{4}{*}{ ENQ } & 0,432 & 0,011 & 0,505 \\
\hline Tomador (Commodities) & & $(1,124)$ & 0,121 & 0,105 & & $(0,806)$ & 0,498 & 0,105 & & $(0,491)$ & 0,686 & 0,105 \\
\hline Tomador (Demais) & & 0,038 & $(0,259)$ & 0,389 & & $(0,323)$ & $(0,222)$ & 0,389 & & $(0,428)$ & $(0,199)$ & 0,389 \\
\hline Total & & & & $\overline{1,000}$ & & & & $\overline{1,000}$ & & & & 1,000 \\
\hline 1 & \multirow{6}{*}{$\mathbf{A C U}$} & $(1,226)$ & 0,117 & 0,061 & \multirow{6}{*}{ AVA } & $(0,755)$ & 0,554 & 0,083 & \multirow{6}{*}{ ACO } & 0,089 & 0,494 & 0,072 \\
\hline 2 & & $(0,630)$ & 0,083 & 0,087 & & $(0,757)$ & $(0,246)$ & 0,109 & & 0,685 & 0,168 & 0,161 \\
\hline 3 & & $(0,038)$ & $(0,238)$ & 0,156 & & $(0,262)$ & $(0,202)$ & 0,214 & & 0,167 & $(0,360)$ & 0,289 \\
\hline 4 & & 0,271 & 0,360 & 0,209 & & 0,416 & $(0,048)$ & 0,332 & & $(0,056)$ & 0,143 & 0,266 \\
\hline 5 & & 0,162 & $(0,108)$ & 0,487 & & 0,242 & 0,152 & 0,262 & & $(0,707)$ & 0,014 & 0,212 \\
\hline Total & & & & 1,000 & & & & 1,000 & & & & 1,000 \\
\hline
\end{tabular}

Com base nesses resultados, foi possível elaborar os mapas perceptuais e assim visualizar a relação entre o enquadramento das empresas e as informações usadas, conforme demonstrado na Figura 69. 
Figura 69 - Mapas perceptuais: Enquadramento e informações usadas
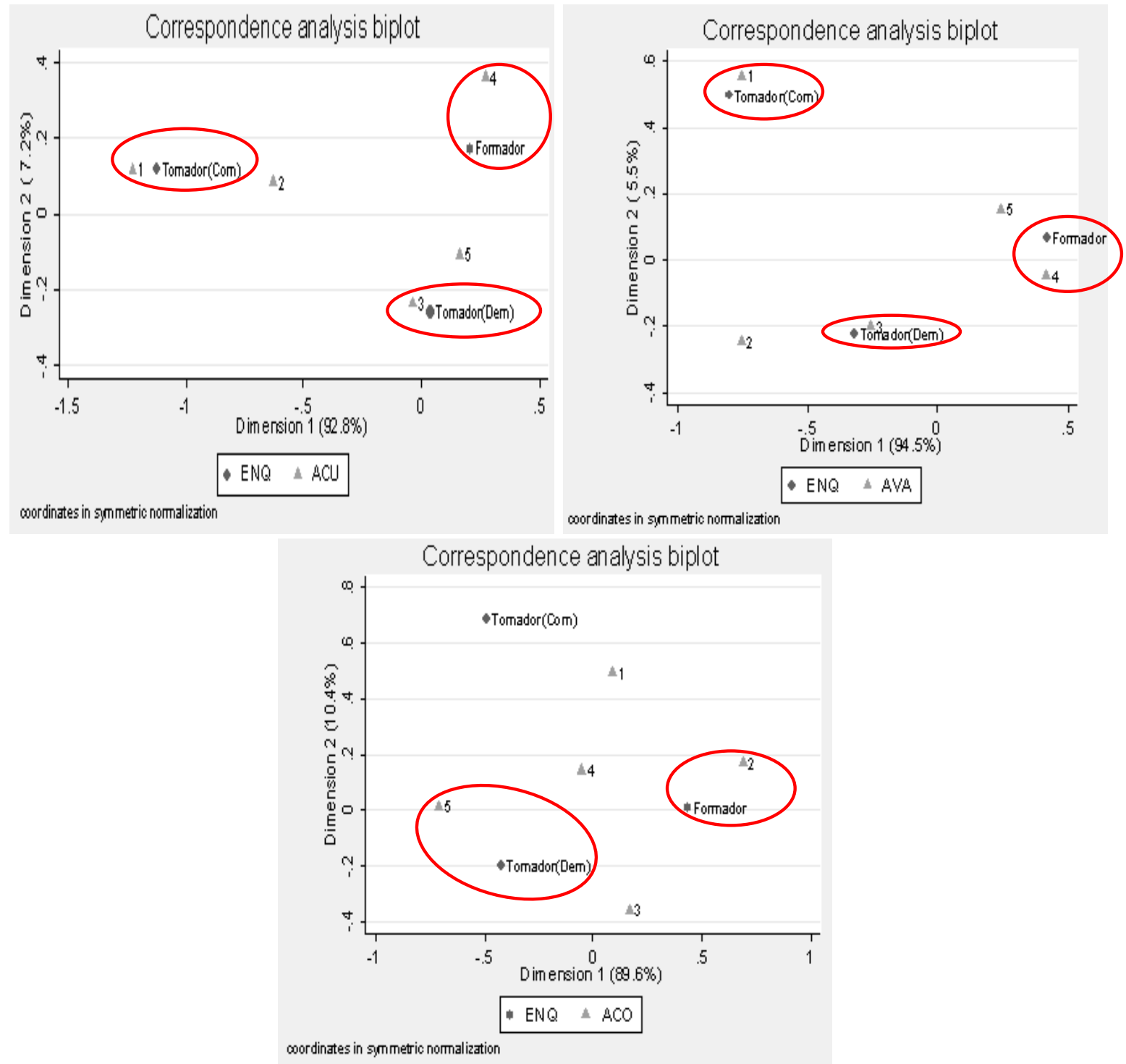

Fonte: Elaborada com a utilização do Stata

Diante desses mapas perceptuais, é possível notar que:

a) a intensidade de uso de informações de custos é alta nos formadores de preços, mas baixa nos tomadores de preços oferecedores de commodities;

b) a intensidade de uso de informações de valor é alta em formadores de preços, mas baixa em tomadores de preços, especialmente naqueles oferecedores de commodities; $\mathrm{e}$

c) a intensidade de uso de informações da concorrência é alta em tomadores de preços (demais), mas baixa em formadores de preços. 


\subsubsection{Em Resumo}

Em suma, a aplicação das ANACOR permitiu, a título exploratório, lançar um novo olhar empírico à prática da definição de preços. Constatou-se que o enquadramento das empresas como tomadoras ou formadoras de preços está associado ao grau de diferenciação (rever Figuras 66 e 67). Baixos níveis de diferenciação e de customização são observados nos tomadores de preços enquanto que altos níveis de diferenciação e de customização são observados nos formadores de preços.

Notou-se também que os tomadores de preços conseguem facilmente usar informações dos preços dos concorrentes, diferentemente dos formadores de preços que encontram dificuldades no uso desse tipo de informação e recorrem a outros tipos, ou seja aos custos e ao valor (rever Figura 68).

Ademais, observou-se que os tomadores de preços acabam definindo seus preços a partir de informações da concorrência complementadas por informações de custos e de valor, enquanto que os formadores tomam suas decisões a partir de informações de custos e de valor (rever Figura 69). A Figura 70 ilustra o resumo dessas constatações, que ratificam as expectativas relacionadas na Figura 65, e permite seguir para a próxima seção na qual se avança para os cernes do processo de estabelecimento dos preços: sua forma e sua essência.

Figura 70 - Resumo dos resultados das ANACOR

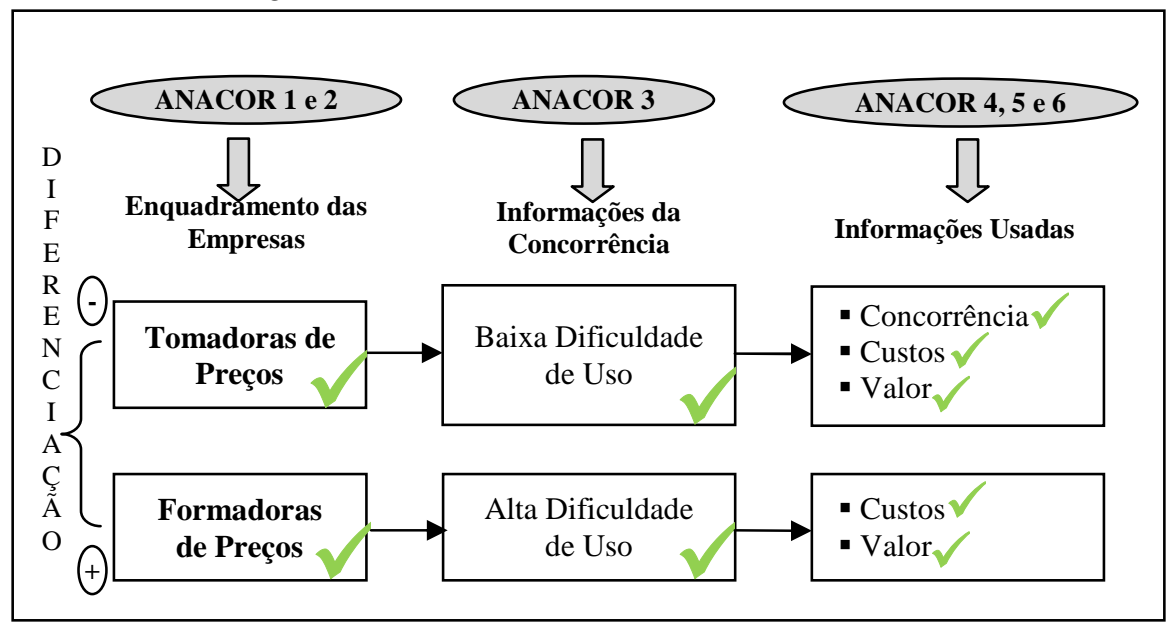

Fonte: Dados da pesquisa 


\subsection{Forma e Essência do Estabelecimento dos Preços}

Primeiramente, cumpre mencionar que esta tese, assim como os trabalhos prévios nacionais e internacionais, detectou que a forma predominante do estabelecimento dos preços é marcada pelos custos mais margem: 265 respondentes afirmaram que essa é a principal maneira de operacionalizar o processo. Além disso, 19 respondentes articulam formas para definir os preços, sendo que uma dessas formas é "custos mais margem”.

Na sequência, mas distantes, aparecem: os preços colocados em consonância aos preços dos concorrentes (45); os preços que espelham o valor ao cliente (23); os preços de mercado (15); os preços definidos por articulações que não incluem custos mais margem (7); e, surpreendentemente ainda, os preços deliberados após uma série de tentativas e erros (2). Ou seja, como ilustra a Figura 71 , apenas $25 \%$ da amostra não delibera os preços a partir dos custos mais margem.

Figura 71 - Principais formas de estabelecer os preços

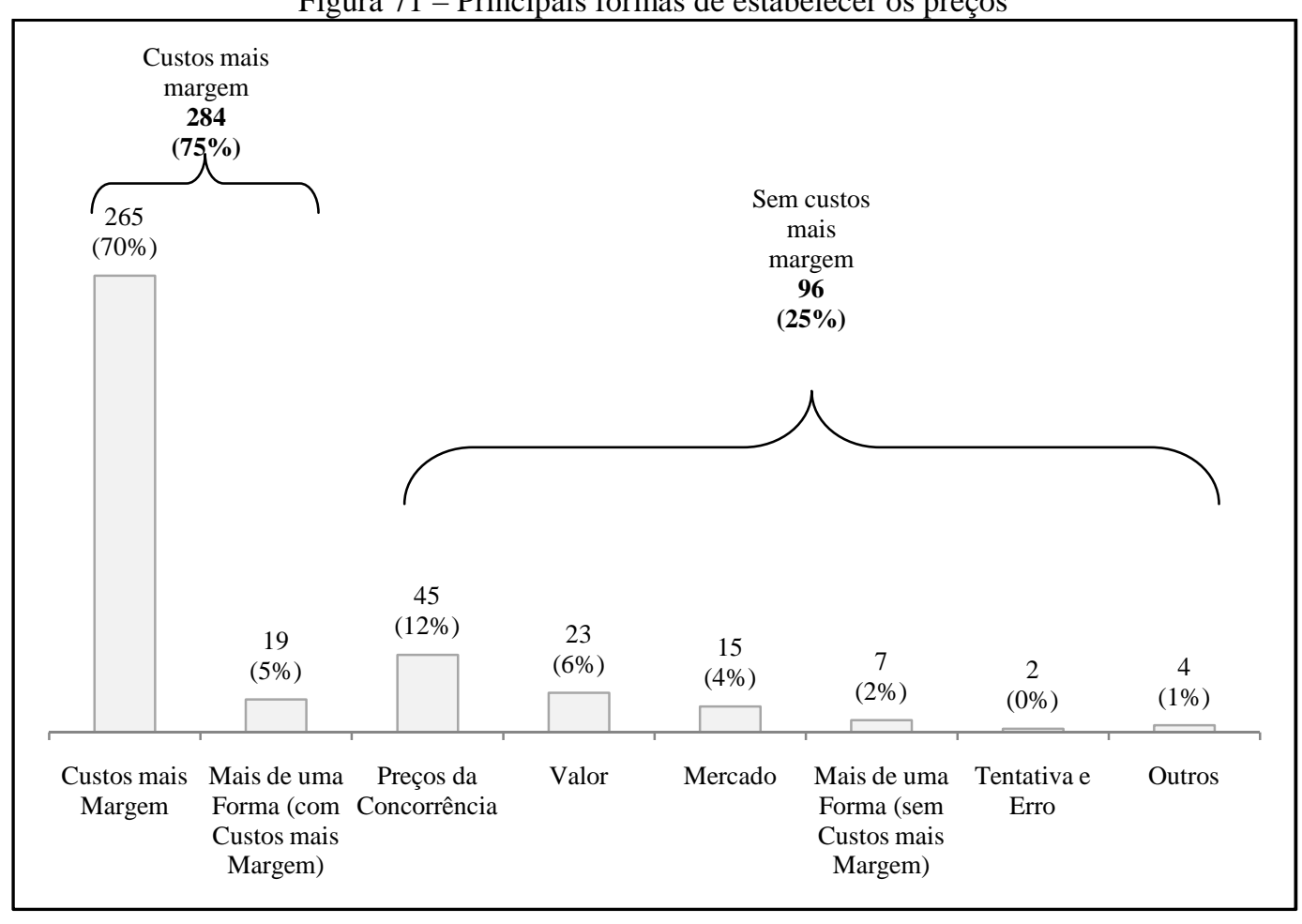

Fonte: Dados da pesquisa

Como a combinação "custos mais margem" domina a amostra desta pesquisa, é relevante explorá-la com mais detalhes. Primeiramente, vale mencionar que $238(84 \%)$ das $284(265+$ 
19) empresas que aderem aos custos mais margem reconhecem que, ao fazerem essa aderência, acabam utilizando uma fórmula matemática. Por esse motivo, a Tabela 91 minudencia a maneira que a margem é incorporada na fórmula.

Tabela 91 - A “margem" dos custos mais margem Priorização da margem percentual à margem unitária

\begin{tabular}{|c|c|c|c|c|c|c|c|c|}
\hline \multicolumn{9}{|c|}{ Priorização da margem percentual à margem unitária } \\
\hline \multirow{2}{*}{ MANIFESTAÇÃO } & \multicolumn{2}{|c|}{ FORMADORES } & \multicolumn{2}{|c|}{ TOMADORES (COMMODITIES) } & \multicolumn{2}{|c|}{ TOMADORES (DEMAIS) } & \multicolumn{2}{|c|}{ TOTAL } \\
\hline & QTDE. & $\%$ & QTDE. & $\%$ & QTDE. & $\%$ & QTDE. & $\%$ \\
\hline Discordância & 19 & $12 \%$ & 5 & $\mathbf{5 0 \%}$ & 16 & $14 \%$ & 40 & $14 \%$ \\
\hline Neutralidade & 28 & $17 \%$ & 3 & $30 \%$ & 19 & $17 \%$ & $\mathbf{5 0}$ & $18 \%$ \\
\hline Concordância & 114 & $71 \%$ & 2 & $20 \%$ & 78 & $69 \%$ & 194 & $68 \%$ \\
\hline TOTAL & 161 & $100 \%$ & 10 & $100 \%$ & 113 & $100 \%$ & 284 & $100 \%$ \\
\hline \multicolumn{9}{|c|}{ Consideração da lucratividade desejada na definição da margem } \\
\hline \multirow{2}{*}{ MANIFESTAÇÃO } & \multicolumn{2}{|c|}{ FORMADORES } & \multicolumn{2}{|c|}{ TOMADORES (COMMODITIES) } & \multicolumn{2}{|c|}{ TOMADORES (DEMAIS) } & \multicolumn{2}{|c|}{ TOTAL } \\
\hline & QTDE. & $\%$ & QTDE. & $\%$ & QTDE. & $\%$ & QTDE. & $\%$ \\
\hline Discordância & 43 & $27 \%$ & 4 & $40 \%$ & 35 & $31 \%$ & 82 & $29 \%$ \\
\hline Neutralidade & 46 & $29 \%$ & 2 & $20 \%$ & 29 & $26 \%$ & 77 & $27 \%$ \\
\hline Concordância & 72 & $45 \%$ & 4 & $40 \%$ & 49 & $43 \%$ & 125 & $44 \%$ \\
\hline TOTAL & 161 & $100 \%$ & 10 & $100 \%$ & 113 & $100 \%$ & 284 & $100 \%$ \\
\hline
\end{tabular}

Nota-se que há ampla tendência ao uso das margens percentuais. 68\% das empresas preferem margens percentuais a margens unitárias (em $\mathrm{R} \$$ ) no processo. Constata-se ainda que a maior parte da amostra (44\%) considera a lucratividade desejada como a principal informação para determinar a margem. Resta agora investigar se a combinação custos mais margem é dominante tanto nos formadores quanto nos tomadores de preços e, mais ainda, averiguar se além da forma, ela também é a essência da definição dos preços.

\subsubsection{Formadores de Preços}

\subsubsection{1 $\quad \underline{\text { Forma }}$}

Considerando que uma empresa tipicamente formadora de preços pode eventualmente instalar uma inteligência de mercado para obter informações sobre os preços dos concorrentes e estabelecer seus preços com base nessas informações (Guerreiro \& Amaral, 2016), optou-se por segregar os formadores de preços entre aqueles com e sem inteligência de mercado. A Tabela 92 demonstra as formas encontradas nesses dois tipos de formadores e evidencia que é a minoria (15) que institui essa inteligência e consegue definir os preços incorporando informações da concorrência. 
Tabela 92 - Formas de estabelecimento dos preços nos formadores de preços

\begin{tabular}{|c|c|c|c|c|c|c|}
\hline \multirow[t]{2}{*}{ FORMA } & \multicolumn{2}{|c|}{$\begin{array}{c}\text { FORMADORES SEM } \\
\text { INFORMAÇÕES DA } \\
\text { CONCORRENCIA }\end{array}$} & \multicolumn{2}{|c|}{$\begin{array}{c}\text { FORMADORES COM } \\
\text { INFORMAÇÕES DA } \\
\text { CONCORRÊNCIA }\end{array}$} & \multicolumn{2}{|c|}{$\begin{array}{c}\text { TOTAL DE } \\
\text { FORMADORES }\end{array}$} \\
\hline & QTDE. & $\%$ & QTDE. & $\%$ & QTDE. & $\%$ \\
\hline Custos mais margem & 153 & $86 \%$ & - & $0 \%$ & 153 & $80 \%$ \\
\hline Valor & 19 & $11 \%$ & - & $0 \%$ & 19 & $10 \%$ \\
\hline Preços da Concorrência & - & $0 \%$ & 9 & $60 \%$ & 9 & $5 \%$ \\
\hline $\begin{array}{l}\text { Mais de uma Forma (com } \\
\text { Custos mais Margem) }\end{array}$ & 4 & $2 \%$ & 4 & $27 \%$ & 8 & $4 \%$ \\
\hline $\begin{array}{c}\text { Mais de uma Forma (sem } \\
\text { Custos mais Margem) }\end{array}$ & - & $0 \%$ & 2 & $13 \%$ & 2 & $1 \%$ \\
\hline Outros & 1 & $1 \%$ & - & $0 \%$ & 1 & $1 \%$ \\
\hline Mercado & - & $0 \%$ & - & $0 \%$ & - & $\mathbf{0 \%}$ \\
\hline Tentativa e erro & - & $0 \%$ & - & $0 \%$ & - & $\mathbf{0 \%}$ \\
\hline ToTAL & 177 & $100 \%$ & 15 & $100 \%$ & 192 & $100 \%$ \\
\hline
\end{tabular}

A Figura 72 ilustra o quão forte é a combinação "custos mais margem" nos formadores que não implantaram inteligência de mercado: $86 \%$ deles adotam essa forma para definir os preços.

Figura 72 - Principais formas nos formadores de preços

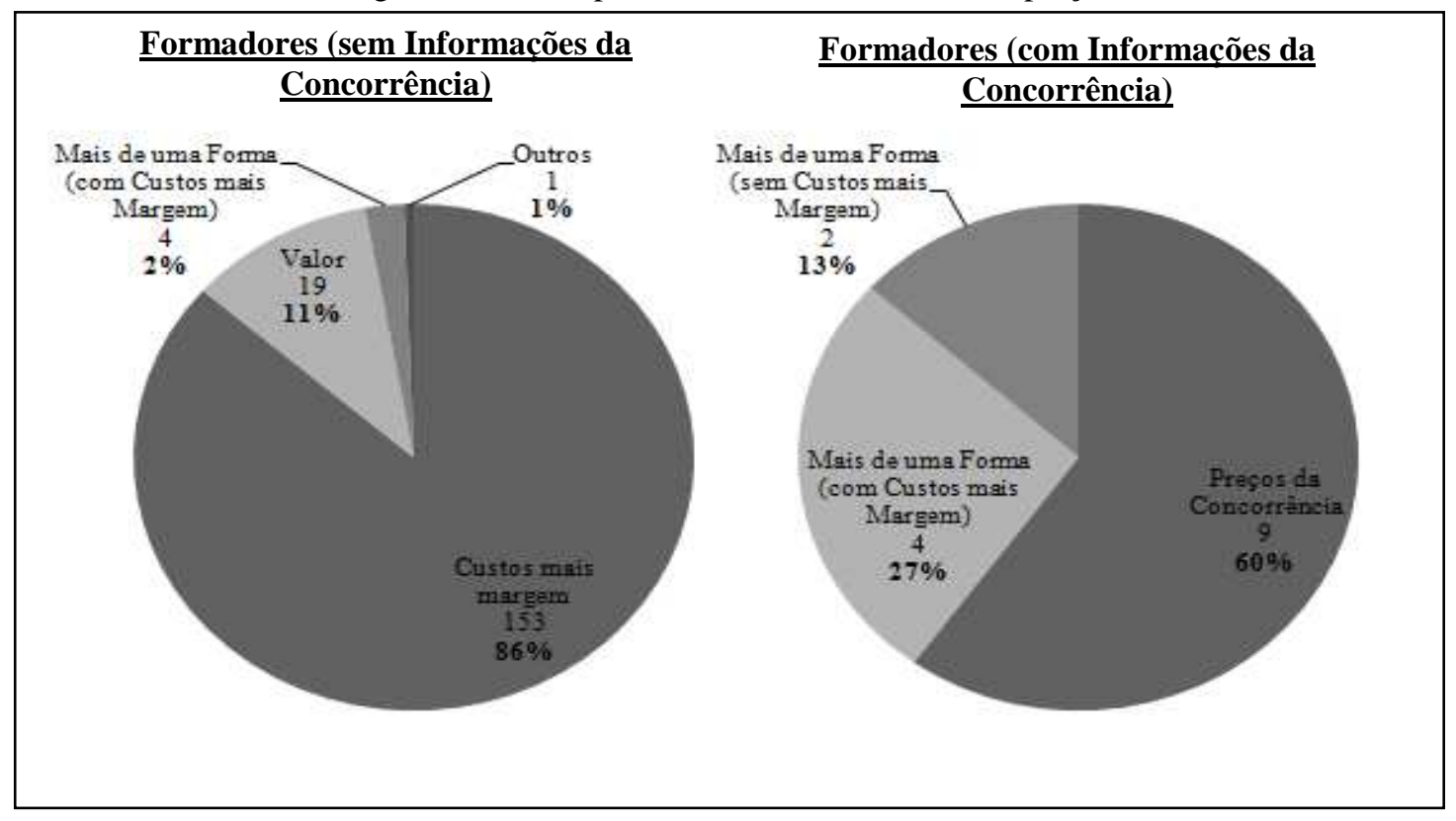

Fonte: Dados da pesquisa

Cabe ressaltar que o fato de os custos mais margem operacionalizarem o estabelecimento dos preços nos formadores não significa que os preços reflitam meramente os custos. Esse fato demonstra que os custos mais margem são a principal forma encontrada para viabilizar a deliberação, mas ainda não revela a essência. 


\subsubsection{2 $\quad \underline{\text { Essência }}$}

O primeiro ponto a ressaltar é que, como a Tabela 93 mostra, os formadores que determinam os preços a partir dos custos mais margem usam não só informações de custos, mas também informações da concorrência e de valor.

Tabela 93 - Formadores de preços e intensidade de utilização de informações

\begin{tabular}{c|c|c|c}
\hline \multirow{2}{*}{ FORMA } & INTENSIDADE DE UTILIZAÇÃo & $\begin{array}{c}\text { MODA DOS FORMADORES } \\
\text { SEM INFORMAÇÕES DA } \\
\text { CONCORRÊNCIA }\end{array}$ & $\begin{array}{c}\text { MODA DOS } \\
\text { FORMADORES COM } \\
\text { INFORMAÇÕES DA } \\
\text { CONCORRÊNCIA }\end{array}$ \\
\hline \multirow{2}{*}{$\begin{array}{c}\text { Com custos mais } \\
\text { margem }\end{array}$} & Informações de custos & 5 & 5 \\
\cline { 2 - 4 } & Informações da concorrência & 4 & $\mathbf{4}$ \\
\cline { 2 - 4 } & Informações de valor & $\mathbf{3}$ & 4 \\
\hline \multirow{2}{*}{$\begin{array}{c}\text { Sem custos mais } \\
\text { margem }\end{array}$} & Informações de custos & 5 & 5 \\
\cline { 2 - 4 } & Informações da concorrência & 4 & 4 \\
\cline { 2 - 4 }
\end{tabular}

Percebe-se que nos formadores sem informações da concorrência, a adoção da combinação "custos mais margem" faz com que a intensidade de uso de informações de valor seja média (concentração do nível 3) enquanto que a adoção de outras formas faz com que a intensidade de uso de informações de valor seja alta (concentração do nível 4). Já nos formadores com informações da concorrência, a adoção da combinação "custos mais margem" faz com que a intensidade de uso de informações da concorrência seja alta (concentração do nível 4) enquanto que a adoção de outras formas faz com que a intensidade de uso de informações da concorrência seja muito alta (concentração do nível 5).

Essa constatação evidencia que a formação dos preços a partir dos custos mais margem é uma questão de forma e não de essência. Afinal, ela mostra que, dependendo do modo de operacionalização do estabelecimento dos preços, há uma variação nos tipos de informações incorporados com mais ou menos intensidade. A escolha da combinação "custos mais margem" orienta, sim, à utilização muito intensa de custos, todavia, pode ser formatada de uma maneira para também incorporar muito intensamente informações de valor e, assim, simplificar o processo de definir preços coerentes com o valor.

Logo, é mister investigar se nos formadores, independentemente da forma adotada, o preço final tem condições de espelhar o valor oferecido ao cliente. Como frisado por Hofstrand (2007), os formadores, por mais que possam estabelecer os preços que quiserem (não 
possuem opções idênticas no mercado), não têm poder para forçar os clientes a comprarem seus produtos a qualquer preço. Para tanto, foi elaborada a Tabela 94 que demonstra o quanto os formadores aderentes dos custos mais margem $(153+4+4)$ concordam ou discordam que "a utilização dos custos e da margem possibilita formar o preço sem ter que avaliar o valor oferecido aos clientes".

Tabela 94 - Formadores de preços e avaliação do valor oferecido aos clientes

\begin{tabular}{c|c|c|c|c|c|c}
\hline \multirow{2}{*}{ MANIFESTAÇão } & $\begin{array}{r}\text { FORMADORES SEM } \\
\text { INFORMAÇÕES DA } \\
\text { CONCORÊNCIA }\end{array}$ & $\begin{array}{c}\text { FORMADORES COM INFORMAÇÕES } \\
\text { DA CONCORRÊNCIA }\end{array}$ & \multicolumn{2}{c}{$\begin{array}{c}\text { TOTAL DE } \\
\text { FORMADORES }\end{array}$} \\
\cline { 2 - 7 } & QTDE. & $\mathbf{\%}$ & QTDE. & $\mathbf{\%}$ & QTDE. & $\%$ \\
\hline Discordância & $\mathbf{6 2}$ & $\mathbf{3 9 \%}$ & $\mathbf{2}$ & $\mathbf{5 0 \%}$ & $\mathbf{6 4}$ & $\mathbf{4 0 \%}$ \\
\hline Neutralidade & 47 & $30 \%$ & 1 & $25 \%$ & $\mathbf{4 8}$ & $\mathbf{3 0 \%}$ \\
\hline Concordância & 48 & $31 \%$ & 1 & $25 \%$ & $\mathbf{4 9}$ & $\mathbf{3 0 \%}$ \\
\hline TotaL & $\mathbf{1 5 7}$ & $\mathbf{1 0 0 \%}$ & $\mathbf{4}$ & $\mathbf{1 0 0 \%}$ & $\mathbf{1 6 1}$ & $\mathbf{1 0 0 \%}$ \\
\hline
\end{tabular}

Como se pode observar, a maior parte dos formadores de preços não concorda que os custos mais margem substituem o valor oferecido ao cliente: $40 \%$ de discordância e $30 \%$ de não concordância nem discordância contra $30 \%$ de concordância. Dessa forma, pode aparecer a dúvida de como os preços são operacionalizados pelos custos mais margem e, ainda assim, correspondem ao valor oferecido ao cliente. A resposta está na margem, que se refere ao elemento chave capaz de conectar as informações de custos ao valor.

Ao analisar como a margem é definida, pode-se constatar se os preços são formados considerando somente o montante preciso para cobrir os custos e obter lucro ou se os preços são definidos a partir dos custos, mas podem incorporar o valor oferecido ao cliente. As respostas às questões relacionadas na Tabela 95 propiciam as bases para realizar essa análise.

Tabela 95 - Formadores de preços e utilização dos custos mais margem

\begin{tabular}{|c|c|c|c|c|c|c|}
\hline \multirow[t]{2}{*}{ MANIFESTAÇÃO } & \multicolumn{2}{|c|}{$\begin{array}{l}\text { FORMADORES SEM INFORMAÇÕES DA } \\
\text { CONCORRÊNCIA }\end{array}$} & \multicolumn{2}{|c|}{$\begin{array}{l}\text { FORMADORES COM INFORMAÇÕES DA } \\
\text { CONCORRÊNCIA }\end{array}$} & \multicolumn{2}{|c|}{ TOTAL DE FORMADORE } \\
\hline & QTDE. & $\%$ & QTDE. & $\%$ & QTDE. & $\%$ \\
\hline Discordância & 105 & $67 \%$ & 3 & $75 \%$ & 108 & $67 \%$ \\
\hline Neutralidade & 25 & $16 \%$ & 0 & $0 \%$ & 25 & $16 \%$ \\
\hline Concordância & 27 & $17 \%$ & 1 & $25 \%$ & 28 & $17 \%$ \\
\hline TOTAL & 157 & $100 \%$ & 4 & $100 \%$ & 161 & $100 \%$ \\
\hline
\end{tabular}


..conclusão

\begin{tabular}{|c|c|c|c|c|c|c|}
\hline \multirow[t]{2}{*}{ MANIFESTAÇÃO } & \multicolumn{2}{|c|}{$\begin{array}{c}\text { FORMADORES SEM INFORMAÇÕES DA } \\
\text { CONCORRÊNCIA }\end{array}$} & \multicolumn{2}{|c|}{$\begin{array}{l}\text { FORMADORES COM INFORMAÇÕES DA } \\
\text { CONCORRÊNCIA }\end{array}$} & \multicolumn{2}{|c|}{ TOTAL DE FORMADORES } \\
\hline & QTDE. & $\%$ & QTDE. & $\%$ & QTDE. & $\%$ \\
\hline Discordância & 84 & $54 \%$ & 2 & $50 \%$ & 86 & $53 \%$ \\
\hline Neutralidade & 38 & $24 \%$ & 0 & $0 \%$ & 38 & $24 \%$ \\
\hline Concordância & 35 & $22 \%$ & 2 & $50 \%$ & 37 & $23 \%$ \\
\hline TOTAL & 157 & $100 \%$ & 4 & $100 \%$ & 161 & $100 \%$ \\
\hline \multicolumn{7}{|c|}{ ESC_3 - Todos os nossos segmentos de clientes têm margens parecidas } \\
\hline \multirow[t]{2}{*}{ MANIFESTAÇÃo } & \multicolumn{2}{|c|}{$\begin{array}{l}\text { FORMADORES SEM INFORMAÇÕES DA } \\
\text { CONCORRÊNCIA }\end{array}$} & \multicolumn{2}{|c|}{$\begin{array}{l}\text { FORMADORES COM INFORMAÇÕES DA } \\
\text { CONCORRÊNCIA }\end{array}$} & \multicolumn{2}{|c|}{ TOTAL DE FORMADORE } \\
\hline & QTDE. & $\%$ & QTDE. & $\%$ & QTDE. & $\%$ \\
\hline Discordância & 89 & $57 \%$ & 2 & $\mathbf{5 0 \%}$ & 91 & $\mathbf{5 7 \%}$ \\
\hline Neutralidade & 30 & $19 \%$ & 1 & $25 \%$ & 31 & $19 \%$ \\
\hline Concordância & 38 & $24 \%$ & 1 & $25 \%$ & 39 & $24 \%$ \\
\hline TOTAL & 157 & $100 \%$ & 4 & $100 \%$ & 161 & $100 \%$ \\
\hline
\end{tabular}

Nota-se que nos formadores de preços poucas são as empresas que têm a margem deliberada apenas pelo departamento financeiro (ESC_1): 67\% da amostra de formadores discorda que a margem colocada sobre os custos é decidida isoladamente por esse setor, $16 \%$ não concorda nem discorda e $17 \%$ concorda. Por esse motivo, tem-se a expectativa que questões alheias àquelas financeiras sejam incorporadas.

As respostas às questões relativas às variáveis ESC_2 e ESC_3 apoiam essa expectativa, pois demonstram que a maior parte dos formadores discorda que todos os produtos (53\%) e todos os clientes (57\%) têm margens parecidas. No que se refere aos produtos, vale mencionar que somente $23 \%$ dos formadores de preços concordam que os produtos têm margens parecidas e $24 \%$ não concordam nem discordam em relação a essa assertiva. No que se refere aos segmentos de clientes, cumpre destacar que somente $24 \%$ dos formadores de preços concordam que os produtos têm margens parecidas e 19\% não concordam nem discordam em relação a essa assertiva. Essas constatações podem indicar que a margem adéqua-se a cada produto e a cada cliente e, portanto, pode atuar como um elemento conector dos custos ao valor.

Em suma, o estudo da Tabela 95 permitiu identificar que a maior parte dos formadores que usam os custos mais margem como forma predominante da determinação dos preços não é escrava da combinação no processo. Afinal, na maioria dos formadores a margem não é definida unicamente pelo departamento financeiro e, além disso, não é única para todos os produtos e para todos os clientes. 
Agora, vale investigar se no uso da combinação dos custos à margem há ou não a tentativa de incorporar o valor na definição dos preços. Para tanto, é relevante analisar as respostas assinaladas às questões expostas na Tabela 96.

Tabela 96 - Formadores de preços e incorporação do valor nos custos mais margem

\begin{tabular}{|c|c|c|c|c|c|c|}
\hline \multirow[t]{2}{*}{ MANIFESTAÇÃO } & \multicolumn{2}{|c|}{$\begin{array}{l}\text { FORMADORES SEM INFORMAÇÕES DA } \\
\text { CONCORRÊNCIA }\end{array}$} & \multicolumn{2}{|c|}{$\begin{array}{l}\text { FORMADORES COM INFORMAÇÕES DA } \\
\text { CONCORRÊNCIA }\end{array}$} & \multicolumn{2}{|c|}{ TOTAL DE FORMADORES } \\
\hline & QTDE. & $\%$ & QTDE. & $\%$ & QTDE. & $\%$ \\
\hline Discordância & 88 & $56 \%$ & 3 & $75 \%$ & 91 & $57 \%$ \\
\hline Neutralidade & 31 & $20 \%$ & 1 & $25 \%$ & 32 & $20 \%$ \\
\hline Concordância & 38 & $24 \%$ & 0 & $0 \%$ & 38 & $24 \%$ \\
\hline TOTAL & 157 & $100 \%$ & 4 & $100 \%$ & 161 & $100 \%$ \\
\hline \multirow[t]{2}{*}{ MANIFESTAÇ̃̃o } & \multicolumn{2}{|c|}{$\begin{array}{l}\text { FORMADORES SEM INFORMAÇõES DA } \\
\text { CONCORRÊNCIA }\end{array}$} & \multicolumn{2}{|c|}{$\begin{array}{l}\text { FORMADORES COM INFORMAÇÕES DA } \\
\text { CONCORRÊNCIA }\end{array}$} & \multicolumn{2}{|c|}{ TOTAL DE FORMADORES } \\
\hline & QTDE. & $\%$ & QTDE. & $\%$ & QTDE. & $\%$ \\
\hline Discordância & 66 & $42 \%$ & 2 & $50 \%$ & 68 & $42 \%$ \\
\hline Neutralidade & 32 & $20 \%$ & 1 & $25 \%$ & 33 & $20 \%$ \\
\hline Concordância & 59 & $38 \%$ & 1 & $25 \%$ & 60 & $37 \%$ \\
\hline TOTAL & 157 & $100 \%$ & 4 & $100 \%$ & 161 & $100 \%$ \\
\hline VN & - A definiç & ndepende d: & leracão da i & ue os clientes & nos prod & \\
\hline \multirow[t]{2}{*}{ MANIFESTAÇÃO } & \multicolumn{2}{|c|}{$\begin{array}{l}\text { FORMADORES SEM INFORMAÇÕES DA } \\
\text { CONCORRÊNCIA }\end{array}$} & \multicolumn{2}{|c|}{$\begin{array}{l}\text { FORMADORES COM INFORMAÇÕES DA } \\
\text { CONCORRÊNCIA }\end{array}$} & \multicolumn{2}{|c|}{ TOTAL DE FORMADORES } \\
\hline & QTDE. & $\%$ & QTDE. & $\%$ & QTDE. & $\%$ \\
\hline Discordância & 77 & $49 \%$ & 2 & $50 \%$ & 79 & $49 \%$ \\
\hline Neutralidade & 35 & $22 \%$ & 1 & $25 \%$ & 36 & $22 \%$ \\
\hline Concordância & 45 & $29 \%$ & 1 & $25 \%$ & 46 & $29 \%$ \\
\hline TOTAL & 157 & $100 \%$ & 4 & $100 \%$ & 161 & $100 \%$ \\
\hline
\end{tabular}

Destarte, observa-se que nos formadores a margem aparentemente busca conectar os custos ao valor, pois não é definida sem considerar características dos produtos e dos clientes. A deliberação da margem depende, sim, de especificidades dos produtos em $57 \%$ dos formadores, de especificidades dos clientes em $42 \%$ e da importância vista pelos clientes em $49 \%$.

\subsubsection{Tomadores de Preços}

\subsubsection{1 $\quad \underline{\text { Forma }}$}

Analisando detidamente a Tabela 97, pode-se perceber que os custos mais margem não são a forma predominante de estabelecer os preços em todos os tomadores. Os tomadores que oferecem commodities priorizam a definição dos preços a partir de bases pautadas nos preços da concorrência e no mercado, enquanto que os demais tomadores, sim, operacionalizam a definição dos preços mediante soma de uma margem aos custos. 
Tabela 97 - Formas de estabelecimento dos preços nos tomadores de preços

\begin{tabular}{|c|c|c|c|c|c|c|}
\hline \multirow[t]{2}{*}{ FORMAS } & \multicolumn{2}{|c|}{$\begin{array}{c}\text { TOMADORES } \\
\text { (COMMODITIES) }\end{array}$} & \multicolumn{2}{|c|}{$\begin{array}{c}\text { TOMADORES } \\
\text { (DEMAIS) }\end{array}$} & \multicolumn{2}{|c|}{$\begin{array}{c}\text { TOTAL DE } \\
\text { TOMADORES }\end{array}$} \\
\hline & QTDE. & $\%$ & QTDE. & $\%$ & QTDE. & $\%$ \\
\hline Custos mais margem & 8 & $20 \%$ & 104 & $\mathbf{7 0 \%}$ & 112 & $60 \%$ \\
\hline Preços da Concorrência & 13 & $32 \%$ & 23 & $16 \%$ & 36 & $19 \%$ \\
\hline Mercado & 14 & $35 \%$ & 1 & $1 \%$ & 15 & $\mathbf{8 \%}$ \\
\hline $\begin{array}{l}\text { Mais de uma Forma (com Custos mais } \\
\text { Margem) }\end{array}$ & 2 & $5 \%$ & 9 & $6 \%$ & 11 & $6 \%$ \\
\hline $\begin{array}{l}\text { Mais de uma Forma (sem Custos mais } \\
\text { Margem) }\end{array}$ & 2 & $5 \%$ & 3 & $2 \%$ & 5 & $3 \%$ \\
\hline $\begin{array}{l}\text { Valor } \\
\end{array}$ & - & $0 \%$ & 4 & $3 \%$ & 4 & $2 \%$ \\
\hline Outros & 1 & $3 \%$ & 2 & $1 \%$ & 3 & $2 \%$ \\
\hline Tentativa e erro & - & $0 \%$ & 2 & $1 \%$ & 2 & $1 \%$ \\
\hline TOTAL & 40 & $100 \%$ & 148 & $100 \%$ & 188 & $100 \%$ \\
\hline
\end{tabular}

A Figura 73 ajuda a perceber o quão forte é nos tomadores, especialmente nos ofertadores de commodities, a operacionalização da decisão dos preços a partir de informações dos preços no mercado e dos preços da concorrência.

Figura 73 - Principais formas nos tomadores de preços

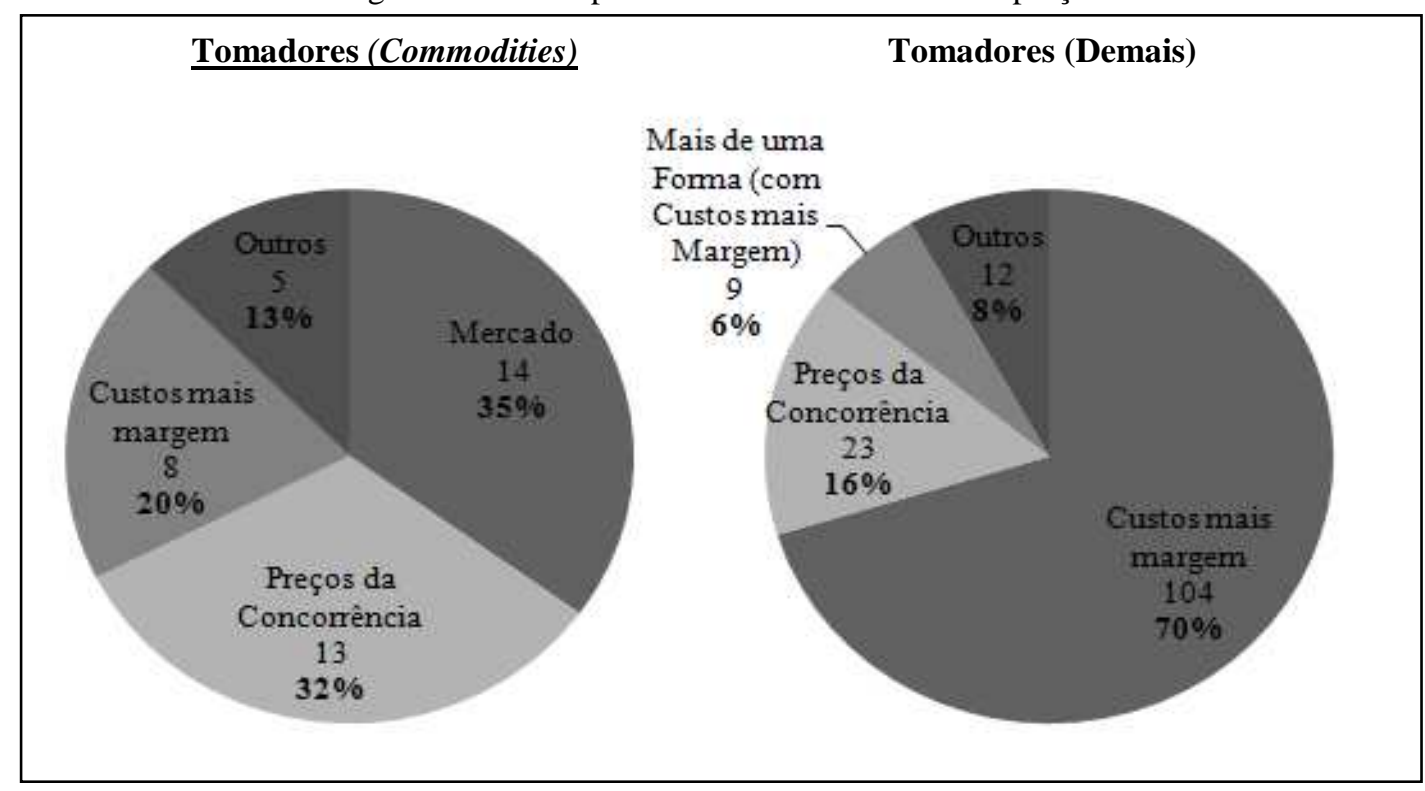

Fonte: Dados da pesquisa

Cabe ressaltar que o fato de os custos mais margem operacionalizarem o estabelecimento dos preços na maior parte dos demais tomadores não significa que os preços sejam espelhos dos custos. Esse fato apenas demonstra que os custos mais margem são a principal forma encontrada para viabilizar a decisão, mas ainda não revela a essência do processo. 


\subsubsection{Essência}

O primeiro ponto a salientar é que, como evidencia a Tabela 98, os tomadores que definem os preços a partir dos custos mais margem usam não só informações de custos, mas também informações da concorrência e de valor.

Tabela 98 - Tomadores de preços e intensidade de utilização de informações

\begin{tabular}{c|c|c|c}
\hline \multirow{2}{*}{ FORMA } & INTENSIDADE DE UTILIZAÇÃO & $\begin{array}{c}\text { MODA DOS TOMADORES } \\
\text { (COMMODITIES) }\end{array}$ & $\begin{array}{c}\text { MODA DOS TOMADORES } \\
\text { (DEMAIS) }\end{array}$ \\
\hline \multirow{2}{*}{\begin{tabular}{c} 
Com custos mais $\begin{array}{c}\text { margem } \\
\text { margẽ }\end{array}$ \\
\cline { 2 - 4 }
\end{tabular}} & Informaçes de custos & 5 & 5 \\
\cline { 2 - 4 } & Informações da concorrência & $\mathbf{4}$ & $\mathbf{3}$ \\
\hline \multirow{2}{*}{$\begin{array}{c}\text { Informações de valor } \\
\text { custos mais }\end{array}$} & Informações de custos & 4 & 5 \\
\cline { 2 - 4 } & Informações da concorrência & 5 & $\mathbf{5}$ \\
\cline { 2 - 4 } & Informações de valor & $\mathbf{5}$ & 4 \\
\hline
\end{tabular}

Percebe-se que nos tomadores oferecedores de commodities, a adoção da combinação "custos mais margem" faz com que a intensidade de uso de informações da concorrência seja alto (concentração do nível 4) enquanto que a adoção de outras formas faz com que a intensidade de uso de informações da concorrência seja muito alto (concentração do nível 5). Já nos demais tomadores, a adoção da combinação "custos mais margem” faz com que a intensidade de uso de informações da concorrência seja médio (concentração do nível 3) enquanto que a adoção de outras formas faz com que a intensidade de uso de informações da concorrência seja muito alto (concentração do nível 5).

Essa constatação demonstra que a definição dos preços a partir dos custos mais margem é, sim, uma questão de forma e não de essência. Ela revela que, dependendo da maneira que o estabelecimento dos preços é operacionalizado, os tipos de informações incorporados com mais ou menos intensidade variam. A escolha da combinação "custos mais margem" orienta, sim, à utilização muito intensa de custos, todavia, pode ser formatada de uma maneira para também incorporar muito intensamente informações da concorrência e, assim, simplificar o processo de definir preços coerentes com os preços da concorrência e, simultaneamente, apurar a lucratividade propiciada por esses preços.

Logo, cabe averiguar se, independentemente da forma adotada, os preços definidos nos tomadores de preços espelham ou não os preços da concorrência. Para tanto, vale analisar a Tabela 99 e perceber que, na maioria dos tomadores, os preços colocados precisam seguir 
estritamente alguma referência do mercado, tendo em vista a massiva não concordância à assertiva "No nosso segmento, não há preços de referência que precisam ser estritamente seguidos”. Em outras palavras, pode-se dizer que não importa a mecânica usada para operacionalizar o processo, a maior parte dos tomadores (55\%) acaba tendo que seguir rigorosamente os preços de referência, ou seja, acaba tendo que definir os preços conforme a concorrência.

Tabela 99 - Tomadores de preços e necessidade de seguir preços de referência

\begin{tabular}{c|c|c|c|c|c|c}
\hline \multirow{2}{*}{ MANIFESTAÇÃo } & TOMADORES (COMMODITIES) & TOMADORES (DEMAIS) & \multicolumn{2}{|c}{ TOTAL DE TOMADORES } \\
\cline { 2 - 7 } & QTDE. & $\mathbf{\%}$ & QTDE. & $\mathbf{\%}$ & QTDE. & $\%$ \\
\hline Discordância & $\mathbf{3 0}$ & $\mathbf{7 5 \%}$ & $\mathbf{7 3}$ & $\mathbf{4 9 \%}$ & $\mathbf{1 0 3}$ & $\mathbf{5 5 \%}$ \\
\hline Neutralidade & 2 & $5 \%$ & 32 & $22 \%$ & $\mathbf{3 4}$ & $\mathbf{1 8 \%}$ \\
\hline Concordância & 8 & $20 \%$ & 43 & $29 \%$ & $\mathbf{5 1}$ & $\mathbf{2 7 \%}$ \\
\hline TOTAL & $\mathbf{4 0}$ & $\mathbf{1 0 0 \%}$ & $\mathbf{1 4 8}$ & $\mathbf{1 0 0 \%}$ & $\mathbf{1 8 8}$ & $\mathbf{1 0 0 \%}$ \\
\hline
\end{tabular}

Nesse momento, pode surgir novamente a dúvida: como os preços são operacionalizados pelos custos mais margem e, ainda assim, correspondem aos preços de referência? A resposta mais uma vez está na margem, que se refere ao elemento chave capaz de conectar as informações de custos a informações da concorrência. Por consequência, ao avaliar como a margem é deliberada, consegue-se perceber se os preços são definidos considerando apenas o quanto é preciso para cobrir os custos e obter lucro ou se os preços são definidos a partir dos custos, mas considerando os preços da concorrência. A análise das respostas às questões relacionadas na Tabela 100 é crucial para esse entendimento (123 é o número dos tomadores que definem os preços a partir dos custos mais margem, isto é, $8+2+104+9$ ).

Tabela 100 - Tomadores de preços e utilização dos custos mais margem

\begin{tabular}{|c|c|c|c|c|c|c|}
\hline \multirow{2}{*}{ MANIFESTAÇÃo } & \multicolumn{2}{|c|}{ TOMADORES (COMMODITIES) } & \multicolumn{2}{|c|}{ TOMADORES (DEMAIS) } & \multicolumn{2}{|c|}{ TOTAL DE TOMADORES } \\
\hline & QTDE. & $\%$ & QTDE. & $\%$ & QTDE. & $\%$ \\
\hline Discordância & 8 & $80 \%$ & 89 & $79 \%$ & 97 & $79 \%$ \\
\hline Neutralidade & 1 & $10 \%$ & 14 & $12 \%$ & 15 & $12 \%$ \\
\hline Concordância & 1 & $10 \%$ & 10 & $9 \%$ & 11 & $9 \%$ \\
\hline \multirow[t]{2}{*}{ TOTAL } & 10 & $100 \%$ & 113 & $100 \%$ & 123 & $100 \%$ \\
\hline & \multicolumn{6}{|c|}{ ESC_2 - Todos os nossos produtos têm margens parecidas } \\
\hline \multirow{2}{*}{ MANIFESTAÇÃO } & \multicolumn{2}{|c|}{ TOMADORES (COMMODITIES) } & \multicolumn{2}{|c|}{ TOMADORES (DEMAIS) } & \multicolumn{2}{|c|}{ TOTAL DE TOMADORES } \\
\hline & QTDE. & $\%$ & QTDE. & $\%$ & QTDE. & $\%$ \\
\hline Discordância & 6 & $60 \%$ & 63 & $56 \%$ & 69 & $56 \%$ \\
\hline Neutralidade & 2 & $20 \%$ & 26 & $23 \%$ & 28 & $23 \%$ \\
\hline Concordância & 2 & $20 \%$ & 24 & $21 \%$ & 26 & $21 \%$ \\
\hline TOTAL & 10 & $100 \%$ & 113 & $100 \%$ & 123 & $100 \%$ \\
\hline
\end{tabular}


..conclusão

\begin{tabular}{|c|c|c|c|c|c|c|}
\hline & - Todos os & gmentos & ientes tên & gens pare & & \\
\hline \multirow{2}{*}{ MANIFESTAÇÃO } & \multicolumn{2}{|c|}{ TOMADORES (COMMODITIES) } & \multicolumn{2}{|c|}{ TOMADORES (DEMAIS) } & \multicolumn{2}{|c|}{ TOTAL DE TOMADORES } \\
\hline & QTDE. & $\%$ & QTDE. & $\%$ & QTDE. & $\%$ \\
\hline Discordância & 5 & $50 \%$ & 65 & $58 \%$ & 70 & $57 \%$ \\
\hline Neutralidade & 3 & $30 \%$ & 22 & $19 \%$ & 25 & $20 \%$ \\
\hline Concordância & 2 & $20 \%$ & 26 & $23 \%$ & 28 & $23 \%$ \\
\hline TotaL & 10 & $100 \%$ & 113 & $100 \%$ & 123 & $100 \%$ \\
\hline
\end{tabular}

Ao analisar a maneira que a margem é definida, pode-se notar que, no geral, ela parece ser mais um elemento conector dos custos aos preços da concorrência do que um elemento arbitrário determinado para obtenção do lucro almejado.

Pode-se primeiramente observar que são raros os tomadores que têm a margem deliberada apenas pelo departamento financeiro: $79 \%$ dos tomadores discordam que a margem colocada sobre os custos é definida isoladamente por esse setor. Por esse motivo, espera-se que questões alheias àquelas financeiras sejam incorporadas.

A análise das respostas assinaladas para as questões relativas às variáveis ESC_2 e ESC_3 ratificam essa expectativa. Por essas respostas, é possível observar que a maior parte dos respondentes discorda que todos os produtos (56\%) e todos os clientes (57\%) têm margens parecidas. Essa constatação indica que a margem adéqua-se a cada produto e a cada cliente e, portanto, pode atuar como um elemento conector dos custos aos preços dos concorrentes.

Em suma, o estudo da Tabela 100 permite perceber que a maior parte dos tomadores que usam os custos mais margem como forma predominante de determinação dos preços não se ata a informações de custos. No geral, a margem não é definida apenas pelo departamento financeiro nem é única para todos os produtos e para todos os clientes.

\subsubsection{Essência Custos e Incorporação do Valor}

Na seção anterior demonstrou-se que, tanto nos formadores quanto nos tomadores de preços, o uso da combinação “custos mais margem” não é sinônimo de preços espelhos dos custos. Afinal, na maior parte da amostra (formadores e tomadores) a margem não é deliberada isoladamente pelo departamento financeiro nem é única para todos os produtos e para todos os clientes. 
Destarte, argumenta-se que a adoção dos custos mais margem não conduz necessariamente a uma determinação de preços ancorada nos custos sem considerar o valor e/ou a concorrência. Dentre os aderentes à combinação há, sim, empresas que concordam que os preços são formados pelos custos somados a uma margem arbitrariamente definida, mas também há empresas em que os custos são somados a uma margem que não é discricionária e que busca conectar os custos ao valor (formadores) ou aos preços dos concorrentes (tomadores).

Para trazer evidências empíricas a esse argumento, decidiu-se classificar as empresas de acordo com sua aderência à essência custos. Essa classificação ocorreu com base em uma análise de conglomerados não hierárquica $K$-means, na qual se optou por três conglomerados por dois motivos: desejava-se agrupar a essência custos em três níveis (baixa, moderada e alta); e 3 foi o número sugerido pela análise hierárquica previamente realizada, considerando a maior diferença entre os coeficientes de aglomeração. $\mathrm{Na}$ análise de $k$-means, diante do objetivo expresso de agrupar as empresas nesses três distintos níveis, estabeleceu-se que os centroides iniciais para as três variáveis fossem 1 no cluster $1 ; 3$ no cluster $2 ; 5$ no cluster 3.

No primeiro agrupamento, denominado como "baixa essência custos", a moda global das respostas assinaladas foi 1 e as modas das variáveis ESC_1, ESC_2 e ESC_3 foram, respectivamente, 1, 1 e 1; no segundo agrupamento, denominado "moderada essência custos", a moda global das respostas assinaladas foi 3 e as modas das variáveis foram 1, 3 e 3; no terceiro, denominado como "alta essência custos", a moda global das respostas assinaladas foi 3 e as modas das variáveis foram 3, 3 e 3. Por meio da ANOVA, verificou-se que as três variáveis utilizadas no estudo eram significantes para a formação dos três agrupamentos (todos os p-valores foram inferiores a 0,01 ).

A Tabela 101 revela a classificação das empresas com bases nesses conglomerados e evidencia que os custos, apesar de corresponderem à forma, não correspondem sozinhos à essência do estabelecimento dos preços nas empresas adotantes dos custos mais margem.

Tabela 101 - Essência custos nos formadores e tomadores de preços

\begin{tabular}{c|c|c|c|c|c|c}
\hline \multirow{2}{*}{ CLuSTERS } & \multicolumn{2}{|c|}{ FORMADORES } & \multicolumn{2}{c}{ TOMADORES } & \multicolumn{2}{c}{ TOTAL } \\
\cline { 2 - 7 } & QTDE. & $\mathbf{\%}$ & QTDE. & $\mathbf{\%}$ & QTDE. & \% \\
\hline Alta Essência Custos - Cluster 3 & 33 & $20 \%$ & 20 & $16 \%$ & $\mathbf{5 3}$ & $\mathbf{1 9 \%}$ \\
\hline Moderada Essência Custos - Cluster 2 & 57 & $35 \%$ & 43 & $35 \%$ & $\mathbf{1 0 0}$ & $\mathbf{3 5 \%}$ \\
\hline Baixa Essência Custos - Cluster 1 & 71 & $\mathbf{4 4 \%}$ & 60 & $\mathbf{4 9 \%}$ & $\mathbf{1 3 1}$ & $\mathbf{4 6 \%}$ \\
\hline ToTAL & $\mathbf{1 6 1}$ & $\mathbf{1 0 0 \%}$ & $\mathbf{1 2 3}$ & $\mathbf{1 0 0 \%}$ & $\mathbf{2 8 4}$ & $\mathbf{1 0 0 \%}$ \\
\hline
\end{tabular}


Como era de se esperar, nos tomadores de preços a essência custos é proporcionalmente mais baixa do que nos formadores de preços (49\% dos tomadores têm baixa essência custos contra $44 \%$ dos formadores). Afinal, neles há a necessidade de tomar os preços do mercado e a forma "custos mais margem" pode ser usada para simplificar essa tomada (mediante margem que conecta os custos aos preços dos concorrentes). Os preços devem ser similares aos preços da concorrência mesmo nos 20 tomadores com alta essência custos, nos quais possivelmente o processo terá uma etapa a mais (comparação e adequação do resultado da fórmula aos preços dos concorrentes).

Observações a parte, nota-se que na maioria dos formadores e tomadores de preços a forma “custos mais margem” não corresponde à essência custos, já que em $46 \%$ das empresas a essência custos é baixa. Logo, pode-se arguir que ela não conflita com a incorporação do valor no estabelecimento dos preços, diferentemente do que a literatura usualmente prega (e.g., Cressman Jr., 1999; Ingenbleek, 2007; Hinterhuber, 2008; Calabrese \& Francesco, 2014). O fato de encontrar formadores e tomadores que definem os preços a partir dos custos mais margem e, ainda assim, incorporam o valor no processo corrobora essa arguição.

Outra análise de conglomerados não hierárquica $K$-means foi realizada para agrupar as empresas de acordo com o nível de incorporação do valor. Embora 5 fosse o número sugerido pela análise hierárquica previamente realizada, considerando a maior diferença entre os coeficientes de aglomeração, optou-se por 3 agrupamentos para que as análises realizadas pudessem ser similares àquelas da essência custos. Como se tinha o objetivo expresso de agrupar as empresas nesses três distintos níveis, estabeleceu-se que os centroides iniciais para as três variáveis fossem 5 no cluster $1 ; 3$ no cluster $2 ; 1$ no cluster 3.

No primeiro agrupamento, denominado como "baixa incorporação do valor", a moda global das respostas assinaladas foi 5 e as modas das variáveis VNE_1, VNE_2 e VNE_3 foram, respectivamente, 4, 5 e 5; no segundo agrupamento, denominado "moderada incorporação do valor", a moda global das respostas assinaladas foi 3 e as modas das variáveis foram 1, 3 e 3; no terceiro, denominado como "alta incorporação do valor", a moda global das respostas assinaladas foi 1 e as modas das variáveis foram 1, 1 e 1 . Por meio da ANOVA, constatou-se que as três variáveis eram significativas para a formação dos agrupamentos ( $\mathrm{p}$-valor $<0,01$ ). 
A Tabela 102 demonstra que, sobretudo nos formadores, há, sim, empresas (38\%) que incorporam fortemente o valor no estabelecimento dos preços, ainda que a forma do processo seja marcada pelos custos mais margem.

Tabela 102 - Incorporação do valor nos formadores e tomadores de preços

\begin{tabular}{c|c|c|c|c|c|c}
\hline \multirow{2}{*}{ CLUSTERS } & \multicolumn{2}{|c|}{ FORMADORES } & \multicolumn{2}{c|}{ TOMADORES } & \multicolumn{2}{c}{ TOTAL } \\
\cline { 2 - 7 } & QTDE. & $\mathbf{\%}$ & QTDE. & $\mathbf{\%}$ & QTDE. & \% \\
\hline Alta Incorporação do Valor - Cluster 3 & 63 & $\mathbf{3 9 \%}$ & 44 & $36 \%$ & $\mathbf{1 0 7}$ & $\mathbf{3 8 \%}$ \\
\hline Moderada Incorporação do Valor - Cluster 2 & 62 & $39 \%$ & 55 & $\mathbf{4 5 \%}$ & $\mathbf{1 1 7}$ & $\mathbf{4 1 \%}$ \\
\hline Baixa Incorporação do Valor - Cluster 1 & 36 & $22 \%$ & 24 & $20 \%$ & $\mathbf{6 0}$ & $\mathbf{2 1 \%}$ \\
\hline ToTAL & $\mathbf{1 6 1}$ & $\mathbf{1 0 0 \%}$ & $\mathbf{1 2 3}$ & $\mathbf{1 0 0 \%}$ & $\mathbf{2 8 4}$ & $\mathbf{1 0 0 \%}$ \\
\hline
\end{tabular}

Como era de se esperar, a incorporação do valor é proporcionalmente mais alta nos formadores do que nos tomadores (39\% dos formadores têm alta incorporação do valor contra $36 \%$ dos tomadores). Afinal, nos tomadores, a existência de referências externas tende a fazer com que os custos mais margem priorizem a conexão dos custos aos preços da concorrência, enquanto que nos formadores (sem inteligência de mercado) a única conexão viável dos custos é com o valor.

Defende-se, portanto, que o que conflita com a incorporação do valor não é a forma, mas, sim, a essência custos. Em outras palavras, o que conflita com a incorporação do valor é a decisão de estabelecer os preços a partir de uma margem que, por ser definida arbitrariamente, não tem a finalidade de conectar os custos a outros tipos de informação. Para sustentar esse argumento, foram realizadas duas análises estatísticas: correlação de Pearson e teste de MannWhitney. A Tabela 103 mostra a primeira análise, isto é, relata a correlação de Pearson entre as variáveis da essência custos e os níveis de incorporação do valor.

Tabela 103 - Correlação entre incorporação do valor e variáveis da essência custos

\begin{tabular}{c|c|c|c}
\hline ESTATíSTICA & ESC_1 & ESC_2 & ESC_3 \\
\hline Correlação de Pearson & $-0,138$ & $-0,294$ & $-0,341$ \\
\hline p-valor & $\mathbf{0 , 0 2 0}$ & $\mathbf{0 , 0 0 0}$ & $\mathbf{0 , 0 0 0}^{* * * * * * * * *}$ \\
\hline
\end{tabular}

Nota. $* * \mathrm{p}<0,05 * * * \mathrm{p}<0,01$

Considerando um nível de significância de 0,05, nota-se que a incorporação do valor está significativa e negativamente relacionada a todos os aspectos da essência custos. A incorporação moderada e baixa do valor são mais observadas nas empresas em que a essência do estabelecimento dos preços é marcada pela soma dos custos a uma margem definida pelo 
departamento financeira de forma única para todos os produtos e para todos os clientes. Daí, tem-se a primeira evidência empírica que o que conflita com o valor é a essência custos.

A segunda análise visou testar estatisticamente se duas amostras independentes (incorporadores de alto valor - cluster 3 e não incorporadores de alto valor - clusters 1 e 2) foram extraídas de populações com médias iguais. Selecionou-se o teste de Mann-Whitney porque a hipótese de normalidade das variáveis foi violada, impedindo a realização de testes paramétricos. A Tabela 104 exibe os resultados do teste.

Tabela 104 - Resultados do teste Mann-Whitney para grupos de incorporação do valor

\begin{tabular}{c|c|c}
\hline HIPÓTESE NULA & P-VALOR & DECISÃo \\
\hline A distribuição da ESC_1 é a mesma entre as categorias do grupo & $\mathbf{0 , 0 1 5}$ & Rejeitar a hipótese nula \\
\hline A distribuição da ESC_2 é a mesma entre as categorias do grupo & $\mathbf{0 , 0 0 0}$ & Rejeitar a hipótese nula \\
\hline A distribuição da ESC_3 é a mesma entre as categorias do grupo & $\mathbf{0 , 0 0 0}{ }^{* * * *}$ & Rejeitar a hipótese nula \\
\hline
\end{tabular}
Nota. $* * \mathrm{p}<0,05 * * * \mathrm{p}<0,01$

Percebe-se que os incorporadores de alto valor diferem significativamente (nível de significância de 0,05$)$ dos não incorporadores de alto valor no que se refere à atribuição do departamento financeiro de definição da margem e à colocação de margens diferenciadas para distintos produtos e distintos segmentos de clientes. A Tabela 105 detalha que tanto a moda quanto a média das variáveis da essência custos são maiores naqueles que não incorporam altamente o valor.

Tabela 105 - Essência custos nos incorporadores e não incorporadores do valor

\begin{tabular}{c|c|c|c|c}
\hline & Grupos & ESC_1 & ESC_2 & ESC_3 \\
\hline \multirow{2}{*}{ Moda } & Incorporação de Alto Valor & 1 & 1 & 1 \\
\cline { 2 - 5 } & Não Incorporação de Alto Valor & 1 & 3 & 3 \\
\hline \multirow{2}{*}{ Média } & Incorporação de Alto Valor & 1,78 & 2,04 & 1,92 \\
\cline { 2 - 5 } & Não Incorporação de Alto Valor & 2,12 & 2,69 & 2,77 \\
\hline
\end{tabular}

Com essas evidências, conclui-se, mais uma vez, que a incorporação do valor não conflita com a forma, mas, sim, com a essência custos. As empresas que incorporam altamente o valor são aquelas nas quais a essência custos é menor, isto é, são aquelas nas quais a margem busca conectar os custos a outros tipos de informações. 


\subsubsection{Problemas da Essência Custos e Incorporação do Valor}

Ao inibir a incorporação do valor, a essência custos traz variados problemas ao processo de estabelecimento dos preços. Conforme já abordado, esses problemas surgem porque as empresas fazem suas deliberações considerando os custos mais margem arbitrária e tornam-se inflexíveis com relação aos preços (Tzokas et al., 2000).

De acordo com Shipley e Jobber (2001), essa inflexibilidade pode prejudicar os objetivos estratégicos, como, por exemplo, de entrar em novos segmentos, e impedir o aproveitamento de oportunidades esporádicas, como de acatar preços menores para completar a capacidade ociosa de produção. A Tabela 106 demonstra o quanto a amostra da pesquisa discorda ou concorda que vivencia esses problemas.

Tabela 106 - Problemas nos formadores e tomadores que adotam custos mais margem

\begin{tabular}{|c|c|c|c|c|c|c|}
\hline \multirow{3}{*}{ MANIFESTAÇÃo } & \multicolumn{6}{|c|}{$\begin{array}{c}\text { PRO_1 - Quando o preço resultante da fórmula não é bem aceito no mercado, optamos por } \\
\text { descontinuar o produto }\end{array}$} \\
\hline & \multicolumn{2}{|c|}{ FORMADORES } & \multicolumn{2}{|c|}{ TOMADORES } & \multicolumn{2}{|c|}{ TOTAL } \\
\hline & QTDE. & $\%$ & QTDE. & $\%$ & QTDE. & $\%$ \\
\hline Discordância & 81 & $50 \%$ & 49 & $40 \%$ & 130 & $46 \%$ \\
\hline Neutralidade & 34 & $21 \%$ & 39 & $32 \%$ & 73 & $26 \%$ \\
\hline Concordância & 46 & $29 \%$ & 35 & $28 \%$ & 81 & $29 \%$ \\
\hline TOTAL & 161 & $100 \%$ & 123 & $100 \%$ & 284 & $100 \%$ \\
\hline \multicolumn{7}{|c|}{$\begin{array}{c}\text { PRO_2 - Nós desistimos de entrar em um segmento no qual o preço aceitável pelos } \\
\text { clientes é inferior ao preço sugerido pela fórmula }\end{array}$} \\
\hline \multirow{2}{*}{ MANIFESTAÇÃO } & \multicolumn{2}{|c|}{ FORMADORES } & \multicolumn{2}{|c|}{ TOMADORES } & \multicolumn{2}{|c|}{ TOTAL } \\
\hline & QTDE. & $\%$ & QTDE. & $\%$ & QTDE. & $\%$ \\
\hline Discordância & 39 & $24 \%$ & 22 & $18 \%$ & 61 & $21 \%$ \\
\hline Neutralidade & 28 & $17 \%$ & 29 & $24 \%$ & 57 & $20 \%$ \\
\hline Concordância & 94 & $58 \%$ & 72 & $59 \%$ & 166 & $58 \%$ \\
\hline TOTAL & 161 & $100 \%$ & 123 & $100 \%$ & 284 & $100 \%$ \\
\hline \multicolumn{7}{|c|}{$\begin{array}{c}\text { PRO_3 - Mesmo quando há capacidade ociosa de produção, nós rejeitamos propostas } \\
\text { de preços inferiores ao resultado da fórmula }\end{array}$} \\
\hline \multirow{2}{*}{ MANIFESTAÇÃo } & \multicolumn{2}{|c|}{ FORMADORES } & \multicolumn{2}{|c|}{ TOMADORES } & \multicolumn{2}{|c|}{ TotaL } \\
\hline & QTDE. & $\%$ & QTDE. & $\%$ & QTDE. & $\%$ \\
\hline Discordância & 59 & $37 \%$ & 54 & $44 \%$ & 113 & $40 \%$ \\
\hline Neutralidade & 39 & $24 \%$ & 37 & $30 \%$ & 76 & $27 \%$ \\
\hline Concordância & 63 & $39 \%$ & 32 & $26 \%$ & 95 & $33 \%$ \\
\hline TOTAL & 161 & $100 \%$ & 123 & $100 \%$ & 284 & $100 \%$ \\
\hline \multicolumn{7}{|c|}{$\begin{array}{l}\text { PRO_4 - Por assegurar a obtenção do lucro desejado, o resultado da fórmula é mais } \\
\text { importante do que a informação do valor oferecido aos clientes }\end{array}$} \\
\hline \multirow{2}{*}{ MANIFESTAÇÃO } & \multicolumn{2}{|c|}{ FORMADORES } & \multicolumn{2}{|c|}{ TOMADORES } & \multicolumn{2}{|c|}{ TOTAL } \\
\hline & QTDE. & $\%$ & QTDE. & $\%$ & QTDE. & $\%$ \\
\hline Discordância & 50 & $31 \%$ & 44 & $36 \%$ & 94 & $33 \%$ \\
\hline Neutralidade & 59 & $37 \%$ & 40 & $33 \%$ & 99 & $35 \%$ \\
\hline Concordância & 52 & $32 \%$ & 39 & $32 \%$ & 91 & $32 \%$ \\
\hline TOTAL & 161 & $100 \%$ & 123 & $100 \%$ & 284 & $100 \%$ \\
\hline
\end{tabular}


O fato de encontrar empresas concordantes e discordantes dentre as 284 aderentes dos "custos mais margem" permite defender que não é a forma que traz os problemas usualmente relacionados na literatura. Logo, cabe mais uma vez arguir que a combinação não implica necessariamente a essência custos e, por consequência, não implica necessariamente esses problemas.

Pode-se perceber que nem todas as empresas, tomadoras e formadoras de preços, que definem os preços a partir dos custos mais margem apresentam os problemas comumente levantados para o processo pautado nos custos. No geral, a maior parte das empresas discorda ou nem concorda nem discorda sobre a presença desses problemas (maior concentração nos pontos 1 , 2 e 3), exceto com relação à entrada em um novo segmento. Para esse problema em específico, vale destacar que a maioria de formadores e tomadores de preços parece estar perdendo oportunidades por se ater ao resultado da fórmula.

Diante dessas evidências, argumenta-se que a essência custos, além de inibir a incorporação do valor, potencializa esses problemas. A fim de reforçar esse argumento, conduziu-se mais uma ANACOR para explorar a relação dos dois potenciais efeitos da essência custos: a não incorporação do valor e os problemas. A um nível de significância de 0,05, os resultados dos testes Qui-Quadrado permitiram prosseguir com a análise (p-valor 0,025). A Figura 74 apresenta o mapa perceptual elaborado com a aplicação da ANACOR.

Figura 74 - Mapa perceptual: Problemas da essência custos e incorporação do valor

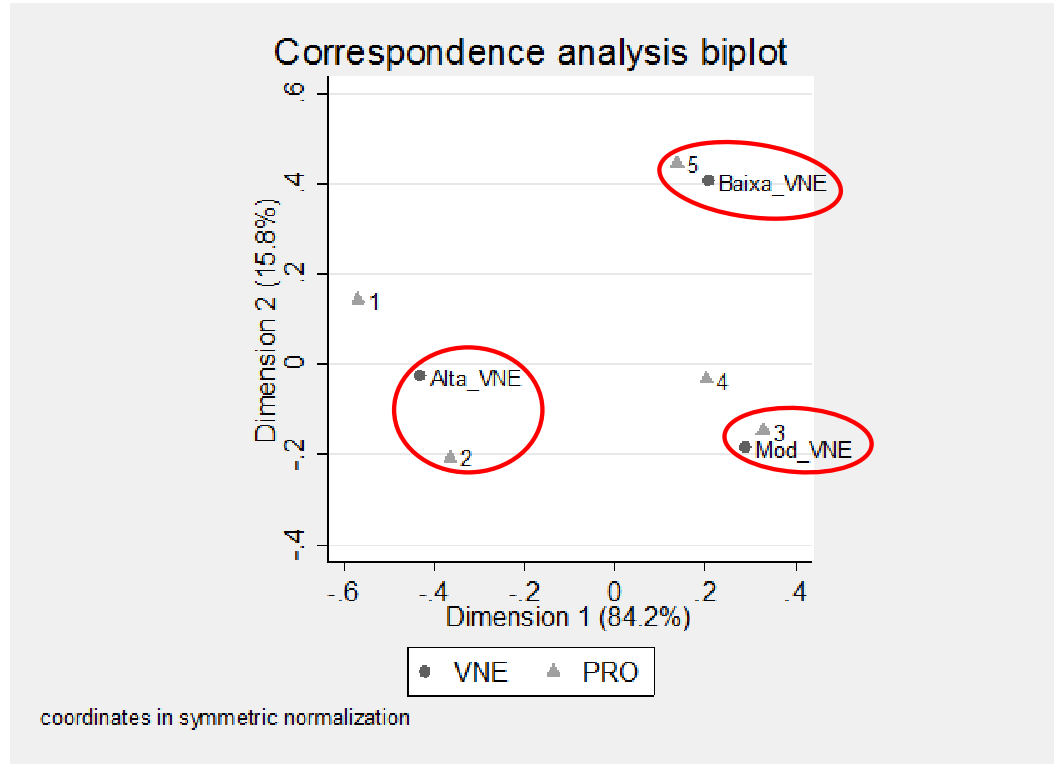

Fonte: Elaborada com a utilização do Stata 
Primeiramente, como esperado, nota-se que os problemas mais intensos (ponto 5) aparecem próximos daquelas empresas que tem uma baixa incorporação do valor nos preços. Percebe-se também que nas empresas em que a incorporação do valor é alta, há maior proximidade a pontos menos intensos dos problemas (ponto 2). Quando a incorporação do valor é moderada, os problemas também são moderados (ponto 3).

Diante desses resultados, chega-se à conclusão que a aderência à forma "custos mais margem”, per si, não traz problemas. É a essência custos que, além de inibir a incorporação do valor, pode trazer os problemas de inflexibilidade nos preços, desalinhamento aos objetivos, perda de oportunidades e desconsideração dos clientes. As empresas com baixa incorporação do valor são aquelas nas quais esses problemas são mais observados.

\subsection{Fatores Explicativos da Essência Custos}

Considerando que a essência custos conflita com a incorporação do valor no estabelecimento dos preços e que a não incorporação do valor está associada a problemas, resta entender os motivos pelos quais as empresas ainda definem os preços dessa maneira. Em outras palavras, é mister compreender quais fatores fazem com que as empresas optem por definir seus preços a partir dos custos somados a uma margem arbitrária.

Para identificar esses fatores, sem cometer os mesmos equívocos dos trabalhos anteriores, decidiu-se analisar separadamente os formadores e os tomadores de preços, uma vez que, conforme já abordado, há diferenças no contexto do estabelecimento de preços de cada um deles. Ora, quando a essência custos é encontrada nos formadores, ela indica que os preços são formados a partir de uma margem ancorada em questões financeiras que não promove a conexão dos custos ao valor. Já quando a essência custos é encontrada nos tomadores, ela indica que os preços são definidos a partir de uma margem ancorada em questões financeiras que, por não promover a conexão dos custos aos preços da concorrência, pede uma etapa adicional de comparação dos resultados aos preços do mercado.

Além disso, há fatores que fazem sentido aos formadores de preços, mas não fazem sentido aos tomadores de preço e vice-versa. Esse é o caso da diferenciação, da posição de liderança e 
da adoção de estratégias de preços premium, presente nos formadores mas não nos tomadores, e da concorrência intensa, presente nos tomadores mas não nos formadores.

A amostra das 284 empresas que aderiam à forma custos mais margem foi, portanto, segregada entre os 161 formadores de preços e os 123 tomadores de preços. Duas análises de regressão ordinal foram conduzidas, uma separadamente para os formadores de preços e outra separadamente para os tomadores de preços.

\subsubsection{Avaliação dos Pressupostos das Análises de Regressão Ordinal}

A escolha da análise de regressão ordinal decorreu do fato de a variável dependente (ESC) ter a natureza ordinal (baixa, moderada e alta essência custos) e violar, portanto, a assunção da regressão linear de igualdade nas distâncias entre os valores designados para as categorias (Long \& Freese, 2006). De acordo com Chen e Hughes Jr. (2004), cabe usar a análise de regressão ordinal quando se quer investigar o efeito de múltiplas variáveis explicativas em uma variável dependente ordinal, variável essa que não pode ser tratada nem como contínua nem como binária.

Staus (2008) ressalta que cuidados devem ser tomados ao ordenar a variável dependente. O autor alega que a possibilidade de ranquear a variável não significa que a ordem faz sentido em quaisquer circunstâncias. Ele cita que as cores, por exemplo, podem ser organizadas de acordo com seu eletromagnetismo. Entretanto, a preferência das cores dos clientes no momento de comprar um carro normalmente não tem relação com a ordem eletromagnética, mas, sim, com gostos particulares.

Nesta tese, a variável dependente está ordenada em função da essência custos, tomando como base a análise de conglomerados realizada a partir das variáveis ESC_1, ESC_2 e ESC_3. Tanto nos formadores quanto nos tomadores de preços, a categoria 1 refere-se à essência custos baixa, a categoria 2 refere-se à essência custos moderada e a categoria 3 refere-se à essência custos alta.

No que se refere às variáveis independentes da regressão ordinal, Elamir e Sadeq (2010) sugerem buscar incluir as fontes de explicações significativas da variável dependente, assim 
como acontece nos demais tipos de regressões. Com base no arcabouço teórico abordado neste estudo, foram incluídas as variáveis independentes descritas na Tabela 107.

Tabela 107 - Variáveis das análises de regressão ordinal

\begin{tabular}{|c|c|c|c|c|c|c|c|}
\hline $\begin{array}{c}\text { TIPO DE } \\
\text { VARIÁVEL }\end{array}$ & CóD. & QUESTÃo & ESCALA & $\begin{array}{c}\text { POSSÍVEIS } \\
\text { VALORES }\end{array}$ & HIPÓTESE & $\begin{array}{c}\text { SINAL } \\
\text { ESPERADO } \\
\text { FORMADOR }\end{array}$ & $\begin{array}{c}\text { SINAL } \\
\text { ESPERADO } \\
\text { TOMADOR }\end{array}$ \\
\hline Dependente & ESC & $6 a / 6 f / 6 g$ & Ordinal & $1,2,3$ & $1-10$ & Dependente & Dependente \\
\hline Independente & DIF & $1 \mathrm{c}$ & Ordinal & $1,2,3$ & 1 & + & N/A \\
\hline Independente & TAM & $\begin{array}{l}\text { Questão de } \\
\text { conclusão }\end{array}$ & Nominal & $0,1,2,3$ & 2 & - & - \\
\hline Independente & LID & $\begin{array}{l}\text { Questão de } \\
\text { conclusão }\end{array}$ & Nominal & 0,1 & 3 & + & N/A \\
\hline Independente & EST & $1 \mathrm{f}$ & Ordinal & $1,2,3$ & 4 & - & N/A \\
\hline Independente & INC & $1 \mathrm{a}$ & Ordinal & $1,2,3$ & 5 & N/A & - \\
\hline Independente & COP & $1 \mathrm{e}$ & Ordinal & $1,2,3$ & 5 & N/A & - \\
\hline Independente & PCV & $8 a$ & Ordinal & $1,2,3$ & 6 & + & + \\
\hline Independente & FUV & $8 b$ & Ordinal & $1,2,3$ & 6 & + & + \\
\hline Independente & PRV & $7 \mathrm{c}$ & Ordinal & $1,2,3$ & 6 & + & + \\
\hline Independente & DIV & $8 \mathrm{c}$ & Ordinal & $1,2,3$ & 6 & + & + \\
\hline Independente & ISC & $8 \mathrm{~d}$ & Ordinal & $1,2,3$ & 7 & + & + \\
\hline Independente & ISN & $8 \mathrm{e}$ & Ordinal & $1,2,3$ & 7 & + & + \\
\hline Independente & ISM & $8 \mathrm{f}$ & Ordinal & $1,2,3$ & 7 & + & + \\
\hline Independente & AMB & $\begin{array}{l}\text { Questão de } \\
\text { conclusão }\end{array}$ & Nominal & 0,1 & 8 & - & - \\
\hline Independente & EXP & $\begin{array}{l}\text { Questão de } \\
\text { conclusão }\end{array}$ & Contínua & Contínua & 9 & - & - \\
\hline Independente & CFX & $5 a$ & Ordinal & $1,2,3$ & 10 & + & + \\
\hline Independente & DES & $5 b$ & Ordinal & $1,2,3$ & 10 & + & + \\
\hline
\end{tabular}

Como $44 \%$ dos formadores e $48 \%$ dos tomadores são da categoria correlata à baixa essência custos, ou seja, estão concentrados na categoria mais baixa (1), escolheu-se a função log-log negativo (negative log-log).

Com esses parâmetros deliberados, partiu-se à execução das análises de regressão ordinal no SPSS. Entretanto, antes de analisar especificamente os resultados, cumpre avaliar os ajustes dos modelos, o atendimento à assunção de linhas paralelas e os acertos nas classificações.

A primeira avaliação explora o ajuste global do modelo ao verificar se ele melhora ou não a habilidade de explicar o resultado. Essa verificação é feita ao comparar um modelo sem qualquer variável explicativa (apenas com o intercepto) com o modelo com todas as variáveis explicativas. A comparação implica o teste Qui-Quadrado e p-valores inferiores ao nível de significância estabelecido sugerem que o modelo final oferece uma melhor predição do que o modelo só com o intercepto. A Tabela 108 apresenta os resultados e demonstra que, tanto na 
regressão dos formadores quanto na regressão dos tomadores, os modelos melhoram a habilidade de explicar as variáveis dependentes.

Tabela 108 - Ajuste dos modelos

\begin{tabular}{|c|c|c|c|}
\hline \multicolumn{2}{|c|}{ FORMADORES } & \multicolumn{2}{|c|}{ TOMADORES } \\
\hline Qui-Quadrado & p-valor & Qui-Quadrado & p-valor \\
\hline 40,803 & $0,056^{*}$ & 53,840 & $0,002^{\text {***: }}$ \\
\hline
\end{tabular}

Nota. $* \mathrm{p}<0,10 * * * \mathrm{p}<0,01$

A segunda avaliação testa se os dados observados são consistentes com o modelo. Como a hipótese nula é que a aderência é boa, o modelo é considerado consistente se no teste QuiQuadrado os p-valores forem superiores ao nível de significância estabelecido. A Tabela 109 evidencia os resultados dos testes Qui-Quadrado, com base na estatística de Pearson e nos desvios, e revela que os modelos dos formadores e dos tomadores podem ser considerados consistentes.

Tabela 109 - Aderência dos modelos

\begin{tabular}{c|c|c|c|c}
\hline \multirow{2}{*}{ BASE } & \multicolumn{2}{|c|}{ FORMADORES } & \multicolumn{2}{c}{ TOMADORES } \\
\cline { 2 - 5 } & QUI-QUADRADO & P-VALOR & QUI-QUADRADO & P-VALOR \\
\hline Pearson & 317,118 & 0,150 & 227,505 & 0,299 \\
\hline Desvios & 298,431 & 0,385 & 195,343 & 0,852 \\
\hline
\end{tabular}

A terceira avaliação refere-se aos pseudos $R^{2}$ da regressão. Vale mencionar que o $R^{2}$ na regressão ordinal é diferente do $\mathrm{R}^{2}$ na regressão linear porque ele, ao invés de calcular precisamente a proporção da variância explicada pelas variáveis independentes, oferece cálculos aproximados, uma vez que lida com probabilidades. Por ser aproximado, não preciso, existe mais de uma possível forma de cálculo do $\mathrm{R}^{2}$ na regressão ordinal.

Fávero et al. (2009) explicam que na regressão linear, o $\mathrm{R}^{2}$ parte do método dos mínimos quadrados a fim de minimizar os desvios quadrados, enquanto que na regressão ordinal (análoga à regressão logística) o $\mathrm{R}^{2}$ parte do método de máxima verossimilhança e busca maximizar a probabilidade de um evento ocorrer. A Tabela 110 relata os três pseudo $\mathrm{R}^{2}$ calculados para os modelos dos formadores e dos tomadores e indica que parcelas razoáveis da variação nos resultados podem ser explicadas pelos modelos propostos. 
Tabela 110 - Pseudos $\mathrm{R}^{2}$ dos modelos

\begin{tabular}{l|c|c}
\hline PSEUDO R $^{2}$ & FORMADORES & TOMADORES \\
\hline Cox e Snell & 0,224 & 0,354 \\
\hline Nagelkerke & 0,255 & 0,408 \\
\hline McFadden & 0,120 & 0,216 \\
\hline
\end{tabular}

A próxima avaliação analisa as classificações corretas e incorretas dos modelos, isto é, compara as reais classificações da essência custos às classificações da essência custos estimadas pelos modelos. A Tabela 111 reporta os resultados e demonstra que o modelo dos formadores de preços apresenta 57\% de classificações corretas e que o modelo dos tomadores de preços apresenta $65 \%$ de classificações corretas. Na categoria mais baixa (baixa essência custos) esse percentual chega a $76 \%$ nos formadores de preços e a $83 \%$ nos tomadores de preços.

Tabela 111 - Acertos nas classificações dos modelos

\begin{tabular}{c|c|c|c|c}
\hline \multirow{2}{*}{ AVAliação } & \multicolumn{2}{|c|}{ FORMADORES } & \multicolumn{2}{c}{ TOMADORES } \\
\cline { 2 - 5 } & $\begin{array}{c}\text { QUANTIDADE DE } \\
\text { ACERTOS }\end{array}$ & $\begin{array}{c}\text { PERCENTUAL DE } \\
\text { ACERTOS }\end{array}$ & $\begin{array}{c}\text { QUANTIDADE DE } \\
\text { ACERTOS }\end{array}$ & $\begin{array}{c}\text { PERCENTUAL DE } \\
\text { ACERTOS }\end{array}$ \\
\hline Modelo & $91 \mathrm{de} 161$ & $57 \%$ & $80 \mathrm{de} 123$ & $65 \%$ \\
\hline Categoria 1 & $54 \mathrm{de} 71$ & $76 \%$ & $50 \mathrm{de} 60$ & $83 \%$ \\
\hline
\end{tabular}

Embora os percentuais de acertos não sejam demasiadamente elevados, pode-se considerar que, em linhas gerais, os modelos têm um ajuste aceitável em termos de expectativa de predição.

Finalmente, a última avaliação refere-se às linhas paralelas para todos os níveis da variável dependente. Chen e Hughes Jr. (2004) frisam que a regressão ordinal não exige nem normalidade nem constância da variância, entretanto, requer essas linhas paralelas. A regressão ordinal assume que a relação entre as variáveis explicativas e o resultado independe da categoria e, consequentemente, indica que os coeficientes não dependem das categorias do resultado. Em outras palavras, o modelo assume que os coeficientes da regressão são iguais para cada ponto de corte.

A análise das linhas paralelas é feita mediante um teste que compara o modelo que tem um conjunto de coeficientes para todas as categorias (hipótese nula) a um modelo que traz coeficientes diferentes às categorias. Se o resultado do teste exibe um p-valor superior ao nível de significância estabelecido, não se rejeita a assunção de probabilidades proporcionais 
e prossegue-se com o modelo. A Tabela 112 demonstra p-valores para os modelos dos formadores e dos tomadores que permitem persistir com as análises de regressão ordinal.

Tabela 112 - Testes das linhas paralelas dos modelos

\begin{tabular}{c|c|c|c}
\hline \multicolumn{2}{c|}{ FORMADORES } & \multicolumn{2}{c}{ TOMADORES } \\
\hline QUI-QUADRADO & P-VALOR & QUI-QUADRADO & P-VALOR \\
\hline 37,298 & 0,112 & 19,171 & 0,864 \\
\hline
\end{tabular}

Agora que os modelos já foram avaliados, pode-se passar especificamente para a análise dos resultados e identificar, por fim, quais fatores explicam a essência custos nos formadores e nos tomadores de preços.

\subsubsection{Análise dos Resultados das Análises de Regressão Ordinal}

A Tabela 113 apresenta os resultados obtidos a partir dos dados da pesquisa. Ela revela os parâmetros estimados para os modelos de regressão dos formadores e dos tomadores de preços. Vale rememorar que a codificação das variáveis bem como os critérios adotados para suas classificações (alta, média e baixa) estão de acordo com os procedimentos detalhados na seção 6.4.2.

Tabela 113 - Resultados dos modelos de regressão ordinal

\begin{tabular}{|c|c|c|c|c|}
\hline \multirow{2}{*}{ VARIÁVEIS } & \multicolumn{2}{|c|}{ FORMADORES } & \multicolumn{2}{|c|}{ TOMADORES } \\
\hline & COEFICIENTE & P-VALOR & COEFICIENTE & P-VALOR \\
\hline $\mathrm{ESC}=$ Baixa (pontos de corte - Threshold) & 1,460 & $0,091^{*}$ & $(0,189)$ & 0,867 \\
\hline ESC = Média (pontos de corte - Threshold) & 2,891 & $0,001^{* * * * \%}$ & 1,627 & 0,153 \\
\hline DIF $=$ Alta & 0,644 & $0,061^{*}$ & N/A & N/A \\
\hline DIF = Média & 0,631 & $0,084^{*}$ & N/A & N/A \\
\hline TAM = Grande & $(0,371)$ & 0,411 & $(\mathbf{1 , 5 0 0 )}$ & $\mathbf{0 , 0 3 8} 8^{* * *}$ \\
\hline TAM = Média & 0,719 & $0,081^{*}$ & $(1,694)$ & $\mathbf{0 , 0 2 1} 1^{* *}$ \\
\hline TAM = Pequena & $\mathbf{0 , 8 5 1}$ & $0,029^{* * *}$ & $(0,929)$ & 0,189 \\
\hline LID = Líder & 0,096 & 0,708 & N/A & N/A \\
\hline EST = Alto Premium & $(1,215)$ & $\mathbf{0 , 0 0 1} 1^{* * * *}$ & N/A & N/A \\
\hline EST = Médio Premium & $(0,964)$ & $0,024^{* *}$ & $\mathrm{~N} / \mathrm{A}$ & N/A \\
\hline $\mathrm{INC}=$ Alta & N/A & N/A & $(0,040)$ & 0,951 \\
\hline INC $=$ Média & N/A & N/A & $(0,295)$ & 0,660 \\
\hline $\mathrm{COP}=$ Alta & N/A & N/A & $(0,910)$ & $0,020^{* * *}$ \\
\hline COP = Média & N/A & N/A & $(0,184)$ & 0,653 \\
\hline
\end{tabular}


...conclusão

\begin{tabular}{|c|c|c|c|c|}
\hline \multirow{2}{*}{ VARIÁVEIS } & \multicolumn{2}{|c|}{ FORMADORES } & \multicolumn{2}{|c|}{ TOMADORES } \\
\hline & COEFICIENTE & P-VALOR & COEFICIENTE & P-VALOR \\
\hline $\mathrm{PCV}=$ Alta & 0,354 & 0,232 & 0,474 & 0,192 \\
\hline PCV = Média & $(0,016)$ & 0,964 & 0,703 & $0,077^{*}$ \\
\hline FUV = Alta & 0,061 & 0,842 & 0,645 & 0,115 \\
\hline FUV = Média & 0,720 & 0,020 *** & 0,428 & 0,308 \\
\hline PRV = Alta & 0,542 & 0,050 ** & 0,809 & $\mathrm{0,032}^{* *}$ \\
\hline PRV = Média & 0,387 & 0,313 & 1,089 & $0,015^{* * *}$ \\
\hline DIV $=$ Alta & 0,177 & 0,554 & $(0,801)$ & $0,039^{* *}$ \\
\hline DIV = Média & $(0,017)$ & 0,957 & 0,195 & 0,603 \\
\hline ISC $=$ Alto & $(0,423)$ & 0,148 & 0,934 & $0,010^{* * * *}$ \\
\hline ISC $=$ Médio & $(0,543)$ & 0,208 & 0,748 & $0,052^{*}$ \\
\hline ISN = Alto & 0,085 & 0,804 & $(1,052)$ & $0,007^{* * * *}$ \\
\hline ISN = Médio & $(0,332)$ & 0,319 & $(0,701)$ & $0,100^{*}$ \\
\hline ISM = Alto & 0,080 & 0,817 & 0,432 & 0,235 \\
\hline ISM = Médio & $(0,196)$ & 0,618 & 0,373 & 0,388 \\
\hline B2B & 0,396 & 0,461 & $(0,196)$ & 0,599 \\
\hline EXP & 0,013 & 0,313 & $(0,050)$ & $0,007^{* * * *}$ \\
\hline CFX = Alta inclusão & 0,241 & 0,608 & 1,786 & $0,012^{* *}$ \\
\hline CFX = Média inclusão & $(0,009)$ & 0,988 & 0,439 & 0,671 \\
\hline DES = Alta inclusão & 0,010 & 0,980 & $(0,528)$ & 0,426 \\
\hline DES = Média inclusão & 0,631 & 0,220 & $(0,981)$ & 0,232 \\
\hline
\end{tabular}

Nota. $* \mathrm{p}<0,10 ; * * \mathrm{p}<0,05 ; * * * \mathrm{p}<0,01$

Antes de analisar os resultados, vale ressaltar que as regressões não apresentam o problema de multicolinearidade entre as variáveis explicativas, pois foram calculadas as estatísticas "Variance Inflation Factor" (VIF) e o valor máximo constatado foi 2,106 para a dummy correspondente ao nível 3 de FUV dos tomadores (no modelo dos formadores todos os VIF foram inferiores a 2; no modelo dos tomadores somente dois VIF foram superiores a 2). Considerando que a recomendação é obter VIF menores do que 10, preferencialmente menores do que 5 (Fávero et al., 2009), percebe-se que não foi diagnosticado o problema de multicolinearidade.

Cumpre também esclarecer que os pontos de corte (Threshold) referem-se às variáveis de resultado nos modelos de regressão ordinal. Nos formadores, estimativas até 1,460 originaram classificações de baixa essência custos, estimativas superiores a 1,460 até 2,891 originaram classificações de moderada essência custos e estimativas superiores a 2,891 originaram classificações de alta essência custos. Nos tomadores, estimativas até $(0,189)$ originaram classificações de baixa essência custos, estimativas superiores a $(0,189)$ até 1,627 originaram classificações de moderada essência custos e estimativas superiores a 1,627 originaram classificações de alta essência custos. 
No que se refere aos resultados encontrados para as variáveis independentes, pode-se primeiramente observar que, apesar de terem sido incluídas variáveis relativas a todas as hipóteses de pesquisa, nem todos os parâmetros obtiveram significância estatística, mesmo assumindo um nível de significância de 0,10 .

No modelo dos formadores de preços, as variáveis explicativas com nível de significância a 10\% são: (1) a diferenciação alta; (2) a diferenciação média; (3) o tamanho médio; (4) o tamanho pequeno; (5) a estratégia premium; (6) a estratégia médio premium; (7) a percepção sobre a preparação média dos funcionários para calcular o valor; e (8) a percepção alta sobre a chance de ter prejuízos no caso de os preços serem inferiores aos custos mais margem. A posição de liderança, as pressões isomórficas, a atuação no ambiente B2B, a experiência e o uso de custos totais não obtiveram significância estatística.

No modelo dos tomadores de preços, as variáveis explicativas com nível de significância a 10\% são: (1) o tamanho grande; (2) o tamanho médio; (3) a alta propensão de cópia dos concorrentes; (4) a percepção de investimentos médios necessários para definir preços conforme o valor; (5) a percepção alta sobre a chance de ter prejuízos no caso de os preços serem inferiores aos custos mais margem; (6) a percepção média sobre a chance de ter prejuízos no caso de os preços serem inferiores aos custos mais margem; (7) a percepção alta sobre a não disposição dos clientes em pagar o valor; (8) altas pressões coercitivas; (9) médias pressões coercitivas; (10) altas pressões normativas; (11) médias pressões normativas; (12) experiência; e (13) alta inclusão dos custos fixos. A atuação no ambiente B2B foi o único constructo que não teve qualquer variável com significância estatística.

Larasati et al. (2011) esclarecem que na regressão ordinal, da mesma forma que nos demais tipos de regressão, o pesquisador deve considerar os sinais do modelo, pois eles representam a existência de efeitos positivos ou negativos das variáveis independentes no resultado. Coeficientes positivos indicam uma relação positiva entre as variáveis explicativas e os resultados, enquanto que coeficientes negativos indicam uma relação inversa. Especificamente nesta tese, coeficientes positivos significam que o fator em questão explica positivamente a essência custos (mais a essência custos é encontrada) enquanto que coeficientes negativos significam que o fator em questão explica negativamente a essência custos (menos a essência custos é encontrada). 
Os aumentos nos valores de variáveis explicativas cujos coeficientes são positivos correspondem a aumentos na probabilidade de estar nas categorias mais altas do resultado. Já os aumentos nos valores de variáveis explicativas cujos coeficientes são negativos correspondem a aumentos na probabilidade de estar nas categorias mais baixas do resultado. Para as variáveis explicativas categóricas (nominais ou ordinais), o sinal também demonstra o efeito na variável dependente em relação à categoria de referência.

Logo, cabe comparar, mediante análise da Tabela 114, os resultados observados àqueles esperados de acordo com a literatura. Vale mencionar que, para as variáveis independentes categóricas, os sinais observados apresentados referem-se àqueles encontrados nas menores categorias (1 para as ordinais, 0 para as nominais), que são as categorias mais distantes da referência (as maiores categorias são as categorias de referência). Em outras palavras, para as variáveis independentes categóricas os sinais observados referem-se às menores categorias, que são correlatas aos níveis altos (alta diferenciação, alta estratégia premium, alta intensidade da concorrência etc.), ao grande porte, à posição de liderança e à atuação no ambiente B2B. A variável experiência é contínua.

Tabela 114 - Sumário dos resultados das análises de regressão ordinal

\begin{tabular}{|c|c|c|c|c|c|c|c|c|}
\hline \multirow[b]{2}{*}{ CONSTRuCtos } & \multirow[b]{2}{*}{ VAR. } & \multirow[b]{2}{*}{ HIPÓTESES } & \multicolumn{3}{|c|}{$\begin{array}{l}\text { FORMADORES } \\
\end{array}$} & \multicolumn{3}{|c|}{$\begin{array}{l}\text { TOMADORES } \\
\end{array}$} \\
\hline & & & $\begin{array}{c}\text { SINAIS } \\
\text { ESPERADOS } \\
\end{array}$ & $\begin{array}{c}\text { SINAIS } \\
\text { OBSERVADOS } \\
\end{array}$ & SIG. & $\begin{array}{c}\text { SINAIS } \\
\text { ESPERADOS } \\
\end{array}$ & $\begin{array}{c}\text { SINAIS } \\
\text { OBSERVADOS } \\
\end{array}$ & SIG. \\
\hline Diferenciação & DIF & 1 & + & + & Sim & N/A & N/A & $\mathrm{N} / \mathrm{A}$ \\
\hline Tamanho da empresa & TAM & 2 & - & - & Não & - & - & Sim \\
\hline $\begin{array}{c}\text { Posição de liderança no } \\
\text { mercado }\end{array}$ & LID & 3 & + & + & Não & N/A & N/A & N/A \\
\hline $\begin{array}{c}\text { Estratégia de preço } \\
\text { premium }\end{array}$ & EST & 4 & - & - & Sim & N/A & N/A & N/A \\
\hline \multirow{2}{*}{$\begin{array}{c}\text { Intensidade da } \\
\text { concorrência } \\
\end{array}$} & INC & 5 & N/A & N/A & N/A & - & - & Não \\
\hline & $\mathrm{COP}$ & 5 & N/A & N/A & N/A & - & - & Sim \\
\hline \multirow{4}{*}{$\begin{array}{c}\text { Dificuldades para definir } \\
\text { os preços conforme o } \\
\text { valor }\end{array}$} & $\mathrm{PCV}$ & 6 & + & + & Não & + & + & Não \\
\hline & FUV & 6 & + & + & Não & + & + & Não \\
\hline & PRV & 6 & + & + & Sim & + & + & Sim \\
\hline & DIV & 6 & + & + & Não & + & - & Sim \\
\hline \multirow{3}{*}{ Pressões isomórficas } & ISC & 7 & + & - & Não & + & + & Sim \\
\hline & ISN & 7 & + & + & Não & + & - & Sim \\
\hline & ISM & 7 & + & + & Não & + & + & Não \\
\hline Ambiente de atuação & AMB & 8 & - & + & Não & - & - & Não \\
\hline $\begin{array}{c}\text { Experiência no } \\
\text { estabelecimento dos } \\
\text { preços }\end{array}$ & EXP & 9 & - & + & Não & - & - & Sim \\
\hline \multirow{2}{*}{$\begin{array}{l}\text { Custos totais na fórmula } \\
\text { "custos mais margem" }\end{array}$} & CFX & 10 & + & + & Não & + & + & Sim \\
\hline & DES & 10 & + & + & Não & + & - & Não \\
\hline
\end{tabular}


Constata-se que tanto nos formadores quanto nos tomadores de preços, há, no geral, uma forte correspondência entre os sinais esperados e os sinais observados.

Para os formadores, cumpre salientar os resultados encontrados para (i) a diferenciação, (ii) a estratégia premium e (iii) a alta percepção sobre a chance de ter prejuízos no caso de os preços serem inferiores aos custos mais margem. Os três resultados, além de coincidirem com as expectativas, são estatisticamente significativos.

Esses resultados demonstram que a essência custos é estimulada pelo poder mais sustentável de definir os preços (proporcionado pela diferenciação) e pela intuição (equivocada) que preços inferiores aos sugeridos pelos custos mais margem causam prejuízos. Os achados também revelam que a estratégia de preço premium desestimula a essência custos, afinal, a colocação dos preços em níveis permanentemente elevados (inerentes a essa estratégia) normalmente estimula a incorporação do valor para justificar esses níveis.

No que se refere aos constructos que não apresentam qualquer variável com significância estatística cumpre incluir considerações. A inclusão do tamanho como fator explicativo seguiu os trabalhos de Guilding et al. (2005) e de Al-Hussari (2006). Assim como nesta tese, nesses dois trabalhos não foi identificada significância estatística entre o fator e a configuração do estabelecimento dos preços. Diante dessas três refutações, a melhor opção parece ser admitir que pelo menos para os formadores de preços não há relação entre o porte das empresas e o estabelecimento dos preços.

A posição de liderança no mercado foi incluída também seguindo Guilding et al. (2005) e AlHussari (2006). No primeiro trabalho, o fator foi sugerido como sugestão alternativa para o tamanho da empresa; no segundo trabalho, duas variáveis (a fatia de mercado e a influência na determinação dos preços) possibilitavam ter uma visão do quão líderes as empresas eram. O problema é que no segundo trabalho as duas variáveis, embora tenham sido estatisticamente significativas, caminhavam em direções opostas (fatia de mercado explicava negativamente a importância atribuída aos custos mais margem; influência na determinação dos preços explicava positivamente a importância atribuída aos custos mais margem). Esses resultados conflitantes somados a não significância estatística constatada nesta tese podem ser mais um indício de que a liderança não tem condições de explicar o estabelecimento dos preços. 
As pressões isomórficas, sobretudo aquelas coercitivas, podem não ter sido estatisticamente significativas porque, segundo Hinterhuber (2008), a falta de apoio da alta gerência é uma das fontes de obstrução da incorporação do valor. Logo, nos casos em que a alta gerência da matriz é mais ativa e mais envolvida com a definição dos preços, pode haver estímulos não só para usar os custos mas também para incorporar o valor.

O ambiente de atuação pode não ter obtido significância estatística porque a amostra desta pesquisa está altamente concentrada no ambiente B2B (90\% dos formadores). Em todos os níveis de essência custos (baixa, moderada e alta), as empresas concentravam-se no ambiente B2B. Uma amostra mais balanceada poderia apresentar resultados distintos, coerentes às expectativas da pesquisa.

A resistência a mudanças na maneira de definir os preços, relacionada por Hinterhuber (2008), pode ajudar a entender por que a experiência não obteve resultados significativos. Os anos atuando na formação dos preços, ao invés de aprimorarem, podem ter estimulado a repetição dos processos inicialmente implantados.

Já a não significância estatística das duas variáveis do constructo custos totais na fórmula “custos mais margem" pode decorrer do fato que, de acordo com Soutes (2006), para efeito gerencial no Brasil, a maior parte das empresas usa o custeio por absorção. Logo, os custos fixos podem ser incluídos por impulso, não por uma decisão rigorosamente pensada, já que correspondem a uma informação prontamente disponível, previamente elaborada para outras finalidades. As despesas fixas, por sua vez, podem não ser incluídas também por impulso, já que correspondem a uma informação que não foi elaborada previamente (teria sido, se o custeio pleno fosse adotado).

Para resumir os achados, vale apresentar a Figura 75 e relacionar os fatores significativos que explicam positiva e negativamente a essência custos nos formadores de preços. 
Figura 75 - Fatores explicativos significativos da essência custos nos formadores

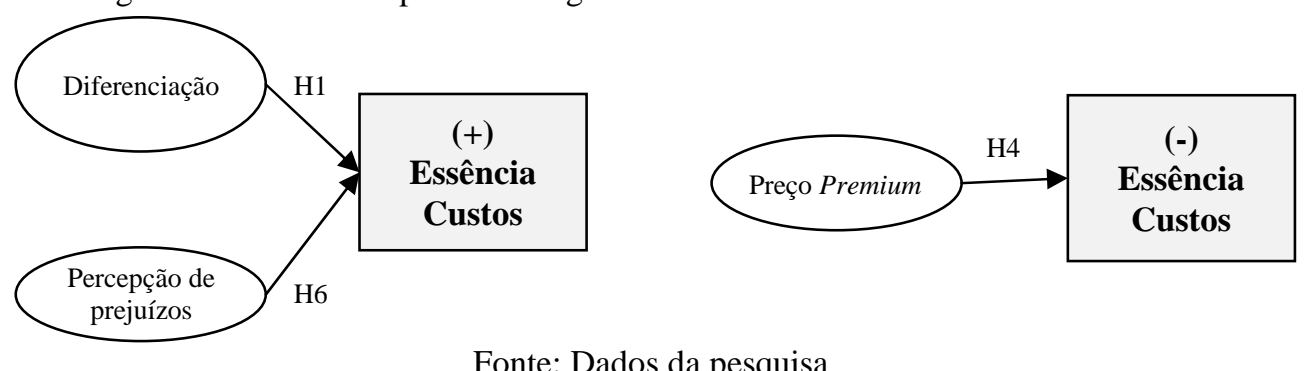

Fonte: Dados da pesquisa

Passando para os tomadores de preços, cumpre salientar que, exceto pelo ambiente de atuação, todos os constructos apresentaram pelo menos uma variável que explicou significativamente a (maior ou menor) essência custos. Destaques recaem para os resultados obtidos com relação ao tamanho grande, à alta propensão de cópia dos concorrentes, a percepção alta sobre a chance de ter prejuízos no caso de os preços serem inferiores aos custos mais margem, às altas pressões isomórficas coercitivas, à experiência e à alta inclusão dos custos fixos. Os resultados dessas seis variáveis, além de serem estatisticamente significativos, coincidem com as expectativas.

O grande porte tende a mais bem estruturar as decisões e a alta propensão de cópia dos concorrentes tende a pedir processos mais eficientes, explicando o desestímulo à essência custos. Da mesma forma, a experiência melhora o processo decisório e também afasta a essência custos.

No que se refere à experiência, especificamente, vale destacar que os preços nos tomadores precisam necessariamente equiparar-se aos preços dos concorrentes. Os anos de experiência tendem a demonstrar essa necessidade aos tomadores. Em outras palavras, os anos de experiência mostram que, no contexto da tomada de preços, o embasamento excessivo nos custos não é suficiente e incentiva a conexão dos custos aos preços dos concorrentes.

Por outro lado, a intuição (equivocada) que preços inferiores aos sugeridos pelos custos mais margem causam prejuízos, as altas pressões isomórficas coercitivas e a alta inclusão dos custos fixos estimulam a essência custos.

A alta percepção que preços inferiores àqueles indicados pela combinação "custos mais margem" causam prejuízos é o único fator que se mostra significativo e positivo tanto nos 
formadores quanto nos tomadores de preços. Essa percepção ignora o alerta de Shipley e Jobber (2001) contra a inflexibilidade dos preços. De acordo com os autores, melhor do que obter nada é obter recursos que ao menos ajudem a cobrir os custos fixos e despesas fixas que são irreversíveis. Na tomada de preços, esse alerta ainda é mais pertinente, pois os preços têm que ser compatíveis com os preços do mercado, cobrindo ou não os custos.

O isomorfismo coercitivo nos tomadores, diferentemente do que acontece nos formadores, aproxima o estabelecimento dos preços da essência custos. Imposições da matriz podem justificar por que a definição dos preços é primeiramente embasada nos custos, sendo que o mais eficiente seria já conectar os custos aos preços dos concorrentes por intermédio da margem. Se a matriz ou demais órgãos impõem, o tomador de decisão precisa arcar com essa imposição, sendo ou não ela a melhor opção.

A inclusão dos custos totais limita a faixa de opções da margem para os tomadores de preços, o que acaba inibindo a incorporação de aspectos alheios aos custos. A faixa restrita de variação da margem, segundo Cavusgil (1988), pode sugerir preços tão utópicos a ponto de prejudicar a competitividade das empresas, caso não haja uma adequação aos preços dos concorrentes.

Além dessas variáveis que se mostraram significativas e de acordo com as expectativas da pesquisa, há duas variáveis com significância estatística que não coincidem com os sinais esperados. Elas são a percepção alta sobre a não disposição dos clientes em pagar o valor e o isomorfismo normativo.

No que se refere à percepção alta sobre a não disposição dos clientes em pagar o valor, podese inferir que, nos tomadores de preços, ela, em específico, além de desmotivar a incorporação do valor, desmotiva o embasamento nos custos. Ora, ao ver que os clientes mostram-se ríspidos com relação aos preços, os tomadores podem optar por ter o menor esforço possível no processo, simplesmente tomando os preços do mercado. Vale ressaltar, entretanto, que essa é a única dificuldade para definir os preços conforme o valor com sinal negativo. As outras três dificuldades apresentaram sinal positivo. 
No que se refere ao isomorfismo normativo, entende-se que o sinal negativo decorre do fato que no contexto da tomada de preços são nítidas as orientações para tomar os preços do mercado, não a definir os preços a partir dos custos (Simons, 2012). Logo, os livros e estudos de casos consultados para orientar o processo tendem a desestimular a essência custos. Cabe mencionar que esse é o único isomorfismo que se mostrou negativo nos tomadores de preços, sendo os outros dois, como esperado, explicações positivas para a essência custos.

O único constructo que não obteve qualquer variável estatisticamente significativa no modelo dos tomadores de preços foi o ambiente de atuação (B2B). Ora, assim como aconteceu com os formadores de preços, a alta concentração da amostra desta pesquisa no ambiente B2B (67\% dos tomadores) pode ser o motivo que fez com que a variável não fosse capaz de explicar a maior ou a menor essência custos. Em todos os níveis de essência custos, houve forte concentração de empresas do B2B.

Para resumir os achados, vale trazer a Figura 76 e sumarizar os fatores significativos que explicam positiva e negativamente a essência custos nos tomadores de preços. Ressalta-se que uma dificuldade para definir os preços conforme o valor explica positivamente a essência custos (alta percepção que preços inferiores àqueles indicados pela combinação dos custos mais margem causam prejuízos), enquanto que outra explica negativamente a essência custos (percepção alta sobre a não disposição dos clientes em pagar o valor). Da mesma forma, uma pressão isomórfica explica positivamente a essência custos (coercitiva), enquanto que outra explica negativamente a essência custos (normativa).

Figura 76 - Fatores explicativos significativos da essência custos nos tomadores
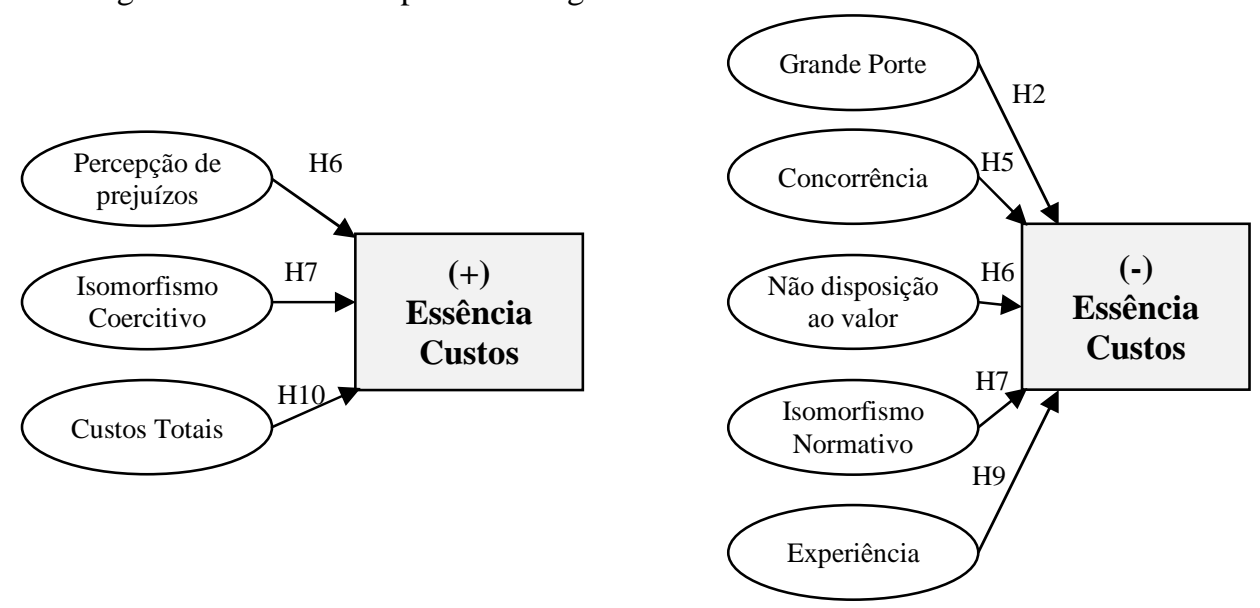

Fonte: Dados da pesquisa 


\subsubsection{Resumo dos Resultados dos Fatores Explicativos da Essência Custos}

Para finalizar a análise dos resultados, vale trazer a Tabela 115 e, assim, demonstrar de forma resumida quais hipóteses de pesquisa foram aceitas (não rejeitadas) e quais fatores explicam a essência custos nos formadores e nos tomadores de preços.

Tabela 115 - Sumário das hipóteses da pesquisa

\begin{tabular}{|c|c|c|c|c|c|}
\hline \multirow{2}{*}{ CONSTRuCto } & \multirow{2}{*}{ HIP. } & \multicolumn{2}{|c|}{ FORMADORES } & \multicolumn{2}{|c|}{ TOMADORES } \\
\hline & & SITUAÇÃo & \begin{tabular}{|l|} 
SINAL \\
\end{tabular} & SITUAÇÃO & SINAL \\
\hline Diferenciação & 1 & Não rejeitada & + & N/A & \\
\hline Tamanho da Empresa & 2 & Rejeitada & & Não rejeitada & - \\
\hline Posição de Liderança no Mercado & 3 & Rejeitada & & N/A & \\
\hline Estratégia de Preço Premium & 4 & Não rejeitada & - & $\mathrm{N} / \mathrm{A}$ & \\
\hline Intensidade da Concorrência & 5 & N/A & & Não rejeitada & - \\
\hline $\begin{array}{l}\text { Dificuldades para Definir os Preços conforme o } \\
\text { Valor }\end{array}$ & 6 & Não rejeitada & + & $\begin{array}{c}\text { Parcialmente } \\
\text { rejeitada }\end{array}$ & $+/-$ \\
\hline Pressões Isomórficas & 7 & Rejeitada & & $\begin{array}{l}\text { Parcialmente } \\
\text { rejeitada }\end{array}$ & $+/-$ \\
\hline Ambiente de Atuação B2B & 8 & Rejeitada & & Rejeitada & \\
\hline Experiência no Estabelecimento dos Preços & 9 & Rejeitada & & Não rejeitada & - \\
\hline Custos Totais na Fórmula "Custos mais Margem" & 10 & Rejeitada & & Não rejeitada & + \\
\hline
\end{tabular}

Observa-se que os fatores que explicam a essência custos nos formadores de preços não são os mesmos que explicam a essência custos nos tomadores de preços. Logo, percebe-se que conclusões equivocadas nos trabalhos anteriores podem ter sido originadas pela não segregação da amostra.

No que se refere aos formadores de preços, vale ressaltar que a não rejeição da hipótese relativa à diferenciação ratifica as constatações empíricas já levantadas por Gordon et al. (1981) e por Al-Hussari (2006). Essas reiteradas constatações aumentam a confiabilidade de que o fator explica o estabelecimento dos preços.

A não rejeição da hipótese referente à estratégia de preço premium também vai ao encontro do trabalho prévio de Ingenbleek e van der Lans (2013) e colabora com a constituição de resultados recorrentes para incorporar o fator na ciência, de forma confiável, como explicação para a definição dos preços.

A não rejeição da hipótese relativa às dificuldades para definir os preços conforme o valor, por sua vez, colabora com as defesas de que as empresas esquivam-se do embasamento no 
valor, dadas as dificuldades, e recorrem ao embasamento nos custos. Vale, entretanto, mencionar que, embora as quatro dificuldades relacionadas tenham explicado positivamente a essência custos, apenas uma obteve significância estatística. Esse resultado sugere que nem todos os obstáculos relacionados de forma estruturada por Hinterhuber (2008) e Töytäri et al. (2015) inibem significativamente o embasamento no valor. Nesse sentido, futuros estudos ainda são necessários para aumentar a confiabilidade do fator.

Passando para os tomadores de preços, obteve-se, finalmente, uma primeira relação estatisticamente significativa para o fator tamanho da empresa. Guilding et al. (2005), AlHussari (2006) e até mesmo a presente tese no modelo dos formadores obtiveram resultados não significativos que sugeriam a exclusão do fator como explicação para o estabelecimento dos preços. Contudo, o resultado encontrado no modelo dos tomadores indicou que o fator pode, sim, explicar a definição de preços, mas apenas nos tomadores de preços. Pesquisas futuras ainda são indispensáveis para confirmar o achado desta tese e ratificar que os resultados não significativos dos trabalhos prévios deviam-se à consideração dos formadores de preços, já que o fator explica apenas a determinação dos preços nos tomadores.

No que se refere à intensidade da concorrência, tão discutida ao longo do capítulo 5, vale ressaltar que os achados desta tese assemelham-se àqueles de Fabiani et al. (2005) e de AlHussari (2006), isto é, demonstram que quanto mais intensa é a concorrência menor é a essência custos. Esse resultado contrasta com as conclusões de Ingenbleek et al. (2003) e de Guilding et al. (2005). Com esses achados, o pêndulo volta-se à relação negativa (3 estudos contra 2), todavia, ainda são necessárias mais evidências para incorporar o fator consistentemente no arcabouço científico.

No que diz respeito às dificuldades para definir os preços conforme o valor, cabe observação similar àquela realizada para os formadores de preços, ao passo que nem todas as variáveis obtiveram significância estatística. Para os tomadores, há ainda o agravante de que uma das dificuldades (a percepção da não disposição de pagamento dos clientes) tem relação significativa negativa, ao invés de positiva, com a essência custos. Por esse motivo, mais uma vez, defende-se que a confiabilidade dos obstáculos relacionados por Hinterhuber (2008) e Töytäri et al. (2015) ainda depende de futuras evidências. 
As pressões isomórficas apresentaram resultados que parcialmente coincidiram com o que se esperava. Segundo Muller (1997), uma razão para as empresas ainda ignorarem a incorporação de informações alheias aos custos é o ímpeto, por parte dos gestores, em adotar modelos tradicionais e simplistas pautados nos custos, mas não foi isso que foi constatado nos tomadores de preços. Afinal, enquanto pressões coercitivas explicaram, sim, positivamente a essência custos, pressões normativas explicaram negativamente tal essência. A explicação que pode ser trazida para esse achado é que, no contexto da tomada de preços, são escancaradas as orientações para tomar os preços do mercado, não para definir os preços a partir dos custos (Simons, 2012). Vindouros trabalhos podem ratificar essa constatação.

Os resultados da experiência confirmaram as expectativas e demonstraram consistência aos argumentos de Shipley e Jobber (2001) que gestores pouco experientes, sem uma visão estratégica nem um entendimento razoável do funcionamento do mercado, priorizam a essência custos. No entanto, como a presente tese foi a primeira que testou empiricamente essa relação, evidências adicionais ainda são necessárias para que o fator experiência possa ser incorporado com confiabilidade na ciência do tema.

Por último, mas não menos importante, tem-se a confirmação de que o uso dos custos totais é rígido e, segundo Cavusgil (1988), pode originar preços utópicos que impedem as empresas de serem competitivas. Todavia, assim como mencionado para o fator experiência, esta tese foi a primeira que testou a relação entre a essência custos e o uso dos custos totais, sendo indispensáveis mais evidências para confirmar empiricamente a explicação proposta. 


\section{CONCLUSÕES}

\subsection{Contribuições}

Gummerson e Polese (2009) destacam que no final de um trabalho o momento da verdade inevitavelmente aparece. É nesse ponto que o pesquisador mostra se seu estudo de fato trouxe contribuições e implicações para os demais pesquisadores e para os profissionais. Os autores citam que nesse momento deve ficar evidente o "e então" 25 do trabalho bem como o que os pesquisadores e profissionais devem passar a fazer de diferente diante dos resultados revelados.

\subsubsection{E então?}

O estabelecimento dos preços é explicado teoricamente por duas disciplinas: a economia e o marketing. A teoria econômica explica que os preços refletem a igualdade entre o custo marginal e a receita marginal enquanto que a teoria de marketing recomenda que os preços espelhem o valor. As pesquisas empíricas de toda parte do mundo, todavia, mostram que a maior parte das empresas define os preços a partir dos custos.

Diante do aparente conflito entre as teorias e a prática, foi proclamada a existência de dois gaps. O primeiro, entre a teoria econômica e a prática, assume que o estabelecimento dos preços a partir dos custos não corresponde aos pressupostos econômicos de paridade entre os custos marginais e as receitas marginais. O segundo, entre a teoria de marketing e a prática, assume que a definição dos preços a partir dos custos não atende às recomendações do marketing de pautar as decisões de preços no valor.

Para o primeiro gap (teoria econômica versus prática), já foram levantados contra-argumentos (instrumentalismo e marginalismo implícito) que demonstram que as empresas podem definir preços de acordo com a equidade entre os custos marginais e as receitas marginais, mesmo que essa definição seja operacionalizada pela combinação dos custos à margem. Esses contra-

\footnotetext{
${ }^{25}$ O termo em inglês é "so what?"
} 
argumentos frisam que a teoria econômica é válida porque ela explica o estabelecimento dos preços, independentemente da forma que ele é operacionalizado.

Para o segundo gap (teoria de marketing versus prática), por sua vez, faltam contraargumentos para demonstrar que o estabelecimento dos preços, independentemente da forma que é operacionalizado, pode ser coerente com as recomendações do marketing. Essa falta de contra-argumentos revela que o processo de estabelecimento dos preços merece ser estudado com um novo olhar.

A costumeira não segregação dos formadores e dos tomadores de preços bem como o foco excessivo na forma, não na essência, da definição dos preços evidenciam que uma reorganização do entendimento sobre o assunto é necessária. A falta de consenso sobre o motivo pelo qual as empresas ainda se embasam excessivamente nos custos para determinar os preços constitui a motivação derradeira para o desenvolvimento desta tese.

O presente estudo teve o objetivo geral de investigar os fatores que explicam o estabelecimento dos preços marcado pela essência custos em empresas industriais localizadas no Brasil. Para atingir esse objetivo geral, foram definidos seis objetivos específicos.

O primeiro objetivo específico foi pesquisar a presença de formadores e de tomadores de preços nas empresas industriais localizadas no Brasil. Por mais que se saiba claramente que há empresas que precisam tomar os preços do mercado e empresas que formam os preços, as pesquisas empíricas normalmente cometem a falha de não segregá-las e tratar seus processos de definição dos preços como se fossem indistintos. Nesta tese, percebeu-se que há, sim, os dois tipos de empresas: dos 380 componentes da amostra, 192 classificaram-se como formadores de preços (51\%) e 188 classificaram-se como tomadores de preços (49\%).

O segundo objetivo foi comparar os formadores aos tomadores de preços no que se refere à dificuldade de obtenção de informações dos preços da concorrência. Ora, os tomadores de preços precisam colocar preços similares àqueles disponíveis no mercado e, para isso, ancoram-se em referências externas. Já os formadores de preços oferecem produtos diferenciados que não possuem substitutos diretos e precisam formar os preços a partir de referências internas. Neste estudo, constatou-se empiricamente que os tomadores de preços 
conseguem facilmente aderir ao uso de informações da concorrência, enquanto que os formadores de preços encontram dificuldades para tanto.

O terceiro objetivo foi confrontar as informações usadas nos formadores de preços com as informações usadas nos tomadores de preços. Nesta pesquisa, constatou-se que: a intensidade de uso de informações de custos é alta nos formadores de preços, mas baixa nos tomadores de preços oferecedores de commodities; a intensidade de uso de informações da concorrência é baixa em formadores de preços, mas alta em tomadores de preços; e a intensidade de uso de informações de valor é alta em formadores de preços, mas baixa em tomadores de preços, especialmente naqueles oferecedores de commodities.

O quarto objetivo foi examinar a forma do processo de estabelecimento dos preços nos formadores e nos tomadores de preços. Em linha aos estudos prévios, constatou-se neste trabalho que a combinação "custos mais margem" caracteriza, sim, a forma predominante de definição dos preços, tanto nos formadores quanto nos tomadores de preços. Os tomadores de preços oferecedores de commodities são os únicos que têm fórmulas com base na concorrência (preços do mercado ou preços dos concorrentes) à frente dos custos mais margem.

O quinto objetivo foi investigar a essência do processo de estabelecimento dos preços nos formadores e nos tomadores de preços. Um dos principais problemas encontrados nos trabalhos empíricos sobre o assunto tem sido a assunção que a forma corresponde necessariamente à essência da definição dos preços, ou seja, que os preços são uma função dos custos simplesmente porque a forma é caracterizada pelos custos mais margem.

Nesta tese, expôs-se que a margem pode ser um elemento conector dos diferentes tipos de informações, sendo, consequentemente, possível definir preços correspondentes ao valor e aos preços dos concorrentes a partir dos custos. A essência é marcada pelos custos quando a margem é simplesmente um parâmetro financeiro que reflete apenas o almejo de lucratividade de forma indistinta entre produtos e clientes. Quando a essência custos está presente, ela origina preços que destoam do valor nos formadores de preços e traz uma etapa adicional ao processo nos tomadores de preços, já que nestes o resultado da combinação "custos mais margem" precisa invariavelmente ser comparado aos demais preços no mercado. 
Empiricamente, observou-se que os custos mais margem correspondiam à forma, mas não à essência do estabelecimento dos preços nos formadores e especialmente nos tomadores de preços. Na minoria das empresas, a margem era uma questão apenas financeira sem se distinguir entre produtos e clientes.

Finalmente, o sexto objetivo foi averiguar os fatores explicativos da essência custos nos formadores e nos tomadores de preços. No processo de revisão dos trabalhos prévios, percebeu-se que as críticas à definição dos preços a partir dos custos reiteravam-se, mas os fatores explicativos para essa prática eram dispersos e, por vezes, contraditórios (e.g., intensidade da concorrência). Por esse motivo, nesta pesquisa buscou-se reorganizar a investigação do tema, explorando o que explica a essência custos, não a forma "custos mais margem", de forma segregada entre tomadores e formadores de preços. As análises permitiram identificar que os seguintes fatores explicavam significativamente a essência custos:

a) formadores de preços: a diferenciação e as dificuldades de definir os preços conforme o valor explicavam positivamente a essência custos (maiores níveis de essência custos), enquanto que a estratégia de preço premium explicava negativamente a essência custos (menores níveis de essência custos); e

b) tomadores de preços: a percepção que preços inferiores aos custos mais margem causam prejuízos, o isomorfismo coercitivo e a inclusão dos custos totais explicavam positivamente a essência custos (maiores níveis de essência custos), enquanto que o grande porte, a intensidade da concorrência, a percepção da não disposição de pagamento dos clientes, o isomorfismo normativo e a experiência explicavam negativamente a essência custos (menores níveis de essência custos).

Percebe-se que, de fato, a realidade dos formadores de preços merece ser investigada apartadamente dos tomadores de preços, uma vez que os fatores explicativos para as empresas de um enquadramento não correspondem aos fatores explicativos para as empresas do outro enquadramento. 
O conjunto dessas evidências permite defender a tese que a utilização da fórmula "custos mais margem" não conflita com a incorporação de informações da concorrência e do valor. Não raramente, a fórmula é a forma usada para simplificar a operacionalização da definição dos preços. Por meio da margem, os formadores de preços conseguem, a partir dos custos, estabelecer preços que reflitam o valor oferecido aos clientes. Também por meio da margem, os tomadores de preços conseguem definir, a partir dos custos, preços que correspondam aos preços dos concorrentes e/ou prevalecentes no mercado. Nota-se, portanto, que o gap entre a teoria de marketing e a prática não é da dimensão difundida, pois o uso da combinação “custos mais margem”, desde que não seja marcado pela essência custos, não corrói as recomendações de embasamento no valor.

A fórmula "custos mais margem" corresponde à essência custos e conflita com a incorporação de outros tipos de informação quanto maiores forem: a diferenciação e as dificuldades de definir os preços conforme o valor nos formadores de preços; e a percepção que preços inferiores aos custos mais margem causam prejuízos, o isomorfismo coercitivo e a inclusão dos custos totais nos tomadores de preços.

Por outro lado, a fórmula "custos mais margem" corresponde estritamente à forma do estabelecimento dos preços, afasta-se da essência custos e permite a incorporação de outros tipos de informação (valor nos formadores, preços da concorrência nos tomadores) quanto maiores forem: a estratégia de preço premium nos formadores de preços; e o grande porte, a intensidade da concorrência, a percepção da não disposição de pagamento dos clientes, o isomorfismo normativo e a experiência nos tomadores de preços.

\subsubsection{Implicações para Pesquisadores}

Os achados desta tese demonstram que os pesquisadores devem mudar sua forma de investigar o processo de estabelecimento dos preços. Alem disso, eles evidenciam que os resultados dos trabalhos prévios devem ser interpretados com cuidado.

Não há qualquer sentido na análise não segregada de formadores e tomadores de preços. As características e necessidades específicas de cada um deles impõem avaliações separadas a fim de não enviesar as conclusões. Por exemplo, numa amostra constituída proporcionalmente 
por mais tomadores de preços, pode-se concluir que os preços são mais embasados na concorrência, enquanto que noutra amostra composta proporcionalmente por mais formadores de preços, pode-se concluir que os preços são mais embasados nos custos.

Quando não há separação entre formadores e tomadores, as conclusões variam muito dependendo da constituição da amostra e, no final, trazem descrições cuja maior relevância acaba sendo revelar se os preços são mais tomados (embasados na concorrência) ou mais formados (embasados nos custos). A segregação entre os enquadramentos das empresas é imperativa para que as pesquisas possam avançar nos seus achados.

Outro ponto que necessita ser alterado refere-se à análise apartada da forma e da essência do estabelecimento dos preços. É praxe dos pesquisadores concluir que os preços são baseados nos custos simplesmente por que a combinação "custos mais margem” é empregada. Ora, conforme demonstrado no decorrer desta tese, a forma nada diz sobre a essência do estabelecimento dos preços. É possível que preços definidos a partir dos custos reflitam o valor ou os preços da concorrência por intermédio da margem.

Logo, os pesquisadores devem buscar formas de capturar informações não somente referentes à forma, mas também referentes à essência dos preços. Além disso, cuidados devem ser tomados na análise dos estudos prévios, já que a maior parte deles limitou-se a investigar a forma.

Em suma, acredita-se que os resultados desta tese demonstram que não há mais como ignorar esses dois aspectos nos momento de definir constructos e variáveis, bem como de elaborar questionários e/ou roteiros de entrevistas em pesquisas sobre o estabelecimento dos preços. Além disso, não há mais como ignorar esses dois pontos no momento de analisar criticamente a literatura sobre o assunto.

Incorporando a segregação entre formadores e tomadores de preços e tratando apartadamente a forma e a essência, os pesquisadores terão condições de avançar no entendimento do estabelecimento dos preços. Sugere-se que análises mais específicas e focadas sejam empreendidas, como, por exemplo, investigações sobre a definição da margem em empresas nas quais a essência é o valor. 


\subsubsection{Implicações para Profissionais}

Primeiramente, embora possa parecer trivial, cumpre ressaltar que os resultados deste trabalho revelam aos profissionais a importância de compreender se suas empresas são formadoras ou tomadoras de preços. Com essa revelação, os profissionais podem compreender por que eventuais desacertos já foram ou têm sido cometidos no estabelecimento dos preços. Por exemplo, não adianta a um tomador de preços querer colocar um preço correspondente a todo o valor ofertado, se os concorrentes estão dispostos a não cobrar por todo o valor e colocam preços mais baixos. Da mesma forma, não adianta a um formador de preços querer colocar preços similares aos concorrentes se não há, na realidade, competidores oferecendo produtos que entregam o mesmo nível de valor.

Em segundo lugar, os resultados deste trabalho evidenciam aos profissionais responsáveis pela determinação dos preços, sejam eles de empresas formadoras ou tomadoras de preços, que é possível, sim, continuar fazendo uso dos custos mais margem, apesar de todas as críticas normalmente levantadas para esse tipo de fórmula.

Já era consenso na literatura que os profissionais mostravam-se inclinados ao uso da fórmula “custos mais margem" pela simplicidade que ela traz ao processo de estabelecimento dos preços. Nesta tese, evidenciou-se que essa simplicidade pode ser aproveitada sem deixar de refletir o valor oferecido aos clientes ou os preços dos concorrentes. A margem da fórmula pode ser o elemento conector dos custos ao valor ou ao preço da concorrência, desde que o processo não seja marcado pela essência custos. Quando a margem não é arbitrária e tampouco precisa ser única para todos os produtos e para todos os clientes, há flexibilidade na sua variação, o que permite a incorporação do valor e dos preços da concorrência.

Por exemplo, se a essência custos não estiver presente, uma empresa formadora de preços que opta pela utilização dos "custos mais margem" pode colocar preços distintos para um mesmo produto (de alta qualidade) no mercado interno no qual já atua e no mercado externo ao qual almeja entrar. Como no mercado interno o produto já é reconhecido e valorizado, o valor percebido pelos clientes é alto e permite optar por uma margem elevada (para conectar os custos ao elevado valor). Já no mercado externo, o produto ainda é desconhecido e pouco valorizado, o que faz com que o valor percebido pelos clientes seja baixo. Para colocar preços 
correspondentes a esse baixo valor e conseguir entrar no mercado, a empresa pode optar por uma margem inferior àquela selecionada no mercado interno.

Destarte, os profissionais passam a ter ciência que um dos aspectos centrais da definição dos preços está na deliberação da margem. Passam a perceber também que devem ser cautelosos nessa deliberação, a fim de incorporar na margem questões específicas sobre os produtos e sobre os clientes, sem se limitar aos custos e a questões financeiras.

Para que isso aconteça, o processo da deliberação da margem deve envolver profissionais de diferentes áreas da empresa, ao invés de ser restrito a representantes do departamento financeiro. Por exemplo, profissionais do departamento de engenharia podem colaborar com a deliberação da margem ao demonstrarem, tecnicamente, os atributos oferecidos pelos produtos. Profissionais do departamento de vendas podem contribuir com a deliberação da margem ao discutirem o valor correspondente a esses atributos. Profissionais administrativos, por sua vez, podem contribuir com a deliberação da margem, ao debaterem as estratégias de preços adotadas e, consequentemente, a relação entre o nível de valor e o nível dos preços.

Finalmente, ao revelar os fatores que explicam a essência custos nos formadores e nos tomadores de preços, esta tese evidencia aos profissionais a propensão de suas empresas aproximarem-se ou afastarem-se da essência custos. Com essa revelação, clama-se que mais atenção recaia no processo de estabelecimento dos preços em: empresas formadoras de preços que ofertam produtos altamente diferenciados e que acreditam que preços inferiores ao resultado da combinação "custos mais margem" causam prejuízos bem como de empresas tomadoras de preços que também acreditam que preços inferiores ao resultado da combinação “custos mais margem” causam prejuízos, têm matrizes que obrigam a definir os preços a partir dos custos e que incluem todos os custos fixos na fórmula.

\subsubsection{Implicações para o Ensino e a Aprendizagem}

S. Maxwell (1998) adverte que o estabelecimento dos preços, comparado a outros tópicos, recebe pouca atenção no processo de ensino e aprendizagem. Não é difícil entender porque isso acontece, uma vez que o assunto faz parte do currículo de vários cursos de graduação, mas em nenhum deles é o tema central. Em outras palavras, no processo de ensino e 
aprendizagem do estabelecimento dos preços, a amplitude (presença do tema em vários cursos) prevalece sobre a profundidade (tema é discutido superficialmente em cada curso, sem ser relacionado ao conteúdo de outros cursos).

Para clarificar o argumento aqui apresentado, cumpre mencionar que o tópico de definição dos preços é ministrado, sobretudo, em cursos de negócios e, por esse motivo, as implicações ora discutidas baseiam-se na realidade dessa área. Sabe-se, contudo, que o tema transcende as fronteiras dessa área e pode ser encontrado, mesmo que de forma sucinta, em disciplinas dos cursos de engenharia de produção, de farmácia, de história etc.

Nos três principais cursos de negócios (Administração, Ciências Econômicas, Ciências Contábeis), os núcleos de estudo não se referem ao estabelecimento dos preços. Afinal, o curso de Administração tem o objetivo de difundir o conhecimento sobre o processo de planejar, organizar, dirigir e controlar o uso de recursos a fim de alcançar objetivos de maneira eficiente e eficaz (Chiavenato, 2007). O foco na gestão global faz com que a definição dos preços seja vista apenas como um dos processos que carece de planejamento, organização, direção e controle.

Já o curso de Ciências Econômicas, de acordo com Mankiw (2014), tem a meta de difundir o conhecimento sobre como a sociedade administra seus recursos escassos. O foco na lei da escassez faz com que a definição dos preços seja percebida como somente uma das (importantes) decisões tomadas pela sociedade para gerir os recursos escassos.

Finalmente, o curso de Ciências Contábeis tem a finalidade de difundir o conhecimento sobre o fornecimento de informação econômica, física, de produtividade e social relevante para que cada usuário possa tomar as corretas decisões e realizar seus julgamentos com segurança (Iudícibus, 2009). A determinação dos preços é unicamente uma dentre as várias decisões tomadas a partir das informações elaboradas pela Contabilidade.

Destarte, pode-se observar que o estabelecimento dos preços não é o cerne dos cursos de negócios e acaba sendo ensinado e aprendido como uma mera aplicação do conteúdo central de cada curso. Por ser uma mera aplicação, ele torna-se um de vários tópicos de determinadas disciplinas e ancora-se em conceitos fechados e não interdisciplinares. No curso de Ciências 
Contábeis, por exemplo, é comum explorar o assunto como uma das aplicações da Contabilidade de Custos em disciplinas de "Análise de Custos" e "Controladoria".

Nesta tese, evidencia-se que a definição dos preços envolve conceitos de diferentes disciplinas, não devendo ser tratada como um processo isolado. Especificamente, os achados aqui levantados mostram que o uso da fórmula "custos mais margem" não se refere exclusivamente à aplicação de um conteúdo de custos difundido em cursos contábeis e, por consequência, não deve ser repreendido por docentes e discentes de Administração e Ciências Econômicas.

Os resultados deste trabalho escancaram a necessidade de aprimorar o processo de ensino e aprendizagem do estabelecimento dos preços. Tanto os docentes quanto os discentes devem mostrar-se dispostos a deixar de estudar as decisões de preços como uma aplicação estrita dos seus cursos, passando a ensiná-las e aprendê-las como um conteúdo verdadeiramente interdisciplinar.

De modo específico, as revelações desta pesquisa trazem, minimamente, as seguintes implicações para docentes e discentes de cursos de negócios:

a) a margem não deve ser vista como um percentual aleatório (ou valor em $\mathrm{R} \$$ aleatório) a ser somado aos custos. Para os estudantes contábeis, deve ficar claro que aspectos alheios aos custos definem a margem, sobretudo aspectos referentes aos clientes e à concorrência, recorrentemente debatidos nos cursos de Administração e Economia;

b) o uso da fórmula "custos mais margem" deve ser visto como uma das possíveis formas de operacionalização do estabelecimento dos preços com base no valor, com resultados coincidentes àqueles postulados pela teoria econômica. Logo, deve ficar claro para os estudantes dos cursos de Administração e Ciências Econômicas que a fórmula merece críticas somente se não promover a conexão entre os custos e outras informações, difundidas e valorizadas nesses cursos; e

c) o enquadramento das empresas em tomadoras e formadoras de preços, comum no curso de Economia quando há discussão da estrutura de mercado, deve ser visto 
como um dos pilares para o entendimento da determinação dos preços. A conexão dos custos ao valor ou aos preços da concorrência depende desse enquadramento.

Em suma, pode-se dizer que esta pesquisa demonstra a docentes e discentes que o estabelecimento dos preços é um tema interdisciplinar. O estudo do assunto depende do entendimento de conceitos que, apesar de serem difundidos em diferentes cursos, complementam-se e não se contradizem. O processo de ensino e aprendizagem do tema está atualmente prejudicado por estar presente em muitos cursos, mas não ser abordado neles em uma perspectiva profunda e interdisciplinar.

\subsection{Limitações}

Demo (1995) faz questão de frisar que nenhuma teoria explica tudo completamente. Segundo o autor, isso ocorre porque os seres humanos são condicionados e também produzem teorias científicas condicionadas que se limitam no tempo e no espaço. Kerlinger (1980) também tem esse entendimento e adverte que, em todas as pesquisas, a compreensão de um fenômeno sempre é incompleta, parcial e probabilística.

Ora, esta tese não se diferencia dos demais estudos científicos e, apesar de oferecer contribuições, possui limitações. Nesta seção, o objetivo é justamente evidenciar essas limitações para que o devido cuidado seja tomado na utilização dos seus resultados.

A primeira limitação desta pesquisa decorre do fato que nem todas as empresas industriais foram investigadas. Logo, os resultados apresentados não devem ser generalizados, pois eles demonstram a realidade que se aplica às empresas que compõem a amostra e que realmente foram pesquisadas. A utilização de uma amostra não probabilística acentua essa limitação, todavia a contraposição entre a viabilidade da pesquisa e os procedimentos de amostragem disponíveis impediu que métodos de amostragem probabilística (e.g., simples, sistemática, estratificada, por conglomerado) fossem seguidos. Vale, no entanto, novamente mencionar que, para Castro (1977), a não aleatoriedade da amostra, apesar de restringir o alcance dos resultados, é capaz de fornecer informações extremamente importantes e úteis quando o que se busca é identificar a relação entre variáveis. 
A segunda limitação está relacionada ao instrumento de coleta de dados. Embora o questionário tenha sido pré-testado e a sua validade e a sua confiabilidade tenham sido avaliadas, não se pode deixar de advertir sobre as interpretações de cada respondente às questões. Tais interpretações podem ser distintas por refletirem o discernimento e o julgamento que cada um dos profissionais respondentes possui ao que está sendo perguntado. Essa limitação é inerente da escolha do levantamento como estratégia de pesquisa (Nazari et al., 2006).

A terceira limitação refere-se aos respondentes. Diferentemente de outros objetos de investigação que tendem a possuir um público alvo de pesquisa bem definido (e.g., sistema de custos - controller; gestão logística - profissionais logísticos etc.), o estabelecimento dos preços é um tema que está nas mãos de diferentes cargos, dependendo da empresa. Como os profissionais invariavelmente carregam, em maior ou menor extensão, os vieses da sua profissão, a amostra desta tese acabou composta por respondentes que enfatizam diferentes aspectos de sua percepção.

Por fim, ainda nesse âmbito dos respondentes, a quarta limitação relaciona-se à participação de somente um profissional em cada empresa Um único indivíduo, apesar de reportar suas percepções nas respostas, responde por toda empresa. De fato, se um grupo de profissionais, e não apenas um representante, respondesse a pesquisa em cada empresa, resultados mais robustos poderiam ser obtidos. No entanto, a perspectiva quantitativa que este estudo adota requer um número mínimo de empresas respondentes para que os resultados apresentem significância estatística e sabe-se que a imposição da participação de mais de um profissional por companhia diminuiria substancialmente a quantidade de empresas participantes. Como a redução expressiva de empresas poderia inviabilizar a realização da pesquisa, optou-se por atuar com apenas um respondente por companhia, assumindo a limitação que decorre dessa escolha.

\subsection{Direções para Futuros Estudos}

Para concluir este trabalho, cumpre mencionar que esta tese não exaure o conhecimento sobre o estabelecimento dos preços. Afinal, o conhecimento apresenta-se, recorrentemente, em devir, é sempre provisório, nunca acabado ou definitivo (Japiassu, 1992; G. Martins \& 
Theóphilo, 2009). Esta tese chegou a um ponto do saber sobre o tema, cabendo a futuros estudos transcendê-lo.

As mais evidentes direções para futuros estudos surgem, justamente, das limitações desta tese. Pesquisas vindouras que tenham condições de replicar a investigação em outra população e/ou de usar amostras probabilísticas permitirão verificar se os achados desta tese não são refutados e, assim, consolidar os resultados já difundidos.

Estudos futuros que façam uso de outras estratégias de pesquisa, como estudos de caso, por exemplo, contribuirão, com a triangulação das informações levantadas sobre o estabelecimento dos preços e, dessa maneira, aumentarão a confiabilidade do objeto em análise.

Trabalhos vindouros que foquem em um público-alvo definido (e.g., exclusivamente gestores de vendas ou contadores ou engenheiros etc.), independentemente de esse público-alvo ser ou não composto pelos principais responsáveis pela definição dos preços, propiciarão um avanço na ciência do tema. Afinal, com eles será possível identificar qual contribuição cada tipo de profissional oferece à determinação dos preços.

Pesquisas futuras que consigam explorar, qualquer que seja a estratégia de pesquisa adotada, vários profissionais de uma mesma empresa viabilizarão ainda mais a evolução do conhecimento sobre o assunto. Mediante eles será possível avaliar, por exemplo, quais fatores explicam o fato de em uma empresa o principal responsável pela definição dos preços ser da área de vendas e em outra empresa ser da área de engenharia.

Além das sugestões elaboradas a fim de superar as limitações desta tese, podem ser relacionadas recomendações para dar continuidade a este trabalho e investigar especificidades sobre o estabelecimento dos preços.

Uma primeira especificidade refere-se à definição da margem. Os resultados desta tese evidenciaram que, tanto nos formadores de preços quanto nos tomadores de preços, diferentes produtos e diferentes segmentos de clientes têm margens diferentes. Nos formadores de preços, as diferenças nas margens decorrem, sobretudo, da incorporação de características 
específicas dos produtos, dos clientes e da importância vista pelos clientes. Nos tomadores de preços, as diferenças nas margens decorrem, sobretudo, da incorporação de preços de referência. Cabe agora às futuras pesquisas investigar de que forma os formadores e os tomadores de preços imputam essas informações na margem, isto é, como coletam essas informações, como traduzem essas informações para um percentual ou para unidades monetárias etc..

Uma segunda especificidade refere-se aos custos usados no processo. Nesta tese, verificou-se que há tanto formadores quanto tomadores de preços que incluem necessariamente os custos fixos de produção e as despesas fixas na definição dos preços. Resta agora aos trabalhos vindouros averiguar como os responsáveis pelo estabelecimento dos preços decidem se os elementos fixos de custos e despesas são ou não incluídos nas fórmulas de preços. Mais do que isso, sugere-se que esses trabalhos vindouros investiguem se há fatores que explicam a decisão da incorporação dos elementos fixos. Ou seja, recomenda-se que haja a investigação dos fatores explicativos de um dos fatores explicativos desta tese (custos totais na fórmula “custos mais margem"). Se oportunidades forem identificadas, é possível também investigar os fatores explicativos dos demais fatores explicativos desta tese.

Uma terceira especificidade refere-se à forma que a margem é incorporada na fórmula "custos mais margem". Neste trabalho, observou-se que a maior parte das empresas (68\%) prioriza o uso de margens percentuais. Compete, portanto, aos futuros estudos avaliar por que isso acontece, ou seja, avaliar quais vantagens os profissionais percebem que a margem percentual oferece em relação à margem em unidade monetária (em $\mathrm{R} \$)$.

Finalmente, cumpre relacionar uma sugestão referente a uma forma de determinar os preços que, embora não tenha sido discutida nesta tese, tende a se propagar com a expansão da tecnologia, sobretudo com a expansão da digitalização. Afinal, Grewal et al. (2010) e Iveroth et al. (2013) explanam que com a digitalização dos produtos, o tradicional estabelecimento dos preços pode perder o sentido.

Ora, os métodos da abordagem baseada no valor podem ser pouco importantes quando se chega à conclusão que, diante da abundância das informações a que os clientes têm acesso, o valor percebido para os produtos digitais oferecidos é igual (ou muito próximo) a zero. A 
aplicação de métodos da abordagem baseada na concorrência também não se torna mais fácil: ao contrário, é praticamente impossível identificar concorrentes para produtos digitais únicos (por exemplo, uma determinada música não é igual a outra música, por mais que ambas sejam disponibilizadas num mesmo formato, MP3, por exemplo). Até os métodos da abordagem baseada nos custos tende a ser irrelevante, pois não raramente o custo, variável e total, de cópia de produtos digitais é igual (ou muito próximo) a zero.

Em virtude disso, C. Anderson (2009) propôs uma nova forma de estabelecer os preços, denominada freemium, na qual um produto digital é oferecido gratuitamente na sua versão básica, mas cobrado na sua versão diferenciada. O progresso tecnológico tende a acentuar a escolha dessa nova forma de definir os preços e cabe, portanto, aos futuros estudos aprofundar a discussão teórica do conceito bem com levantar empiricamente a sua aplicação. 


\section{REFERÊNCIAS}

Abel, R. (1978, April). The role of costs and cost accounting in price determination. Management Accounting, 59(10), 29-32. Disponível na base de dados ProQuest ABI/INFORM Complete

Abratt, R., \& Pitt, L. F. (1985, November). Pricing practices in two industries. Industrial Marketing Management, 14(4), 301-306. doi:10.1016/0019-8501(85)90023-9

Aeppel, T. (2007, March 27). Changing the formula: seeking perfect prices, CEO tears up the rules. The Wall Street Journal. Disponível em

http://www.wsj.com/articles/SB117496231213149938

Alberta - Agriculture and Rural Development (2009, September). Methods to price your product (Agri-facts). Disponível em http://www1.agric.gov.ab.ca/\$department/deptdocs.nsf/all/agdex1133/\$file/8452.pdf?OpenElement

Al-Hussari, H. (2006, February). The influence of contextual factors on cost system design and pricing decisions: a study of UK companies in the food processing and other industries (Doctoral thesis). Huddersfield University Business School, Huddersfield, England. Disponível em http://eprints.hud.ac.uk/5969/

Almeida, L. B., \& Santos, A. R. (2007, primeiro semestre). Práticas de contabilidade de custos: Uma investigação nas indústrias paranaenses. Sociedade, Contabilidade e Gestão, 2(1), 19-34. Disponível em http://www.atena.org.br/revista/ojs-2.2.306/index.php/ufrj/article/viewFile/574/563

Álvarez, L. J., \& Hernando, I. (2005, October). The price setting behaviour of Spanish firms: evidence from survey data (Working Paper No. 538). Disponível no site do European Central Bank:

https://www.ecb.europa.eu/pub/pdf/scpwps/ecbwp538.pdf?24c204e14fc946aef88853743 $7514 \mathrm{a} 31$

Alves, C. A., Varotto, L. F., Gonçalves, M. N. (2011, mai./ago.). Objetivos de preço e estratégias de preço no varejo: uma análise empírica no varejo paulistano. REMark Revista Brasileira de Marketing, 10(2), 84-105. doi:10.5585/remark.v10i2.2259

Alves, C. A., Varotto, L. F., Gonçalves, M. N. (2012, nov./dez.). Objetivos e métodos de preço no varejo: estudo na zona sul de São Paulo. RAE, 52(6), 595-612. doi:10.1590/S0034-75902012000600003

American Psychological Association - APA. (2010). Publication manual of the American Psychological Association. (6th ed.). Washingnton, DC: American Psychological Association.

Amirault, D., Kwan, C., \& Wilkinson, G. (2004/2005, Winter). A survey of the price-setting behaviour of Canadian companies. Bank of Canada Review, 29-40. Disponível na base de dados ProQuest ABI/INFORM Complete 
Amirault, D., Kwan, C., \& Wilkinson, G. (2006, September). Survey of price-setting behaviour of Canadian companies (Working Paper Series No. 35). Disponível no site do Bank of Canada: http://www.bankofcanada.ca/wp-content/uploads/2010/02/wp06-35.pdf

Anderson, C. (2009). Free: the future of a radical price. New York, NY: Hyperion.

Anderson, S., \& Guilding, C. (2006). Competitor-focused accounting applied to a hotel context. Contemporary Hospitality Management, 18(3), 206-218. doi:10.1108/09596110610658616

Apel, M., Friberg, R. \& Hallsten, K. (2005, April). Microfoundations of macroeconomic price adjustment: survey evidence from Swedish firms. Journal of Money, Credit, and Banking, 37(2), 313-338. Disponível em http://www.jstor.org/stable/3838929

Armstrong, J. S., \& Overton, T. S. (1977, August). Estimating nonresponse bias in mail surveys. Journal of Marketing Research, 14(3), 396-402. doi:10.2307/3150783

Atkin, B., \& Skinner, R. C. (1975). How British industry prices. London, England: Industrial Market Research Ltd.

Aucremanne, L., \& Druant, M. (2005, March). Price-setting behaviour in Belgium: what can be learned from an ad hoc survey? (Working Paper Series No. 448). Disponível no site do European Central Bank:

https://www.ecb.europa.eu/pub/pdf/scpwps/ecbwp448.pdf?fe13759f11efc9c26044ef1746 e3a 258

Avlonitis, G. J., \& Indounas, K. A. (2004). The impact of market structure on pricing objectives of service firms. Journal of Product \& Brand Management, 13(5), 343-358. doi:10.1108/10610420410554421

Avlonitis, G. J., \& Indounas, K. A. (2005a). Pricing objectives and pricing methods in the service sector. Journal of Services Marketing, 19(1), 47-57.

doi:10.1108/08876040510579398

Avlonitis, G. J., \& Indounas, K. A. (2005b). Pricing of services: an empirical analysis from the Greek service sectors. Journal of Marketing Management, 21(3-4), 339-362. doi:10.1362/0267257053779109

Avlonitis, G. J., \& Indounas, K. A. (2006a). How are prices set? An exploratory investigation in the Greek services sector. Journal of Product \& Brand Management, 15(3), 203-213. doi:10.1108/10610420610668649

Avlonitis, G. J., \& Indounas, K. A. (2006b). Pricing practices of service organizations. Journal of Services Marketing, 20(5), 346-356. doi:10.1108/08876040610679954

Avlonitis, G. J., \& Indounas, K. A. (2007a). An empirical examination of the pricing policies and their antecedents in the service sector. European Journal of Marketing, 41(7/8), 740764. doi:10.1108/03090560710752384 
Avlonitis, G. J., \& Indounas, K. A. (2007b, January). Service pricing: an empirical investigation. Journal of Retailing and Consumer Services, 14(1), 83-94. doi:10.1016/j.jretconser.2006.04.003

Avlonitis, G. J., Indounas, K. A., \& Gounaris, S. P. (2005). Pricing objectives over the service life cycle: some empirical evidence. European Journal of Marketing, 39(5/6), 696-714. doi:10.1108/03090560510590773

Babecký, J., Dybczak, K. \& Galuščák, K. (2008). Survey on wage and price formation of Czech firms (Working Paper No. 12). Disponível no site do Czech National Bank: http://www.cnb.cz/en/research/research_publications/cnb_wp/download/cnbwp_2008_12 .pdf

Balakrishnan, R., \& Sivaramakrishnan, K. (2002, December). A critical overview of the use of full-cost data for planning and pricing. Journal of Management Accounting Research, 14(1), 3-31. doi:10.2308/jmar.2002.14.1.3

Banterle, A., Carraresi, L., \& Cavaliere, A. (2011, July). What is the role of marketing capability to be a price maker? An empirical analysis in Italian food SMEs. Economia \& Diritto Agroalimentare, XVI(2), 245-261. Disponível em http://www.fupress.net/index.php/eda/article/view/9621

Barback, R. H. (1979). The pricing of industrial products. European Journal of Marketing, 13(4), 160-166. doi:10.1108/EUM0000000004938

Barbosa, R. V. N. (2003, Noviembre). O emprego de informações de custos na formação de preços de indústrias brasileiras: uma pesquisa de campo. Anais do Congreso del Instituto Internacional de Costos, Punta del Este, Uruguay, VIII. Disponível no site do Instituto Internacional de Costos:

http://www.intercostos.org/es/component/congresos/822?view=documento

Bassett, T. J. (2014, July). Capturing the margins: world market prices and cotton farmer incomes in West Africa. World Development, 59, 408-421. doi:10.1016/j.worlddev.2014.01.032

Be a price maker, not a price taker, says Jackson. (2004, February 20). Farmers Guardian, 17. Disponível na base de dados ProQuest ABI/INFORM Complete

Bella, R. S. (1983, October). Confusing the Concepts. Management Accounting, 65(4), 17, 85. Disponível na base de dados ProQuest ABI/INFORM Complete

Bella, R. S. (1984, May). Are the Conclusions Relevant? Management Accounting, 65(11), 24, 84. Disponível na base de dados ProQuest ABI/INFORM Complete

Bender, R., Benner, A. (2000). Calculating ordinal regression models in SAS and S-Plus. Biometrical Journal, 42(6), 677-699. doi:10.1002/1521-4036(200010)42:6<677::AIDBIMJ677>3.0.CO;2-O 
Beņkovskis, K., Fadejeva, L., \& Kalnbērziṇa, K. (2011). Price setting behaviour in Latvia: econometric evidence from CPI micro data (Working Paper No. 1). Disponível no site do Latvijas Banka:

https://www.bank.lv/images/stories/pielikumi/publikacijas/petijumi/WP_1-2011-BenkKalnb-Fadejeva.pdf

Beņkovskis, K., Fadejeva, L., \& Kalnbērziņa, K. (2012, November). Price setting behaviour in Latvia: econometric evidence from CPI micro data. Economic Modelling, 29(6), 21152124. doi:10.1016/j.econmod.2012.07.003

Blinder, A. S. (1991, May). Why are prices sticky? Preliminary results from an interview study. American Economic Association, 81(2), 89-96. Disponível em http://www.jstor.org/stable/2006832

Borraz, F., Licandro, G., \& Sola, D. (2013). Wage and Price Setting: New Evidence from Uruguayan Firms (Documento de trabajo No. 008). Disponível no site do Banco Central del Uruguay: http://www.bcu.gub.uy/Estadisticas-e-

Indicadores/Documentos\%20de\%20Trabajo/8.2013.pdf

Braga, A. X. V., \& Souza, M. A. Kronbauer, C., Braga, D. P. G. (2012, March). Costs, prices and results' management: a study conducted in fruit canning companies located in Rio Grande do Sul state, Brazil. International Business Research, 5(3), 58-70. doi:10.5539/ibr.v5n3p58

Braga, D. P. G., Braga, A. X. V., \& Souza, M. A. (2010, maio-agosto). Gestão de custos, preços e resultados: um estudo em indústrias conserveiras do Rio Grande do Sul. Contabilidade, Gestão e Governança, 13(2), 20-35. Disponível em https://cggamg.unb.br/index.php/contabil/article/view/226/pdf_124

Braga, D. P. G., Kronbauer, C. A., Braga, D. P. G., Ott, E. (2009, novembro). Gestão de custos, preços e resultados: um estudo em indústrias de conservas. Anais do Congresso Brasileiro de Custos, Fortaleza, CE, XVI. Disponível em https://anaiscbc.emnuvens.com.br/anais/article/view/927/927

Brandau, M., Endenich, C., Trapp, R. \& Hoffjan, A. (2013, April). Institutional drivers of conformity: evidence for management accounting from Brazil and Germany. International Business Review, 22(2), 466-479. doi:10.1016/j.ibusrev.2012.07.001

Bruegelmann, T. M., Haessly, G., Wolfangel, C. P., \& Schiff, M. (1985, April). How variable costing is used in pricing decisions. Management Accounting, 66(10), 58-65. Disponível na base de dados ProQuest ABI/INFORM Complete

Calabrese, A., \& Francesco, F. (2014). A pricing approach for service companies: service blueprint as a tool of demand-based pricing. Business Process Management Journal, 20(6), 906-921. doi:10.1108/BPMJ-07-2013-0087

Callado, A. L. C., Machado, M. R., Callado, A. A. C., \& Machado, M. A. V. (2005, outubro). Análise da gestão de custos e formação de preços em organizações agroindustriais 
paraibanas. Anais do Congresso USP de Controladoria e Contabilidade, São Paulo, SP, 5. Disponível em http://www.congressousp.fipecafi.org/web/artigos52005/142.pdf

Callado, A. L. C., Machado, M. R., Callado, A. A. C., Machado, M. A. V., \& Almeida, M. A. (2007, janeiro/abril). Custos e formação de preços no agronegócio. Faces: Revista de Administração, 6(1), 52-61. Disponível em http://www.fumec.br/revistas/facesp/article/view/87/84

Campbell, M. C. (1999). "Why did you do that?" The important role of inferred motive in perceptions of price fairness. Journal of Product \& Brand Management, 8(2), 145-153. doi:10.1108/10610429910266995

Campell, D. J. (1988, January). Task complexity: a review and analysis. The Academic Management Review, 13(1), 40-52. Disponível em http://www.jstor.org/stable/258353

Canever, F. P., Lunkes, R. L., Schnorrenberger, D., \& Gasparetto, V. (2012, maio/agosto). Formação de preços: um estudo em empresas industriais de Santa Catarina. Revista de Contabilidade do Mestrado em Ciências Contábeis da UERJ (online), 17(2), 14-27. Disponível em http://www.epublicacoes.uerj.br/index.php/rcmccuerj/article/view/5390/4096

Canever, F. P., Schnorrenberger, D., \& Gasparetto, V. (2010, novembro). Formação de preços: um estudo em empresas industriais de Santa Catarina. Anais do Congresso Brasileiro de Custos, Belo Horizonte, MG, XVII. Disponível em https://anaiscbc.emnuvens.com.br/anais/article/view/664/664

Cannon, H. M., \& Morgan, F. W. (1990, spring). A strategic pricing framework. The Journal of Services Marketing, 4(2), 19-30. doi:10.1108/EUM0000000002508

Carlson, W. (2005, August). Is your price right? Greenhouse Grower, 23(9), 18-21. Disponível na base de dados ProQuest ABI/INFORM Complete

Carnegie, G. D., Tuck, J., \& West, B. (2011, June). Price Setting Practices in Australian Local Government. Australian Accounting Review, 21(2), 193-201. doi:10.1111/j.18352561.2011.00127.x

Carricano, M. (2014). Pricing myopia: do leading companies capture the full value of their pricing strategies? Management Decision, 52(1), 159-178. doi:10.1108/MD-03-20130184

Carricano, M., Trinquecoste, J. F. \& Mondejar, J.A. (2010). The rise of the pricing function: origins and perspectives. Journal of Product \& Brand Management, 19(7), 468-476. doi:10.1108/10610421011086883

Carson, D., Gilmore, A., Cummins, D., O’Donnel, A., \& Grant, K. (1998). Price setting in SMEs: some empirical findings. Journal of Product \& Brand Management, 7(1), 74-86. doi:10.1108/10610429810209755

Castro, C. M. (1977). A prática da pesquisa. São Paulo, SP: McGraw-Hill do Brasil. 
Cavusgil, S. T. (1988, May-June). Unraveling the mystique of export pricing. Business Horizons, 31(3), 54-63. doi:10.1016/0007-6813(88)90009-2

Chand, U. (2009, spring). Pricing strategies in the Canadian frozen chicken sector (Master's thesis). Department of Rural Economy, University of Alberta, Edmonton, Canada. Disponível na base de dados ProQuest Dissertations \& Theses Global

Chang, C., \& Dibb, S. (2012, Autumn). Reviewing and conceptualising customer-perceived value. Marketing Review, 12(3), 253-274. doi:10.1362/146934712X13420906885395

Chen, C. K. \& Hughes Jr., J. (2004, May). Using ordinal regression model to analyze student satisfaction questionnaires. IR Applications, 1(1), 1-13. Disponível em http://eric.ed.gov/?id=ED504366

Chia, J. A. L., \& Noble, P. M. (1999, August). Industrial pricing strategies in Singapore and the US: same or different? Asia Pacific Journal of Management, 16(2), 293-303. doi:10.1023/A:1015451328373

Chiavenato, I. (2007). Administração: teoria, processo e prática (4a ed.). Rio de Janeiro, RJ: Elsevier.

Choudhary, A., Faheem, A., Hanif, N., Naeem, S., \& Pasha, F. (2012, December). Pricesetting discoveries: results from a developing country. In F. Pasha, Essays on business cycles in developing countries (Doctoral Dissertation). Department of Economics of the Graduate School of Arts and Sciences, Boston College, Boston, MA. Disponível em http://hdl.handle.net/2345/3408

Christensen, J., \& Demski, J. S. (1997, March). Product costing in the presence of endogenous subcost functions. Review of Accounting Studies, 2(1), 65-87. doi:10.1023/A:1018373627347

Codini, A., Saccani, N., \& Sicco, A. (2012). The relationship between customer value and pricing strategies: an empirical test. Journal of Product \& Brand Management, 21(7), 538-546. doi:10.1108/10610421211276321

Cogan. S., Cabral, I., Castro, F. A. R., \& Bispo, P. L. (2007, dezembro). O processo de formação do preço de venda das micro e pequenas empresas em dois municípios do interior do Rio de Janeiro. Anais do Congresso Brasileiro de Custos, João Pessoa, PB, XIV. Disponível em https://anaiscbc.emnuvens.com.br/anais/article/view/1443/1443

Collins, M., \& Parsa, H. G. (2006, March). Pricing strategies to maximize revenues in the lodging industry. Hospitality Management, 25(1), 91-107.

doi:10.1016/j.ijhm.2004.12.009

Colvin, G. (2009). Yes, you can raise prices. Fortune, 159(4), 20. Disponível na base de dados EBSCOhost Business Source Complete

Cooke, E. F. (1986, fall). What is business and industrial marketing? Journal of Business \& Industrial Marketing, 1(1), 9-17. doi:10.1108/eb006008 
Coordenação de Aperfeiçoamento de Pessoal de Nível Superior, Diretoria de Avaliação. (2009). Documento de Área 2009. Disponível em http://www.capes.gov.br/images/stories/download/avaliacao/ADMIN17jun10.pdf

Coordenação de Aperfeiçoamento de Pessoal de Nível Superior, Webqualis. (2016). Plataforma Sucupira. Disponível em https://sucupira.capes.gov.br/sucupira/public/consultas/coleta/veiculoPublicacaoQualis/lis taConsultaGeralPeriodicos.jsf

Copaciu, M., Neagu, F., \& Braun-Erdei, H. (2010, March-April). Survey evidence on pricesetting patterns of Romanian firms. Managerial and Decision Economics, 31(2-3), 235247. doi: $10.1002 / \mathrm{mde} .1484$

Coricelli, F., \& Horváth, R. (2010, March-April). Price setting and market structure: an empirical analysis of micro data in Slovakia. Managerial and Decision Economics, 31(23), 209-233. doi:10.1002/mde. 1480

Costa, R. P., Ferreira, H. A. S., Saraiva Júnior, A. F. (2010). Preços, orçamentos e custos industriais. Rio de Janeiro, RJ: Elsevier.

Cova, B., \& Salle, R. (2008). The industrial/consumer marketing dichotomy revisited: a case of outdated justification? Journal of Business \& Industrial Marketing, 23(1), 3-11. doi:10.1108/08858620810841443

Coviello, N. E., \& Brodie, R. J. (2001). Contemporary marketing practices of consumer and business-to-business firms: how different are they? Journal of Business \& Industrial Marketing, 16(5), 382-400. doi:10.1108/08858620110400223

Cravens, K. S., \& Glover, H. D. (1995). Pricing complexities in the pharmaceutical industry. Managerial Auditing Journal, 10(7), 8-16. doi:10.1108/02686909510090285

Cressman Jr., G. E. (1999). Commentary on "industrial pricing: theory and managerial practice”. Marketing Science, 18(3), 455-457. doi:10.1287/mksc.18.3.455

Cunningham, D., \& Hornby, W. (1993). Pricing decision in small firms: Theory and practice. Management Decision, 31(7), 46-55. doi:10.1108/00251749310046765

D'Aveni, R. A. (2009). Beating the commodity: how to maximize your competitive position and increase your pricing power. Boston, MA: Harvard Business Press.

Dallabona, A. S., Melz, L. J., Santos, J. S. C., \& Nunes, E. S. (2013, janeiro/junho). Formação do preço de honorários contábeis em Tangará da Serra-MT: análise dos componentes do preço. Revista UNEMAT de Contabilidade, 2(3), 7-24. Disponível em http://periodicos.unemat.br/index.php/ruc/article/view/372/344

Davidson, A., \& Simonetto, M. (2005). Pricing strategy and execution: an overlooked way to increase revenues and profits. Strategy \& Leadership, 33(6), 25-33.

doi:10.1108/10878570510631639 
Demo, P. (1995). Metodologia científica nas ciências (3a ed.). São Paulo, SP: Atlas.

Demo, P. (2000). Metodologia do conhecimento científico. São Paulo, SP: Atlas.

Diamantopoulos, A., \& Mathews B. P. (1994). The specification of pricing objectives: empirical evidence from an oligopoly firm. Managerial and Decision Economics, 15(1), 73-85. doi:10.1002/mde.4090150109

Dias, L. N., Carvalho, F. M., Cogan, S. (2006, outubro-novembro). Formação do preço de venda: teoria versus prática em lojas do setor de vestuário. Anais do Congresso Brasileiro de Custos, Belo Horizonte, MG, XIII. Disponível em https://anaiscbc.emnuvens.com.br/anais/article/view/1709/1709

DiMaggio, P. J., \& Powell, W. W. (1983, April). The iron cage revisited: institutional isomorphism and collective rationality in organizational fields. American Sociological Review, 48(2), 147-160. Disponível em http://www.jstor.org/stable/2095101

Downward, P. (1999). Pricing theory in post Keynesian economics: a realist approach. Cheltenham, England: Edward Elgar Publishing.

Downward, P. (2000, March). A realist appraisal of post-Keynesian pricing theory. Cambridge Journal of Economics, 24(2), 211-224. Disponível em http://www.jstor.org/stable/23600717

Drury, C., \& Tayles, M. (2006, December). Profitability analysis in UK organizations: an exploratory study. The British Accounting Journal, 38(4), 405-425. doi:10.1016/j.bar.2006.05.003

Dutta, S., Zbaracki, M. J., \& Bergen, M. (2003). Pricing process as a capability: a resourcebased perspective. Strategic Management Journal, 24(7), 615-630. doi:10.1002/smj.323

Eco, U. (2010). Como se faz uma tese? (25a ed.). São Paulo, SP: Perspectiva.

Edwards, R. (1952, August). The pricing of manufactured products. Economica, 19(75), 298307. doi:10.2307/2550658

Elamir, E., Sadeq, H. (2010, Winter). Ordinal regression to analyze employees' attitudes towards the application of total quality management. Journal of Applied Quantitative Methods, 5(4), 647-658. Disponível em http://www.jaqm.ro/issues/volume-5,issue4/10_elamir_sadiq.php

Fabiani, S., Druant, M., Hernando, I., Kwapil, C., Landau, B., Loupias, C., . . Stokman, A. C. J. (2005, October). The pricing behaviour of firms in the euro area: new survey evidence (Working Paper No. 535). Disponível no site do European Central Bank: https://www.ecb.europa.eu/pub/pdf/scpwps/ecbwp535.pdf?97de0031adf0ce431c627637d $57 \mathrm{ff} 6 \mathrm{f0}$ 
Fabiani, S., Druant, M., Hernando, I., Kwapil, C., Landau, B., Loupias, C., . . Stokman, A. C. J. (2006, September). What firms' surveys tell us about price-setting behavior in the Euro area. International Journal of Central Banking, 2(3), 3-47. Disponível em http://www.ijcb.org/journal/ijcb06q3a1.pdf

Fabiani, S., Gattulli, A. \& Sabbatini, R. (2004, April). The pricing behaviour of Italian firms: new survey evidence on price stickiness (Working Paper No. 333). Disponível no site do European Central Bank: https://www.ecb.europa.eu/pub/pdf/scpwps/ecbwp333.pdf?3bc82949a3b597532e47746f3 7046628

Farres, R. (2012, January). Optimal pricing models in B2B organizations. Journal of Revenue and Pricing Management, 11(1), 35-39. doi:10.1057/rpm.2011.36

Fávero, L. P., Belfiore, P. P., Chan B. L., \& Silva, F. L. (2009). Análise de dados: modelagem multivariada para tomada de decisões. Rio de Janeiro, RJ: Elsevier.

Federação das Indústrias do Estado de São Paulo (FIESP). (2016, 31 de agosto). Panorama da indústria de transformação brasileira. Disponível no site do E Business Consultoria Empresarial e T.I.:

http://www.ebusinessconsultoria.com.br/infonews/panoramadaindustriadetransformacaob rasileira

Ferguson, J. L. (2008). Fair or foul? Determining the rules of the fair pricing game (Doctoral dissertation). Department of Marketing, Georgia State University, Atlanta, GA. Disponível na base de dados ProQuest Dissertations \& Theses Global. (UMI No. 3354482)

Forbis, J. L., \& Mehta, N.T. (1981, May-June). Value-based strategies for industrial products. Business Horizons, 24(3), 32-42. doi:10.1016/0007-6813(81)90125-7

Ford, D., Gadde, L. E., Hakansson, H., \& Snehota, I. (2003). Managing Business Relationships. (2nd ed.). Chichester, England: Wiley.

Forman, H., \& Hunt, J. M. (2005, February). Managing the influence of internal and external determinants on international industrial pricing strategies. Industrial Marketing Management, 34(2), 133-146. doi:10.1016/j.indmarman.2004.07.011

Foxall, G. R. (1972). A descriptive theory of pricing for marketing. European Journal of Marketing, 6(3), 190-194. doi:10.1108/EUM0000000005139

Foxall, G. R. (1980). The logic of price decision-making. Management Decision, 18(5), 235245. doi:10.1108/eb001243

Frank, R. H., \& Bernanke, B. S. (2012). Princípios de economia. (4a ed.). Porto Alegre, RS: AMGH Editora.

Fratto, G. M. (2006). A longitudinal retail price analysis of intra-channel and inter-channel competitors (Doctoral dissertation). North Carolina State University, Raleigh, NC. 
Disponível na base de dados ProQuest Dissertations \& Theses Global. (UMI No. 3306582)

Freystätter, H. (2003). Price setting behavior in an open economy and the determination of Finnish foreign trade prices (Study No. E:25) Disponível no site do Finlands Bank Eurosystemet: http://www.suomenpankki.fi/pdf/107877.pdf

Friedman, M. (1953). Essays in positive economics. Chicago, IL: University of Chicago Press.

Gale, B. T., \& Swire, D. J. (2012, January). Implementing strategic B2B pricing: constructing value benchmarks. Journal of Revenue and Pricing Management, 11(1), 40-53. doi:10.1057/rpm.2011.44

Galhanone, R. F. (2013). Valor percebido pelo consumidor de produtos de luxo: proposição de um modelo teórico (Tese de doutorado). Faculdade de Economia, Administração e Contabilidade, Universidade de São Paulo, São Paulo, SP. Disponível em http://www.teses.usp.br/teses/disponiveis/12/12139/tde-03062013-152622/pt-br.php

Garda, R. (1991). Use tactical pricing to uncover hidden profits. Journal of Business Strategy, 12(5), 17-23. doi:10.1108/eb039438

Garófalo, G. L. (2004). Considerações sobre a microeconomia. In D. B. Pinho \& M. A. S. Vasconcellos (Orgs.), Manual de economia. (5a ed.). São Paulo, SP: Saraiva.

Garrison, R. H., \& Noreen, E. W. (2001). Contabilidade gerencial. (9a ed.). São Paulo, SP: LTC - Livros Técnicos e Científicos Editora.

Gatignon, H., \& Xuereb, J. M. (1997, February). Strategic orientation of the firm and new product performance. Journal of Marketing Research, 34(1), 77-90.doi: 10.2307/3152066

Gebert, P., Goldenberg, C. B., \& Peters, D. (1996, September). Managing customers through cost-to-serve. CMA Magazine, 70(7), 22-23. Disponível na base de dados ProQuest ABI/INFORM Complete

Gil, A.C. (2008). Métodos e técnicas de pesquisa social. (6a ed.). São Paulo, SP: Atlas.

Goetz, J. F. (1985, April). The pricing decision: a service industry's experience. Journal of Small Business Management, 23(2), 61-67. Disponível na base de dados ProQuest ABI/INFORM Complete

Google, Google Acadêmico. (2016). Google Acadêmico. Disponível em https://scholar.google.com.br/

Gordon, L. A., Cooper, R., Falk, H., \& Miller, D. (1981). The pricing decision. Montvale (NJ): National Association of Accountants.

Govender, D. (2000). The choice of a cost base for product pricing. Meditari Accountancy Research, 8(1), 47-67. doi:10.1108/10222529200000004 
Govindarajan, V., \& Anthony, R. N. (1983, July). How firms use cost data in price decisions. Management Accounting, 65(1), 30-36. Disponível na base de dados ProQuest ABI/INFORM Complete

Granlund, M., \& Lukka, K. (1998). It's a small world of management accounting practices. Journal of Management Accounting Research, 10(1), 153-179. Disponível na base de dados ProQuest ABI/INFORM Complete

Greenslade, J., \& Parker, M. (2008). Price-setting behaviour in the United Kingdom. Bank of England Quarterly Bulletin, Q4, 404-415. Disponível em http://www.bankofengland.co.uk/publications/Documents/quarterlybulletin/qb080403.pdf

Greenslade, J., \& Parker, M. (2010, July). New insights into price-setting behaviour in the UK: introduction and survey results (Working Paper No. 395). Disponível no site do Bank of England:

http://www.bankofengland.co.uk/research/Documents/workingpapers/2010/wp395.pdf

Greenslade, J., \& Parker, M. (2012, February). New insights into price-setting behaviour in the UK: introduction and survey results. The Economic Journal, 122(558), F1-F15. doi:10.1111/j.1468-0297.2011.02492.x

Grewal, D., Janakiraman, R., Kalyanam, K., Kannan, P. K., Ratchford, B., Song, R., \& Tolerico, S. (2010, May). Strategic online and offline retail pricing: a review and research agenda. Journal of Interactive Marketing, 24(2), 138-154. doi:10.1016/j.intmar.2010.02.007

Guerreiro, R., \& Amaral, J. V. (2016). Cost-based price and value-based price: Are they conflicting approaches? Anais do Congresso USP de Controladoria e Contabilidade, São Paulo, SP, XVI. Disponível em http://www.congressousp.fipecafi.org/web/artigos162016/86.pdf

Guerreiro, R., Bio, S. R., \& Merschmann, E. V. V. (2008). Cost-to-serve measurement and customer profitability analysis. International Journal of Logistics Management, 19(3), 389-407. doi:10.1108/09574090810919215

Guerreiro, R., Cornacchione Jr., E. B, \& Kassai, C. A. (2012). Determining the "plus" in costplus-pricing: a time-based approach. Journal of Applied Management Accounting Research, 10(1), 1-16. Disponível na base de dados EBSCOhost Business Source Complete

Guilding, C., Drury, C., \& Tayles, M. (2005). An empirical investigation of the importance of cost-plus pricing. Managerial Auditing Journal, 20(2), 125-137. doi:10.1108/02686900510574548

Guler, I., Guillén, M. F., \& Macpherson, J. M. (2002, June). Global competition, institutions, and the diffusion of organizational practices: The international spread of ISO 9000 quality certificates. Administrative Science Quarterly, 47(2), 207-232. doi:10.2307/3094804 
Gummesson, E. (2014). The theory/practice gap in B2B marketing: reflections and search for solutions. Journal of Business \& Industrial Marketing, 29(7-8), 619-625.

doi:10.1108/JBIM-10-2013-0222

Gummesson, E., \& Polese, F. (2009). B2B is not an island! Journal of Business \& Industrial Marketing, 24 (5/6), 337-350. doi:10.1108/08858620910966228

Günther, H. (2003). Como elaborar um questionário. Série Planejamento de Pesquisa nas Ciências Sociais do Laboratório Ambiental da Universidade de Brasília, 1, 1-15. Disponível em www.psi-ambiental.net/pdf/01Questionario.pdf

Hague, D. C. (1967). Price formation in various economies. London, England: Macmillan.

Hair, J. F., Anderson, R. E., Tatham, R. L., \& Black, W. C. (2009). Análise multivariada de dados. (6a ed.). Porto Alegre, RS: Bookman.

Hall, R. I., \& Hitch, C. J. (1939, May). Price theory and business behaviour. Oxford Economic Papers, 2, 12-45. Disponível em http://www.jstor.org/stable/2663449

Hall, S., Walsh, M., \& Yates, A. (1997). How do UK companies set prices? (Working Paper No. 67). Disponível no site do Bank of England:

http://www.bankofengland.co.uk/archive/Documents/historicpubs/workingpapers/1997/w p67.pdf

Hall, S., Walsh, M., \& Yates, A. (2000, July). Are UK companies' prices sticky? Oxford Economic Papers, 52(3), 425-446. Disponível em http://www.jstor.org/stable/3488636

Hamann, E. V., Pereira, E. M., Barreto Junior, E. A. M., Nascimento Júnior, E. R. N., \& Silva, B. F. (2010, novembro). Custos para tomada de decisão para agroindústrias familiares da região de Planaltina-DF. Anais do Congresso Brasileiro de Custos, Belo Horizonte, $M G$, XVII. Disponível em https://anaiscbc.emnuvens.com.br/anais/article/view/674/674

Hambrick, D. C. (2007, April). Upper echelons theory: an update. Academy of Management Review, 32(2), 334-343. Disponível em http://www.jstor.org/stable/20159303

Hample, R. E. (1977, July). Pricing policies and profitability. Management Accounting, 59(1), 53-56. Disponível na base de dados ProQuest ABI/INFORM Global

Hankinson, A. (1995). The small firm's preoccupation with cost-based pricing. Pricing Strategy \& Practice, 3(4), 14-20. Disponível na base de dados ProQuest ABI/INFORM Complete

Hansen, D. R., \& Mowen, M. M. (2013). Gestão de custos: contabilidade e controle. São Paulo, SP: Cengage Learning.

Harper, D. (1966). Price policy and procedure. New York, NY: Harcourt, Brace \& World. 
Haynes, J. B., \& Wilkens, P. L. (1974, October). The pricing of marketing research services. Business Horizons, 17(5), 75-80. doi:10.1016/0007-6813(74)90043-3

Haynes, W. W. (1964, April). Pricing practices in small firms. Southern Economic Journal, 30(4), 315-324. doi:10.2307/1055309

Hinterhuber, A. (2004, November). Towards value-based pricing - an integrative framework for decision making. Industrial Marketing Management, 33(8), 765-778.

doi:10.1016/j.indmarman.2003.10.006

Hinterhuber, A. (2008). Customer value-based pricing strategies: why companies resist. Journal of Business Strategy, 29(4), 41-50. doi:10.1108/02756660810887079

Hinterhuber, A. (2016, January-February). The six pricing myths that kill profits. Business Horizons, 59(1), 71-83. doi:10.1016/j.bushor.2015.09.002

Hinterhuber, A., \& Hinterhuber, G. (2012). An empirical analysis of the role of industrial brands for industrial distributors. Journal of Strategy and Management, 5(3), 252-265. doi:10.1108/17554251211247562

Hinterhuber, A., \& Liozu, S. M. (2012, summer). Is it time to rethink your pricing strategy? MIT Sloan Management Review, 53(4), 68-77. Disponível na base de dados EBSCOhost Business Source Complete

Hoch, S. J., \& Schkade, D. A. (1996, January). A psychological approach to decision support systems. Management Science, 42(1), 51-64. Disponível em http://www.jstor.org/stable/2633015

Hoeberichts, M., \& Stokman, A. (2006, April). Pricing setting behaviour in the Netherlands (Working Paper No. 607). Disponível no site do European Central Bank: https://www.ecb.europa.eu/pub/pdf/scpwps/ecbwp607.pdf?332f5fd003599a89a4ab6dd6f 9c819a8

Hofstrand, D. (2007, March). Commodities versus differentiated products. Disponível no site da Iowa State University: https://www.extension.iastate.edu/agdm/wholefarm/html/c5203.html

Holbrook, M. B. (1996). Customer value - a framework for analysis and research. Advances in Consumer Research, 23, 138-142. Disponível em http://acrwebsite.org/volumes/7929/volumes/v23/NA-23

Hoque, Z. (2006). Dealing with human ethical issues in research: some advice. In Z. Hoque (Ed.), Methodological issues in accounting research: theories and methods. London, England: Spiramus.

Horkan, L. (2003, April). Price it right. ColoradoBiz, 30(4), 39-42. Disponível na base de dados ProQuest ABI/INFORM Complete 
Howard, C., \& Herbig, P. (1996). Japanese pricing policies. Journal of Consumer Marketing, 13(4), 5-17. doi:10.1108/07363769610124500

Hsu, S. H. (2006). The use of cost information in pricing decisions and cost management strategies (Doctoral dissertation). University of Wisconsin-Madison, Madison, WI. Disponível na base de dados ProQuest Dissertations \& Theses Global. (UMI No. 3234775)

Indounas, K. A. (2006, September-October). Making effective pricing decisions. Business Horizons, 49(5), 415-424. doi:10.1016/j.bushor.2006.02.003

Indounas, K. A. (2008). The relationship between pricing and ethics in two industrial service industries. Journal of Business \& Industrial Marketing, 23(3), 161-169. doi:10.1108/08858620810858427

Indounas, K. A. (2009). Successful industrial service pricing. Journal of Business \& Industrial Marketing, 24(2), 86-97. doi:10.1108/08858620910931703

Indounas, K. A. (2014). The antecedents of strategic pricing and its effect on company performance in the case of industrial service firms. Journal of Services Marketing, 28(5), 402-413. doi:10.1108/JSM-02-2013-0031

Indounas, K. A. (2015). The adoption of strategic pricing by industrial service firms. Journal of Business \& Industrial Marketing, 30(5), 521-535. doi:10.1108/JBIM-02-2013-0028

Indounas, K. A., \& Avlonitis, G. J. (2009). Pricing objectives and their antecedents in the services sector. Journal of Service Management, 20(3), 342-374. doi:10.1108/09564230910964426

Indounas, K. A., \& Avlonitis, G. J. (2011). New industrial service pricing strategies and their antecedents: empirical evidence from two industrial sectors. Journal of Business \& Industrial Marketing, 26(1), 26-33. doi:10.1108/08858621111097184

Indounas, K. A., \& Roth, S. (2012, May). Antecedents and consequences of strategic price management: An analysis in the New Zealand industrial service context. Australasian Marketing Journal, 20(2), 113-121. doi:10.1016/j.ausmj.2011.10.006

Ingenbleek, P. T. M. (2007). Value-informed pricing in its organizational context: literature review, conceptual framework, and directions for future research. Journal of Product \& Brand Management, 16(7), 441-458. doi:10.1108/10610420710834904

Ingenbleek, P. T. M., Debruyne, M., Frambach, R. T., \& Verhallen, T. M. M. (2003, December). Successful new product pricing practices: a contingency approach. Marketing Letters, 14(4), 289-305. doi:10.1023/B:MARK.0000012473.92160.3d

Ingenbleek, P. T. M., \& van der Lans, I. A. (2013). Relating price strategies and price-setting practices. European Journal of Marketing, 47(1/2), 27-48.

doi:10.1108/03090561311285448 
Iregui Bohórquez, A. M., Melo Becerra, L. A. \& Ramírez Giraldo, M. T. (2011). Wage adjustment practices and the link between price and wages: survey evidence from Colombian firms. Borradores de Economía, 660, 1-54. Disponível em http://www.banrep.gov.co/sites/default/files/publicaciones/pdfs/borra660.pdf

Iregui Bohórquez, A. M., Melo Becerra, L. A. \& Ramírez Giraldo, M. T. (2012, enero-junio). Wage adjustment practices and the link between price and wages: survey evidence from Colombian firms. Lecturas de Economía, 76, 17-53. Disponível em http://www.redalyc.org/articulo.oa?id=155224311001

Iudícibus, S. (2009). Teoria da contabilidade. (9a ed.). São Paulo, SP: Altas.

Iveroth, E., Westelius, A., Petri, C. J., Olve, N. G., Cöster, M., \& Nilsson, F. (2013, April). How to differentiate by price: proposal for a five-dimensional model. European Management Journal, 31(2), 109-123. doi:10.1016/j.emj.2012.06.007

Iyer, G. R., Xiao, S., Sharma, A., \& Nicholson, M. (2015, May). Behavioral issues in price setting in business-to-business marketing: a framework for analysis. Industrial Marketing Management, 47, 6-16. doi:10.1016/j.indmarman.2015.02.001

Japiassu, H. (1992). Introdução ao pensamento epistemológico. (6a ed.). Rio de Janeiro, RJ: Francisco Alves.

Japiassu, H., \& Marcondes, D. (2001). Dicionário básico de filosofia. (3a ed). Rio de Janeiro, RJ: Jorge Zahar Editor.

Johansson, M. \& Andersson, L. (2012, January). Pricing practices and value creation logics. Journal of Revenue and Pricing Management, 11(1), 64-75. doi:10.1057/rpm.2011.43

Julio Roman, J. M., \& Zárate Solano, H. M. (2008). The price setting behavior in Colombia: evidence from PPI micro data. Borradores de Economía, 483, 1-38. Disponível em http://banrep.gov.co/docum/ftp/borra483.pdf

Kahneman, D., Knetsch, J., \& Thaler, R. (1986a, September). Fairness as a constraint on profit seeking: entitlements in the market. The American Economic Review, 76(4), 728741. Disponível em http://www.jstor.org/stable/1806070

Kahneman, D., Knetsch, J., \& Thaler, R. (1986b, October). Fairness and the assumptions of economics. The Journal of Business, 59(4), S285-S300. Disponível em http://www.jstor.org/stable/2352761

Keeney, M., Lawless, M., \& Murphy, A. (2010, May). How do firms set prices? Survey evidence from Ireland (Research Technical Paper No. 7/RT/10). Disponível no site do Central Bank of Ireland: http://www.centralbank.ie/publications/documents/7RT10.pdf

Keil, S. K., Reibstein, D., \& Wittink, D. R. (2001, June).The impact of business objectives and the time horizon of performance evaluation on pricing behavior. International Journal of Research in Marketing, 18(1-2), 67-81. doi:10.1016/S0167-8116(01)00027-1 
Kerlinger, F. N. (1980). Metodologia da pesquisa em ciências sociais: um tratamento conceitual. São Paulo, SP: EPU/EDUSP.

Kohli, C., \& Suri, R. (2011, November-December). The price is right? Guidelines for pricing to enhance profitability. Business Horizons, 54(6), 563-573.

doi:10.1016/j.bushor.2011.08.001

Kortge, G. D., \& Okonkwo, P. A. (1993, May). Perceived value approach to pricing. Industrial Marketing Management, 22(2), 133-140. doi:10.1016/0019-8501(93)90039-A

Kotler, P. (2000). Administração de marketing: a edição do novo milênio. (10a ed.). São Paulo, SP: Prentice Hall.

Kotler, P., \& Armstrong, G. (2007). Princípios de marketing. (12a ed.). São Paulo, SP: Pearson.

Kotler, P., \& Keller, K. L. (2012). Marketing Management. (14th ed.). Upper Saddle River, NJ: Prentice Hall.

Kruger, S. D., Mazzioni, S., Glustak, E., \& Zanin, A. (2014). A contabilidade como instrumento de gestão dos estabelecimentos rurais. REUNIR: Revista de Administração, Contabilidade e Sustentabilidade, 4(2), 134-153. doi:10.18696/reunir.v4i2.246

Kuusela, H., Närvänen, E., Saarijärvi, H., \& Yrjölä, M. (2014). Challenges for B2B research relevance: a top executive perspective. Journal of Business \& Industrial Marketing, 29(7/8), 593-600. doi:10.1108/JBIM-09-2013-0199

Kwapil, C., Baumgartner, J., \& Scharler, J. (2005, March). The price-setting behavior of Austrian firms: some survey evidence (Working Paper No. 464). Disponível no site do European Central Bank:

https://www.ecb.europa.eu/pub/pdf/scpwps/ecbwp464.pdf?a78052ed993b5d0f4ff612749f e81f16

Lancioni, R. (2005, February). Pricing issues in industrial marketing. Industrial Marketing Management, 34(2), 111-114. doi:10.1016/j.indmarman.2004.07.009

Langbraaten, N., Nordbø, E. W., \& Wulfsberg, F. (2008, October). Price-setting behaviour of Norwegian firms - results of a survey. Norges Bank Economic Bulletin, 79(2), 13-34. Disponível em http://www.norges-bank.no/pages/71744/EN/Price-setting_behaviour.pdf

Langholm, O. (1969). Full cost and optimal pricing. Oslo, Norway: Universitetsforlaget.

Larasati, A., Yong, C., \& Slevitch, L. (2011). Comparing neural network and ordinal logistic regression to analyze attitude responses. Service Science, 3(4), 304-312.

doi:10.1287/serv.3.4.304

Laric, M. V. (1980). Pricing strategies in industrial markets. European Journal of Marketing, 14(5/6), 303-321. doi:10.1108/EUM0000000004908 
Lazer, W. (1957, March). Price determination in the western Canadian garment industry. The Journal of Industrial Economics, 5(2), 124-136. doi:10.2307/2097420

Lere, J. C. (1979, July). What cost is right for pricing? The CPA Journal, 49(7), 76-77. Disponível na base de dados ProQuest ABI/INFORM Global

Lima, F. G., Ferrarezi, M. A.; Smith, M. S. J. (2007, setembro). Formação de preços à luz da teoria das restrições: um estudo aplicado às indústrias metalúrgicas da cidade de Franca. Anais do Congresso UFSC de Iniciação Científica em Contabilidade, Florianópolis, SC, I. Disponível em http://dvl.ccn.ufsc.br/congresso/anais/1CCF/20090727153741.pdf

Liozu, S. M., \& Hinterhuber, A. (2012). Industrial product pricing: a value-based approach. Journal of Business Strategy, 33(4), 28-39. doi:10.1108/02756661211242681

Liozu, S. M., \& Hinterhuber, A. (2013). Pricing orientation, pricing capabilities, and firm performance. Management Decision, 51(3), 594-614. doi:10.1108/00251741311309670

Liozu, S. M., Hinterhuber, A., Boland, R., \& Perelli, S. (2012, January). The conceptualization of value-based pricing in industrial firms. Journal of Revenue and Pricing Management, 11(1), 12-34. doi:10.1057/rpm.2011.34

Liozu, S. M., Hinterhuber, A., Perelli, S., \& Boland, R. (2012). Mindful pricing: transforming organizations through value-based pricing. Journal of Strategic Marketing, 20(3), 197209. doi:10.1080/0965254X.2011.643916

Long, J. S., \& Freese, J. (2006). Regression Models for Categorical Dependent Variables Using Stata. (2nd ed.). College Station, TX: Stata Press.

Loupias, C., \& Ricart, R. (2004, December). Price setting in France: new evidence from survey data (Working Paper No. 423). Disponível no site do European Central Bank: http://www.ecb.europa.eu/pub/pdf/scpwps/ecbwp423.pdf

Lucas, M. R. (2003, September). Pricing decisions and the neoclassical theory of the firm. Management Accounting Research, 14(3), 201-217. doi:10.1016/S1044-5005(03)00044-1

Lucas, M. R., \& Rafferty, J. (2008, June). Cost analysis for pricing: exploring the gap between theory and practice. The British Accounting Review, 40(2), 148-160. doi:10.1016/j.bar.2007.11.002

Lünnemann, P., \& Mathä, T. Y. (2006, May). New survey evidence on the pricing behaviour of Luxembourg firms (Working Paper No. 617). Disponível no site do European Central Bank: https://www.ecb.europa.eu/pub/pdf/scpwps/ecbwp617.pdf

Machado, D. G., Fiorentin, M., \& Scarpin, J. E. (2010, setembro). Formação de preços: um estudo em empresas do setor metalúrgico do estado de Santa Catarina. Anais dos Seminários em Administração, São Paulo, SP, XIII. Disponível em http://sistema.semead.com.br/13semead/resultado/trabalhosPDF/206.pdf 
Machado, D. G. \& Souza, M. A. (2005, novembro). Análise das relações entre a gestão de custos e a gestão do preço de venda: um estudo das práticas adotadas por empresas industriais conserveiras no RS. Anais do Congresso Internacional de Custos, Florianópolis, SC, IX. Disponível em http://intercostos.org/documentos/custos_118.pdf

Machado, D. G. \& Souza, M. A. (2006). Análise das relações entre a gestão de custos e a gestão do preço de venda: um estudo das práticas adotadas por empresas industriais conserveiras no RS. Revista Universo Contábil, 2(1), 43-60. Disponível em http://proxy.furb.br/ojs/index.php/universocontabil/article/view/109/68

Machado, M. A. V., Machado, M. R., Holanda, F. M. A. (2006, setembro). Análise do processo de formação de preços do setor hoteleiro da cidade de João Pessoa/PB: um estudo exploratório. Anais do Encontro da ANPAD, Salvador, BA, 30. Disponível em http://www.anpad.org.br/enanpad/2006/dwn/enanpad2006-ficb-2869.pdf

Machlup, F. (1946, September). Marginal analysis and empirical research. The American Economic Review, 36(4), 519-554. Disponível em http://www.jstor.org/stable/1801722

Mahabir, R., Primus, K., Cox, D., Jagessar, V., \& Neptun, C. (2012, November). Price setting in Trinidad and Tobago: evidence from survey data (Working Paper No. 09/2012).

Disponível no site do Central Bank of Trinidad \& Tobago: http://www.centralbank.org.tt/sites/default/files/Price\%20Setting\%20in\%20Trinidad\%20and\%20Tobago\%2 0Evidence\%20from $\% 20$ Survey\%20Data\%20-

\%20Mahabir\%20Primus\%20Jagessar\%20Cox\%20Neptune.pdf

Mahabir, R., Primus, K., Cox, D., Jagessar, V., \& Neptun, C. (2013). Price setting in Trinidad and Tobago: evidence from survey data. Business, Finance \& Economics in Emerging Economies, 8(1), 55-78. Disponível em http://www.ccmfuwi.org/files/publications/journal/2013_1_8/54_77.pdf

Malik, W. S., Satti, A. H., \& Saghir, G. (2010). Pricing setting behavior of Pakistani firms: evidence from four industrial cities of Punjab (Working Paper No. 65). Disponível no site do Pakistan Institute of Development Economics:

http://pide.org.pk/pdf/Working\%20Paper/WorkingPaper-65.pdf

Malmi, T. (1999, November). Activity-based costing diffusion across organizations: an exploratory empirical analysis of Finnish firms. Accounting, Organizations and Society, 24(8), 649-672. doi:10.1016/S0361-3682(99)00011-2

Mankiw, N. G. (2014). Introdução à economia. (6a ed.). São Paulo, SP: Cengage Learning.

Marn, M. V., \& Rosiello, R. L. (1992, September-October). Managing price, gaining profit. Harvard Business Review, 70(5), 84-94. Disponível em https://hbr.org/1992/09/managing-price-gaining-profit

Maroco, J., \& Garcia-Marques, T. (2006). Qual a fiabilidade do alfa de Cronbach? Questões antigas e soluções modernas. Laboratório de Psicologia, 4(1), 65-90. Disponível no site do Instituto Universitário de Ciências Psicológicas, Sociais e da Vida: http://hdl.handle.net/10400.12/133 
Marques, K. C. M. (2012). Custeio alvo à luz da Teoria da Contingência e da Nova Sociologia Institucional: estudo de caso sobre sua adoção, implementação e uso (Tese de doutorado). Faculdade de Economia, Administração e Contabilidade, Universidade de São Paulo, São Paulo, SP. Disponível em http://www.teses.usp.br/teses/disponiveis/12/12136/tde-29012013-190708/pt-br.php

Martins, E. (2010). Contabilidade de custos. (10a ed.). São Paulo, SP: Atlas.

Martins, E. \& Rocha, W. (2010). Métodos de custeio comparados: custos e margens analisados sob diferentes perspectivas. São Paulo, SP: Atlas.

Martins, F. (2005, December). The price setting behaviour of Portuguese firms: evidence from survey data (Working Paper No. 562). Disponível no site do European Central Bank: http://www.ecb.europa.eu/pub/pdf/scpwps/ecbwp562.pdf

Martins, G., \& Theóphilo, C. R. (2009). Metodologia da investigação científica para ciências sociais aplicadas. (2a ed.). São Paulo, SP: Atlas.

Mattar, F. N. (1997). Pesquisa de marketing: metodologia, planejamento. (4a ed.). São Paulo, SP: Atlas.

Maxwell, S. (1998). Pricing education in the United States of America: responding to the needs of business. Journal of Product \& Brand Management, 7(4), 336-341. doi:10.1108/10610429810229861

Maxwell, W. D. (1970). Price theory and Applications in business administration. Los Angeles, CA: Goodyear Publishing Co.

May, R. (1970, June). Pricing policies and corporate strategy. Long Range Planning, 2(4), 4953. doi:10.1016/0024-6301(70)90025-7

McCullagh, P., \& Nelder, J. A. (1989). Generalized Linear Models (2nd ed.). London, England: Chapman and Hall.

Mello, E. E. (2000, novembro). A política de preços na indústria de produtos alimentares. Economia e Desenvolvimento, 12, 19-47. Disponível em http://periodicos.ufsm.br/eed/article/view/3392/1906

Mendonça, H. (2014, 30 de dezembro). Petrobras suspende negócios com 23 empresas citadas na Lava Jato [Versão eletrônica]. El Pais. Disponível em http://brasil.elpais.com/brasil/2014/12/30/politica/1419950034_081994.html

Mills, R. W. (1988, November). Pricing decisions in UK manufacturing and service companies. Management Accounting, 66(10), 38-39. Disponível na base de dados ProQuest ABI/INFORM Complete

Mises, L. V. (1995). Ação humana: um tratado de economia. (2a ed.). Rio de Janeiro, RJ: Instituto Liberal. 
Mochtar, K., \& Arditi, D. (2001). Pricing strategy in the US construction industry. Construction Management and Economics, 19(4), 405-415.

doi:10.1080/01446190010020372

Monroe, K. B. (1979). Pricing: making profitable decisions. New York, NY: McGraw-Hill.

Monroe, K. B. (2003). Pricing: making profitable decisions. (3rd ed.). New York, NY: McGraw-Hill.

Montoro Filho, A. F. (2013). Teoria elementar do funcionamento do mercado. In D. B. Pinho, M. A. S. Vasconcellos, \& R. Toneto Jr. (Eds.), Manual de economia. (6a ed.). São Paulo, SP: Saraiva.

Morris, M. H., \& Calantone, R. J. (1990, November). Four components of effective pricing. Industrial Marketing Management, 19(4), 321-329. doi:10.1016/0019-8501(90)90004-F

Morris, M. H., \& Fuller, D. A. (1989, May). Pricing an industrial service. Industrial Marketing Management, 18(2), 139-146. doi:10.1016/0019-8501(89)90030-8

Morris, M. H., \& Schurink, C. V. E. (1993). Pricing behavior in industrial markets. Journal of Business \& Industrial Marketing, 8(3), 28-43. doi:10.1108/08858629310044156

Muller, C. C. (1997, June). Redefining value: the hamburger price war. Cornell Hotel and Restaurant Administration Quarterly, 38(3), 62-73. doi:10.1016/S0010-8804(97)89509-2

Munnukka, J., \& Järvi, P. (2012). The price-category effect and the formation of customer value of high-tech products. Journal of Consumer Marketing, 29(4), 293-301. doi:10.1108/07363761211237362

Murray, J. (2013, July). Pricing Practices in New Amsterdam Business. Management Dynamics, 3(1), 58-65. Disponível em http://bmdynamics.com/issue_pdf/bmd110374$\% 2058-65 . p d f$

Myers, M. B. (1997, Autumn). The pricing of export products: why aren't managers satisfied with the results? Journal of World Business, 32(3), 277-289. doi:10.1016/S10909516(97)90012-2

Myers, M. B., Griffith, D. A., Daugherty, P. J., \& Lusch, R. F. (2004, Spring). Maximizing the human capital equation in logistics: education, experience, and skills. Journal of Business Logistics, 25(1), 211-232. doi:10.1002/j.2158-1592.2004.tb00175.x

Nagle, T. T., \& Hogan, J. E. (2007). Estratégia e táticas de preços. (4a ed.). São Paulo, SP: Pearson Prentice Hall.

Nakagawa, F. (2016, 04 de Março). Brasil cai para a posição de $9^{a}$ economia do mundo [Versão eletrônica]. Exame.com. Disponível em http://exame.abril.com.br/economia/pibem-dolar-cai-25-e-brasil-cai-para-a-posicao-de-9a-economia-do-mundo/ 
Nakagawa, M. (2001). ABC: custeio baseado em atividades. (2a ed.). São Paulo, SP: Atlas.

Nakagawa, S., Hattori, R., \& Takagawa, I. (2000, August). Price-setting behavior of Japanese Companies (Working Paper). Disponível no site do Bank of Japan: https://www.boj.or.jp/en/research/brp/ron_2000/data/ron0009b.pdf

Narayandas, D. (2005, September). Building loyalty in business markets. Harvard Business Review, 83(9), 131-139. Disponível em https://hbr.org/2005/09/building-loyalty-inbusiness-markets

Nazari, J., Kline, T., \& Herremans, I. (2006). Conducting survey research in management accounting. In Z. Hoque (Ed.), Methodological issues in accounting research: theories and methods. London, England: Spiramus.

Nchake, M. A., Edwards, L., \& Rankin, N. (2015, June). Price-setting behaviour in Lesotho: stylised facts from consumer retail prices. South African Journal of Economics, 83(2), 199-219. doi:10.1111/saje.12054

Nicolitsas, D. (2013, April). Price setting practices in Greece: evidence from a small-scale firm-level survey (Working Paper No. 156). Disponível no site do Bank of Greece: http://www.bankofgreece.gr/BogEkdoseis/Paper2013156.pdf

Nicolitsas, D. (2015, August 17). Price setting practices in Greece: evidence from a smallscale firm-level survey. Bulletin of Economic Research, Early View. doi:10.1111/boer.12058

Noble, P. M., \& Gruca, T. S. (1999a). Industrial pricing: theory and managerial practice. Marketing Science, 18(3), 435-454. doi:10.1287/mksc.18.3.435

Noble, P. M., \& Gruca, T. S. (1999b). Response to the comments on "Industrial pricing: theory and managerial practice". Marketing Science, 18(3), 458-459.

doi: $10.1287 / \mathrm{mksc} .18 .3 .458$

Noreen, E. W., \& Burgstahler, D. (1997). Full-cost pricing and the illusion of satisfying. Journal of Management Accounting Research, 9, 239-263. Disponível na base de dados ProQuest ABI/INFORM Global

O’Connell, A. A. (2006). Logistic regression models for ordinal response variables. Thousand Oaks, CA: Sage Publications.

Ohmae, K. (1982). The mind of the strategist - the art of Japanese business. New York, NY: McGraw-Hill.

Owens, R. W. (1983, December). Several unanswered questions. Management Accounting, 65(6), 15, 71. Disponível na base de dados ProQuest ABI/INFORM Complete

Oxenfeldt, A. R. (1961). Pricing for marketing executives. San Francisco, CA: Wadsworth Publishing Company. 
Park, A., Rayner, V., \& D’Arcy, P. (2010, June). Price-setting behaviour - insights from Australian firms. Reserve Bank of Australia Bulletin, 7-14. Disponível em http://www.rba.gov.au/publications/bulletin/2010/jun/pdf/bu-0610-2.pdf

Parker, M. (2014, August). Price-setting behaviour in New Zealand (Discussion Paper No. 4). Disponível no site do Reserve Bank of New Zealand: http://www.rbnz.govt.nz//media/ReserveBank/Files/Publications/Discussion\%20papers/2014/dp14-04.pdf

Pearce, I. F. (1956, May). A Study in price policy. Economica, 23(90), 114-127. Disponível em http://www.jstor.org/stable/2550951

Pestana, M. H., \& Gageiro, J. N. (1998). Análise de dados para ciências sociais: A complementaridade do SPSS. Lisboa, Portugal: Edições Sílabo.

Piercy, N. F. (1981, October). British export market selection and pricing. Industrial Marketing Management, 10(4), 287-297. doi:10.1016/0019-8501(81)90038-9

Piercy, N. F., Cravens, D. W., \& Lane, N. (2010). Thinking strategically about pricing decisions. Journal of Business Strategy, 31(5), 38-48. doi:10.1108/02756661011076309

Polícia Federal. (2017). Operação Lava Jato. Disponível no site da Polícia Federal: http://www.pf.gov.br/imprensa/lava-jato

Prado, E. F. S. (2007, outubro-dezembro). Formação de preços como processo complexo. Estudos Econômicos, 37(4), 745-769. doi:10.1590/S0101-41612007000400002

Preston, C. C., \& Colman, A. M. (2000, March). Optimal number of response categories in rating scales: reliability, validity, discriminating power, and respondent preferences. Acta Psychologica, 104(1), 1-15. doi:10.1016/S0001-6918(99)00050-5

Queiroz, L. L., Conceição, I. E. P., Santos, S. M., Cabral, A. C. A., \& Pessoa, M. N. M. (2013, setembro-dezembro). Estratégias de determinação de preços em microempresas do setor artesanal: um estudo comparativo entre Brasil e Cabo Verde. Revista da Micro e Pequena Empresa, Campo Limpo Paulista - FACCAMP, 7(3), 19-32. Disponível em http://www.faccamp.br/ojs/index.php/RMPE/article/view/622/293

Queiroz, L. L., Conceição, I. E. P., Silva, J. F. B. A., Santos, S. M., Cabral, A. C. A., \& Pessoa, M. N. M. (2013, novembro). Estratégias de determinação de preços em microempresas no setor de artigos turísticos: um estudo comparativo entre Fortaleza e Mindelo. Anais do Congresso Brasileiro de Custos, Uberlândia, MG, XX. Disponível em https://anaiscbc.emnuvens.com.br/anais/article/view/152/152

Raju, J., \& Zhang, Z. J. (2010). Smart pricing: how Google, Priceline, and leading business use pricing innovation for profitability. Upper Saddle River, NJ: Pearson Education.

Ray, K., \& Gramlich, J. (2016, Spring). Reconciling full-cost and marginal-cost pricing. Journal of Management Accounting Research, 28(1), 27-37. doi:10.2308/jmar-51285 
Rezende, A. J. (2009). Um estudo sobre o processo de desinstitucionalização das práticas contábeis de correção monetária em empresas brasileiras (Tese de doutorado). Faculdade de Economia, Administração e Contabilidade, Universidade de São Paulo, São Paulo, SP. Disponível em http://www.teses.usp.br/teses/disponiveis/12/12136/tde03092009-112111/pt-br.php

Rizzieri, J. A. B. (2013). Introdução à economia. In D. B. Pinho, M. A. S. Vasconcellos, \& R. Toneto Jr. (Eds.), Manual de economia. (6a ed.). São Paulo, SP: Saraiva.

Rocha, L. F., \& Leal, E. A. (2015). Gestão de preços: um estudo em pequenas empresas participantes do programa Empreender - Uberlândia-MG. Revista de Auditoria, Governança e Contabilidade, 3(6), 61-77. Disponível em http://www.fucamp.edu.br/editora/index.php/ragc/article/view/568/418

Rocha, W. (1999). Contribuição ao estudo de um modelo conceitual de sistema de informação de gestão estratégica (Tese de doutorado). Faculdade de Economia, Administração e Contabilidade, Universidade de São Paulo, São Paulo, SP.

Roll, O. (2009, August). Pricing trends from a management perspective. Journal of Revenue and Pricing Management, 8(4), 396-398. doi:10.1057/rpm.2009.22

Rosadas, L. A. S., \& Macedo, M. A. S. (2004, outubro). Formação do preço de venda: uma análise do setor de material de construção. Anais do Congresso Brasileiro de Custos, Porto Seguro, BA, XI. Disponível em https://anaiscbc.emnuvens.com.br/anais/article/view/2440/2440

Ruggles, R. (1952, June). Review - Price determination: business practice versus economic theory, by W. J. Eiteman. The American Economic Review, 42(3), 414-416. Disponível em http://www.jstor.org/stable/1810401

Rusetski, A. (2014). Pricing by intuition: Managerial choices with limited information. Journal of Business Research, 67, 1733-1743. doi: 10.1016/j.jbusres.2014.02.020

Sahinöz, S., \& Saraçoglu, B. (2008, December). Price-setting behavior in Turkish industries: evidence from survey data. The Developing Economies, XLVI(4), 363-385. doi:10.1111/j.1746-1049.2008.00070.x

Sangster, R. L. (1993, December). Question order effects: are they really less prevalent in self-administered surveys? (Doctoral dissertation). Department of Sociology, Washington State University, Pullmann, WA. Disponível na base de dados ProQuest Dissertations \& Theses Global. (UMI No. 9430079)

Santos, A. R., \& Almeida, L. B. (2006, outubro-novembro). Práticas de contabilidade de custos em indústrias paranaenses. Anais do Congresso Brasileiro de Custos, Belo Horizonte, MG, XIII. Disponível em https://anaiscbc.emnuvens.com.br/anais/article/view/1713/1713 
Santos, R. V. (1995). Modelos de decisão para gestão de preço de venda (Dissertação de mestrado). Faculdade de Economia, Administração e Contabilidade, Universidade de São Paulo, São Paulo, SP.

Scapens, R. W. (2006, March). Understanding management accounting practices: A personal journey. The British Accounting Review, 38(1), 1-30. doi:10.1016/j.bar.2005.10.002

Schoenherr, T., Modi, S. B., Talluri, S., \& Hult, G. T. M. (2014, September). Antecedents and performance outcomes of strategic environmental sourcing: an investigation of resourcebased process and contingency effects. Journal of Business Logistics, 35(3), 172-190. doi: $10.1111 / \mathrm{jbl} .12052$

Schulz, A., Schröder, M., Guerreiro, R., \& Souza, R. P. (2014, May). Cost accounting in Brazil - empirical evidence from an emerging economy. Proceedings of the Annual Congress of the European Accounting Association, Tallinn, Estonia, 37.

Schuman, H., \& Presser, S. (1981). Questions and answers in attitude surveys: Experiments in question form, wording, \& content. New York, NY: Academic.

Serviço de Apoio às Micro e Pequenas Empresas de São Paulo - SEBRAE/SP (2016).

Definição de porte de estabelecimentos segundo o número de empregados. Disponível em

http://www.sebraesp.com.br/arquivos_site/biblioteca/EstudosPesquisas/mpes_numeros/M PE_conceito_empregados.pdf

Shapiro, B. P. (1998, Second Quarter). Commodity busting: be a price maker, not a price taker! Strategy Business, 4(11), 7-9. Disponível em http://www.strategybusiness.com/article/15859?gko=82617

Shapiro, B. P., \& Jackson, B. B. (1978, November). Industrial pricing to meet customer needs. Harvard Business Review, 56(6), 119-127. Disponível em https://hbr.org/1978/11/industrial-pricing-to-meet-customer-needs

Shim, E., \& Sudit, E. F. (1995, February). How manufacturers price products. Management Accounting, 76(8), 37-39. Disponível na base de dados ProQuest ABI/INFORM Complete

Shipley, D. D. (1983, December). Pricing flexibility in British manufacturing industry. Managerial and Decision Economics, 4(4), 224-233. doi:10.1002/mde.4090040405

Shipley, D. D., \& Bourdon, E. (1990, August). Distributor Pricing in Very Competitive Markets. Industrial Marketing Management, 19(3), 215-224. doi:10.1016/00198501(90)90013-L

Shipley, D. D., \& Jobber, D. (2001, April). Integrative pricing via the pricing wheel. Industrial Marketing Management, 30(3), 301-314. doi:10.1016/S0019-8501(99)00098-X 
Silva, J. O. (1997, novembro-dezembro). Utilização do conceito de mark-up na mineração do ouro. Anais do Congresso Brasileiro de Gestão Estratégica de Custos, Belo Horizonte, $M G, I V$. Disponível em https://anaiscbc.emnuvens.com.br/anais/article/view/3316/3316

Silva, L. P., \& Santos, R. V. (2005, novembro). Formação do preço e do lucro em indústrias exportadoras de equipamentos médico-hospitalares e odontológicos. Anais do Congresso Brasileiro de Custos, Florianópolis, SC, XII. Disponível em https://anaiscbc.emnuvens.com.br/anais/article/view/2153/2153

Simons, F. (2012, December 17). Price-takers have three choices. FT.com. Disponível na base de dados ProQuest ABI/INFORM Complete

Sizer, J. S. (1966, May). The accountant contribution to the pricing decision. Journal of Management Studies, 3(2), 129-148. doi:10.1111/j.1467-6486.1966.tb00973.x

Skinner, M. (2003, October 18). Rarely the price-maker. Crops, 6. Disponível na base de dados ProQuest ABI/INFORM Complete

Skinner, R. C. (1970, July). The determination of selling prices. The Journal of Industrial Economics, 18(3), 201-217. doi:10.2307/2097610

Skouras, T. S., Avlonitis, G. J., \& Indounas, K. A. (2005). Economics and marketing on pricing: how and why do they differ? Journal of Product \& Brand Management, 14(6), 362-374. doi:10.1108/10610420510624512

Smith, G. E. (1995). Managerial pricing orientation: the process of making pricing decisions. Pricing Strategy \& Practice, 3(3), 28-39. Disponível na base de dados ProQuest ABI/INFORM Global

Smith, G. E., \& Nagle, T. T. (1994, Spring). Financial analysis for profit-driven pricing. Sloan Management Review, 35(3), 71-84. Disponível na base de dados ProQuest ABI/INFORM Complete

Smith, G. E., \& Nagle, T. T. (2005, July/August). A question of value. Marketing Management, 14(4), 38-43. Disponível na base de dados EBSCOhost Business Source Complete

Smith, P. F. (1983, October). The conclusion is overstated. Management Accounting, 65(4), 85. Disponível na base de dados ProQuest ABI/INFORM Complete

Solberg, C. A., Stöttinger, B., \& Yaprak, A. (2006, March). A taxonomy of the pricing practices of exporting firms: evidence from Austria, Norway, and the United States. Journal of International Marketing, 14(1), 23-48. doi:10.1509/jimk.14.1.23

Soutes, D. O. (2006). Uma investigação do uso de artefatos da contabilidade gerencial por empresas brasileiras (Dissertação de mestrado). Faculdade de Economia, Administração e Contabilidade, Universidade de São Paulo, São Paulo, SP. Disponível em http://www.teses.usp.br/teses/disponiveis/12/12136/tde-12122006-102212/pt-br.php 
Special products: value added to nickel at Clydach and Copper Cliff. (2002, April-May). Canadian Mining Journal, 123(3), 51. Disponível na base de dados ProQuest ABI/INFORM Complete

Stahl, H. (2005, December). Price setting in German manufacturing: new evidence from new survey data. (Working Paper No. 561). Disponível no site do European Central Bank: https://www.ecb.europa.eu/pub/pdf/scpwps/ecbwp561.pdf

Staus, A. (2008). An ordinal regression model using dealer satisfaction data (Working Paper No. 15). Disponível no site da Universität Hohenheim: http://opus.unihohenheim.de/volltexte/2007/197/

Strickland, L. (2007, January 11). Price taker or price maker - cost matters. CarolinaNewswire.com. Disponível em http://carolinanewswire.com/news/News.cgi?database=columns.db\&command=viewone \&id=297

Tancini, G. R. (2013). Itens regulatórios: um estudo aplicado à regulamentação tarifária da energia elétrica no Brasil (Dissertação de mestrado). Faculdade de Economia, Administração e Contabilidade, Universidade de São Paulo, São Paulo, SP. Disponível em http://www.teses.usp.br/teses/disponiveis/12/12136/tde-22102013-155609/pt-br.php

Thaler, R. (1985, August). Mental accounting and consumer choice. Marketing Science, 4(3), 199- 214. doi:10.1287/mksc.4.3.199

Theóphilo, C. R. (2004). Pesquisa em contabilidade no Brasil: uma análise críticoepistemológica (Tese de doutorado). Faculdade de Economia, Administração e Contabilidade, Universidade de São Paulo, São Paulo, SP.

Tishlias, D. P. (1984). The influence of alternative cost allocations on the new product pricing decision: an empirical investigation (Doctoral dissertation). Department of Accounting of the College of Business Administration, University of Cincinnati, Cincinnati, $\mathrm{OH}$. Disponível na base de dados ProQuest Dissertations \& Theses Global. (UMI No. 8420918)

Töytäri, P., Rajala, R., \& Alejandro, T. B. (2015, May). Organizational and institutional barriers to value-based pricing in industrial relationships. Industrial Marketing Management, 47, 53-64. doi:10.1016/j.indmarman.2015.02.005

Tzokas, N., Hart, S., Argouslidis, P., \& Saren, M. (2000, May). Industrial export pricing practices in the United Kingdom. Industrial Marketing Management, 29(3), 191-204. doi:10.1016/S0019-8501(98)00045-5

Universidade de São Paulo. Sistema Integrado de Bibliotecas. (2016). Diretrizes para apresentação de dissertações e teses da USP - Parte II (APA). (3a ed.). São Paulo, SP: SIBI/USP. doi:10.11606/9788573140576

Urbany, J. E. (2001). Justifying profitable pricing. Journal of Product \& Brand Management, 10(3), 141-159. doi:10.1108/10610420110395386 
Van Bruggen, G. H., Smidts, A., \& Wierenga, B. (2001). The powerful triangle of marketing data, managerial judgment, and marketing management support systems. European Journal of Marketing, 35(7-8), 796-816. doi:10.1108/EUM0000000005726

Van Der Steen, M. P. (2005). Human agency in management accounting change: a cognitive approach to institutional theory (Doctoral dissertation). Rijksuniversiteit Groningen, Ridderkerk, The Netherlands. Disponível em http://www.rug.nl/research/portal/files/13152262/thesis.pdf!null

Virbickas, E. (2009). Wage and price setting behaviour of Lithuanian firms. Pinig $\varnothing$ Studijos Ekonomikos Teorija ir Praktika, 2, 5-21. Disponível em https://www.lb.lt/virbickas

Virbickas, E. (2010, May). Wage and price setting behaviour of Lithuanian firms (Working Paper No. 1198). Disponível no site do European Central Bank:

https://www.ecb.europa.eu/pub/pdf/scpwps/ecbwp1198.pdf?7a951d2c4f99fd1ef433896d $3 \mathrm{e} 52723 \mathrm{c}$

Waller, W. S., Shapiro, B., \& Sevcik, G. (1999, November). Do cost-based pricing biases persist in laboratory markets? Accounting, Organizations and Society, 24(8), 717-739. doi:10.1016/S0361-3682(99)00009-4

Weijters, B., Cabooter, E., \& Schillewaert, N. (2010, September). The effect of rating scale format on response styles: the number of response categories and response category labels. International Journal of Research in Marketing, 27(3), 236-247. doi:10.1016/j.ijresmar.2010.02.004

Wentz, T.E. (1966, April). Realism in pricing analyses. Journal of Marketing, 30(2), 19-26. doi:10.2307/1249059

Whittaker, G., Ledden, L., \& Kalafatis, S. P. (2007). A re-examination of the relationship between value, satisfaction and intention in business services. Journal of Services Marketing, 21(5), 345-357. doi:10.1108/08876040710773651

Wilson, D. F. (2000). Why divide consumer and organizational buyer behaviour? European Journal of Marketing, 34(7), 780-796. doi:10.1108/03090560010331207

Woodruff, R. B. (1997, March). Customer value: the next source for competitive advantage. Journal of the Academy of Marketing Science, 25(2), 139-153. doi:10.1007/BF02894350

Zeithaml, V. A., Parasuraman, A., \& Berry, L. L. (1985, spring). Problems and strategies in services marketing. Journal of Marketing, 49(2), 33-46. doi:10.2307/1251563

Zonu.com. (2009). Continents of the world. Disponível em http://www.zonu.com/detailen/2009-11-06-10860/Continents-of-the-World.html 


\section{APÊNDICES}

APÊNDICE A - Formulário da Segunda Fase do Pré-Teste

Prezado consultor

Expresse a percepção que você teve do questionário da pesquisa respondendo às nove seguintes perguntas.

1) No geral, quais notas (de 0 a 10) você atribui para os seguintes itens no questionário:

\begin{tabular}{l|l}
\hline \multicolumn{1}{c|}{ ITENS AVALIADOS } & NOTA \\
\hline Compreensão dos termos das perguntas & \\
\hline Clareza das perguntas & \\
\hline Completude das opções de respostas nas perguntas fechadas & \\
\hline Sequência lógica das perguntas & \\
\hline Inexistências de contradições e vieses & \\
\hline Facilidade de preenchimento & \\
\hline
\end{tabular}

2) Você considera que alguma pergunta mereça ser reescrita para melhorar sua compreensão? No caso positivo, qual pergunta?

3) Você considera que o questionamento de alguma pergunta está de difícil entendimento? No caso positivo, qual pergunta?

4) Você considera que alguma pergunta merece ter o acréscimo de opções de respostas? No caso positivo, qual pergunta? 
5) Você considera que a sequência de apresentação das perguntas merece ser modificada? No caso positivo, quais perguntas deveriam ter sua ordem alterada?

6) Você considera que alguma pergunta apresenta dupla interpretação? No caso positivo, qual pergunta?

7) Você considera que há dificuldade em operacionalizar o preenchimento do questionário?

8) Quantos minutos você levou para ler e compreender o questionário completo?

9) Há alguma sugestão de melhoria que você queira oferecer? 


\section{APÊNDICE B - Mensagens de Apresentação}

\section{B1. Convite por Mensagem Eletrônica}

\section{Assunto do email}

Participação em Pesquisa de Doutorado - FEA/USP

\section{Conteúdo do email (fonte: Arial tamanho 10)}

Prezado(a) profissional

Participe, por favor, da pesquisa promovida pela Faculdade de Economia, Administração e Contabilidade da USP.

Se o(a) senhor(a) é um(a) profissional envolvido(a) na determinação dos preços da sua empresa, peço a gentileza de responder ao questionário disponível na versão anexa em Word para juliana.ventura.amaral@usp.br, ou se preferir, no link:

https://docs.google.com/forms/d/1cX1s1E7vHkV 139PPw6YyztSwhyR4d90jzEhG45W61M/viewform?usp=send form. Se o(a) senhor(a) não está envolvido(a) na determinação dos preços, peço a gentileza de encaminhar este email ao profissional da sua empresa que é o principal responsável pelo estabelecimento dos preços.

O questionário contém apenas 8 questões centrais e seu tempo médio de resposta é de somente 15 minutos. Como retribuição, encaminharei aos respondentes um relatório individualizado dos resultados e também disponibilizarei uma cópia eletrônica completa da tese.

Os pesquisadores envolvidos sou eu, doutoranda Juliana Ventura Amaral, e o professor Reinaldo Guerreiro. $O$ professor Reinaldo Guerreiro é professor titular da FEA/USP, foi diretor da FEA/USP e já escreveu diversos livros e artigos, nacionais e internacionais. Eu também já escrevi capítulos de livros e artigos nacionais e internacionais. $O$ questionário faz parte da minha tese de doutorado. O sucesso da tese depende de uma quantidade suficiente de respostas ao questionário, por isso, sua participação é imprescindível.

Todos os dados coletados serão tratados com absoluta confidencialidade e com total anonimato, não havendo divulgação dos dados de forma individual. A participação é voluntária, podendo-se responder ao questionário a qualquer momento, até ** de ** de 2016.

Sinceramente, conto com sua participação e antecipadamente agradeço a colaboração.

Juliana Ventura Amaral

Doutoranda em Controladoria e Contabilidade

EAC/FEA/USP

juliana.ventura.amaral@usp.br

Orientação:

Prof. Dr. Reinaldo Guerreiro

Professor Titular da FEA/USP

\section{Anexo do email}

Questionario.docx (nesse arquivo consta a versão anterior do questionário apresentado no Apêndice $C$ - versão que incluía um bloco específico de avaliação do instrumento da pesquisa e sem as alterações promovidas na terceira fase do pré-teste) 


\section{B2. Convite após Ligação Telefônica}

\section{Assunto do email}

Participação em pesquisa de Doutorado - USP

\section{Conteúdo do email (fonte: Arial tamanho 10)}

Prezado ***

Peço a gentileza de responder ao questionário sobre o processo de definição dos preços na sua empresa. $O$ questionário faz parte da minha tese de doutorado que investiga os tipos de informações usadas no estabelecimento dos preços (custos, concorrência e valor ao cliente) e, sobretudo, o papel dos custos no processo.

O sucesso da tese depende de uma quantidade suficiente de respostas ao questionário, por isso, conto com a sua ajuda. Sua participação é imprescindível! Como retribuição, encaminharei aos respondentes um relatório individualizado dos resultados e também disponibilizarei uma cópia eletrônica completa da tese.

$\begin{array}{llll}\text { Esse } & \text { questionário } & \text { disponível } & \text { no link }\end{array}$ https://docs.google.com/forms/d/1cX1s1E7vHkV 139PPw6YyztSwhyR4d90jzEhG45W61M/viewform?usp=send f orm ou, se preferir, na versão anexa em Word (respondê-lo para juliana.ventura.amaral@usp.br). O tempo médio de resposta é de somente 15 minutos.

Os pesquisadores envolvidos sou eu, doutoranda Juliana Ventura Amaral, e o professor Reinaldo Guerreiro. $\mathrm{O}$ professor Reinaldo Guerreiro é professor titular da USP, foi diretor da FEA/USP e já escreveu diversos livros e artigos, nacionais e internacionais. Eu também já escrevi capítulos de livros e artigos nacionais e internacionais.

Todos os dados coletados serão tratados com absoluta confidencialidade e com total anonimato, não havendo divulgação dos dados de forma individual. A participação é voluntária, podendo-se responder ao questionário a qualquer momento, até ${ }^{* \star}$ de ** de 2016.

Sinceramente, conto com sua participação e antecipadamente agradeço a colaboração.

Juliana Ventura Amaral

Doutoranda em Controladoria e Contabilidade

EAC/FEA/USP

juliana.ventura.amaral@usp.br

Orientação:

Prof. Dr. Reinaldo Guerreiro

Professor Titular da FEA/USP

\section{Anexo do email}

Questionario.docx (nesse arquivo consta o questionário apresentado no Apêndice C) 


\section{CARTA DE APRESENTAÇĀO}

Essa empresa esta sonda convidada a parsciper de pegquisa que compoe lese de doutarado scber o estabelecinenlo dus presus em empresas industrais:

A psrticipaça na pasqussa inplica no prosenchimento do euesbonario da tese. Esse questionario foi erviade come anese em mensegem eletronice de assunto "Partiopacas em Pesquisa do
Deuterado
PENUSP
e tarnbem
osts disponinel

$\mathrm{gm}$

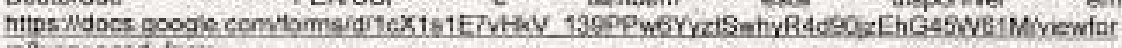
m?usn-esend form

\section{PROTOCOLO ETICO DE PESOUISA}

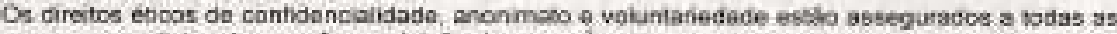
ampresas paricipantas. confome detahodo a seguir:

a) Os pesqueadores compromatem-se a manter a confiencialidade das informaç6es colotadas nas questiondrios:

b) Apenas os pesquisadoces emvolvidas terato acesso aas questionerios fespondidos:

c] Os quastionackos rescondidos serâ amecenedos em ambienle seguro.

d) Naso havertás identificsealo dos respondenins na tesc;

a) A finaludade da pesquisa e exclusivamente acadervica; $\theta$

5. A pertecipacso et volurtyria, podendo-se responder ad questionario a cualquer momento dentro do prazo acordado.

\section{PESQUISADORES ENYOLVIDOS}

A pesquisa osk sendo desermolvida polo doshoranda Juilana Ventura Amaral que pode ser

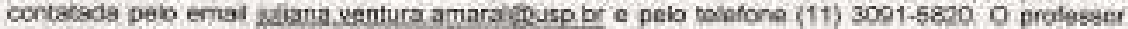
doutar Renaldo Guerreino a a orientador da peeguisa

Pars aus sesuranca, intomsmos que a vinculaça dos pesquisadones a unversidade de 580 Paulo pode sar coneutedo ne sistama Uxania do USP, com acesso en

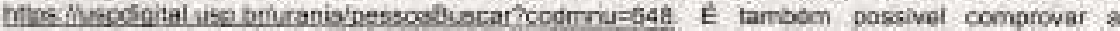

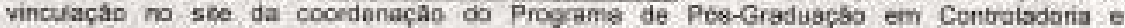

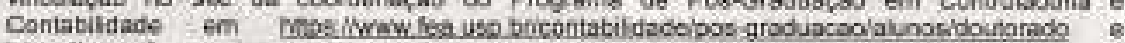

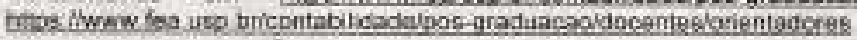

\section{BENEFICIOS PARA A ORGANIZACĀO}

A. erturesa rocobera un relatocio ndividusizado sobre seut resultados e lerb acosso a versabo cigitalzede da lese:

\section{ESCL.ARECIMENTOS ADICIONAIS}

Quaisquer esclanectmentos adicionats podem sei solicilados a qualquer mornamia do pesquisa psra lufand ventura arro alpusp.tir

Atnncioramente

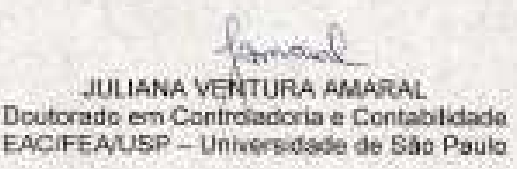

Foculdode de Emonia, Aomiritractis e Contabitidade da Unerersidede de 5 te Paulo

Departamerto de Contabilidade a Afulria

Av. Prof. Lucisno Gusiberta 946

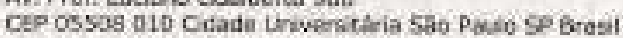

Teit $551130915920 \mathrm{Fax}+5511309 \mathrm{t} 5822$ 
APÊNDICE C - Questionário

QUESTIONÁRIO DE PESQUISA SOBRE O ESTABELECIMENTO DOS PREÇOS EM INDÚSTRIAS NO
BRASIL

FACULDADE DE ECONOMIA, ADMINISTRAÇÃO E CONTABILIDADE - UNIVERSIDADE DE SÃO PAULO PESQUISADORA: JULIANA VENTURA AMARAL (juliana.ventura.amaral@usp.br)

ORIENTADOR: PROF. DR. REINALDO GUERREIRO

\section{Instruções}

-Este questionário foi elaborado para identificar características do estabelecimento dos preços em empresas industriais instaladas no Brasil.

-As questões aplicam-se ao estabelecimento dos preços dos produtos do principal segmento da sua empresa, ou seja, daquele segmento que tem a maior expressividade nos seus negócios. -As respostas ao questionário devem espelhar a situação que predomina na sua empresa.

\section{CARACTERIZAÇÃO GERAL DO PRINCIPAL SEGMENTO}

\footnotetext{
*1- Em que extensão você concorda com as seguintes assertivas:
}

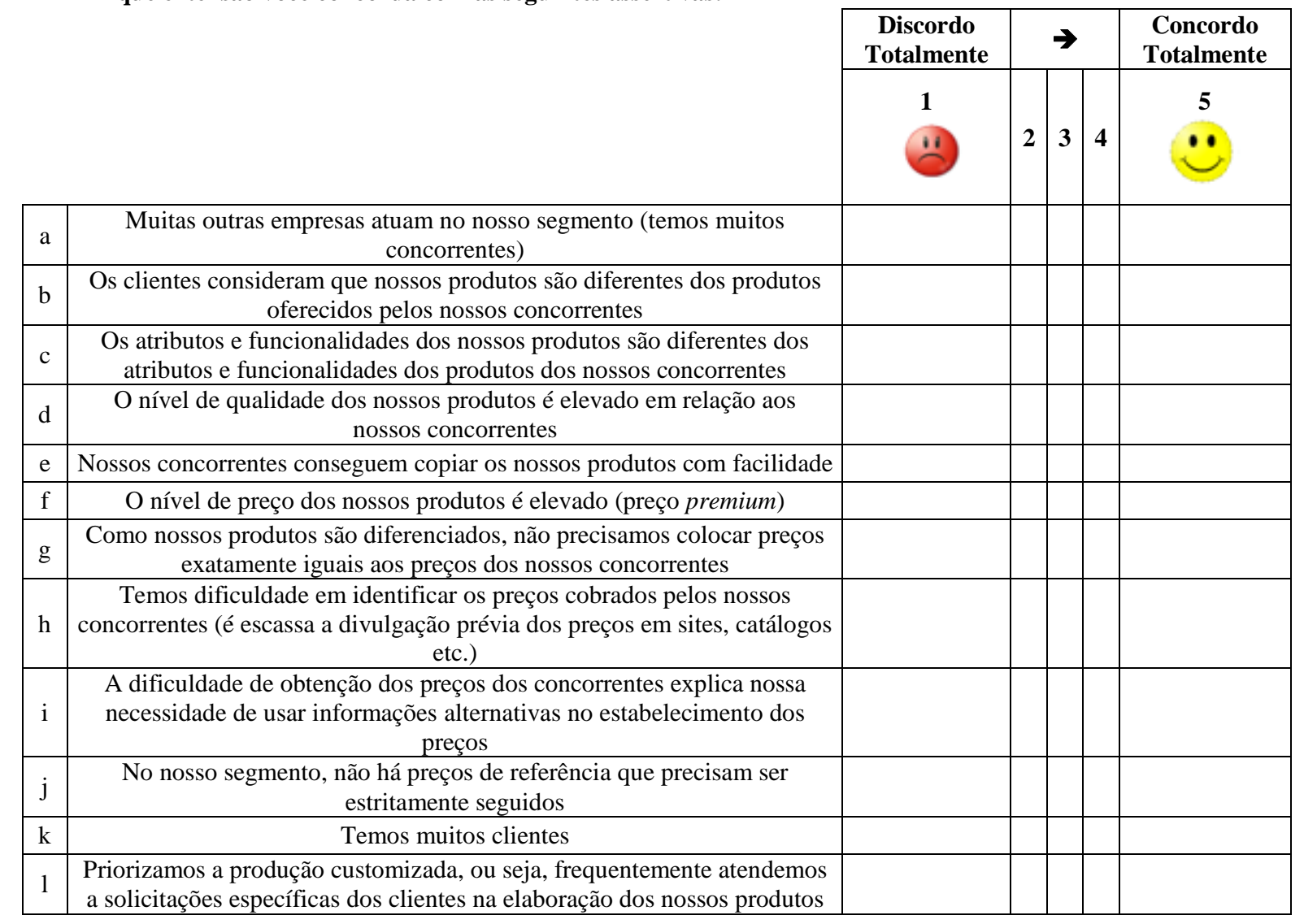




\section{INFORMAÇÕES E FÓRMULAS USADAS NO ESTABELECIMENTO DOS PREÇOS}

\section{Nesta parte do questionário, o objetivo é levantar detalhes sobre as informações e fórmulas usadas no processo de estabelecimento dos preços dos produtos do principal segmento.}

*2- Indique a intensidade do uso das seguintes informações no estabelecimento dos preços:

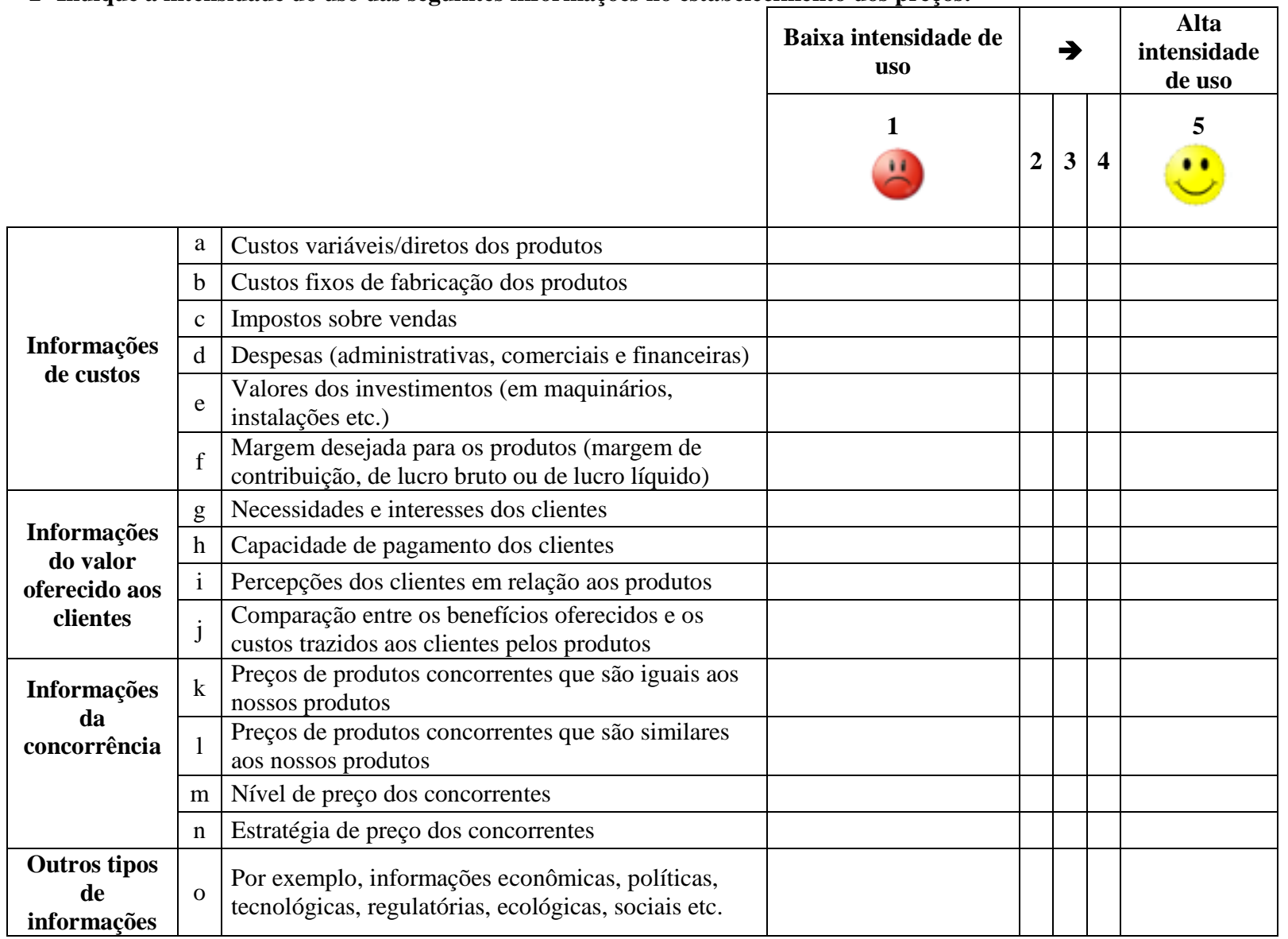

*3- Indique dentre as seguintes afirmações qual demonstra a PRINCIPAL forma de operacionalização do estabelecimento dos preços:

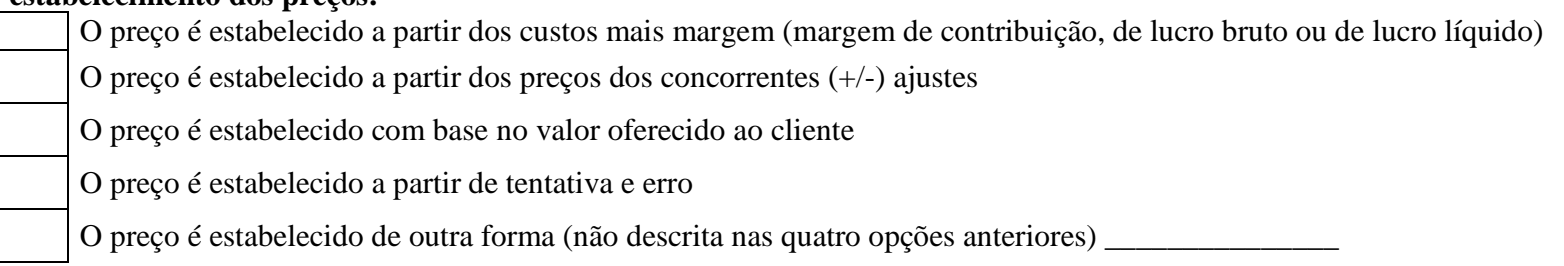

*4- Alguma fórmula matemática de custos mais margem é usada no estabelecimento dos preços?

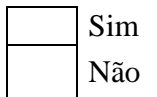




\section{CUSTOS MAIS MARGEM}

Nesta parte do questionário, o objetivo é levantar detalhes do uso dos custos e da margem no processo de estabelecimento dos preços.

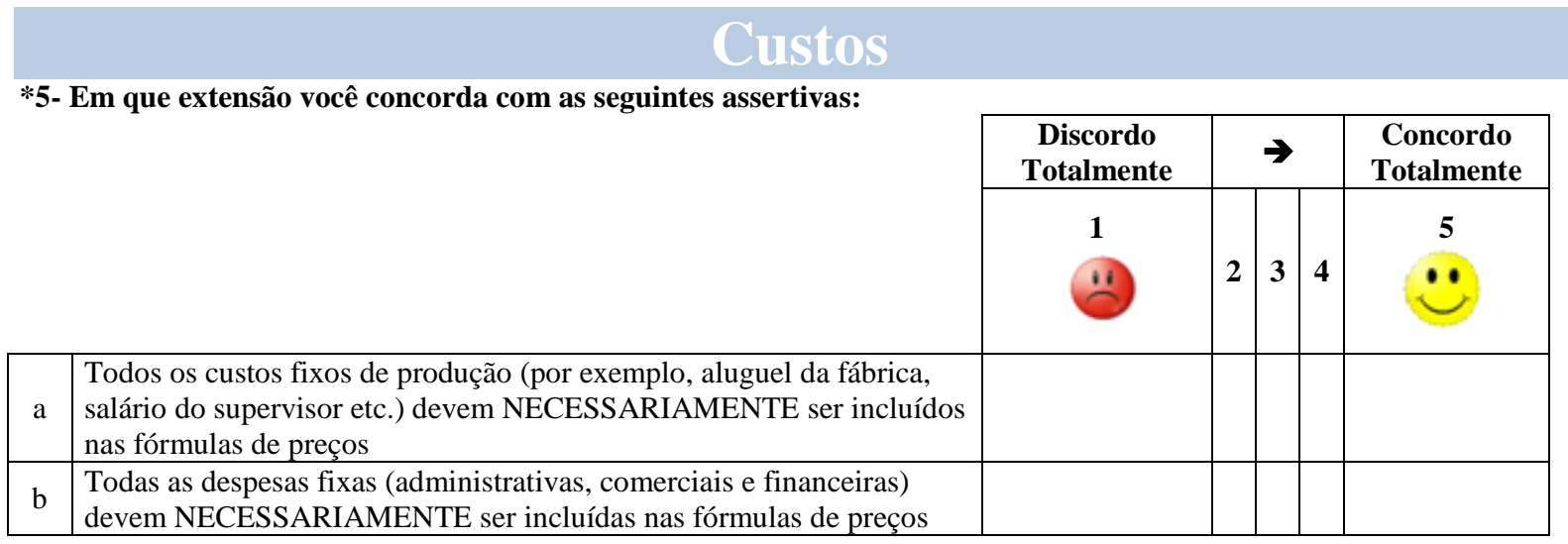

\section{Naregen}

*6- Em que extensão você concorda com as seguintes assertivas:

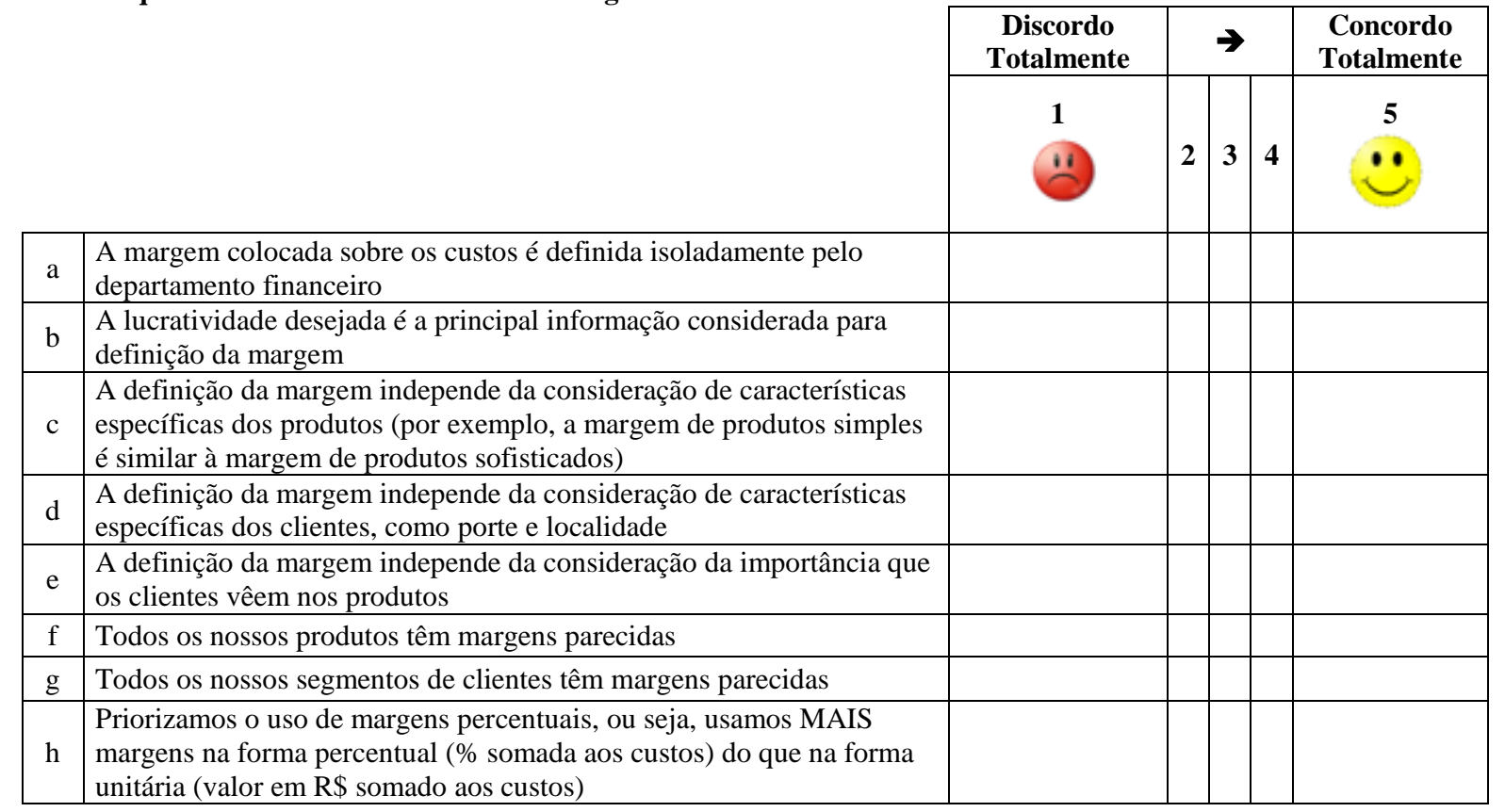

\section{Custos mais margem}

Obs.: Considere que o "valor oferecido aos clientes" corresponde à combinação entre os benefícios e os custos dos produtos, segundo a PERCEPÇÃO DOS CLIENTES

*7- Em que extensão você concorda com as seguintes assertivas: 


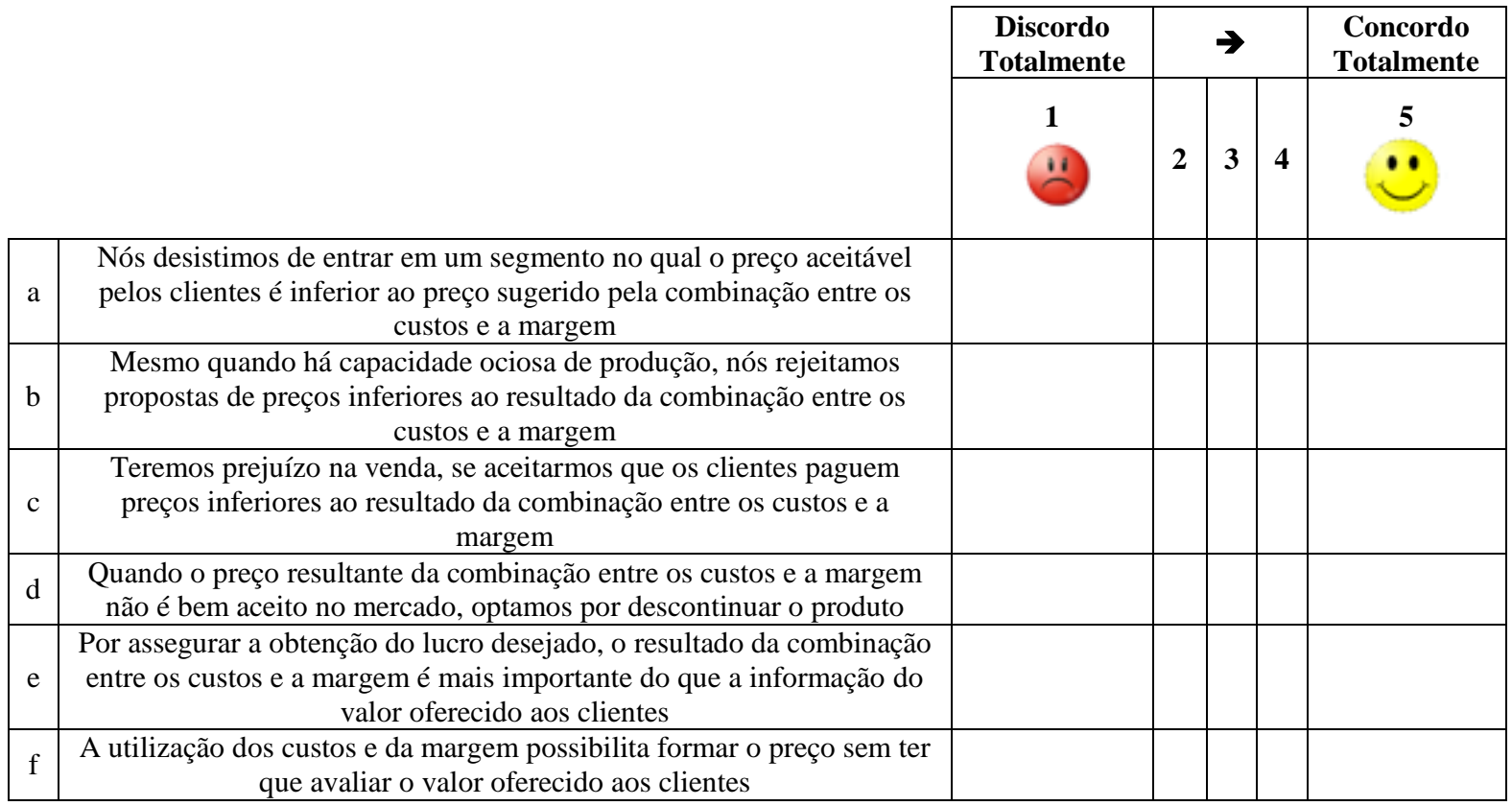

\section{FATORES RELACIONADOS AO ESTABELECIMENTO DOS PREÇOS}

\section{Nesta parte do questionário, o objetivo é identificar os fatores que influenciaram sua empresa a decidir como os preços dos produtos do principal segmento seriam estabelecidos.}

*8- Em que extensão você concorda com as seguintes assertivas:

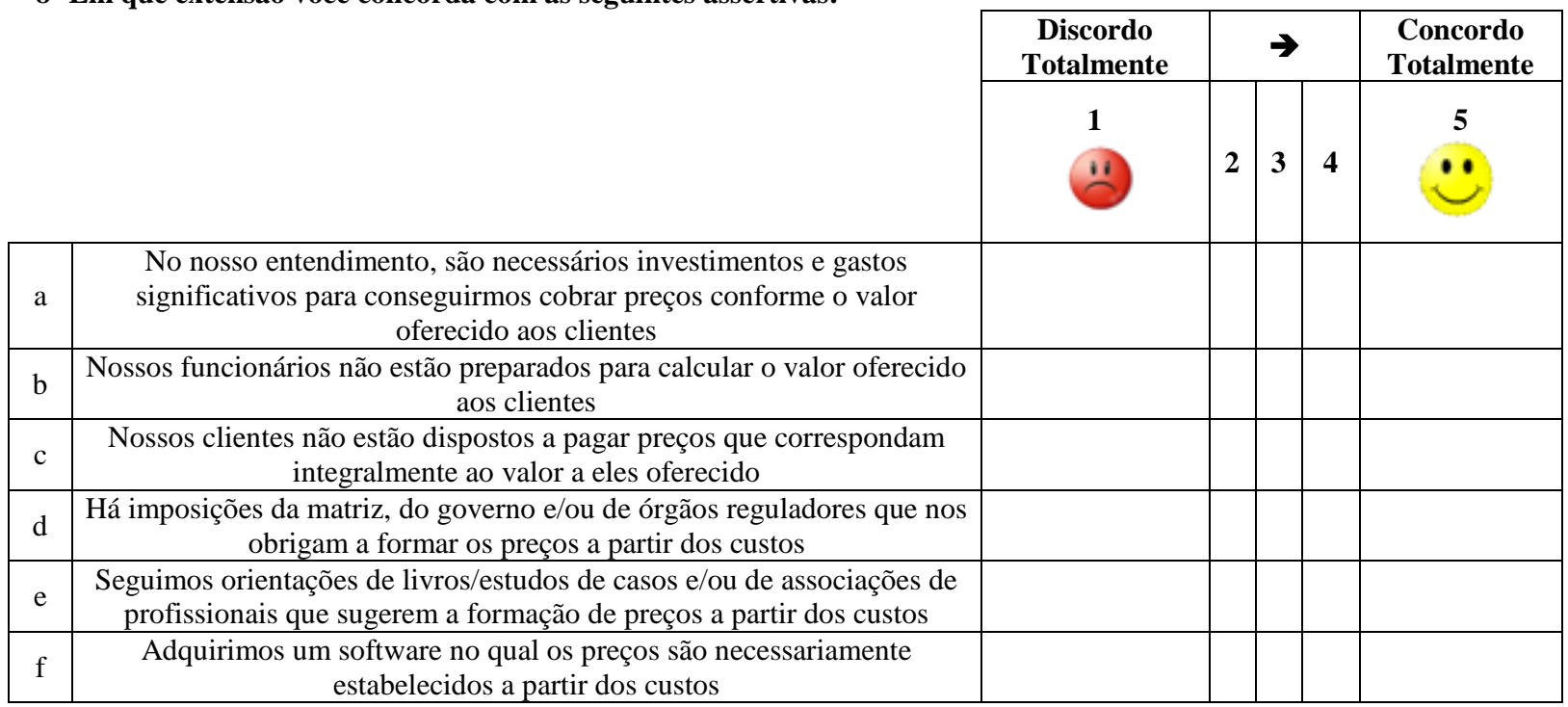

\section{CONCLUSÃO}

Esta é a última seção do questionário. Nela, são trazidas perguntas para conhecer um pouco mais sobre os respondentes e sobre as empresas que compõem a amostra da pesquisa. 
*Nome do respondente:

*Empresa:

*E-mail:

* Departamento/área que atua na empresa

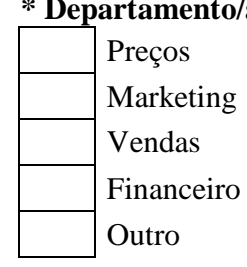

* Cargo que atua na empresa

\begin{tabular}{|l|l|}
\hline & Analista \\
Supervisor/Coordenador \\
Gerente/Diretor \\
Outro
\end{tabular}

*Há APROXIMADAMENTE quanto tempo você (ou o principal responsável pelo processo) atua no estabelecimento dos preços?

Anos

* Existe na empresa área especificamente dedicada a estabelecer preços?

\begin{tabular}{ll}
\hline & Sim \\
\hline & Não
\end{tabular}

* Existindo área especificamente voltada ao estabelecimento dos preços, há APROXIMADAMENTE quanto tempo ela existe? $\square$ Anos

* APROXIMADAMENTE, quantos empregados trabalham na empresa?

\begin{tabular}{|l|l}
\hline & Até 19 empregados \\
De 20 a 99 empregados \\
De 100 a 499 empregados \\
Mais de 500 empregados
\end{tabular}

* No principal segmento, a sua empresa é a líder de mercado (é a empresa com maior participação de vendas)?

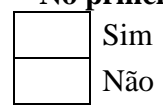

*Quais são os três principais produtos vendidos pela empresa?

\section{Muito Obrigada!}


APÊNDICE D - Cabeçalhos dos Relatórios de Controle da Pesquisa

Cabeçalho do Relatório de Dados Cadastrais de Empresas Oriundas da Revista Exame Melhores \& Maiores

\begin{tabular}{|c|c|c|c|c|c|c|c|c|c|c|c|c|c|}
\hline $\begin{array}{c}\text { BANCO } \\
\text { DE } \\
\text { DADOS }\end{array}$ & $\begin{array}{l}\text { NOME DA } \\
\text { EMPRESA }\end{array}$ & GRUPO & $\begin{array}{c}\text { Código } \\
\text { Pesquisa }\end{array}$ & $\begin{array}{l}\text { CóDIGO } \\
\text { M\&M }\end{array}$ & CNAE & $\begin{array}{c}\text { LOCALIZAÇão } \\
\text { GEOGRÁFICA } \\
\text { (CIDADE, } \\
\text { ESTADO) }\end{array}$ & $\begin{array}{c}\text { TELEFONES } \\
\text { COMPLETOS } \\
\text { (POTENCIAL } \\
\text { CONTATO; } \\
\text { ASSESSORIA; } \\
\text { CENTRAL) } \\
\end{array}$ & $\begin{array}{c}\text { NOME DO } \\
\text { CONTATO INICIAL } \\
\text { (SE EXISTENTE, } \\
\text { CADASTRADO NO } \\
\text { BANCO DE DADOS) }\end{array}$ & $\begin{array}{c}\text { CARGO do } \\
\text { CONTATO } \\
\text { INICIAL, SE } \\
\text { EXISTENTE }\end{array}$ & $\begin{array}{c}\text { TELEFONES } \\
\text { LOCALIZADOS } \\
\text { EM TRABALHOS } \\
\text { ANTERIORES }\end{array}$ & $\begin{array}{c}\text { EMAILS } \\
\text { CADASTRADOS }\end{array}$ & $\begin{array}{c}\text { EMAILS } \\
\text { LOCALIZADOS } \\
\text { EM TRABALHOS } \\
\text { ANTERIORES }\end{array}$ & $\begin{array}{c}\text { CONSTA } \\
\text { NA NEI? } \\
\text { (TAMBÉM) }\end{array}$ \\
\hline$M \& M$ & & & & & & & & & & & & & \\
\hline
\end{tabular}

Cabeçalho do Relatório de Dados Cadastrais de Empresas Oriundas da Revista NEI

\begin{tabular}{|c|c|c|c|c|c|c|c|c|c|c|c|c|}
\hline $\begin{array}{l}\text { BANCO } \\
\text { DE } \\
\text { DADOS }\end{array}$ & $\begin{array}{l}\text { NOME DA } \\
\text { EMPRESA }\end{array}$ & GRUPO & $\begin{array}{c}\text { Código } \\
\text { PESQuisa }\end{array}$ & $\begin{array}{c}\text { ANOS } \\
\text { NEI }\end{array}$ & $\begin{array}{l}\text { No CATEGORIAS } \\
(\mathbf{2 0 1 4 ;} \text { 2015) }\end{array}$ & $\begin{array}{c}\text { LOCALIZAÇ̃̃o } \\
\text { GEOGRÁFICA } \\
\text { (CIDADE, ESTADO) }\end{array}$ & $\begin{array}{c}\text { TELEFONES DE } \\
\text { CONTATO (COM } \\
\text { DDD) }\end{array}$ & $\begin{array}{c}\text { TELEFONES } \\
\text { LOCALIZADOS EM } \\
\text { TRABALHOS } \\
\text { ANTERIORES }\end{array}$ & $\begin{array}{c}\text { EMAILS } \\
\text { CADASTRADOS }\end{array}$ & $\begin{array}{c}\text { EMAILS } \\
\text { LOCALIZADOS EM } \\
\text { TRABALHOS } \\
\text { ANTERIORES }\end{array}$ & SITE & $\begin{array}{c}\text { CONSTA } \\
\text { NA } \\
\text { M\&M? } \\
\text { (TAMBÉM) }\end{array}$ \\
\hline NEI & & & & & & & & & & & & \\
\hline
\end{tabular}

Cabeçalho do Relatório de Controle de Contatos

\begin{tabular}{|c|c|c|c|c|c|c|c|c|c|c|c|c|c|}
\hline $\begin{array}{c}\text { BANCO } \\
\text { DE } \\
\text { DADOS }\end{array}$ & $\begin{array}{l}\text { NOME DA } \\
\text { EMPRESA }\end{array}$ & GRUPO & $\begin{array}{c}\text { Código } \\
\text { Pesquisa }\end{array}$ & BASES & $\begin{array}{c}\text { EMAILS (JÁ } \\
\text { EXCLUíDOS OS } \\
\text { INVÁLIDOS) } \\
\end{array}$ & $\begin{array}{c}\text { EMAILS } \\
\text { ORIGINALMENTE } \\
\text { CADASTRADOS } \\
\end{array}$ & $\begin{array}{c}\text { TELEFONES DE } \\
\text { CONTATO } \\
\text { (COM DDD) }\end{array}$ & $\begin{array}{l}\text { CONTATO } \\
\text { INDIVIDUAL? }\end{array}$ & $\begin{array}{c}\text { RESPONDEU? } \\
\text { RECUSOU?OUTROS? }\end{array}$ & $\begin{array}{c}\text { Motivo } \\
\text { DE } \\
\text { RECUSA } \\
\end{array}$ & $\begin{array}{c}\text { Data do } \\
\text { AgradeCiMENTo }\end{array}$ & $\begin{array}{l}\text { EMAILS A } \\
\text { REITERAR }\end{array}$ & OBS. \\
\hline
\end{tabular}

\begin{tabular}{|c|c|c|c|c|c|c|c|c|}
\hline $\begin{array}{l}\text { DATA DO } \\
\text { CONTATO }\end{array}$ & $\begin{array}{l}\text { HistóRICO DO } \\
\text { CONTATO }\end{array}$ & $\begin{array}{c}\text { DADOS DO } \\
\text { RESPONDENTE }\end{array}$ & $\begin{array}{c}\text { PRAZO } \\
\text { ORIGINALMENTE } \\
\text { ACORDADO } \\
\end{array}$ & $\begin{array}{c}\text { DATAS DE } \\
\text { REITERAÇÃo }\end{array}$ & $\begin{array}{c}\text { RESPOSTA APÓS QUAL } \\
\text { QUANTIDADE DE } \\
\text { REITERAÇÕES? } \\
\end{array}$ & $\begin{array}{c}\text { SOLICITAÇÕES DE } \\
\text { COMPLEMENTO EM } \\
\text { ABERTO } \\
\end{array}$ & $\begin{array}{c}\text { CÓDIGO DE } \\
\text { RESPONDENTE }\end{array}$ & $\begin{array}{c}\text { RESPONDENTE } \\
\text { RECEBEU RELATÓRIO? }\end{array}$ \\
\hline
\end{tabular}


APÊNDICE E - Mensagem de Agradecimento

\section{Assunto do email}

Agradecimento por Participação em Pesquisa de Doutorado - FEA/USP

\section{Conteúdo do email (fonte: Arial tamanho 10)}

Prezado ****

Agradeço a sua participação na pesquisa de doutorado da USP. Assim que a análise de dados for concluída, encaminharei o relatório individualizado com a comparação entre as suas respostas e as respostas dominantes na amostra. Ao fim do trabalho, também encaminharei a cópia digital da tese.

Muito obrigada pela sua valiosa contribuição, que é fundamental para a realização da pesquisa!

Juliana Ventura Amaral

Doutoranda em Controladoria e Contabilidade

EAC/FEA/USP

juliana.ventura.amaral@usp.br

Orientação:

Prof. Dr. Reinaldo Guerreiro

Professor Titular da FEA/USP 
APÊNDICE F - Mensagem de Envio dos Resultados

\section{Assunto do email}

Envio do relatório individualizado da pesquisa de doutorado da USP

\section{Conteúdo do email (fonte: Arial tamanho 10)}

Código do Respondente: ***

Prezado ***

Aproveito a oportunidade para novamente agradecer sua participação na pesquisa de doutorado da USP e para encaminhar o relatório individualizado com os resultados da pesquisa. O relatório individualizado contém, para cada uma das questões, a comparação entre a sua resposta e a média apurada nas respostas das empresas: (1) do seu segmento; (2) do seu ambiente; (3) do seu porte; e (4) da amostra como um todo. Estão em fonte vermelha todas as questões em que se constatou, nessa comparação, uma diferença igual ou maior a dois pontos.

A classificação da sua empresa quanto ao segmento, ao ambiente e ao porte tomou como base suas respostas ao questionário, sobretudo às perguntas que pediam informar os três principais produtos vendidos e o número de empregados. Caso haja alguma discordância em relação a essa classificação, peço a gentileza de informar para que seja possível Ihe encaminhar uma nova versão do relatório com as informações do segmento, do ambiente e/ou do porte mais apropriados.

Após a tese ser defendida e finalizada (previsão: primeiro semestre de 2017), será encaminhado um link para acesso completo à versão eletrônica. A tese conterá as explicações e os embasamentos teóricos dos resultados obtidos.

Estamos também avaliando a possibilidade de promover uma palestra gratuita na FEA/USP exclusiva para os respondentes na qual os resultados serão expostos e relacionados ao arcabouço teórico. Caso seja confirmada, essa palestra acontecerá após a defesa da tese (previsão: primeiro semestre de 2017). Na mensagem com o link para acesso à tese, fornecerei maiores detalhes.

Coloco-me à disposição para quaisquer esclarecimentos.

Muito obrigada pela sua valiosa contribuição que tornou factível a realização da pesquisa!

Juliana Ventura Amaral

Doutoranda em Controladoria e Contabilidade

EAC/FEA/USP

juliana.ventura.amaral@usp.br

Orientação:

Prof. Dr. Reinaldo Guerreiro

Professor Titular da FEA/USP

\section{Anexo do email:}

"Código do respondente".pdf, vide modelo reproduzido na sequência 
PESQUISA SOBRE O ESTABELECIMENTO DOS PREÇOS EM INDÚSTRIAS NO BRASIL

FACULDADE DE ECONOMIA, ADMINISTRAÇÃO E CONTABILIDADE - UNIVERSIDADE DE SÃO PAULO

PESQUISADORA: JULIANA VENTURA AMARAL (juliana.ventura.amaral@usp.br)

ORIENTADOR: PROF. DR. REINALDO GUERREIRO

CÓDIGO:

EMPRESA:

SEGMENTO (vide lista ao fim do relatório):

AMBIENTE (B2B; B2C; Commodities; Engenharia e Construção):

PORTE (Micro; Pequena; Média; Grande Empresa):

\section{QUESTÕES DE DISCORDÂNCIA/CONCORDÂNCIA}

(1- Discordo Totalmente; 5- Concordo Totalmente)

\begin{tabular}{|c|c|c|}
\hline $\begin{array}{c}\text { Suas } \\
\text { resposta } \\
\mathbf{s}\end{array}$ & $\begin{array}{c}\text { Respostas } \\
\text { dominantes } \\
\text { nas } \\
\text { empresas } \\
\text { do seu } \\
\text { SEGMENTO }\end{array}$ & \\
& &
\end{tabular}

Respostas

dominantes

empresas $\quad \begin{gathered}\text { nas } \\ \text { empresas }\end{gathered}$

do seu

do seu

AMBIENTE PORTE

1-Muitas outras empresas atuam no nosso segmento (temos

muitos concorrentes)

1-Os clientes consideram que nossos produtos são diferentes

dos produtos oferecidos pelos nossos concorrentes

1-Os atributos e funcionalidades dos nossos produtos são

diferentes dos atributos e funcionalidades dos produtos dos

nossos concorrentes

1-O nível de qualidade dos nossos produtos é elevado em

relação aos nossos concorrentes

1-Nossos concorrentes conseguem copiar os nossos produtos

com facilidade

1-O nível de preço dos nossos produtos é elevado (preço

premium)

1-Como nossos produtos são diferenciados, não precisamos

colocar preços exatamente iguais aos preços dos nossos

concorrentes

1-Temos dificuldade em identificar os preços cobrados pelos

nossos concorrentes (é escassa a divulgação prévia dos

preços em sites, catálogos etc.)

1-A dificuldade de obtenção dos preços dos concorrentes

explica nossa necessidade de usar informações alternativas no

estabelecimento dos preços

1-No nosso segmento, não há preços de referência que

precisam ser estritamente seguidos

1-Temos muitos clientes

1-Priorizamos a produção customizada, ou seja,

frequentemente atendemos a solicitações específicas dos

clientes na elaboração dos nossos produtos

5- Todos os custos fixos de produção (por exemplo, aluguel da fábrica, salário do supervisor etc.) devem

NECESSARIAMENTE ser incluídos nas fórmulas de precos

5- Todas as despesas fixas (administrativas, comerciais e

financeiras) devem NECESSARIAMENTE ser incluídas nas

fórmulas de preços

6-A margem colocada sobre os custos é definida isoladamente pelo departamento financeiro

6-A lucratividade desejada é a principal informação considerada para definição da margem

6-A definição da margem independe da consideração de

características específicas dos produtos (por exemplo, a

margem de produtos simples é similar à margem de produtos sofisticados)

6-A definição da margem independe da consideração de

características específicas dos clientes, como porte e

localidade

6-A definição da margem independe da consideração da

importância que os clientes vêem nos produtos

6-Todos os nossos produtos têm margens parecidas

6-Todos os nossos segmentos de clientes têm margens

parecidas

6-Priorizamos o uso de margens percentuais, ou seja, usamos

MAIS margens na forma percentual (\% somada aos custos) do

que na forma unitária (valor em $\mathrm{R} \$$ somado aos custos)

7-Nós desistimos de entrar em um segmento no qual o preço

aceitável pelos clientes é inferior ao preço sugerido pela

combinação entre os custos e a margem

7-Mesmo quando há capacidade ociosa de produção, nós

rejeitamos propostas de preços inferiores ao resultado da

combinação entre os custos e a margem

7-Teremos prejuízo na venda, se aceitarmos que os clientes

paguem preços inferiores ao resultado da combinação entre os

custos e a margem 


\begin{tabular}{|l|l|l|l|l|}
\hline $\begin{array}{l}\text { 7-Quando o preço resultante da combinação entre os custos e } \\
\text { a margem não é bem aceito no mercado, optamos por } \\
\text { descontinuar o produto }\end{array}$ & & & & \\
\hline $\begin{array}{l}\text { 7-Por assegurar a obtenção do lucro desejado, o resultado da } \\
\text { combinação entre os custos e a margem é mais importante do } \\
\text { que a informação do valor oferecido aos clientes }\end{array}$ & & & & \\
\hline $\begin{array}{l}\text { 7-A utilização dos custos e da margem possibilita formar o } \\
\text { preço sem ter que avaliar o valor oferecido aos clientes }\end{array}$ & & & & \\
\hline $\begin{array}{l}\text { 8-No nosso entendimento, são necessários investimentos e } \\
\text { gastos significativos para conseguirmos cobrar preços } \\
\text { conforme o valor oferecido aos clientes }\end{array}$ & & & & \\
\hline $\begin{array}{l}\text { 8-Nossos funcionários não estão preparados para calcular o } \\
\text { valor oferecido aos clientes }\end{array}$ & & & & \\
\hline $\begin{array}{l}\text { 8-Nossos clientes não estão dispostos a pagar preços que } \\
\text { correspondam integralmente ao valor a eles oferecido }\end{array}$ & & & & \\
\hline $\begin{array}{l}\text { 8-Há imposições da matriz, do governo e/ou de órgãos } \\
\text { reguladores que nos obrigam a formar os preços a partir dos } \\
\text { custos }\end{array}$ & & & & \\
\hline $\begin{array}{l}\text { 8-Seguimos orientações de livros/estudos de casos e/ou de } \\
\text { associações de profissionais que sugerem a formação de } \\
\text { preços a partir dos custos }\end{array}$ & & & & \\
\hline $\begin{array}{l}\text { 8-Adquirimos um software no qual os preços são } \\
\text { necessariamente estabelecidos a partir dos custos }\end{array}$ & & & & \\
\hline
\end{tabular}

\section{QUESTÕES SOBRE INTENSIDADE DE USO DAS INFORMACÕES}

(1- Baixa intensidade de uso; 5- Alta intensidade de uso)

\begin{tabular}{|c|} 
Suas \\
respostas
\end{tabular}

2-Custos variáveis/diretos dos produtos

2-Custos fixos de fabricação dos produtos

2-Impostos sobre vendas

2-Despesas (administrativas, comerciais e financeiras)

2-Valores dos investimentos (em maquinários, instalações

etc.)

2-Margem desejada para os produtos (margem de

contribuição, de lucro bruto ou de lucro líquido)

2-Necessidades e interesses dos clientes

2-Capacidade de pagamento dos clientes

2-Percepções dos clientes em relação aos produtos

2-Comparação entre os benefícios oferecidos e os custos

trazidos aos clientes pelos produtos

2-Preços de produtos concorrentes que são iguais aos

nossos produtos

2-Preços de produtos concorrentes que são similares aos

nossos produtos

2-Nível de preço dos concorrentes

2-Estratégia de preço dos concorrentes

2-Outros tipos de informações (por exemplo, informações

econômicas, políticas, tecnológicas, regulatórias, ecológicas,

sociais etc.)

\section{POSSÍVEIS SEGMENTOS}

Açúcar e Energia

Agrícola e Florestal

Alimentos

Automotivo

Engenharia e Construção

Equipamentos

Farmacêutico

Fertilizantes e Defensivos

Insumos para Indústria de Bens de Consumo

Materiais para Construção

Metalúrgico

Mineração

Papel, Plástico e Embalagens

Peças e Acessórios

Produtos de Higiene e Limpeza

Químico

Roupas e Calçados

Tecidos e Confecções Profissionais

Utensílios e Aparelhos Domésticos e de Escritório 